UNIVERSIDADE DE SÃO PAULO

FACULDADE DE FILOSOFIA, LETRAS E CIÊNCIAS HUMANAS DEPARTAMENTO DE GEOGRAFIA

PROGRAMA DE PÓS-GRADUAÇÃO EM GEOGRAFIA HUMANA

PEDRO PAULO CADENA GIBERTI

SISTEMAS DE MOVIMENTO DE PASSAGEIROS NA MACROMETRÓPOLE PAULISTA: CONSOLIDAÇÃO E ATUAÇÃO DOS FRETADOS

São Paulo 
UNIVERSIDADE DE SÃO PAULO

FACULDADE DE FILOSOFIA, LETRAS E CIÊNCIAS HUMANAS DEPARTAMENTO DE GEOGRAFIA

PROGRAMA DE PÓS-GRADUAÇÃO EM GEOGRAFIA HUMANA

PEDRO PAULO CADENA GIBERTI

SISTEMAS DE MOVIMENTO DE PASSAGEIROS NA MACROMETRÓPOLE PAULISTA: CONSOLIDAÇÃO E ATUAÇÃO DOS FRETADOS

São Paulo 
PEDRO PAULO CADENA GIBERTI

\section{SISTEMAS DE MOVIMENTO DE PASSAGEIROS NA MACROMETRÓPOLE PAULISTA: CONSOLIDAÇÃO E ATUAÇÃO DOS FRETADOS}

Dissertação apresentada ao Departamento de Geografia da Faculdade de Filosofia, Letras e Ciências Humanas da Universidade de São Paulo para obtenção do título de M estre em Geografia.

Área de Concentração: Geografia Humana Orientador: Prof. Dr. Fabio Betioli Contel

São Paulo 
BANCA EXAMINADORA

PROF.DR.FABIO BETIOLI CONTEL

ORIENTADOR

PROF.DR. RICARDO CASTILLO

(UNICAMP)

PROFA. DRA. MARIA MÓNICA ARROYO

(USP)

PEDRO PAULO CADENA GIBERTI

ORIENTANDO

São Paulo (SP), 11 de julho de 2012

RESULTADO: 
LOMBADA

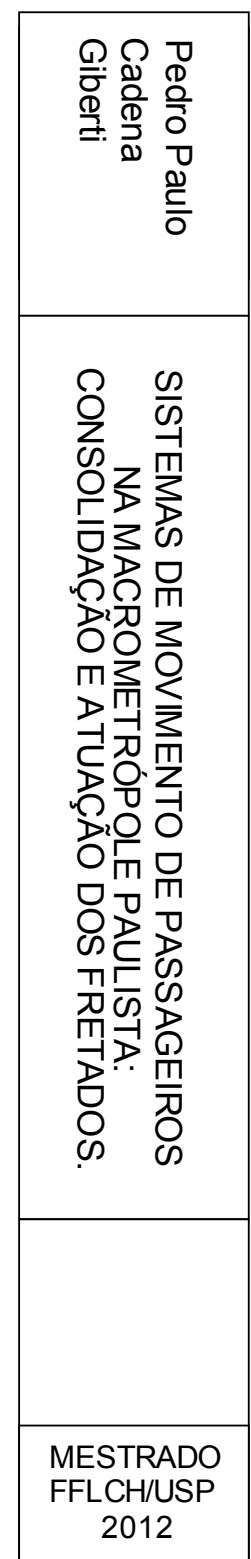




\section{Sumário}

Agradecimentos

Resumo

03

Abstract

04

Índice de Figuras, Fotos, Mapas, Tabelas, Gráficos, Quadros

05

Siglas e Abreviações

10

Introdução

Capitulo 1: Os sistemas de movimento e a formação da metrópole paulista

1.1 Rede urbana, metropolização e transportes 24

1.2 Os limites da metrópole paulista 35

1.3 Sistemas de movimento, acessibilidade e mobilidade urbana

CAPITULO 2: Sistemas técnicos, organização e a questão dos transportes metropolitanos

2.1 Organização dos transportes de passageiros na Região Metropolitana de São Paulo

2.2 Sistemas técnicos, modais de transportes e características gerais dos fluxos

2.3 Os fluxos de passageiros: análise a partir da pesquisa Origem/Destino e do IBGE 
CAPITULO 3: Consolidação e atuação dos fretados como alternativa de transporte metropolitano

3.1 Gênese e evolução do sistema de movimento dos fretados 175

3.2 Organização, normas, atores e usuários dos fretados 189

3.3 Pólos, densidades, direções, alcance e impacto dos fretados 197

$\begin{array}{ll}\text { Considerações Finais } & 226\end{array}$

$\begin{array}{ll}\text { Bibliografia } & 232\end{array}$

Anexo 243 


\section{Agradecimentos}

Sou muito grato ao Departamento de Geografia da Universidade de São Paulo; ao Laboratório de G eografia Política, Planejamento Territorial e Ambiental (LABOPLAN).

Ao Prof. Dr. Fábio Betioli Contel pela oportunidade prestada e orientação durante estes 3 anos.

À Prof. Dra. Maria Mónica Arroyo e ao P rof. Dr. Ricardo Castillo pelas contribuições valiosas no e xame de qu alificação, permitindo-me uma leitura crítica com enfoque geográfico do tema enfrentado.

À Prof. Dra. Maria Laura Silveira pela orientação do t rabalho de graduação individual que teve como desdobramento esta dissertação.

Ao Dr. Renato Balbim, cuja tese de doutorado me serviu de inspiração e referência.

Também sou extremamente grato ao Prof. Dr. Nestor Goulart Reis Filho, um dos maiores estudiosos da realidade urbana brasileira e r eferência fundamental na elaboração desta dissertação.

Ao Laboratório de Estudos sobre Urbanização Arquitetura e Preservação da Faculdade de Arquitetura e Urbanismo (LAP-FAU) desta Universidade, pelo apoio, orientação e oportunidade que $\mathrm{m}$ e deram de par ticipar do $\mathrm{P}$ rojeto Temático: Urbanização Dispersa e M udanças no Tec ido Urbano, Estudo de Caso: Estado de São Paulo, como pesquisador de iniciação científica (20042006) e como bolsista de treinamento técnico nível 3 (2007-2008) na Fundação Sistema Estadual de Análise de Dados (SEADE) sob orientação do Prof. Dr. Aurílio Caiado. 
À Fundação de Amparo à Pesquisa do Estado de São Paulo (FAPESP) não só pela concessão de auxílio à pesquisa das atividades anteriores, mas também pelas críticas construtivas e sugestões teóricas.

Agradeço às Secretarias dos Transportes de $S$ ão Paulo, Campinas, Valinhos, Americana e São José dos Campos, assim como, ao Departamento dos Transportes Públicos (DTP) da Secretaria Municipal de Transportes (SMT), à Empresa Metropolitana de Transporte Urbano (EMTU) e à A gência Reguladora de Serviços Públicos Delegados de Transporte do Estado de São Paulo (ARTESP).

Agradeço também ao Sindicato das Empresas de $T r$ ansporte de Passageiros por Fretamento e para Turismo de $S$ ão Paulo e $R$ egião (TRANSFRETUR), em especial ao Diretor Sr. Jorge Miguel, e a Sra. Regina Rocha, da Federação das Empresas de Transporte de $\mathrm{P}$ assageiros por Fretamento do Estado de São Paulo (FRESP).

Gostaria finalmente de agradecer à minha família e a todas as pessoas que direta ou indiretamente contribuíram para a r ealização desta pesquisa, especialmente à Olívia, pelo carinho, apoio, paciência e contribuições. 


\section{Resumo}

O objetivo central da pesquisa é c ompreender o surgimento dos chamados 'fretados', os motivos de sua consolidação, suas características e seu significado no cotidiano dos transportes macrometropolitanos.

A dissertação busca num primeiro momento analisar a rede urbana paulista e seu processo de metropolização, apresentando os diversos entendimentos e leituras desse fenômeno. Também se destaca a importância dos transportes no processo de metropolização e a i mplantação dos sistemas técnicos e administrativos da infra-estrutura de transporte de passageiros, tendo como premissa os conceitos de acessibilidade e mobilidade. Os fluxos de passageiros são analisados mediante suas modalidades, origens, destinos e densidades, especialmente os deslocamentos pendulares, um dos principais elementos da $v$ ida de relações da r ede urbana paulista, que muitas vezes utiliza os fretados como suporte.

Outra questão fundamental abordada é o entendimento da alta demanda das viagens diárias, que integram toda a Região Metropolitana de São Paulo. Nota-se aqui uma "crise dos transportes" e uma busca por alternativas à crise. Nesse contexto, procuramos identificar os impactos positivos e negativos da ação dos fretados, assim como buscamos analisar o ponto de vista dos órgãos reguladores das empresas prestadoras desses serviços, de seus contratantes e usuários.

Palavras-Chaves: rede urbana, metropolização, mobilidade, sistemas de movimento, transporte fretado. 


\section{Abstract}

The main objective of this research is to comprehend the origins of "charterers", the reasons of it's consolidation, it's characteristics and it's meaning on macrometropolitan transportation.

At first, this dissertation intends to analyse São Paulo's urban network and it's process of metropolization, by presenting some understandings and readings about this phenomenon.

By having the concepts of acessibility and mobility as a premiss, it's also of main importance to look at the implantation of technical and administrative systems related to the passengers transport infrastructure.

The flowing of passengers is analysed by it's origins, destinies, densities and especially by pendulous orientations, one of the most important elements on São Paulo's urban network of relationships, using "charteres" as a support.

Also, an understanding is made on the high demand of daily trips that intregrates the entire São Paulo's Metropolitan Region. We can see a "transportation crisis" aproaching and a pursuance of alternatives to it. In this context, we can identify the positive and negative impacts of the "charteres", and at the same time analyse the various points of views of users, public and private hirers, and companies that offer the service.

Keywords: urban network, metropolization, mobility, movement systems, charter transportation. 


\section{Índice de Figuras, Fotos, Mapas, Tabelas e Gráficos}

Figura 1: Rede Urbana Paulista $2007 \quad 28$

Figura 2: Imagem de Satélite da Macrometrópole Paulista 30

Figura 3: Imagem de satélite RMSP $\quad 51$

Figura 4: Densidade do pessoal ocupado e unidades locai

da indústria - Total da indústria - 2001

Figura 5: Estabelecimentos de ensino superior e número

de cursos oferecidos/municípios - $2002 \quad 65$

Figura 6: Organização do transporte municipal de São Paulo 93

Figura 7: Transporte Regular Intermunicipal - ARTESP 98

Figura 8: RMSP - Rede do Transporte Metropolitano (2012) 106

Figura 9: Município de São Paulo - Área com rodízio municipal de veículos 166

Figura 10: RMSP - Uso do transporte coletivo (2011) 167

Figura 11: Estado de São Paulo - Pontos de amostragem dos fretados 174

Figura 12: Município de São Paulo - Zona de Máxima Restrição de Fretamento 194

Figura 13: Fábrica da LG PHILIPS na beira da Dutra 200

Figura 14: Fábrica da Volkswagen. 201

Figura 15: Secretaria da Agricultura do estado de São Paulo 207

Figura 16: Campus da UNIP 207

Figura 17: Campus da UNIP 207

Figura 18: Bairro Quiririm 211

Figura 19: Bairro Quiririm $\quad 211$

Figura 20: Hopi Hari $\quad 216$

Figura 21: Hopi Hari 216

Figura 22: Alphaville 218

Figura 23: Alphaville 218

Figura 24: Avenida Paulista e arredores $\quad 219$

Figura 25: Avenida Paulista e arredores $\quad 219$

$-X-$ 
Mapa 1: Complexo Metropolitano Expandido

Mapa 2: Macrometrópole Paulista 48

Mapa 3: Macrometrópole Paulista - Sistema Viário 91

Mapa 4: Macrometrópole Paulista - Fluxo Rodoviário - 2009

Mapa 5: Macrometrópole Paulista - Fluxo diário de passageiros

(STM - 2011)

108

Mapa 6: Macrometrópole Paulista - Principais Sistemas de engenharia de transporte de passageiros

Mapa 7: RMSP - Densidade Demográfica - $2007 \quad 118$

Mapa 8: RMSP - População Absoluta - $2007 \quad 119$

Mapa 9: RMSP - Concentração da Oferta de Emprego - 2007

Mapa 10: RMSP - Concentração das Matrículas Escolares - 2007

Mapa 11: RMSP - Densidade de Viagens Produzidas - 2007

Mapa 12: RMSP - Viagens Produzidas - Valores Absolutos - $2007 \quad 125$

Mapa 13: RMSP - Densidade de Viagens Atraídas - 2007

Mapa 14: RMSP - Viagens Atraídas - Valores Absolutos - $2007 \quad 128$

Mapa 15: RMSP - Saldo das Viagens - $2007 \quad 130$

Mapa 16: RMSP - Viagens Atraídas por Motivo - 2007

Mapa 17: RMSP - Viagens Diárias - Destino:

Município de São Paulo - 2007

Mapa 18: RMSP - Viagens Diárias - Origem:

Município de São Paulo - 2007

Mapa 19: Macrometrópole Paulista - Pendularidade - Destino:

RMSP - 2000

Mapa 20: Macrometrópole Paulista - Pendularidade - Destino:

RMBS - 2000

Mapa 21: Macrometrópole Paulista - Pendularidade - Destino:

RMC - 2000

Mapa 22: Macrometrópole Paulista - Pendularidade - Destino:

RMSP, RMC e RMBS - 2000

Mapa 23: Macrometrópole Paulista - Pendularidade Absoluta 2000/2010

Mapa 24: Macrometrópole Paulista - Pendularidade Absoluta - 
Mapa 25: Macrometrópole Paulista - Pendularidade Relativa (\%) 2010

Mapa 26: VOLKSWAGEM - Linhas Fretadas -

Raio de atração - 2005

Mapa 27: EMBRAER - Linhas Fretadas -

Raio de atração - 2005

Mapa 28: EATON - Linhas Fretadas -

Raio de atração - 2005

Mapa 29: Secretaria da Agricultura do Estado de São Paulo -

Linhas Fretadas - Raio de atração - 2005

Mapa 30: UNIP - Linhas Fretadas - Raio de atração - 2005

Mapa 31: USP - Linhas Fretadas - Raio de atração - 2005

Mapa 32: UNICAMP - Linhas Fretadas - Raio de atração - 2005

Mapa 33: Quiririm - Linhas Fretadas - Raio de atração - 2005

Mapa 34: Hopi Hari - Linhas Fretadas - Raio de atração - 2005

Mapa 35: Alphaville - Linhas Fretadas - Raio de atração - 2005

Mapa 36: Região da Av. Paulista - Linhas Fretadas -

Raio de atração - 2005

Mapa 37: Município de São Paulo - Pontos de Concentração

de Fretados - 2005

Mapa 38: Macrometrópole Paulista - Principais Pontos de

Origem e Destino das Viagens Fretadas Pesquisadas

$-x-$

Foto 1: Vista parcial da RMSP

Foto 2: Centro expandido de SP

Foto 3: Região Oeste de SP

Foto 4: Favela Paraisópolis (SP)

Foto 5: Bairro da Lapa (SP)

Foto 6: Vista parcial do centro (SP)

Foto 7: Marginal Tietê (SP)

Foto 8: Av. Paulista (SP) 
Foto 9: Pedestres na região central de SP

Foto 10: Fluxos na Av. Paulista (SP) 89

Foto 11: Cruzamento da Av.Paulista (SP) 89

Foto 12: Marginal Tietê x Av. Cruzeiro do Sul 89

Foto 13: Marginal Pinheiros $\times$ Ponte Estaiada $\quad 89$

Foto 14: Ônibus fretado da EMBRAER 174

Foto 15: Van 190

Foto 16: Micro-ônibus 190

Foto 17: Ônibus executivo 191

Foto 18: Ônibus de luxo 191

Foto 19: Chegada do primeiro ônibus fretado 201

Foto 20: Concentração de fretados e desembarque dos funcionários 201

Foto 21: Campus da UNIP em área dispersa 209

Foto 22: Entrada do campus 209

Foto 23: Acesso do campus à rodovia Dutra 209

Foto 24: Estacionamento do campus 209

Foto 25: Cecap 1

Foto 26: Cecap $3 \quad 214$

Foto 27: Novos conjuntos habitacionais em inauguração e construção 214

Foto 28: Hopi Hari 216

Foto 29: Hopi Hari 216

Foto 30: Av. Paulista

$-x-$

Tabela 1: Brasil, Sudeste e Estado de São Paulo -

Pendularidade 2000 e $2010 \quad 64$

Tabela 2: Estado de São Paulo - Evolução da malha

rodoviária (entre 1989 - 2011) 88

Tabela 3: Município de São Paulo - Veículos Cadastrados

no Departamento de Transportes Públicos (2012)

Tabela 4: RMSP, RMBS, RMC - Dados Gerais -

Empresa Metropolitana de Transportes Urbanos (EMTU - 2011) 
Tabela 5: Município de São Paulo - Evolução da

frota por tipo de veículo (1980/2011)

Tabela 6: Estado e Município de São Paulo -

Relação da Frota de Veículos (2011)

101

Tabela 7: Município de São Paulo - Demanda de

Passageiros do Metrô (2011)

Tabela 8: RMSP - Passageiros Transportados por

Linha - CPTM - Média de Dia Útil (2010)

Tabela 9: RMSP - Dados gerais da Pesquisa

O/D (1967, 1977, 1987, 1997, 2007)

Tabela 10: RMSP e Município de São Paulo -

Evolução absoluta das viagens por modo (1987, 1997 e 2007)

Tabela 11: RMSP e Município de São Paulo -

Evolução relativa (\%) das viagens por modo (1987, 1997 e 2007)

Tabela 12: RMSP e Município de São Paulo -

Evolução relativa (\%) das viagens coletivas (1987, 1997 e 2007)

Tabela 13: RMSP e Município de São Paulo - Evolução

relativa (\%) das viagens individuais (1987, 1997 e 2007)

Tabela 14: RMSP - Viagens diárias por modo e motivo (2007)

Tabela 15: RMSP - Matriz Origem/Destino das viagens -

Valores absolutos (2007)

Tabela 16: RMSP - Matriz Origem/Destino das viagens -

Valores relativos (\%) (2007)

Tabela 17: RMC - Viagens diárias por modo e motivo (2003)

Tabela 18: Estado de São Paulo - Pendularidade -

Valores absolutos (2000)

Tabela 19: Município de São Paulo - Taxa de Motorização

(1990/2011)

Tabela 20: Estado de São Paulo - Índice de Passageiros por Quilômetro (IPK), passageiros transportados e quilômetros rodados dos sistemas de transporte público dos municípios paulistas (1998/2009)

Tabela 21: RMSP e Município de São Paulo - Viagens diárias por fretamento Evolução da Pesquisa O/D (1987, 1997 e 2007)

Tabela 22: Benefícios do fretamento segundo empresas e funcionários 
Gráfico 1: Município de São Paulo -

Evolução da frota de veículos (1980/2011)

Gráfico 2: Município de São Paulo -

Evolução relativa dos veículos por tipo (2000/2011)

Gráfico 3: Município de São Paulo -

Composição relativa dos veículos (2011)

Gráfico 4: RMSP - Evolução dos dados gerais da

Pesquisa O/D (1967, 1977, 1987, 1997 e 2007)

Gráfico 5: RMSP e Município de São Paulo - Evolução relativa das viagens por modo coletivo e individual (1967, 1977, 1987, 1997 e 2007)

Gráfico 6: RMC - Viagens por destino (2003)

Gráfico 7: RMBS - Número de Viagens por Modal (2007)

Gráfico 8: Município de São Paulo - Evolução da Velocidade Média (km/h) no Trânsito (1980/2008)

Gráfico 9: RMSP - Evolução da frota regular e fretada cadastrada na EMTU (1992/2011)

Gráfico 10: RMSP, RMBS e RMC - Evolução da frota de v eículos fretados cadastrados na EMTU (2007/2011)

$-x-$

Quadro 1: Organização dos Transportes de Passageiros da Macrometrópole Paulista

Quadro 2: Macrometrópole Paulista - Órgãos controladores das diferentes escalas de atuação do transporte fretado contínuo

Quadro 3: RMC e Vale do Paraíba Paulista - Registro de campo - Instituições que utilizam transporte fretado (2005)

\section{Siglas e Abreviações}


ABCD - Municípios de Santo André, São Bernardo, São Caetano e Diadema; localizados na porção sudeste da Região Metropolitana de São Paulo.

ANTP - Associação Nacional de Transportes Públicos.

ARTESP - Agência Reguladora dos Transportes do Estado de São Paulo.

CBTU - Companhia Brasileira de Transportes Urbanos.

CET - Companhia de Engenharia de Tráfego.

CMTC - Companhia Municipal de Transportes Coletivos.

CPTM - Companhia Paulista de Trens Metropolitanos.

DER-SP - Departamento de Estradas de Rodagem do Estado de São Paulo.

DETRAN - Departamento Estadual de Trânsito de São Paulo.

DNIT- Departamento Nacional de Infraestrtutura de Transporte

DTP - Departamento de Transporte Público

EMPLASA - Empresa Metropolitana de Planejamento de São Paulo.

EMTU - Empresa Metropolitana de Transportes Urbanos.

FAU - Faculdade de Arquitetura e Urbanismo

FEPASA - Ferrovias Paulistas S.A.

IBGE - Instituto Brasileiro de Geografia e Estatística.

IPEA - Instituto de Pesquisa Econômica Aplicada.

LAP - Laboratório de Estudos sobre Urbanização, Arquitetura e Preservação

METRO - Companhia do Metropolitano de São Paulo.

Pesquisa O/D - Pesquisa Origem/Destino.

ORCA - Operador Regional de Coletivo Autônomo.

PITU - Programa Integrado de Transportes Urbanos.

RMSP - Região Metropolitana de São Paulo.

REGIC - Região de Influência das Cidades.

RMC - Região Metropolitana de Campinas.

RMBS - Região Metropolitana da Baixada Santista.

SEADE - Fundação Sistema Estadual de Análise de Dados

SMT - Secretaria Municipal de Transportes.

SPTrans - São Paulo Transportes.

STM - Secretaria de Estado dos Transportes Metropolitanos.

UNICAMP - Universidade Estadual de Campinas

UNIP - Universidade Paulista

USP - Universidade de São Paulo 
"As metrópoles contemporâneas são os maiores objetos culturais jamais construídos pelo homem" (SANTOS, 2009, p.7)

"As grandes cidades dos países em desenvolvimento são claramente identificadas por condições inadequadas de deslocamento de pessoas e mercadorias" (VASCONCELLOS, 2000, p.9) 


\section{Introdução}

O presente trabalho sintetiza uma extensa pesquisa iniciada em um projeto de iniciação científica (2004-2006) sob orientação do Prof. Dr. Nestor Goulart Reis Filho, cujo tema foi aprimorado no trabalho de graduação individual (2008) para obtenção do título de bacharel em Geografia e nes ta dissertação de mestrado.

Os intensos levantamentos de campo e pesquisas de ga binete que realizamos desde a iniciação científica e em nosso trabalho de graduação permitiram certa "continuidade" desta busca. Esta dissertação, com dados empíricos sólidos e inéditos, é portanto fruto desta longa jornada de pesquisa, que procura oferecer uma leitura geográfica sobre o tema dos transportes fretados na Região Metropolitana de São Paulo.

A preocupação com a rede urbana e seus fluxos, com of enômeno metropolitano, sua territorialidade e significado para o nosso cotidiano pode ser identificada em várias ciências, como a arquitetura, a sociologia, a economia etc; nesse contexto, a pes quisa que h oje constitui esta dissertação de mestrado busca compreender como a mobilidade cotidiana se estruturou na metrópole e como a consolidação do transporte fretado expressa uma nova dinâmica territorial e uma busca por alternativas de transporte.

Abordar questões de alta complexidade como a metropolização paulista, sua evolução demográfica, sua territorialidade, a organização do tecido urbano, as redes, seus fluxos, assim como a mobilidade do cidadão e a questão dos transportes envolve uma grande responsabilidade por tratar de temas de cunho multidisciplinar. A ciência geográfica com todas suas ferramentas e metodologias apresenta uma responsabilidade ímpar na l eitura de temas e objetos compartilhados por outras ciências, interesses políticos e econômicos. A Geografia urbana e regional, combinadas, permitem tratar dos temas citados anteriormente com uma perspectiva socioespacial, sob o es pectro da territorialidade, do c otidiano, do espaço construído e do m ovimento; o que confere uma leitura peculiar da Geografia em relação às demais ciências. 
Este trabalho não tem a pretensão de propor soluções para os grandes problemas metropolitanos de mobilidade, nem tampouco criticar os organismos públicos e privados diretamente ligados ao tema, mas sim construir uma leitura sistemática, com o rigor de uma dissertação de mestrado, para que possamos compreender um pouco mais dam obilidade cotidiana da sociedade macrometropolitana paulista sob a ótica dos fretados.

O enfoque da Geografia pode ser desenvolvido com algumas premissas básicas consagradas na literatura, a saber, as relações sociais que se realizam enquanto relações espaciais; a $\mathrm{m}$ aterialidade do espaço construído, as cidades, as metrópoles que expressam tais relações; os sistemas técnicos que condicionam e normatizam o cotidiano. Dessa forma, podemos compreender o espaço geográfico como um sistema de ações e sistema de objetos, com redes instaladas no território sob o c omando de atores que executam ações com objetivos específicos, resultando em diferentes formas de uso do t erritório. Desta forma, a mobilidade urbana como prática socioespacial cotidiana, elemento fundamental para realização das atividades básicas, é a um a das principais categorias de análise utilizadas neste trabalho.

Os desdobramentos da sociedade macrometropolitana contemporânea e suas novas formas de organização espacial invocam questões fundamentais das chamadas "práticas socioespaciais", como é o c aso da mobilidade cotidiana. Os meios de $\mathrm{t}$ ransporte permitem o m ovimento cotidiano dos cidadãos metropolitanos, que por sua vez se dão em função de duas lógicas principais: sua mobilidade como "força de trabalho" e como "consumidor".

A alta densidade demográfica, a convergência dos fluxos em pontos saturados das redes-suporte, a ausência de $r$ acionalidade e eficiência dos sistemas de t ransportes acarretam em enormes congestionamentos e "deseconomias externas" para as empresas e indivíduos. A baixa eficiência do sistema e a bus ca por alternativas não "convencionais" e "formais" expressam o que pod e ser denominada a "crise dos transportes". Neste contexto, o transporte fretado mostra um aumento de i mportância nas últimas décadas, revelando-se como uma alternativa real de $\mathrm{c}$ aráter coletivo e pr ivado. A 
consolidação do modo fretado pode ser considerada fruto da convergência das necessidades da nov a dinâmica territorial e da pend ularidade, assim como, pela insatisfação dos usuários dos serviços convencionais oferecidos.

Quando abordamos a rede urbana e a m etropolização, a mobilidade e pendularidade ganham extrema importância por constituir os principais elementos da vida de relações das cidades. Os deslocamentos diários locais ou regionais conformam uma troca de fluxos que expressa as hierarquias e relações econômicas entre os diferentes núcleos urbanos. A própria organização dos meios de transporte, as infraestruturas instaladas no território, condicionam a divisão territorial do trabalho e a conseqüente organização dos fluxos de passageiros. Neste contexto, de alta diversidade dos fluxos, das origens, das densidades e des tinos, dos modais, dos contrastes, dos conteúdos sociais, dos tempos lentos e t empos rápidos, observamos na paisagem metropolitana uma diversidade de elementos que formam o sistema de movimento de passageiros da Macrometrópole ${ }^{1}$ Paulista. Dentre os elementos que compõem esse sistema de movimento, nos interessa sobremaneira os fretados.

Podemos observar em toda Macrometrópole - e especialmente na cidade de São Paulo -, pontos de alta convergência de veículos fretados, sua intensa presença nas rodovias, sua consolidação em atividades cotidianas diversas (trabalho, estudo, lazer), organizadas por empresas, órgãos públicos, escolas, universidades, condomínios, grupo de m oradores ou pel a internet. Essas linhas fretadas atuam em escala municipal, metropolitana ou macrometropolitana, com itinerários flexíveis se comparados ao s istema publico, com características de t ransporte "porta a porta", com conforto, segurança, conectando residências, indústrias, escolas, universidades, áreas de lazer, constituindo uma forma alternativa de transporte de caráter coletivo e privado, com maior equidade da divisão dos custos reais, maior racionalidade

1 "A Macrometrópole possui rede urbana diferenciada quanto ao porte populacional, configuração e perfil funcional e caracteriza-se pelo elevado grau de complementaridade e integração, bem como pela intensa troca de fluxos na esfera do consumo de bens e serviços e, sobretudo, na relação pendular moradia-trabalho" (EMPLASA, 2011, p.105) 
na ocupação dos espaços de fluxos, interligando áreas dispersas e centrais com demandas menores de passageiros.

Neste cenário geral nos perguntamos, afinal, qual os ignificado de mobilidade e acessibilidade? Como estão organizados os fluxos pendulares e os modais de transporte? Quais as principais origens, densidade e destino dos fluxos? Qual é a hi erarquia dos fluxos pendulares? O que são os "fretados", como e porque eles surgiram? Como se dá sua forma de organização? Quais são os impactos nos usuários e nas cidades? Qual o significado dos fretados em um sistema metropolitano cada vez mais complexo, do ponto de vista das massas de passageiros transportadas? O que ele representa para o cotidiano e para a vida de r elações da m etrópole e de s ua rede urbana? Qual é sua importância? Qual o alcance geográfico deste fenômeno? Quais os principais atores e usuários envolvidos? Como o Estado (em sua escala local, regional e nacional) vem trabalhando a questão? Em que cidades eles atuam (pequenas, médias, ou grandes)? Como funciona a mobilidade metropolitana a partir dos "fretados"? Qual é sua relação com as formas de transportes "oficiais"? Que relação há entre os fretados e a reestruturação da metrópole? E finalmente, podemos pensar em uma metrópole a partir dos fretados?

A resposta a estas perguntas poderia ajudar-nos a entender a dinâmica dos fluxos pendulares, parte constituinte da vida de $r$ elações da Macrometrópole e ainda, a des vendar as novas formas de or ganização dos espaços metropolitanos brasileiros. Parte-se da h ipótese de que tais fluxos estão ampliando cada vez mais a es cala geográfica do "cotidiano" das metrópoles, permitindo a pr oposta de u ma "regionalização do cotidiano" (WERLEN, 2000) a partir da a nálise desta forma específica de mobilidade pendular. Portanto, caberia ainda questionar como o c onceito de "região metropolitana" é def inido pelos órgãos de planejamento, pelos estudos de caráter acadêmico, e como ele "efetivamente se dá", tendo como parâmetro os fluxos recentes dos chamados "fretados".

A partir deste contexto mais geral, podemos dizer que o obj etivo de nosso trabalho é analisar a formação e a dinâmica do sistema de transporte 
fretado na c hamada "Macrometrópole Paulista", sua relação com a mobilidade e pendularidade da população, com a organização espacial dos grandes centros urbanos, considerando oE stado como agente de normatização, fiscalização e pl anejamento das redes de c irculação de pessoas. Nosso estudo visa ainda identificar os principais atores e usuários envolvidos nos fluxos dos fretados, contribuindo assim para o entendimento da polarização que São Paulo exerce sobre a rede urbana regional.

Pensando ainda nestes objetivos do trabalho, podemos dizer que foi também uma de nossas principais preocupações definir as principais formas de mobilidade que compõe a vida de relações da Macrometrópole Paulista, sua organização, pensando nas formas "consolidadas" (sistema público e transporte individual) e formas "alternativas" (das quais os fretados seriam sua expressão mais significativa). Também foram buscadas a identificação da $s$ principais origens, densidades e destinos dos fluxos pendulares "convencionais", assim como suas hierarquias e os principais modais utilizados, assim como procuramos registrar e mapear a at uação dos fretados na Macrometrópole Paulista, visando estabelecer uma amostragem empírica da sua dinâmica, analisando sua diversidade de organização e raio de abrangência.

A definição do f enômeno metropolitano revela-se uma preocupação constante da geogr afia urbana e regional, desde a m etade do s éculo XX. Recentemente, novos fenômenos vêm contribuindo para considerar que certos espaços sejam considerados "metropolitanos" (ou não), somando-se aos critérios/elementos já tradicionais que caracterizam as metrópoles. Uma das principais preocupações que guiou a pesquisa desde seu início é a de que 0s fluxos dos fretados podem ser elementos da $m$ obilidade cotidiana que permitem caracterizar of enômeno metropolitano, daí a nec essidade destes elementos serem estudados.

A dinâmica da rede urbana paulista mostra arranjos que expressam o avançado estágio do capitalismo nacional, especialmente concentrado nas Regiões Metropolitanas e grandes centros urbanos do estado. Estas regiões 
apresentam uma integração muito forte, não s ó pelas manchas urbanas interligadas pelos sistemas de transporte, especialmente os eixos viários, mas também pelos fluxos constantes de c apitais, mercadorias, informações e da própria população: ora como força de trabalho, ora como população consumidora de bens es erviços. Os fluxos populacionais pendulares motivados principalmente por trabalho e educação entre as cidades demonstrase considerável e crescente, exigindo uma atenção especial e uma decodificação pela ciência geográfica.

Para a c oncretização da investigação em termos práticos, foi inicialmente realizada uma revisão bibliográfica a respeito dos temas e conceitos que constituíam parte de nossas preocupações, permitindo uma reflexão das problemáticas e elaboração dos eixos norteadores do trabalho. Posteriormente, diversos esforços foram feitos para a r ealização de u ma exaustiva pesquisa documental, incluindo pesquisa em arquivos históricos e cartográficos, levantamento de dados estatísticos, assim como busca de documentos qualitativos e qu antitativos em órgãos públicos e pr ivados. Também foram realizadas pesquisas de reportagens em jornais no período de 1980 - 2000 relacionadas ao tema mais geral dos "transportes metropolitanos".

Nos municípios de São Paulo, São José dos Campos, Taubaté, Valinhos, Campinas e Americana foram aplicadas rotinas pré-estabelecidas para um levantamento de campo sistemático e comparativo, a saber: entrevista e pesquisa nas Secretarias de Transporte de cada município; registro fotográfico da at uação dos fretados em rodovias e $v$ ias importantes de circulação; registro de pólos urbanos variados que utilizam o transporte fretado. Também foram entrevistados funcionários dos órgãos públicos de transporte e representantes dos sindicatos das empresas de fretamento.

Todo o m aterial obtido foi sistematizado e subsidiou a el aboração de mapas, tabelas, quadros, gráficos e as reflexões sobre os temas abordados, constituindo a principal base empírica deste trabalho. Mediante programas específicos de c artografia e s istemas de i nformação geográfica (SIG) foram integradas e $\mathrm{s}$ istematizadas bases cartográficas diversas com os 
levantamentos de c ampo e dem ais dados coletados, gerando produtos cartográficos e imagens que visam substantivar nosso argumento.

Vale destacar que t oda a r evisão bibliográfica realizada permitiu a construção de um quadro teórico de referência, isto é, possibilitou a identificação de conceitos, temas e problemas que embasaram o discurso em seus aspectos mais "teóricos".

A relação do homem com o meio geográfico se faz principalmente por intermédio das técnicas, que evoluíram e permitiram que o m eio natural fosse modificado e o espaço fosse construído para os interesses dos seres humanos. Desde as técnicas mais rudimentares da pré-história até as mais modernas da idade contemporânea, o hom em se mostra um criador do es paço geográfico. "As técnicas são um conjunto de meios instrumentais e sociais, com os quais o homem realiza sua vida, produz e, ao mesmo tempo cria o espaço" (SANTOS 2002, p. 29). As conseqüências ocasionadas pela revolução técnico-científica, especialmente após a r evolução industrial, acarretaram em fortes mudanças econômicas, políticas, culturais, sociais e territoriais. O fenômeno técnico deve ser compreendido não apenas no sentido "mecânico" ou instrumental, mas sim considerando as formas de relações sociais, ou seja, a diversidade de "vida de relações" que ela permite a todos os indivíduos.

A constante evolução das técnicas permite, de um ponto de $v$ ista instrumental, um aumento expressivo da "produtividade espacial" dos lugares, ou a solução de novos problemas até então inexistentes, resultando na maioria das vezes no completo abandono das técnicas ultrapassadas. Nos trabalhos de Milton Santos (2002) identificamos os objetos técnicos como elementos que conformam verdadeiros "sistemas técnicos", já que s ua produção tem base intelectual - a pesquisa sistemática - e não a descoberta ocasional.

Por de trás de c ada "sistema de objetos" é pos sível identificar um "sistemas de aç ões" que o c oncebeu e que o ut iliza. Para "acionar" estes sistemas de objetos atualmente são necessárias também "ações informadas", 
isto é, ações coordenadas, que trazem uma racionalidade obediente à "razão do instrumento". Neste sentido, podemos dizer que:

"Sistemas de objetos e sistemas de ações interagem. De um lado, os sistemas de objetos condicionam a forma como se dão as ações e, de outro lado, o sistema de ações leva à criação de objetos novos ou se realiza sobre objetos preexistentes. É assim que o espaço encontra sua dinâmica e se transforma" (SANTOS 2002, p. 63).

As ações são o resultado das necessidades "naturais" ou criadas, sejam necessidades materiais, imateriais, econômicas, sociais, culturais, morais ou afetivas, são esses elementos que conduzem a ação do homem. Os atores hegemônicos projetam suas ações e, consequentemente, seus objetos técnicos no território de $\mathrm{t}$ al maneira que os resultados atendam às suas expectativas.

Partindo destas considerações sobre o espaço geográfico como um "sistema de obj etos" indissociado de um "sistema de aç ões" 2, portanto conjuntamente analisados, podemos também entender que a "divisão territorial do trabalho cria uma hierarquia entre lugares e redefine, a cada momento, a capacidade de agir das pessoas, das firmas e das instituições" (SANTOS e SILVEIRA 2008, p. 21).

Outro conceito importante que nos auxilia a entender a mobilidade e a formação metropolitana paulista é o " meio-técnico-científico-informacional”, também proposto pelo geógrafo Milton Santos. Segundo o aut or este meio geográfico:

\footnotetext{
"é marcado pela presença da ciência e da técnica nos processos de remodelação do território essenciais às produções hegemônicas que necessitam desse novo meio geográfico para sua realização. A informação, em todas as suas formas, é o motor fundamental do processo social e o território é, também, equipado para facilitar a sua circulação" (SANTOS, 2009, p. 38)
}

\footnotetext{
2 "O espaço é formado por um conjunto indissociável, solidário e também contraditório, de sistemas de objetos e sistemas de ações, não considerados isoladamente, mas como o quadro único no qual a hi stória se dá. No começo era a natureza selvagem, formado por objetos naturais, que ao longo da historia vão sendo substituídos por objetos fabricados, objetos técnicos, mecanizados e, depois cibernéticos, fazendo com que a nat ureza artificial tenda a funcionar como uma máquina" (SANTOS, 2002, p. 63).
} 
Além das componentes materiais, também os conteúdos culturais e jurídicos podem ser considerados como elementos constitutivos do espaço geográfico. Neste sentido, as "normas" são fundamentais para o entendimento do funcionamento do espaço geográfico, já que regulam os diversos fluxos entre agentes, por intermédio dos quais os fluxos internos e os fluxos externos reunidos encontram uma superfície de operação e influência mais extensa que a de c ada agente (SANTOS, 2002). Mediante ações normatizadas e objetos técnicos, a regulação da economia e do território vai impor-se com ainda mais força, uma vez que um processo produtivo tecnicamente fragmentado e geograficamente espalhado exige uma permanente reunificação para ser eficaz; isto é, o aprofundamento resultante da divisão do trabalho impõe formas novas mais elaboradas de cooperação e controle.

Neste contexto, a materialidade das cidades ganha significado geográfico pela existência ou ausência de s istemas técnicos, de obj etos técnicos instalados no território (fixos) que organizam os fluxos materiais e imateriais, normatizando e segregando a organização sócio-espacial. Para Santos (2002) o território aparece como forma, e o território usado como objetos e ações que são sinônimos de "espaço humano, espaço habitado" e mesmo a fluidez que atualmente rege as relações econômicas passa por ele.

Quando falamos em território, em fluxos e em fluidez, necessariamente temos de abordar o conceito de Redes. Segundo Raffestin ([1980] 1993) tanto a circulação como a comunicação poderiam ser consideradas como "uma coisa só". Entretanto, a tecnologia moderna acabou por dissociá-las, ou s eja, as distâncias em matéria de comunicação são rapidamente transpostas, sendo quase imediatas as transferências de bens "imateriais" de um ponto a outro do globo. As técnicas de des locamentos (para bens "materiais") também reduziram drasticamente as distâncias em matéria de c irculação. $O$ autor salienta que a especialização das redes de comunicação e circulação acabou por separá-las claramente, entretanto, ambas estão diretamente relacionadas à 
mobilidade e à es truturação do território, através das redes que trocam fluxos materiais e imateriais ${ }^{3}$.

O autor conclui que as redes são "[...] fios seguros de uma rede flexível que pode se moldar conforme as situações concretas e, por isso mesmo, se deformar para melhor reter" (RAFFESTIN, [1980] 1993, p. 204). Ele considera que as redes são sempre "inacabadas", com a capacidade de adaptação segundo variações do espaço e tempo, sempre de acordo com os interesses dos atores que c ontrolam os pontos das redes, seja enquanto elas são traçadas, construídas, utilizadas e ou consumidas. Todavia, ressalta que sua construção depende dos meios de disposição (energia e informação), assim como do contexto técnico, social, político e econômico.

Segunda Dias (2005) as redes suportam basicamente quatro grandes tipos de fluxos que constituem o espaço geográfico:

- Fluxos Migratórios;

- Fluxos de Mercadorias;

- Fluxos Informacionais;

- Fluxos Monetários e Financeiros.

Para a aut ora, tais fluxos, na s ua maioria, eram restritos aos seus territórios nacionais em um primeiro momento. Contemporaneamente eles começaram a atuar numa escala mais ampla e até global, gerando uma nova ordem de problemas advindos de sistemas reticulares de controle territorial cada vez mais difícil. Estes fluxos estão tornando-se mais espessos a cada dia, ampliando as necessidades de circulação e exigindo técnicas cada vez mais eficazes.

\footnotetext{
3 “Circulação e comunicação são as duas faces da mobilidade e são complementares, estando presentes em todas as estratégias que os atores desencadeiam para dominar as superfícies e os pontos por meio da gestão e d o controle das distâncias. A circulação refere-se à transferência de pes soas e de ben s; e a c omunicação à transferência de informação. Esta inter-relação pode ser bem sintetizada em "Os homens ou bens que circulam são portadores de uma informação, e assim, comunicam alguma coisa. Da mesma forma, a i nformação comunicada é, ao mesmo tempo, um bem que circula" (RAFFESTIN, [1980] 1993,p.201)
} 
Este quadro, para Santos (1998), comporia a realidade que criaria novos recortes ao território devido à "construção do espaço e do novo funcionamento do território" ao qu al Milton Santos dá o nom e de "horizontalidades e verticalidades". As horizontalidades seriam os "domínios da contigüidade dos lugares vizinhos" (reunidos por uma contigüidade territorial) e as verticalidades, seriam formadas pelos "pontos distantes um dos outros, ligados por todas as formas e processos sociais" (1998. p 256.). ou seja, as redes.

No que se refere à anál ise da metropolização, dos transportes, da mobilidade e pendularidade com ênfase nos fretados, este trabalho tem como embasamento a proposta de $\mathrm{R}$ eis Filho (2006) para o es tudo da chamada "urbanização dispersa", que aborda duas escalas de observação, a intraurbana (tecido urbano) e a macrometropolitana , ambas interligadas.

A primeira equivale às formas de parcelamento do solo, onde se definem os espaços de uso público e privado, a organização e o uso coletivo do espaço, a propriedade privada, suas edificações, as redes-suporte, os espaços de acesso e de $\mathrm{c}$ irculação, onde as desigualdades se concretizam enquanto segregação socioespacial. Equivale à escala 1:1, ao espaço construído, à apropriação e às formas de uso. $\mathrm{O}$ autor ainda define:

\begin{abstract}
“(...) é fundamentalmente concreto e tende a ser registrado por suas formas geométricas de divisões de propriedade e edificação (tecido urbano) e pela infra-estrutura e pelos serviços, que the dão acessibilidade e condições de us o. É constituído também pelos espaços acessíveis, adequados para edificar, de valor de mercado determinado por essa potencialidade, por essa virtualidade. São espaços cuja análise (leitura) envolve as questões de racionalidade dos projetos." (REIS FILHO, 2002, p.6)
\end{abstract}

Em outra perspectiva com visão de conjunto, em um nível mais geral, definida pelo autor como "escala da área metropolitana" - e neste trabalho incorporada como escala macrometropolitana - que, na verdade é um recorte da rede urbana paulista mais intensamente articulada. Neste recorte, se destaca a di spersão crescente de núcleos ou pól os urbanos, das atividades cotidianas, da ur banização, dos fluxos, com tendência de redução de densidade de oc upação, conformando uma nova dinâmica territorial que 
envolve diversos municípios, com novos padrões de deslocamentos, em um cotidiano regionalizado. Essa situação teve como base a r eestruturação urbanoindustrial que será abordada adiante, para o autor:

“(...) a cidade de São Paulo é pólo central de um sistema integrado de regiões metropolitanas, com cerda de 25 milhões de habitantes. As condições de alta mobilidade oferecidas à população estão possibilitando uma dispersão crescente de urbanização, das pessoas e das atividades. Para grandes parcelas da po pulação, a $v$ ida cotidiana se desenrola em dois ou três municípios diferentes, em pelo menos duas regiões metropolitanas. Entre um e dois milhões de pessoas se deslocam diariamente entre municípios, e ônibus fretados para trabalhar, estudar, para o lazer e o consumo. A esses, devem ser acrescentados outros milhões que se deslocam em veículos particulares e em linhas regulares de ôni bus, nos terminais rodoviários comuns. O número crescente de casais jovens passa a residir em outros municípios e a trabalhar ou estudar em São Paulo ou o inverso. A vida metropolitana se desenrola em uma imensa área ao redor de São Paulo. A velha Capital é cada vez mais o centro financeiro, de serviços e de comércio especializado, de pesquisa científica e tecnológica e s obretudo de decisão. A Região Metropolitana de São Paulo já não se contém nos limites do município de 1835. Interage cotidianamente em uma área com mais de $100 \mathrm{Km}$ de raio. É muito provável que com as obras do Anel rodoviário esse processo de dispersão e integração inter-regional seja acelerado" (REIS FILHO 2004, p. 224)

\section{Capitulo 1: Os sistemas de movimento e a formação da metrópole paulista}

\subsection{Rede urbana, metropolização e transportes.}

Os sistemas técnicos que compõem a bas e material do $\mathrm{m}$ undo contemporâneo operacionalizam, normatizam e i nfluenciam o cotidiano das cidades da rede urbana paulista, que conjuntamente exercem um papel integrado na atividade econômica nacional. A chamada "vida de relações" das cidades (ROCHEFORT, 1961), ou s eja, as trocas e i nterações físicas e imateriais cotidianas na esfera econômica e s ocial são os elementos que definem a hi erarquização e o ní vel de interdependência na rede. Mas como mensurar e identificar as relações mais efetivas e freqüentes, ao pont o de caracterizar uma rede de relações hierárquica, ou seja, uma "rede urbana" (no sentido mais clássico do conceito)? 
Os primeiros trabalhos sobre geografia urbana e regional estudaram as cidades como lugares que abrigam atividades econômicas não-agrícolas, e que funcionam como elementos de organização das regiões onde se exercem essas atividades, considerando a influência de uma cidade sobre a região que a cerca, utilizando fatores que representam as causas - ou os resultados - da rede urbana, como por exemplo: a função, a organização dos transportes com seu raio de ação, telefonia, composição profissional da população e o setor terciário. Cada elemento difere nos resultados e nos dados de base utilizados.

Neste sentido, uma cidade não pode ser estudada isoladamente a partir das diferentes atividades que apr esenta, como lembra um importante texto de Michel Rochefort (1961, p. 3):

\footnotetext{
"a unidade deverá ser a rede urbana, definida dentro dos limites da influencia de uma grande cidade, capital da região, pela existência e a localização de um certo número de tipos de cidades intermediárias (centres-relais), - elas próprias hierarquizadas, que constituem as malhas da rede"
}

O autor, todavia, propõe um estudo no estado de São Paulo com dados do Recenseamento Geral do Brasil de 1950 agregados por unidade municipal. A análise definiu tipos e categorias de centros de acordo com o s etor terciário. Segundo o mesmo estudo, é possível dar um destaque para a cidade de São Paulo, que já contava na época com $44,5 \%$ dos valores totais do setor terciário do estado, seguido de Santos com 5,8\%, consolidando claramente a posição de capital de uma rede urbana regional. As demais regiões espalhadas pelo interior também já se reconheciam como centros regionais de "primeira ordem", como Campinas, Bauru e Ribeirão Preto.

A síntese do estudo foi expressa mediante técnicas de cartografia temática, resultando num mapa da rede urbana do estado com nove classes na legenda, ou seja, diferentes tipos de hierarquia entre os núcleos urbanos. A organização das redes de transporte também foi um elemento complementar no es tudo, especialmente ar ede ferroviária. O autor ressalta que o resultado é extremamente esquemático e s erve como ponto de par tida para estudos 
complementares e diretos, que devem considerar não apenas a situação atual, mas também o dinamismo e mudança de hierarquia (ROCHEFORT, 1961).

Como atualizar a discussão original da rede urbana, tão bem trabalhada nos textos considerados "clássicos" de $\mathrm{M}$ ichel Rochefort? Nos trabalhos mais recentes do P rofessor Roberto Lobato Corrêa (2006) identificamos a r ede urbana como um reflexo e condição para a divisão territorial do trabalho, onde as grandes metrópoles - também conectadas às redes urbanas de extensão mundial -, condicionam as ações que estão atreladas à dinâmica do capitalismo, ou seja, a dinâmica das redes urbanas pode ser considerada como um reflexo das ações de grandes corporações multifuncionais e multilocalizadas, que introduzem atividades que geram diferenciações entre os centros urbanos.

Esta conexão das metrópoles com a rede urbana mundial caracteriza a rede nacional como intermediadora da divisão internacional do trabalho; podemos dizer, neste sentido, que

\footnotetext{
"a rede urbana passou a s er o m eio através do qual produção, circulação e consumo se realizam efetivamente. Por meio da rede urbana e da crescente rede de comunicação a ela vinculada, distantes regiões puderam ser articuladas, estabelecendo-se uma economia mundial" (CORRÊA, 2006, p 15).
}

O autor ressalta que a rede urbana é o conjunto de centros urbanos funcionalmente articulados, onde os centros mais importantes exercem um controle econômico e político sobre os demais centros, resultando em diferentes níveis de hierarquia. Sua forma espacial é uma expressão fenomênica particular dos processos sociais no território envolvendo mediações diversas entre as cidades. Ainda segundo Roberto Lobato Correa (2006, p. 29):

\footnotetext{
"Em razão de necessidades vinculadas à $p$ rodução, circulação e consumo no âmbito do capitalismo - decisão, produção, concentração, beneficiamento, armazenamento, venda no varejo, consumo final e, ainda, tendo em vista o alcance espacial máximo e m ínimo dos consumidores e em presas localizados no am plo território -, torna-se necessária a existência de vários pontos interferindo no processo de circulação. Estes pontos são os centros urbanos [...]. O conjunto de
} 
centros urbanos que participam da criação, apropriação e circulação do valor excedente é a rede urbana"

No sentido de tentar atualizar a discussão sobre a rede urbana brasileira e paulista, devemos considerar os trabalhos do Instituto Brasileiro de Geografia e Estatística (IBGE), os mais abrangentes e sistemáticos. O estudo intitulado "Região de Influência das Cidades" (REGIC) define a hi erarquia urbana e estabelece a del imitação das regiões de influência das cidades brasileiras, inicialmente, com base em dados da distribuição de bens e serviços. Foram realizados estudos desta natureza para os anos de 1966, 1978, 1993 e, o mais atual, de 2007. Cada versão apresentou adaptações metodológicas condizentes a cada momento histórico nacional (incorporando também novas formas de se pensar teoricamente o território).

No estudo de 2007 a função de "gestão do território" foi privilegiada, considerando a presença de diversos órgãos administrativos do Estado e as sedes de empresas privadas, identificando os níveis de centralidade administrativa, jurídica e ec onômica de cada centro urbano (REGIC, 2008) ${ }^{4}$. Também foram considerados dados referentes a diversos equipamentos urbanos, principalmente aqueles ligados às seguintes atividades: comércio, serviços, atividades financeiras, ensino superior, serviços de saúde, redes de televisão aberta, internet, transporte aéreo e t errestre. Para a anál ise das ligações entre as cidades (isto é, sua "vida de relações"), e de suas influências de fato, pesquisas identificaram os lugares onde a população buscava bens e serviços não oferecidos no seu município de residência, assim como procurava identificar a intensidade das ligações entre as cidades, com destaque para as principais ligações de transporte coletivo.

Os resultados permitem identificar os pontos do território a pa rtir dos quais são emitidas decisões e de onde é exercido o comando em uma rede de

${ }^{4} \mathrm{O}$ estudo objetiva "subsidiar o planejamento estatal e as decisões quanto à localização das atividades econômicas de produção, consumo privado e coletivo, bem como prover ferramentas para o conhecimento das relações sociais vigentes dos padrões espaciais que delas emergem... a es trutura e organização do território são o substrato que condiciona, e sobre o qual atuam, as políticas públicas e os agentes sociais e econômicos que compõem a sociedade... A gestão pública e em presarial mantém relações de controle e comando entre centros urbanos, propagando decisões, definindo relações e destinando investimentos...Os centros de gestão do território caracterizam-se como aquelas cidades onde se localizam uma grande diversidade de órgãos do Estado e sedes de empresas" (REGIC 2007, p 1-2). 
cidades. Entretanto, além da r elação hierárquica entre os centros urbanos, ocorre também uma relação não-hierárquica, ou seja, uma relação de interação, especialização e complementaridade. Análises comparativas (1966, 1978, 1993, 2007) apontam uma notável estabilidade dos níveis hierárquicos mais altos; somente nos níveis intermediários e mais baixos ocorreram mudanças, sendo que a per da ou ganho de centralidade seguramente tem relações diretas com as alterações nas redes de comunicação e transporte. As hierarquias dos centros urbanos e a r egião de influência - segundo a REGIC, para o caso de São Paulo - são expressas na figura a seguir:

Figura 1: Rede Urbana Paulista 2007

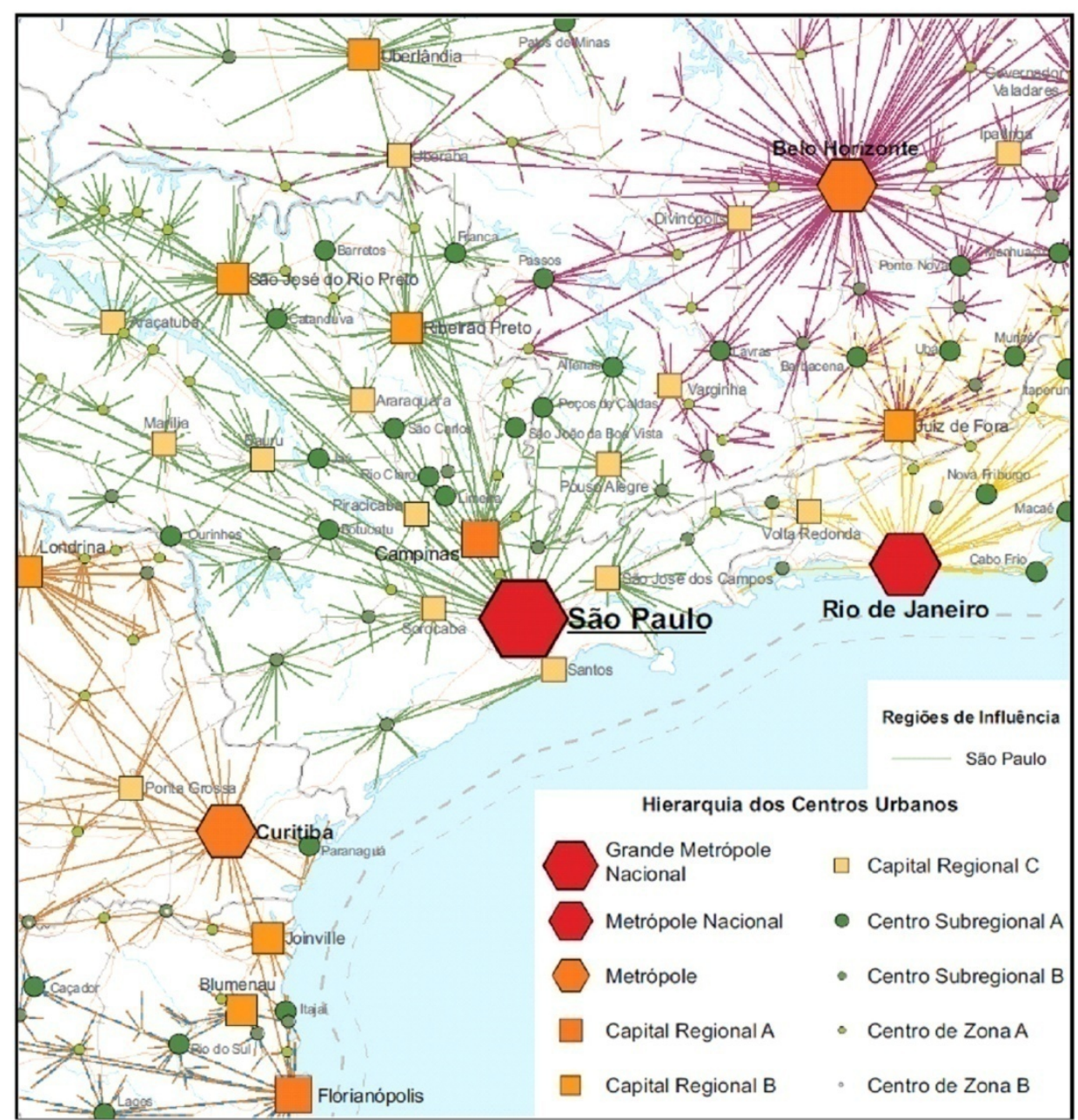

Fonte: Região de Influência das Cidades 2007 - IBGE 2008.

Por questões metodológicas o REGIC 2007 definiu o conceito de "Área de Concentração de População" (doravante ACP) para cidades que constituem 
grandes aglomerações urbanas caracterizadas principalmente por apresentar: amplas manchas urbanas de ocupação contínua, pelo notável tamanho e densidade da população, pelo grau de urbanização e pela coesão interna da área, dada pelos deslocamentos da po pulação para trabalho ou estudo. As ACP's se desenvolvem ao $r$ edor de um núcleo urbano (ou mais núcleos urbanos, em caso de centros conurbados), assumindo o nome do município da capital, ou do $m$ unicípio de $m$ aior população. Destaque para as seguintes ACP's: São Paulo, a capital do estado, seguida por C ampinas, Jundiaí, Santos, São José dos Campos e Sorocaba.

O estudo dos fluxos pendulares que s erá desenvolvido neste trabalho deve considerar a at ratividade espacial dos lugares e os motivos de deslocamentos; seguramente o conhecimento da hierarquia urbana e a área de influência das cidades elucidam os principais vetores, pontos de or igem e destino das viagens. Adiante pretendemos abordar quantitativamente $\mathrm{e}$ qualitativamente as características desse movimento pendular, considerando também a questão da mobilidade como prática social e tendo como pano de fundo a rede urbana.

Em uma primeira análise, o fenômeno metropolitano paulista pode ser analisado como um processo sócio-econômico-territorial, onde uma parcela do território nacional (resultante de um processo histórico complexo) configurou uma extensa mancha urbana, contígua ou não, de alta densidade demográfica. Como observado na geometria da i magem de s atélite abaixo (figura 2), a mancha urbana envolve diversos municípios e é i nterligada por ferrovias e rodovias, evidenciando uma organização territorial que tem como pólo principal a cidade de São Paulo e sub-pólos como Campinas, Santos, Sorocaba e São José dos Campos. Suas atividades cotidianas são extremamente conectadas, conformando uma unidade regional: uma unidade metropolitana. 
Figura 2: Imagem de Satélite da Macrometrópole Paulista

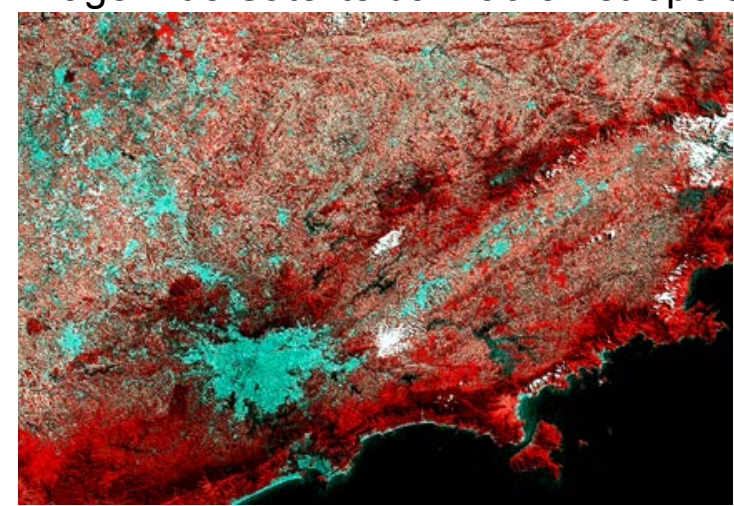

Fonte: Imagem do Sensor WFI do Satélite CBERS 2 - INPE 2005.

O processo de $\mathrm{m}$ etropolização pode $\mathrm{s}$ er caracterizado quando numa determinada região

\footnotetext{
"duas ou mais aglomerações, contíguas ou separadas no espaço, se desenvolvem, em escala significativa, formas de relações que correspondem a um único núcleo urbano. A metropolização é um processo social característico do $m$ undo contemporâneo, segundo 0 qual um conjunto de a glomerações urbanas desenvolve entre si relações tais que pa ssam a c onstituir um sistema, cuja significação para a sociedade é $\mathrm{m}$ aior do que a simples soma de suas partes. Esses sistemas assumem a configuração de c onstelações" (REIS FILHO 1996, p 15).
}

Do ponto de vista normativo (jurídico), a f ormação de um a região metropolitana está ligada ao intenso crescimento urbano, econômico e social que se dá a partir do aparecimento de núcleos urbanos principais. Em torno destes, outros núcleos são agregados, formando um único aglomerado com relações e interações mútuas, frequentemente evidenciado pela conurbação.

A institucionalização de uma região metropolitana vem fazer frente a esta nova realidade espacial, e é sempre fruto de uma política que objetiva o planejamento territorial integrado entre vários municípios que compartilham problemas e demandas regionais de interesse coletivo; ou seja, segundo a legislação federal (que criou as mais antigas regiões metropolitanas) e as leis complementares estaduais, o objetivo principal deste tipo de regionalização do território é organizar e promover a integração do planejamento e a e xecução das funções públicas de interesse comum, que são, conceitualmente, serviços e atividades executados que podem causar impacto nos municípios vizinhos, se executados isoladamente. 
É neste sentido que pode ser também retomada aqui a proposta de Milton Santos para o fenômeno metropolitano, quando o autor assevera que:

\begin{abstract}
"As atuais regiões metropolitanas tem como pontos comuns dois elementos essenciais: a ) são formadas por mais de um município, com o município núcleo - que lhes da o $\mathrm{n}$ ome - representando uma área bem maior que as demais; b) são objeto de programas especiais, levados adiante dos organismos regionais especialmente criados, com a utilização de normas e de r ecursos em boa parte federais. São, na verdade, regiões de planejamento, onde, todavia, o que é feito não atende à problemática geral da área, limitando-se a aspectos setoriais. A socialização capitalista favorecida pelo poder publico nessa áreas metropolitanas é acompanhada por uma expansão periférica, que inclui a criação de direitos industriais explícitos e implícitos, e pela concentração geográfica dos serviços de interesse coletivo" (SANTOS 2009, p. 84).
\end{abstract}

A Região Metropolitana de São Paulo foi oficialmente criada por uma lei federal de $1973^{5}$, que define os municípios que a constitui, além de obrigar o estado de São Paulo a criar um conselho consultivo e um conselho deliberativo (por lei estadual), sendo este último conselho o responsável por promover a elaboração do Plano de Desenvolvimento Integrado da Região Metropolitana e a programação dos serviços comuns; é também tarefa deste plano coordenar a execução de programas e projetos de interesse da região. São definidos como interesses comuns os seguintes temas ${ }^{5}$ :

I - planejamento integrado do desenvolvimento econômico e social;

II - saneamento básico, notadamente abastecimento de água, rede de esgotos e serviços de limpeza pública;

III - uso do solo metropolitano;

IV - transportes e sistema viário;

V - produção e distribuição de gás combustível canalizado;

VI - aproveitamento dos recursos hídricos e controle da poluição

ambiental, na forma que dispuser a lei federal;

VII - outros serviços incluídos na área de competência do Conselho

Deliberativo por lei federal.

\footnotetext{
${ }^{5}$ Lei Complementar Federal do Brasil 14 de 1973
} 
O artigo sexto da referida Lei - que promove novos conteúdos normativos para esta parcela do território -, todavia, ressalta que os municípios da região metropolitana que participarem da ex ecução do planejamento integrado e dos serviços comuns, terão preferência na obtenção de recursos federais e estaduais, inclusive sob a forma de financiamentos, bem como de garantias para empréstimos. Posteriormente (em 1996), foi criada a Região Metropolitana da Baixada Santista ${ }^{6}$, tornando-se esta a pr imeira região metropolitana do país sem status de capital do estado, seguida pela Região Metropolitana de Campinas ${ }^{7}$ em 2000, ambas criadas por leis estaduais.

Sem dúvida alguma é difícil estabelecer precisamente quais municípios devem ser considerados na criação de uma região metropolitana, ainda mais quando consideramos a es fera política es uas conseqüências práticas estipuladas no planejamento regional, que utiliza o conceito de região como instrumento técnico-operacional das intenções políticas.

No contexto da $m$ etropolização a qu estão dos transportes é, sem dúvida alguma, um elemento fundamental na estruturação do território. Os sistemas técnicos implantados em diversos períodos históricos estão intimamente ligados aos ciclos econômicos e à c onexão ou isolamento de determinadas parcelas do território nacional.

A atividade econômica e o funcionamento das metrópoles exigem um sistema de t ransporte de pas sageiros e cargas com um mínimo de eficiência, de tal forma que, tecnicamente e economicamente o sistema seja produtivo, mesmo que funcione a bas e de subsídios. Além de representar elemento fundamental para a atividade econômica de diversos setores (setor primário, secundário e terciário), a própria atividade de transporte é em sim mesmo um grande negócio. Por conseguinte, o investimento em transportes tem importância fundamental na localização da atividade econômica e organização dos fluxos dos trabalhadores, assim como na conexão de áreas

\footnotetext{
${ }^{6}$ Lei Complementar Estadual 815, em 30 de julho de 1996

${ }^{7}$ Lei Complementar Estadual 870, de 19 de junho de 2000
} 
de produção e c onsumo, funcionando como poderoso fator na di visão territorial do trabalho.

O desenvolvimento regional e a r ede urbana dependem muito das redes e dos serviços de transporte oferecidos; a diversidade, freqüência e densidade dos fluxos entre as cidades são elementos de extrema relevância para compreender o gr au de c onexão e hierarquia da r ede urbana. $\mathrm{O}$ sistema de transportes é o que mantêm a metrópole em movimento; sem um sistema efetivo, as atividades cotidianas da $\mathrm{m}$ etrópole podem ficar, literalmente, estagnadas.

Josef Barat (1978) descreve a forte relação entre economia, transporte, desenvolvimento urbano e regional. Segundo o aut or, a disponibilidade de serviços de transporte condiciona o processo e os padrões de expansão urbana, definindo e reorientando o uso do solo. Um sistema de transportes racionalmente concebido constitui um instrumento de distribuição de renda, elevação do nível de vida em geral, com ganho de tempo e conforto aos usuários. Constitui fator de integração, compatibilização e racionalização dos mercados de bens e serviços, assim como dos fatores de produção.

Ainda segundo Josef Barat (1978), para abordar o planejamento de transportes nas áreas metropolitanas devem ser considerados 3 ní veis de planejamento:

(1) Soluções de Trânsito - (nível superficial) - soluções de engenharia, soluções operacionais, sinalização sincronizada, escoamento rápido de $v$ eículos, segurança dos pedestres, eliminação de pontos de congestionamentos. Não consideram estudos econômicos urbanos e regionais que buscam a estrutura mais complexa do transporte e da realidade metropolitana.

(2) Tráfego - (planejamento prévio) - determinação dos pontos de gr andes concentrações de geração de tráfego, identificando as origens e destinos dos fluxos de passageiros e de $\mathrm{c}$ argas, distribuição do tráfego por modalidade, simulação do tráfego futuro. 
(3) Transporte - (estudos de base para o pl ano diretor de t ransporte metropolitano) - são projetadas as variáveis macroeconômicas mais significantes para identificar o crescimento da área metropolitana, examinando o inter-relacionamento destas com as projeções de fluxos de passageiros e cargas, frotas de $v$ eículos, regulamentação do us o do s olo e anál ise de alternativas de transportes.

Por trás destes três níveis de planejamento, ainda existe o planejamento urbano e o planejamento intersetorial, o qual examina as relações do setor de transportes com os demais setores da ec onomia regional/metropolitana, compatibilizando as metas de ex pansão do sistema de transportes com os objetivos econômicos e sociais globais.

Em outra esfera, há t ambém o planejamento modal que e xamina o emprego de um único recurso em diferentes alternativas. As alternativas de escolha de modalidade são feitas dentro de limites de natureza econômica, tecnológica ou prática. O planejamento intermodal, em contrapartida, examina as relações entre as diferentes modalidades de transporte adequando suas capacidades de at endimento em relação à demanda total, de maneira que o equilíbrio no atendimento decorra de uma racional distribuição de fluxos a um custo econômico menor, considerando a integração entre diferentes modais como a base de um sistema de transporte global.

O grande objetivo dos diversos níveis e tipos de planejamento citados é possibilitar a maior mobilidade pelo menor custo econômico. O planejamento intermodal deve buscar medidas executivas no sentido de complementaridade de soluções e não no de competição entre as modalidades. O sistema de transporte deve ser compreendido como a conjugação de várias modalidades de transporte, e tais modalidades devem integrar e complementar um sistema de etapas articuladas nas viagens. Para tanto, devem ser realizadas análises das características técnicas, econômicas e s ociais das vantagens e desvantagens de cada modal, em busca da melhor solução para o transporte de massa para cada situação específica. 
Os resultados de um planejamento integrado efetivo podem organizar e reorganizar os padrões de us o dos olo e dos fluxos cotidianos, além de melhorar o apr oveitamento da i nfraestrtutura já existente, buscando evitar a ociosidade e superlotação em determinados horários. Também pode contribuir para elevação da renda e consolidar uma conexão eficiente entre parcelas do território; mas, para tanto, sua integração com o planejamento metropolitano global é fundamental.

\subsection{Os limites da metrópole paulista}

A intensa vida de relações das cidades paulistas se dá em grande parte em função desta banalizada rede-suporte rodoviária. Assim, podemos nos perguntar: quais as regionalizações existentes que procuram explicar, e agir, sobre esta parcela do território brasileiro? Como os estudos urbano-regionais interpretaram essa parcela do território nacional? Quais as diferentes regionalizações propostas para a cidade de São Paulo e sua região adjacente?

Passando de um tratamento "político" para uma análise acadêmica do fenômeno da regionalização, vários autores buscaram definir a formação das "regiões". Entretanto, os critérios e obj etivos distintos criaram várias interpretações desse fenômeno. De acordo com as temáticas selecionadas, podem variar as leituras que decidem se este ou aquele município deve entrar na "região" definida. Cabe lembrar que "Região" é uma categoria de análise da Geografia, portanto, sua relação com o fenômeno metropolitano deve ser explorada.

Podemos identificar na extensa e completa revisão bibliográfica feita por Lencioni (2009) na obra "Região e G eografia", a ev olução da categoria "Região", sua importância para a c iência geográfica e s ua concepção mais atual que se aproxima das definições atualizadas de "Região Metropolitana".

A idéia de região, que inicialmente buscava identificar leis gerais, foi sendo progressivamente abandonada e passou a incorporar aspectos da vida social, 
cultural e a dimensão histórica da vida dos lugares, resultando em análises mais particulares. No que se refere aos estudos regionais metropolitanos que surgem a partir da década de 1950, pode-se dizer que:

\begin{abstract}
"A análise da sociedade, cada vez mais urbana e m etropolitana, traduziu-se na idéia de espaço como um campo de ação de fluxos. Entendiam que esses fluxos, ao c onfluírem para uma determinada cidade, acabavam transformando-a num pólo regional. Como conseqüência, os geógrafos, vinculados a per spectiva da $\mathrm{G}$ eografia Ativa, consideram que a região se define pela dinâmica dos fluxos espaciais. Nesse sentido, a região se coloca como uma área sob o raio de ação de uma cidade [...[ Urbanização, industrialização e centralização tornam-se, assim, as questões de relevo da Geografia na segunda metade do século XX. Impôs-se novas referências na análise regional: fluxos, rede urbana, área de influência de uma cidade e polarização" (Lencioni, 2009, p. 141)
\end{abstract}

A proposta de entendimento do que é uma "região", portanto, deixa de buscar uma síntese dos aspectos naturais e humanos e vincula-se à idéia de organização do espaço, com foco nas funções urbanas e regionais, hierarquia dos lugares, concentração das atividades e divisão do trabalho, aproximandose mais da economia e ciências sociais. Por fim, Lencioni (2009) enfatiza que a região é produto das leis gerais do processo socioespacial, mas resultam em particularidades regionais, sendo, portanto uma entidade mediadora entre 0 universal e o singular, entre o global e o local.

Tendo como base os esclarecimentos anteriores, tanto no que se refere ao processo de metropolização, como no que tange ao significado atual do conceito de região, podemos analisar algumas definições sobre o tema.

A área de estudo inicialmente definida para a realização deste trabalho de mestrado pode ser identificada de diversas formas e por vários autores. Dentre aquelas definições que já foram alvo de nossas leituras mais sistemáticas, podemos destacar:

1. O centro da "Região Concentrada", descrita como "Metrópole Corporativa Fragmentada" (SANTOS 1990);

2. "Região da Metrópole Desconcentrada" (LENCIONI 1994);

3. "Sistema Metropolitano Integrado" (REIS FILHO 2004); 
4. ou a inda como "Complexo Metropolitano Expandido" (EMPLASA 1996)

5. "Macrometrópole" (EMPLASA 2011).

Todas as definições têm como característica básica a cidade de São Paulo como o centro da r egião, que converge e articula todas as redes de circulação e c omunicação responsáveis pela troca def luxos e, consequentemente, o s tatus de região economicamente mais dinâmica do Brasil.

Em uma abordagem a nível nacional SANTOS e S ILVEIRA (2008) afirmam que o $\mathrm{m}$ eio técnico-científico-informacional se instala densamente nas Regiões Sul e Sudeste do Brasil, com alta densidade demográfica e de objetos técnicos, constituindo a chamada "Região Concentrada". Nas proximidades da capital paulista, essas densidades são ainda mais acentuadas. Este meio geográfico é seletivamente difundido no território, e se concentra em certos pontos do país; é nestas regiões que aumentam as áreas destinadas à c irculação dita "moderna", resultando em movimentos internos mais intensos que no resto do Brasil.

\footnotetext{
"A união entre ciência e técnica que, a par tir dos anos 70 , havia transformado o território brasileiro revigora-se com novos e portentosos recursos da informação, a par tir do pe ríodo de gl obalização e s ob a égide do mercado. E o mercado, graças exatamente à ciência, à técnica e à informação torna-se um mercado global. O território ganha novos conteúdos e impõe novos comportamentos, graças às enormes possibilidades da produção e, sobretudo, da circulação dos insumos, dos produtos, do dinheiro, das idéias e informações, das ordens e dos homens. É a irradiação do meio técnico-científico-informacional que se instala sobre o território, em áreas contínuas no sudeste e no sul ou constituindo manchas e pontos no resto do país" (SANTOS e SILVEIRA 2008, p 52-53).
}

Sob o ponto de vista da economia política, na leitura de Milton Santos (2009), é no centro desta "Região Concentrada" que se encontra a Região Metropolitana de S ão Paulo, denominada pelo autor de " metrópole corporativa fragmentada". Seu entendimento considera inúmeras características, tais como: o papel do estado, a d istribuição de r enda, contrastes agudos entre riqueza e pobreza, o crescimento econômico, sua 
influência sob aspectos da $v$ ida social, ot amanho da c idade, sua repercussão sobre a sociedade e ec onomia, a es peculação e os vazios urbanos.

A metrópole corporativa fragmentada expressa a m odernidade incompleta e seletiva, de grandes contrastes. O mais moderno encontra-se ao lado das carências mais gritantes, com presença massiva da el evada disparidade de renda, da pobreza como situação estrutural e não residual. Seu crescimento é marcado pela preferência de áreas distantes para a implantação de programas habitacionais para as classes pobres, pela modernização do sistema viário e c riação de infraestrutura de m aneira seletiva, pela política privada de manipulação de loteamentos, pela valorização diferencial dos terrenos, pela expansão da especulação, com preocupações particulares e de caráter individualista.

Outra questão inerente à metrópole corporativa fragmentada é a relativa imobilidade dos mais pobres; o gasto público e sua seletividade espacial. As cidades se expandiram tendo como base o modelo radial, em direção aos eixos de circulação regional, permitindo uma dinâmica em que s e criam espaços vazios e a es peculação fundiária, a v alorização relativa dos terrenos e a expansão urbana com base na implantação de infraestrutura pelo Estado.

\footnotetext{
"A enorme expansão dos limites territoriais da área metropolitana construída, a presença na aglomeração de uma numerosa população de pobres e a forma como o Estado utiliza os seus recursos para a animação das atividades econômicas hegemônicas em lugar de responder às demandas sociais conduzem à formação do fenômeno a que chamamos de metrópole corporativa, voltada essencialmente à solução dos problemas das grandes firmas e considerando os demais como questões residuais" (SANTOS 2009, p106)
}

O autor usa como referência empírica dados da região metropolitana oficial, mas sua leitura não se restringe aos limites institucionais, traduzindo a lógica geral da metrópole contemporânea. Não são apresentados limites rígidos estabelecidos por um agrupamento de municípios, a preocupação do autor reside na a nálise da ec onomia política da cidade, e ne $\mathrm{m}$ tanto na análise do "poder regionalizador" do município de São Paulo. 
Em outra abordagem, buscando já apresentar os limites desta região, Lencioni (1994) afirma que o c rescimento da agl omeração metropolitana paulista tem como centro a capital do estado e abrange um raio de cerca de $150 \mathrm{~km}$, estendendo-se principalmente pelos eixos rodoviários mais dinâmicos do estado, constituindo uma unidade de paisagem metropolitana, embora se apresente fragmentada espacialmente. Segundo a autora,

\begin{abstract}
"A reestruturação da metrópole de São Paulo, produto dos processos de concentração e centralização do capital, se traduz num fenômeno sócio-espacial novo, criação e reiteração de uma região metropolitana mais complexa, fragmentada e hierarquizada, em que a conurbação de cidades, o crescimento relativamente menor de algumas ou exacerbado de outras - como, por exemplo, o grande crescimento de Campinas -, não significam processos autônomos de metropolização. Ao contrário, são manifestações constitutivas da expansão do espaço metropolitano paulista, que se configura numa "macro-metrópole" que é r eforçada e não n egada pela dispersão das suas atividades. Ai são reproduzidas as mesmas contradições e penúrias urbanas da capital: degradação do m eio ambiente, poluição ambiental, problemas de transportes, saúde, educação, saneamento, delinqüência, moradia, crescimento de favelas, e, sobretudo, desemprego" (LENCIONI 1994, p 59).
\end{abstract}

A autora, todavia, frisa que o pr ocesso de di spersão industrial reestruturou a m etrópole, resultando na homogeneização de espaços e, também, na criação de diferenças, onde a c apital e s eu entorno são homogeneizados pela expansão da atividade econômica. Estes processos recentes permitem que falemos na formação de uma "metrópole desconcentrada" (LENCIONI, 1994); entretanto, é j ustamente a especialização das atividades terciárias na capital que a torna ao mesmo tempo bastante distinta do seu entorno:

"Do ponto de vista da or ganização territorial, o que vem ocorrendo é um reforço da metropolização porque se processa um adensamento e ampliação do centro metropolitano. A centralização da capital se afirma ainda mais, novas formas de hierarquizações no interior do aglomerado metropolitano se colocam. Em outros termos, novas re-hierarquizações urbanas no interior da região da metrópole desconcentrada se impõem. $\mathrm{Na}$ região da metrópole desconcentrada, produto de ex pansão e adensamento, o centro se consolida reafirmando o primado da metrópole e a primazia da capital. Nesta realidade em que a vida das pessoas e ritmada pela esfera técnico-econômica a qual se submete as outras esferas da vida social às suas exigências e à sua racionalidade, o discurso de pol íticas de descentralização do pode $r$ e de democratização da vida social ficam comprometidos. Em São Paulo, na metrópole desconcentrada, a tríade industrial, urbano e regional se 
recompõe exprimindo o passado e o presente de uma região epicentro do desenvolvimento industrial brasileiro" (LENCIONI 1994, p 60).

Alguns trabalhos mais recentes do Professor Nestor Goulart Reis Filho (1996; 1997; 2004; 2006; 2007) evidenciam historicamente o processo de metropolização paulista com dimensões macro-regionais. Suas análises concentram-se principalmente nas características e novas formas do tecido urbano e nas principais atividades urbanas que $s$ e dispersam geograficamente pelo território, tendo como suporte os grandes eixos rodoviários e a oferta de s erviços básicos, chamando a at enção também para os "modos de vida" metropolitanos. Para o autor,

\begin{abstract}
"A partir de 1960, foi ficando claro para os pesquisadores da área de urbanismo - e a seguir para os próprios habitantes - que São Paulo havia deixado de ser apenas uma metrópole, passando a atender um mercado regional. Havia adquirido uma nova configuração: era o pólo central de uma região com quase 5 milhões de habitantes e alto poder indutor sobre a urbanização das regiões vizinhas [...]. Em 2000 a região metropolitana de S ão Paulo alcançava quase 18 milhões de habitantes [...] havia se transformado no centro de um sistema metropolitano integrado, um pólo ao redor do qual cresceram e continuam a crescer outros núcleos e outras regiões metropolitanas. Transformou-se em uma constelação de formas de urbanização dispersa" (REIS FILHO, 2004, p 209),
\end{abstract}

Reis Filho destaca que oc onceito de r egião em seu molde mais tradicional, por estar atrelado à idéia de um único núcleo central, não é mais tão adequado para análises contemporâneas. Isto se dá pelo fato de que as áreas urbanizadas dispersas geograficamente com características metropolitanas já não apr esentam o pes o de um único centro, mas se caracterizam pela existência de uma multiplicidade de pequenos centros, onde todas as formas de atividade podem estar distribuídas pelas áreas dispersas; portanto, o aut or prefere o termo "Áreas Metropolitanas", como fica evidenciado a seguir:

"O conjunto que d enominamos Sistema Integrado de Áreas Metropolitanas envolve as três regiões metropolitanas oficiais (as de São Paulo, Campinas e Baixada Santista), as duas principais regiões de governo do Vale do $\mathrm{P}$ araíba (as de São José dos Campos e Taubaté) e as regiões adjacentes de Sorocaba e Itú, as de Jundiaí, de Piracicaba, Limeira e Rio Claro, a de Moji-Mirim e Mogi-Guaçu e a de Atibaia" (REIS FILHO, 2006, p. 77). 
Não são apenas intelectuais ligados à produção do conhecimento nas universidades que vêm trabalhando com oc onceito de "Região Metropolitana". A Empresa Paulista de P lanejamento Metropolitano S.A. (EMPLASA), criada em 1975 i nicialmente para cuidar do pl anejamento Região Metropolitana de São Paulo, também se tornou neste ínterim uma importante autarquia que pe nsa e "age" na metrópole paulistana, pois se trata de um órgão vinculado à Secretaria de Economia e Planejamento do Governo do E stado. Sua principal função é dar apoio ao pl anejamento, programação, organização, coordenação e execução de serviços comuns de interesse metropolitano. Atualmente, aE MPLASA atua nas três regiões metropolitanas existentes no Estado e tem como objetivo principal subsidiar a tomada de decisões de órgãos públicos e privados que atuam nas regiões metropolitanas, elaborando diversos trabalhos cartográficos e estatísticos que caracterizem as regiões, além defornecer assessoria técnica aos municípios envolvidos.

A EMPLASA (1996) reconhece o fenômeno metropolitano dentro de uma perspectiva de pl anejamento, organização regional e de sconcentração espacial. O termo "Macrometrópole" foi adotado pela Empresa para designar o "espaço organizado pelas metrópoles de São Paulo e Rio de Janeiro" sob influência do conceito de megalópole ${ }^{8}$. As formações metropolitanas no espaço "circundante" da chamada "Grande São Paulo" são marcadas pelo processo de desconcentração industrial que busca ganhos de produtividade, pela difusão e descentralização de pólos de serviço, pela disseminação e complementaridade de funções metropolitanas e, por fim, pelas políticas regionais de abastecimento com reversões de bacias e unidades de proteção ambiental.

\footnotetext{
${ }^{8}$ Foi Jean Gottmann, geógrafo francês, que em 1961 cunhou o termo Megalópole. Suas análises se referem a região que envolve Nova York, Boston e Washington, no nordeste do território norte-americano. As características fundamentais da megalópole referem-se à escala gigante do poder das grandes cidades modernas, alta concentração de população, de trabalhadores categorizados e e scritórios, além de uma rede extremamente complexa de corredores de trânsito em terra, no ar, e com intensos movimentos pendulares envolvendo diversas cidades.
} 
Ainda segundo a EMPLASA, com a es pecialização dos lugares dentro de uma lógica macro-regional, formando um sistema macro-metropolitano, foram identificadas e classificadas algumas unidades regionais:

A: Formações Metropolitanas Nucleares;

B: Formações Protometropolitanas Associadas;

C: Unidades Regionais Intersticiais ou Perimetropolitanas;

D: Unidades Regionais Homogêneas Perimetropolitanas Organizadas pelo Pólo Metropolitano.

Essas unidades foram agrupadas por especialidade $\mathrm{e} v$ ocação, constituindo o "Complexo Metropolitano Expandido de São Paulo" (EMPLASA, 1996). Este "Complexo Metropolitano", por sua vez, se caracterizaria pelos seguintes elementos de classificação:

\section{Grande São Paulo (Classe A):}

- Centro financeiro nacional e internacional;

- Centro de serviços especializados para a produção e negócio;

- Grande oferta de serviços e produtos diversificados;

- Centro educacional, científico e tecnológico;

- Ênfase nos setores de ener gia, recursos naturais, construção e m eio ambiente;

- Pólo nacional e internacional em redes de comunicação;

- Produção industrial moderna e diversificada;

- Pólo comercial do setor primário;

- Entreposto estratégico de importação/exportação;

- Centro de organização política, sindical e profissional.

\section{Região de Campinas (Classe A):}

- Produção industrial moderna e diversificada;

- Grande oferta de serviços e produtos diversificados;

- Centro educacional, científico e tecnológico; 
- Ênfase nos setores de informática, biotecnologia e medicina;

- Pólo de entroncamento estratégico multimodal para exportação e importação;

- Centro de apoio ao setor agropecuário.

\section{Região da Baixada Santista (Classe A):}

- Produção industrial com ênfase na química, siderurgia e petróleo;

- Oferta de serviços e produtos diversificados;

- Principal pólo portuário e retroportuário nacional;

- Centro de veraneio e turismo.

Região do Vale do Paraíba Paulista (Classe B):

- Produção Industrial moderna e diversificada;

- Oferta de serviços e produtos diversificados;

- Centro educacional, científico e tecnológico;

- Ênfase no setor aeroespacial.

Região de Sorocaba (Classe B):

- Produção industrial moderna diversificada;

- Oferta de serviços e produtos diversificados.

Região de Jundiaí (Classe C):

- Produção industrial diversificada;

- Produção agropecuária associada à agroindústria;

- Funções "relais" com São Paulo e C ampinas no fornecimento de mão de obra;

- Oferta de serviços e produtos diversificados.

Região de São Roque (Classe C):

- Produção industrial em gêneros pesados; 
- Produção agropecuária associada à agroindústria;

- Funções "relais" com São Paulo e Sorocaba;

- Entroncamento importante do corredor ferroviário de exportação;

- Função de veraneio e turismo.

Região de Alto Paraíba e Bocaina (Classe C):

- Função de preservação ambiental e paisagística;

- Potencial para o turismo ecológico.

Região Bragantina (Classe C):

- Produção industrial diversificada;

- Funções "relais" com São Paulo, Campinas e Vale do Paraíba;

- Função de veraneio, potencial turístico de baixo aproveitamento.

\section{Região Litoral Norte (Classe D):}

- Função portuária, transporte de petróleo e derivados;

- Função de veraneio, potencial turístico alto.

\section{Região Circuito das Águas (Classe D):}

- Função turística no aspecto climático/medicinal.

Há vários elementos do es paço geográfico (sistemas de eng enharia, redes-suporte, dados da configuração "natural" da região etc.) que podem ser considerados como fatores de integração entre essas unidades regionais, dentre as quais podem ser destacadas: o s istema energético interligado e soluções "supra-regionais" de geração; a regionalização do uso dos recursos hídricos e reversões de bac ia; a or ganização dos sistemas suburbanos de transporte; a i ntegração regional dos sistemas telefônicos; as funções e corredores multimodais especializados de importação e exportação; o mercado de atividades del azer/veraneio/turismo de al cance nacional; os fluxos interindustriais; os meios de pr oteção ambiental com atenção a expansão 
urbana e peri-urbans; a concentração de centros de pesquisa, tecnologia e funções direcionais, financeiras e de suporte de negócios em geral EMPLASA (1996).

Essas unidades regionais combinadas, portanto, configuram uma parcela do território nacional extremamente dinâmica do pont $\mathrm{o}$ de $\mathrm{v}$ ista econômico, e em função disso foi denominada como o " Complexo Metropolitano Expandido", altamente competitivo no contexto da economia globalizada (mapa1).

Na releitura da EMPLASA (2011), o Estado de São Paulo é descrito como o sistema de cidades mais amplo e complexo do país, com uma rede de intensas articulações funcionais, com forte expressão no espaço dos fluxos e relações conformadas no ent orno da $\mathrm{R}$ egião Metropolitana de São Paulo, espaço denominado "Macrometrópole Paulista".

O entendimento desta unidade passa pela análise do pr ocesso de metropolização, reestruturação produtiva e interiorização do desenvolvimento. Neste cenário, o que se constata é uma ampliação da extensão territorial da metropolização, sob novos padrões de fluxos, incorporação de áreas novas e reafirmação do centro, com dispersão das unidades produtivas e gestão concentrada.

\footnotetext{
"As transformações físico-espaciais em processo no E stado de São Paulo, que formam impulsionadas pela reestruturação econômica em curso, apontam novo desenho de metropolização, em que o conjunto urbano, formado por metrópoles e por cidades médias, tende a ampliar o grau de interdependência a partir do pólo principal, configurando uma grande região urbana" (EMPLASA, 2011, p.104)
}

Assim como no estudo anterior (EMPLASA, 1996), é reforçada a idéia de espaço econômico moderno altamente competitivo na economia globalizada, composto por unidades regionais especializadas e articuladas para pleno desenvolvimento da atividade econômica. 


\section{Mapa 1: Complexo Metropolitano Expandido}

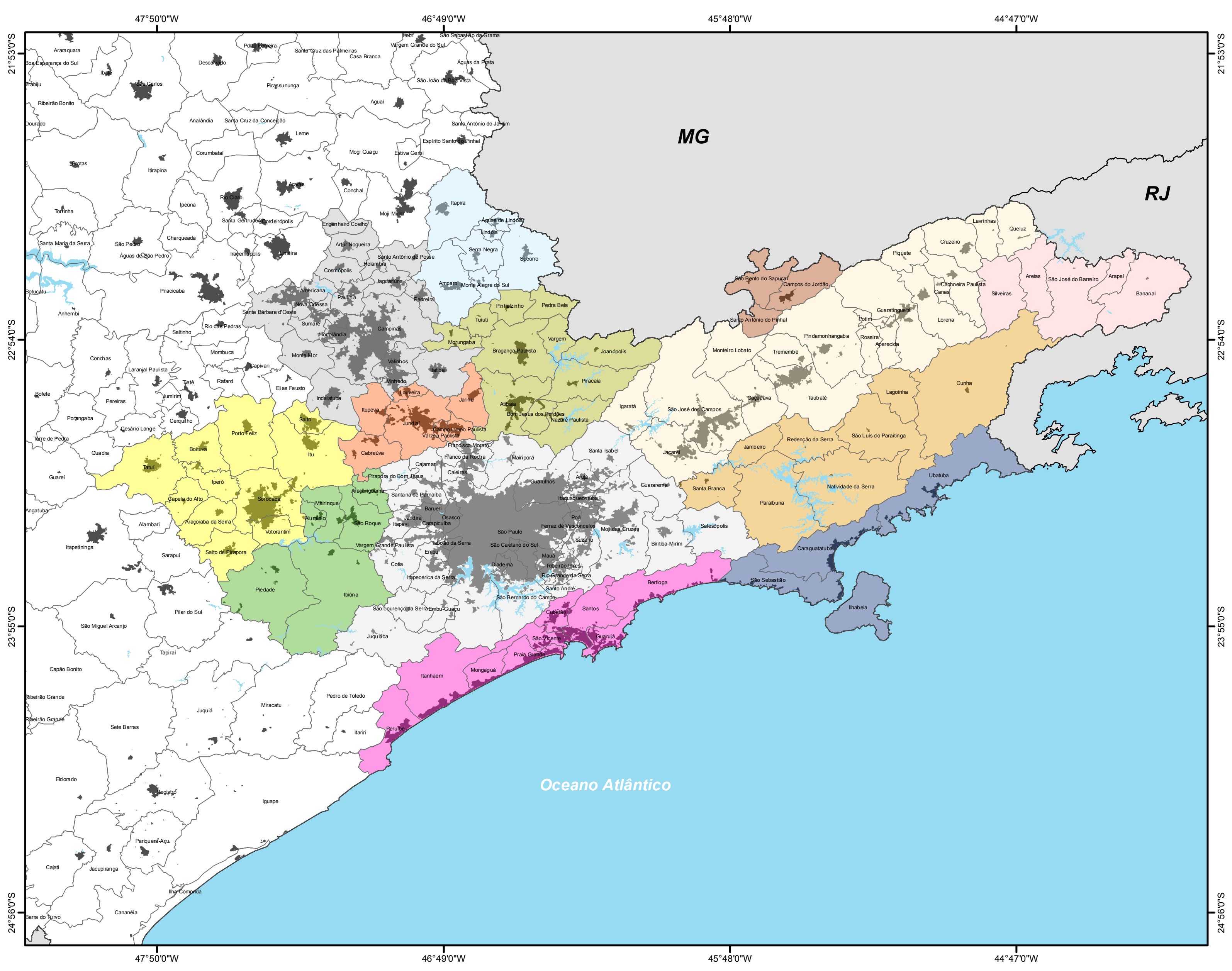

Localização Geral no Estado de São Paulo

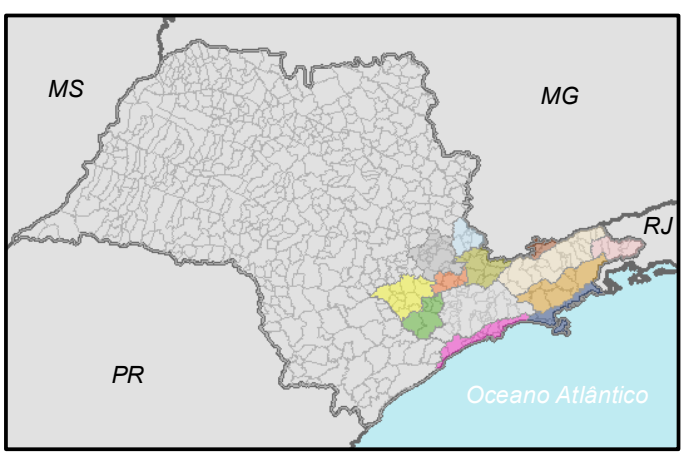

\section{Legenda}

$\square$ Limite Estadual

Limite Municipal

Oceano / Represa

Área Urbanizada 2005

Alto Paraíba (RM)

Circuito das Águas (MR)

Litoral Norte (MR)

Macroeixo Paraíba (AU)

RMBS (RM)

RMC (RM)

RMSP (RM)

Região da Bocaina (MR)

Região da Bragantina (MR)

Região da Maniqueira (MR)

Região da São Roque (AU)

Região de Jundiaí (AU)

Região de Sorocaba (AU)

Fontes:

imite Municipal e Estadual - IBGE 2012

Complexo Metropolitano Expandido - EMPASA 1996. Mancha Urbana - ProBio 2005.

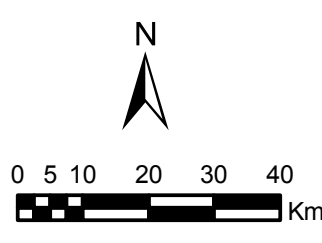

Sistema de Coordenadas Geográficas Datum WGS 84 
elevado grau de c omplementaridade e i ntegração, bem como pela intensa troca de fluxos na esfera do consumo de bens e serviços e, sobretudo, na relação pendular moradia-trabalho" (EMPLASA, 2011, p.105)

Esta região se destaca pelo desenvolvimento "avançado", em nível nacional, por oferecer condições ou pot encialidades de des envolvimento econômico, social e urbano diferenciadas, mas também pela contraditória dívida social, caracterizada pelas precárias condições de moradia, ocupações em áreas de risco, carência de infraestrutura urbana e serviços básicos de caráter social.

A preocupação de diversos setores de planejamento em nível regional exige uma política integrada de planejamento, já que i nteresses setoriais compartilham da mesma trama territorial. O decreto estadual n 52.748/2008 sob atribuição da $S$ ecretaria de $S$ aneamento e E nergia institui os limites territoriais do plano diretor da Macrometrópole Paulista englobando todas as bacias hidrográficas que abastecem os municípios mais densamente povoados do estado. Apesar de ser alvo de estudos técnicos há décadas, somente em 2008 foi institucionalizada formalmente; sua definição serve como parâmetro para esta nova regionalização da E mplasa (2011), que c onsidera outros objetivos e critérios técnicos que visam o planejamento integrado do sistema de transporte, suprimento energético, uso e ocupação do solo, expansão urbana, manutenção do espaço econômico global. Como mostra o documento,

\footnotetext{
"O enfrentamento das questões que incidem sobre essa área ampliada de metropolização exige nas formas de gestão urbana, que esta escala de urbanização requer. Hoje, as intervenções são, em geral, fortemente concentradas na e sfera municipal, concebidas e i mplementadas de forma setorial ef ragmentadas, sem que haj a exercício de compartilhamento de decisões entre os agentes envolvidos na esfera pública, privada e da sociedade civil. Portanto, cabem avanços nos mecanismos de ges tão e na c oncepção de novos instrumentos de intervenção, que possam dar suporte à formulação de políticas de corte regional, predominantemente urbano, capazes de enfrentar as expressivas demandas e desafios que se apresentam nesta escala de metropolização." (EMPLASA, 2011, p.107)
}

A definição de "Macrometrópole" apresenta, assim, diferenças em relação ao conceito de "Complexo Metropolitano Expandido", conforme revela o mapa 2. Do ponto de vista formal, a principal distinção diz respeito à exclusão 


\section{Mapa 2: Macrometrópole Paulista}

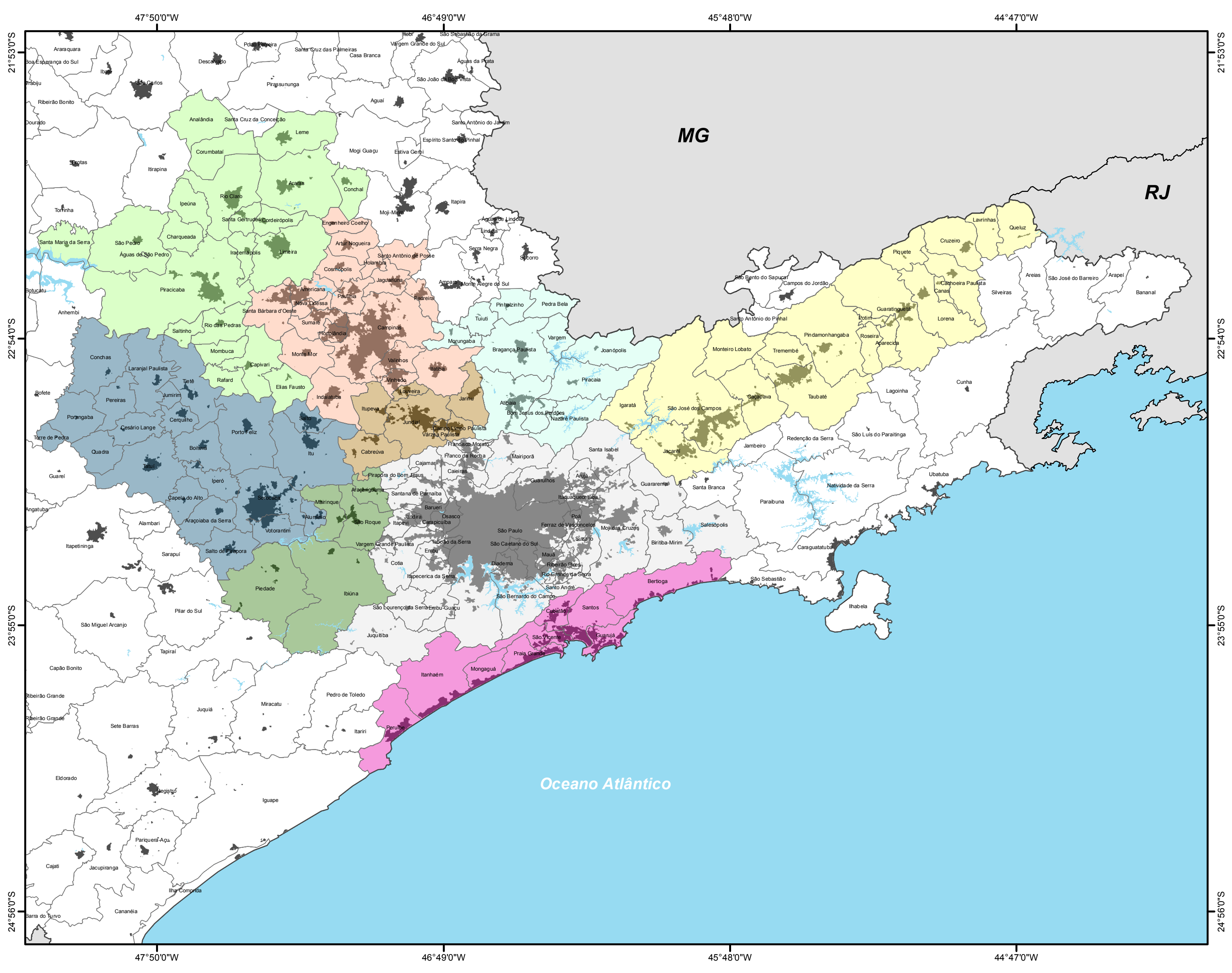

Localização Geral no Estado de São Paulo

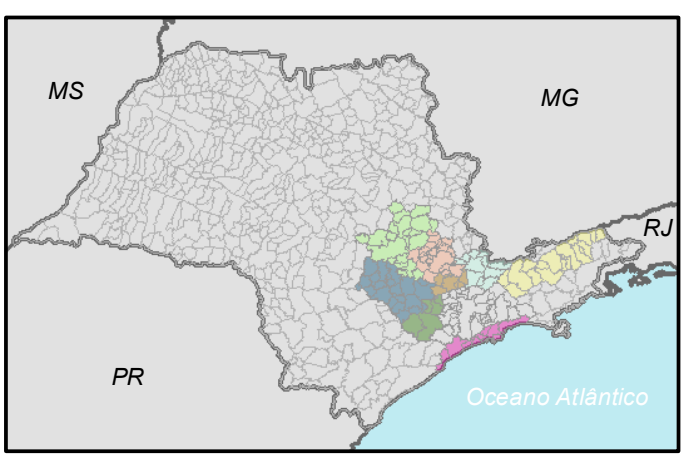

\section{Legenda}

$\square$ Limite Estadual

Limite Municipal

Oceano / Represa

Área Urbanizada 2005

AU de Jundiaí

AU de Piracicaba

AU de Sorocaba

AU de São José dos Campo

MR Bragantina

MR São Roque

RMBS

RMC

RMSP

Fontes:

Limite Municipal e Estadual - IBGE 2012. Mancha Urbana - ProBio 2005.

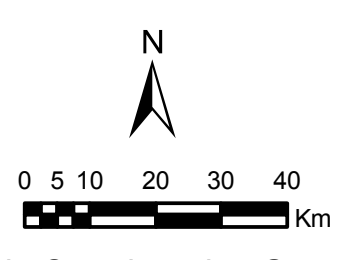

Sistema de Coordenadas Geográficas Datum WGS 84

Elaboração: GIBERTI 2012 
de município da r egião do vale do $\mathrm{P}$ araíba e a inclusão de municípios na porção oeste e noroeste do estado na definição.

Após analisar os conceitos expostos anteriormente, podemos identificar algumas diferenças de abordagem que resultam em definições distintas sobre a formação da m etrópole paulista; entretanto, cada conceito oferece contribuições importantes para a interpretação da "vida de relações" da área de estudo desta pesquisa.

Definitivamente, a cidade de São Paulo sempre concentrou e continua concentrando o comando político e econômico do estado, principalmente pela localização das sedes das empresas ali instaladas (seja no período em que as unidades fabris ali se encontravam, ou no período de dispersão territorial das mesmas). A intensa urbanização que s e seguiu nas regiões adjacentes (Campinas, Santos, Vale do Paraíba, Sorocaba) sempre esteve atrelada ao modelo metropolitano da capital; neste sentido, o centro da região permanece na capital, sem que nov os centros "autônomos" se formem, na perspectiva político-econômica. Entretanto, no que se refere ao modo de vida metropolitano (educação, consumo, programação cultural, lazer e s erviços diversificados) realmente é pos sível detectar a di spersão espacial das atividades e consolidação de novos centros e sub-centros regionais, assim como em pontos de urbanização dispersa.

Essa nova configuração do tecido urbano, representada por núcleos urbanos especializados descontínuos, conectados por grandes eixos rodoviários, apresenta, portanto, um modo de vida metropolitano e, ao mesmo tempo, o c aráter de um a organização local, de vizinhança limitada, uma espécie de "província".

Nesta perspectiva, as Regiões Metropolitanas de Campinas e da Baixada Santista fazem sentido sob o pon to de vista da ges tão pública, mas não do $p$ onto de $v$ ista de $s$ ua "vida de relações" concreta, pois seu funcionamento depende de lógicas geográficas mais abrangentes, referentes à 
Região Metropolitana de São Paulo, configurando, portanto, uma ordem Macrometropolitana, termo adotado neste trabalho.

Em relação às definições anteriores cabe uma reflexão geral dos principais pontos: o ent endimento do processo de formação e reestruturação da metrópole está intimamente ligado aos arranjos produtivos, aos sistemas técnicos que intermedeiam as relações econômicas e sociais. O território aparece como recurso para o desenvolvimento econômico, os investimentos públicos priorizam grupos econômicos em detrimento das demandas básicas sociais. Essa modernização de parcelas específicas do território, assim como a consolidação das redes e $r$ elações entre as cidades são elementos de "regionalização". Entretanto, podemos ver a r egião como um espaço econômico moderno e al tamente competitivo, com elevados níveis de tecnologia e des envolvimento, com grande potencial de atração de investimentos e, ao mesmo tempo, como cenário dos maiores contrastes e dívidas sociais.

Independentemente da definição adotada, o ol har geográfico nos permite identificar uma paisagem metropolitana que materializa as formas de organização socioeconômica e as relações socioespaciais, ambas reguladas pelo estado. A urbanização, em suas diversas facetas, sob a lógica da divisão territorial da cidade, constituiu espaços heterogêneos e contrastantes, tanto na forma como em conteúdo, com áreas residenciais de alto e baixo padrão, com e sem infraestrutura básica, áreas industriais, comerciais, de lazer e prestação de serviços, espaço de fluxos, com a pr esença de gr andes obras de engenharia, especialmente de transporte, energia e abastecimento de á gua. Todos esses elementos formam, portanto, um campo de relações econômicas, políticas e sociais de alta densidade demográfica considerada o maior pólo econômico nacional.

Para se ter uma idéia da magnitude da metropolização, só a mancha urbana dentro dos limites oficiais da RMSP (pólo principal da Macrometrópole Paulista), de I este a oeste chega a medir $75 \mathrm{~km}$, de norte a sul $36 \mathrm{~km}$, totalizando, aproximadamente, uma área de $190 \mathrm{~km}^{2}$. A imagem de satélite 
(figura 3) permite identificar claramente sua extensão, assim como as áreas mais densas e verticalizadas. A metrópole se perde no horizonte, à medida que avançamos ao epi centro da $\mathrm{m}$ ancha urbana percebemos a di versidade de elementos, geometrias, regulações e us os, formas e conteúdos do tecido urbano, a or ganização dos fluxos, os meios de transporte, a disputa entre distintos interesses cotidianos pelo mesmo espaço, a l uta do cidadão pela mobilidade urbana, pela inserção social, pelo direito à c idade. A seguir podemos observar nas fotos a complexidade e heterogeneidade da paisagem metropolitana.

Figura 3 e Foto 1: Imagem de satélite RMSP; Vista parcial da RMSP

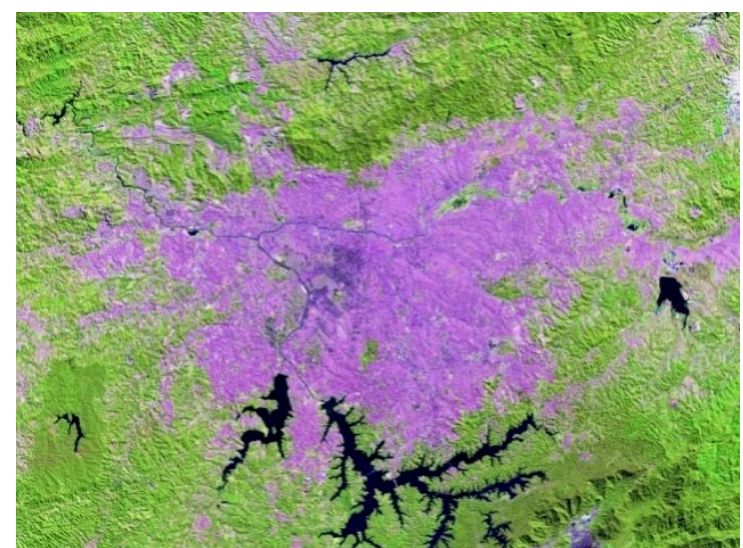

Fonte: Landsat 2010 - INPE

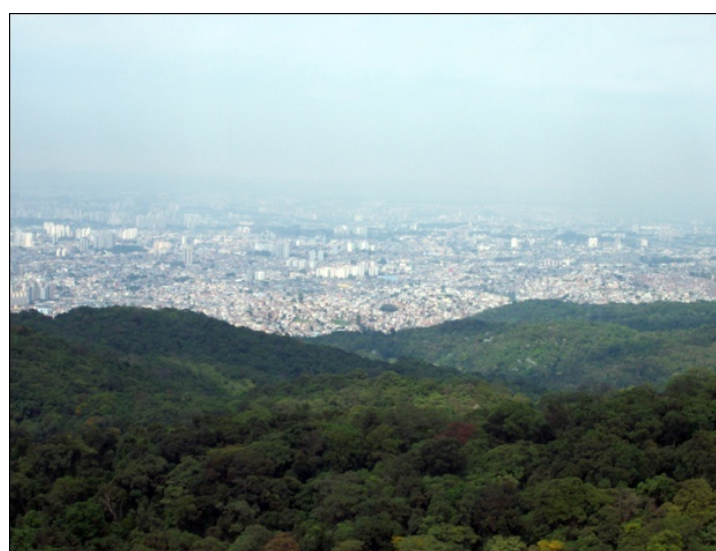

Autor: Giberti 2012

Foto 2 e 3: Centro expandido de SP; Região oeste de SP

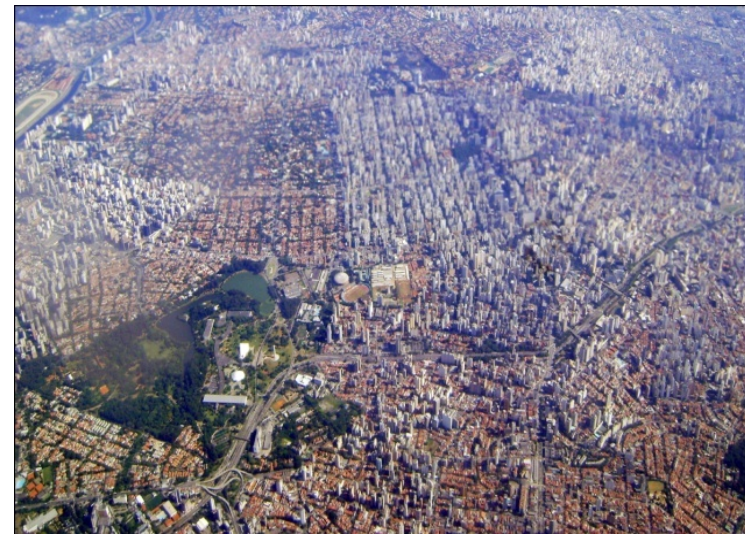

Autor: Giberti 2012

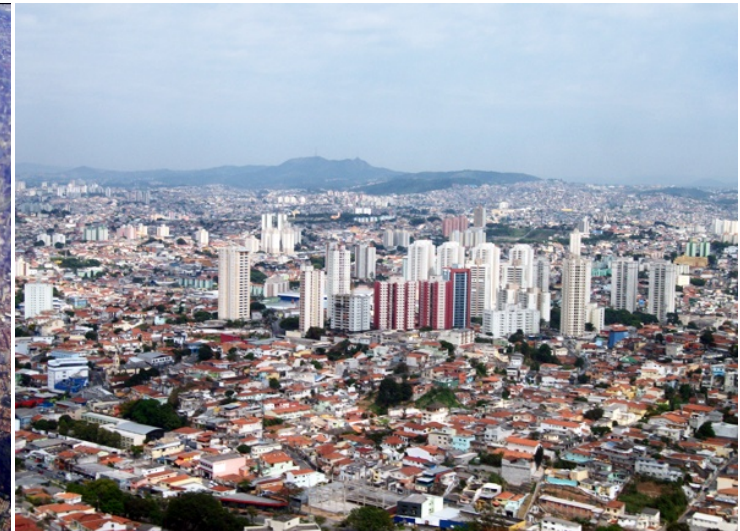

Autor: Giberti 2012 
Foto 4 e 5: Favela Paraisópolis (SP); Bairro da Lapa (SP)

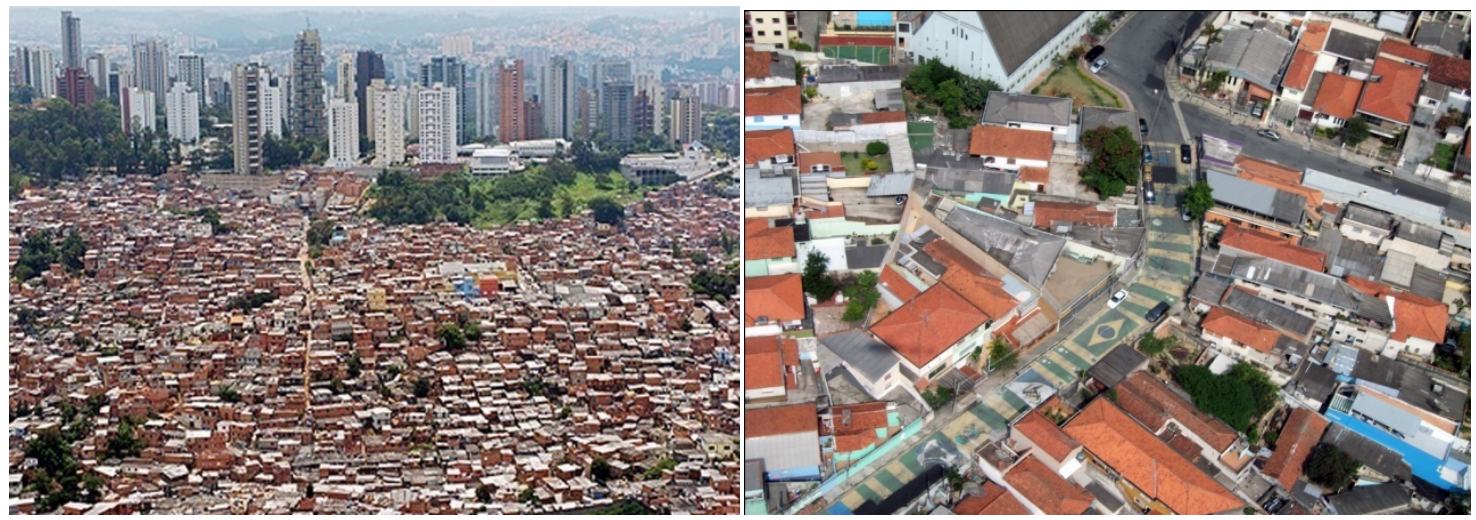

Autor: Desconhecido

Autor: Giberti 2012

Foto 6 e 7: Vista parcial do centro (SP); Marginal Tietê (SP)

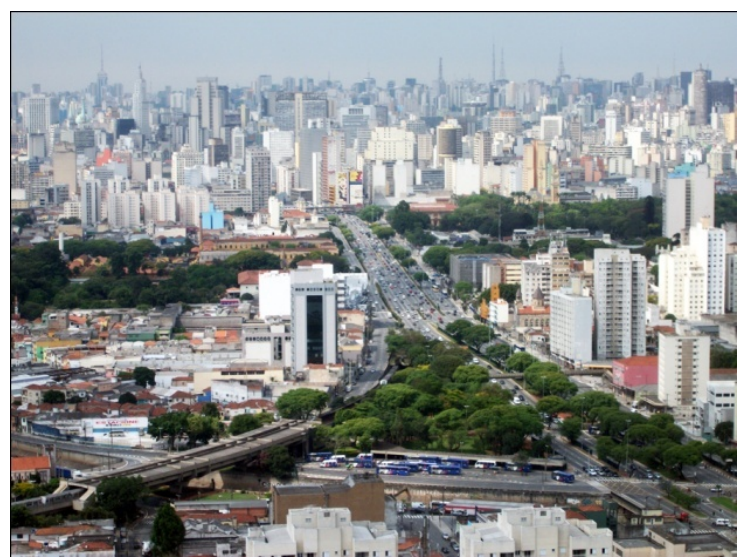

Autor: Giberti 2012

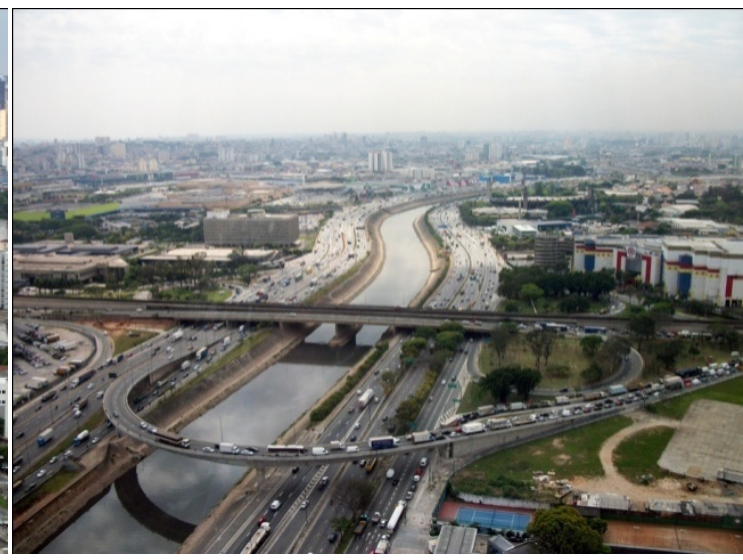

Autor: Giberti 2012

Foto 8 e 9: Av. Paulista (SP); Pedestres na região central de SP.
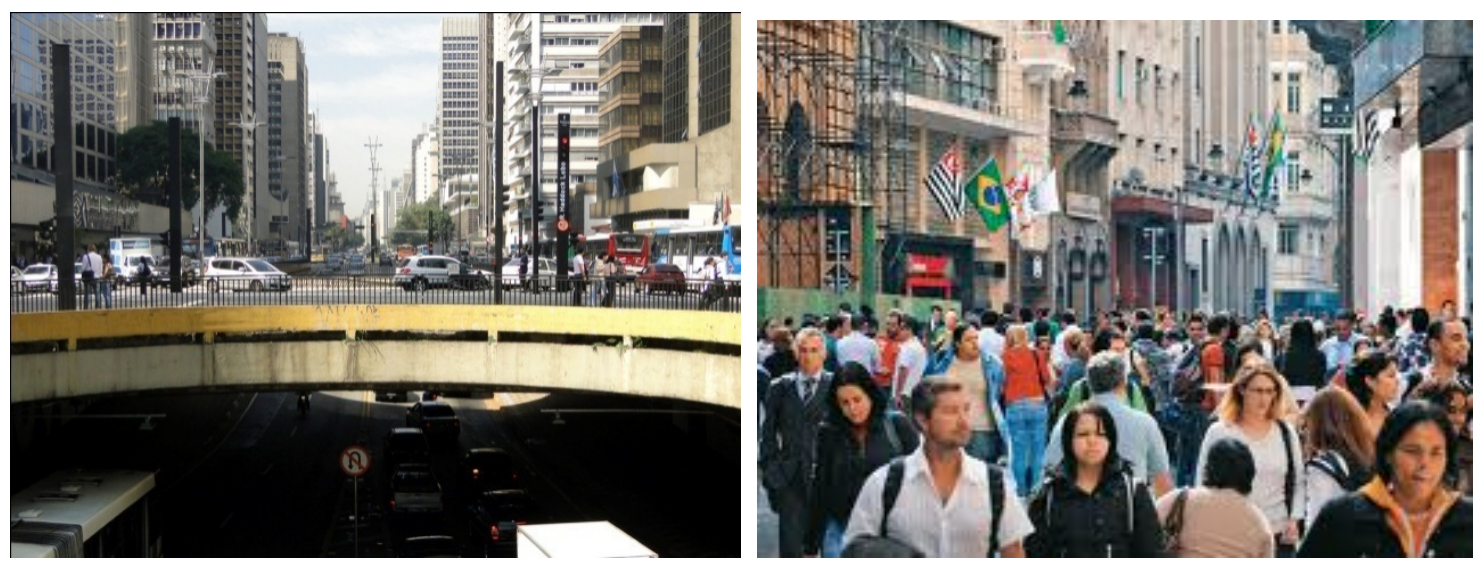

Autor: Giberti 2012.

Autor: Desconhecido. 
Esse território Macrometropolitano altamente dotado de "sistemas de engenharia" (as rodovias, ferrovias, hidrovias, aeroportos, portos, linhas de transmissão de dados, energia etc.) de todo tipo (SANTOS, 2008), constitui o principal pólo econômico do território brasileiro, e deve ser caracterizado, acima de tudo, por intensas relações econômicas e dem ográficas cotidianas, entre diversas cidades que formam a Rede Urbana Paulista.

Para captar o funcionamento do território, devemos analisar tanto estes sistemas de engenharia, quanto os movimentos, os fluxos, as trocas entre as regiões. Outro conceito que pode ser operacional a esta análise é, portanto, o de "sistemas de movimento", isto é, "um conjunto indissociável de sistemas de engenharia (fixos) e de $s$ istema de fluxos (materiais ou i materiais) que respondem pela solidariedade geográfica entre os lugares" (CONTEL, 2008, p. 357).

A intensa e diversificada troca de fluxos de pessoas, mercadorias e informações é par te constitutiva desse sistema de m ovimento. Definir a amplitude, direção e a intensidade destes fluxos nucleados pela cidade de São Paulo pode ser bastante interessante para o ent endimento da realidade em foco. Neste estudo, como já mencionado, serão considerados apenas alguns dos fluxos materiais, especificamente aqueles ligados à movimentação urbanoregional de passageiros, com enfoque no deslocamento cotidiano para o trabalho.

O Sistema de Movimento de passageiros da Macrometrópole Paulista atual é r esultado de uma configuração territorial que herdou formas e conteúdos de diversos períodos históricos, sobre os quais se somaram as inovações técnicas dos meios de transportes, sistemas de engenhar ia e regulações mais recentes. 
O entendimento do sistema de movimento também invoca dois conceitos fundamentais": a "acessibilidade" como atributo do es paço e a "mobilidade" como atributo do agente. A relação entre ambos os conceitos deve ser claramente explicitada e particularizada, pois os mesmos são "instrumentos de justiça social" (BALBIM 2003). Tratar de fluxo de passageiros, parte constitutiva do $\mathrm{s}$ istema de $\mathrm{m}$ ovimento, é t ratar da coletividade dos deslocamentos cotidianos dos indivíduos. O deslocamento efetivo, como veremos as eguir, é f ruto da possibilidade (neste caso conceituado como acessibilidade) e da c apacidade do cidadão de usar o sistema de serviços oferecidos, ou seja, a mobilidade.

Acessibilidade é um conjunto de m eios materiais (vias, sistemas de engenharia), regulações e serviços que combinados oferecem a possibilidade de acesso aos meios de transporte; refere-se à ex istência de um sistema efetivo de c irculação e conexão geográfica entre vários pontos do território nacional, cada qual com sua freqüência, densidade e alcance. Redes de serviços de transporte (rodoviário, metroviário, aeroviário) operam no cotidiano, suas estratégias e as sociações são orientadas pelas regulamentações e burocracias de caráter público e conformam, portanto, um sistema global de possibilidades, normatizado e fiscalizado. Para um mesmo deslocamento, seja em escala municipal, estadual ou federal, são ofertados serviços diferenciados, sistemas técnicos distintos e, obviamente, os custos também variam. Na leitura do Espaço Intra-Urbano, Villaça afirma que:

\begin{abstract}
"A acessibilidade é o v alor de uso mais importante para a terra urbana, embora toda e qualquer terra o tenha em maior ou menor grau. Os diferentes pontos do espaço urbano têm diferentes acessibilidades a todo o conjunto da cidade [...] A acessibilidade de determinada localização é função do tempo dos diversos percursos a partir dessa localização, da freqüência com que esse diversos percursos precisam ser feitos, da freqüência do meio de transporte disponível (horário por exemplo) e do custo do transporte em si" (VILLAÇA, 1998.p.81;82).
\end{abstract}

Para Vasconcellos (2001) o conceito de acessibilidade é subdividido em dois tipos: a $\mathrm{m}$ acroacessibilidade e a microacessibilidade. A primeira

${ }^{9}$ Devemos destacar que nossa apropriação dos conceitos de 'acessibilidade' e 'mobilidade' apresentados neste trabalho foram em grande parte influenciada pelas sugestões do Prof. Dr. Ricardo Castillo e da Prof. Dra. Mónica Arroyo, por ocasião de nosso exame de qualificação desta pesquisa. 
representa um conjunto global de pos sibilidades de deslocamentos, uma escala abrangente das redes dos sistemas de eng enharia e prestação de serviços, "reflete a variedade de destinos que podem ser alcançados e, consequentemente, o arco de possibilidades de relações sociais, econômicas, políticas e culturais dos habitantes do local“ (VASCONCELLOS, 2001. p.91). Encontra-se no $\mathrm{n}$ ível do planejamento dos transportes. Já a microacessibilidade seria uma escala menor, referindo-se "à facilidade relativa de ter acesso direto aos veículos ou destinos desejados (por exemplo, condições de estacionamento e de acesso ao ponto do ônibus)".

O autor define quatro tempos que compõem uma "viagem completa":

1- de acesso ao veículo / espera do transporte público;

2- dentro do veículo / caminhando;

3- possível transferência entre veículos;

4- destino final.

A microacessibilidade é u $\mathrm{m}$ componente da macroacessibilidade, responsável por momentos importantes da ação do deslocamento (carga e descarga; embarque e desembarque; localização dos pontos de acesso ao transporte público).

Identificamos nos trabalhos de Flávia Ulian (2008) e C occo (2011) a relação entre acessibilidade e mobilidade no Estado de São Paulo, sendo a acessibilidade expressa como a facilidade de um cidadão, em determinado lugar, de chegar ao lugar desejado, deslocar-se para a e xecução de suas atividades cotidianas, seja a pé ou por algum meio de transporte; cada lugar, neste sentido, pode ser mais ou m enos acessível, assim como, cada lugar pode oferecer mais ou menos conexões com outros lugares. A acessibilidade seria portanto a possibilidade de acesso, já a mobilidade surge como realização do movimento que carrega a prática socioespacial, que depende da condição econômica e da acessibilidade.

As diversas formas de entendimento da mobilidade sempre se referem a um movimento de pessoas no espaço. Cada período histórico revela um ou 
mais tipos de mobilidades, ou seja, o conceito foi se adaptando ao diferentes contextos históricos.

Pensando historicamente sobre o tema da mobilidade, podemos lembrar que Max Sorre ([1955] 1984) considera que ela se revela em escalas e tempos históricos mais diversos, e por isso é c onsiderada também nas sociedades ditas "pré-capitalistas". O autor nos mostra dois aspectos importantes da mobilidade que devem sempre ser levados em consideração: tempo e escala. Sorre trabalha com a idéia de que a mobilidade é uma característica inerente ao homem, que des de sempre percorreu espaços em busca de sua sobrevivência, se adaptando e transformando estes espaços. Considera, portanto, que a mobilidade é movimento, e no caso da geografia existiriam diversos tipos de mobilidade do homem pelo espaço, ou seja, o espaço tido como extensão e ap resentando limites. Estes limites para ele seriam dados pelo tempo e pel a escala de analise. "O movimento surge como única realidade, a permanência como ilusão causada pela mobilidade atenuada, imperceptível, e às vezes também pelo emprego simultâneo de duas escalas diferentes de mobilidade." (SORRE, [1955] 1984, p.128).

Destaca-se ainda, para Sorre, a formulação sobre limites e difusão da espécie humana através de "mobilidades no ecúmeno". Essas se apresentariam em graus diversos, todos relacionados a um "habitat", ou seja, em relação a uma negação da mobilidade.

Jean Paul de Gaudemar (1977) trabalhou com a categoria "mobilidade", teorizando a c hamada "mobilidade do trabalho". Seus escritos mencionam temas referentes a deslocamentos espaciais, entendidos como condições especiais num processo amplo do m odo de pr odução capitalista. "Uma mobilidade profissional e geográfica da mão-de-obra adaptada à evolução da estrutura do emprego é uma das condições de expansão de uma economia em estabilidade". (GAUDEMAR, 1977, p.19/21) Segundo Gaudemar, a pr imeira mobilidade seria aquela na qual o trabalho humano passa a ser considerado força de trabalho e pode ser vendido no mercado. Esta ação marcaria o inicio de todas as mobilidades modernas, nas quais homens se deslocariam em 
busca de sua sobrevivência em espaços onde esta força pudesse ser vendida. Juntamente a esta mobilidade um conjunto de fatores também se transformou norteando o modo de produção capitalista.

A relação entre mobilidade e situação econômica foi também fortemente evidenciada por Villaça (1998), destacando o modelo rodoviário concentrado e destinado ao transporte particular. Para o autor,

\begin{abstract}
"As necessidades e c ondições de de slocamento, como também as tecnologias de transportes, variam conforme as classes sociais. Quem é obrigado a morar longe do em prego e das compras é forçado a condições mais penosas de deslocamento. Se o e stado privilegia o transporte individual construindo vias expressas, está privilegiando as condições de deslocamento dos proprietários de automóveis. De maneira geral, as camadas populares são mais prisioneiras do espaço do que a s camadas de mais alta renda, pois a m obilidade dessas camadas é bem maior" (VILLAÇA, 1998, p.87).
\end{abstract}

A perspectiva da mobilidade como papel fundamental do desenvolvimento urbano que envolve os diversos elementos da estruturação e circulação das cidades é referida também por Cadaval (2001). O autor destaca a tendência de aumento da mobilidade da população associada à urbanização acelerada, onde o setor privado de transporte (automóveis, empresas privadas, fretados, alternativos e clandestinos) está ganhando a concorrência com o setor público.

Para Vasconcellos (2001) a m obilidade deve ser entendida como um elemento para a avaliação das políticas de transporte, como meio de satisfação das necessidades dos indivíduos, permitindo aos mesmos chegar aos destinos desejados. "Os fatores principais que interferem na mobilidade das pessoas parecem ser a renda, o gêner o, a idade, a ocupação e o nível educacional” (Vasconcellos, 2001, p. 115). Dentre as variáveis destacadas pelo autor, a renda conta com maior peso, evidenciando uma relação direta entre renda e mobilidade. No caso das populações de menor renda, as atividades são menos diversificadas (compras, negócios, atividades culturais e d e lazer), pois a menor disponibilidade de renda limita os gastos com transporte ao realmente essencial. Essa disparidade entre diferentes níveis de $r$ enda e m obilidade resulta em grandes diferenças dos padrões de viagens. 
Nas demais variáveis o aut or ressalta alguns pontos, dentre os quais podemos destacar: os homens viajam mais que as mulheres; os adultos com trabalho fixo deslocam-se mais que jovens e idosos e aqueles com ocupação "instável"; pessoas com maior nível educacional viajam mais que os demais. Assim, diferenças na mobilidade são acompanhadas de diferenças no uso de modos de transporte. Essas relações são bem caracterizadas pelo autor:

\begin{abstract}
"A apropriação do espaço de circulação éf eita pelos usuários, segundo estratégias condicionadas por condições sociais, políticas e econômicas. Sob o ponto de vista da reprodução social, estas estratégias são decididas no núcleo familiar, quando tanto aspectos individuais como coletivos são considerados. As estratégias de deslocamentos variam acentuadamente em função das características, assinalando uma apropriação altamente diferenciada do espaço: estratos de renda mais elevada gastam menos tempo por deslocamento, circulam a velocidades mais altas, consomem mais espaço por pessoa e apresentam uma diversidade maior de atividades, viabilizada pela maior disponibilidade de tempo. Os extratos de renda mais baixa, ao contrário, circulam mais vagarosa e desconfortavelmente e dispõem de pouco tempo para atividades não ligadas ao trabalho, a $r$ eprodução biológica pura e $s$ imples" (Vasconcellos, 2001, p. 204).
\end{abstract}

Cabe considerar que um grande número de des locamentos não representa necessariamente boas condições de $v$ ida, pois pode refletir a necessidade de des locamentos excessivos frente à precariedade e falta de racionalidade do sistema de transporte.

Para Balbim (2003) a reflexão sobre mobilidade sofreu uma evolução e foi sendo adaptada aos tempos, sendo indiscutivelmente hoje considerada como uma prática social que insere o indivíduo em seu meio e o faz respeitar as normas de circulação para que tenha a capacidade de deslocamento, ou seja, sendo submetido a um circuito, a uma rede.

\footnotetext{
"A mobilidade cotidiana pode ser interpretada então como base de trocas e relações sociais. Nesse contexto, o indivíduo que se desloca é ator social, com suas reivindicações e práticas próprias, sujeito de estudos, diretrizes e planificações, um agente da produção do espaço da circulação" (BALBIM, 2003. p.181)
}

Para o autor, a prática social da mobilidade tem como características as temporalidades curtas e os ritmos sociais repetitivos, implicando no r etorno cotidiano à origem. As melhorias nas técnicas de deslocamento permitiram que 
as atividades não se concentrassem mais em um único lugar, e neste sentido pode-se dizer que a "lógica temporal" se sobrepõe à "lógica da proximidade física".

Essa prática e inserção social é fruto de diversos elementos que se inter-relacionam, sendo que "a mobilidade cotidiana se estrutura a par tir da ordem econômica, da diversidade técnica do sistema de transporte, da vida de relações (incluindo os lugares de permanência, os motivos das viagens, etc) e da configuração do território" (BALBIM, 2003, p.176).

A mobilidade fica condicionada às redes de circulação e às modalidades de transporte. A estruturação das redes e a c ondição econômica de c ada indivíduo acabam por permitir uma maior ou m enor mobilidade, variando a velocidade, distância, qualidade de des locamento e, consequentemente a percepção e atuação espaço-temporal das pessoas.

Jacques Lévy (2002), importante referência sobre o conceito, define mobilidade como relação social em três aspectos: possibilidade, competência e capital. O primeiro aspecto refere-se à a cessibilidade, ou s eja, a of erta de mobilidade mediante a of erta de transporte, o que implica em formas diferenciadas de interação com a cidade. O segundo aspecto, o que de fato é realizado, seria uma competência da c apacidade de consumo/realização da possibilidade de acesso/deslocamento, associada à posse de bens materiais e financeiros. Para o aut or "a posse de uma competência de mobilidade é u m componente, muito mais do que uma conseqüência, de uma posição social hierarquicamente inferior. Em particular, é porque são pouco móveis que as populações mais despossuídas são despossuídas” (LÉVY, 2002, p.12). Por fim, o terceiro aspecto é $r$ esultado da possibilidade e da competência, representando um bem, um capital social que:

"permite ao indivíduo desdobrar melhor a sua estratégia no interior da sociedade [...] A cidade é um espaço necessariamente muito estruturado, coletivamente organizado de tal forma que a concentração de uma grande quantidade de homens, atividades e instituições não degenere numa Babel ingovernável. $O$ que à $s$ vezes quase acaba acontecendo...O surpreendente é c omo, no interior deste conjunto, 
cada um pode inventar a sua cidade, escolhendo os lugares que the interessam e eliminando outros" (LÉVY, 2002, p.13).

O autor sintetiza as três virtualidades da mobilidade em uma relação triangular entre o de sejado, o possível e o realizado; também considera que vivemos num mundo que se movimenta em várias velocidades, cada qual com sua métrica e percepção espaço-temporal da cidade por parte do indivíduo. A urbanidade, a r elação rede-território, intermedeia a prática socioespacial da mobilidade.

Feitas estas aproximações mais gerais sobre os temas da "mobilidade" e da "acessibilidade", podemos nos perguntar: qual é o tipo de mobilidade que mais nos interessa para este estudo? Que tipo de mobilidade mais nos auxilia na análise da dinâmica dos fretados na Região Metropolitana de São Paulo?

Pela revisão bibliográfica realizada, outro conceito central que permite melhor definir a m obilidade dos fretados é a c hamada "pendularidade". A pendularidade é um tipo de $\mathrm{m}$ obilidade relacionado diretamente com $\mathrm{o}$ processo de metropolização e com a rede urbana. Os movimentos pendulares são descritos como "deslocamentos diários realizados pela população ocupada [...] entre o município de moradia e o de t rabalho" (ANTICO, 2004, p. 1) Nos trabalhos de Aranha (2005) também identificamos referências sobre a mobilidade pendular, caracterizada pelo indivíduo que reside em um município, mas trabalha e/ou estuda em outro município.

Nota-se uma forte relação da pendularidade com a r eestruturação urbanoindustrial e a di spersão territorial da $m$ etrópole. A interpretação dos fluxos pendulares (origens, densidades e des tinos), deve considerar a concentração das ofertas de $p$ ostos de trabalho e de estudo no c ontexto regional.

A mutação da m etrópole moderna para a metrópole contemporânea e sua dispersão territorial representa um elemento fundamental para compreender o aum ento da pendularidade e s eu significado. Como mostra 
documento publicado em conjunto pelo IBGE, IPEA e pes quisadores da UNICAMP,

\begin{abstract}
"O processo de dispersão urbana foi impulsionado pelo progresso nos transportes, que alimentava as novas formas de migrações pendulares, pela evolução das telecomunicações e, muitas vezes, pela intervenção direta das autoridades, para facilitar o acesso à moradia individual" (IBGE. UNICAMP. IPEA. 2002).
\end{abstract}

Quais os motivos e c aracterísticas dos fluxos pendulares e qual sua relação com a dispersão territorial da metrópole? Quais os principais locais de origem e destino dos fluxos? Como a concentração da of erta de trabalho e estudo organiza a pendularidade entre as cidades? Existe uma hierarquia de fluxos entre as cidades?

Neste contexto, é pos sível afirmar que a di spersão territorial da metrópole é ac ompanhada por fluxos pendulares que s e intensificam e diversificam, conformando um cotidiano regionalizado e uma vida de relações de ordem macrometropolitana.

Devemos perguntar afinal: porque uma parcela da população trabalha ou estuda fora do município onde reside? Porque esse movimento pendular, que já tinha relevância na d écada de 80 ( SEADE 2008), aumentou significativamente nas décadas seguintes?

A progressiva concentração da oferta de trabalho, educação e serviços básicos nos centros e sub-centros regionais, acabou por atrair e es timular ainda mais a pendularidade. Para Cunha (2003) a dinâmica econômica, social e demográfica nacional ocorrida a $\mathrm{p}$ artir da déc ada de $80 \mathrm{~s}$ ofreu transformações complexas, afetando os processos de redistribuição espacial da população e urbanização, diminuindo o ímpeto concentrador que até então caracterizava a dinâmica demográfica brasileira.

O autor também destaca o surgimento de nov as formas de assentamentos humanos que ganharam importância na dinâmica demográfica nacional, com a consolidação de "novos espaços regionais e outros tipos de 
mobilidade populacional com claras conseqüências nos padrões locacionais da população dentro e fora dos grandes centros urbanos" (CUNHA, 2003, p.218). Essa nova configuração urbana passa a reorganizar as atividades cotidianas da população e as premissas de ocupação no território, como descreve Cunha (2003, p. 230):

\footnotetext{
"O sistema urbano brasileiro tornou-se mais complexo, apresentando em termos espaciais, novas e diversificadas modalidades de assentamentos humanos, alterando as relações entre o urbano-rural, surgindo novas territorialidades intensificando-se os movimentos de mais curta distância, em particular os tipo urbano-urbano, ampliandose as alternativas de ocupação econômica e demográfica".
}

A mudança na configuração urbana ocorrida nas ultimas décadas pode ser descrita como uma transição da m etrópole moderna para a m etrópole contemporânea. Segundo Lencioni (2008) a metrópole moderna constituiu-se pelo processo de ur banização em forma de aglomeração concentrada, em extensão territorial coesa de alta densidade e forma contínua, com limites bem definidos. Seu crescimento foi radioconcêntrico e pol icêntrico, com foco do capital na produção. Com a pr ogressiva modernização do t erritório, especialmente nos meios de comunicação e c irculação associados às mudanças econômicas globais e nac ionais, a m etrópole contemporânea se conformou pelo processo de metropolização em aglomeração dispersa e extensão territorial difusa, com tendência à di minuição da de nsidade, com limites indefinidos de crescimento linear, com intensificação do policentrismo e capital focado na gestão. Qual a relação da pen dularidade com a reestruturação urbano industrial e a dispersão territorial da metrópole?

A pendularidade, portanto, se adaptou a essas mudanças; se num primeiro momento as oportunidades de emprego eram mais concentradas na mancha urbana densa, no caso de São Paulo, especialmente pela concentração industrial no centro, posteriormente estas oportunidades também foram se dispersando. Como nos revelam os trabalhos de Diniz (2000) e Sampaio (2009), ambos preocupados com a dinâmica espacial resultante da reestruturação econômica, especialmente na r elação industrialização/urbanização, em uma análise mais abrangente, o B rasil 
ganhou fôlego após a s egunda guerra mundial e consolidou o p adrão urbanoindustrial.

Essa extrema concentração da atividade industrial foi um dos elementos importantes para a or ganização dos fluxos residência-trabalho, afetando diretamente a formação dos bairros residenciais, cada vez mais distantes, ultrapassando os limites municipais.

Com a dispersão industrial das unidades fabris ocorre uma verdadeira "regionalização" do mercado de trabalho. "Entre 1950 e 1960, com a organização em escala regional do sistema industrial as empresas passaram a recrutar e a transportar seus empregados num raio de cem quilômetros ao redor das fábricas" (REIS FILHO, 2006, p.90). O autor explica que, após a dispersão industrial, houve a dispersão progressiva das demais atividades (bairros residenciais, serviços, escritórios, lazer); esses estudantes, trabalhadores e c onsumidores são oriundos de diversos municípios, conformando uma "organização do cotidiano em âmbito regional".

Com o pr ocesso de metropolização e c oncentração das ofertas de trabalho e estudo nos centros e sub-centros regionais conforma-se um padrão de deslocamento sentido bairro-centro em escala municipal, es entido municípios periféricos-município central em escala regional. Entretanto, com a transição da metrópole moderna para a metrópole contemporânea os fluxos se ampliaram em número, diversidade e alcance.

O fluxo pendular no Brasil está ligado aos circuitos produtivos modernos e concentra-se especialmente no S udeste e no Estado de São Paulo. Entretanto, na última década perdeu um pouco de sua extrema concentração para as demais regiões do país, conforme revelam os dados do IBGE (2000 e $2010)^{10}$. Neste último decênio, em termos absolutos em nível nacional, a pendularidade sudestina passou de 56\% para 51\%, o Estado de São Paulo de $29 \%$ para $28 \%$. Em contrapartida, houve um crescimento extremamente

\footnotetext{
${ }^{10}$ Censo Demográfico 2000 e 2010.
} 
elevado dos fluxos pendulares em todos os níveis (federal, regional, estadual), conforme a t abela a seguir. O número total de ha bitantes com a prática pendular mais que dobrou para o território como um todo, assim como para o estado; em termos relativos passou de $5,8 \%$ para $10,6 \%$ da população total do estado de São Paulo, justamente onde o fator de dinamismo são os serviços complexos e a indústria moderna. Todavia, nota-se que a pendularidade é uma prática que predomina na população urbana.

Tabela 1: Brasil, Sudeste e Estado de São Paulo - Pendularidade 2000 e 2010

\begin{tabular}{|c|c|c|c|c|c|c|}
\hline Unidade & $\begin{array}{c}\text { População } \\
\text { Total 2000 }\end{array}$ & $\begin{array}{c}\text { População } \\
\text { Pendular } \\
\mathbf{2 0 0 0}\end{array}$ & $\begin{array}{c}\text { Pendularidade I } \\
\text { População (\%) } \\
\mathbf{2 0 0 0}\end{array}$ & $\begin{array}{c}\text { População } \\
\text { Total 2010 }\end{array}$ & $\begin{array}{c}\text { População } \\
\text { Pendular } \\
\mathbf{2 0 1 0}\end{array}$ & $\begin{array}{c}\text { Pendularidade I } \\
\text { População (\%) } \\
\mathbf{2 0 1 0}\end{array}$ \\
\hline Brasil & 169.872 .856 & 7.403 .362 & 4,4 & 190.755 .799 & 15.472 .863 & 8,1 \\
\hline Sudeste & 72.430 .193 & 4.137 .024 & 5,7 & 80.364 .410 & 7.908 .941 & 9,9 \\
\hline $\begin{array}{c}\text { Estado de } \\
\text { São } \\
\text { Paulo }\end{array}$ & 37.035 .456 & 2.161 .870 & 5,8 & 41.262 .199 & 4.371 .186 & 10,6 \\
\hline
\end{tabular}

Fonte: Censo Demográfico IBGE 2000 e 2010. Adaptação: GIBERTI 2012.

A análise dos números da pendularidade (que será detalhadamente abordada no próximo capítulo) pode ser entendida, portanto, em função da existência de uma complexa divisão territorial do trabalho, mas também pela disponibilidade de sistemas de transporte que permitem tal prática. A rede rodoviária moderna é altamente capilarizada no território, caracteriza-se como a rede-suporte dos fluxos pendulares na região de estudo, variando os níveis de mobilidade e as modalidades de transporte, a saber: automóvel particular, transporte regular metropolitano ou transporte fretado.

A alta concentração da of erta de em prego e ed ucação em alguns municípios e, em contrapartida, a sua escassez em outros municípios, acaba, portanto, organizando os fluxos pendulares. Uma cidade que não consegue oferecer vagas de trabalho e estudo obviamente verá sua população se deslocar em busca de tais ofertas em outras cidades próximas. As opções do cotidiano são consideradas em escala regional, existem meios técnicos e redes sociais, as possibilidades são analisadas além dos limites do município de 
residência; a rede urbana, acessibilidade e mobilidade acabam por definir a estratégia do cotidiano do cidadão.

Essa concentração/escassez foi conformada por questões do histórico econômico, político, demográfico e territorial da região. A polarização da oferta de educação e trabalho também foi se alterando nas últimas décadas com tendência a uma desconcentração concentrada, o que levou a ampliação das direções dos fluxos pendulares.

Figura 4

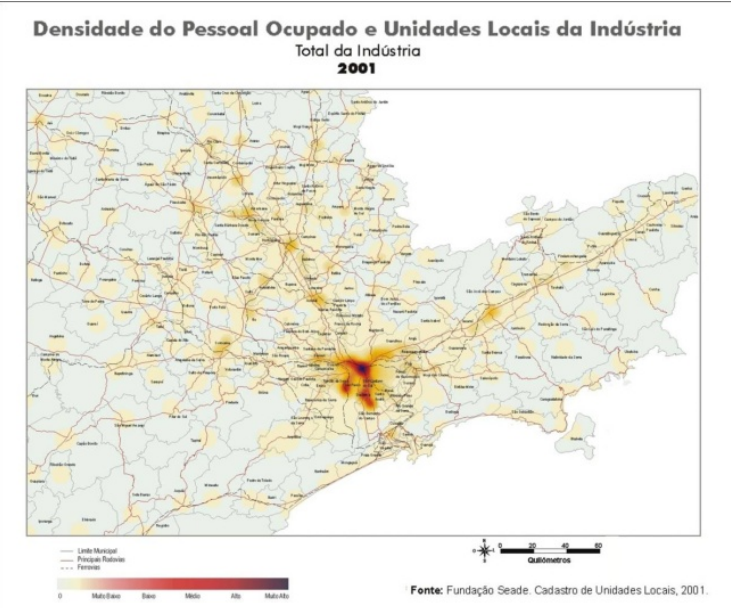

Mesmo assim, como mostram as figuras 4 e 5, as cidades responsáveis por concentrar a maior parte dos destinos dos fluxos são as que oferecem mais oportunidades de trabalho e estudo.

Figura 5

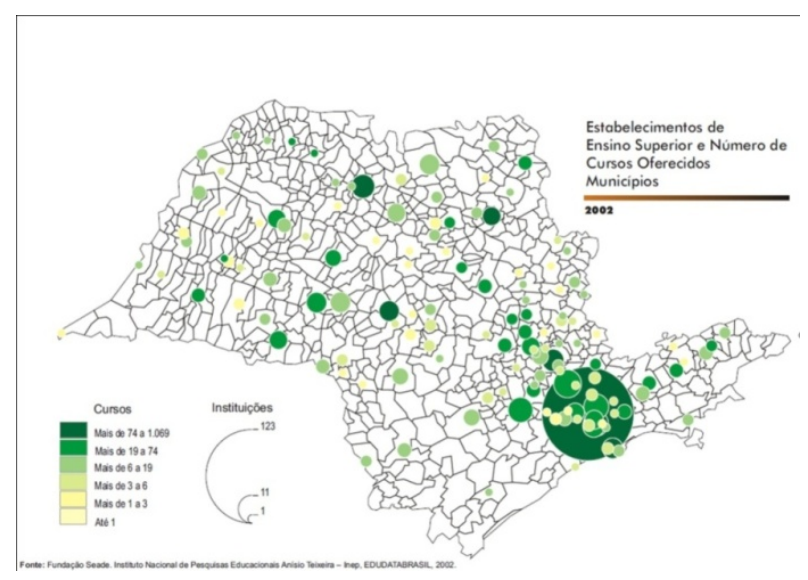


Outra questão de suma importância: a pr ópria urbanização já não s e prende aos limites municipais, a dispersão da metrópole carrega consigo um cotidiano regionalizado, onde as possibilidades são consideradas em uma escala regional, onde o residir em um município e trabalhar ou es tudar em outro já não é encarado como uma "anomalia", mas sim como uma nova forma de organização territorial. O tamanho da mancha urbana interligada por eixos de comunicação e circulação realmente atingiu proporções imensas, constituindo uma Macrometrópole.

Como resultado dessa configuração metropolitana dispersa, os fluxos residência/trabalho/estudo devem ser analisados considerando este fenômeno que o IBGE vem denominando de "região de influência das cidades". Os fluxos pendulares, de fato, parecem acompanhar essa hierarquia. Essa pendularidade, permitida pelos eixos rodoviários, surge como elemento associado à di spersão urbana, onde os meios de transportes disponíveis estimulam as viagens intermunicipais para o trabalho, estudo, lazer e comercio, como frisa Reis Filho (2006, p. 91):

\footnotetext{
"As cidades deixam de ser as sedes da vida cotidiana, para se transformarem em pólos de um sistema articulado em escala mais ampla, regional, no qual se desenvolve a vida cotidiana. A urbanização dispersa conduz a u ma flexibilização dos transportes. As oportunidades oferecidas pelo comércio e pelos serviços já não são analisadas pelos empresários em escala local, mas em escala regional pressupondo uma mobilidade constante dos habitantes dessas regiões".
}

Os novos empreendimentos dispersos nos eixos rodoviários pressupõem essa alta mobilidade de todos os tipos de fluxos, incluindo os fluxos populacionais. Identificamos, portanto, um cenário diversificado em relação à qualidade destes fluxos: pessoas que moram em centros urbanos tradicionais e trabalham em locais dispersos; ou moram em lugares dispersos e trabalham nos centros tradicionais; ou moram e trabalham em áreas dispersas, ou moram em um centro urbano e trabalham em outro, tudo sustentado por uma alta mobilidade dos atores. Tal situação nos remete a entender e identificar esses fluxos e as polaridades existentes. Como os motivos das viagens pendulares são originados basicamente pela mobilidade dos 
trabalhadores - assim como pela busca de serviços básicos -, foi necessária essa reflexão sobre o conceito de rede urbana, no sentido de compreender melhor as hierarquias e a divisão territorial do trabalho que se estabelecem entre as cidades.

A acessibilidade, mobilidade, pendularidade, vida de $r$ elações e dispersão territorial da $m$ etrópole, conjugadas, organizam os fluxos de passageiros, a c onexão geográfica entre diversos pontos da r egião. Sob o ponto de vista histórico, cabe um resgate e destaque dos principais marcos deste processo histórico socioespacial.

\section{CAPITULO 2: Sistemas técnicos, organização e a questão dos transportes metropolitanos}

\subsection{Organização dos transportes de passageiros na Região Metropolitana de} São Paulo

Para abordar a organização dos transportes na área de estudo torna-se fundamental uma contextualização histórica básica para destacar os principais elementos do processo de formação regional do Sistema de Movimento de Passageiros. Inicialmente devemos considerar a r egião de e studo em uma escala mais abrangente, neste caso no da esfera nacional e regional. Em 1950, a Região Sudeste já concentrava mais de $40 \%$ da população nacional; só o estado de São Paulo abrigou, entre 1950-2010, em média, 20\% da população nacional. De fato, a extrema concentração desta região pouco se alterou. $O$ Sudeste atualmente, se comparado às demais regiões do país, apresenta a maior concentração de pop ulação, de capitais, atividades industriais, tecnologias e un iversidades, assim como o sistema viário mais articulado e moderno, configurando uma rede urbana complexa e competitiva.

Tal situação teve como base diversos fatores históricos relacionados à ocupação do território nacional e às atividades desenvolvidas nele. Esta região é - em termos relativos - a que abriga maior parcela do Produto Interno Bruto 
(PIB) nacional, e funciona como principal porta de entrada dos investimentos estrangeiros no território. Sua articulação com o resto do $m$ undo é a mais avançada do Brasil em termos das redes de circulação, informação, bancárias, institucionais etc., com Metrópoles que cumprem um papel fundamental em uma economia globalizada que exige uma troca de fluxos materiais e imateriais de várias ordens, com fluidez competitiva, representando a maior parcela nacional de importação e exportação comercial, seja pela navegação ou via aérea.

A concentração das atividades industriais modernas na região sudeste pode também ser considerada como uma adaptação das mudanças nas formas de produção, surgidas a cada novo "modelo de desenvolvimento econômico", como nos mostram os trabalhos do professor Manuel Correia de Andrade ${ }^{11}$.

A disparidade regional do $B$ rasil e a c oncentração de $t$ ais atividades modernas sem dúvida são responsáveis pelas fortes migrações que ocorreram nas décadas passadas com destino às regiões mais desenvolvidas, sobretudo as migrações para a "Região Concentrada", dando grande peso às demandas sociais das metrópoles que se seguiria nas décadas posteriores; dentre elas, para este estudo, destacam-se as demandas geradas de habitação e de transporte.

Num modo de produção capitalista, os altos níveis de metropolização e atividade econômica geram inevitavelmente altos contrastes na pai sagem metropolitana, demandando também sistemas de transportes modernos que possibilitem as interações socioespaciais básicas do cotidiano metropolitano,

11 "A oligarquia do $S$ udeste organizou o s eu sistema de po der no pe ríodo colonial, se enriqueceu com o surto do café no período Imperial e na Primeira República e soube adaptarse a compartilhar o poder com outro grupo gerado e formado com o crescimento industrial propiciado pela acumulação oriunda da cafeicultura. Este grupo detém um grande poder sobre o país, face ao acordo existente entre ele e a tecnocracia que nos últimos anos implantou um modelo de desenvolvimento concentrado, possibilitando o enriquecimento de determinados grupos nacionais em níveis nunca antes conhecidos no $\mathrm{p}$ aís, provocou o desenvolvimento industrial a níveis não alcançados antes, com uma grande participação do capital estrangeiro e determinou ao lado da concentração financeira uma ponderável concentração geográfica. Assim o modelo concentrou a renda tanto do ponto de vista financeiro, em termos de empresas e grupos econômicos, como também em termos geográficos, permitindo que o S udeste se tornasse cada vez mais rico e que o crescimento das demais regiões se fizesse em função dos interesses e do crescimento dessa região" (ANDRADE, 1983, p. 26), 
mesmo com suas "deseconomias". Nesta parcela diferenciada do t erritório nacional a análise dos transportes de passageiros e da mobilidade cotidiana ganha importância para os estudos regionais brasileiros. Como os principais sistemas de transporte de pas sageiros, especialmente o r odoviário, foram organizados? Quais os principais agentes reguladores do transporte coletivo e individual, quais suas jurisdições? Como o sistema de transporte metropolitano se consolidou?

Diversos autores explicam muito bem a evolução histórica e os processos políticos, econômicos e s ociais da r egião influenciada pela cidade de São Paulo, propondo periodizações que caracterizam os principais elementos de cada época analisada. Dentre estes estudos, podemos dar destaque para a obra clássica de Pierre Monbeig ([1952] 1984) "Pioneiros e Fazendeiros de São Paulo"; assim como o trabalho de Nestor Goulart Reis Filho (2004) "São Paulo; Vila Cidade Metrópole"; e, por fim, aos textos de Maria Adélia de Souza (2004) "Metrópole e paisagem: caminhos e descaminhos da urbanização".

A modernização progressiva e incompleta do território brasileiro, sobretudo do estado paulista, é apresentada por SANTOS e SILVEIRA (2008) em "O Brasil: território e s ociedade no i nício do s éculo XXI", em que s e mostra a sucessão do meio natural para o meio técnico-científico, chegando ao m eio técnico-científico-informacional, que $r$ ege a c onfiguração territorial atual (proposta que oferece grande operacionalidade ao nos so estudo). Não cabe neste trabalho invocar tais periodizações exaustivamente, mas sim esclarecer que o sistema de transporte de passageiros se constituiu sob influência direta dos diversos períodos históricos.

A proposta aqui é destacar os principais marcos históricos na organização dos transportes ${ }^{12}$ da metrópole paulista e seu entorno, assim como os marcos

\footnotetext{
12 Na literatura que trata da "geografia" e "economia" dos transportes destaque para Moacir Silva (1949) e sua obra "Geografia dos Transportes no Brasil", assim como Josef Barat (1978) e "A Evolução dos Transportes no Brasil"; onde podemos encontrar extensas análises e minuciosa descrição da c onformação do s istema de transporte brasileiro. Uma leitura mais atualizada sobre as políticas públicas de transporte em São Paulo é apresentada na obra de Eduardo Vasconcellos (2001), intitulada "Transporte Urbano, Espaço e Equidade". Também
} 
legais de como o poder público criou órgãos em distintas esferas para administrar o planejamento, gestão e fiscalização dos transportes públicos.

Com base na bibliografia citada anteriormente, podemos identificar que 0 processo de formação territorial paulista, a partir do século XIX, foi marcado por uma sucessiva modernização técnica dos meios de transportes, com a implantação de objetos técnicos "inéditos", que revolucionaram a organização desta parcela do território nacional, ampliando as perspectivas econômicas regionais. A relação direta entre transporte e economia é ressaltada por Barat (1978):

"O investimento em transportes, atuando como poderoso fator no espaço econômico, condiciona novos esquemas de divisão geográfica do trabalho nessas economias, influenciando a localização de atividades industriais, extrativas e agrícolas" (BARAT. 1978, p. 5)

A implantação da rede ferroviária, o primeiro grande marco para a integração regional, esteve diretamente ligada às áreas produtoras e a um modelo econômico de agroexportação e expansão territorial de sua atividade.

Com o início da atividade cafeeira na s egunda metade do s éculo XIX, profundas mudanças na estrutura econômica, social e tecnológica ocorreram. De acordo com Reis Filho, "A partir de 1867 S ão Paulo iria se tornar o centro do sistema ferroviário mais importante do paí s e $C$ apital de e xtensa região produtora de café" (1996, p. 28).

Ainda segundo o autor a ligação ferroviária do interior com o litoral e, consequentemente, aos mercados mundiais, trouxe também imigrantes, inovações, máquinas e mercadorias de luxo, rompendo "a rotina dos tempos coloniais". Um forte processo de modernização e novos modos de vida tiveram início. O serviço de diligência (carros puxados por cavalos) que ligava Santos a São Paulo já era regular em 1865, a viagem durava aproximadamente 7 horas. Após o início da atividade ferroviária, as diligências passaram a oferecer seus serviços próximos às estações de trem, funcionando como um complemento de transporte, estimulando o desenvolvimento de uma rede de estradas. Em 1871 planejamento e gestão dos transportes públicos. 
foi fundada a Companhia de São Paulo, responsável pela operação das linhas de bondes com tração animal. Com o aumento da demanda fundou-se também a Companhia Viação Paulista (1889) para atender os bairros novos.

Os novos sistemas técnicos modificaram profundamente as relações sociais, políticas, econômicas na região. A ferrovia e a indústria surgem como novos eixos norteadores da morfologia da cidade de São Paulo e sua área de influência, assim como a criação de bairros operários.

A cidade se desenvolvia com a consolidação de novos bairros onde se construíam as mansões dos ricos fazendeiros, o c entro se especializava no comércio e na concentração de escritórios, os serviços urbanos se expandiam com a i mplantação de redes de água, esgoto, iluminação, calçamento, arborização e, posteriormente, pela chegada da energia elétrica. A fundação da empresa São Paulo Railway, Light \& Power Company Ltda em 1899 representa um marco, atuando na urbanização e nos transportes. Neste mesmo ano a cidade ganha sua primeira linha de bonde elétrico, com concessão da Light para operar os serviços por 40 anos.

O sistema de transporte por bondes em 1905 já apresentava uma rede considerável, e a cidade de São Paulo assumia padrões europeus em suas feições mais gerais. O automóvel surgia como uma alternativa de transporte de luxo, sendo que em 1909 foi fundado o Automóvel Clube, que promovia a divulgação do novo modo de transporte, sob liderança de Washington Luis ${ }^{10}$.

Concomitantemente às mudanças nos conteúdos técnicos do território, importantes mudanças em seus conteúdos normativos - relacionadas aos transportes urbanos - também eram processadas. Em 19 de outubro de 1904 é publicada uma lei que

"proibia a circulação, dentro do perímetro central, de c arros de tração animal com eixo móvel - carroça -, com a justificativa de preservar o macadame, revestimento de superfície mais regular do que os paralelepípedos, porém de baixa resistência, que fora adotado nas ruas de maios tráfego. A proibição, que objetivava preservar o piso para veículos de transporte mais sofisticados - os 
tílburis de rodas de borracha e a utomóveis -, assegurariam um aspecto mais civilizado par as ruas da cidade" (ROLNIK, 1997, p. 106)

O automobilismo até então era considerado um "esporte da elite", sendo que a passagem da "atividade esportiva" para um efetivo programa de obras públicas e ações empresariais ainda demandaria um prazo maior para se consumar. As políticas estaduais iniciavam estudos e planos de obras rodoviárias, sempre ligadas ao nome de Washington Luis. Em 1913 é criada ${ }^{13}$ a lei que atribui ao Estado a competência de definir as especificações técnicas, construir, conservar e melhorar as estradas em regime de administração direta. No mesmo ano foi estabelecido um plano rodoviário que priorizava obras nas ligações entre São Paulo-Jundiaí, São Paulo-Sorocaba e São Paulo-Santos. Posteriormente também foram incluídas outras ligações, como São Paulo - Rio de Janeiro. Com a posse de Washington Luis no governo do es tado de São Paulo, diversas rodovias foram inauguradas progressivamente.

Logo depois da chegada do primeiro automóvel importado (1891), também começam as preocupações com as normas de c irculação desses veículos. Em $1903^{14}$, o prefeito da cidade de São Paulo instituiu algumas leis para regulamentar o us o dos veículos. Com a introdução dos automóveis, o número de tílburis foi decrescendo progressivamente. Em 1916, haviam 38 veículos desse tipo em circulação nas ruas centrais da cidade, e em 1917, somente 20. O mercado automobilístico no Brasil teve seu início mesmo em 1919, quando a Ford abre a primeira linha na cidade de São Paulo. No Estado de São Paulo, a preocupação em disciplinar o trânsito começou pela criação da Diretoria do Serviço de Trânsito (DST) em 1903, posteriormente a di retoria passou a ser vinculada à Secretaria de Estado dos Negócios da Justiça e da Segurança Pública. Em 1904 existiam apenas 84 automóveis em São Paulo, já em 1920 esse número cresceu para 5.596 veículos e 222 caminhões.

Em 1925 foi inaugurada a General Motors Brasil, linha de montagem de automóveis instalada em território brasileiro, completando em 1926 a quantidade de 25 mil veículos fabricados. Segundo Raquel Rolnik (1997, p.160)

\footnotetext{
${ }^{13}$ REIS FILHO 1997

${ }^{14}$ DETRAN - SP (2012)
} 
"O final dos anos 20 inaugurou a era dos grandes projetos viários, do incremento da intervenção do gov erno na provisão de s erviços e da emergência da expansão de f ronteira interna como estratégia de acomodação dos assentamentos populares. Enquanto a c idade se expandia e se densificava, a partir de 1920 o número de bondes se reduzia, em função do de senvolvimento da indústria que consumia a maior parte da energia elétrica. Por outro lado, esses anos marcaram a primeira grande expansão da i ndústria automobilística com a popularização iniciada por FORD. Os primeiros ônibus na cidade datam de 1924 [...]. Dada sua versatilidade o s erviço de ônibus logo se transformou num seríssimo competidor para os bondes e, em 1926, atingia o número de 150 veículos"

No trabalho da autora identifica-se que o modelo adotado de crescimento da cidade teve como base a expansão horizontal, orientada pelo sistema viário rádio-concêntrico e pelo uso do ônibus a diesel. Com essa flexibilização dos trajetos, dos fluxos e do transporte por automóveis em relação ao bonde (que tinha os trajetos limitados pelas estações), o ac esso aos bairros periféricos tornou-se a solução para a crise de moradia, permitindo a autoconstrução de casas em lotes periféricos. Do ponto de vista urbanístico, data também deste período o "Plano de Avenidas de P restes Maia" (1930), um dos primeiros planos que pensava na totalidade de São Paulo, nos fluxos globais e locais, e o desenho da cidade, portanto, seguiu o modelo rodoviarista, estruturando o crescimento da cidade ao longo das décadas posteriores.

Ainda neste contexto, no an o de 1934 foi criado $^{15}$ o Departamento de Estradas de $\mathrm{R}$ odagem (DER) e, com a ajuda do I nstituto de $\mathrm{P}$ esquisas Tecnológicas (IPT), foram elaborados estudos e en saios de materiais de estabilidade das estruturas viárias, além de i ncorporar técnicas de aerofotogrametria para o traçado das rodovias.

A transição do $m$ odelo ferroviário para o r odoviário teve como base a própria mudança no ciclo econômico nacional (BARAT 1978), isto é, o modelo agro-exportadora, que implantou as linhas férreas conectando o interior com os portos regionais, revelou-se inadequado para as necessidades da i ntensa industrialização que ocorria a partir das décadas de 1930 e 40 . O s istema rodoviário surge como solução para o movimento geral de cargas e fluxos de

15 http://www.der.sp.gov.br/home.aspx. . O objetivo geral do DER era planejar, projetar, implantar, pavimentar, manter, operar e administrar as estradas de rodagem do estado de São Paulo. 
bens intermediários, assim como para o atendimento do mercado interno que começa a se formar. As ligações rodoviárias apresentavam, neste início da substituição do padrão de circulação, ainda um "caráter local".

A transição da metrópole moderna para a metrópole contemporânea teve enorme influência destas bases técnicas novas do $p$ eríodo. Se os primeiros impulsos da metropolização foram estruturados pelas ferrovias, pelo motor a v apor alimentado pelo carvão, pela concentração das indústrias e bairros operários no centro das cidades, a segunda "modernização" se deu pelas rodovias, energia elétrica e início da dispersão territorial das atividades, o que claramente afetou as demandas por transporte de pas sageiros e de cargas.

Com o c rescimento e d iversificação da indústria, são também incrementados os fluxos da migração interna (urbana-rural e urbana-urbana) no pós-segunda guerra mundial; especialmente as populações nor destinas e mineiras eram atraídas a São Paulo, em busca de melhores condições de vida. A capital demonstra desde então uma grande concentração populacional e de atividades industriais, assim como uma explosão da demanda de s erviços básicos, dentre eles o de transporte.

O surgimento de nu merosos atores "autônomos" que exploravam o serviço de ônibus se tornou preocupante. O contrato com a empresa Light que cuidava dos transportes públicos paulistas da ép oca - também teria sua vigência encerrada em 1941; a empresa, ávida por reajustes nas tarifas, já não se interessava mais pelos serviços de transporte e a pop ulação estava insatisfeita com a qual idade dos serviços. A situação era de $f$ alta de racionalidade na prestação dos serviços de transporte, e a idéia geral era que uma única empresa atenderia melhor à coletividade, podendo planejar e controlar a gestão dos transportes. Segundo nos mostra também Raquel Rolnik (1997, p. 172),

"Estudos sobre transporte publico começaram a ser realizados nesse período com o objetivo de preparar a municipalização dos serviços, o que se concretizaria em 1945 com a criação da CMTC - Companhia Municipal de Transportes Coletivos -, que substituiu a LIGHT na gestão 
e operação de toda a rede de transporte público municipal da cidade de São Paulo".

A CMTC, com concessão de 30 anos para a prestação dos serviços de transporte público, deveria atender às necessidades de transporte da população de maneira econômica, eficiente e r acional, ajustando a of erta à demanda, eliminando os desperdícios da competição e tendo como elemento central o monopólio da prestação dos serviços. A frota da Light foi assumida pela CMTC em 1947, quando os bondes transportavam $65 \%$ da população, restando $35 \%$ do transporte aos ônibus.

Neste contexto, uma "revolução" nos sistemas de transporte, especialmente nas rodovias, define um novo marco na integração nacional, no acesso aos mercados, na c irculação de m atérias primas e m ercadorias, assim como na conectividade entre as populações de diversas cidades. Para Milton Santos (2009, p. 38),

\begin{abstract}
"É apenas após a S egunda Guerra mundial que a i ntegração do território se torna viável, quando as estradas de ferro, até então desconectadas na maior parte do país, são interligadas, constroem-se estradas de rodagem, pondo em contato as diversas regiões entre elas e com a região polar do país, empreende-se um ousado programa de investimentos em infra-estruturas."
\end{abstract}

Até então, a i nfra-estrutura viária interna da cidade era limitada ao sistema rádio-concêntrico de Prestes Maia, estruturada pelas avenidas radiais e perimetrais, que no " centro velho" recebeu ainda algumas vias complementares. Entretanto, os congestionamentos já eram uma realidade com a multiplicação dos ônibus e automóveis.

Juscelino Kubitschek (1956) consolidou a indústria automotiva, criou o GEIA (Grupo Executivo da Indústria Automobilística) e neste mesmo ano foi inaugurada, em São Bernardo do Campo, a primeira fábrica de caminhões com motor nacional da Mercedes-Benz. Essas novas localizações industriais ligadas à produção automotiva trouxeram ao estado tecnologia de $p$ onta, empregos, desenvolvimento industrial e uma nova relação de capital-trabalho, com o crescimento e fortalecimento dos sindicatos de classes. 
A bem sucedida indústria automobilística - somada à progressiva deterioração do sistema ferroviário - consolidou de tal modo a disseminação do modelo rodoviário, que na década de 1960 já se constatava uma hipertrofia do sistema rodoviário, pois o significativo aumento das classes médias e a intensa atividade industrial resultaram em um expressivo aumento do tráfego de pessoas e cargas ${ }^{16}$. A concentração das atividades na área central da cidade de São Paulo já provocava as primeiras crises de circulação, ameaçando o próprio desenvolvimento econômico local.

Neste período, podemos identificar nos trabalhos de Grostein e Meyer (2004) a pol ítica pública de c onstrução de av enidas em fundos de $v$ ales, objetivando mitigar problemas de saneamento básico dos grandes rios, além de criar novos eixos importantes no sistema viário da cidade, buscando aliviar o tráfego já carregado na par te central da c idade. É nesse contexto que começam a avançar a construção da Marginal Tietê e Marginal Pinheiros.

Com o aum ento da dem anda por serviços e i nfra-estrutura de transportes que integrasse diversos municípios, foi criada em 1963 a Secretaria Estadual de Logística e $\operatorname{Tr}$ ansportes ${ }^{17}$. Neste mesmo ano, também foram criadas as comissões de es tado e municipio para os estudos de criação do "Metrô". Em 1966 formou-se o Grupo Executivo do Metropolitano (GEM), que tinha como objetivo organizar nova concorrência internacional para um estudo de viabilidade econômico-financeira deste complexo sistema de engenh aria. Assim, a Câmara Municipal aprovou em 1966, a c riação da Companhia do Metropolitano de São Paulo. Em 1968 o s istema de bondes da cidade, após anos de decadência, foi desativado, e ne ste mesmo ano a $P$ refeitura cria a

\footnotetext{
${ }^{16}$ Principalmente no que se refere aos fluxos entre matéria prima/indústria/mercado consumidor

17 "época na qual o crescente desenvolvimento industrial paulista, principalmente o do s etor automobilístico, passava a exigir uma rede de rodovias cada vez mais sofisticada. Ao mesmo tempo, o surgimento de centros populacionais e industriais ao redor das estradas solidificava a importância do modal para o de senvolvimento do Estado. Nessa época, o Departamento de Estradas de Rodagem - DER já havia construído 15 mil quilômetros de importantes rodovias como a Via Anchieta, Via Anhanguera, Oswaldo Cruz e M arechal Rondon. Esse cenário, associado ao papel dos modais ferroviário e ae roviário, sinalizava ao $\mathrm{p}$ oder público a necessidade de um a administração que c oordenasse o setor de transportes de responsabilidade do Estado" (Secretaria Estadual de Logística e Transportes, 2012). http://www.transportes.sp.gov.br/default.asp
} 
Companhia do Metropolitano de São Paulo iniciando as obras da "linha NorteSul". Porém, por seu alto custo, logo a Companhia do Metrô foi assumida pelo governo estadual. Finalmente, em 1974 a Li nha 1 (Azul) começa a oper ar comercialmente, sendo concluída em 1975. Com o passar das décadas outras linhas foram sendo construídas, vagarosamente e sempre aquém da demanda necessária.

Em $1963^{18}$ é criada a S ecretaria Municipal de Transporte, progressivamente também foram criados setores especializados dentro desta secretaria, como o Departamento de O peração do Sistema Viário (DSV) e o Departamento dos Transportes Públicos (DTP). A necessidade de $\mathrm{m}$ aior controle sobre os transportes a nível local torna-se uma realidade, a explosão demográfica que ocorreria nas próximas décadas aumentaria dramaticamente a demanda por transporte, assim como a necessidade de planejamento, gestão e fiscalização.

Paralelamente à melhoria e complementação das vias arteriais e vias expressas, ocorria a modernização da gestão pública da c irculação com a criação da Cia. de Engenharia de Tráfego ${ }^{19}$. (CET) em 1976. Esses elementos constituíram na década de 80 um espaço inteiramente interligado, melhorando as condições de circulação da capital (tanto em seus aspectos intra-urbanos quanto inter-urbanos).

A consolidação do sistema rodoviário se acentuava na década de 1970 com a política de arrecadação de impostos sobre lubrificantes e combustíveis consumidos pelo setor industrial e dom éstico, os recursos eram destinados principalmente aos programas de expansão da malha rodoviária.

18 "a Secretaria Municipal de Transportes é responsável por estudar o planejamento, integração, supervisão, fiscalização e controle dos transportes coletivos, táxis, veículos de carga e out ros. É de s ua competência os serviços de transportes da Prefeitura e a manutenção, suprimento e controle dos respectivos veículos e máquinas de terraplanagem e equipamentos especiais, e os serviços de trânsito da competência do M unicípio e os que eventualmente lhe sejam delegados pelos poderes competentes, na forma legal própria". (Secretaria Municipal dos Transportes,

2012). http://www.prefeitura.sp.gov.br/cidade/secretarias/transportes/.

${ }_{19}$ A CET é contratada pelo DSV que pertence Secretaria Municipal de Transporte, sua função é planejar e implantar, nas vias e logradouros do município, a operação do sistema viário, com o fim de assegurar maior segurança e fluidez do trânsito. 
Além do avanço do sistema rodoviário que ocorria, em 1971 é criada a Ferrovia Paulista S/A (FEPASA), empresa de estradas de ferro brasileira que pertencia ao governo do estado de S ão Paulo (embora sua malha se estendesse por outros estados da Federação). Sua concepção surgiu por parte deste governo, com a proposta de unificação das diversas ferrovias existentes, por medidas de ordem econômica e administrativa. A empresa incorporou no ato de sua criação o acervo total da Companhia Mogiana de Estradas de Ferro, da Estrada de Ferro Araraquara S/A, Estrada de Ferro Sorocabana S.A. e a Estrada de Ferro São Paulo e Minas.

Foi através do decreto estadual n 13.325 de 1979 que o Detran/SP foi reorganizado e estruturado ${ }^{20}$. O Departamento participa do Conselho da Polícia Civil através da S ecretaria de Segurança Pública, e vincula-se também ao Conselho Estadual de Trânsito - CETRAN. Atualmente o Departamento Estadual de Trânsito de São Paulo (Detran. SP) faz parte do Sistema Nacional de Trânsito (SNT) e é r esponsável no estado pelas atividades de t rânsito estabelecidas pelo Código de Trânsito Brasileiro (CTB) e p or normatização própria.

É neste contexto que surge também a nec essidade de controle e expansão dos transportes coletivos urbanos de caráter intermunicipal, já que ele apresenta forte relação com a metropolização ${ }^{21}$; a demanda intermunicipal aumentava drasticamente enquanto os serviços ainda eram prestados em nível local. A Empresa Metropolitana de Transportes Urbanos do E stado de São

\footnotetext{
${ }^{20}$ São competências do Detran.SP promover educação para o trânsito, planejar, coordenar, executar e controlar ações relacionadas à habilitação de condutores, documentação e serviços para veículos com unidades de atendimento em todos os municípios do estado. Seu principal objetivo é a prestação de serviços à sociedade civil, no que se refere ao c ontrole de informações sobre direitos e transações de veículos, emissões e r enovações de Carteiras Nacionais de Habilitação, controle de multas de trânsito, entre outros. DETRAN-SP (2012).

21 "A industrialização, além de provocar a conurbação entre os municípios, fez com que parte deles se transformasse em bolsões residenciais, abrigando os trabalhadores com ocupação na Capital e nos municípios principais (região do ABC, Osasco e Guarulhos). Essa massa de trabalhadores necessitava de transporte público para seus deslocamentos diários. Num processo que pode chamar-se de convergente, de um lado era necessário 'esticar' as linhas urbanas para os municípios vizinhos, ao m esmo tempo em que as linhas interurbanas rodoviárias começavam a adquirir características urbanas. Na década de 70 o transporte intermunicipal urbano já era uma realidade, com seu controle atribuído ao DER" (EMTU/SP 2010)
} 
Paulo (EMTU/SP) é c riada em $1977^{22}$, quando se institucionaliza o chamado "Sistema Metropolitano de Transportes Urbanos". Em 1988 a EMTU/SP recebe a atribuição de gerenciar e fiscalizar o Sistema de Transporte Intermunicipal de passageiros por ônibus na Região Metropolitana, que a té então era responsabilidade do Departamento de E stradas de Rodagem (DER), este processo é explicado pela própria EMTU/SP:

A Companhia Brasileira de Trens Urbanos (CBTU) ${ }^{23,}$ criada em 1984 com a junção da E mpresa de Engenharia Ferroviária S.A. (ENGEFER) e a Diretoria de Transportes Metropolitanos (DTM) da R ede Ferroviária Federal S.A. (RFFSA), tinha como atribuições a responsabilidade da operação e exploração comercial do transporte de passageiros em todo o Brasil, além de planejar, realizar estudos, projetos e i mplantar o s istema de $t$ ransporte de passageiros, ficando sob a responsabilidade da RFFSA o ger enciamento do transporte de carga sobre trilhos.

Mesmo com alguns avanços no sistema ferro-metroviário, segundo dados das pesquisas origem/destino ${ }^{24}$ de 1967, 1977, 1987 mais de $80 \%$ das viagens eram realizadas pelo sistema rodoviário nesse período. $\mathrm{O}$ sistema de transporte público de massa sempre foi dependente dos ônibus, constituindo um grande erro, pois segundo Barat (1978) os ônibus têm características técnicas e operacionais que o definem como um transporte de "natureza complementar". O autor também destaca que a precariedade e deficiência nos serviços de ônibus foram estímulos adicionais ao uso do transporte individual, onde o a utomóvel surge como "personagem mais importante das vias urbanas".

O processo de g lobalização, que c onstantemente modifica a configuração territorial dos países, também acarretou em fortes mudanças na organização do t ransporte. Para Figueroa (2005) as transformações econômicas na A mérica Latina a par tir da década de 1980, motivadas

\footnotetext{
${ }^{22} \mathrm{http}: / /$ www.emtu.sp.gov.br/

23 http://www.cbtu.gov.br/

24 Fonte: Pesquisa O/D-Metro (RMSP).
} 
principalmente por políticas "de livre mercado", assim como pelo desenvolvimento de novas tecnologias da informação (com maior participação das atividades de serviços), resultaram em mudanças nas políticas de transporte público, a saber: tendência a liberalização das políticas do s etor; competição com o aut omóvel particular; surgimento de nov as estruturas de viagens e cobertura de áreas urbanas mais extensas com menor densidade de demanda.

Neste contexto identificamos uma grande "instabilidade" e descontinuidade institucional nos serviços públicos formais das metrópoles brasileiras, dadas as características que estes serviços apresentam, como: baixo rendimento dos sistemas, perda de clientela, aumento nos custos e tarifas, congestionamentos, abundancia do automóvel privado e novas formas precárias e i nseguras de t ransporte coletivo (clandestinos). Estas "instabilidades" levaram a um verdadeiro esgotamento do s istema de ôni bus municipal, a partir da década de 1990. A redução do papel do Estado resultou na abolição dos subsídios, na falta de financiamento para a operação das empresas públicas, gerando déficit, estimulando os ucateamento e a privatização das empresas públicas de transporte. Surgem novos empresários no setor, assim como se banaliza o transporte informal (clandestino) e precário, especialmente nas áreas periféricas e de d ifícil acesso nas grandes cidades. Os espaços de altas e baixas densidades criaram fluxos diversos com maior número de viagens e menor demanda.

Este esgotamento institucional foi ainda agravado com of enômeno recente da banalização do automóvel particular nas grandes cidades brasileiras. Com a recuperação econômica na década de 2000, a abertura do mercado e a r edução considerável dos preços relativos dos automóveis, o crescimento da taxa de motorização foi elevado, ocasionando uma pressão ainda maior dos automóveis nas cidades, gerando grandes congestionamentos e levando a uma degradação da qualidade de vida nos espaços urbanos de média e grande dimensão. Os custos dos transportes aumentaram significativamente, segmentando os usuários ao acesso diferenciado aos serviços. No caso específico de São Paulo, as políticas de ajuste fiscal e de 
"diminuição da aç ão do E stado" - típicas da globalização - tiveram como resultado a decomposição da CMTC na década de 90 , que desempenhava funções de gestão e operação do sistema de transporte coletivo, detendo cerca de $1 / 3$ de participação no sistema urbano de transporte coletivo por ônibus ${ }^{25}$.

O sistema, na época, remunerava as empresas operadoras pelo serviço com base em uma forte política de subsídios públicos à tarifa do transporte urbano. Com a crise fiscal do Estado e a política de corte de gastos, no ano de 1995 a CMTC foi transformada numa nova empresa, a São Paulo Transporte S.A. (SPTrans) tendo a função exclusiva de gestão, elaboração de projetos, programas dos transportes e fiscalização. As atividades operacionais (serviços prestados / linhas de ônibus) são terceirizadas e executadas por empresas contratadas por licitações públicas.

A necessidade de um órgão que cuidasse especificamente do transporte metropolitano resultou na criação ${ }^{21}$ da Secretaria de Estado dos Transportes Metropolitanos (STM) em 1991, estabelecendo a ex ecução da política de transportes na R egião Metropolitana de S ão Paulo. Foram atribuídas a es ta nova Secretaria o g erenciamento, fiscalização e administração do transporte público intermunicipal das Regiões Metropolitanas do Estado. Inicialmente, estavam vinculadas à STM a Companhia do $M$ etropolitano de São Paulo (Metrô) e aE mpresa Metropolitana de Transportes Urbanos (EMTU); posteriormente, foram incorporados também aE mpresa Paulista de Planejamento S.A. (EMPLASA) e o Fund o Metropolitano de $F$ inanciamento (Fumefi). A Companhia Paulista de Trens Metropolitanos (CPTM), criada em 1992, já nasceu vinculada à STM.

Neste complexo sistema de ações voltado para garantir o funcionamento de um novo padrão de c irculação na Região Metropolitana, a $C$ ompanhia Paulista de Trens Metropolitanos (CPTM) deveria assumir os sistemas de trens da Região Metropolitana de São Paulo, operados pela CBTU e pela FEPASA, de forma a assegurar a continuidade, modernização e melhoria dos serviços. Em setembro de 1993, a CBTU deixa de ser subsidiária da RFFSA, tornando-

${ }^{25}$ www.sptrans.com.br/a_sptrans/ 
se uma empresa ligada diretamente ao Ministério dos Transportes, com sua missão, a partir de então, focada na modernização e expansão dos sistemas que operava, visando transferir a administração e gestão do sistema para os poderes locais de governo. Em 1994, o sistema ferroviário é transferido para o Governo do Estado de São Paulo, representado pela Companhia Paulista de Trens Metropolitanos (CPTM), que t ambém incorporou a parte da $\mathrm{m}$ alha ferroviária da FEPASA que é utilizada, sobretudo, para o transporte suburbano nas regiões Oeste e Sul da "Grande São Paulo".

Nesta etapa de transição da administração do s istema ferroviário de passageiros, a situação era de enorme carência e deficiência estrutural, não sendo incomum que usuários circulassem nas vias férreas para passar de uma plataforma a out ra, assim como trens que $v$ iajam de por tas abertas com pessoas dependuradas, vagões depredados, freqüentes mortes e acidentes, surfistas de trem, entre outras infelizes cenas rotineiras. A frota herdada pela CPTM se encontrava bastante deteriorada, o que I evou à i mplantação do primeiro programa de modernização das composições pela aquisição de novos carros e de reforma de outros.

A partir de 2000, sob coordenação da STM, a C PTM passa a oper ar estações subterrâneas integradas com o Metrô, revelando a busca pela conexão intermodal. As estações e as linhas da CPTM são ampliadas, modernizadas e i nformatizadas, assim como novos trens são adquiridos e reformados; surgem ainda novos centros de controle operacional. A integração com o Metrô é r eforçada com o "bilhete único" ${ }^{26}$, surgem os bicicletários em algumas estações, obras para melhorar a acessibilidade nas estações também são executadas. Novos sistemas de s inalização e de c ontrole dos trens

${ }^{26}$ Bilhete Único é um cartão inteligente que armazena valores em reais para o pagamento de passagens no transporte público da cidade (ônibus, micro-ônibus, Metrô e CPTM). A integração ocorre da seguinte forma: da pr imeira vez em que oc artão é encostado no validador, é debitada a tarifa-padrão (ônibus ou Metrô/CPTM). Quando o passageiro troca de modal, o validador desconta a diferença entre as tarifas, no período de até duas horas. Nos ônibus, você pode fazer quatro embarques no prazo de até três horas, utilizando o Bilhete Único Comum e até duas horas utilizando o Bilhete Único Vale-Transporte. Se, usar Metrô ou trem dentro das primeiras duas horas, você pagará apenas a di ferença para completar o valor da tarifa integrada (SPTrans 2012). 
baseado nas telecomunicações são implantados, resultando na redução dos intervalos, na maior segurança das operações, ou seja, instala-se uma maior racionalização do sistema.

Atualmente, a S TM atua sobre o transporte urbano metropolitano de passageiros nas três regiões metropolitanas paulistas - de São Paulo (RMSP), da Baixada Santista (RMBS), de Campinas (RMC) e da aglomeração urbana de Jundiaí. São seus objetivos ${ }^{27}$ :

1. Execução da política estadual de transportes urbanos de passageiros para as regiões metropolitanas, abrangendo os sistemas metroviário, ferroviário, de ônibus e trólebus, e demais divisões modais de interesse metropolitano;

2. Organização, coordenação, operação ef iscalização do s istema metropolitano de transportes públicos de passageiros e de $s$ ua infraestrutura viária;

3. Planejamento do transporte coletivo de c aráter regional e e laboração, execução e fiscalização de programas e obr as para os eu cumprimento e controle;

4. Estabelecimento de normas e regulamentos referentes ao planejamento, à implantação, à e xpansão, à melhoria, à operação e à manutenção dos serviços;

5. Outorga de c oncessões, permissões e autorizações dos serviços, sua fiscalização e fixação das respectivas tarifas nos termos da legislação vigente.

6. Promoção do sistema metropolitano de transportes públicos de passageiros junto aos municípios integrantes das regiões metropolitanas, podendo ser realizada em conjunto com outros órgãos públicos ou entidades privadas que atuem no setor.

\footnotetext{
27 "A Secretaria dos Transportes é u m órgão articulador de políticas que promovam a integração dos modais e que resultem em eficiência logística à serviço das demandas da sociedade e das futuras gerações. S ua missão é desenvolver um sistema de transportes seguro, rápido, econômico, integrado, confortável e abrangente que assegure a mobilidade de bens e de pe ssoas e estimule o desenvolvimento econômico, social e ambiental sustentáveis para o Estado de S ão Paulo" (Secretaria dos Transporte Metropolitanos, 2010) http://www.stm.sp.gov.br
} 
Entre os grandes planos e programas da STM destaque para o Plano Integrado de $\mathrm{Tr}$ ansportes Urbano (PITU), um processo permanente de planejamento com base em cenários futuros de $\mathrm{c}$ rescimento econômico, demográfico, situação do us o do s olo e dem anda por transporte cujas propostas são revisadas periodicamente, para ajustá-las as mudanças de conjuntura, mantidos seus objetivos elementares.

O Plano ${ }^{28}$ visa caminhos para mudar a $\mathrm{m}$ atriz dos transportes nas regiões metropolitanas, atualmente marcada pela primazia do automóvel particular, buscando a m elhoria gradativa e c ontinuada dos transportes públicos. Foram elaborados cenários de médio prazo desejáveis para as três Regiões Metropolitanas do Estado.

Em 2002 foi criada a A gência Reguladora de Serviços Públicos Delegados de Transporte do Estado de São Paulo (ARTESP), uma autarquia da Secretaria Estadual de Lo gística e Transporte com a finalidade de regulamentar ef iscalizar todas as modalidades de serviços públicos de transporte de passageiros intermunicipal em todo o estado, exceto nas ligações de competência da EMTU, permitidos ou concedidos a entidades de direito privado, além de implementar a política estadual de transportes. Também têm como objetivo regular ef iscalizar o programa de concessões rodoviárias executado pelo governo do estado.

Após os esclarecimentos básicos da organização histórica dos principais órgãos de planejamento, gestão e fiscalização dos transportes públicos de passageiros na área de estudo, podemos analisar detalhadamente cada sistema técnico que, conjuntamente, formam a macroacessibilidade da Região Metropolitana de São Paulo, assim como o uso que a população faz desse conjunto de sistemas, ou seja, a mobilidade.

Interpretada de maneira geral e em escala abrangente, esse coletivo de deslocamentos conforma os fluxos de passageiros da Região. Por

\footnotetext{
${ }^{28}$ Secretaria dos Transportes Metropolitanos 2012.
} 
conseguinte, este conjunto dado pelas redes-suporte e pel os fluxos possibilitados pelas redes, compõem os istema de $\mathrm{m}$ ovimento de passageiros da Macrometrópole.

2.2 Sistemas técnicos, modais de transportes e características gerais dos fluxos

A organização do sistema de transporte de passageiros está dividida na esfera municipal, estadual e federal, cada qual com suas atribuições bem definidas pela legislação vigente.

Os órgãos federais definem as diretrizes gerais e as políticas de referência para estados e m unicípios, instâncias estas responsáveis pelas medidas executivas, de planejamento, gestão, execução e fiscalização a nível regional el ocal. As normas de trânsito também são condicionantes da acessibilidade pela regulação dos deslocamentos motorizados e não motorizados. O conjunto desses órgãos forma um sistema geral de acessibilidade (sistemas de e ngenharia, regulações públicas e of erta de serviços de transporte).

As possibilidades efetivas de deslocamento terrestre no c otidiano das metrópoles se operacionalizam sob regulação estadual e municipal, na of erta de serviços de transporte coletivo, ou na infraestrutura viária (também envolve a esfera federal) disponível para o aut omóvel particular, ou ainda, nos logradouros para pedestres e ciclistas.

Dentre esse conjunto de modais disponíveis destaca-se a distinção entre meios motorizados/não motorizados; individuais/coletivos; públicos/privados. Essas relações serão desenvolvidas adiante, pois expressam a realização das possibilidades de transporte, variando a mobilidade e tipo de tecido urbano (acessibilidade).

Em linhas gerais, ao que se refere este estudo, destacam-se o transporte rodoviário (veículos particulares, sistema público regular e veículos 
fretados); o metroviário ef erroviário. Essa trama é r esponsável pela estruturação das viagens terrestres motorizadas, realizadas pelo modo individual ou coletivo, público ou privado, agrupadas segundo sua regulação, atuação e jurisdição, a saber:

\section{Quadro 1: Organização dos Transportes de Passageiros da Macrometrópole}

Paulista

\begin{tabular}{|c|c|c|c|c|c|c|}
\hline $\begin{array}{c}\text { Esfera } \\
\text { Político- } \\
\text { Administrativa }\end{array}$ & \multicolumn{2}{|c|}{ Órgãos Responsáveis } & Atividade & Tipo & Modo & $\begin{array}{l}\text { Jurisdição } \\
\text { Territorial }\end{array}$ \\
\hline \multirow{5}{*}{ Municipal } & \multirow{5}{*}{$\begin{array}{l}\text { Prefeitura da } \\
\text { Cidade de São } \\
\text { Paulo }\end{array}$} & \multirow{5}{*}{$\begin{array}{l}\text { Secretaria } \\
\text { Municipal dos } \\
\text { Transportes }\end{array}$} & $\begin{array}{l}\text { Fiscalização da } \\
\text { circulação de } \\
\text { veículos }\end{array}$ & $\begin{array}{l}\text { Veículos } \\
\text { Particulares }\end{array}$ & \multirow{5}{*}{ Individual } & \multirow{5}{*}{ Municipal } \\
\hline & & & $\begin{array}{l}\text { Regulação, } \\
\text { fiscalização dos } \\
\text { serviços e da } \\
\text { circulação dos } \\
\text { veículos }\end{array}$ & Táxi & & \\
\hline & & & $\begin{array}{c}\text { Regulação, } \\
\text { licitação e } \\
\text { fiscalização dos } \\
\text { veículos e dos } \\
\text { serviços prestados } \\
\text { por empresas } \\
\text { terceirizadas }\end{array}$ & $\begin{array}{c}\text { Transporte } \\
\text { Municipal (Ônibus, } \\
\text { Micro-Ônibus e } \\
\text { Vans) }\end{array}$ & & \\
\hline & & & $\begin{array}{l}\text { Regulação, } \\
\text { fiscalização dos } \\
\text { veículos e do } \\
\text { serviço prestados } \\
\text { por empresas } \\
\text { terceirizadas }\end{array}$ & Escolar & & \\
\hline & & & $\begin{array}{l}\text { Regulação e } \\
\text { fiscalização da } \\
\text { circulação dos } \\
\text { veículos }\end{array}$ & $\begin{array}{l}\text { Fretado (Ônibus, } \\
\text { Micro-Ônibus e } \\
\text { Vans) }\end{array}$ & & \\
\hline & & $\begin{array}{c}\text { Empresa } \\
\text { Metropolitana dos } \\
\text { Transportes }\end{array}$ & $\begin{array}{l}\text { Regulação, } \\
\text { licitação e } \\
\text { fiscalização dos } \\
\text { serviços prestados } \\
\text { por empresas } \\
\text { terceirizadas }\end{array}$ & $\begin{array}{c}\text { Transporte } \\
\text { Metropolitano } \\
\text { (Ônibus, Micro- } \\
\text { Ônibus e Vans) }\end{array}$ & & \\
\hline & $\begin{array}{l}\text { Secretaria dos } \\
\text { Transportes } \\
\text { Metropolitanos }\end{array}$ & Urbanos (EMTU) & $\begin{array}{l}\text { Regulação e } \\
\text { fiscalização da } \\
\text { circulação dos } \\
\text { veículos }\end{array}$ & $\begin{array}{l}\text { Fretado (Ônibus, } \\
\text { Micro-Ônibus e } \\
\text { Vans) }\end{array}$ & Coletivo & Metropolitano \\
\hline & & $\begin{array}{c}\text { Companhia } \\
\text { Paulista de Trens } \\
\text { Metropolitanos } \\
\text { (CPTM) }\end{array}$ & $\begin{array}{l}\text { Empresa } \\
\text { prestadora de } \\
\text { serviço }\end{array}$ & Trem & & \\
\hline & & $\begin{array}{l}\text { Companhia do } \\
\text { Metropolitano em } \\
\text { São Paulo (Metrô) }\end{array}$ & $\begin{array}{c}\text { Empresa } \\
\text { prestadora de } \\
\text { serviço }\end{array}$ & Metrô & & \\
\hline Estadual & & $\begin{array}{c}\text { Agência } \\
\text { Reguladora de }\end{array}$ & Regulação, & $\begin{array}{c}\text { Transporte } \\
\text { Rodoviário } \\
\text { (Ônibus) }\end{array}$ & & \\
\hline & $\begin{array}{l}\text { Secretaria } \\
\text { Estadual de } \\
\text { Logística e } \\
\text { Transnorte }\end{array}$ & $\begin{array}{l}\text { Serviços Públicos } \\
\text { Delegados de } \\
\text { Transporte do }\end{array}$ & $\begin{array}{l}\text { licitação e } \\
\text { fiscalização de } \\
\text { serviços prestados } \\
\text { nor emnresas }\end{array}$ & $\begin{array}{c}\text { Transporte } \\
\text { Suburbano } \\
\text { (Ônibus) }\end{array}$ & Coletivo & $\begin{array}{l}\text { Intermunicipal - } \\
\text { Não Metropolitano }\end{array}$ \\
\hline & & $\begin{array}{l}\text { Estado de São } \\
\text { Paulo (ARTESP) }\end{array}$ & terceirizadas & $\begin{array}{l}\text { Fretado (Ônibus, } \\
\text { Micro-Ônibus e } \\
\text { Vans) }\end{array}$ & & \\
\hline & $\begin{array}{l}\text { Secretaria de } \\
\text { Planejamento e } \\
\text { Desenvolvimento } \\
\text { Regional }\end{array}$ & $\begin{array}{l}\text { Departamento } \\
\text { Estadual de } \\
\text { Trânsito de São } \\
\text { Paulo (DETRAN) }\end{array}$ & $\begin{array}{l}\text { Controladas ações } \\
\text { relacionadas à } \\
\text { habilitação de } \\
\text { condutores, } \\
\text { documentação e } \\
\text { serviços de } \\
\text { regulação dos } \\
\text { veículos }\end{array}$ & $\begin{array}{l}\text { Veículos } \\
\text { Particulares e } \\
\text { Coletivos }\end{array}$ & $\begin{array}{l}\text { Individual / } \\
\text { Coletivo }\end{array}$ & Estadual \\
\hline
\end{tabular}

Elaboração: Giberti 2012. 
O quadro anterior permite visualizar a or ganização dos transportes públicos com os respectivos níveis administrativos, cabendo ao es tado a responsabilidade do transporte intermunicipal (metropolitano ou não) e ao município o transporte de nível local. $O$ transporte fretado também se enquadra nessa estrutura; caso um itinerário atue nesses 3 níveis, o cadastro deverá ser realizado em todos os órgãos competentes.

Para entendermos melhor a organização efetiva dos transportes no estado, em seus diferentes modais, apresentamos a seguir as principais características de seu funcionamento no modelo rodoviário, metroviário e ferroviário.

\section{Sistema Rodoviário}

A infraestrutura da malha viária é composta por vias classificadas de acordo com sua dimensão, capacidade de fluxo e relação com todo o sistema, denominadas via local, via coletora, via estrutural, estrada e rodovia. Esse conjunto formado pelas vias interconectadas de diferentes níveis, cada qual com sua jurisdição (municipal, estadual, federal) forma uma malha viária global.

O território paulista apresenta a $\mathrm{m}$ aior densidade de $\mathrm{m}$ alha viária do país, estando mais concentrada nos principais centros urbanos e nas regiões metropolitanas, seguida pelas principais aglomerações urbanas. Segundo a Secretaria Estadual de Logística e Transporte (2010) "a malha pavimentada do Estado totaliza 35 mil quilômetros, sendo 22 mil estaduais, 1.050 federais e 12 mil estradas vicinais.

O atual sistema rodoviário possibilita que mais de $90 \%$ da população do Estado esteja a menos de $5 \mathrm{k} \mathrm{m}$ de um a rodovia pavimentada". A tabela a seguir apresenta a evolução da malha rodoviária no estado juntamente com suas características. 
Tabela 2: Estado de São Paulo - Evolução da malha rodoviária (1989 - 2011)

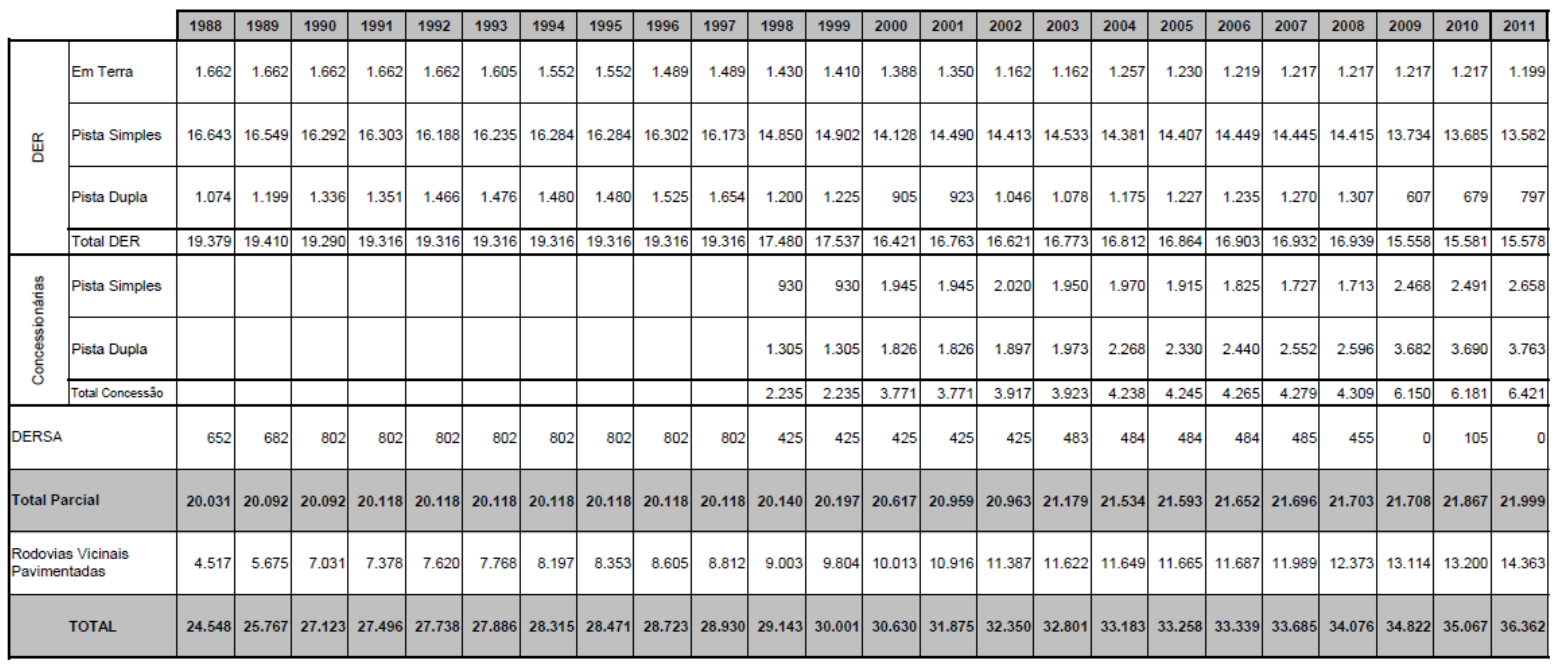

Fonte: DER 2011.

Além das estradas e r odovias, somam-se as vias municipais (locais, coletoras e arteriais), administradas pelas respectivas prefeituras. No caso do município de São Paulo ${ }^{29}$, em 2004, a extensão de vias pavimentadas era de $17.970 \mathrm{~km}$. Segundo análises de fotointerpretação, podemos estimar que aproximadamente $1 / 4$ da ár ea urbanizada é c onstituída pelo sistema viário e calçamento, ou seja, um espaço de fluxos. Nesse espaço de fluxos circulam carros, motos, ônibus, vans, caminhões, ciclistas e pedestres.

Em pontos saturados do tecido urbano a alta convergência de fluxos diversos conforma uma paisagem aparentemente confusa, composta por elementos heterogêneos extremamente regulados ef iscalizados, o m esmo ponto do tecido urbano é di sputado por distintos veículos e i nteresses cotidianos, o congestionamento de veículos e pedestres torna-se uma situação normal do dia a dia. As fotos a seguir mostram bem essa diversidade e disputa pelo mesmo espaço.

\footnotetext{
${ }^{29}$ Prefeitura de São Paulo (2011).

http://infocidade.prefeitura.sp.gov.br/index.php?cat=11\&titulo=Infra-Estrutura
} 
Foto 10 e 11: Fluxos na Av. Paulista (SP); Cruzamento da Av. Paulista (SP)
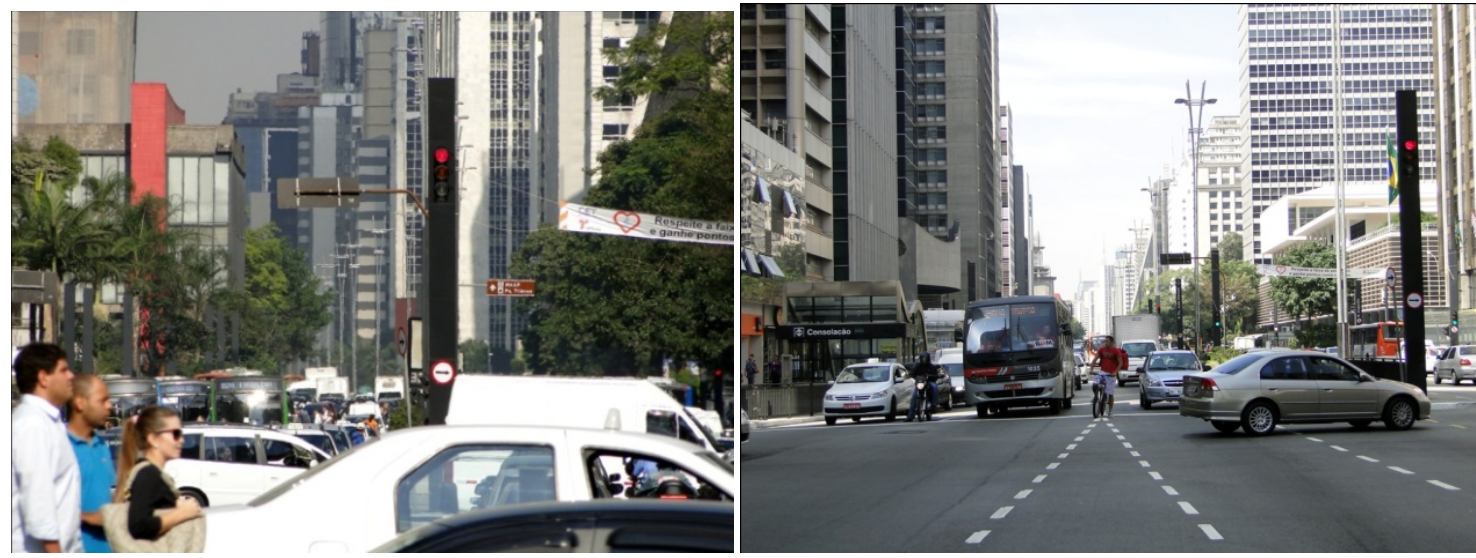

Autor: Giberti 2012.

Autor: Giberti 2012

Foto 12 e 13: Marginal Tietê x Av. Cruzeiro do Sul; Marginal Pinheiros x Ponte Estaiada
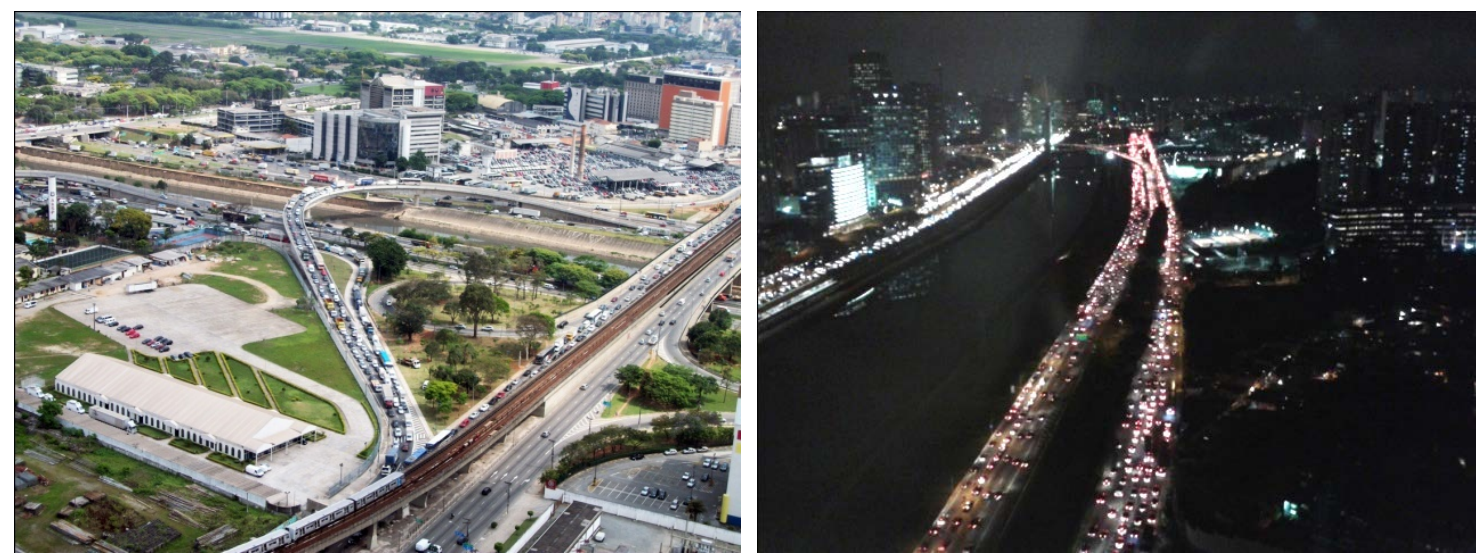

Autor: Giberti 2012.

Autor: Giberti 2012

O sistema viário tem relação direta com a realidade urbana paulista, pois foi responsável pela estruturação histórica do tecido urbano, baseada no us o de veículos automotores, na criação de eixos rodoviários de integração regional, de espaços vazios intermediários e na especulação fundiária. A alta capilaridade do sistema viário no território paulista cria uma dinâmica imobiliária de expansão urbana, apropriação de $\mathrm{n}$ ovas áreas, com implantações de fragmentos urbanos dispersos, condomínios fechados de alto padrão, conjuntos habitacionais populares, indústrias, universidades, ou até mesmo a formação de novos bairros com a tendência de implantação de infraestrtutura pública e conseqüente valorização das áreas intermediárias vazias. 
Outro aspecto importante é o pes o do sistema viário na acessibilidade do território, o que af eta o valor e o ef etivo parcelamento do solo, resultando em diferentes usos funcionais e conteúdos sociais do tecido urbano.

O processo de urbanização, portanto, é orientado pelo sistema viário; a rede urbana paulista tratada no c apítulo 1, sem dúvida alguma, é a mais dinâmica e importante do paí s, por contar com essa densa infraestrtutura rodoviária.

A cidade de São Paulo, epicentro da Macrometrópole Paulista, converge e articula 10 importantes rodovias nacionais, que representam os eixos de integração regional e suporte da troca de fluxos de passageiros, trabalhadores, matéria prima e m ercadorias. Atualmente sete das dez rodovias já estão interligadas pelo Rodoanel ${ }^{30}$, que em breve conectará a todas, fortalecendo ainda mais o modelo rádio-concêntrico, conforme será apresentado no Mapa 3.

No que se refere ao sistema de movimento rodoviário atual do estado de São Paulo, pode-se dizer que o resultado histórico das políticas de transporte permitiu alta fluidez da circulação nesta parcela do território, fluidez que foi fundamental para a viabilidade da instalação de um setor industrial moderno e que permitiu ainda um padrão complexo de ar ticulação da rede urbana regional, tendo como principal ponto articulador a cidade de São Paulo.

O Mapa 3 apresenta a seguir as principais vias que compõe a malha rodoviária paulista, rede-suporte que permite uma intensa vida de relações das cidades desta região do território brasileiro.

As ligações permitem, por exemplo, que as mercadorias importadas pelo Porto de $S$ antos sejam distribuídas em todo o es tado rapidamente, assim como permitem que a produção agropecuária e industrial seja escoada para exportação; a R egião Metropolitana de C ampinas e a

30 O Rodoanel é um anel viário que interligará 10 rodovias que chegam ao município de São Paulo ordenando o fluxo de veículos que entram e saem da capital. O projeto possibilita que veículos se conectem diretamente de uma rodovia a outra sem que tenham de passar pelas vias já saturadas da capital, aliviando o tráfego. 


\section{Mapa 3: Macrometrópole Paulista - Sistema Viário}

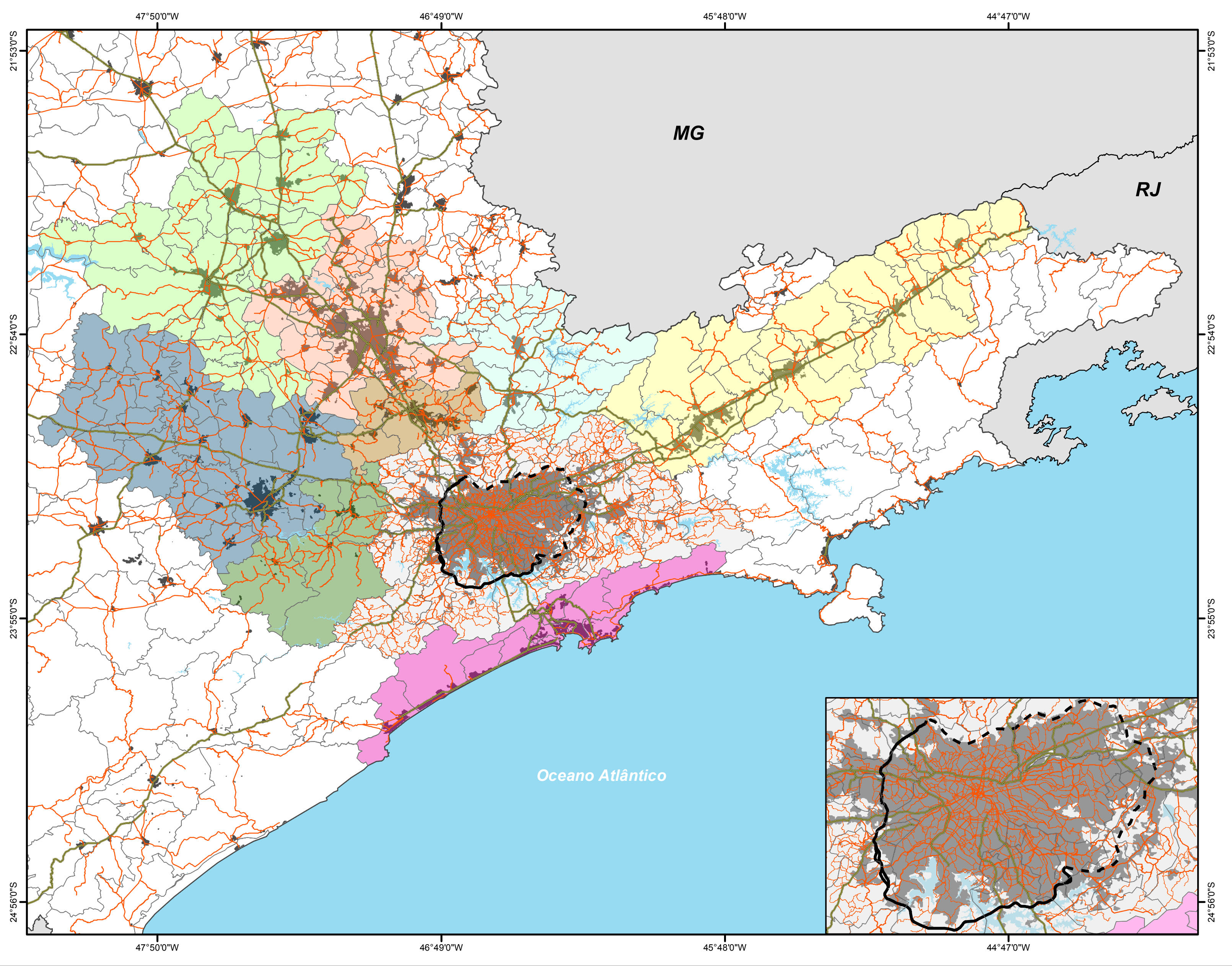

Localização Geral no Estado de São Paulo

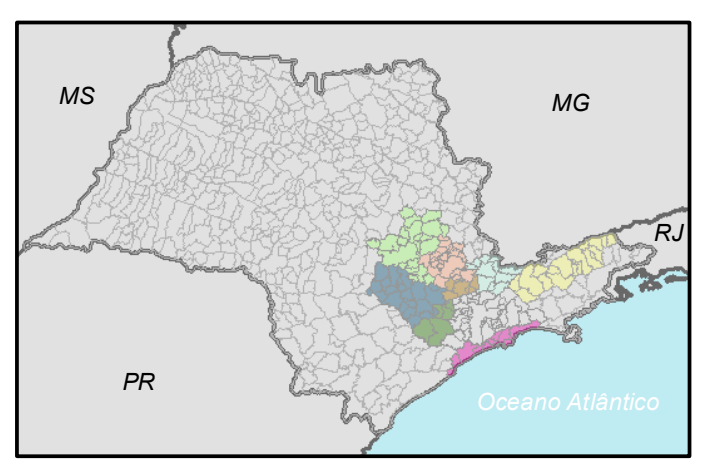

\section{Legenda}

$\square$ Limite Estadual

Limite Municipal

Oceano / Represa

Área Urbanizada 2005

$\square$ AU de Jundiaí AU de Piracicaba

AU de Sorocaba

AU de São José dos Campo

MR Bragantina

MR São Roque

RMBS

RMC

RMSP

_ Malha Viária Básica

— Rodovia Dupla

- Rodoanel Existente

- - Rodoanel Planejado

Fontes:

Limite Municipal e Estadual - IBGE 2012. Macrometrópole Paulista - EMPLASA 2011. Mancha Urbana - ProBio 2005.

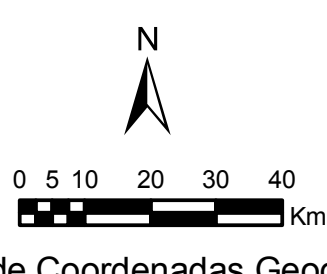

Sistema de Coordenadas Geográficas Datum WGS 84 
Região de Sorocaba funcionam como uma interface para o interior; o Vale do Paraíba forma o macro-eixo Rio de Janeiro -

São Paulo.

A capital funciona, assim, como um pólo articulador para o qua I convergem nada menos que dez importantes rodovias do estado. Os demais sub-centros regionais, apesar de contar com um menor número de ligações diretas, sem dúvida estão da mesma forma bem localizados entre os principais "nós" rodoviários.

Trafegam sobre esta complexa rede viária automóveis particulares (carros e motos), diversas linhas de ôni bus, mini-ônibus, vans, veículos sob regime de fretamento, além dos caminhões (transporte de $\mathrm{c}$ argas). Todos esses veículos transportam pessoas (ora mão de obra, ora consumidores), matérias primas, produtos agropecuários e i ndustriais, revelando uma diversidade defluxos que $\mathrm{c}$ irculam na m esma rede. Fluxos de diferentes ordens disputam a mesma rede, contribuindo para seus diferentes usos, assim como para sua "saturação", em alguns casos.

No que se refere ao serviço de transporte de passageiros em São Paulo, a frota que circula no âmbito q municipal é de aproximadamente 15 mil veículos (ônibus e microônibus), deslocando aproximadamente cinco milhões e meio de passageiros por dia útil.

A prestação dos serviços é $\mathrm{f}$ iscalizada pela SPTrans, as atividades operacionais são terceirizadas ex ecutadas por empresas que $f$ oram contratadas por licitações públicas. Atualmente as linhas de ônibus são operadas pelo setor privado, são $16 \mathrm{c}$ onsórcios (empresas e c ooperativas) responsáveis por 14.933 mil veículos (8.925 estrutural / 6.008 local) em 1.349 linhas (867 concessões / 482 permissão). No mês de março de 2012 foram realizados 262,6 milhões de e mbarques, uma média de 11,9 milhões de embarques por dia útil ${ }^{31}$. Os serviços são organizados por zonas, a saber:

\footnotetext{
${ }^{31}$ Prefeitura de São Paulo (2012).
} 
Figura 6: Organização do transporte municipal de São Paulo

\section{SISTEMA INTEGRADO}

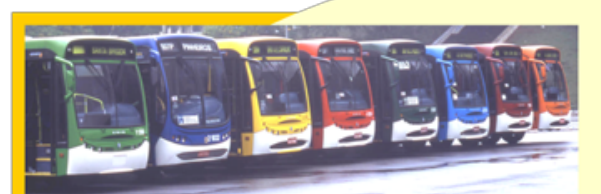

Linhas estruturais

operadas por veículos de grande capacidade (concessão)
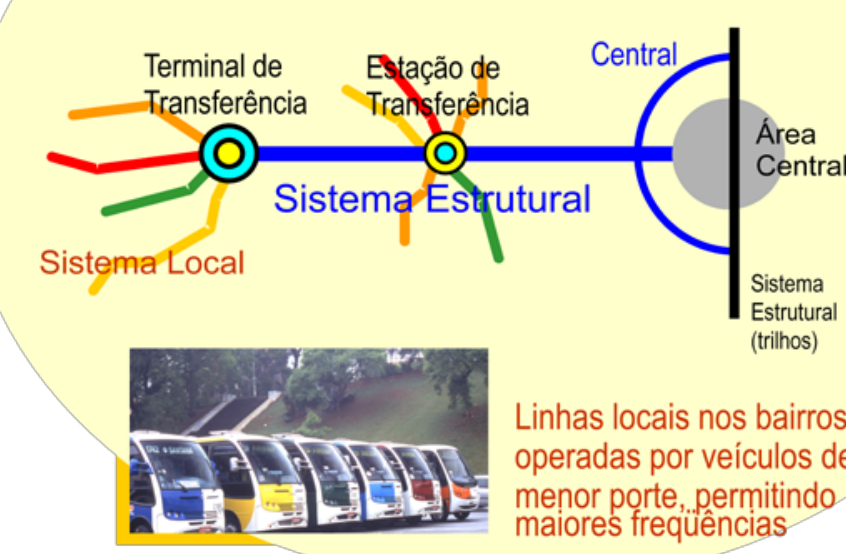

Linhas locais nos bairros operadas por veículos de menor porte, permitindo maiores frequêencias (permissão + concessão)

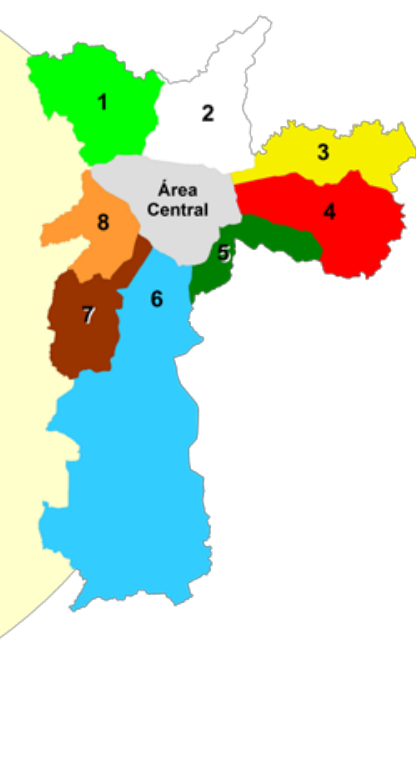

Fonte: Prefeitura Municipal de São Paulo (2012).

O sistema municipal é c omposto por linhas estruturais (veículos de grande capacidade) e linhas locais (veículos de menor capacidade), ambas se articulam e formam conexões entre as 8 zonas da cidade e oc entro. A prefeitura, além de cuidar do transporte regular municipal por intermédio da SPTrans, também cuida de o utras modalidades pelo Departamento dos Transportes Públicos, que é responsável pelo cadastro das seguintes modalidades:

Tabela 3: Município de São Paulo - Veículos Cadastrados no Departamento de Transporte Público (2012)

\begin{tabular}{|c|c|}
\hline Modalidade & Número de veículos \\
\hline Transporte Escolar & 11.589 \\
\hline Táxi & 33.697 \\
\hline Fretamento Municipal & 12.824 \\
\hline
\end{tabular}

Fonte: Departamento de Transportes Públicos - DTP/SMT (base: posição em fevereiro/12) 
A soma de todos os veículos cadastrados na prefeitura (transporte regular, escolar, táxi e fretamento), cada qual em sua modalidade, corresponde a uma frota total de aproximadamente 73 mil veículos sobre pneus, formando juntos a of erta de s erviço de transporte de caráter municipal. No caso do fretamento, modalidade que s erá trabalhada detalhadamente no pr óximo capítulo, qualquer ônibus que entre na cidade é cadastrado no Departamento dos Transporte Públicos (DTP).

No âmbito metropolitano, a EMTU (2011) atua nas 3 regiões metropolitanas do estado e na aglomeração urbana de Jundiaí, englobando 74 municípios, servidos por mais de 850 linhas em 6.114 veículos, 10 terminais na RMSP e 2 na RMC, transportando em média 2,6 milhões de passageiros por dia, além dos 15.626 veículos fretados cadastrados. O serviço é operado por empresas privadas e gerenciado pela EMTU. As atribuições e serviços de competência da EMTU ${ }^{32}$ são:

- Sistema Regular: regulamentado pelo Decreto $n^{\circ}$ 24.675/86 oferece transporte metropolitano coletivo de passageiros por ônibus.

- Serviço Comum: composto por conjuntos de linhas ligando pelo menos dois municípios que fazem parte da mesma região metropolitana. São atendidos por ônibus urbanos comuns, com transporte de passageiros sentados e em pé.

- Serviço Seletivo: composto por conjuntos de linhas ligando pelo menos dois municípios que fazem parte da mesma região metropolitana. São atendidos por ônibus do tipo rodoviário, com transporte apenas de passageiros sentados.

- Sistema ORCA: Operador Regional de Coletivo Autônomo, composto por linhas intermunicipais operadas por empresas individuais que operam, cada uma, um único veículo coletivo de pequeno porte (microônibus e vans até 20 lugares).

- Operação do Corredor Metropolitano (ABD) São Mateus - Jabaquara, de 33 $\mathrm{Km}$ de $\mathrm{v}$ ias exclusivas percorrendo cinco municípios da RMSP. O sistema ${ }^{32}$ EMTU (2012). 
conta com nove Terminais de Transferência, 111 paradas e uma frota de mais de 200 veículos. Transporta diariamente mais de 200 mil passageiros. Desde 1997 é objeto de u ma Concessão operada pela empresa Metra - Sistema Metropolitano de Transportes Ltda.

- Corredor Metropolitano Noroeste: Com 32,7 Km de extensão e $7 \mathrm{Km}$ de faixas exclusivas para ônibus, $\mathrm{OC}$ orredor liga Campinas aos municípios de Hortolândia, Sumaré, Nova Odessa, Monte Mor e Americana.

- Serviço Aeroporto (Airport Bus Service): transporte entre o A eroporto Internacional de $\mathrm{G}$ uarulhos, prestado por duas modalidades de serviço; 1. o "comum", operado por ônibus urbanos, ligando o Aeroporto e aE stação Tatuapé do Metrô; e 2. o "especial", ligando aquele terminal ao Aeroporto de Congonhas, Praça da R epública, Terminal Rodoviário do Ti etê, Circuito dos Hotéis (Região da Av. Paulista) e Shopping Eldorado.

- Ponte Orca Zoo: oferecendo transporte direto entre o Terminal Metropolitano do Jabaquara e o Zoológico de São Paulo, operado por ORCA's.

- Sistema Fretamento: Decreto $n^{0}$ 19.835/82. Apresenta como característica básica a cobrança periódica para execução do serviço. A EMTU é responsável pelo cadastro e vistoria de veículos sob regime de fretamento.

A tabela as eguir apresenta dados gerais do sistema regular metropolitano, porém, não contabiliza os fretados. Caber ressaltar que as linhas são de c aráter intra-metropolitano e não at endem às conexões intermetropolitanas de competência da ARTESP. A pendularidade se realiza em grande parte pelas linhas da EMTU, mas também pelas linhas fretadas e pelos veículos particulares, como veremos adiante. 
Tabela 4: RMSP, RMBS, RMC - Dados Gerais - Empresa Metropolitana de Transportes Urbanos (EMTU) - 2011.

\begin{tabular}{|c|c|c|c|c|}
\hline & RMSP & RMBS & RMC & Total \\
\hline $\begin{array}{c}\text { Passageiros I Mês } \\
\text { (Milhões) }\end{array}$ & 34,1 & 5 & 3,5 & 42,6 \\
\hline Frota & 4,8 mil & 494 & 601 & 5,9 mil \\
\hline Linhas & 568 & 60 & 167 & 795 \\
\hline Empresas I Consórcio & 30 & 5 & 10 & 45 \\
\hline
\end{tabular}

Fonte: EMTU (2011).

Fora do âm bito metropolitano oficial, mas também muito importante no contexto macrometropolitano, é preciso destacar toda a riqueza de atores, fluxos e rotas que está sob regulação da ARTESP que regulamenta e fiscaliza a operação do sistema de transporte intermunicipal de passageiros em todo o estado, exceto nas ligações de competência da EMTU. O serviço ${ }^{33}$ também é $^{2}$ operado por empresas particulares, e as operações obedecem ao Decreto $\mathrm{n}^{\circ}$ 29.913 de 1989 e alterações complementares, caracterizado pela operação de um conjunto de I inhas que of erecem serviço público de $t$ ransporte de passageiros entre municípios, de forma contínua e c om regularidade, de acordo com o pl ano operacional estabelecido e r ealizado nas modalidades "rodoviário" e "suburbano". O serviço rodoviário ${ }^{33}$ é de caráter expresso, com embarque e desembarque em terminais rodoviários ou agências de venda de passagens, com utilização de veículos com poltronas individuais, porta única para embarque e desembarque, bagageiro externo, sendo proibido o transporte de passageiros em pé.

O serviço suburbano realiza a cobrança de passagens no interior do veículo, com paradas efetuadas em pontos e abrigos ao I ongo do t rajeto, utilizando veículos do tipo urbano convencional com portas independentes para embarque e desembarque e as sentos não numerados. Nessa modalidade é permitido ot ransporte de pas sageiros em pé. A seguir apresentamos as conexões mais importantes.

${ }^{33}$ ARTESP (2012). 
Segundo os dados da ARTESP, as cinco maiores ligações rodoviárias em número de passageiros transportados são:

- São Paulo / Campinas

- São Paulo / São Jose dos Campos

- São Paulo / Santos

- São Paulo / Sorocaba

- $\quad$ São Paulo / Jundiaí

As cinco maiores ligações suburbanas, no que di z respeito ao número de passageiros transportados são:

- Jundiaí / Várzea Paulista

- $\quad$ São Jose dos Campos / Jacareí

- Votorantim / Sorocaba

- Guaratinguetá / Aparecida

- $\quad$ Presidente Prudente / Álvares Machado

Em janeiro de 2011 o s istema de transporte regular (rodoviário e suburbano) contava com 128 empresas, 1.130 linhas (676 linhas rodoviárias e 454 linhas suburbanas), com frota total de 4.731 (3.026 ônibus rodoviários; 1.705 ônibus suburbanos). A ARTESP também é responsável pelo cadastro e controle do serviço de fretamento, com 455 em presas cadastradas e 11.829 veículos registrados.

A demanda de $\mathrm{p}$ assageiros do sistema regular tem apresentado tendência de queda desde 1995, passando de 317 milhões de passageiros para 143,8 milhões em $2010^{34}$. Desse total o sistema rodoviário responde por 48,9 milhões de passageiros e 291,4 milhões de quilômetros percorridos; o sistema suburbano por 94,9 milhões de passageiros transportados e 111,4 milhões de quilômetros percorridos. Essa redução pode s er atribuída, entre outros fatores, a transferências para a EMTU dos serviços suburbanos nas regiões metropolitanas e à migração de passageiros do sistema regular público para o serviço de fretamento coletivo privado de caráter contínuo.

${ }^{34}$ ARTESP (2012). 
Figura 7: Transporte Regular Intermunicipal - ARTESP

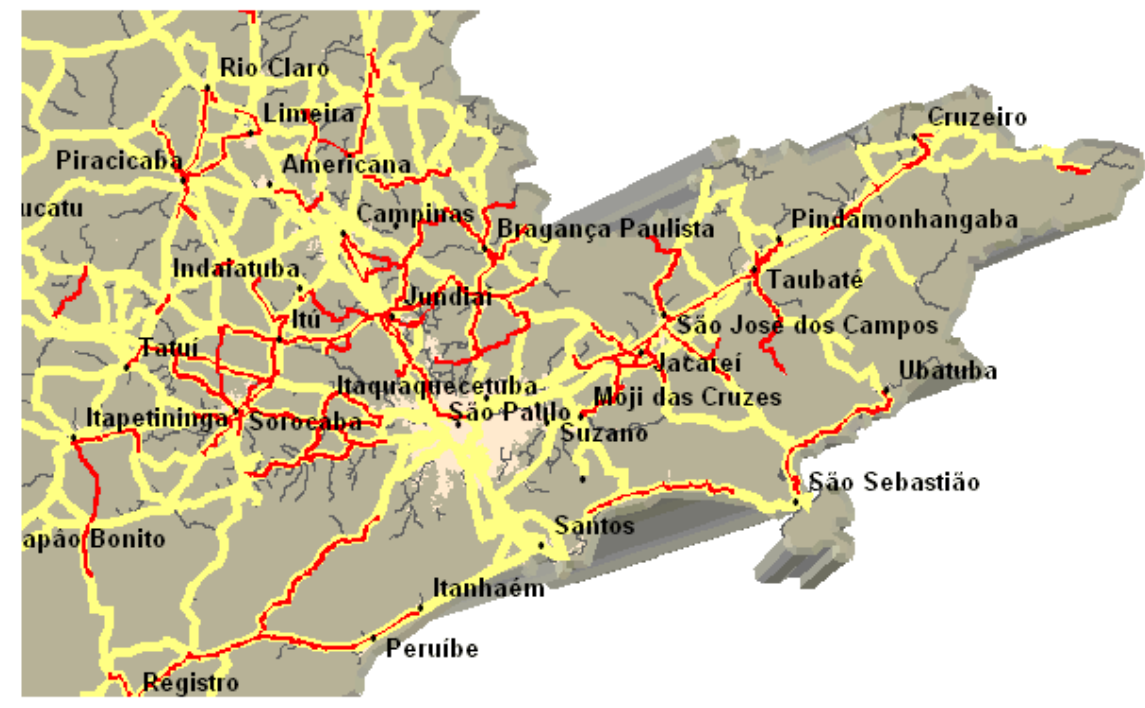

Estado de São Paulo

Transporte Intermunicipal de Passageiros

Linhas Rodoviárias

Linhas Suburbanas

Fonte: Secretaria dos Transportes do Estado de São Paulo 2005

Após caracterizar os serviços de transporte regular sobre pneus, sua infra-estrutura, organização e jurisdição, devemos analisar a s eguir os dados referentes ao cadastro de veículos, usando como exemplo o município de São Paulo, o epicentro da Macrometrópole; dessa forma, observamos uma dimensão melhor do universo rodoviário e seus fluxos.

São Paulo concentra aproximadamente $10 \%$ da frota nacional e $30 \%$ da frota estadual de veículos automotores ${ }^{35}$. Os dados obtidos podem ser analisados de varias maneiras; inicialmente, podemos constatar (gráfico 1) que de 1980 até $2011 \mathrm{~h}$ ouve um crescimento de $447 \%$ no nú mero total de veículos, chegando à i ncrível marca de 7.177.082 o que $r$ epresenta uma densidade aproximada de 47 veículos/ha no município ${ }^{36}$.

${ }^{35}$ DETRAN-SP (2012).

36 São Paulo conta com aproximadamente $1.523 \mathrm{Km}^{2}$ de área (IBGE 2012). 
Gráfico 1: Município de São Paulo - Evolução da frota de veículos (1980/2011)

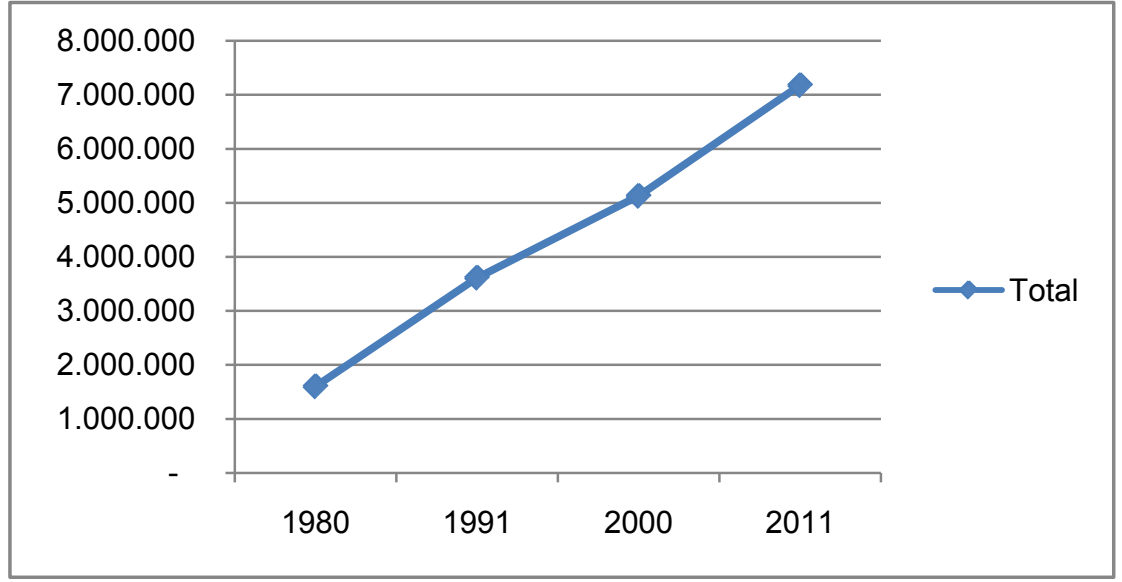

Fonte: Departamento Estadual de Trânsito/Detran SP (2012).

Elaboração: Giberti 2012.

Conforme a tabela 5 e os gráficos 2 e 3, no último decênio (2000/2011) identificamos que a s upremacia do aut omóvel teve uma leve queda relativa, passando de $78 \%$ para $72,6 \%$ da frota total. Destaca-se também o crescimento da frota de $m$ otos e motonetas, subindo de $7,2 \%$ para $12,9 \%$, superando 0 utilitário ${ }^{37}$ que se manteve na faixa dos $10 \%$. Por fim, os caminhões tiveram uma queda considerável de $3 \%$ para $2,2 \%$, assim como os ônibus de $1,1 \%$ para $0,6 \%$. O incremento total de veículos foi de 2.048.848 unidades, esse montante foi distribuído de $\mathrm{m}$ aneira desigual nas médias anuais, variando bastante, chegando a ex tremos como entre 2008 e 2009, onde s e pode constatar uma incrível média de 919 veículos novos por dia, dos quais o automóvel representava pouco mais de 2/3.

Tabela 5: Município de São Paulo - Evolução da frota por tipo de veículo (1980/2011)

\begin{tabular}{|c|c|c|c|c|}
\hline Veículo & $\mathbf{1 9 8 0}$ & $\mathbf{1 9 9 1}$ & $\mathbf{2 0 0 0}$ & $\mathbf{2 0 1 1}$ \\
\hline Automóvel & - & - & 4.000 .271 & 5.210 .725 \\
\hline Ônibus & - & - & 58.499 & 43.248 \\
\hline Caminhão & - & - & 152.189 & 155.438 \\
\hline Utilitário & - & - & 484.091 & 759.128 \\
\hline Moto/Motoneta & - & - & 368.690 & 926.278 \\
\hline Outros & - & - & 64.494 & 82.265 \\
\hline Total & 1.604 .135 & 3.614 .769 & 5.128 .234 & 7.177 .082 \\
\hline
\end{tabular}

Fonte: Departamento Estadual de Trânsito/Detran SP (2012)

37 Utilitário - veículo misto caracterizado pela versatilidade do seu uso, inclusive fora de estrada. (DETRAN-SP 2012). 
A frota paulista em 2011 contava com 72,6\% de automóveis, seguida por $12,91 \%$ de motos, $10,58 \%$ de utilitários, $2,17 \%$ por caminhões e $1,75 \%$ pelos ônibus e outros veículos, ou seja, a maior parte dos veículos é está associado ao transporte individual.

Gráfico 2: Município de São Paulo - Evolução relativa dos veículos por tipo $(2000 / 2011)$

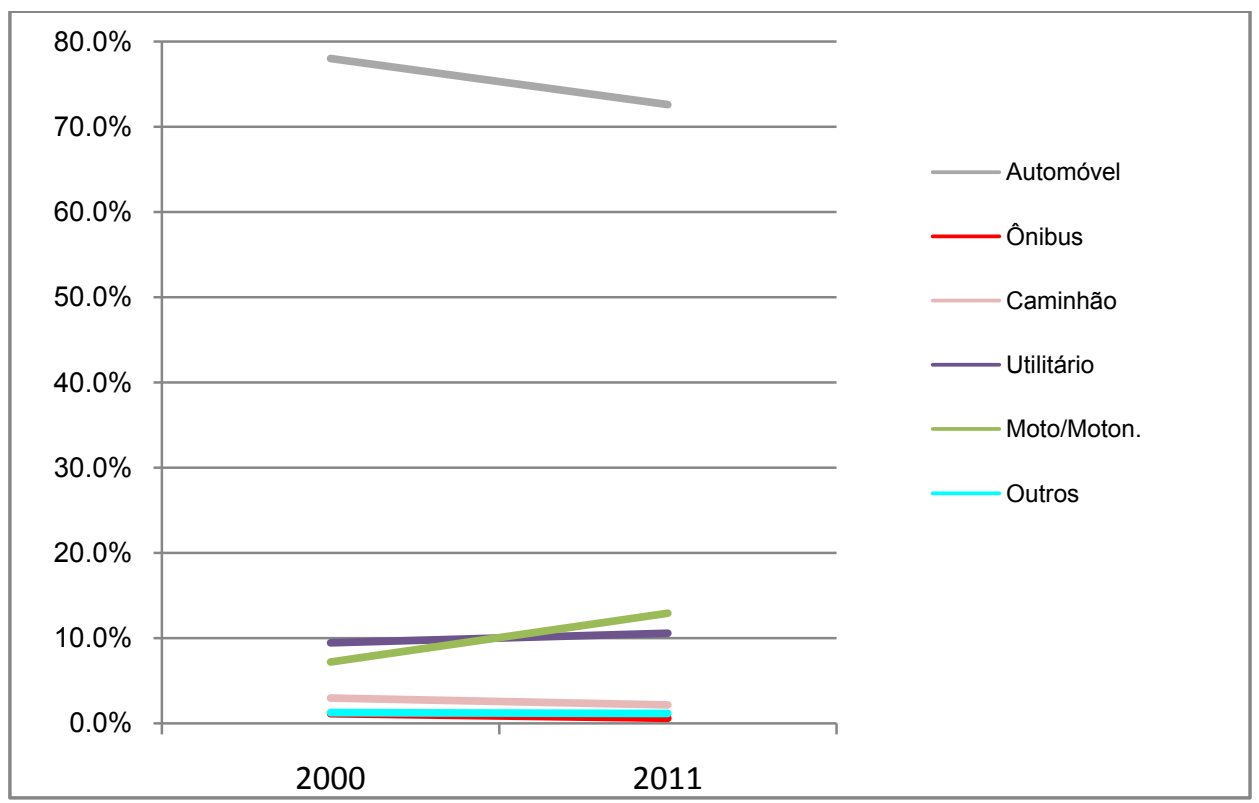

Fonte: Departamento Estadual de Trânsito/Detran SP (2012)

Gráfico 3: Município de São Paulo - Composição relativa dos veículos (2011)

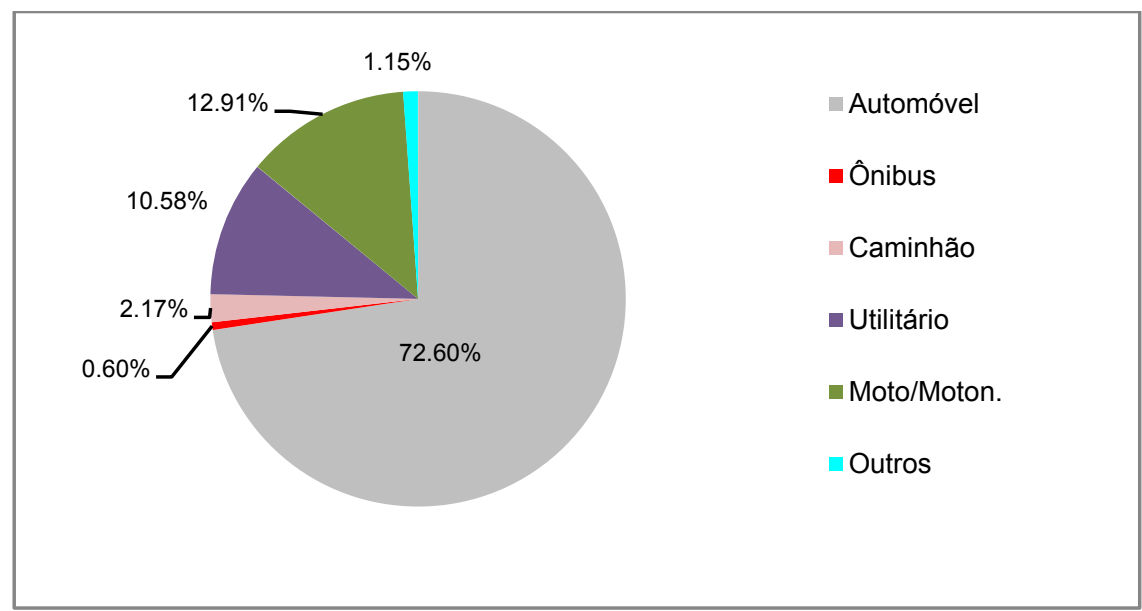

Fonte: Departamento Estadual de Trânsito/Detran SP (2012)

Ao compararmos estes números relativos ao estado de São Paulo como um todo (tabela 6) com o município, vemos que s e apresentam algumas 
diferenças como, por exemplo, a presença relativa da moto, que é bem maior no estado: $19,2 \%$ contra $12,9 \%$ no município; a frota de ônibus do município corresponde a $30,9 \%$ do estado, a de automóveis $35,3 \%$, a de caminhões $20,4 \%$. Em contrapartida o automóvel cai de 72,6\% (município) para $64,4 \%$ (estado).

Tabela 6: Estado e Município de São Paulo - Relação da frota de veículos (2011)

\begin{tabular}{|l|c|c|c|c|c|}
\hline \multicolumn{7}{|c|}{ Município } & \multicolumn{2}{c|}{ Estado } & \\
\hline \multicolumn{1}{|c|}{ Veículos } & Absoluto & Relativo & Absoluto & Relativo & Município / Estado (\%) \\
\hline Automóvel & 5.210 .725 & 72.60 & 14.745 .579 & 64.46 & 35.3 \\
\hline Moto/Moton. & 926.278 & 12.91 & 4.394 .172 & 19.21 & 21.1 \\
\hline Utilitário & 759.128 & 10.58 & 2.309 .569 & 10.10 & 32.9 \\
\hline Caminhão & 155.438 & 2.17 & 762.787 & 3.33 & 20.4 \\
\hline Outros & 82.265 & 1.15 & 524.554 & 2.29 & 15.7 \\
\hline Ônibus & 43.248 & 0.60 & 139.966 & 0.61 & 30.9 \\
\hline Total & 7.177 .082 & 100.00 & 22.876 .627 & 100.00 & 31.4 \\
\hline
\end{tabular}

Fonte: Departamento Estadual de Trânsito/Detran-SP.

Os dados analisados anteriormente são gerais e limitam-se ao município de São Paulo, mas permitem uma boa noção da quant idade dos veículos existentes e de como a vida de relações cotidianas depende deste sistema de movimento rodoviário, de c aracterística flexível, porta a por ta, com alta capilaridade territorial.

Reconhecidos o universo de veículos e o s erviço de transporte de passageiros oferecido, juntamente com a $\mathrm{m}$ alha viária existente, podemos observar dados referentes ao fluxo diário de veículos nas principais rodovias da Macrometrópole.

Conforme já citado anteriormente, a C idade de São Paulo converge e articula as principais e mais modernas rodovias do país em um padrão rádioconcêntrico que estão em fase final de interconexão pelo Rodoanel. Tendo como referência a c apital do estado, no mapa 4 ficam claros os vetores de maior fluxo diário de veículos; destacam-se por ordem de maior grandeza as seguintes conexões (DNIT 2009): 
Mapa 4: Macrometrópole Paulista - Fluxo Rodoviário - 2009

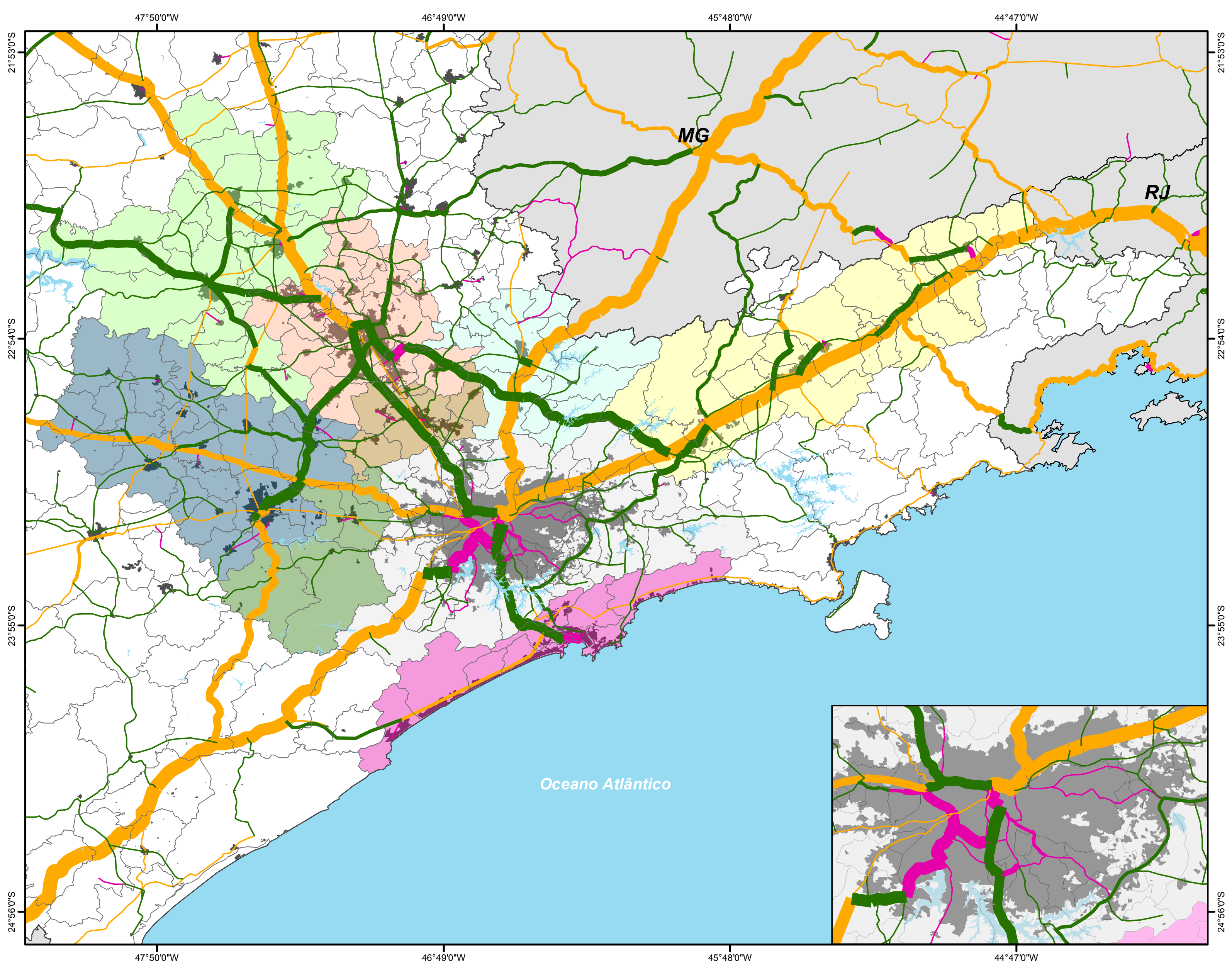

Localização Geral no Estado de São Paulo

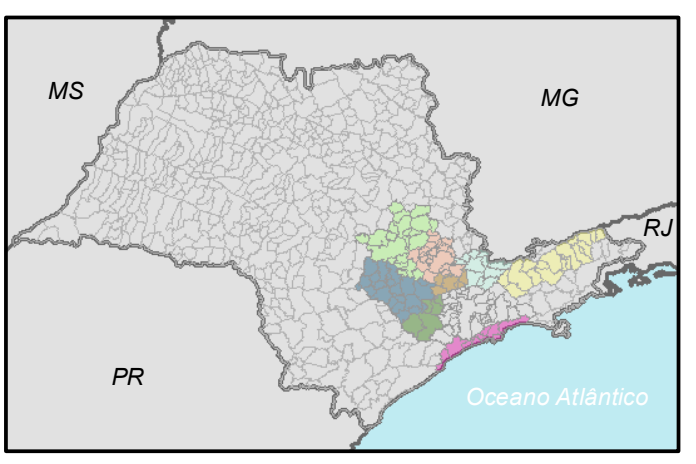

Legenda

$\square$ Limite Estadual

Limite Municipal

Oceano / Represa

Área Urbanizada 2005

AU de Jundiaí

AU de Piracicaba

AU de Sorocaba

AU de São José dos Campo

MR Bragantina

MR São Roque

RMBS

RMC

RMSP

_ Rodovia Federal

_ Rodovia Estadual

- Rodovia Municipal

Média /Fluxo Veículos / Dia / 2007

$0-400$

$400-800$

$800-1600$

$1600-3200$

$3200-6400$

$6400-12800$

$12800-25600$

$25600-33000$

Fontes:

Limite Municipal e Estadual - IBGE 2012. Macrometrópole Paulista - EMPLASA 2011. Mancha Urbana - ProBio 2005.

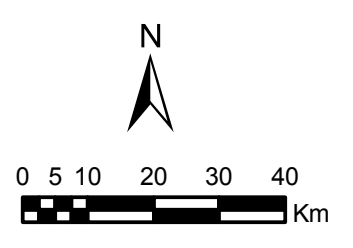

Sistema de Coordenadas Geográficas Datum WGS 84

Elaboração: GIBERTI 2012. 
1. Leste (São Paulo/Vale do Paraíba/Rio de Janeiro), com mais de 30.000 veículos/dia;

2. Nordeste (São Paulo/Minas Gerais) chegando a 15.000 veículos/dia;

3. Sudoeste (São Paulo/Paraná) com pouco mais de 10.000 veículos/dia;

4. Sul (São Paulo/Santos) com pouco mais de 8.000 veículos/dia;

5. Noroeste (São Paulo/Campinas) com quase 6.000 veículos/dia; e, por fim

6. Oeste (São Paulo/Região de Sorocaba) com quase 3.000 veículos/dia.

Observando os demais centros regionais cabe ressaltar a c onexão Campinas/Americana/Interior Paulista com pouco mais de 8. 000 veículos, seguida pela conexão Campinas/São José dos Campos, com mais de 6.000 veículos/dia e, por fim, a conexão Campinas/Sorocaba com aproximadamente 3.000 veículos/dia (DNIT 2009).

Os dados citados referem-se ao f luxo total de veículos, incluindo caminhões de transporte de cargas, veículos particulares de passageiros, veículos de transporte coletivo público e privado. Fica claro que a capital é o principal "nó" rodoviário, seguida por Campinas, São José dos Campos e Sorocaba. Desta forma, concluímos uma caracterização geral das modalidades existentes do modelo rodoviário juntamente com seus principais fluxos.

Esta é um a síntese do serviço de transporte rodoviário oferecido no estado, juntamente com o universo de veículos e os fluxos diários entre os principais "nós" do s istema rodoviário da Macrometrópole Paulista. A seguir abordamos o s istema metroviário e ferroviário, que somados ao rodoviário, compõem os sistemas de enge nharia de transporte de passageiros terrestres da área de estudo. 


\section{Sistema Metroviário e Ferroviário}

O sistema metroviário, do ponto de vista técnico, é de caráter altamente estrutural e i ntramunicipal, representando os principais vetores de m aior demanda de passageiros da cidade; é $t$ ambém por essência o $m$ eio mais adequado para o transporte de massa, atendendo às áreas mais densamente povoadas e construídas da cidade. O sistema atual ${ }^{38}$ (2012) é composto por 74,2 quilômetros de extensão, 64 estações e 984 carros, 5 linhas (linha 1: azul, linha 2: verde, linha 3: vermelha, linha 4: amarela e linha 5: lilás). As conexões entre as estações são todas internas, representando um sistema de al ta capacidade e alta velocidade. Destaque para o alto fluxo da conexão lesteoeste (linha 3) e para a conexão norte-sul (linha 1) ${ }^{38}$ conforme apresentado na tabela 7 .

Tabela 7: Município de São Paulo - Demanda de Passageiros do Metrô (2011)

\begin{tabular}{|c|c|c|c|c|c|}
\hline Demanda & $\begin{array}{c}\text { Linha 1- } \\
\text { Azul }\end{array}$ & $\begin{array}{c}\text { Linha 2- } \\
\text { Verde }\end{array}$ & $\begin{array}{c}\text { Linha 3- } \\
\text { Vermelha }\end{array}$ & $\begin{array}{c}\text { Linha 5- } \\
\text { Lilás }\end{array}$ & Rede* \\
\hline Total & 291.204 & 121.409 & 335.713 & 63.332 & 811.657 \\
\hline $\begin{array}{c}\text { Média dos dias } \\
\text { úteis }\end{array}$ & 982 & 428 & 1.119 & 213 & 2.742 \\
\hline $\begin{array}{c}\text { Média dos } \\
\text { Sábados }\end{array}$ & 552 & 178 & 663 & 124 & 1.517 \\
\hline $\begin{array}{c}\text { Média dos } \\
\text { Domingos }\end{array}$ & 307 & 96 & 379 & 63 & 845 \\
\hline \begin{tabular}{c} 
Máxima Diária \\
\hline
\end{tabular} & 1.094 & 537 & 1.261 & 262 & 3.148 \\
\hline
\end{tabular}

*Não contabiliza a linha amarela, OBS: Valores em milhares Fonte: Metro (2012).

O sistema ferroviário ${ }^{39}$ (2012) pode ser considerado uma extensão do metroviário, de caráter intermunicipal. É composto por 6 linhas (linha 7: rubi, linha 8: diamante, linha 9: esmeralda, linha 10: turquesa, linha 11: coral, linha 12: safira), inclui 89 estações, $260,8 \mathrm{Km}$ de linhas operando com uma média diária de 2.437 viagens programadas e 2, 6 milhões de passageiros

\footnotetext{
${ }^{38}$ Metro (2012).

${ }^{39}$ CPTM (2012)
} 
transportados, atendendo 22 municípios. A linha de m aior demanda é exatamente o vetor leste-centro (linha 11), o mesmo vetor de maior demanda do metrô, conforme dados apresentados na tabela a seguir:

Tabela 8: RMSP - Passageiros Transportados por Linha - CPTM - Média de Dia Útil (2010)

\begin{tabular}{|c|c|}
\hline Linhas & Usuários \\
\hline 7 (Luz - Jundiaí) & $386 \mathrm{mil}$ \\
\hline 8 (Júlio Prestes - Itapevi) & $414 \mathrm{mil}$ \\
\hline 9 (Osasco - Grajaú) & $266 \mathrm{mil}$ \\
\hline 10 (Luz - Rio Grande da Serra) & $330 \mathrm{mil}$ \\
\hline 11 (Luz - Estudantes) & $526 \mathrm{mil}$ \\
\hline 12 (Brás - Calmon Viana) & $199 \mathrm{mil}$ \\
\hline
\end{tabular}

Fonte: CPTM (2012) Dados: Dezembro de 2010

Os traçados das linhas do m etrô e trem são complementares, representando os principais eixos dos istema de movimento da Macrometrópole Paulista. Esta rede-suporte apresenta estações integradas (Luz, Pinheiros, Tamanduateí, Brás, Palmeiras-Barra Funda, Tatuapé, Corinthians-Itaquera e Santo Amaro), sendo que o sistema de trilhos (metrô e trem) tem como "nó" central a estação da Luz.

Atualmente (2012) as empresas vinculadas à Secretaria de Transportes Metropolitanos (Metrô; CPTM; EMTU) são responsáveis pelo deslocamento de aproximadamente 7,3 milhões de passageiros/dia ${ }^{40}$. O sistema intermodal de transporte coletivo metropolitano (metrô/trem/ônibus) apresenta estações que integram em diferentes combinações o Metrô, os trens (CPTM), e os ônibus metropolitanos (EMTU), assim como se valem de t erminais de ôni bus municipais, exercendo um papel fundamental na acessibilidade da região metropolitana mais populosa do B rasil. A rede da STM pode ser esquematicamente visualizada na figura 8.

${ }^{40}$ Secretaria dos Transportes Metropolitanos (2012). 
Figura 8: RMSP - Rede do Transporte Metropolitano (2012)

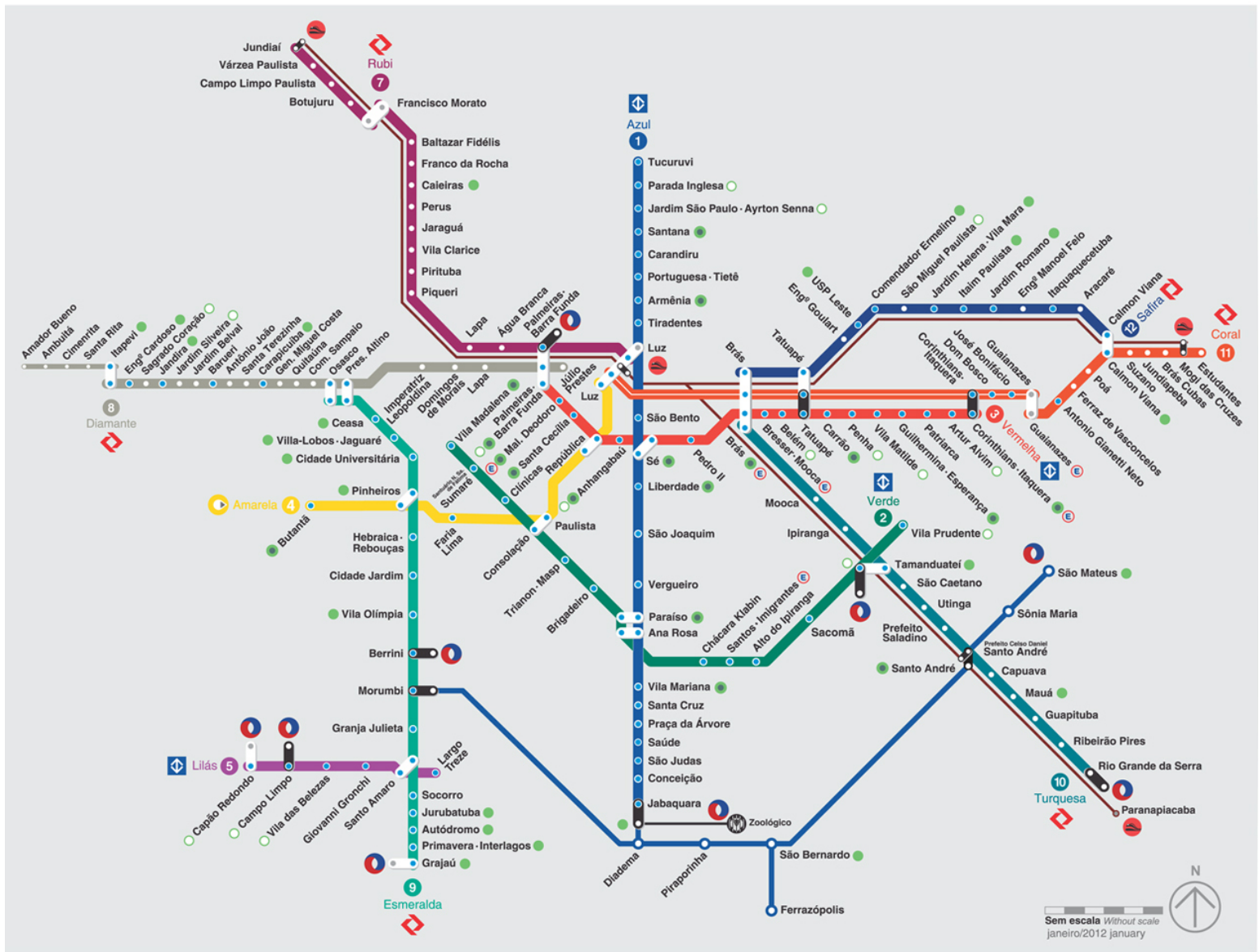

Legenda Legend

\begin{tabular}{|c|c|c|}
\hline 00 & $\begin{array}{l}\text { Linha 1· Azul } \\
\text { Line 1-Blue }\end{array}$ & METRÔ \\
\hline 02 & $\begin{array}{l}\text { Linha 2. Verde } \\
\text { Line 2-Green }\end{array}$ & METRÔ \\
\hline 03 & $\begin{array}{l}\text { Linha } 3 . \text { Vermelha } \\
\text { Line 3-Red }\end{array}$ & METRÔ \\
\hline 004 & $\begin{array}{l}\text { Linha 4, Amarela } \\
\text { Line 4-Yellow }\end{array}$ & VIAQUATRO \\
\hline 05 & $\begin{array}{l}\text { Linha } 5 \text {, Lilás } \\
\text { Line 5-Lilac }\end{array}$ & METRÔ \\
\hline 000 & $\begin{array}{l}\text { Linha 7. Rubi } \\
\text { Line 7-Ruby }\end{array}$ & CPTM \\
\hline$\circ \quad 8$ & $\begin{array}{l}\text { Linha 8. Diamante } \\
\text { Line 8-Diamond }\end{array}$ & СРТМ \\
\hline 00 & $\begin{array}{l}\text { Linha 9. Esmeralda } \\
\text { Line 9-Emerald }\end{array}$ & CPTM \\
\hline 0 (10 & $\begin{array}{l}\text { Linha } 10 \cdot \text { Turquesa } \\
\text { Line 10-Turquoise }\end{array}$ & СРТМ \\
\hline ○ (1) & $\begin{array}{l}\text { Linha } 11 \cdot \text { Coral } \\
\text { Line 11-Coral }\end{array}$ & СРTM \\
\hline$\Longrightarrow$ (1) & $\begin{array}{l}\text { Linha 11. Coral - Expresso Leste } \\
\text { Line 11-Coral - East Express }\end{array}$ & СРTM \\
\hline 1 & $\begin{array}{l}\text { Linha } 12 \text {. Safira } \\
\text { Line 12-Sapphire }\end{array}$ & CPTM \\
\hline-1 & $\begin{array}{l}\text { Linha de Ônibus Especial } \\
\text { Especial Bus Line }\end{array}$ & СРTM \\
\hline$\infty-\theta$ & $\begin{array}{l}\text { Expresso Turístico } \\
\text { Touristic Express }\end{array}$ & CPTM \\
\hline & $\begin{array}{l}\text { Ponte ORCA - tarifada } \\
\text { Orca Shuttle Service }\end{array}$ & EMTU \\
\hline$\infty$ & $\begin{array}{l}\text { Corredor Metropolitano de Ônibus ABD } \\
A B D \text { Metropolitan Bus Corridor }\end{array}$ & EMTU \\
\hline
\end{tabular}

\begin{tabular}{|c|c|}
\hline 0 & $\begin{array}{l}\text { Terminal Metropolitano de Ônibus } \\
\text { Metropolitan Bus Terminal }\end{array}$ \\
\hline 0 & $\begin{array}{l}\text { Estação } \\
\text { Station }\end{array}$ \\
\hline$\circ$ & $\begin{array}{l}\text { Estação de Integração - gratuita } \\
\text { Integration Station - Free Interchange }\end{array}$ \\
\hline 0 & $\begin{array}{l}\text { Estação de Integração - tarifada } \\
\text { Integration Station - Paid Interchange }\end{array}$ \\
\hline ○ & $\begin{array}{l}\text { Estações com elevador } \\
\text { Station with elevator }\end{array}$ \\
\hline 0 & $\begin{array}{l}\text { Paraciclos } \\
\text { Bike Attaching Post }\end{array}$ \\
\hline • & $\begin{array}{l}\text { Bicicletário } \\
\text { Bike Parking Terminal }\end{array}$ \\
\hline - & $\begin{array}{l}\text { Bicicletário com empréstimo de bicicleta } \\
\text { Bike Parking \& Rental Terminal }\end{array}$ \\
\hline & $\begin{array}{l}\text { Estacionamento de Carro Integrado } \\
\text { Integrated Car Parking }\end{array}$ \\
\hline
\end{tabular}

Informações úteis Useful Information

\begin{tabular}{lll}
\hline CPTM & www.cptm.sp.gov.br & $\mathbf{0 8 0 0 0 5 5 0 1 2 1}$ \\
\hline EMTU & www.emtu.sp.gov.br & $\mathbf{0 8 0 0 7 2 4 0 5 5 5}$ \\
\hline METRÔ & www.metro.sp.gov.br & $\mathbf{0 8 0 0 7 7 0 7 7 2 2}$ \\
\hline VIAQUATRO & $\mathbf{0 8 0 0 7 7 0 7 1 0 0}$ \\
\hline
\end{tabular}

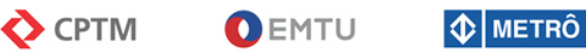

$\underset{\text { SOVERNO DO ESTADO }}{\text { SAOPAULO }}$

Fonte: Secretaria dos Transportes Metropolitanos 2012. 
O fluxo diário de passageiros da STM é apresentado no mapa 5. Nota-se que as redes e os fluxos tendem ao padrão de deslocamento periferia/centro, especialmente no v etor leste/centro, onde as linhas da C PTM e m etrô se complementam (linhas 3 e 11) para atender o vetor de maior demanda de passageiros da c idade. Juntas, transportam diariamente aproximadamente 1.645.000 passageiros ${ }^{41}$.

2.3 Os fluxos de passageiros: análise a partir da pesquisa Origem/Destino e do IBGE

Conforme explicitado no início do trabalho, preocupa-nos sobremaneira a análise das condições que permitem o movimento pendular da população da Macrometrópole paulista, que se utiliza cotidianamente dos meios de transporte coletivo ou individual, de caráter público ou privado. Cada prefeitura organiza a oferta de transporte de ní vel municipal, restando à STM prover o chamado "transporte metropolitano" e à ARTESP o denominado "suburbano".

Os serviços de t ransporte, as opções de des locamento, suas modalidades, as conexões, a m acro e micro acessibilidade, são elementos centrais deste estudo. Outros elementos como a organização do tecido urbano, a divisão territorial do trabalho na cidade, os bairros residenciais de alto e baixo padrão, a c oncentração das ofertas de trabalho e ed ucação, também fazem parte das variáveis que criam um campo de atuação do cidadão, que se efetiva de acordo com sua mobilidade e intencionalidade.

Essa interação sócio-espacial cotidiana com a cidade resulta em deslocamentos oriundos da separação entre os lugares de habitação, trabalho, educação, lazer e c onsumo. Esses elementos conformam um universo de fluxos com grande variação de origens, destinos, densidades, temporalidades e significados. Essa demanda de viagens é ex tremamente alta e s azonal, e praticamente toda a pes quisa bibliográfica e documental realizada para esta

\footnotetext{
${ }^{41}$ Secretaria dos Transportes Metropolitanos (2012).
} 
Mapa 5: Macrometrópole Paulista - Fluxo Diário de Passageiros (STM) - 2011

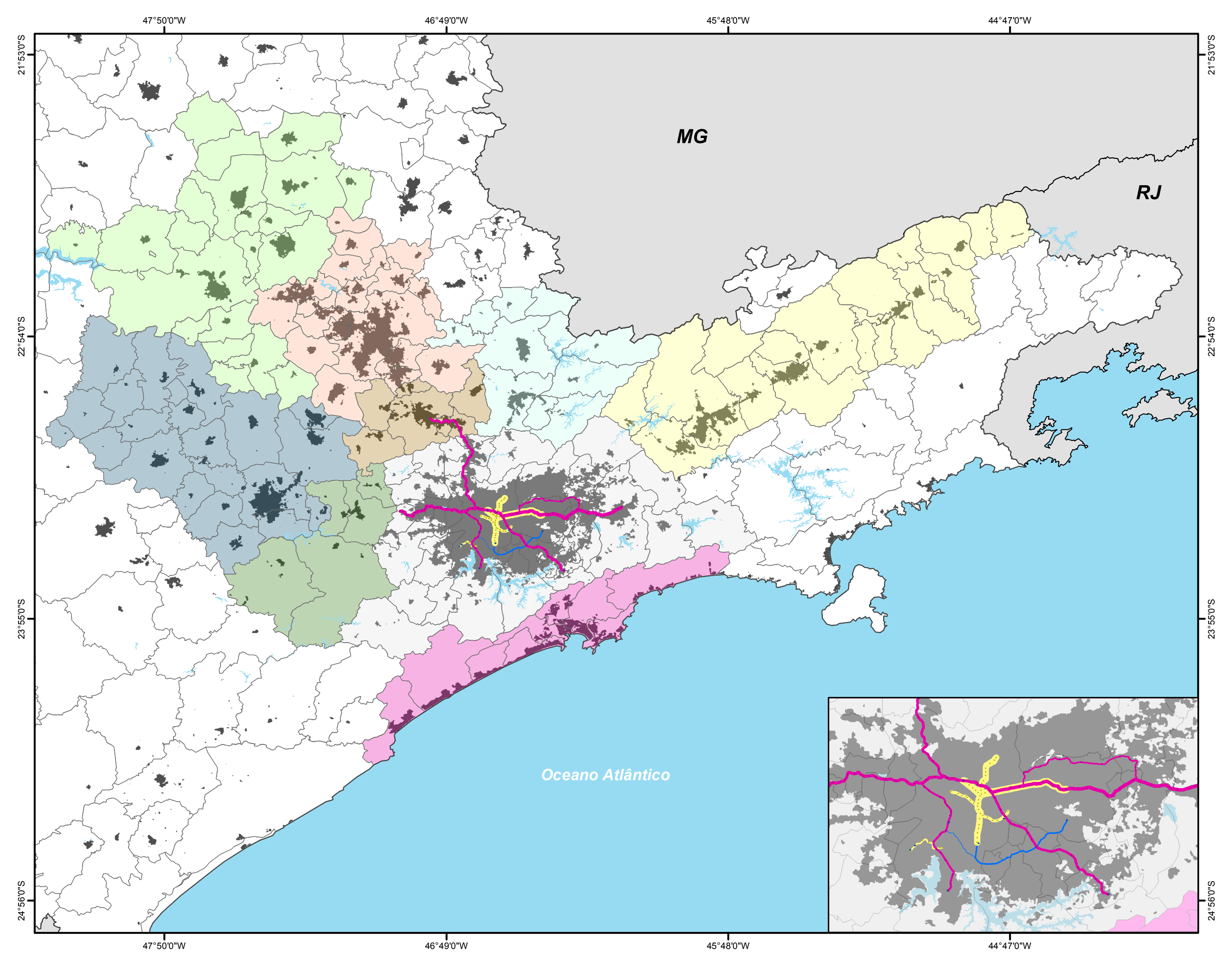

Localização Geral no Estado de São Paulo

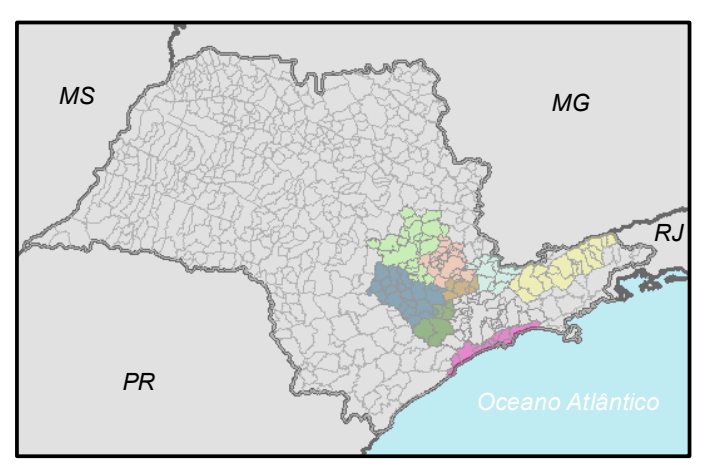

\section{Legenda}

$$
\begin{array}{|l|l}
\hline \hline & \text { Limite Estadual } \\
\hline & \text { Limite Municipal } \\
& \text { Oceano / Represa } \\
\hline & \text { Área Urbanizada } \\
\hline & \text { AU de Jundiaí } \\
& \text { AU de Piracicaba } \\
& \text { AU de Sorocaba } \\
\hline & \text { AU de São José dos } \\
\hline & \text { MR Bragantina } \\
\text { MR São Roque } \\
\text { RMBS } \\
\text { RMC } \\
\text { RMSP } \\
\hline \text { Malha Metroviária } \\
\text { Estação Metrô } \\
\hline \text { Malha Ferroviária } \\
\text { Estação CPTM } \\
\text { Corredor de Ônibus } \\
\text { Terminal Metropol } \\
\hline \text { Média Diária de Passageiros } \\
100.000 \\
250.000 \\
500.000 \\
750.000 \\
1.000 .000
\end{array}
$$

Oceano / Represa

Área Urbanizada 2005

AU de Piracicaba

AU de São José dos Campo

Malha Metroviária

— Malha Ferroviária

Corredor de Ônibus

Terminal Metropolitano EMTU

Média Diária de Passageiros Transportados

Fontes:

Limite Municipal e Estadual - IBGE 2012. Macrometrópole Paulista - EMPLASA 2011 Mancha Urbana - ProBio 2005.

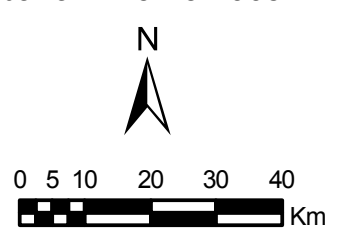

Sistema de Coordenadas Geográficas Datum WGS 84

Elaboração: GIBERTI 2012. 
dissertação mostra que os sistemas de transporte estão claramente saturados. Como empreender uma análise dessa "saturação"?

Podemos considerar que o c onjunto destes sistemas de engenharia e seus fluxos compõem o Sistema de Movimento da Macrometropole Paulista, conforme já frisado. O mapa 6 procura mostrar os principais sistemas de engenharia que dã o suporte aos deslocamentos de pa ssageiros na Macrometrópole Paulista. Neste sistema (que na verdade é uma parcela dos diferentes sistemas de movimento do território nacional), as principais viagens são motivadas por dois principais fatores: trabalho e educ ação. Do ponto de vista das direções destes deslocamentos, pode-se dizer que existe predominância do sentido bairro-centro de manhã e centro-bairro à noite, o que deixa claro que a oferta de emprego e educação localiza-se mais no cento da capital. Mas afinal, como a população faz uso dos sistemas de transporte? Quais as modalidades mais utilizadas? Quais são os principais fluxos pendulares? Quais as principais características desse movimento, as origens, densidades e destinos?

Para responder às questões anteriores foi analisado um universo abrangente de dados quantitativos e qualitativos, atentando às referências mais confiáveis e consagradas, tendo sidos os principais materiais coletados nos Censos Demográficos do IBGE, assim como nas Pesquisas de Origem/Destino (O/D) do Metrô, Esta extensiva pesquisa documental acabou exigindo um esforço de s eleção e síntese de $t$ abelas, gráficos e m apas diretamente relacionados aos objetivos deste trabalho.

Os dados da chamada "Pesquisa Origem/Destino (O/D)" ${ }^{42}$, com divisão das viagens diárias por modalidade na Região Metropolitana de São Paulo, são

\footnotetext{
${ }^{42}$ A Pesquisa Origem/Destino tem por objetivo o levantamento do volume e das características dos deslocamentos realizados pela população em suas atividades diárias, em uma aglomeração urbana. Esse levantamento procura estabelecer relações quantitativas entre as viagens realizadas e diversas outras variáveis, como características sócio-econômicas, aspectos físicos e urbanos da o cupação, de forma a es tabelecer projeções futuras para os desejos de deslocamentos da população. Foram realizadas pesquisas nos anos de 1967, 1977, 1987, 1997 e 2007. A pesquisa mais atual apresenta 460 zonas, permitindo assim mensurar as densidades das viagens entre as diferentes zonas.
} 


\section{Mapa 6: Macrometrópole Paulista}

Principais Sistemas de Engenharia de Transporte de Passageiros

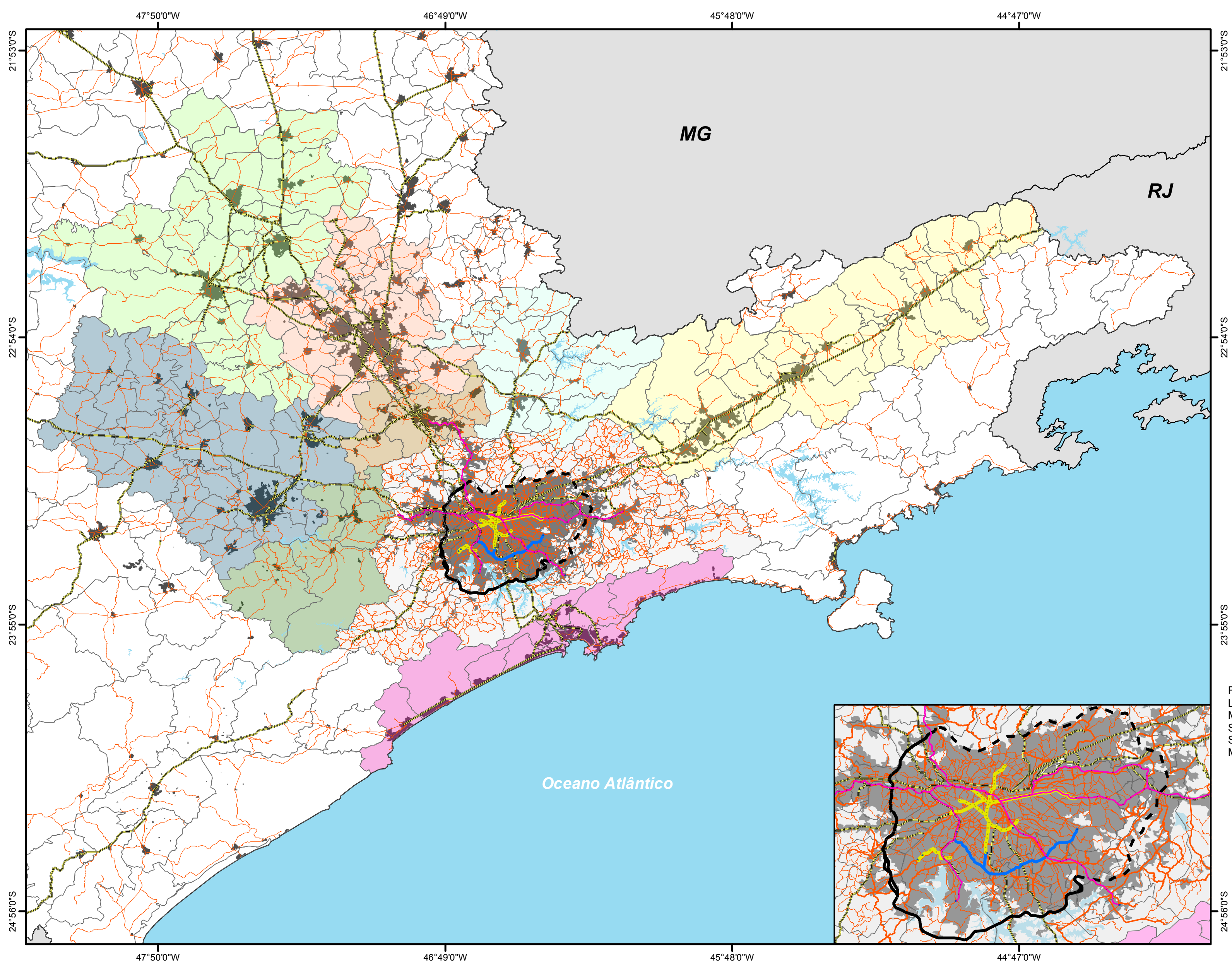

Localização Geral no Estado de São Paulo

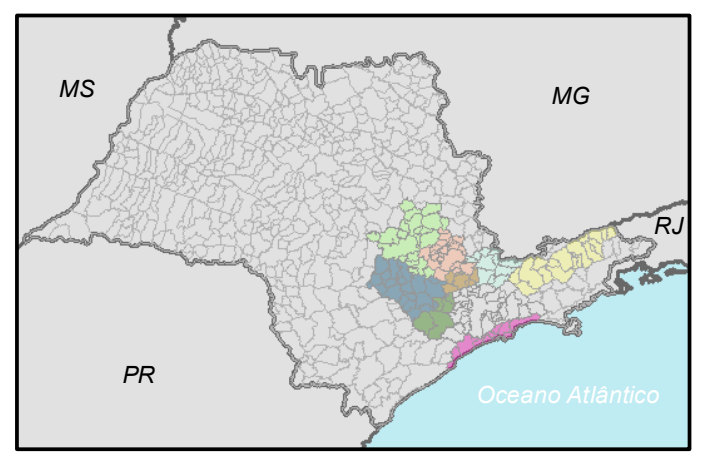

\section{Legenda}

$\square$ Limite Estadual

Limite Municipal

Oceano / Represa

Área Urbanizada 2005

AU de Jundiaí

AU de Piracicaba

AU de Sorocaba

AU de São José dos Campo

MR Bragantina

MR São Roque

RMBS

RMC

RMSP

Malha Viária Básica

- Rodovia Dupla

- Rodoanel Existente

- - Rodoanel Planejado

- Malha Metroviária

Estação Metrô

— Malha Ferroviária

Estação CPTM

Corredor de Ônibus

Terminal Metropolitano EMTU

imite Municipal e Estadual - IBGE 2012.
Macrometrópole Paulista - EMPLASA 2011.

EMPLASA 2002.
viário e Corredor de Ônibus - STM 2011.

Mancha Urbana - ProBio 2005.

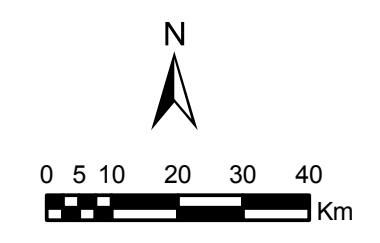

Sistema de Coordenadas Geográficas Datum WGS 84 
os dados mais detalhados e com a maior série histórica, e que permitem uma dimensão mais aproximada da complexidade dos fluxos dos sistemas de movimento metropolitano de passageiros. Nossa proposta é analisar os dados por etapas, abordando inicialmente as características gerais de todo o período em que ela foi realizada (1967, 1977, 1987, 1997 e 2007), para posteriormente identificar a evolução das seguintes variáveis: 1. viagens não m otorizadas e motorizadas; 2 . as viagens coletivas e individuais; e 3 . os principais modais. Para reconhecer as características mais atuais da pesquisa (2007) observamos os seguintes indicadores: 1. a distribuição espacial da pop ulação; 2. A distribuição dos empregos e das matrículas escolares. 3. A concentração das origens e destinos. 4. A relação motivo/modal; e, por fim, 5. A densidade dos fluxos mediante uma matriz O/D especialmente agrupada para este estudo.

Para iniciarmos esta análise mais empírica, e com recuo histórico um pouco maior, pareceu-nos necessário num primeiro momento distinguir a organização dos dados dos deslocamentos em "não motorizados" dos "motorizados". O primeiro tipo de deslocamento subdivide-se em dois modos: por bicicleta ou a pé ; o segundo tipo se divide em coletivo e individual. As estratégias familiares e individuais de moradia e deslocamentos da população estão sujeitas às condições de acessibilidade, mobilidade e renda, nesse campo de relações acreditamos que os dados apresentados possam oferecer uma contribuição efetiva sobre realidade dos fluxos.

A tabela 9 a seguir apresenta uma síntese das principais características das pesquisas em valores absolutos. De maneira geral, podemos ver que nesses 40 anos houve um crescimento progressivo da população, empregos, matrículas e v iagens diárias, revelando que $\mathrm{t}$ odas as facetas da vida metropolitana se complexificam, seja em termos da divisão social do trabalho, assim como na di visão territorial do trabalho. De fato, esse ritmo de crescimento foi maior entre 1967/1987, apresentando redução entre $1987 / 2007$. 
Tabela 9: RMSP - Dados gerais da Pesquisa O/D

(1967, 1977, 1987, 1997 e 2007)

\begin{tabular}{|c|c|c|c|c|c|}
\hline Variáveis Básicas & 1967 & 1977 & 1987 & 1997 & 2007 \\
\hline População & 7.097 & 10.276 & 14.248 & 16.792 & 19.535 \\
\hline Empregos & - & 3.758 & 5.647 & 6.959 & 9.066 \\
\hline Matrículas Escolares & 1.088 & 2.506 & 3.676 & 5.011 & 5.251 \\
\hline Viagens Diárias & 7.187 & 21.304 & 29.400 & 31.432 & 38.094 \\
\hline Viagens Motorizadas & 7.187 & 15.263 & 18.642 & 20.458 & 25.167 \\
\hline Viagens Não Motorizadas & - & 6.041 & 10.758 & 10.974 & 12.927 \\
\hline Motorizadas - Coletivo & 4.894 & 9.580 & 10.455 & 10.473 & 13.913 \\
\hline Motorizadas - Individual & 2.293 & 5.683 & 8.187 & 9.985 & 11.254 \\
\hline Índice de Mobilidade Total & - & 2.07 & 2.06 & 1.87 & 1.95 \\
\hline $\begin{array}{c}\text { Índice de Mobilidade } \\
\text { Motorizada }\end{array}$ & 1.01 & 1.49 & 1.31 & 1.22 & 1.29 \\
\hline
\end{tabular}

Fonte: Metrô-Pesquisa OD 1967/1977/1987/1997/2007. Organização: Giberti 2012.

OBS: Valores em milhares.

Tais dados acompanharam as mudanças da $m$ etrópole, seus ciclos econômicos, a i mplementação de $s$ istemas técnicos, a c omplexificação dos circuitos espaciais da produção e dos meios de transporte. Cabe destacar também a ampliação e $v$ ulgarização das possibilidades de deslocamento, oferta de c rédito, distribuição de $r$ enda e, por fim, a am pliação das necessidades de deslocamentos para realização das atividades básicas do cotidiano que a c ada dia estão mais distribuídas pela metrópole, fruto da separação entre residência, trabalho, estudo, lazer e c ompras. Essas mudanças no contexto metropolitano associadas a um incremento populacional progressivo resultaram em um aumento expressivo do número dos deslocamentos diários realizados pela população metropolitana. O gráfico 4 abaixo permite uma melhor visualização cronológica das variáveis básicas e seus diferentes ritmos de crescimento. 
Gráfico 4: RMSP - Evolução dos dados gerais da Pesquisa O/D $(1967,1977,1987,1997$ e 2007)

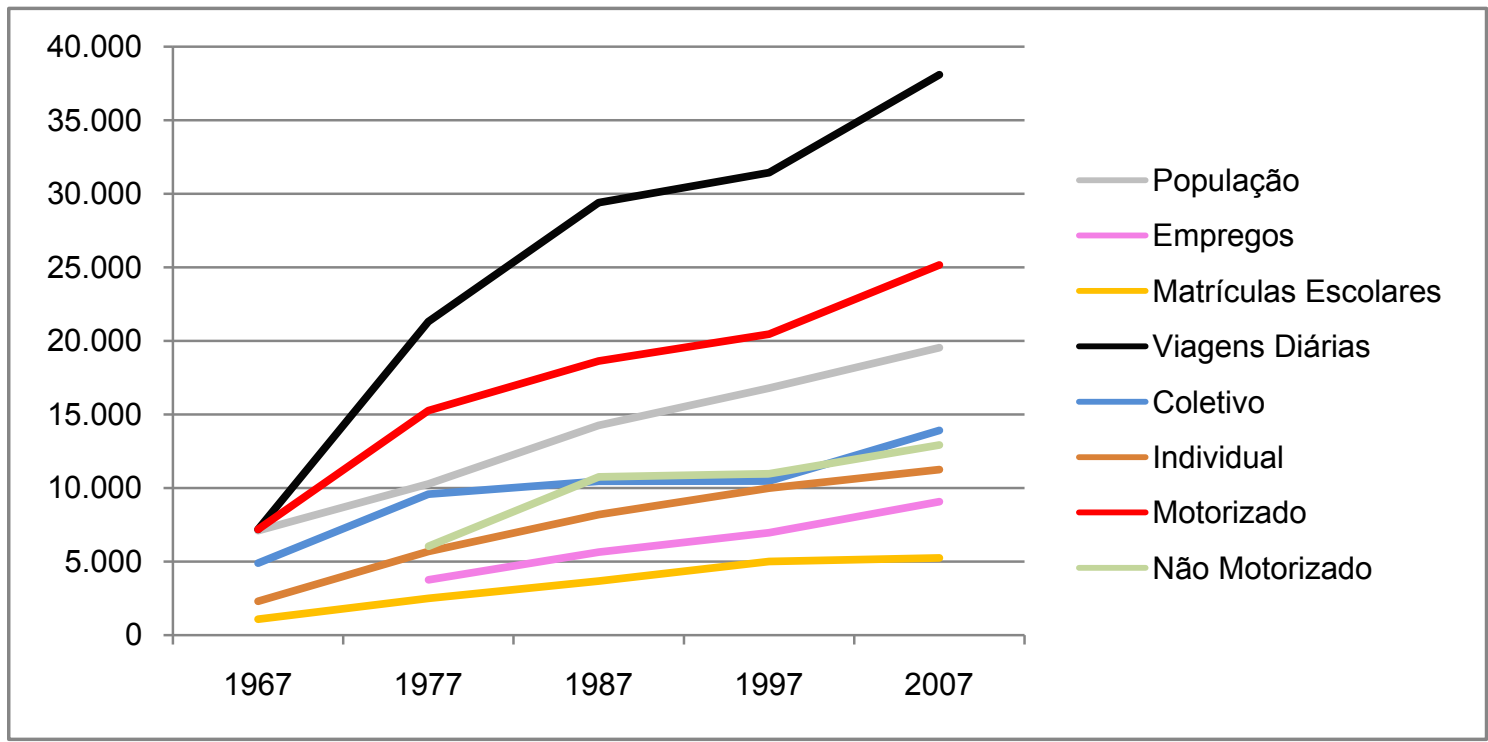

Fonte: Metrô-Pesquisa OD 1967/1977/1987/1997/2007. Organização: Giberti 2012

Os dados disponíveis indicam progressiva perda de par ticipação das formas de transporte "coletivas" e crescimento dos modos "individuais", com tendência atual de equilíbrio (gráfico 5). Entre 1967 e 200 7, os modos individuais passaram de $31,9 \%$ para $44,7 \%$ das viagens motorizadas na RMSP; em 1997 essa relação quase se equiparou, chegando a 48,8\% (individual) e $51,2 \%$ (coletivo). Na capital houve uma leve queda, de $45,3 \%$ para $44,1 \%$.

Gráfico 5: RMSP e Município de São Paulo - Evolução relativa das viagens por modo coletivo e individual (1967, 1977, 1987, 1997 e 2007)

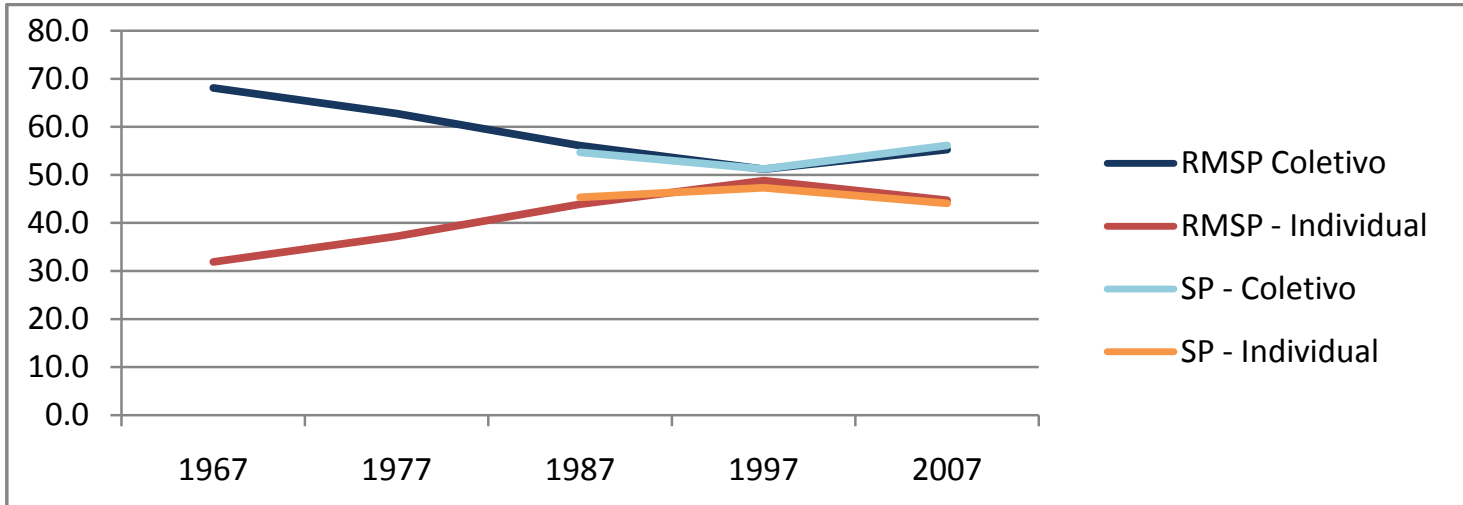

Fonte: Metrô-Pesquisa OD 1967/1977/1987/1997/2007. Organização: Giberti 2012

Em uma análise mais detalhada do período (1987/1997/2007), sob a ótica dos valores absolutos e r elativos (tabelas 10 e 11) ficam evidentes 
algumas tendências. A capital comparada com toda a RMSP teve uma diminuição progressiva de participação no número total de viagens variando de $68,1 \%$ para $62,4 \%$ e $62,7 \%$. No que diz respeito aos valores absolutos, o total de viagens da capital sofreu uma considerável diminuição, de 20.021 milhões para 19.615 milhões entre 1987/1997. Essa tendência foi seguida pelo modo não motorizado, coletivo, táxi, outros, moto, trem, ônibus, e a p é. Na RMSP, nesse mesmo período, houve uma pequena diminuição da participação do modal trem. As demais variáveis tiveram crescimento para ambas as jurisdições. O caso dos fretados será tratado especificamente no pr óximo capítulo. Reforçar limites internos da tabela

Tabela 10: RMSP e Município de São Paulo - Evolução absoluta das viagens por modo (1987, 1997 e 2007).

\begin{tabular}{|c|c|c|c|c|c|c|c|}
\hline \multirow{2}{*}{\multicolumn{2}{|c|}{ Variáveis }} & \multicolumn{2}{|c|}{1987} & \multicolumn{2}{|c|}{1997} & \multicolumn{2}{|c|}{2007} \\
\hline & & \multirow{2}{*}{$\begin{array}{c}\text { São Paulo } \\
20.021\end{array}$} & \multirow{2}{*}{$\begin{array}{l}\text { RMSP } \\
29.400\end{array}$} & \multirow{2}{*}{$\begin{array}{c}\text { São Paulo } \\
19.615\end{array}$} & \multirow{2}{*}{$\begin{array}{l}\text { RMSP } \\
31.432\end{array}$} & \multirow{2}{*}{$\begin{array}{c}\text { São Paulo } \\
23.520\end{array}$} & \multirow{2}{*}{$\begin{array}{l}\text { RMSP } \\
38.094\end{array}$} \\
\hline \multirow{16}{*}{$\begin{array}{l}\text { Viagens } \\
\text { Diárias } \\
(\times 1.000)\end{array}$} & $\begin{array}{l}\text { Total de } \\
\text { Viagens }\end{array}$ & & & & & & \\
\hline & $\begin{array}{c}\text { Não } \\
\text { Motorizado }\end{array}$ & 6.712 & 10.758 & 6.213 & 10.974 & 7.391 & 12.927 \\
\hline & Motorizado & 13.309 & 18.642 & 13.456 & 20.458 & 16.096 & 25.167 \\
\hline & Individual & 6.029 & 8.188 & 6.368 & 9.985 & 7.092 & 11.254 \\
\hline & Coletivo & 7.280 & 10.454 & 6.891 & 10.473 & 9.036 & 13.913 \\
\hline & Automóvel & 5.692 & 7.706 & 6.133 & 9.638 & 6.588 & 10.381 \\
\hline & Táxi & 100 & 114 & 91 & 103 & 78 & 91 \\
\hline & Moto & 122 & 181 & 99 & 146 & 394 & 721 \\
\hline & Outros & 116 & 187 & 46 & 98 & 32 & 61 \\
\hline & Metrô & 1.342 & 1.461 & 1.533 & 1.698 & 1.944 & 2.223 \\
\hline & Trem & 472 & 891 & 322 & 649 & 435 & 815 \\
\hline & Ônibus* & 4.984 & 7.098 & 4.772 & 7.254 & 5.729 & 9.034 \\
\hline & Fretado & 249 & 654 & 162 & 461 & 167 & 514 \\
\hline & Escolar & 233 & 350 & 244 & 411 & 761 & 1.327 \\
\hline & Bicicleta & 45 & 108 & 54 & 162 & 147 & 304 \\
\hline & A Pé & 6.667 & 10.650 & 6.158 & 10.812 & 7.244 & 12.623 \\
\hline
\end{tabular}

Fonte: Metrô-Pesquisa OD 1967/1977/1987/1997/2007. Organização: Giberti 2012. *Inclui lotação e perua.

Entre 1987/2007 as viagens a pé - tanto para o município quanto para toda a Região Metropolitana - sempre foram um pouco maior que $1 / 3$ de todas as viagens, e quase que a totalidade das viagens não motorizadas. O uso da bicicleta vem ganhando maior participação, pois cresceu de $0,7 \%$ para $2 \%$ na capital e de $1 \%$ para 2,4 \% em toda Região. Esta forma de deslocamento, entretanto, representa apenas $0,8 \%$ de todas as viagens (2007). 
Tabela 11: RMSP e Município de São Paulo - Evolução relativa (\%) das viagens por modo (1987, 1997 e 2007)

\begin{tabular}{|c|c|c|c|c|c|c|c|}
\hline \multirow{2}{*}{\multicolumn{2}{|c|}{ Variáveis }} & \multicolumn{2}{|c|}{1987} & \multicolumn{2}{|c|}{1997} & \multicolumn{2}{|c|}{2007} \\
\hline & & São Paulo & RMSP & São Paulo & RMSP & São Paulo & RMSP \\
\hline \multirow{11}{*}{$\begin{array}{c}\text { Porcentagem } \\
\text { em relação ao } \\
\text { número total } \\
\text { de viagens } \\
\text { motorizadas }\end{array}$} & Individual & 45.3 & 43.9 & 47.3 & 48.8 & 44.1 & 44.7 \\
\hline & Coletivo & 54.7 & 56.1 & 51.2 & 51.2 & 56.1 & 55.3 \\
\hline & Automóvel & 42.8 & 41.3 & 45.6 & 47.1 & 40.9 & 41.2 \\
\hline & Táxi & 0.8 & 0.6 & 0.7 & 0.5 & 0.5 & 0.4 \\
\hline & Moto & 0.9 & 1.0 & 0.7 & 0.7 & 2.4 & 2.9 \\
\hline & Outros & 0.9 & 1.0 & 0.3 & 0.5 & 0.2 & 0.2 \\
\hline & Metrô & 10.1 & 7.8 & 11.4 & 8.3 & 12.1 & 8.8 \\
\hline & Trem & 3.5 & 4.8 & 2.4 & 3.2 & 2.7 & 3.2 \\
\hline & Ônibus* & 37.4 & 38.1 & 35.5 & 35.5 & 35.6 & 35.9 \\
\hline & Fretado & 1.9 & 3.5 & 1.2 & 2.3 & 1.0 & 2.0 \\
\hline & Escolar & 1.7 & 1.9 & 1.8 & 2.0 & 4.7 & 5.3 \\
\hline \multirow{2}{*}{$\begin{array}{c}\text { Porcentagem } \\
\text { em relação ao } \\
\text { número total } \\
\text { de viagens } \\
\text { não } \\
\text { motorizadas }\end{array}$} & Bicicleta & 0.7 & 1.0 & 0.9 & 1.5 & 2.0 & 2.4 \\
\hline & A Pé & 99.3 & 99.0 & 99.1 & 98.5 & 98.0 & 97.6 \\
\hline
\end{tabular}

Fonte: Metrô-Pesquisa OD 1967/1977/1987/1997/2007. Organização: Giberti 2012. *Inclui lotação e perua.

Dentre todas as viagens motorizadas, em termos relativos, a primazia do automóvel fica evidente tanto na c apital quanto na R MSP, já que es ta proporção sempre esteve acima de $40,1 \%$ nesse período; essa participação chegou ao extremo em 1997 quando representou 47,1\% das viagens na RMSP e 45,6\% na capital. O ônibus sempre esteve em segundo lugar em termos de importância relativa, com leve queda de $37,4 \%$ para $35,6 \%$ na RMSP e de $38,1 \%$ para $35,6 \%$ na capital. Em terceiro lugar consta o metrô como principal meio de deslocamento, com sua participação variando de $10,1 \%$ para $12,15 \%$ na capital e $7,8 \%$ para $12,1 \%$ na RMSP. O trem, em quarto lugar, também teve uma queda na participação, de $3,5 \%$ para $2,7 \%$ na capital e de $4,8 \%$ para $3,2 \%$ na RMSP. Em quinto lugar o modo escolar com expressivo crescimento (especialmente entre 1997/2007), assim como a m oto em sexto lugar. As demais modalidades tiveram queda. Os fretados - que serão mais analisados no próximo capítulo - também decresceram paulatinamente. Por fim, cabe destacar que a utilização de motos aumenta expressivamente entre 1997/2007, com crescimento de $397 \%$ na capital e $493 \%$ na RMSP.

Analisando os modos coletivos de deslocamento (tabela 12) o ônibus sempre foi o principal responsável pelas viagens, e seu percentual de us o 
passou de 67,9\% para 64,9\% na RMSP, entre os anos de 1987 e 2007 ( com valores bem semelhantes aos da capital). No mesmo período, o metrô (que só existe no município de São Paulo) conta com maior participação na capital, variou de $18,4 \%$ para $21,5 \%$ contra $14 \%$ e $16 \%$ da RMSP. Identificamos ainda o deslocamento por trem com tendência de redução, e os fluxos de transporte escolar com grande aumento na sua participação, mostrando um salto de $3,2 \%$ para $8,4 \%$ na capital e de $3,3 \%$ para $9,5 \%$ na RMSP (superando a participação do trem). Os fretados, por seu turno, mostram uma diminuição de importância progressiva, passando de $3,4 \%$ para $1,9 \%$ na capital e de $6,3 \%$ para $3,7 \%$ na RMSP, perdendo para o es colar, representando o modo menos utilizado em 2007 segundo a pesquisa.

Tabela 12: RMSP e Município de São Paulo - Evolução relativa (\%) das viagens coletivas $(1987,1997$ e 2007$)$

\begin{tabular}{|c|c|c|c|c|c|c|c|}
\hline & \multirow{2}{*}{ Modo } & \multicolumn{2}{|c|}{1987} & \multicolumn{2}{|c|}{1997} & \multicolumn{2}{|c|}{2007} \\
\hline \multirow{7}{*}{$\begin{array}{l}\text { Em relação às } \\
\text { viagens coletivas }\end{array}$} & & SP & RMSP & SP & RMSP & SP & RMSP \\
\hline & Metrô & 18.4 & 14 & 21.2 & 16.2 & 21.5 & 16 \\
\hline & Trem & 6.5 & 8.5 & 4.7 & 6.2 & 4.8 & 5.9 \\
\hline & Ônibus* & 68.5 & 67.9 & 68.2 & 69.3 & 63.4 & 64.9 \\
\hline & Fretado & 3.4 & 6.3 & 2.4 & 4.4 & 1.9 & 3.7 \\
\hline & Escolar & 3.2 & 3.3 & 3.5 & 3.9 & 8.4 & 9.5 \\
\hline & Total & 100 & 100 & 100 & 100 & 100 & 100 \\
\hline
\end{tabular}

Fonte: Metrô-Pesquisa O/D 2007. Organização: Giberti 2012. *Inclui lotação e perua.

Feitas estas considerações mais gerais sobre os modos de deslocamento coletivos no contexto da Região Metropolitana de São Paulo, o que poderíamos dizer em relação às formas individuais de deslocamento? 0 grande crescimento do modo individual em detrimento do coletivo sempre teve a participação (tabela 13) preponderante do automóvel, com leve queda entre $1987 / 2007$, passou de $94,4 \%$ para $92,2 \%$ na capital e de $94,1 \%$ para $92,2 \%$ na RMSP. A moto ocupa o segundo lugar com tendência de expansão, passando de $2 \%$ para $5,5 \%$ na capital e de $2,2 \%$ para $6,4 \%$ na RMSP. Os modos "Táxi" e "outros" tiveram queda progressiva. 
Tabela 13: RMSP e Município de São Paulo - Evolução relativa (\%) das viagens individuais $(1987,1997$ e 2007$)$

\begin{tabular}{|l|c|c|c|c|c|c|c|}
\hline \multirow{2}{*}{} & \multicolumn{2}{|c|}{ Modo } & \multicolumn{2}{|c|}{1987} & \multicolumn{2}{|c|}{1997} & \multicolumn{2}{|c|}{2007} \\
\cline { 2 - 8 } & SP & RMSP & SP & RMSP & SP & RMSP \\
\cline { 2 - 8 } & Automóvel & 94.4 & 94.1 & 96.3 & 96.5 & 92.9 & 92.2 \\
\hline $\begin{array}{l}\text { Em relação } \\
\text { às viagens } \\
\text { individuais }\end{array}$ & Táxi & 1.7 & 1.4 & 1.4 & 1.0 & 1.1 & 0.8 \\
\cline { 2 - 8 } & Moto & 2.0 & 2.2 & 1.6 & 1.5 & 5.6 & 6.4 \\
\cline { 2 - 8 } & Outros & 1.9 & 2.3 & 0.7 & 1.0 & 0.5 & 0.5 \\
\cline { 2 - 8 } & Total & 100 & 100 & 100 & 100 & 100 & 100 \\
\hline
\end{tabular}

Fonte: Metrô-Pesquisa O/D 2007. Organização: Giberti 2012.

No que se refere ao período mais recente (2007) a população chegou à marca de 19,5 milhões de habi tantes desigualmente distribuídos na Região Metropolitana de São Paulo. Para reconhecer essa distribuição/concentração foi utilizada uma média de habitantes por hectare (mapa 7), indicando uma grande amplitude que varia de 0 a 309 hab/ha. As áreas de maior densidade estão concentradas na capital, exatamente no centro e nas áreas limítrofes do município. Bairros nobres tendem a uma menor densidade, enquanto que as áreas com população de $\mathrm{m}$ enor renda tendem a apresentar uma maior densidade de ocupação.

Do ponto de vista absoluto, a capital responde por 10,8 milhões de habitantes, $55 \%$ do total da Região Metropolitana. Desse total da capital, $88 \%$ estão fora do centro expandido. Podemos inferir, portanto, que a maioria dos habitantes da RMSP está densamente concentrada na ár ea circundante ao centro expandido do município de São Paulo. Nesta área destacam-se do ponto de vista populacional os municípios de Guarulhos (com 1,27 milhões de habitantes), São Bernardo do C ampo (795 mil), Osasco (710 mil) e S anto Andre $(673 \mathrm{mil})$, que juntos representam quase $12 \%$ do total de moradores da RMSP. Dos $39 \mathrm{~m}$ unicípios, apenas 5 abrigam $67 \%$ de t oda população metropolitana de São Paulo (mapa 8). 


\section{Mapa 7: RMSP - Densidade Demográfica - 2007}

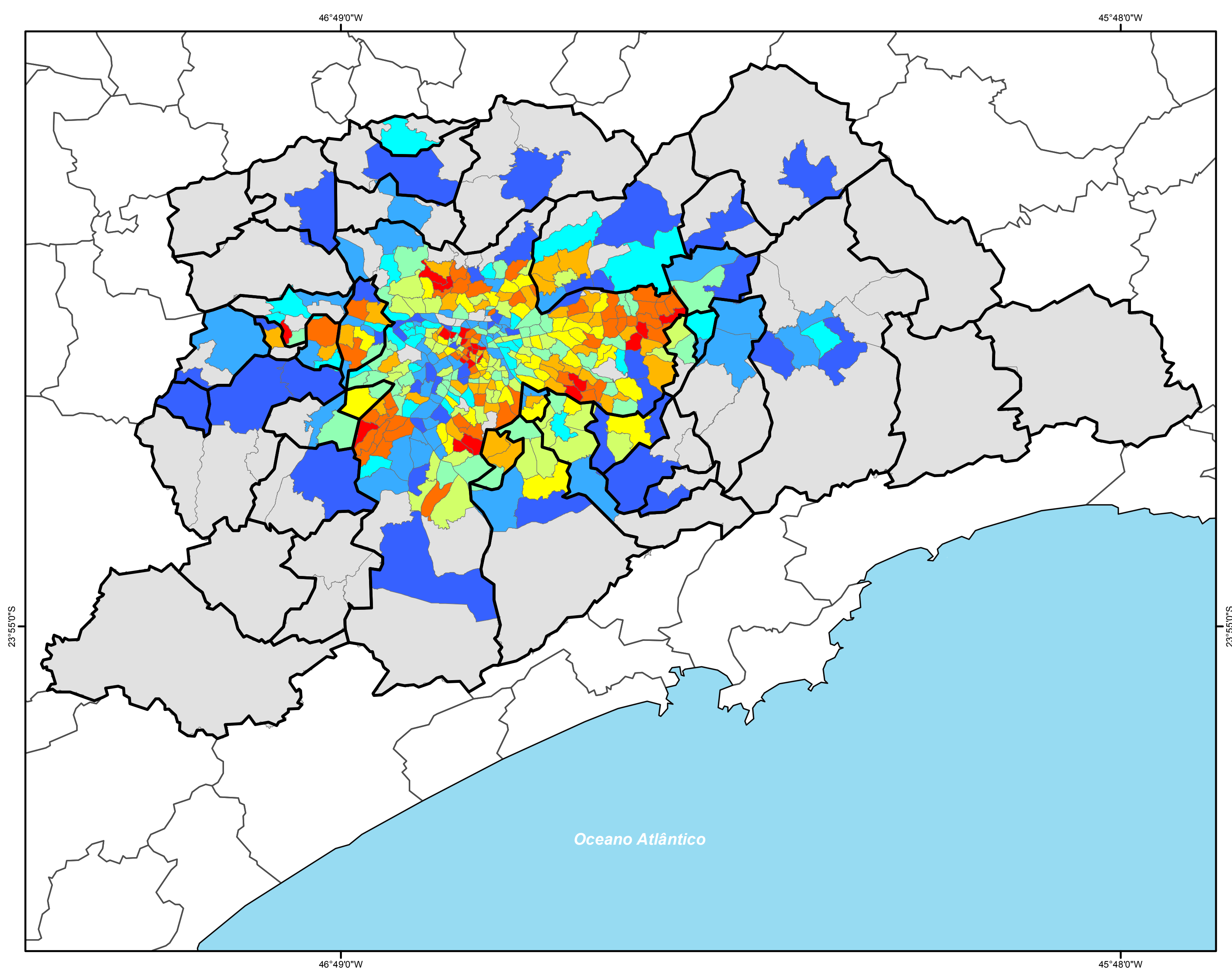

Localização Geral no Estado de São Paulo

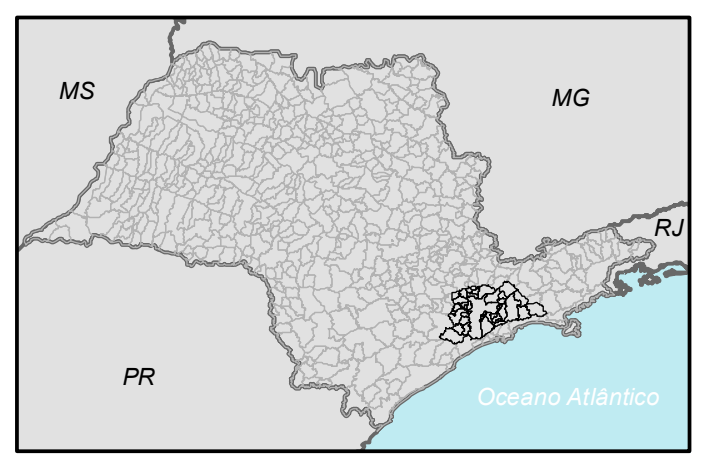

Legenda

$\square$ Limite Estadual Limite Municipal

Habitantes / ha

$\square 0-9,30$

$9,31-27,4$

$27,5-47,9$

$\square 8,0-69,4$

$\square 69,5-89,7$

$\square 89,8-110$

$111-133$

$134-161$

$162-204$

$205-309$

Fontes:
Limite Municipal E Estadual - 1BGE 2012.
Densidada Demograficica - Pesquisa OID - RMSP - 2007

\section{$\bigwedge^{N}$}

Sistema de Coordenadas Geográficas Datum WGS 84

Elaboração: GIBERTI 2012. 


\section{Mapa 8: RMSP - População Absoluta - 2007}

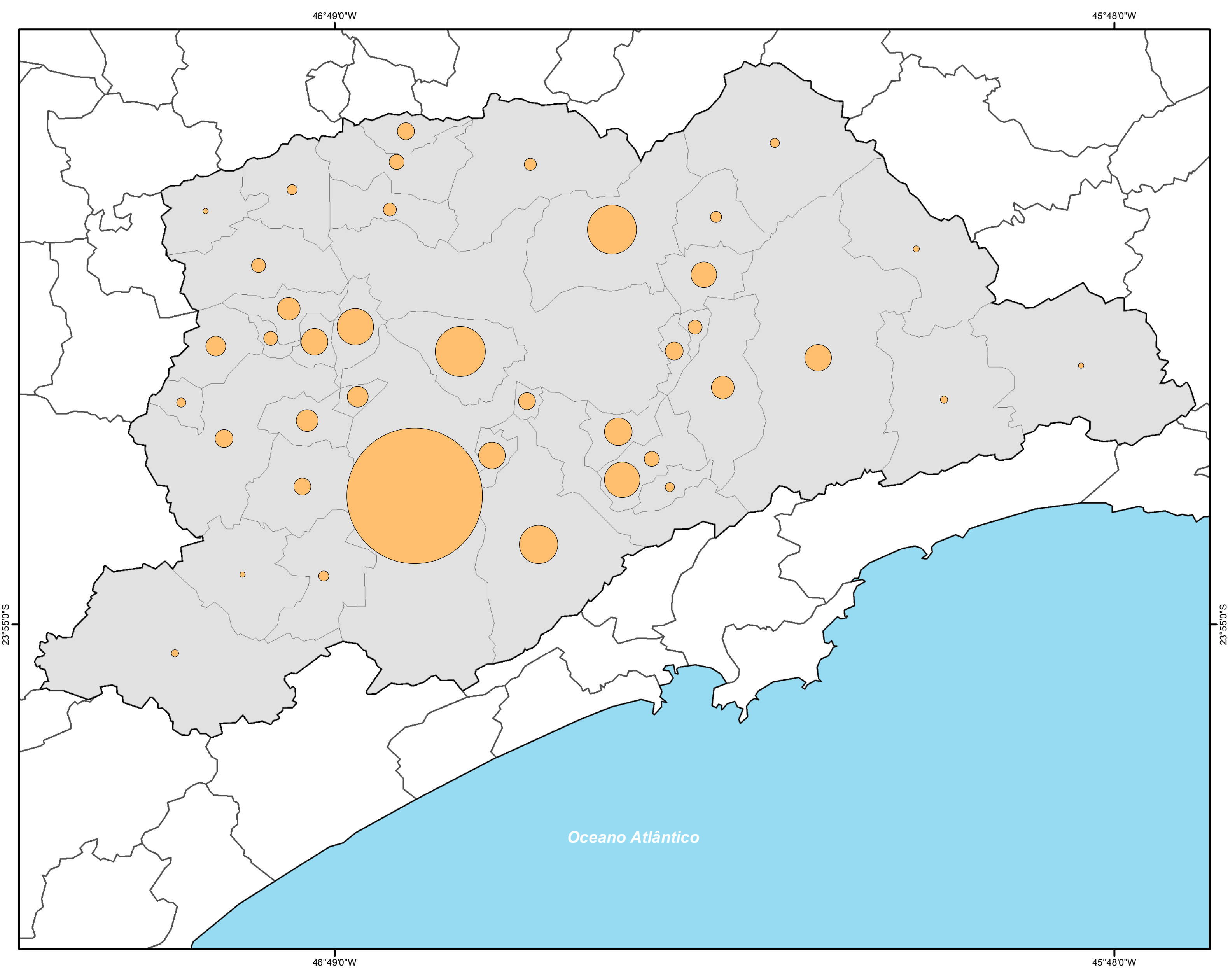

Localização Geral no Estado de São Paulo

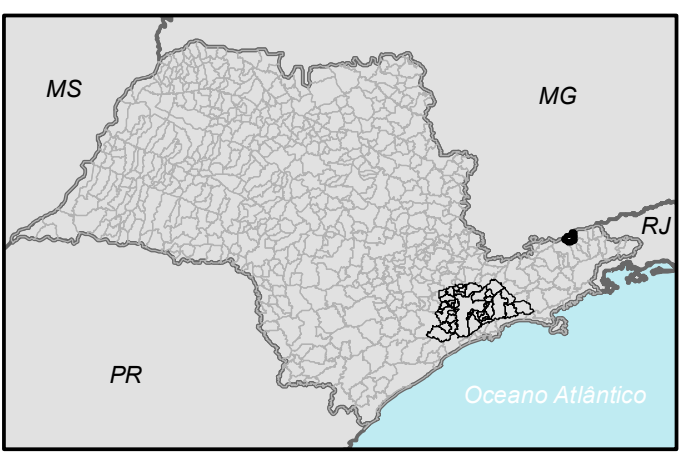

Legenda

$\square$ Limite Estadual Limite Municipal

\section{População Absoluta}

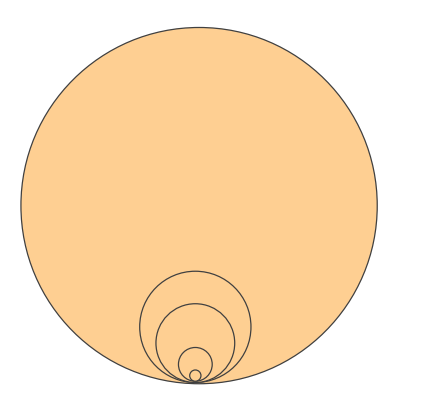

10.000 .000 1.000 .000

100.000

10.000
Fontes:

Limite Municipal e Estadual - IBGE 2012.
População - Pesquisa O/D - RMSP - 2007

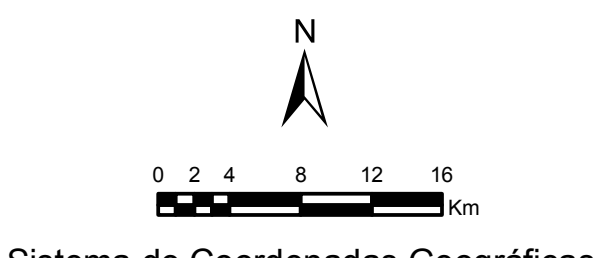

Sistema de Coordenadas Geográficas Datum WGS 84 
Como veremos detalhadamente adiante, $44 \%$ dot otal das viagens diárias são motivadas por "trabalho" e $35 \%$ pelo fator "educação" (Pesquisa O/D RMSP 2007). Como juntas representam $79 \%$ do total dos motivos de deslocamento, devemos analisar a c oncentração espacial da of erta do emprego e da educação, ambas caracterizadas como "zonas de destino" para os movimentos pendulares.

Do total da oferta de empregos (9 milhões) $65 \%$ está localizado na capital, sendo que dessa parcela, $43 \%$ se encontram ofertados no c entro expandido e $57 \%$ fora dele. Espacialmente a dens idade de em prego por hectare varia de "0" postos de trabalho até 1.624, sendo extremamente concentrada no centro da capital (conforme mostra o mapa 9). A densidade relativa é progressivamente menor ao s e afastar do c entro. Desta maneira podemos entender esse alto poder de at ração dos fluxos pendulares, resultando na convergência de diversas origens com destino ao centro, fruto dessa alta concentração de e mprego nessa área específica da metrópole (mapa 9).

Em contrapartida à oferta de em prego, a educ ação é um pouco mais desconcentrada na capital, como procura mostrar o mapa 10, A oferta varia entre "0" até 724 matrículas por hectare. Do ponto de vista da atração dos fluxos, por haver uma maior distribuição da densidade espacial das matrículas, os fluxos também não são tão concentrados. A capital detém $57 \%$ do total da RMSP, também exercendo uma polarização dos destinos dos fluxos de outros municípios. Mesmo que as matrículas apareçam um pouco mais desconcentradas, as maiores intensidades de densidade são novamente no centro da capital.

A distribuição espacial da população residente, dos empregos e das matrículas escolares, principais elementos de formação dos deslocamentos, resulta num campo de "viagens produzidas" e "recebidas", dados também disponibilizados pela pesquisa O/D da R MSP 2007. A análise destas duas variáveis (viagens "produzidas" e "recebidas") nos pareceu bastante elucidativa 
Mapa 9: RMSP - Concentração da Oferta de Emprego - 2007

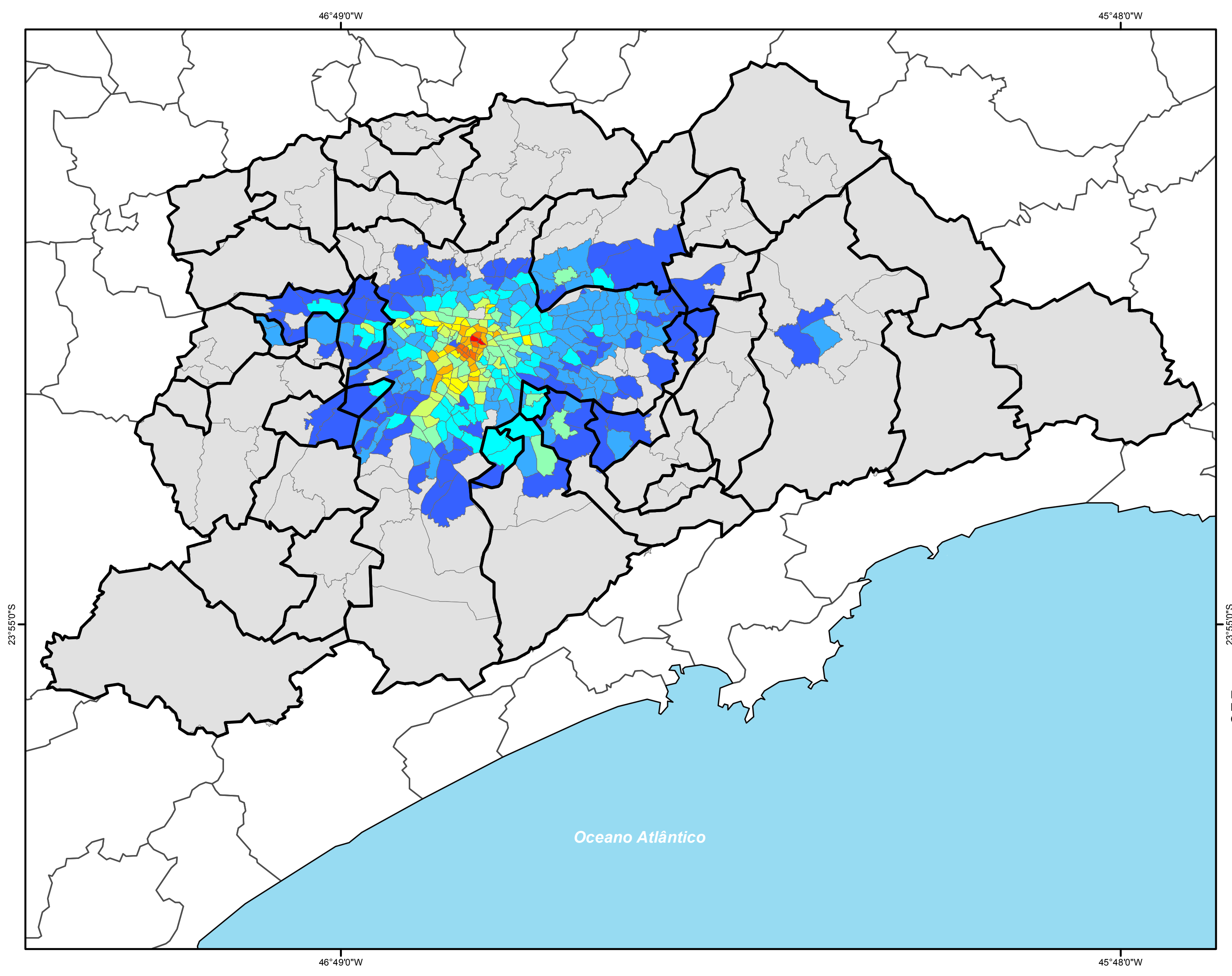

Localização Geral no Estado de São Paulo

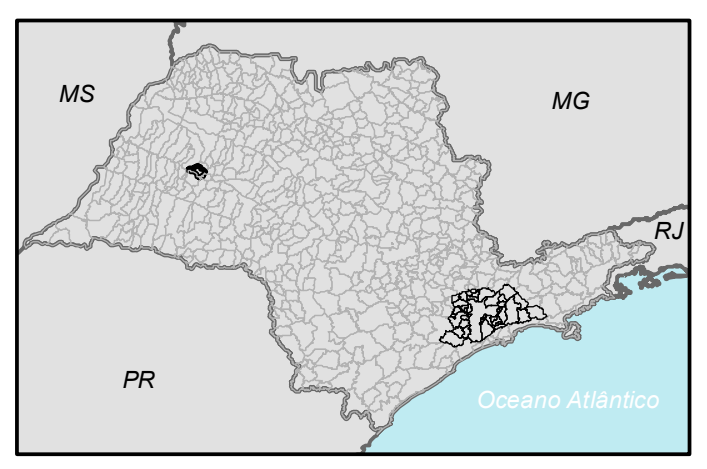

Legenda

$\square$ Limite Estadual Limite Municipal

Empregos / ha

$\square 0-13,99$

$14,00-33,61$

$33,62-55,20$

$55,21-82,18$

$82,19-120,4$

$120,5-173,2$

$173,3-261,7$

$\square 261,8-477,0$

$477,1-706,6$

$706,7-1.624$
Fontes:
Limite Municipal e Estadual - IBGE 2012.
Concentraçăo da Oferta de Emprego - Pes

(1) Emprego - Pesquisa O/D - RMSP - 2007

\section{$\AA^{N}$}

Sistema de Coordenadas Geográficas Datum WGS 84 
Mapa 10: RMSP - Concentração das Matrículas Escolares - 2007

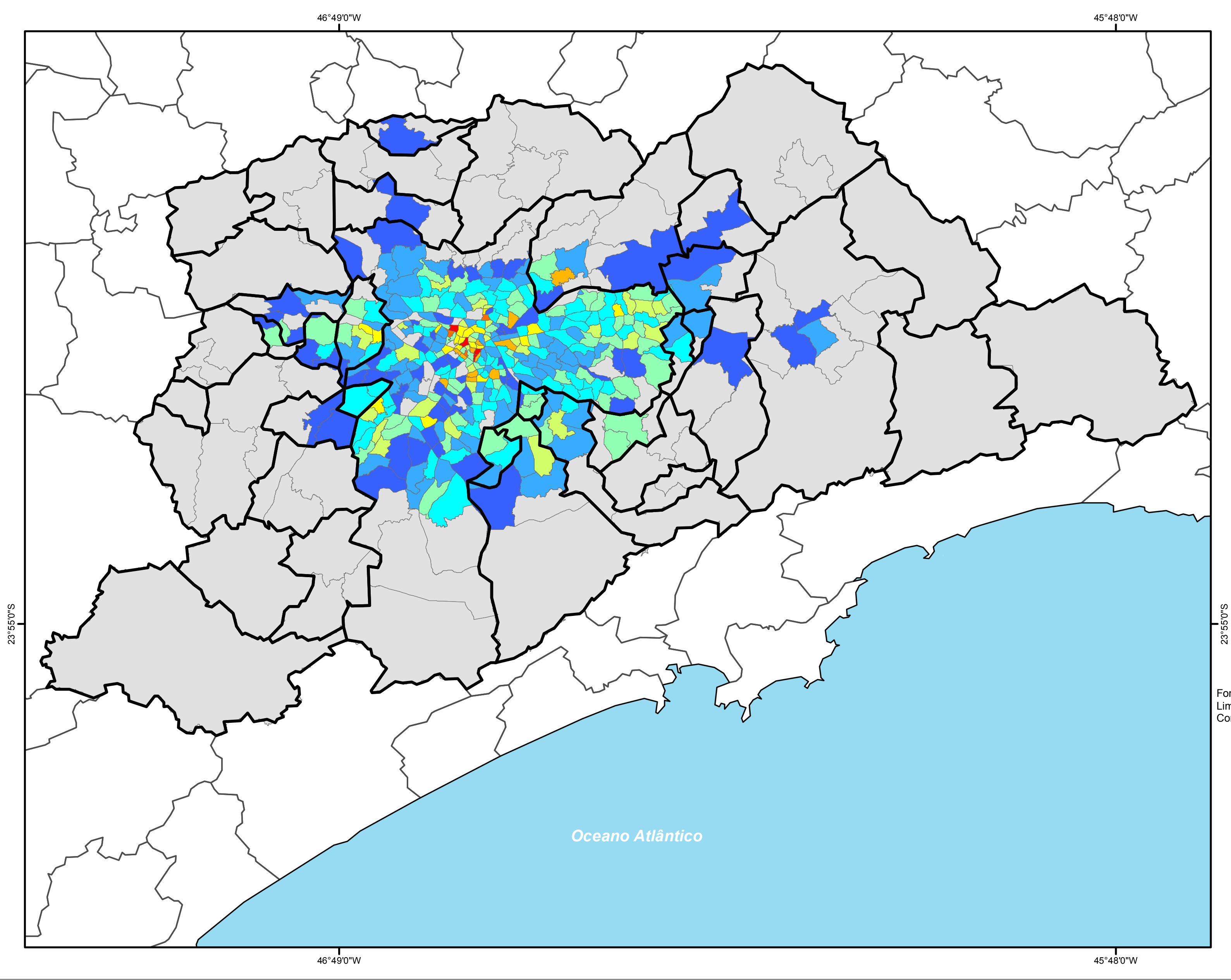

Localização Geral no Estado de São Paulo

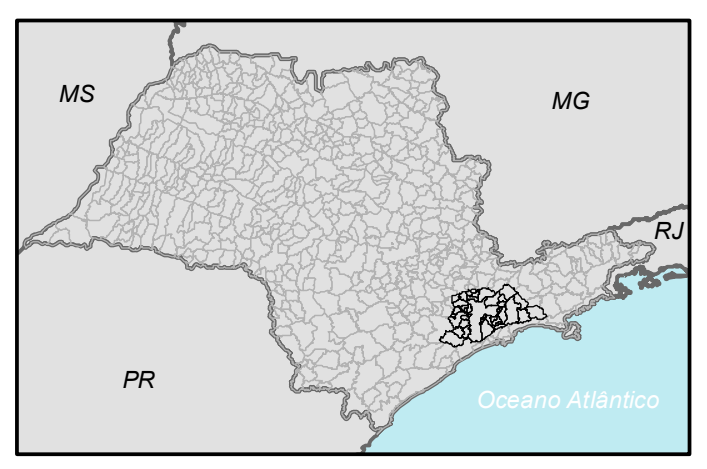

Legenda

$\square$ Limite Estadual Limite Municipal

Matriculas / ha

$\square 0$ - 6

$7-15$

$16-24$

$25-35$

$\square 36-50$

$\square 51-73$

$74-102$

$\square 103-167$

$168-253$

- $254-724$

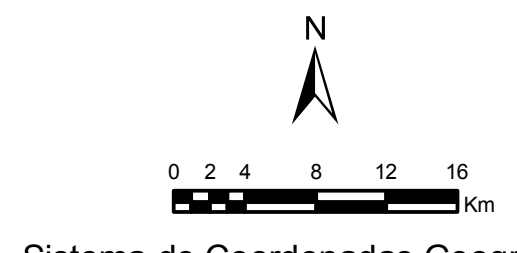


para entendermos o universo mais geral da mobilidade macrometropolitana, assim como, das áreas que polarizam a atração das viagens.

Para facilitar al eitura dos dados da Pesquisa Origem/Destino cartografados a seguir, foram elaborados mapas de dois principais tipos: 1. mapas com dados absolutos do 'fenômeno' analisado; e 2. mapas com dados relativos, que m ostram a r azão 'fenômeno'/hectare, para “ajustar” possíveis distorções provocadas pelo simples agrupamento dos dados por suas respectivas zonas.

Observando o mapa 11 nota-se uma maior concentração das viagens produzidas por hectare na zona central, com tendência de diminuição de densidade conforme é aumentada a distância do centro

Em termos absolutos (como mostra o mapa 12), na análise por zonas constatamos grande contribuição dos municípios periféricos no número de viagens produzidas, especialmente nas seguintes áreas: Guarulhos, região do ABCD e Osasco. Entretanto se somarmos, por exemplo, 5 zonas centrais, chegamos a uma classe de zonas maior do ponto de vista da extensão, porém com o m esmo valor absoluto, daí a i mportância de analisar os dados por hectare, para uma visão mais ampla do universo estatístico.

Em termos mais gerais o maior produtor de viagens é o município de São Paulo em sua área "fora" do centro expandido (com um total de 17.159.352 viagens produzidas). Em segundo lugar neste índice de importância viria o centro expandido (6.360.316 viagens), em terceiro Guarulhos (1.888.549), em quarto São Bernardo do Campo (1.688.083), em quinto Santo André (1.503.598), em sexto Osasco (1.133.227), em sétimo Diadema (782.769), seguido por Mauá, Mogi da Cruzes, Barueri e demais. O município de São Paulo representa $61 \%$ dessas viagens, Guarulhos 5\%, São Bernardo Campo $4,4 \%$, somados constituem pouco mais de $70 \%$ de todas as viagens produzidas da RMSP.

No tocante às "viagens atraídas" (mapa 13), as zonas com maior densidade por hectare também estão no centro da cidade de São Paulo, com 
Mapa 11: RMSP - Densidade de Viagens Produzidas - 2007

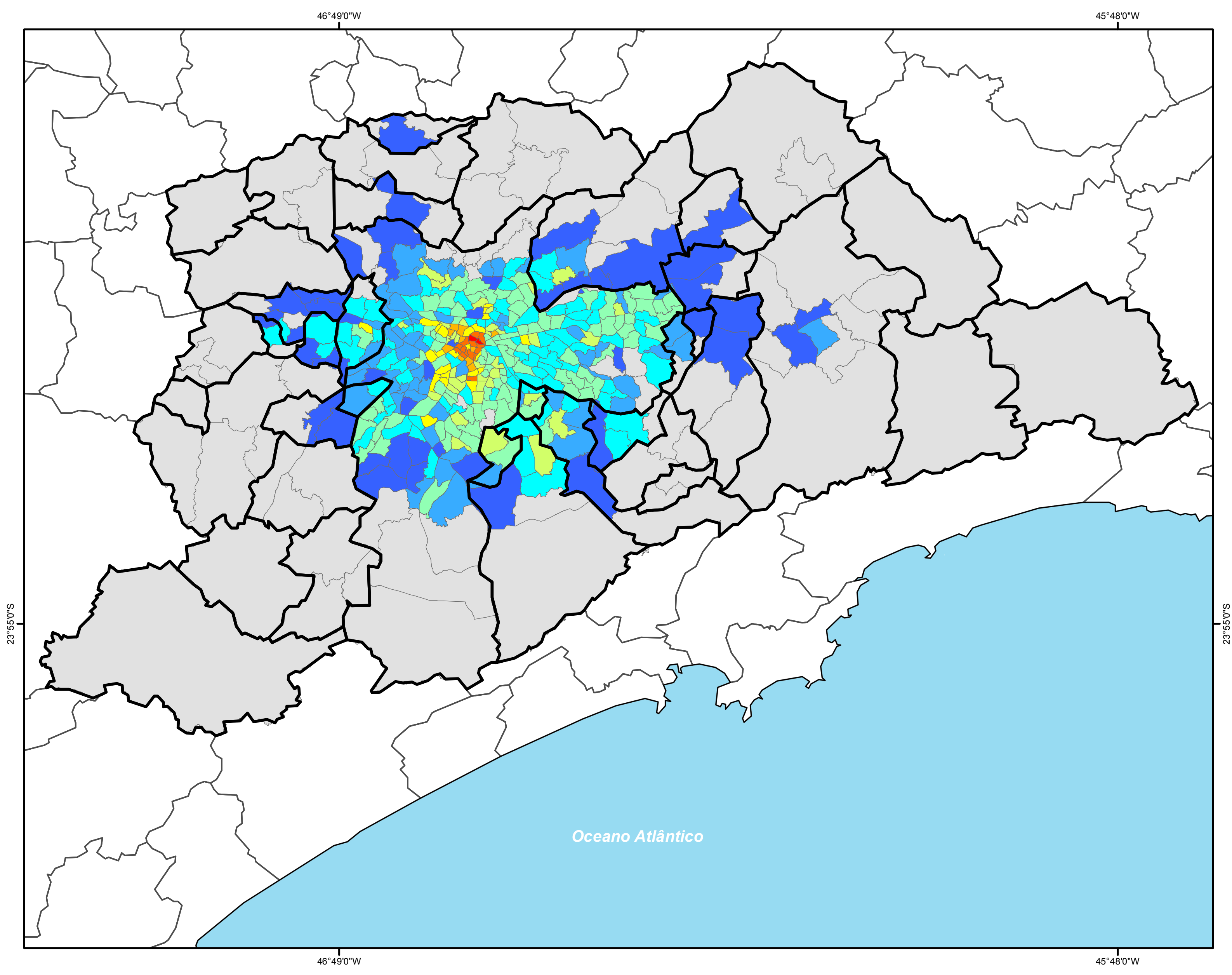

Localização Geral no Estado de São Paulo

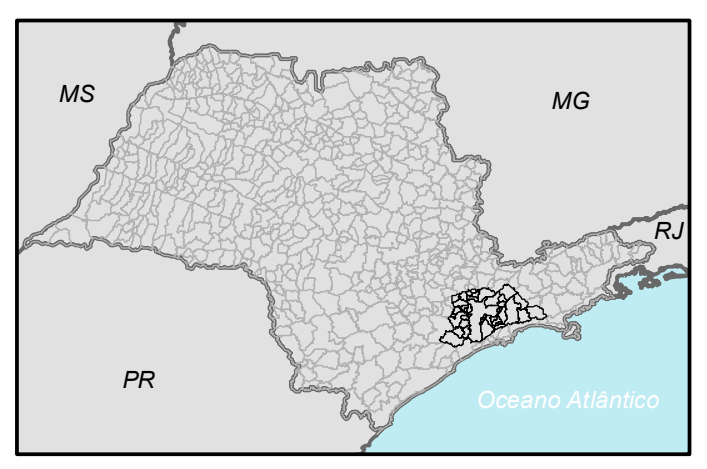

Legenda

$\square$ Limite Estadual

Limite Municipal

Viagens Produzidas / ha

$\square-40$

$41-107$

$108-179$

$\square 180-250$

$\square 251-337$

$\square 338-478$

$\square 479-702$

$703-974$

$975-1.436$

$1.437-2.837$
Fontes:
Limite Municipal EEtadual - 1BGE 2012.
Densidade de Viagens Produzidas - Pesquisa O/D - RMSP - 2007

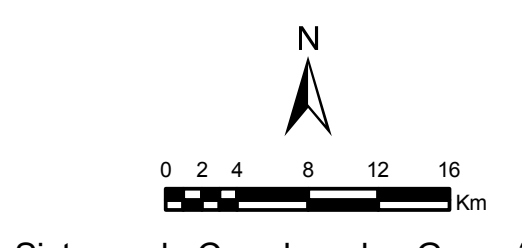

Sistema de Coordenadas Geográficas Datum WGS 84 
Mapa 12: RMSP - Viagens Produzidas - Valores Absolutos - 2007

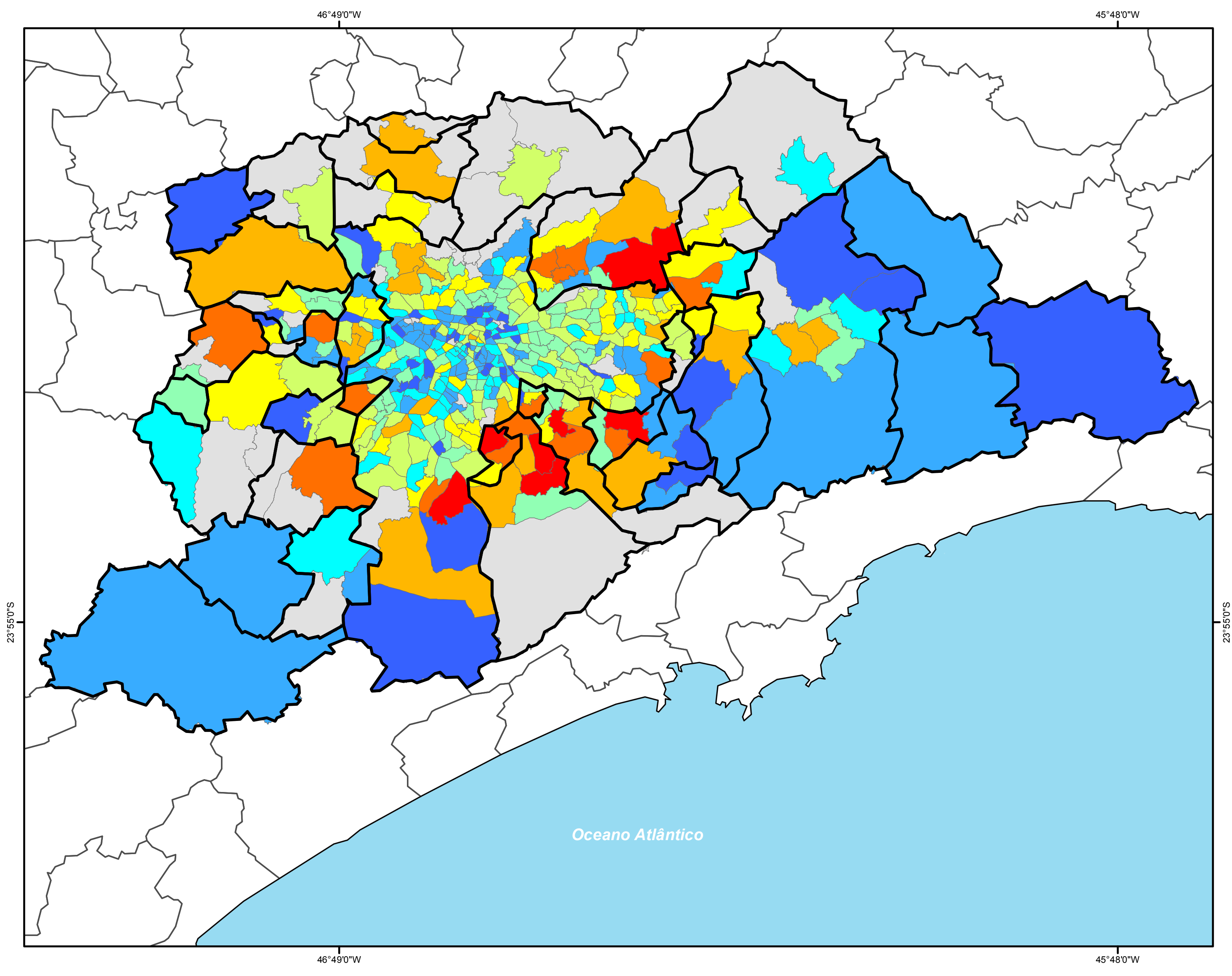

Localização Geral no Estado de São Paulo

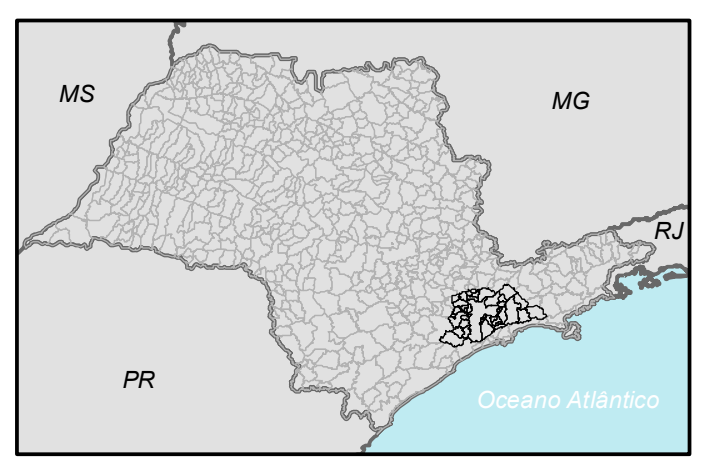

Legenda

$\square$ Limite Estadual Limite Municipal Viagens Produzidas 口 0 - 12.840

$12.841-30.488$

$30.489-46.204$

$\square 46.205-67.282$

$\square 67.283-91.339$ $91.340-121.631$

$121.632-161.876$

प $161.877-218.369$

$218.370-331.952$

$331.953-484.616$

Fontes:
Limite Municipal e Estadual - IBGE 2012.
Viagens Produzidas - Pusquisa O/D - RMSP - 2007

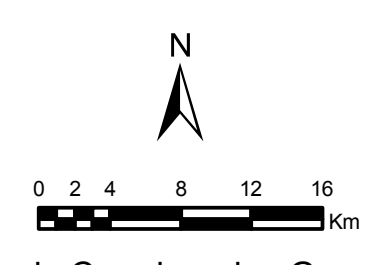

Sistema de Coordenadas Geográficas Datum WGS 84 
Mapa 13: RMSP - Densidade de Viagens Atraídas - 2007

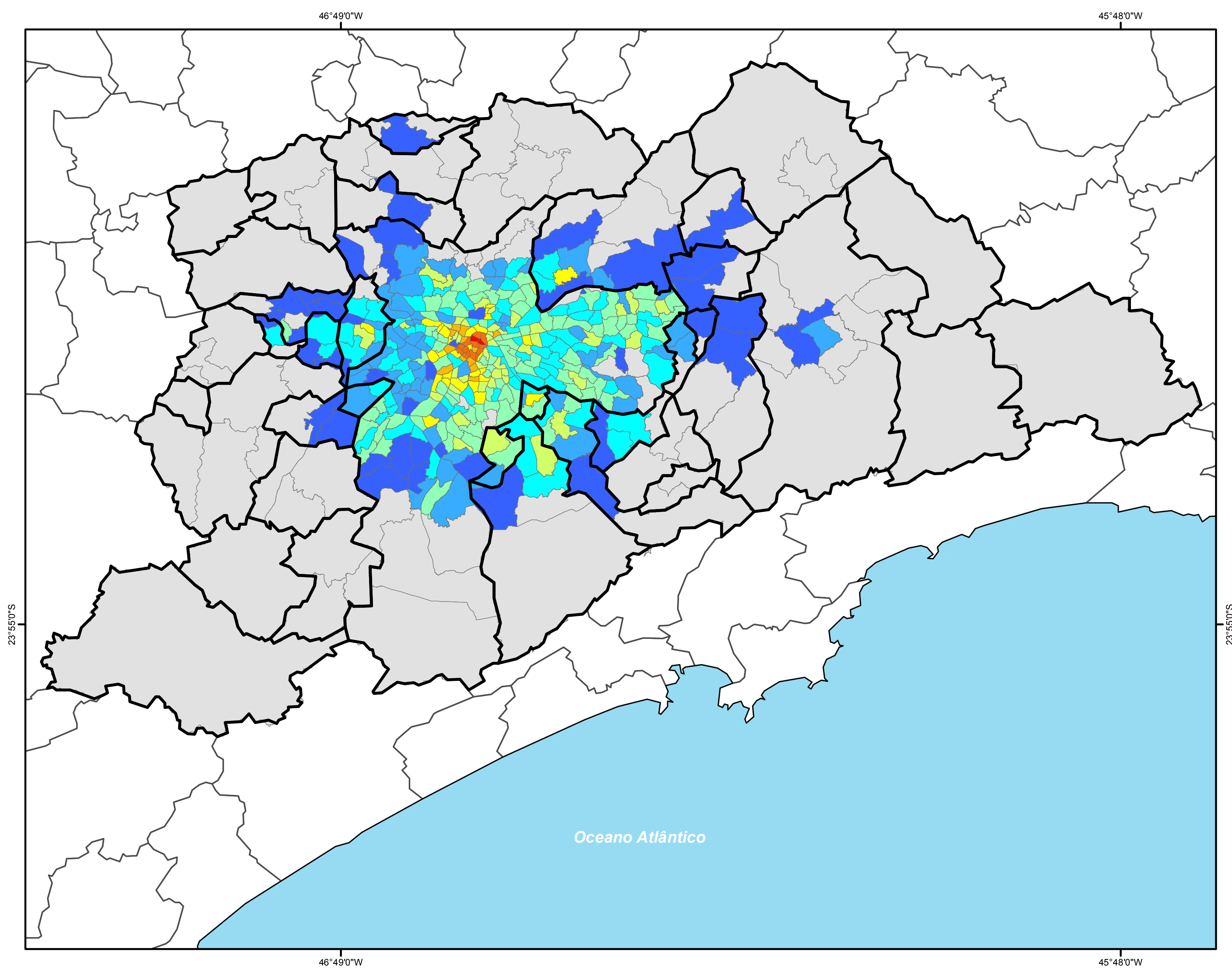

Localização Geral no Estado de São Paulo

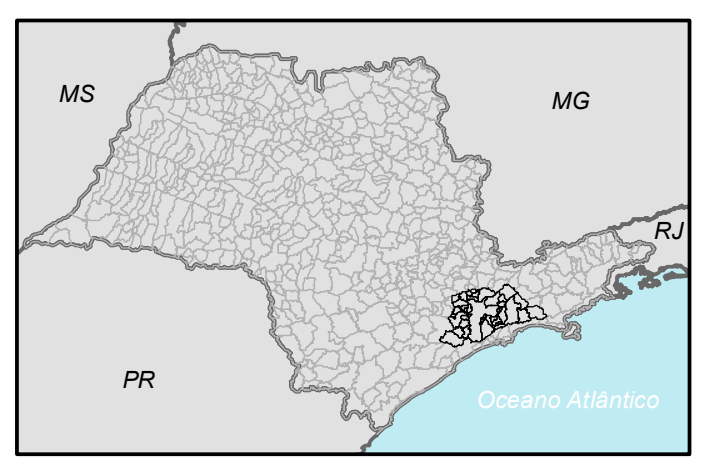

Legenda

$\square$ Limite Estadual

$\checkmark$ Limite Municipal

Viagens Atraídas / ha

$\square 0-40$

$41-107$

$108-176$

$\square 177-243$

$\square 244-318$

$\square 319-452$

$453-692$

$\square 693-1.027$

$1.028-1.435$

$1.436-2.840$

Fontes:

Densidade de Viagens Atraídas - Pesquisa O/D - RMSP - 2007

\section{$\bigwedge^{N}$}

Sistema de Coordenadas Geográficas Datum WGS 84 
diminuição progressiva ao nos afastarmos da zona central. Conforme apresentado em mapas anteriores, a concentração de empregos é maior na capital e de altíssima densidade por hectare em zonas centrais específicas.

Em valores absolutos (mapa 14), novamente, a maior contribuição é da capital com 23.529.066 "viagens atraídas", ou seja, 61\% dos totais registrados para a RMSP; dentro deste universo, 16,8\% referem-se às "viagens atraídas" pelo centro expandido e $45 \%$ pelo resto do $m$ unicípio. E m seguida viria Guarulhos com 18.84.105 das viagens (ou 4,9\%), São Bernardo do C ampo 16.89.142 (4,4\%), Santo André 1.505 .469 (4\%), Osasco 11.26 .515 (3\%) e demais municípios.

Pela análise dos materiais disponibilizados pelos órgãos que produzem estatísticas deste tipo, podemos dizer que essa correlação não quer dizer que as viagens são apenas "internas" (isto é, com origem e des tino na m esma zona), mas que quant o maior a produção de viagens maior é a atração das mesmas. Cada zona apresenta um valor de viagens produzidas e recebidas. Tais valores variam de zona para zona, por motivos das características do tecido urbano; algumas zonas são de c aráter residencial, outras mais empresariais e comerciais. É esta divisão territorial do trabalho, portanto, que está na raiz da explicação da produção e da recepção de fluxos de pessoas cotidianamente.

Feitas estas análises com destaque para as principais "origens" e os principais "destinos" das viagens pendulares, podemos nos perguntar: quais são os municípios que mais geram fluxos, e quai s são aqueles que $m$ ais recebem estes fluxos? Para reconhecer esta situação do saldo das viagens, foi realizado um agrupamento das zonas (contempladas pela pesquisa O/D) por municípios; a partir deste agrupamento, foi possível identificar nos municípios as diferenças do saldo entre "viagens produzidas" e "viagens atraídas". Este procedimento tem como referência o trabalho do SEADE (2008) que analisa a pendularidade entre algumas regiões do estado de São Paulo. Os resultados indicam que os cinco municípios com maior superávit de viagens são: centro expandido de S ão Paulo (24.096), Diadema (2.219), Carapicuíba (2.132), 
Mapa 14: RMSP - Viagens Atraídas - Valores Absolutos - 2007



Localização Geral no Estado de São Paulo

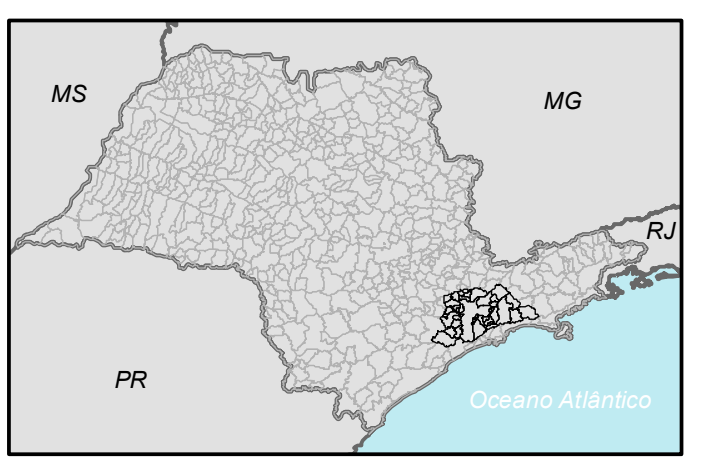

Legenda

$\square$ Limite Estadual Limite Municipal

Viagens Atraídas

$\square 0-11.971$

$11.972-28.930$

$28.931-44.737$

$\square 44.738-65.508$

$\square 65.509-88.756$

$88.757-115.680$

$115.681-155.074$

$155.075-211.425$

$211.426-321.131$

$321.132-485.182$

Fontes:
Limite Municipal e Estadual - IBGE 2012.
Viagens Atraidas - Pesquisa ODD - RMPP - 2007
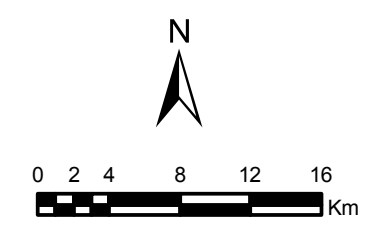

Sistema de Coordenadas Geográficas Datum WGS 84 
Taboão da Serra (1.900), Santo André (1.871). No outro extremo, os cinco municípios com maior déficit de viagens são: Município de São Paulo excetuado o centro expandido - (-14.700), Osasco (-6.711), Guarulhos (-4.444), Itaquaquecetuba (-2.329) e Francisco Morato (-1.963). O mapa 15 apresenta essa variação de saldo entre os municípios da RMSP.

Feito este quadro mais aproximado das zonas de atração e de zonas de envio de passageiros no contexto da Região Metropolitana de São Paulo (com seus respectivos saldos), podemos então nos perguntar: quais as causas destes deslocamentos? Que motivações guiam os atores em seu cotidiano para realizarem estas viagens pendulares? Como analisar a lógica e a distribuição espacial dessas viagens?

Com base nos dados da p esquisa Origem/Destino do Metrô (2007), podemos ver na tabela 14 que das 38.094 milhões de viagens diárias, 44,29\% eram motivadas pelo fator "trabalho", $34,56 \%$ pelo fator "estudo" e $21,15 \%$ por outros motivos (como "compras", "saúde", "procura por emprego" e "assuntos pessoais"). Tendo como referência o número total de viagens por motivo de trabalho, 5.189 milhões correspondem ao uso de ônibus (30,8\%), 4.980 milhões ao automóvel $(29,5 \%), 3.377$ feitas a pé $(20 \%), 1.428$ milhões por metrô $(8,5 \%), 615$ mil por trem (3,6\%), 547 mil por moto (3,2\%), 432 mil por fretados (2,6\%), 214 mil feitas de bicicleta (1,3\%), 32 mil por táxi e $56 \mathrm{mil}$ por veículo escolar e ou tros modos (0,5\%). Desse montante, 3.591 milhões de viagens eram realizadas por meios não motorizados $(21,3 \%)$ e 13.279 milhões por meios motorizados $(78,7 \%)$, dos quais 7.668 milhões referentes a transporte coletivo $(45,5 \%)$ e 5.611 milhões a transporte individual $(33,3 \%)$. 


\section{Mapa 15: RMSP - Saldo das Viagens - 2007}

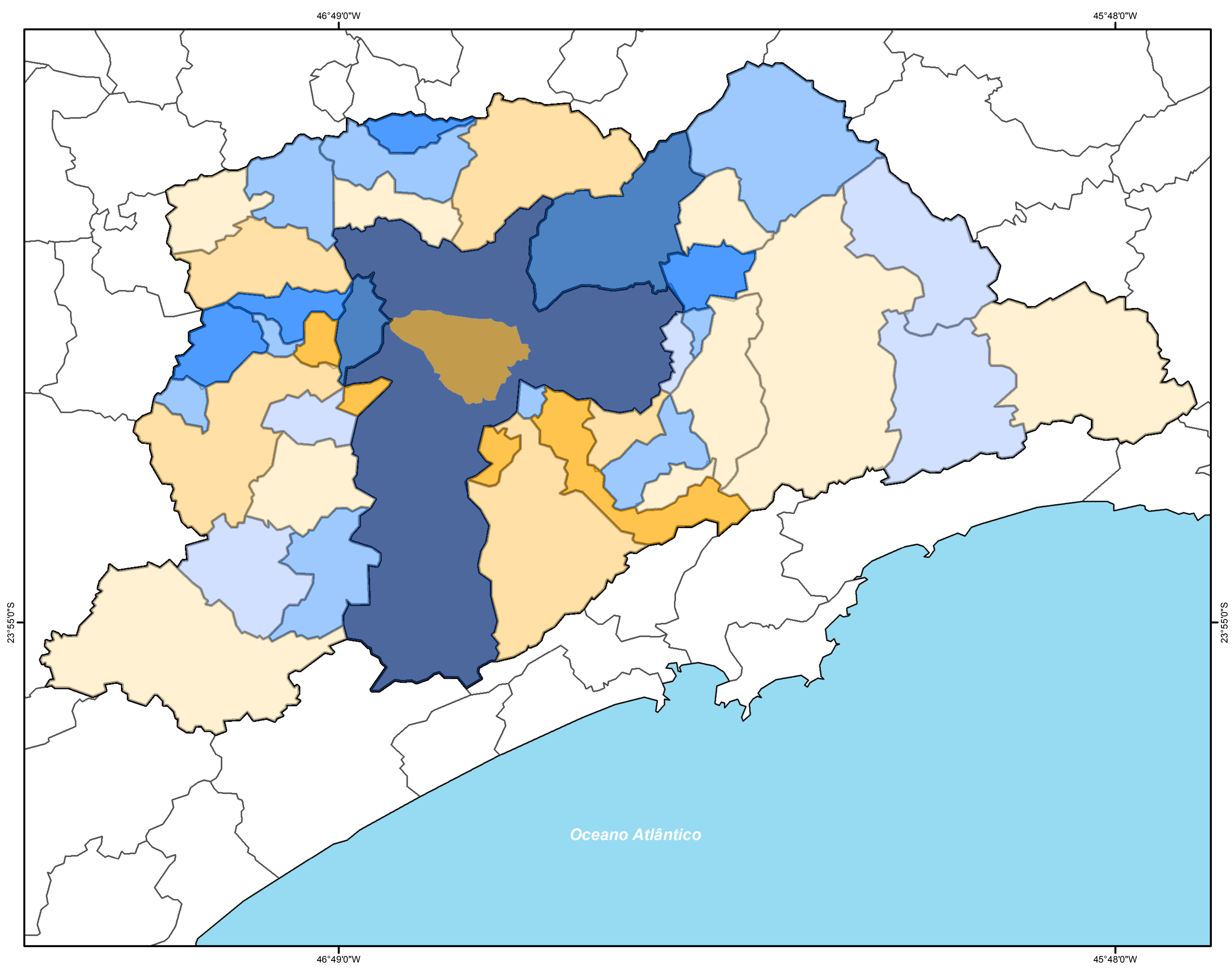

Localização Geral no Estado de São Paulo

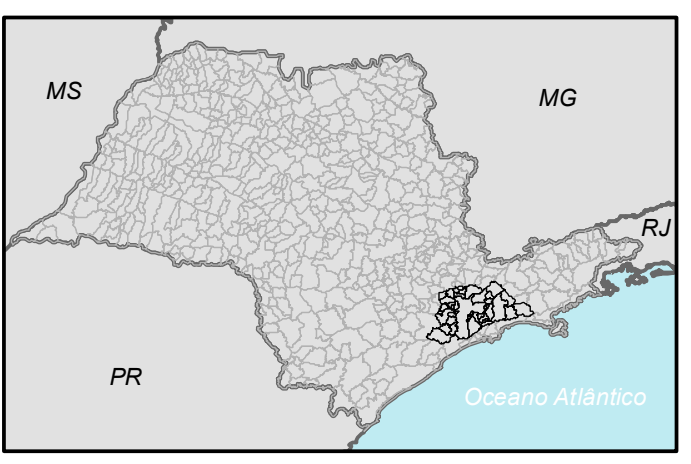

Legenda

$\square$ Limite Estadual Limite Municipal Saldo de Viagens ( Atraídas - Produzidas) $2.220-24.096$ $1.324-2.219$

$\square 644-1.323$ $1-643$

$-588-0$

$-1.403--589$

$-4.443--1.404$

$-14.691--4.444$

$-14.692$

Fontes:
Linite Municipale EStadual -18GE 2012.2
Saldo das Viagens - Pesquisa ODD - RMSP - 2007

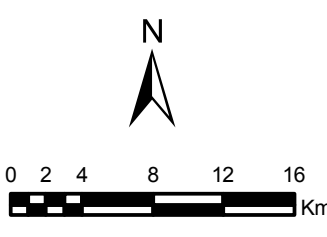

Sistema de Coordenadas Geográficas Datum WGS 84

Elaboração: GIBERTI 2012. 
Tabela 14: RMSP- Viagens diárias por modo e motivo (2007)

\begin{tabular}{|c|c|c|c|c|c|c|c|c|}
\hline \multirow{2}{*}{ Modo } & \multicolumn{2}{|c|}{ Trabalho } & \multicolumn{2}{|c|}{ Educação } & \multicolumn{2}{|c|}{ Outros } & \multicolumn{2}{|c|}{ Total } \\
\hline & Absoluto & Porcentagem & Absoluto & Porcentagem & Absoluto & Porcentagem & Absoluto & Porcentagem \\
\hline Não Motorizado & 3.591 & 27.8 & 7.291 & 56.4 & 2.045 & 15.8 & 12.927 & 100.0 \\
\hline Motorizado & 13.279 & 52.8 & 5.876 & 23.3 & 6.012 & 23.9 & 25.167 & 100.0 \\
\hline Coletivo & 7.668 & 55.1 & 3.520 & 25.3 & 2.725 & 19.6 & 13.913 & 100.0 \\
\hline Individual & 5.611 & 49.9 & 2.356 & 20.9 & 3.287 & 29.2 & 11.254 & 100.0 \\
\hline Metrô & 1.428 & 64.2 & 368 & 16.6 & 427 & 19.2 & 2.223 & 100.0 \\
\hline Trem & 615 & 75.5 & 95 & 11.7 & 105 & 12.9 & 815 & 100.0 \\
\hline Ônibus & 5.189 & 57.4 & 1.696 & 18.8 & 2.149 & 23.8 & 9.034 & 100.0 \\
\hline Fretado & 432 & 84.0 & 53 & 10.3 & 29 & 5.6 & 514 & 100.0 \\
\hline Escolar & 4 & 0.3 & 1.308 & 98.6 & 15 & 1.1 & 1.327 & 100.0 \\
\hline Automóvel & 4.980 & 48.0 & 2.251 & 21.7 & 3.150 & 30.3 & 10.381 & 100.0 \\
\hline Taxi & 32 & 35.2 & 7 & 7.7 & 52 & 57.1 & 91 & 100.0 \\
\hline Moto & 547 & 75.9 & 97 & 13.5 & 77 & 10.7 & 721 & 100.0 \\
\hline Bicicleta & 214 & 70.4 & 39 & 12.8 & 51 & 16.8 & 304 & 100.0 \\
\hline A Pé & 3.377 & 26.8 & 7.252 & 57.5 & 1.994 & 15.8 & 12.623 & 100.0 \\
\hline Outros & 52 & 85.2 & 1 & 1.6 & 8 & 13.1 & 61 & 100.0 \\
\hline Total de Viagens & 16.870 & - & 13.167 & - & 8.057 & - & 38.094 & - \\
\hline
\end{tabular}

Fonte: Metrô-Pesquisa O/D 2007. Organização: Giberti 2012.

Ao analisarmos mais detidamente cada tipo de viagem realizada, encontramos também algumas lógicas interessantes dos deslocamentos cotidianos na metrópole paulista. Das viagens motivadas pelo tema "educação" - e também usando como referência o número total de viagens -, observamos o predomínio das viagens não motorizadas, com 5.876 milhões $(55,4 \%)$, contra 5.876 milhões de viagens motorizadas $(44,6 \%)$. Dentre as não motorizadas, 0 modo a pé conta com mais da metade da porcentagem, representando $55,1 \%$ e restando apenas $0,3 \%$ para a bicicleta. Para as viagens motorizadas, 3.520 milhões eram feitas através de meios coletivos $(26,7 \%)$ e 2.356 milhões por meios individuais (17,9\%); dentro do "universo" destes deslocamentos 2.251 milhões foram realizados por automóvel (17,1\%), 1.696 milhões por ônibus 
(12,9\%), 1.308 milhões por escolar (9,9\%), 368 mil por metrô $(2,8 \%), 97$ mil por moto $(0,7 \%)$ e 155 mil por trem, fretado, táxi e outros $(2,4 \%)$.

Ainda no que diz respeito aos deslocamentos diários para o ano de 2007, podemos ver como o número total de viagens por modo, dividido pelos principais motivos, apresenta ot rabalho como principal razão dos deslocamentos. A motivação pelo "trabalho" representa a maior porcentagem das viagens de quase todas as modalidades, exceto pelo modo não motorizado $(56,4 \%)$, a pé $(57,5 \%)$ e escolar $(98,6 \%)$, ligados mais diretamente à motivação da "educação". As viagens motivadas pelo trabalho representam $49,9 \%$ das viagens individuais, $55,1 \%$ das viagens coletivas, $57,4 \%$ das viagens por ônibus, $64,2 \%$ das viagens por metrô, $70 \%$ das viagens por bicicleta, $75 \%$ das viagens por trem, $75,9 \%$ das viagens por moto e $84 \%$ das viagens por fretamento. Os demais motivos somam $57,1 \%$ via taxi, $30,3 \%$ por automóvel e $29,2 \%$ no modo individual.

Por fim, em relação ao total de viagens motorizadas para trabalho $57,7 \%$ eram realizadas por meios coletivos e $42,3 \%$ por meio individual, sendo que $39,1 \%$ feitas por ônibus, $37,5 \%$ por automóvel, $10,8 \%$ por metrô, $4,6 \%$ por trem, $4,1 \%$ por moto, $3,3 \%$ por fretado e $0,6 \%$ pelos demais modos. No modo não motorizado $94 \%$ das viagens foram feitas a pé e $6 \%$ em bicicleta.

Se este é um quadro geral sobre a lógica dos deslocamentos realizados sob a m otivação do "trabalho", o que pod e ser dito sob ponto de vista das viagens motivadas pela busca da "educação"? Ao analisarmos os mesmo dados da pesquisa O/D para o ano de 2007 , observamos que dos deslocamentos realizados pelo modo motorizado, podemos destacar 0 predomínio do modo coletivo de deslocamento, com $59,9 \%$ dos totais, contra $40,1 \%$ do modo individual. No que tange aos "modos" de deslocamento, $38,3 \%$ se realizou por automóvel, $28,9 \%$ por ônibus, $22,3 \%$ por escolar, $6,3 \%$ por metrô, $1,7 \%$ por moto, $1,6 \%$ por trem, e $1 \%$ pelas demais modalidades. Já o modo não motorizado conta com $99,5 \%$ de participação das viagens a pé e apenas $0,5 \%$ da bicicleta. Nos demais motivos, dentre as viagens motorizadas 
$52,4 \%$ foram feitas por automóvel, $35,7 \%$ por ônibus, $7,1 \%$ por metrô e 4,8\% pelos demais modos.

Ainda no intuito de e stabelecermos essa radiografia das "motivações" dos deslocamentos cotidianos na $m$ etrópole, podemos identificar zonas agrupadas por municípios que também apresentam variações relativas na composição dos motivos no total de viagens (mapa 16). Por exemplo, do total de viagens destinadas ao centro expandido, $53 \%$ foram realizadas pelo fator "trabalho", sendo que $39 \%$ deste "trabalho" se deu no s etor de serviços e 18,9\% para educação; num outro extremo deste escopo, vemos em Itapecerica da Serra que $49,2 \%$ dos deslocamentos se deram pelo fator "educação" e apenas $36,3 \%$ por motivos de trabalho. De maneira geral, as viagens recebidas são predominantemente motivadas por "estudo" e "trabalho em serviços"; dentre as demais classificações de trabalho, estão bem equilibrados os motivos de trabalho em "comércio" e na "indústria", e por fim, os deslocamentos por "assuntos pessoais", "lazer", "saúde", "compras" e a "procura por emprego".

Esclarecidas as características básicas das viagens, seus modais e motivos, podemos analisar o movimento pendular nas tabelas apresentadas a seguir, especialmente agrupadas para uma melhor noção do c ontexto metropolitano, usando como referência o município de São Paulo.

A matriz O/D em valores absolutos e relativos (tabela 15 e 16) revela que, das 23,5 milhões de viagens produzidas por dia pela capital no ano de 2007 , cerca de $92 \%$ eram internas, sendo que a capital recebia diariamente 1.902.111 viagens de outros municípios. Para os demais municípios, também identificamos que a maioria das viagens realizadas eram internas. Para se ter uma ordem dessa grandeza, apenas o centro expandido de $S$ ão Paulo produzia mais viagens que a s oma das viagens produzidas por Guarulhos, Santo André, São Bernardo do Campo e Osasco.

Ainda na capital, cabe destacar as diferenças internas que caracterizam essa "vida de relações". Sabemos que o saldo de viagens recebidas no centro expandido é positivo, ou seja, esta área da cidade "recebe" mais viagens do 
Tabela 15: RMSP - Matriz Origem/Destino das viagens - Valores Absolutos (2007)

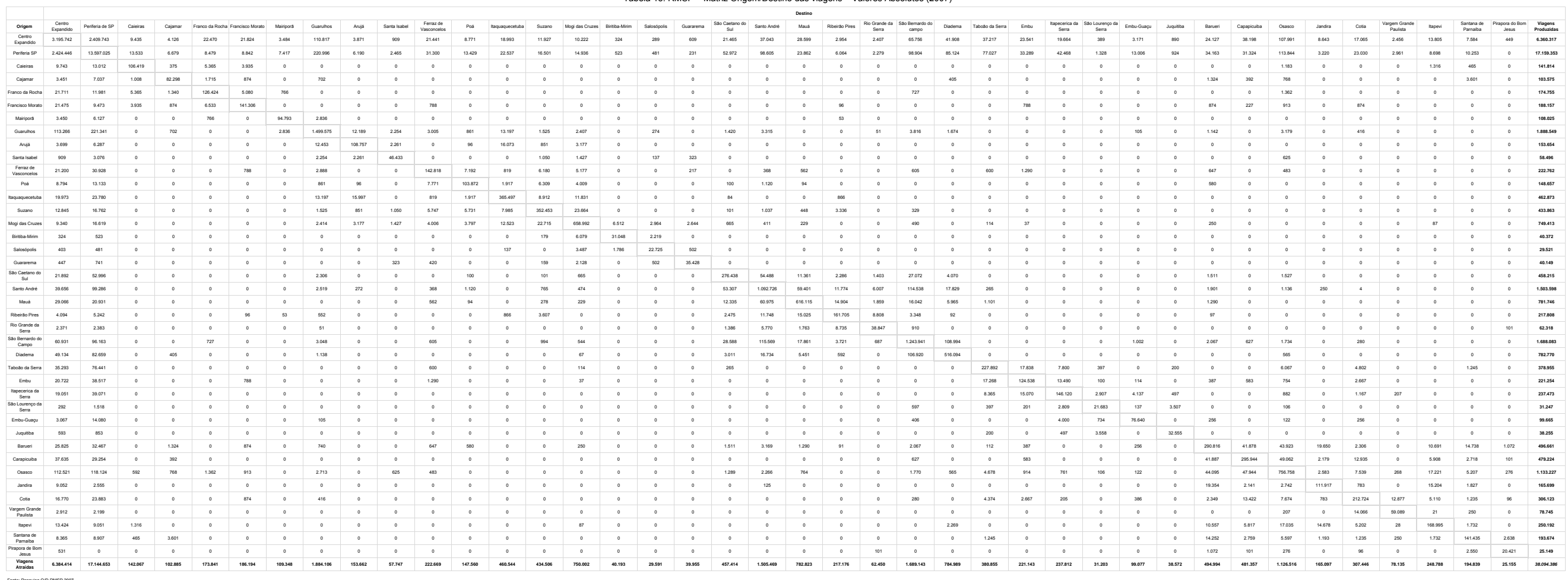


Tabela 16 RMSP - Matriz Origem/Destino das viagens - Valores Relativos (\%) (2007)

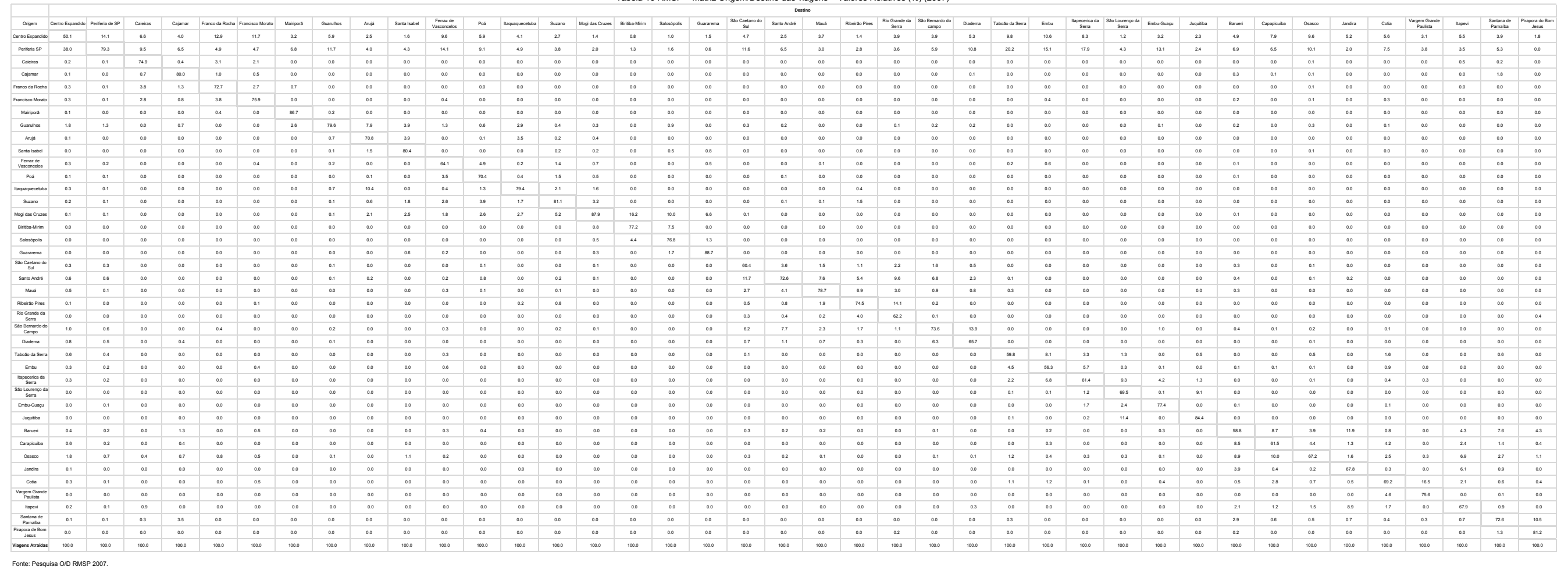


Mapa 16: RMSP - Viagens Atraídas por Motivo - 2007

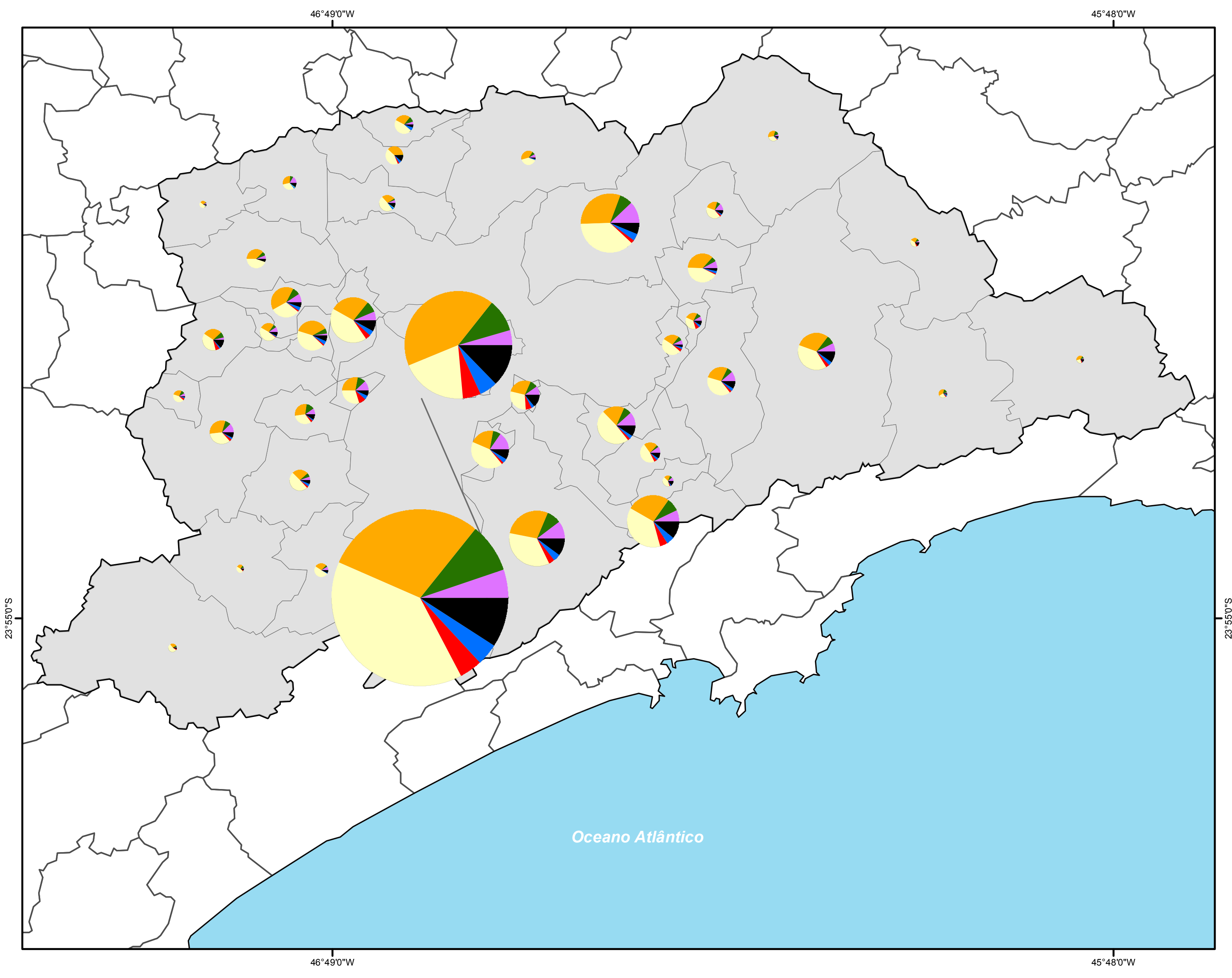

Localização Geral no Estado de São Paulo

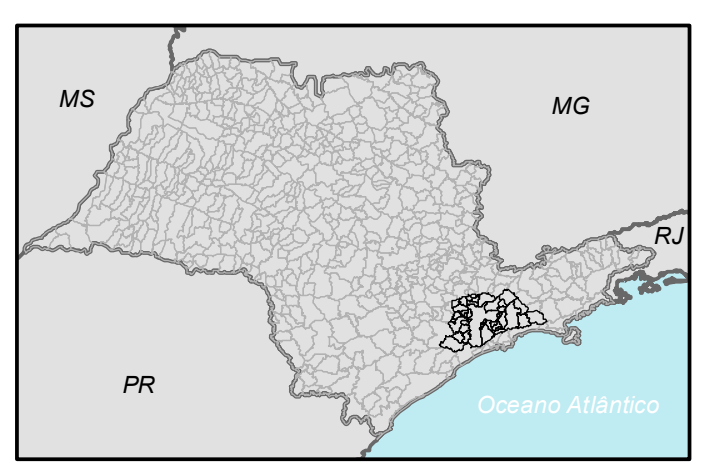

Legenda

$\square$ Limite Estadual

Limite Municipal

Motivo

Trab. Indústria

Trab. Comércio

Trab. Serviço

Educação

Compras

Saúde

Procurar Emprego

Assuntos Particulares

Viagens Atraídas - Absoluto

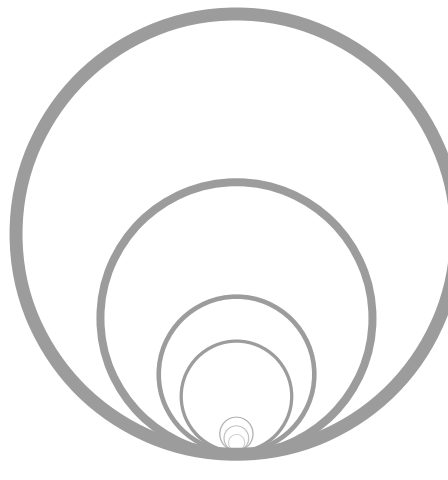

17.000 .000

6.000 .000

2.000 .000

1.000 .000

100.000

50.000

25.000

Fontes:

Limite Municipal e Estadual - IBGE 2012

泣

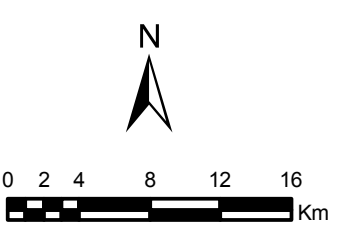

Sistema de Coordenadas Geográficas Datum WGS 84

Elaboração: GIBERTI 2012. 
que "produz". Desse total atraído (6.384.413 viagens) $50,1 \%$ é do pr óprio centro expandido, $38 \%$ das demais regiões da c apital, 1,8\% de Guarulhos, $1,8 \%$ de Osasco e o restante dos demais municípios. Já no resto do município (excetuado o centro expandido) foram atraídas 17.144 .653 viagens, das quais $79,3 \%$ dessa mesma área, $14,1 \%$ do centro expandido, $1,3 \%$ de Guarulhos, 0,7 de Osasco e o restante dos demais municípios.

Depois de São Paulo, os municípios que mais atraíram viagens foram Guarulhos (1.884.105), São Bernardo do C ampo (1.689.142), Santo André (1.505.469) e O sasco (1.126.515). No que diz respeito aos valores relativos, $79,6 \%$ das viagens de Osasco foram internas, $17,6 \%$ oriundas de São Paulo. Em São Bernardo do $C$ ampo $73,6 \%$ das viagens eram internas, $9,8 \%$ provenientes de São Paulo, 6,8\% de Santo Andre, 6,3\% de Diadema e 1,6\% de São Caetano do Sul. Para Santo André 72,6\% eram internas, 9\% oriundas de São Paulo, 7,7\% de São Bernardo do Campo, 4,1\% de Mauá e 3,6\% de São Caetano do Sul. Das viagens atraídas para Osasco $67,2 \%$ foram internas, $19,7 \%$ originadas na capital, 4,4\% em Carapicuíba e 3,9\% em Barueri. Se somarmos São Paulo, Guarulhos, São Bernardo do Campo, Santo André e Osasco chegamos a 78\% de todas as viagens atraídas na RMSP (38.094.386).

Para melhor visualizar essa pendularidade, adotamos como referência a relação da capital com a RMSP, observando as viagens atraídas e produzidas no município de São Paulo (mapas 17 e 18). Das viagens diárias originadas em outros municípios com destino a São Paulo (que somaram um total de 1.902.111 por dia no ano de 2007), pode ser dado um destaque para Guarulhos, que produziu334.607 viagens em direção à c apital, seguida de Osasco (que produziu 230.645 destas viagens), São Bernardo do $C$ ampo (157.094 viagens), Santo André (138.942), Diadema (131.793) e Taboão da Serra (111.733), representando juntas $49,8 \%$ do total. Por outro lado, a capital "exportou" no ano de 2007 nad a menos que 1.892 .770 viagens diárias para outros municípios, com as eguinte distribuição: 331.813 viagens para Guarulhos, 221.834 para Osasco, 164.659 para São Bernardo do $C$ ampo, 135.647 para Santo André, 127.031 para Diadema e 114.243 para Taboão da 
Mapa 17: RMSP - Viagens Diárias - Destino: Município de São Paulo - 2007

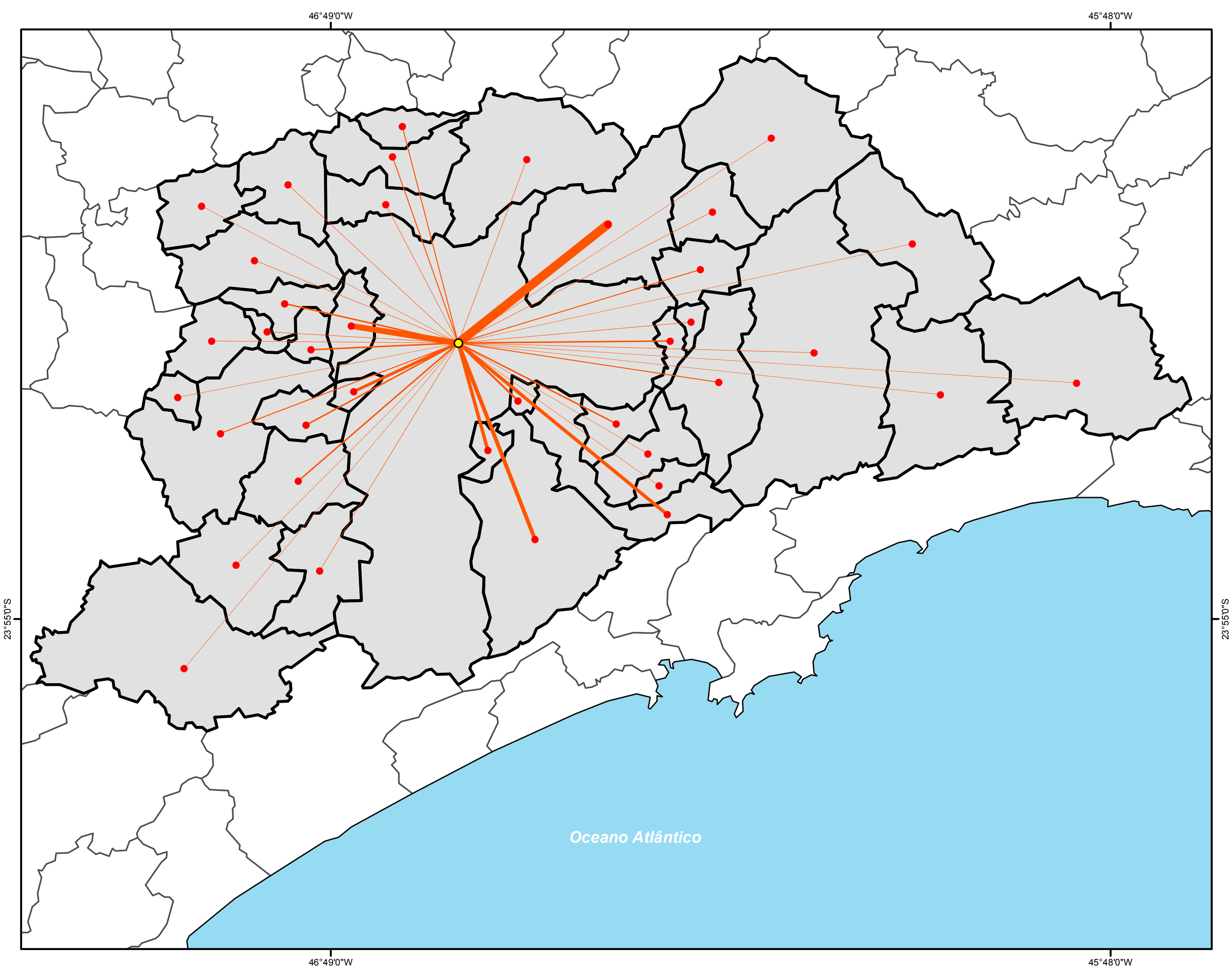

Localização Geral no Estado de São Paulo

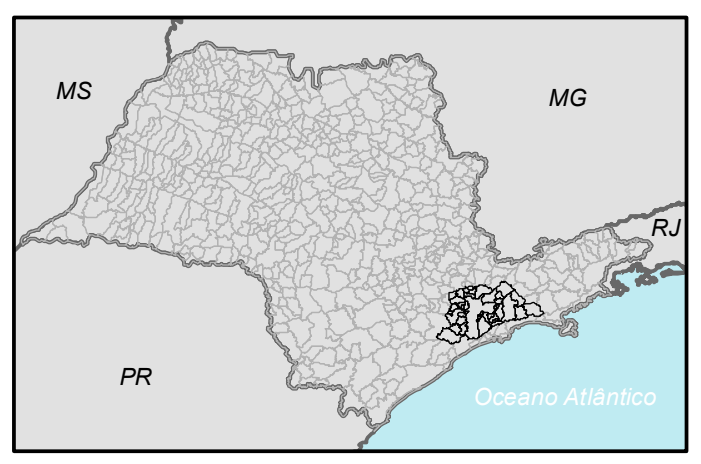

Legenda

$\square$ Limite Estadual

$\checkmark$ Limite Municipal

Viagens Diárias Atraídas

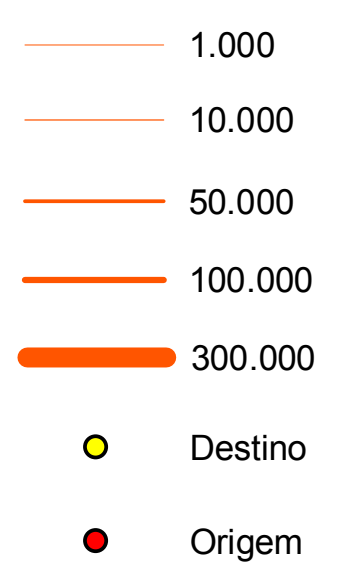

Fontes:
Limite Municipal e Estadual - IBGE 2012.
Viagens Diárias - Pesquisa OID - RMSP - 2007

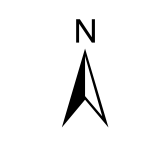

Sistema de Coordenadas Geográficas Datum WGS 84

Elaboração: GIBERTI 2012. 
Mapa 18: RMSP - Viagens Diárias - Origem: Município de São Paulo - 2007

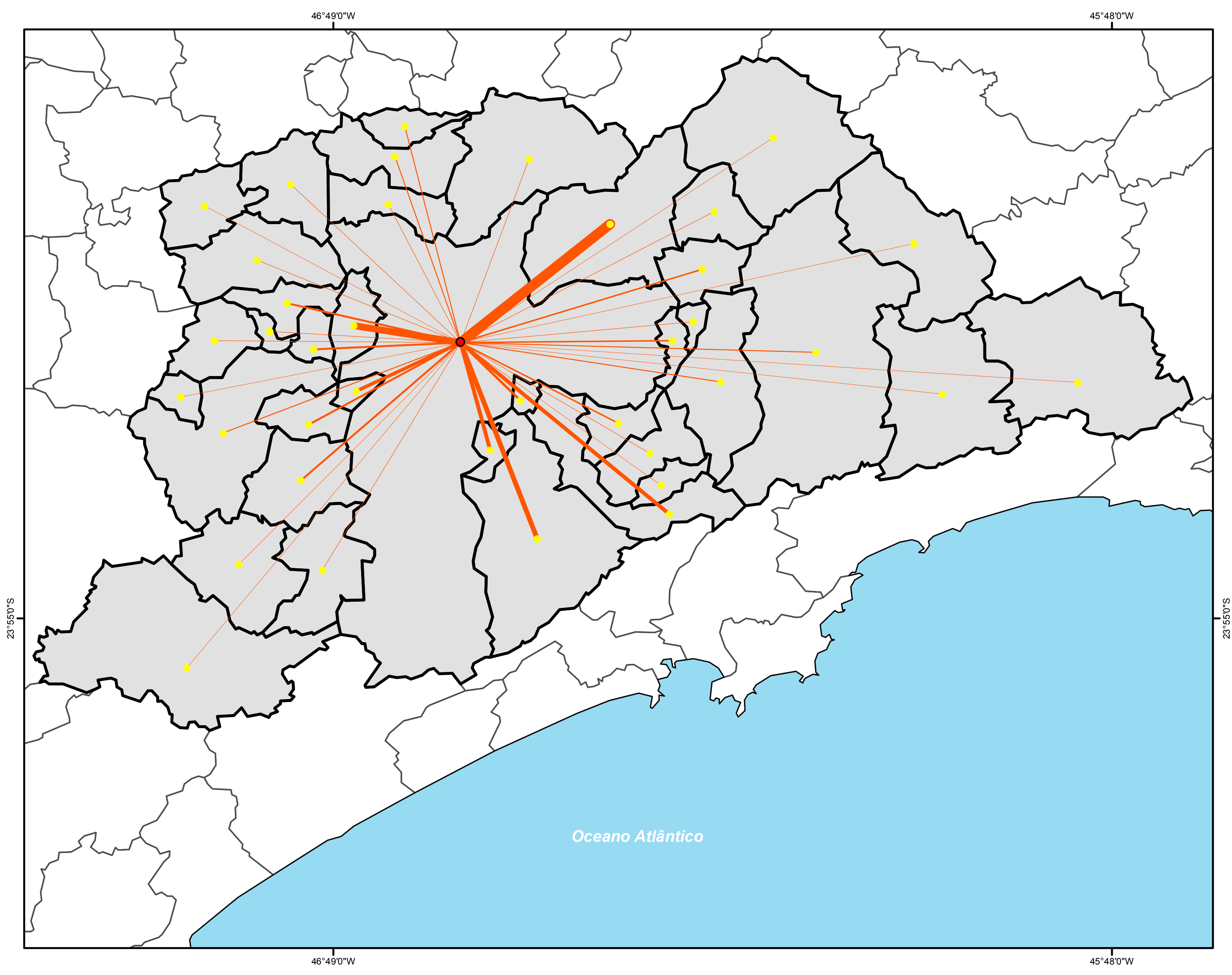

Localização Geral no Estado de São Paulo

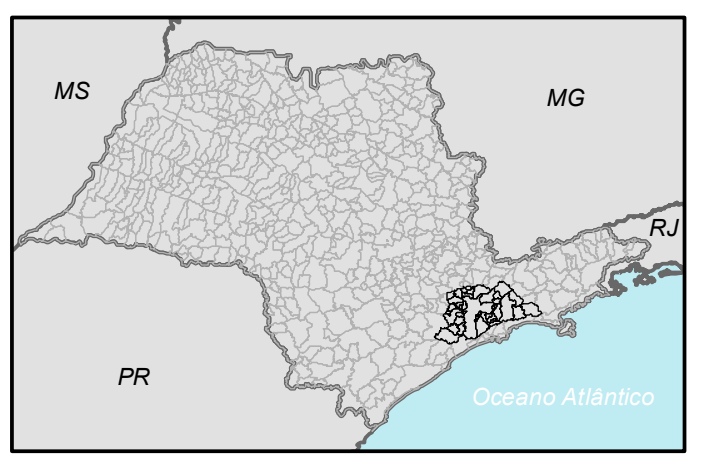

Legenda

$\square$ Limite Estadual

$\checkmark$ Limite Municipal

Viagens Diárias Atraídas

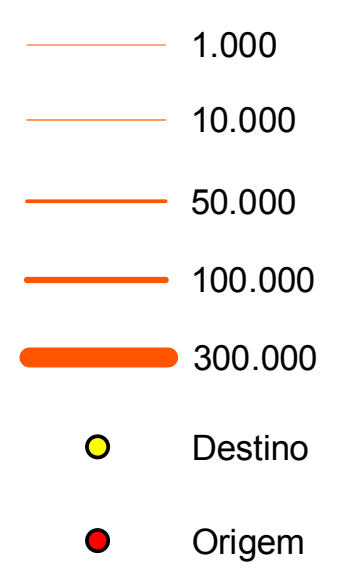
Fontes:
Limite Municipal e Estadual - IBGE 2012.
Viagens Diárias - Pesquisa OID - RMSP - 2007

$$
\bigwedge^{N}
$$

Sistema de Coordenadas Geográficas Datum WGS 84

Elaboração: GIBERTI 2012. 
Serra. Juntos constituem destino de $57,8 \%$ do total de viagens produzidas no município de São Paulo.

No saldo geral para o ano de 2007 , a capital recebeu 1.902.111 deslocamentos diários e exportou 1.892.715 viagens diárias, restando um saldo positivo de 9.396 recebidas. Observamos que 56,7\% de todas as viagens da pesquisa são internas da capital e que $62 \%$ de todas as viagens da R MSP destinam-se à c apital. Também podemos notar que, de t odas as viagens produzidas na c apital, $8 \%$ eram intermunicipais; somando as viagens intermunicipais produzidas pelos demais municípios, $13 \%$ destinavam-se à capital. Dessa forma, fica nítida a relação que o município de São Paulo estabelece com $67 \%$ de todas as viagens da RMSP, ou seja, a capital é objeto de origem ou destino desse total viagens.

Além da Pesquisa O/D histórica da R MSP também encontramos 0 mesmo tipo de pesquisa para a Região Metropolitana de Campinas (RMC) no ano de 2003, assim como para a R egião Metropolitana da B aixada Santista (RMBS) para o ano de 2007. Ambas as pesquisas igualmente apresentam um universo abrangente de variáveis, sendo nossa proposta destacar suas principais características, explicitando os principais modais, motivos e fluxos.

Em 2003 a Região Metropolitana de Campinas contava com 50,62\% dos empregos na área de serviços, $30,82 \%$ na área da indústria, $17,75 \%$ no comércio e apenas $0,81 \%$ na agr icultura ${ }^{43}$. Diariamente foram realizadas 3.602 .236 viagens, das quais $36 \%$ eram a pé e $64 \%$ motorizadas. Do total de viagens motorizadas, $44 \%$ eram pelo modo coletivo e $56 \%$ de forma individual. Em termos de origem/destino, do total das viagens motorizadas $41 \%$ eram internas ao município de $C$ ampinas, $40 \%$ internas aos demais municípios, $11 \%$ intermunicipais entre os demais municípios e $8 \%$ intermunicipais com destino à Campinas. Variações de acordo com cada município podem ser visualizadas no gr áfico 6 , com destaque para os

\footnotetext{
${ }^{43}$ Pesquisa O/D da Região Metropolitana de Campinas 2003.
} 
municípios de $\mathrm{H}$ ortolândia, Sumaré, Valinhos, Jaguariúna, Monte Mor e Paulínia, que mostram alto índice de viagens com destino a Campinas.

Gráfico 6: RMC - Viagens por destino (2003)

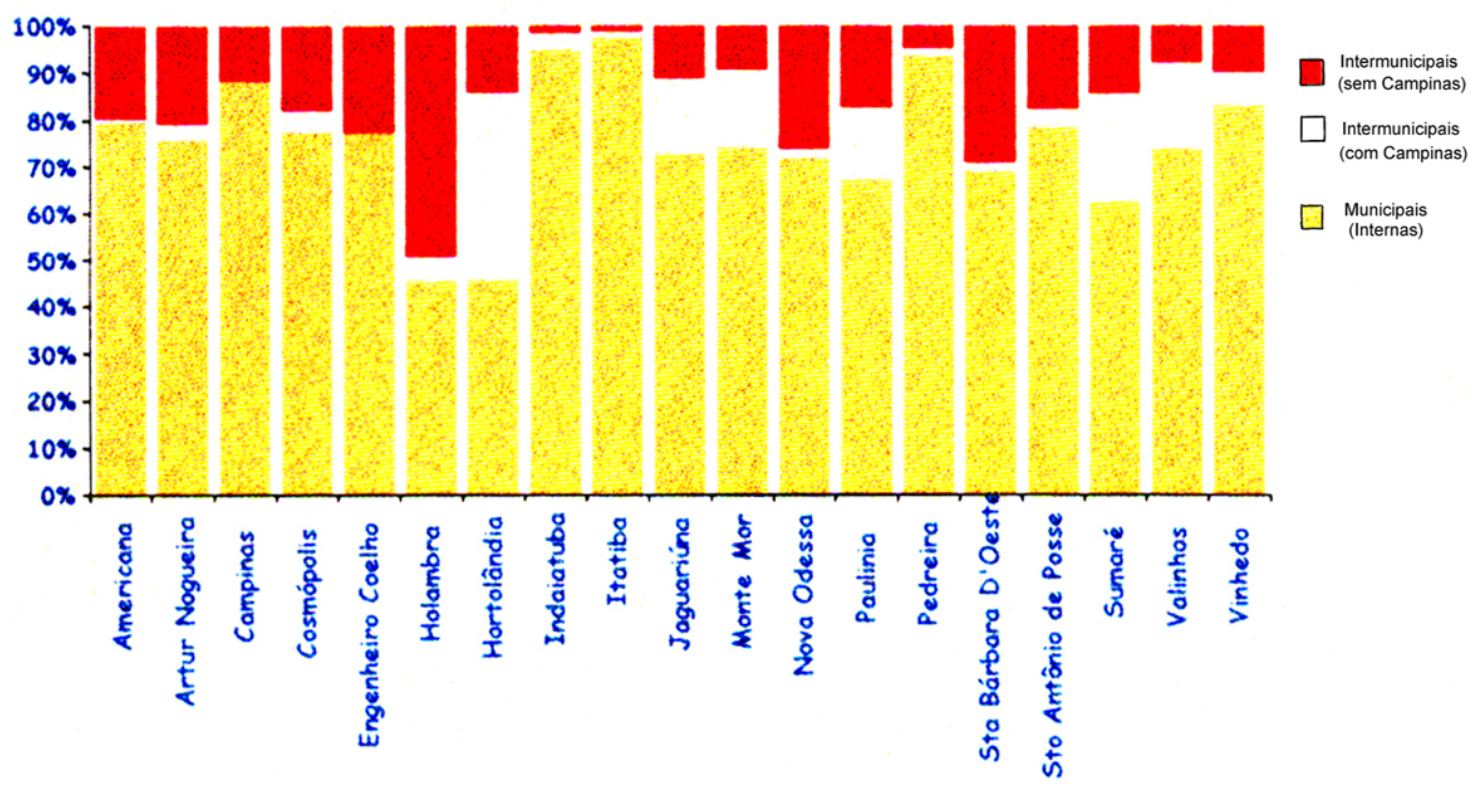

Fonte: Metrô-Pesquisa O/D 2003.

No que se refere aos motivos dos deslocamentos em sua relação com os "modais" utilizados, quase $56 \%$ das viagens para "estudo" foram realizadas a pé, sendo que $20,6 \%$ delas e deram por meio "coletivo" e $23,6 \%$ por forma "individual". Para os deslocamentos por motivos de "trabalho na indústria", $43,1 \%$ se deram a partir de m eio "coletivo", $40,1 \%$ de forma "individual", e $16,8 \%$ a pé; nos deslocamentos por "trabalho no comércio", $27,9 \%$ da movimentação se deu por meio "coletivo", 45,2\% por meio "individual" e 26,9\% a pé. Por fim, no que diz respeito aos deslocamentos por "trabalho em serviços", $34,7 \%$ deles se deram por meio "coletivo", $42,8 \%$ de forma "individual" e 22,5\% a pé.

A seguir, a t abela 17 apresenta detalhadamente a relação entre os "modais" e os "motivos" dos deslocamentos. Esta pesquisa, diferentemente daquela realizada para a $\mathrm{R}$ egião Metropolitana de São Paulo (RMSP), apresenta o motivo "residência" nos deslocamentos, responsável por 47,2\% das viagens, seguido por $23,3 \%$ de "trabalho" (desmembrado, por seu turno, 
em 12,4\% para os serviços; $6,5 \%$ indústria e 4, 4\% comércio), 19,8\% por educação e 9,7\% por outros motivos.

Percebemos que o indicador "trabalho na indústria" conta com $25 \%$ de participação de "fretados", 19\% de "automóveis", 18\% de "ônibus", 17\% "a pé", $9 \%$ em "bicicleta", $6 \%$ em "moto" e $6 \%$ em "outros". No que diz respeito ao indicador "trabalho no comércio", $27 \%$ dos deslocamentos se realizaram por "automóvel", $27 \%$ "a pé", $26 \%$ em "ônibus" e $20 \%$ em "outros modos". Nos fluxos por "trabalho em serviços", $30 \%$ se deram pelo modal "ônibus", $29 \%$ por "automóvel", 23\% "a pé" e 18\% em "outros modos". Por fim, nos deslocamentos motivados pelo fator "educação", cerca de $56 \%$ deles se realizaram "a pé", $12 \%$ por automóvel, $11 \%$ em ônibus, $8 \%$ em escolar e $13 \%$ em outros modos.

Tabela 17: RMC - Viagens diárias por modo e motivo (2003)

\begin{tabular}{|c|c|c|c|c|c|c|c|c|c|c|}
\hline \multirow[b]{2}{*}{$\begin{array}{c}\text { Modo } \\
\text { Principal }\end{array}$} & \multicolumn{9}{|c|}{ Motivo } & \multirow[b]{2}{*}{ Total } \\
\hline & $\begin{array}{c}\text { Trab. } \\
\text { Indústria }\end{array}$ & $\begin{array}{c}\text { Trab. } \\
\text { Comércio }\end{array}$ & $\begin{array}{c}\text { Trab. } \\
\text { Serviços }\end{array}$ & Educação & Compras & Méd/Dent/Saúde & Recreação/Visitas & Residência & Outros & \\
\hline Ônibus & 40.177 & 41.018 & 134.832 & 77.949 & 13.272 & 19.262 & 17.631 & 339.611 & 23.501 & 707.252 \\
\hline $\begin{array}{l}\text { Ônibus } \\
\text { Fretado }\end{array}$ & 58.954 & 1.590 & 12.813 & 8.773 & - & 213 & 684 & 80.025 & 1.413 & 164.464 \\
\hline Escolar & - & 104 & 269 & 56.755 & - & 55 & 650 & 56.985 & 321 & 115.138 \\
\hline $\begin{array}{c}\text { Dirigindo } \\
\text { Automóvel }\end{array}$ & 45.621 & 41.893 & 129.197 & 84.656 & 21.333 & 14.108 & 31.885 & 322.154 & 31.895 & 722.743 \\
\hline $\begin{array}{l}\text { Passageiro de } \\
\text { Auto }\end{array}$ & 12.165 & 12.025 & 24.721 & 65.862 & 11.066 & 12.781 & 22.797 & 148.875 & 14.818 & 325.109 \\
\hline Táxi & 74 & - & - & - & 67 & 921 & 392 & 1.911 & 326 & 3.690 \\
\hline Lotação/Perua & 1.847 & 1.386 & 6.713 & 3.427 & 801 & 1.980 & 947 & 17.358 & 2.590 & 37.049 \\
\hline Moto & 13.017 & 6.952 & 14.186 & 5.947 & 492 & 625 & 2.261 & 41.966 & 1.898 & 87.345 \\
\hline Bicicleta & 22.218 & 8.678 & 15.500 & 9.499 & 889 & 136 & 2.668 & 60.476 & 3.271 & 123.334 \\
\hline A Pé & 39.260 & 42.563 & 100.363 & 397.525 & 19.506 & 8.922 & 26.820 & 619.477 & 37.176 & 1.291 .611 \\
\hline Outros & 753 & 1.856 & 7.136 & 2.574 & 267 & 558 & 248 & 10.980 & 128 & 24.502 \\
\hline Total RMC & 234.087 & 158.065 & 445.730 & 712.965 & 67.692 & 59.561 & 106.982 & 1.699 .818 & 117.335 & 3.602 .236 \\
\hline
\end{tabular}

Fonte: Metrô-Pesquisa O/D 2003.

Feito este quadro mais circunstanciado sobre os deslocamentos cotidianos nas Regiões Metropolitanas de São Paulo e de Campinas, o que pode ser dito em relação ao fenômeno na Região Metropolitana da Baixada Santista? Segundo a pesquisa O/D para esta Região (de 2007), pode-se dizer que diariamente existiam 69.494 viagens no sentido RMSP/RMBS e 64.055 viagens desde a R MBS com destino à R MSP. No total, foram 
identificadas 2.079.516 milhões de viagens diárias, sendo 54\% motorizadas e $46 \%$ não motorizadas. Apenas Santos e S ão Vicente respondem por $49,3 \%$ do total.

Ainda de acordo com a pes quisa, os principais motivos das viagens foram "trabalho" (49\%) e "estudo" (40\%), restando aos itens "lazer", "saúde" e "compras" apenas 11\%. Do total das viagens motorizadas (1.115.192 milhões), $62 \%$ eram coletivas e $38 \%$ individuais. Abaixo, o gráfico 7 apresenta os valores absolutos de todos os modais. Ao analisarmos os números, vemos que se situa em primeiro lugar de relevância o modo "a pé" de deslocamento (configurando $32 \%$ dos totais), seguido do automóvel particular (16\%), do ônibus municipal (16\%), dos deslocamentos por bicicleta (15\%), por ônibus intermunicipal (8\%), seguido de "outros coletivos" (9\%) e movimentação por "moto" (4\%). Do total das viagens intermunicipais internas da RMBS (340.635), Santos e S ão Vicente recebem $60 \%$ dos deslocamentos. A pendularidade compõe $16,3 \%$ do total de viagens diárias.

Gráfico 7: RMBS - Número de viagens por Modal (2007)

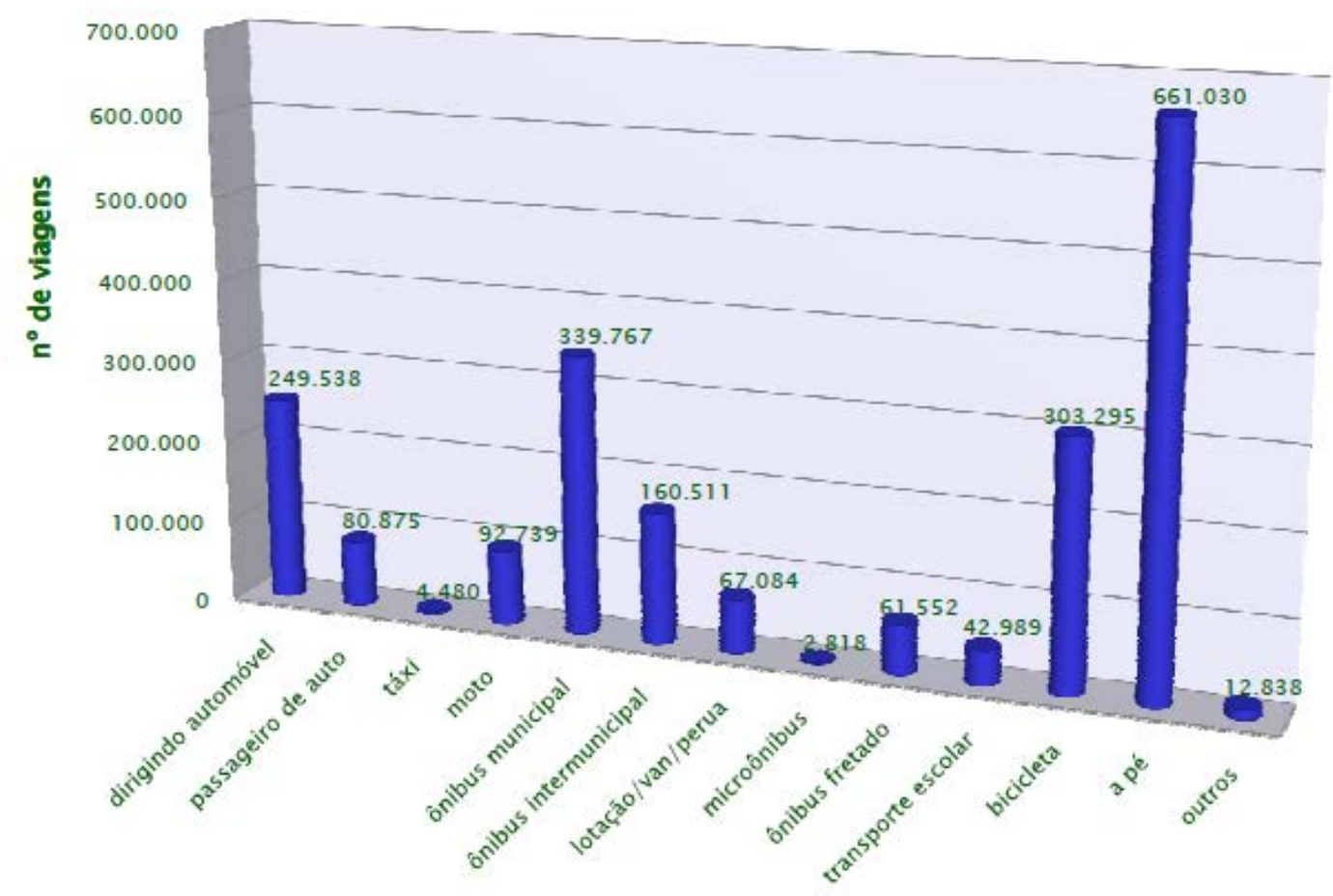

Fonte: Metrô-Pesquisa O/D 2007. 
Feitas estas considerações a respeito dos dados disponibilizados pelas pesquisas Origem/Destino do Metrô, podemos também ampliar nossa análise empírica a par tir do us o de outro universo de d ados sobre pendularidade, aquele disponibilizado pelo IBGE nos Censos Demográficos. Os dados do IBGE serviram de base para estudos de diversos autores que tratam da pendularidade na escala intrametropolitana e macrometropolitana. Dentre esses estudos, Ântico (2004) e A ranha (2005) esclarecem que a maioria dos fluxos da RMSP destina-se à capital. Esse mesmo padrão de fluxo intrametropolitano é des crito nos trabalhos do Núcleo de Estudos de População (NEPO) da U niversidade Estadual de Campinas (UNICAMP) (NEPO, 2004).

O estudo da pendul aridade associado à $r$ ede urbana e à metropolização foi amplamente trabalhado pela Fundação Sistema Estadual de Análise de Dados (o SEADE), dentro do contexto do Projeto Temático Urbanização Dispersa e Mudanças do Tecido Urbano (SP), citado no início desta dissertação. Em relatório publicado (SEADE, 2008), os dados do Censo Demográfico de 2000 do IBGE que tratam da pend ularidade foram especialmente tratados e agr upados para uma análise sistemática das origens e destinos dos fluxos, numa perspectiva macrometropolitana ${ }^{44}$.

Segundo este estudo (tabela 18), o Estado de São Paulo contava no ano de 2000 com 1.902 .688 milhões de pes soas com mais de 15 anos, trabalhando ou es tudando fora do $m$ unicípio de residência (o que representava cerca de $7 \%$ dos totais do universo da amostra). A RMSP foi o maior destino das viagens pendulares (2000), recebendo aproximadamente 1.115.105 pessoas diariamente, o que representa $58,6 \%$ das viagens realizadas no estado. A capital paulista recebeu 673 mil pessoas oriundas, principalmente, dos demais municípios da RMSP, da R MC eR MBS. Posteriormente, a RMC foi as egunda região que $\mathrm{m}$ ais atraiu a pendularidade do Estado, com $8,9 \%$ do total (168.844 pessoas), seguida

\footnotetext{
${ }^{44}$ No estudo foram consideradas as três regiões metropolitanas do estado de São Paulo e mais onze aglomerações urbanas, totalizando quatorze unidades regionais, das quais oito estão inseridas dentro dos limites da Macrometrópole estabelecida pela EMPLASA.
} 
Tabela 18: Estado de São Paulo - Pendularidade - Valores Absolutos (2000)

\begin{tabular}{|c|c|c|c|c|c|c|c|c|c|c|c|c|c|c|c|c|}
\hline \multirow[b]{3}{*}{ Destino de Deslocamento } & \multicolumn{16}{|c|}{ Área de Residencia Atual } \\
\hline & \multirow[b]{2}{*}{ 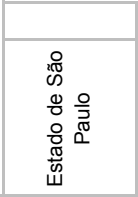 } & \multirow[b]{2}{*}{ 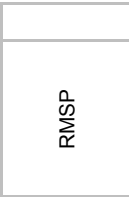 } & \multirow[b]{2}{*}{${ }_{\sum_{\mathbb{N}}^{\infty}}^{\infty}$} & \multirow[b]{2}{*}{$\sum_{\mathbb{N}}^{0}$} & \multicolumn{12}{|c|}{ Aglomerações Urbanas } \\
\hline & & & & & 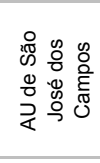 & 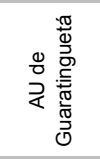 & 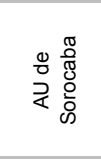 & 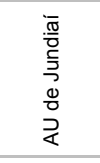 & 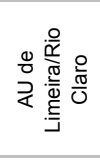 & 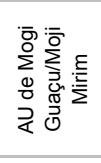 & 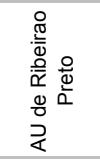 & 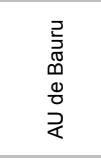 & 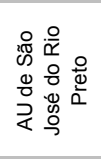 & 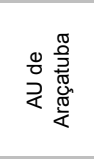 & 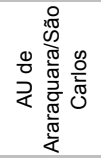 & 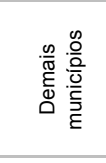 \\
\hline TOTAL & 27.164 .939 & 13.099 .070 & 1.066 .910 & 1.734 .026 & 878.695 & 181.203 & 768.288 & 415.969 & 470.415 & 205.372 & 526.305 & 325.378 & 320.444 & 200.080 & 327.013 & 6.623 .771 \\
\hline $\begin{array}{l}\text { Trabalha ou estuda no } \\
\text { mesmo município }\end{array}$ & 15.350 .279 & 7.315 .039 & 535.08 & 959.769 & 500.478 & 96.986 & 425.133 & 209.439 & 284.289 & 117.776 & 325.758 & 197.986 & 202.762 & 129.752 & 197.751 & 3.852 .281 \\
\hline Não trabalha/nem estuda & 9.911 .972 & 4.732 .432 & 431.357 & 609.823 & 331.678 & 71.7 & 295.659 & 152.829 & 169.987 & 75.832 & 177.471 & 117.776 & 108.155 & 65.350 & 115.357 & 2.456 .766 \\
\hline $\begin{array}{l}\text { Deslocamento para o } \\
\text { trabalho ou estudo }\end{array}$ & 1.902 .608 & 1.051 .599 & 122.473 & 164.434 & 46.539 & 12.517 & 47.496 & 53.701 & 16.139 & 11.964 & 23.076 & 9.616 & 9.257 & 4.978 & 13.905 & 314.724 \\
\hline RMSP & 1.115 .105 & 1.015 .221 & 17.936 & 13.377 & 8.389 & 1.301 & 8.257 & 11.921 & 2.224 & 983 & 1.482 & 1.168 & 824 & 742 & 1.353 & 29.927 \\
\hline RMBS & 111.214 & 5.63 & 102.380 & 281 & 84 & 39 & 111 & 75 & 54 & 77 & 20 & 68 & 35 & 16 & 46 & 2.298 \\
\hline RMC & 168.844 & 7.912 & 391 & 134.796 & 521 & 103 & 2.380 & 4.523 & 3.119 & 2.678 & 281 & 284 & 196 & 103 & 485 & 11.072 \\
\hline $\begin{array}{l}\text { AU de São José dos } \\
\text { Campos }\end{array}$ & 45.708 & 3.326 & 234 & 256 & 33.596 & 2.548 & 53 & 87 & 66 & 30 & 22 & 9 & 20 & 29 & 33 & 5.399 \\
\hline AU de Guaratinguetá & 13.119 & 155 & 32 & 47 & 825 & 6.58 & 10 & 10 & 21 & 21 & 5 & 30 & - & - & 11 & 5.372 \\
\hline AU de Sorocaba & 43.456 & 3.572 & 70 & 1.365 & 176 & 14 & 32.157 & 455 & 31 & 18 & 49 & 91 & 8 & 10 & 26 & 5.414 \\
\hline AU de Jundiaí & 45.267 & 4.005 & 62 & 3.537 & 62 & 9 & 518 & 35.450 & 77 & 51 & 61 & 45 & 10 & 9 & 67 & 1.304 \\
\hline AU de Limeira/Rio Claro & 13.024 & 683 & 28 & 3.137 & 40 & 12 & 63 & 92 & 4.609 & 316 & 91 & 85 & 36 & 20 & 349 & 3.463 \\
\hline $\begin{array}{l}\text { AU de Mogi Guaçu/Moji } \\
\text { Mirim }\end{array}$ & 8.362 & 169 & - & 564 & 27 & - & 26 & 9 & 395 & 5.974 & 10 & 20 & 12 & - & 37 & 1.119 \\
\hline AU de Ribeirao Preto & 35.691 & 344 & 93 & 261 & 39 & 18 & 109 & 39 & 179 & 165 & 16.004 & 152 & 218 & 68 & 624 & 17.378 \\
\hline AU de Bauru & 15.427 & 382 & 42 & 180 & 55 & - & 60 & 14 & 41 & 45 & 73 & 4.233 & 104 & 141 & 222 & 9.835 \\
\hline $\begin{array}{l}\text { AU de São José do Rio } \\
\text { Preto }\end{array}$ & 19.929 & 122 & 17 & 58 & 14 & 10 & 6 & 10 & 77 & 11 & 28 & 54 & 5.431 & 139 & 65 & 13.887 \\
\hline AU de Araçatuba & 8.541 & 75 & - & 64 & 19 & 9 & - & - & - & - & 6 & 22 & 16 & 1.758 & 14 & 6.558 \\
\hline $\begin{array}{l}\text { AU de Araraquara/São } \\
\text { Carlos }\end{array}$ & 19.968 & 896 & 131 & 595 & 168 & - & 185 & 108 & 582 & 58 & 646 & 175 & 221 & 53 & 6.145 & 8.005 \\
\hline Demais municípios & 239.033 & 9.107 & 1.057 & 5.916 & 2.524 & 1.874 & 3.561 & 908 & 4.664 & 1.537 & 4.298 & 3.180 & 2.396 & 1.89 & 2.428 & 193.693 \\
\hline
\end{tabular}

Fonte: SEADE 2008. 
pela RMBS com 5,8\% (111.214); São José dos Campos e Jundiaí, ambas, aparecem nas estatísticas com 2,4\% cada.

Dentre as três metrópoles paulistas que perfizeram o uni verso da pesquisa, vemos que os maiores índices de pendu laridade (referentes a população de 15 anos ou m ais) se deram na B aixada Santista (11,2\%), seguida de Campinas (9,5\%) e d e São Paulo (8,0\%). Dentre as aglomerações urbanas, pode-se dar destaque para a pendu laridade que ocorre no município de Jundiaí (12,9\%) e Guaratinguetá (6,9\%), Sorocaba (6,2\%), Mogi-Guaçu/Moji-Mirim (5,8\%) e São José dos Campos (5,3\%). A tabela 20 , a s eguir, relaciona a popu lação de 15 anos ou mais que se desloca para trabalho ou estudo com suas "origens" e "destinos". Em números absolutos, a R MSP contava com 1.051 .599 viagens pendulares diárias no ano de $2000,55,2 \%$ de todo o estado, com as demais regiões apresentando valores bem inferiores, com as eguinte hierarquia de importância: RMC com 164.434 viagens pendulares (ou 15,6\% dos totais); RMBS com 122.472 deslocamentos (11,6\%), Jundiaí com 53.701(5,1\%), Sorocaba 47.496 (4,5\%) e São José dos Campos com 46.539 (4,4\%). Essas regiões representam 1.486 .242 viagens pendulares, isto é, $78,1 \%$ dos totais movimentados no estado.

A maior parte da p endularidade é de c aráter intra-regional (75\%), o restante $(25 \%)$ é inter-regional. Sob o ponto de vista do saldo pendular das regiões da tabela anterior (entradas-saídas), podemos considerar a R MSP como a maior área de absorção da pendularidade, com saldo positivo de 63.506 pessoas, seguida pela RMC com 4.410 pessoas. No outro extremo, a RMBS conta com saldo de -11.259, Jundiaí com -8.434, Sorocaba com -4.040, Mogi-Guaçu/Moji-Mirim com -3.602, Limeira/Rio Claro com -3.115 e São José dos Campos com -831.

Do ponto de vista da relação dos deslocamentos com a população residente de cada região/município, ao analisarmos a prática pendular (tabela 20, acima), podemos inferir que: 
- das viagens originadas na RMSP, 96,5\% eram internas, 0,8\% com destino à $\mathrm{RMC}, 0,5 \%$ à $\mathrm{RMBS}$ e $0,4 \%$ à região de Jundiaí;

- na RMC, $82 \%$ das viagens eram intrametropolitanas, $8,1 \%$ com destino à RMSP, 2,2\% para Jundiaí, 1,9\% para Limeira/Rio Claro e 0,8\% para Sorocaba;

- na RMBS, 83,6\% das viagens eram internas e 14,6\% para a RMSP;

- na região de São José dos Campos, 72,2\% dos deslocamentos também foram internos, $18 \%$ destinados à RMSP e apenas 1,1\% para a RMC;

- em Guaratinguetá, 52,6\% eram de viagens internas, 20,4\% para São José dos Campos e 10,4\% para a RMSP;

- em Sorocaba, $67,7 \%$ viagens eram internas, $17,7 \%$ pra RMSP e $5 \%$ para a $\mathrm{RMC}$;

- em Jundiaí, 66\% das viagens sendo internas, 22,2\% para RMSP e 8,4\% para $\mathrm{RMC}$;

- em Mogi-Guaçi/Moji-Mirim, 49,9\% eram internas, 22,4\% para RMC e 8,2\% para RMSP.

O caso mais "extremo" é apresentado por Limeira/Rio Claro, onde apenas $28,8 \%$ das viagens eram internas, $19,3 \%$ com destino à RMC e 13,8\% para RMSP.

Para facilitar o ent endimento da atração dos fluxos pendulares em perspectiva macrometropolitana foram elaborados mapas com linhas de densidade dos deslocamentos pendulares atraídos para as RMSP, RMC e RMBS (as três regiões que mais recebem fluxos inter-regionais). Os mapas também apresentam as unidades regionais definidas pelo estudo citado do SEADE (2008).

No caso da RMSP (mapa 19), a maioria dos fluxos pendulares interregionais recebidos tinha sua origem na RMBS (17.936 deslocamentos), na RMC (13.377), em Jundiaí (11.921), São José dos Campos (8.389), Sorocaba (8.257), e em Limeira/Rio Claro (2.224), totalizando 62.104 viagens. As demais regiões apresentaram uma baixa contribuição em relação às supracitadas. Esse universo de viagens recebidas explicita a posição de "centro gravitacional" de atração da pendularidade macrometropolitana exercida pela 
Mapa 19: Macrometrópole Paulista - Pendularidade - Destino: RMSP - 2000

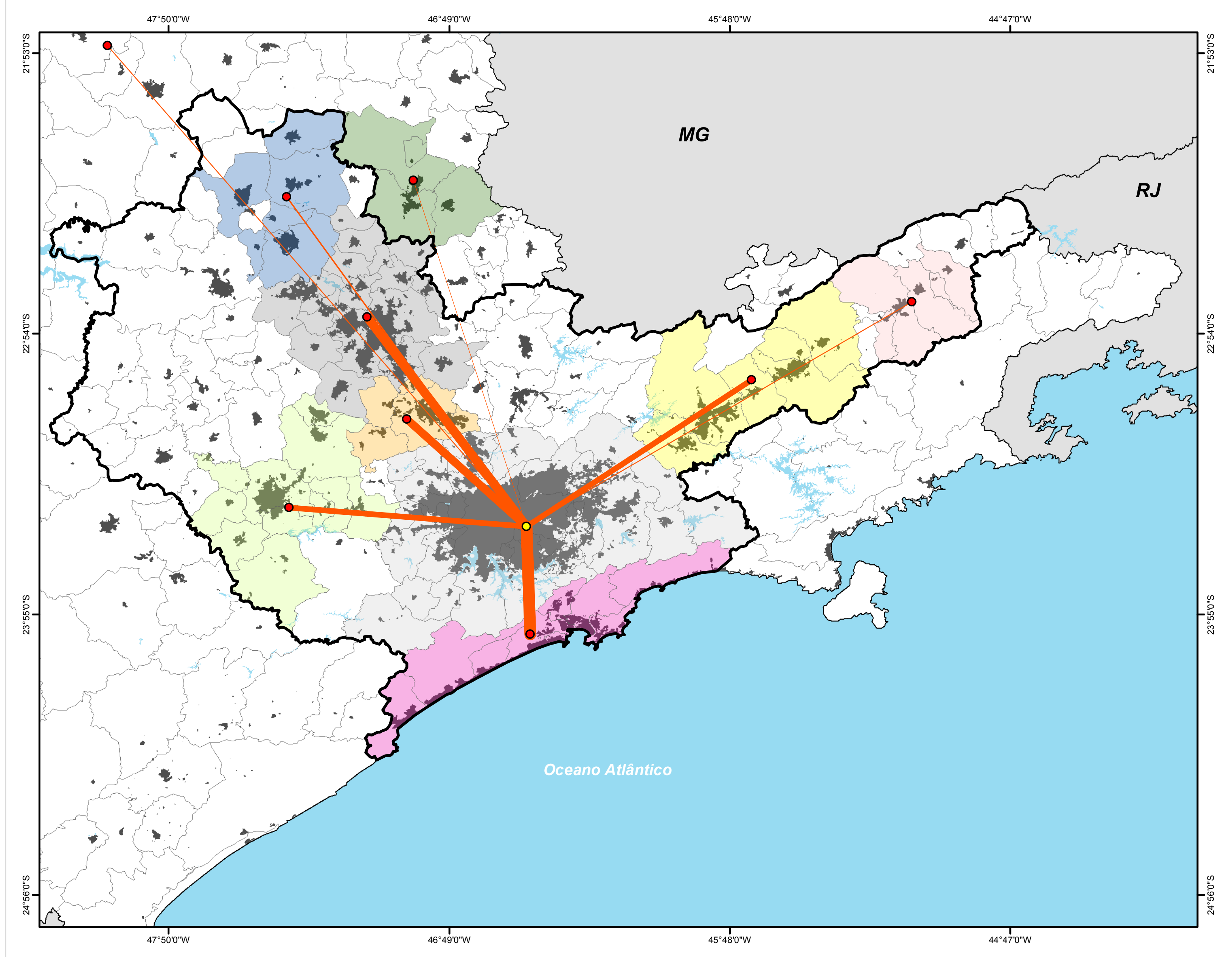

Localização Geral no Estado de São Paulo

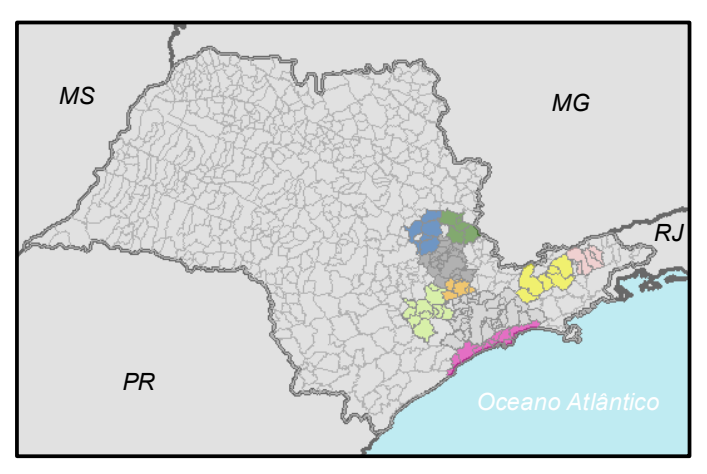

Legenda

$\square$ Limite Estadual

Limite Municipal

Oceano / Represa

Área Urbanizada 2005

AU de Guaratinguetá

AU de Jundiaí

AU de Limeira / Rio Claro

AU de Mogi-Guaçu / Mogi-Mirim

AU de Sorocaba

AU de São José dos Campo

RMBS

RMC

RMSP

$\square$ Macrometrópole

Pendularidade - Densidade de Fluxos

$$
\begin{aligned}
& 1.000 \\
& \begin{array}{r}
1.500 \\
-5.000
\end{array} \\
& 5.000 \\
& \begin{array}{r}
7.500 \\
10.000
\end{array} \\
& \text { - Destino } \\
& \text { - Origem } \\
& 15.000
\end{aligned}
$$

\section{Fontes:}

Limite Municipal e Estadual - IBGE 2012. Aglomerações Urbanas - SEADE 2008. Mancha Urbana - ProBio 2005.

Macrometrópole Paulista - EMPLASA 2011.

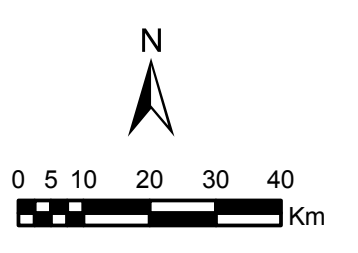

Sistema de Coordenadas Geográficas Datum WGS 84 
RMSP, sendo que as conexões mais densas estão em um raio de aproximadamente $100 \mathrm{~km}$ do centro da capital paulista.

Abaixo no mapa 20, observamos que as viagens destinadas à RMBS são oriundas quase que exclusivamente da RMSP (5.630), com baixa contribuição da RMC (281) e S orocaba (111); as demais regiões de destino são praticamente inexpressivas, com valores inferiores a 100 deslocamentos/dia.

$\mathrm{Na} \mathrm{RMC}$ (mapa 21), a m aior parte das viagens recebidas partiam da RMSP (7.912 deslocamentos), Jundiaí (4.532), Limeira/Rio Claro (3.119), Mogi-Guaçu/Moji-Mirim (2.687), Sorocaba (2.380) e S ão José dos Campos (521), totalizando 21.142 viagens. Por sua localização intermediária, a RMC é o segundo maior destino da pendularidade inter-regional da Macrometrópole.

Podemos considerar essas três regiões metropolitanas como os principais centros de at ração e pr odução "absoluta" da pendularidade macrometropolitana inter-regional. Essa trama de fluxos, apresentada no mapa 22, é um elemento importantíssimo que permite analisar empiricamente a "dimensão espacial do c otidiano" (SANTOS, 2002) destas populações, ou o fenômeno que podemos denominar - junto do geógrafo Benno Werlen (2000) - de "regionalização do c otidiano". A Macrometrópole Paulista, como já descrita no primeiro capítulo, é um conjunto de sub-regiões de intensa vida de relações, das quais os fluxos pendulares podem ser considerados um dos mais expressivos, já que estão na bas e da d efinição do cotidiano de boa pa rte destas populações. A análise desta vida de relações permite ainda compreender a divisão territorial do trabalho existente na região, assim como as hierarquias da rede urbana conformadas pelas movimentações de indivíduos nesta parcela do território brasileiro.

No sentido de atualizarmos esta discussão, foi possível também analisar os dados brutos da pendularidade do último decênio publicados pelo IBGE $^{45}$. Cotejando os dados de 2000 com os de 2010 observamos que o estado teve

${ }^{45}$ Censo Demográfico 2000 e 2010. 
Mapa 20: Macrometrópole Paulista - Pendularidade - Destino: RMBS - 2000

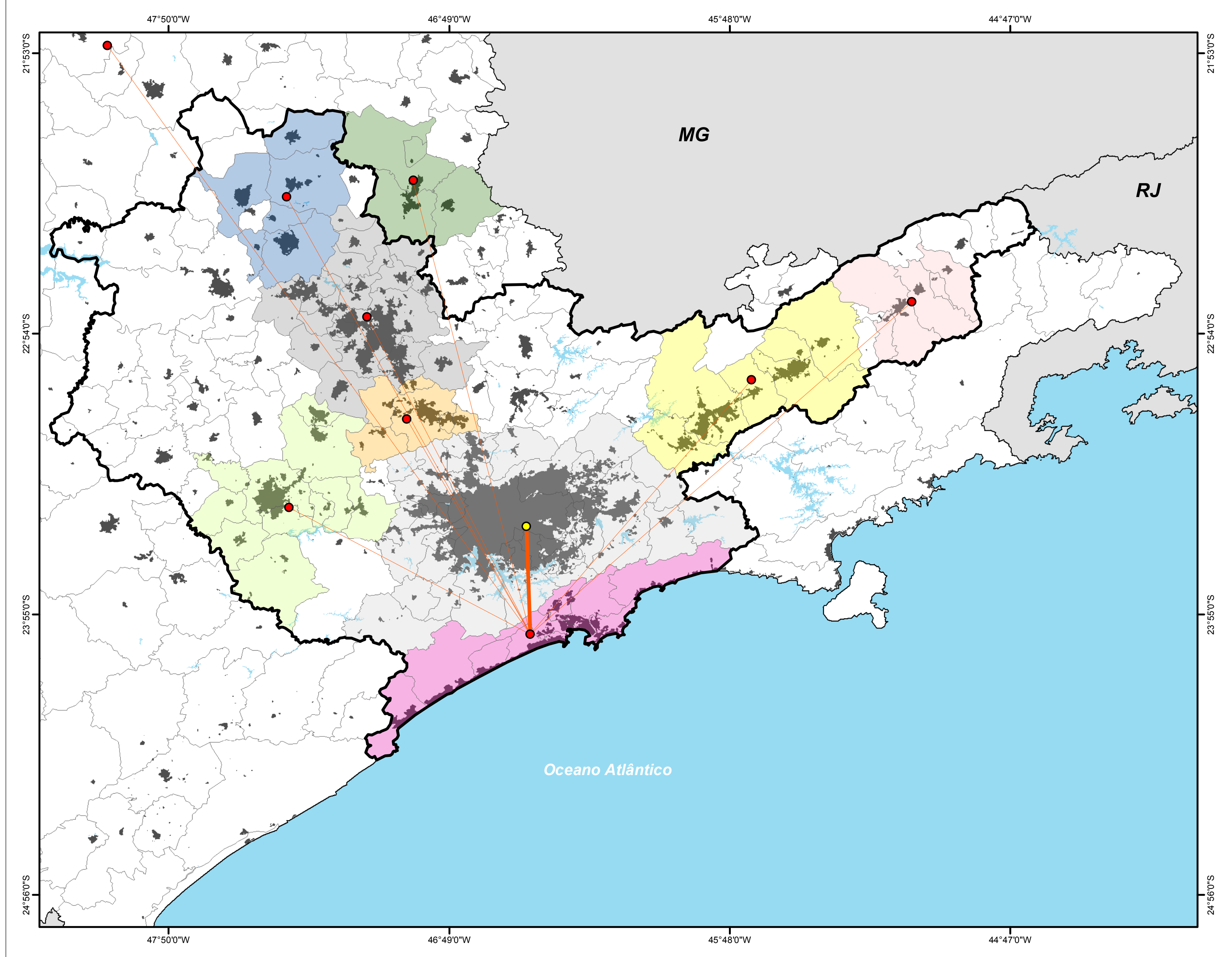

Localização Geral no Estado de São Paulo

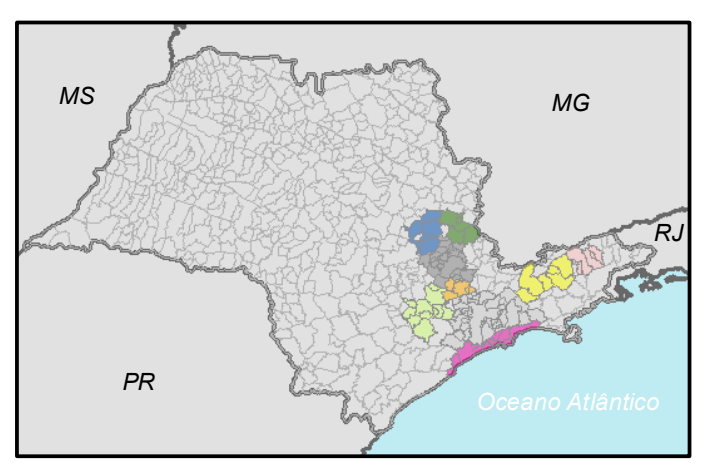

Legenda

$\square$ Limite Estadual

Limite Municipal

Oceano / Represa

Área Urbanizada 2005

AU de Guaratinguetá

AU de Jundiaí

AU de Limeira / Rio Claro

AU de Mogi-Guaçu / Mogi-Mirim

AU de Sorocaba

AU de São José dos Campo

RMBS

RMC

RMSP

$\square$ Macrometrópole

Pendularidade - Densidade de Fluxos

-1.000
-2.500

○ Destino

5.000

- Origem

Fontes:
Limite Municipal e Estadual - IBGE 2012. Aglomerações Urbanas - SEADE 2008.

Mancha Urbana - ProBio 2005.

Macrometrópole Paulista - EMPLASA 2011.

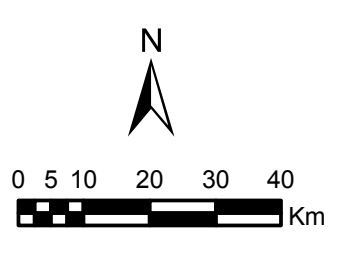

Sistema de Coordenadas Geográficas Datum WGS 84 
Mapa 21: Macrometrópole Paulista - Pendularidade - Destino: RMC - 2000

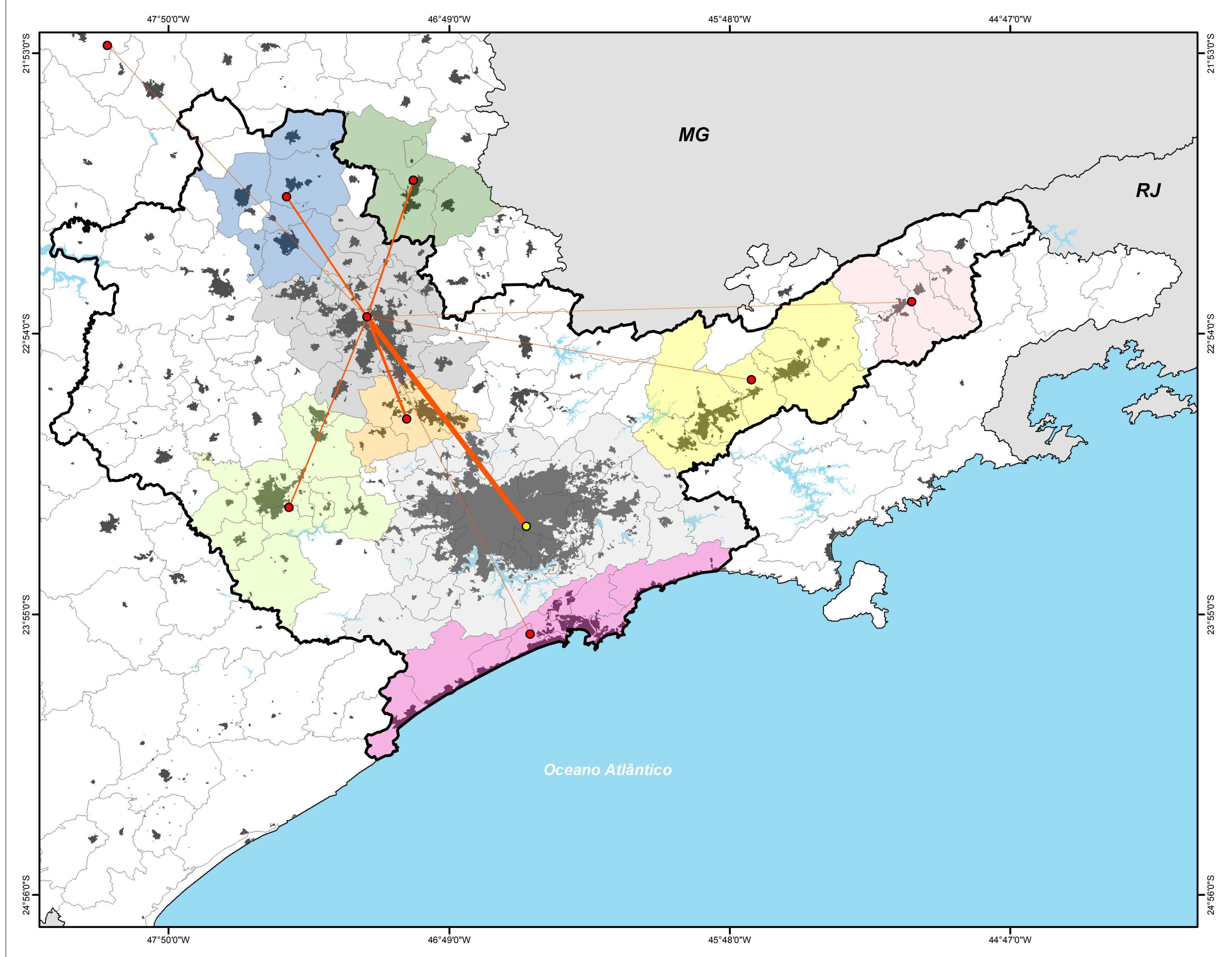

Localização Geral no Estado de São Paulo

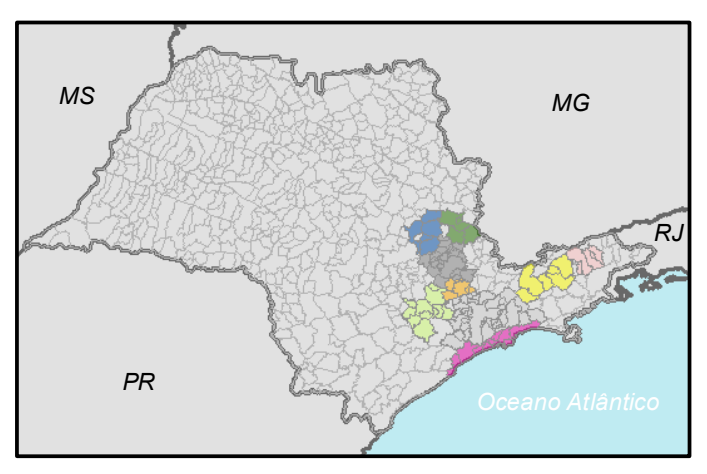

Legenda

$\square$ Limite Estadual

Limite Municipal

Oceano / Represa

Área Urbanizada 2005

AU de Guaratinguetá

AU de Jundiaí

AU de Limeira / Rio Claro

AU de Mogi-Guaçu / Mogi-Mirim

AU de Sorocaba

AU de São José dos Campo

RMBS

RMC

RMSP

$\square$ Macrometrópole

Pendularidade - Densidade de Fluxos

$\begin{array}{rrr}-1.000 & \circ & \text { Destino } \\ 2.500 & & \\ 5.000 & \circ & \text { Origem }\end{array}$

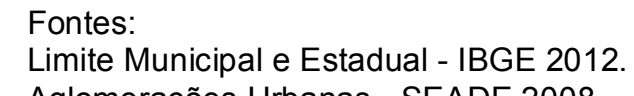
Aglomerações Urbanas - SEADE 2008. Pendularidade - SEADE 2008.
Mancha Urbana - ProBio 2005.

Mancha Urbana - ProBio 2005.
Macrometrópole Paulista - EMPLASA 2011.

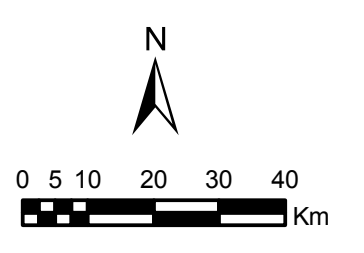

Sistema de Coordenadas Geográficas Datum WGS 84 


\section{Mapa 22: Macrometrópole Paulista}

\section{Pendularidade - Destino: RMSP, RMC e RMBS - 2000}

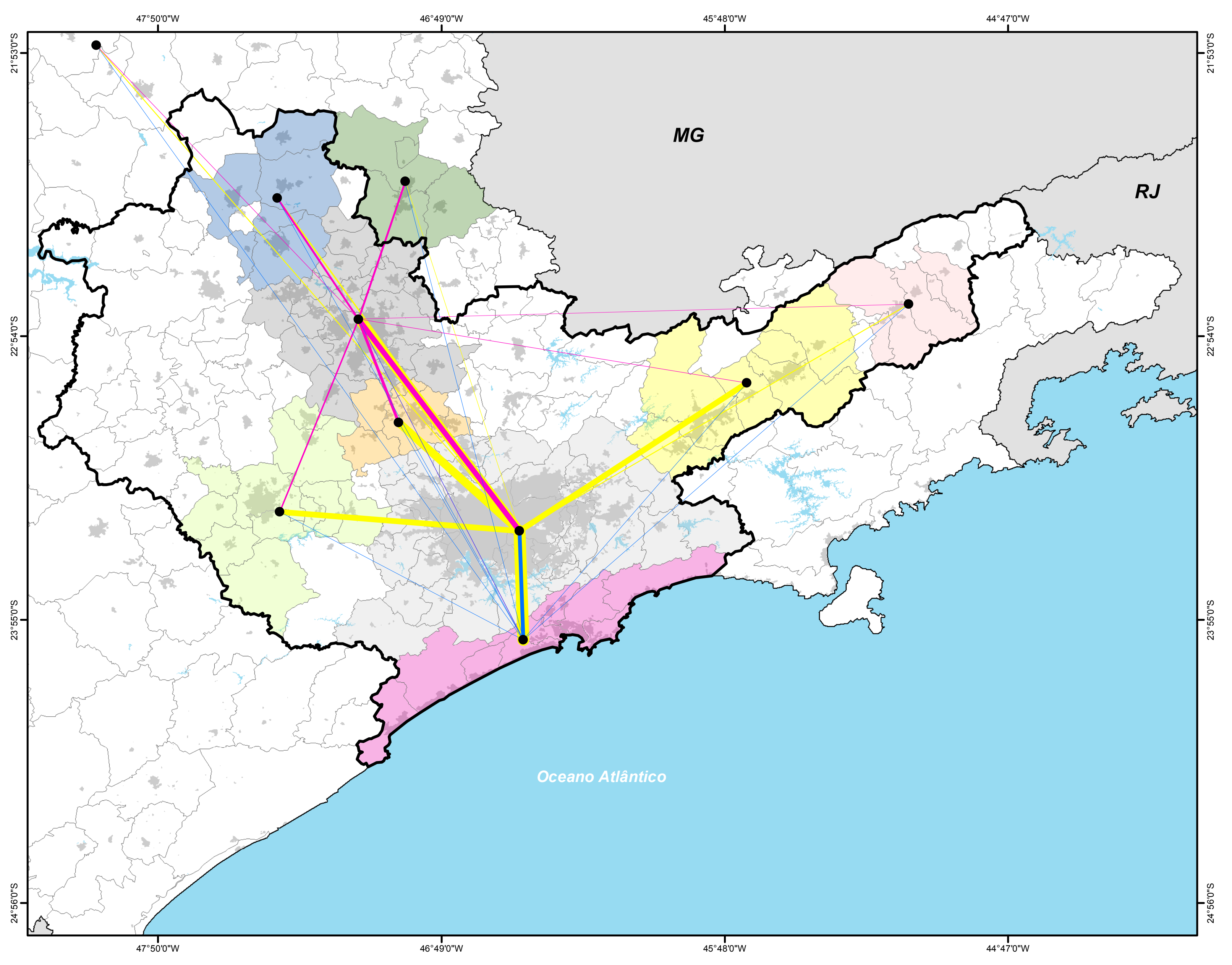

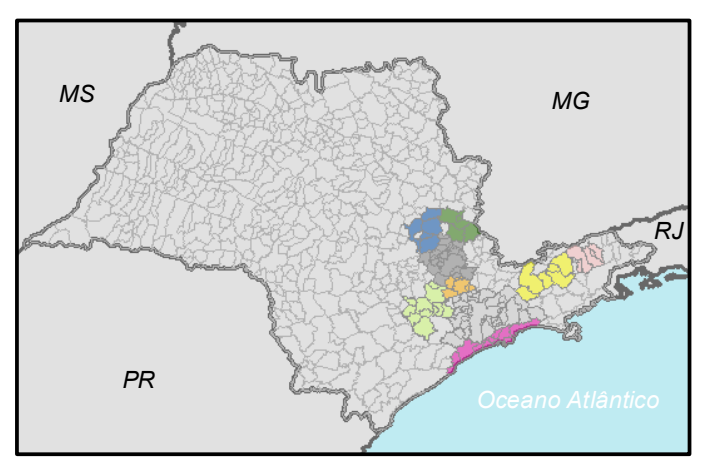

Legenda

$\square$ Limite Estadual

Limite Municipal

Oceano / Represa

Área Urbanizada 2005

AU de Guaratinguetá

AU de Jundiaí

AU de Limeira / Rio Claro

AU de Mogi-Guaçu / Mogi-Mirim

AU de Sorocaba

AU de São José dos Campo

RMBS

RMC

RMSP

$\square$ Macrometrópole

Pendularidade - Densidade de Fluxos

$$
\begin{array}{cc}
1.000 & \\
2.500 & \text { Destino RMBS } \\
5.000 & \text { Destino RMC } \\
7.500 & \text { Destino RMSP } \\
10.000 & \\
15.000 &
\end{array}
$$

\section{Fontes:}

Limite Municipal e Estadual - IBGE 2012. Aglomerações Urbanas - SEADE 2008. Mancha Urbana - ProBio 2005.

Macrometrópole Paulista - EMPLASA 2011.

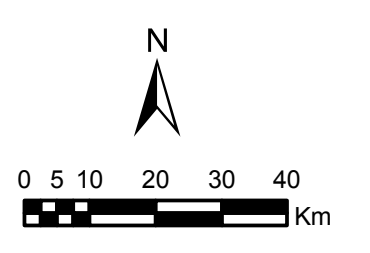

Sistema de Coordenadas Geográficas Datum WGS 84 
um incremento de 2.209.316 milhões de $r$ esidentes que praticam o deslocamento pendular, sendo que os municípios com maior incremento foram os seguintes: São Paulo (288.093 deslocamentos), Santo André (68.720), Guarulhos (63.429), São Bernardo (62.199), Diadema (48.446), Carapicuíba (45.242), Campinas (43.818), Mauá (38.810), Embu (37.811), Taboão da Serra (35.490) e Osasco (34.837). Com exceção do município de Campinas, todos pertencem à $\mathrm{R} M S P$, revelando o pes o desta região na expansão da pendularidade em contexto estadual. Se considerarmos a Macrometrópole com todo o Vale do Paraíba, Litoral Norte e os municípios de Mogi-Guaçu e MojiMirim, os valores incrementados respondem por $77,7 \%$ do total estadual. O mapa 23 apresenta os valores absolutos da pendularidade de 2000 e 2010.

Os dados recém publicados da pendularidade 2010 devem ser analisados em termos absolutos e per centuais, e comparados à popu lação total. De todo o universo de movimento pendular do estado (com um total de 4.371.186 deslocamentos), nada m enos que 79,4\% deles correspondem à região da Macrometrópole (incluindo aí todo o Vale do Paraíba, Litoral Norte e os municípios de Mogi-Guaçu e Moji-Mirim). Só a c apital detém 402.507 deslocamentos no ano de 2010 (9,2\% do estado) e a RMSP abarca 51,3\% dos mesmos (2.244.990 deslocamentos). Os municípios que ap resentam os maiores valores absolutos são, portanto, os da RMSP, liderados pela capital e seguidos pelos demais centros das outras regiões metropolitanas e s ubregiões como Campinas, São José dos Campos e Sorocaba (mapa 24).

Tratando dos valores percentuais (mapa 25), nota-se uma inversão em relação aos valores absolutos, com os municípios centrais apresentando os menores valores: São Paulo com 3,5\%, São José dos Campos com 4,9\%, Sorocaba com 5,3\% e Campinas com 6,9\%. De maneira geral, os maiores valores são os de municípios no entorno do centro de suas respectivas subregiões. Estão no topo da lista os municípios de Jandira com 37\%, Rio Grande da Serra 36,5\%, Várzea Paulista 33,9\%, Potim 33,9\%, Taboão da Serra $32,3 \%$, Ferraz de $\mathrm{V}$ asconcelos 32\%, e C arapicuíba com $31 \%$ dos deslocamentos pendulares para o ano de 2010. Na Macrometrópole Paulista, nove municípios apresentam uma pendularidade maior que $30 \%$, dezessete 


\section{Mapa 23: Macrometrópole Paulista - Pendularidade Absoluta - 2000 / 2010}

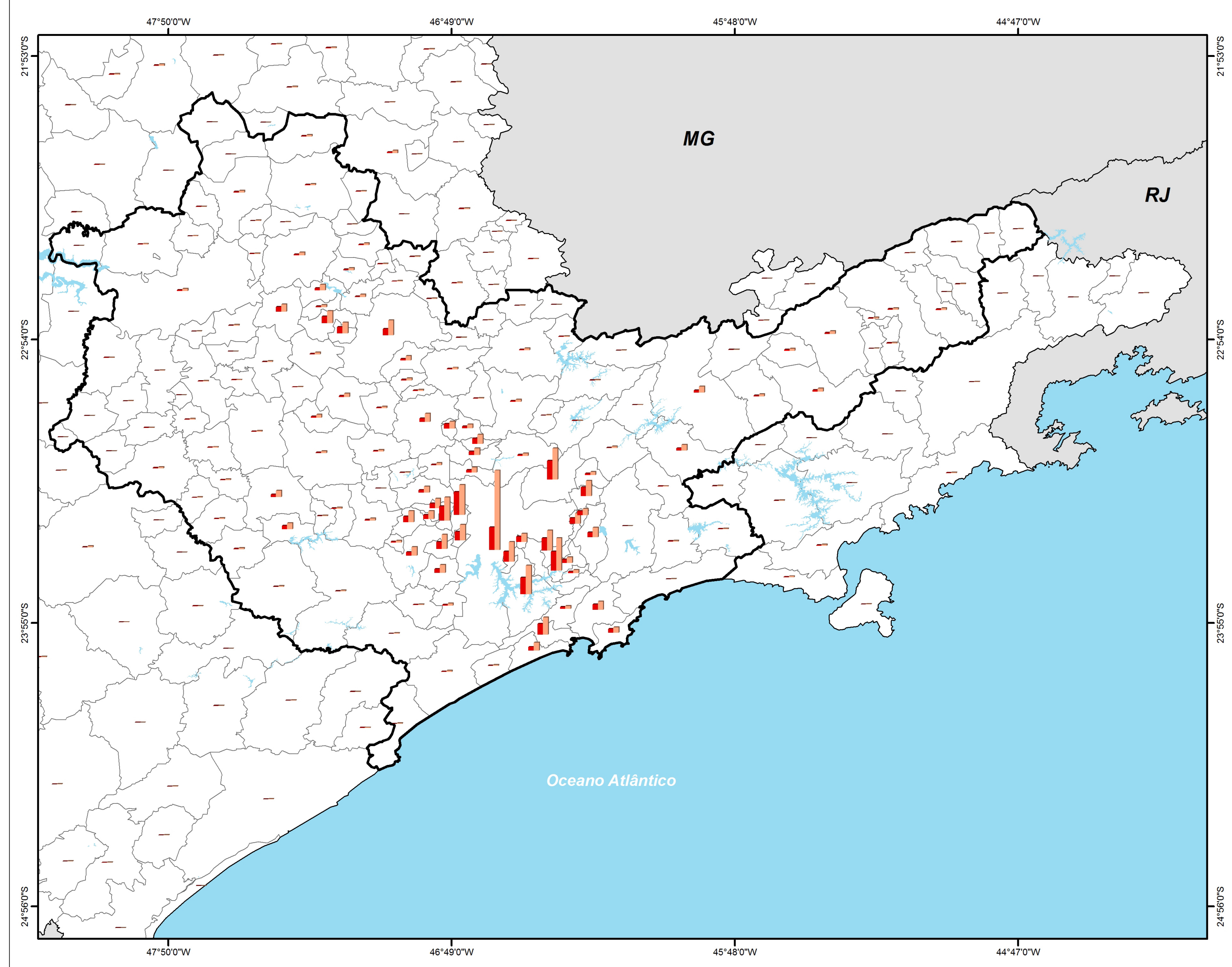

Localização Geral no Estado de São Paulo

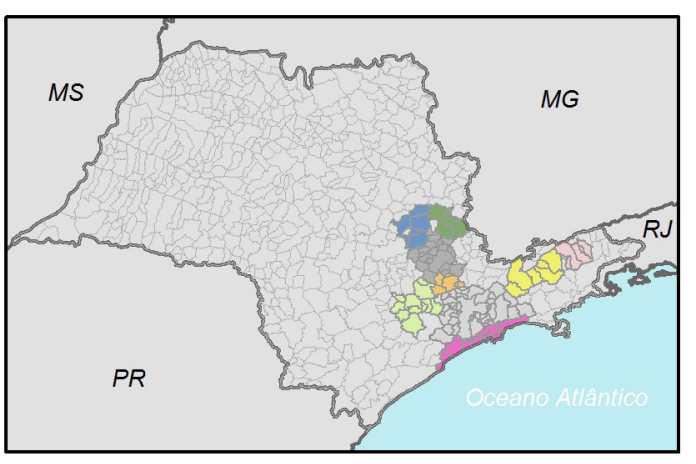

Legenda

$\square$ Limite Estadual

Limite Municipal

Oceano / Represa

$\square$ Macrometrópole

População Pendular 2000

População Pendular 2010

População Pendular

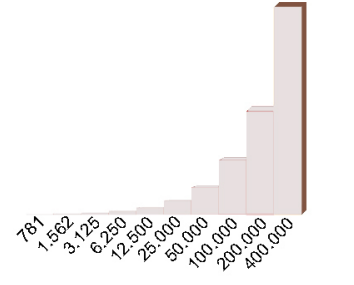

Fontes:

Limite Municipal e Estadual - IBGE 2012.

Pendularidade - IBGE 2000 / 2010.

Macrometrópole Paulista - EMPLASA 2011.

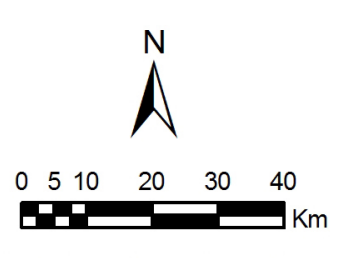

Sistema de Coordenadas Geográficas Datum WGS 84 


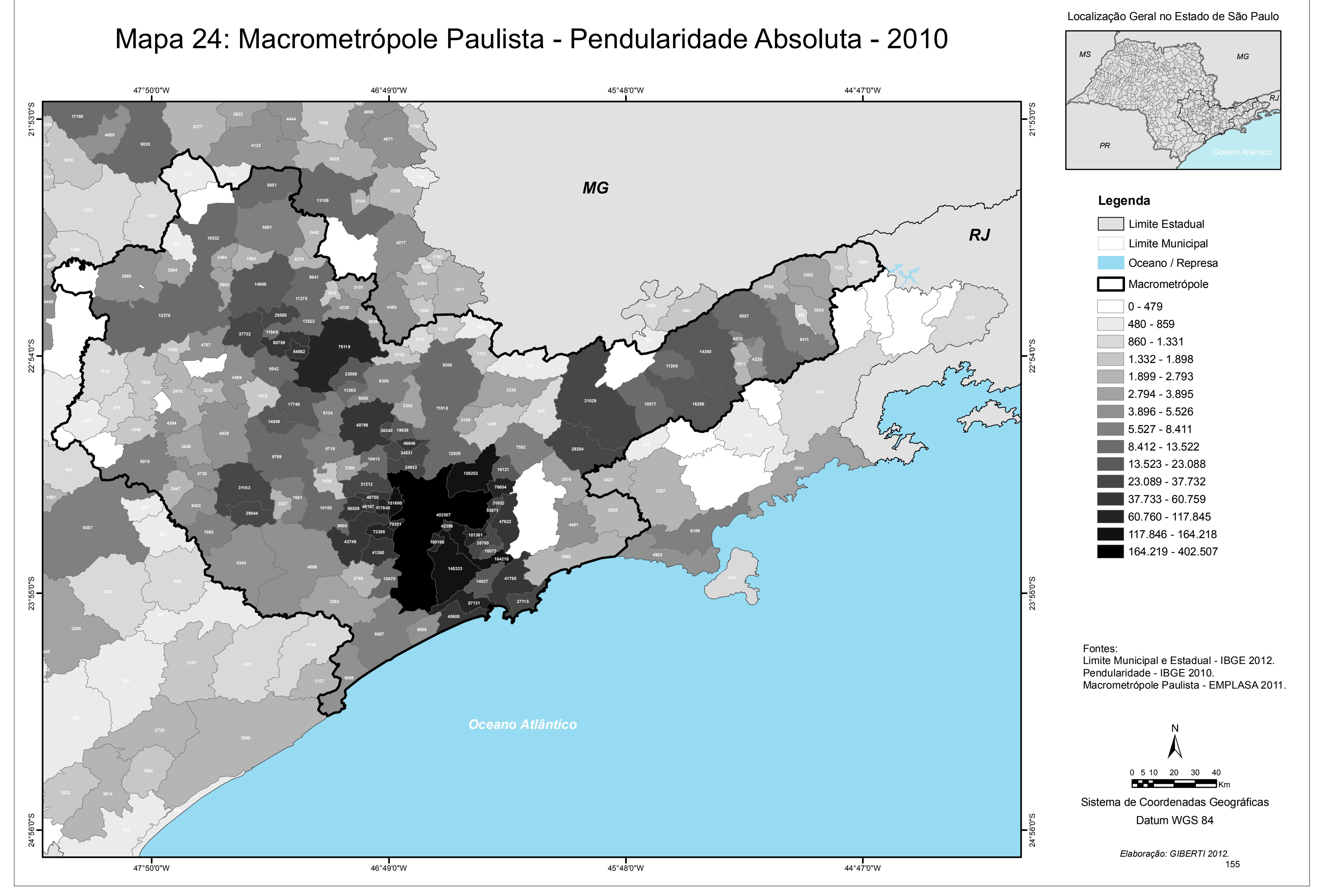


Mapa 25: Macrometrópole Paulista - Pendularidade Relativa (\%) - 2010

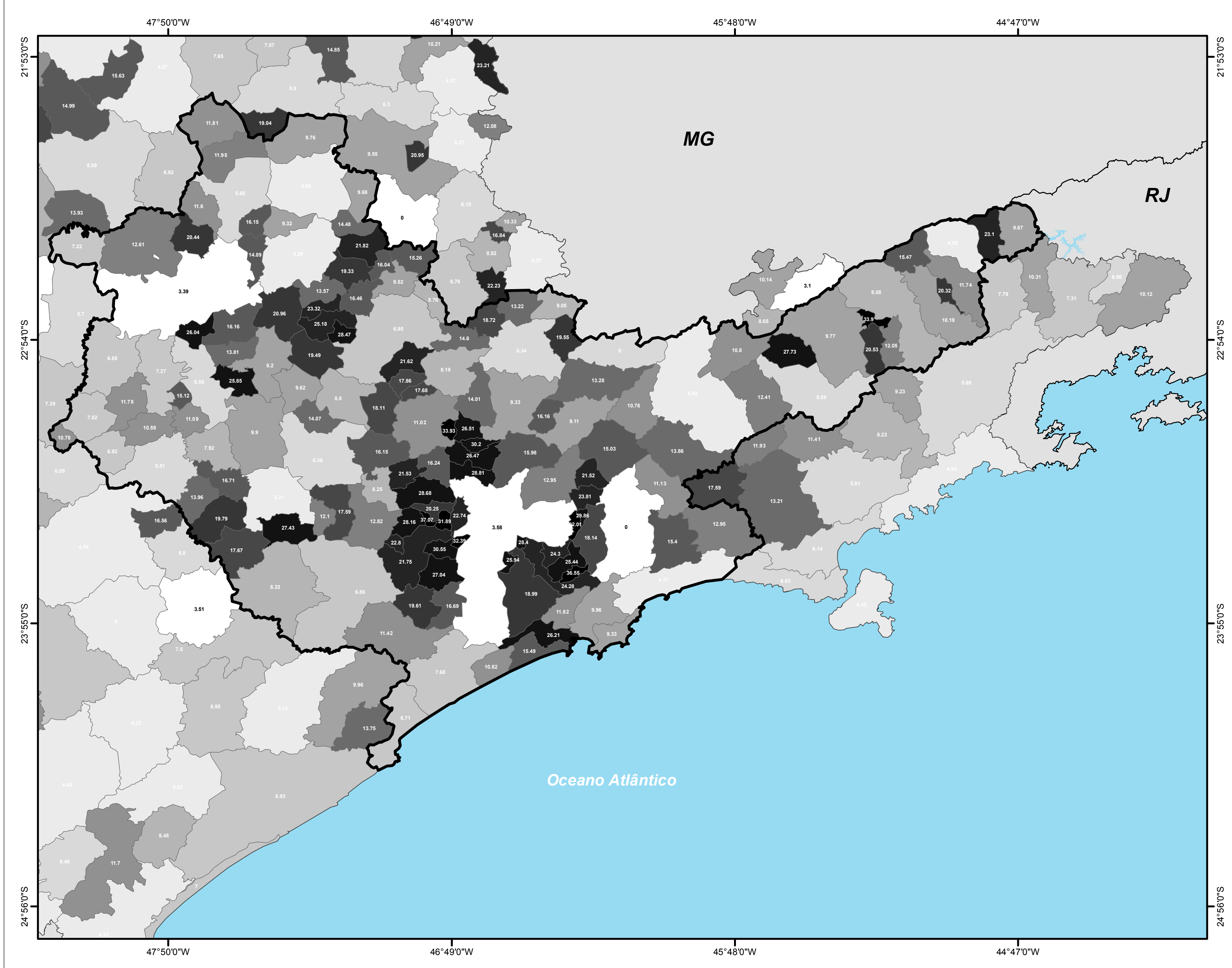

Localização Geral no Estado de São Paulo

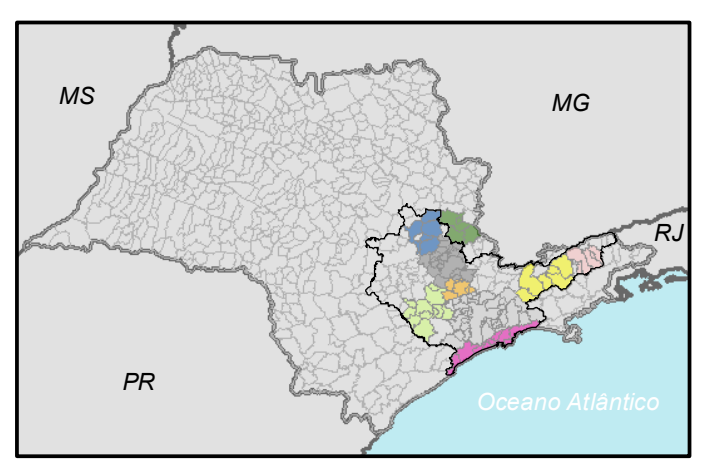

Legenda

$\square$ Limite Estadual

Limite Municipal

Oceano / Represa

$\square$ Macrometrópole

$\square .00-3.82$

$3.83-5.37$

$5.38-6.63$

$6.64-7.82$

$7.83-9.05$

$\square .06-10.41$

$10.42-11.82$

$11.83-13.15$

$13.16-14.75$

$14.76-16.71$

$16.72-18.77$

$18.78-21.12$

$21.13-25.18$

$25.19-30.55$

$30.56-37.34$

Fontes:

Limite Municipal e Estadual - IBGE 2012.

Macrometrópole Paulista - EMPLASA 2011.

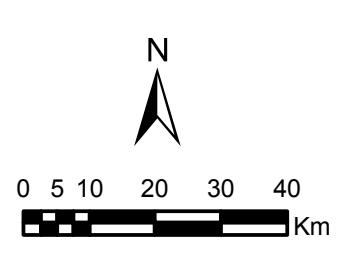

Sistema de Coordenadas Geográficas Datum WGS 84 
municípios entre $25 \%$ e $30 \%$, outros dezessete municípios entre $20 \%$ e $25 \%$, trinta municípios entre $15 \%$ e $20 \%$ e quarenta municípios entre $10 \%$ e $15 \%$. No caso da R MSP, os municípios do c hamado "ABCD" (Santo André, São Bernardo do Campo, São Caetano do Sul e Diadema) e da porção oeste da Macrometrópole apresentam valores relativamente elevados, tanto no que diz respeito aos números absolutos quanto nos números relativos (percentuais).

Para concluirmos este item 2.3, devemos ressaltar que a pend ularidade baseia-se predominantemente no $s$ istema rodoviário, com uso de $v$ eículos particulares e veículos de transporte coletivo sob regime de fretamento. Desta forma, após analisar detalhadamente as principais características dos fluxos cotidianos, suas motivações, conexões, densidades, origens, destinos, abrangência e ev olução temporal (em perspectiva intra e i nter regional), podemos nos aproximar um pouco mais do entendimento das "causas" deste aumento progressivo do número de viagens.

Partindo deste entendimento um pouco mais circunstanciado do fenômeno da pend ularidade, podemos nos perguntar: quais os limites "estruturais" deste aumento da pendularidade na Macrometrópole? O sistema de movimento de pas sageiros comporta com qualidade e ef icácia essa demanda? Qual a opinião da população em relação à qual idade dos transportes que permitem essa pendularidade?

\subsection{A questão dos transportes e a busca por alternativas}

Para entendermos melhor os problemas que afligem esses deslocamentos cotidianos das populações urbanas brasileiras, é pr eciso lembrar que as cidades apresentam um espaço físico limitado, sendo que as atividades econômicas são concentradas segundo uma lógica de di visão territorial dot rabalho fundada em moldes capitalistas. Este padrão de organização econômica do espaço urbano e regional densifica determinadas parcelas do território, e implica ainda numa desconcentração urbana "concentrada", sendo as origens dos fluxos diversas e crescentes, os destinos dos deslocamentos variados; as densidades dos deslocamentos se acentuam, 
novos fluxos se conformam, a demanda aumenta progressivamente, os serviços de t ransporte público oferecidos não at endem adequadamente à demanda e aos anseios da população; esse é o c enário atual da Metrópole Corporativa (SANTOS, 1990).

O transporte, a circulação e os sistemas de movimento são sem duvida alguma os elementos que permitem essa riqueza da $v$ ida de $r$ elações metropolitana no território, autorizando ainda uma ampliação do alcance das atividades cotidianas na Macrometrópole Paulista.

Esta pesquisa identificou exemplos expressivos do que pod eria ser denominada de "crise dos transportes". A oferta de serviços de transporte é uma relação técnico-econômica e dev e ser analisada em vários níveis. A questão do subsídio público para garantir uma tarifa adequada aos usuários, especialmente para o trabalho, responsável pela maioria das viagens, é fundamental.

Também temos de e ntender que deve haver uma demanda real que justifique a implementação de novas linhas (trem, metrô, ônibus e vans) e que seja sustentável economicamente, além de gerar lucro, tendo em vista a situação atual dos serviços terceirizados, onde a lógica do transporte oferecido tende apenas a satisfazer interesses corporativos, e não à cumprir sua função social. Segundo Vasconcellos (2001) as novas linhas devem apresentar itinerários que atendam às necessidades coletivas de forma adequada e eqüitativa, com embasamento técnico-econômico da relação demanda/serviço prestado/eficiência. Linhas de baixa demanda não se sustentam economicamente, exigindo a transferência de recursos para que sua atividade seja mantida e viabilize sua oferta (ainda que seja rentável).

A organização do tecido urbano em suas diversas tipologias de uso conforma a consolidação das demandas pelos deslocamentos entre áreas de residência, trabalho, estudo e outros serviços básicos. A administração pública é a responsável, em todas suas esferas, pelo planejamento, normatização, implementação, gestão ef iscalização dos sistemas de movimento de 
passageiros, mesmo que o serviço executado seja terceirizado (fruto de uma licitação pública).

A revisão bibliográfica realizada, assim como a pe squisa documental empreendida para esta pesquisa permitiu identificar algumas das dificuldades dos órgãos públicos em relação ao c ontrole dos sistemas de $\mathrm{m}$ ovimento metropolitanos. Dentre uma gama enorme de problemas, algumas das suas principais dificuldades estão ligadas à carência de recursos financeiros e de funcionários.

Como organizar então este complexo sistema de m ovimentos, no sentido de suprir a oferta de transportes para todos os itinerários demandados, especialmente aquelas parcelas do território de baixa demanda, que não se sustentam economicamente pela receita gerada? Como lidar com essa questão? O Estado deve realmente atender a todas as demandas, mesmo que sejam de baixa densidade?

Por outro lado, as dificuldades da administração pública não justificam o sacrifício que o cidadão sofre nas condições penosas de deslocamento no uso do transporte coletivo de $\mathrm{c}$ aráter público. Dentre os principais problemas (VASCONCELLOS, 2000) que configuram a bai xa qualidade dos serviços de transporte prestados em áreas metropolitanas, destacam-se os seguintes: superlotação dos veículos; congestionamentos; falta de qualidade e conforto; problemas freqüentes de i nterrupção dos serviços; falta de pont ualidade e regularidade; elevado tempo das viagens; alto valor da tarifa; e algumas vezes problemas de segurança. A lógica econômica de "lotar" um veículo prestador de serviço para gerar uma alta receita não pode se sobrepor às necessidades e anseios do cidadão, que r eclama um meio de transporte com o m ínimo de eficácia e conforto.

Como já tratado anteriormente, o c otidiano macrometropolitano se realiza com maior participação do $t$ ransporte motorizado rodoviário (principalmente por meio de ônibus, vans, carros e motos) que se diferencia, por seu turno, em meios "coletivos" e "individuais". O trem e o metrô também 
são importantes em termos absolutos, entretanto contam com uma baixa participação percentual, além de serem mais "restritos" à RMSP. A hipertrofia do sistema rodoviário fica evidente nos enormes congestionamentos diários da paisagem macrometropolitana. Essa "crise dos transportes" é descrita por vários autores, como Barat (1978), Vasconcellos (2000), Ulian (2008), entre outros.

Ao analisar as transformações e ef eitos negativos desta crise dos transportes na metrópole paulista, Lencioni (2009) constata graves restrições na mobilidade devido aos congestionamentos das principais vias da cidade, com precariedade do transporte coletivo e $v$ alorização dos meios de deslocamento individual pelas políticas públicas, o que acaba por comprometer a fluidez do cidadão no território.

A cada novo dia os índices de congestionamento aumentam, como atestam os informes de diversos tipos de mídia pública, diários televisivos e estações de rádio que tratam especificamente do trânsito. As estimativas de congestionamentos parecem ser também subestimadas, tendo em vista que 0 sistema monitorado $^{46}$ é inferior a $1 / 3$ do total, ou seja, o que é constatado na realidade certamente possui uma contrapartida ainda maior no domínio da realidade concreta das grandes cidades.

Uma das soluções encontradas para esta situação de "esgotamento" foi o aumento da utilização dos helicópteros (LENCIONI, 2009). Se por terra a fluidez está comprometida, a ges tão do capital das grandes empresas e executivos encontraram uma solução: "Os helicópteros se constituem numa nova forma de transporte que superam os obstáculos do terreno e maximizam a aproximação entre 2 pont os" (LENCIONI (2009. P.108). Ainda segundo a autora dos 194 heliportos da capital, 96\% são privados, sendo que a m aioria deles está concentrada nas áreas das Avenidas Paulista, B rigadeiro Faria Lima e Luis Carlos Berrini.

${ }^{46}$ CET-SP 2012. 
Vasconcellos (2000), em artigo publicado pela revista da A ssociação Nacional dos Transportes Públicos (ANTP) ${ }^{47}$, faz uma análise da cidade e dos transportes urbanos, e explicita assuma série de condições inadequadas que caracterizam este padrão de circulação urbana, como por exemplo: deslocamento inadequado de passageiros; má qualidade do transporte coletivo público; elevados congestionamentos; falta de conforto; elevação dos acidentes de trânsito; poluição e os enormes e c rescentes impactos na qualidade de vida das pessoas e das atividades sociais e econômicas. Também frisa que a situação atual de "crise" é f ruto do des envolvimento histórico das redes-suporte e da aç ão dos prestadores des erviços de transporte, assim como é reflexo das decisões de políticas públicas tomadas ao longo de décadas, especialmente as relacionadas ao desenvolvimento urbano e dos transportes. $O$ autor também ressalta a insatisfação geral quanto às condições atuais e sua preocupação em relação ao futuro, além da falta de racionalidade, qualidade e eficiência das políticas de circulação nas cidades.

Essa herança histórica resultou em desigualdades, com crise permanente do sistema de ôn ibus e expansão do espaço ocupado em vias públicas pelos automóveis particulares, aumentando a am plitude entre as diferenças de transporte e a acessibilidade entre aqueles com e sem acesso ao veículo particular. A construção do es paço urbano priorizou os istema rodoviário, privilegiando o uso do automóvel, e essa desigual distribuição dos meios de circulação é assim descrita pelo autor:

"[...] a capacidade de consumir espaço é al tamente distorcida a favor daqueles que tem acesso ao transporte motorizado e, dentro dele, ao transporte individual. Essa iniqüidade pode ser representada por quatro características: tempo de acesso ao veículo, tempo de espera, tempo dentro do veículo e tempo até o destino final após deixar o veículo. Em todos os casos, os usuários de transporte público enfrentam condições piores que os usuários de automóvel: em São Paulo, por exemplo, o tempo de acesso ao transporte público é cerca de 5 a 6 vezes superior ao do automóvel" (VASCONCELLOS, 2000, p.9)

Do ponto de vista econômico, fica evidente o enfoque rígido do mercado e o conflito constante entre o valor da tarifa e expectativa de lucro do negócio

\footnotetext{
${ }^{47}$ O Transporte Clandestino no Brasil. Documentos Setoriais ATNP.
} 
(VASCONCELLOS, 2000). Para concluir, o autor cita o problema do "transporte informal", o crescimento dos custos dos transportes e a e xpansão do uso do automóvel proveniente tanto da precariedade do transporte público quanto das políticas de incentivo ao seu uso e produção.

Por fim, fica evidente a contradição entre a necessidade de melhoria do transporte coletivo e as políticas implementadas, configurando dois mercados do transporte urbano: aquele mercado conformado pelo uso dos ônibus e o mercado que tem no automóvel a base de sua existência, com ausência de alternativas intermediárias aos dois extremos. A saída, ainda segundo o autor, seria direcionar as políticas aos seguintes objetivos: melhor distribuição da acessibilidade (equidade); garantia de que os deslocamentos sejam realizados dentro de níveis aceitáveis de eficiência; melhoria nas condições de vida em função de melhores condições de habitação, transporte e de trânsito. Ou seja, para Eduardo Vasconcellos (2000), organizar formas de acessibilidade e transporte de forma eqüitativa, eficiente e sustentável é condição sine qua non para a instalação de melhores condições de vida nas cidades brasileiras.

Outro tema que permeia a discussão da "crise dos transportes" urbanos é a c hamada "clandestinidade" da of erta deste tipo de s erviços. Segundo Pereira (2000), os motivos para a proliferação das formas de transporte "clandestinas" são, basicamente, ausência/carência/baixa qualidade do sistema de transporte público, assim como a tarifa mais barata e os itinerários mais convenientes (e "capilares"). Para o a utor, se existe demanda para os transportes "clandestinos" é porque algo está faltando nos serviços "regulares"; a existência do clandestino se dá porque existe demanda, e existe demanda pela falta de oferta qualitativa e quantitativa do sistema regular.

Em muitos casos, existem demandas que não s ão de interesse do sistema legal ou "regular", pois não são economicamente rentáveis, ao menos nos moldes das vicissitudes das empresas de $t$ ransporte regulares. As demandas geradas de forma mais "capilar" nas grandes cidades apresentam escassa geração de receita, abrindo espaço para a c onsolidação dos "clandestinos", que ac abam por assumir papel vital na vida dos habitantes, 
sendo a oferta do transporte uma atividade econômica como qualquer outra, e se constitui assim numa forma de inserção profissional na cidade, ainda que muitas vezes considerada "ilegal" e "precária". Uma forma de manifestação das mais comuns destes serviços não-regulados se dá pelo uso freqüente de peruas e kombis por parte de "empreendedores particulares". A estes serviços se convencionou dar o nom e de "lotação", por lotar os veículos, e s eus "empresários" são conhecidos como "perueiros".

De fato, a "clandestinidade" nos transportes públicos coletivos sempre existiu, sendo que muitas das empresas atualmente legalizadas já foram no passado clandestinas, tendo posteriormente se regularizado. De maneira geral, esses serviços nascem para suprir deficiências do sistema regular, gerando uma importante mudança: a per da de pas sageiros e per da de receitas do sistema regular. Na cidade de São Paulo a clandestinidade foi muito presente entre as décadas de 1990/2000, quando a prefeitura acabou por exercer um papel importante no $r$ econhecimento, fiscalização e legalização desses veículos.

Por seu histórico, o E stado criou uma realidade de pr eferência ao sistema rodoviário, com subsídios econômicos e políticas orientadas para a produção e uso do automóvel, associadas à expansão do sistema viário. Dessa forma, a es truturação da $m$ obilidade Macrometropolitana é pautada na desigualdade, no c ontraste e na s egregação entre a população de maior e menor renda, resultando no us o desigual do es paço de fluxo rodoviário e impondo uma certa "dualidade" entre as formas de deslocamento "coletivas" e as "individuais".

As deseconomias e a crise da mobilidade foram geradas por diversos fatores, dentre os quais podemos destacar alguns principais: os congestionamentos, $\mathrm{o}$ incremento acelerado de $\mathrm{v}$ eículos particulares, a decadência dos transportes de massa, a redução da velocidade geral dos deslocamentos, o maior custo operacional, o desgaste dos veículos, a perda de tempo e maior duração das viagens. Tais fatores tiveram impacto direto na economia. 
Em função de $t$ odas estas "deseconomias" acima apontadas, a metrópole apresenta uma evolução histórica em que ocorre a saturação do sistema viário. Como saída para estas situações de saturação, adota-se a expansão do sistema por meio da realização de grandes obras de ampliação das redes-suporte rodoviárias, que resultam em algumas melhorias do fluxo e em relativa prosperidade. Estas melhorias, por sua vez, ao at rair e provocar novos fluxos, leva a uma nova saturação do sistema e, mais uma vez instala-se a crise, em um círculo vicioso que complica cada vez mais os usos do espaço de circulação da cidade.

Outra questão é a dependência dos combustíveis que, pela sistemática do mercado, onera outros setores da economia além de degradar a qualidade do ar. Com mais trânsito, maior o tempo perdido. A seguir, como revela a tabela 19, a taxa de motorização da população paulistana explodiu nas ultimas décadas:

Tabela 19: Município de São Paulo - Taxa de Motorização (1990/2011)

\begin{tabular}{|c|c|c|c|}
\hline Ano & População & Frota & Motorização* $^{*}$ \\
\hline 1990 & 9.512 .545 & 3.421 .059 & 36,0 \\
\hline 2000 & 10.426 .384 & 5.128 .234 & 49,2 \\
\hline 2011 & 11.337 .021 & 7.177 .082 & 63,3 \\
\hline
\end{tabular}

* veíc./100 habitantes

Fonte: CET / Gerência de Planejamento, Logística e Estudos Especiais - GPL; População: SEADE - Informações dos Municípios Paulista, Frota: DETRAN. Adaptação: GIBERTI 2012.

Como resultado da elevação da taxa de motorização de 36 para 63,3 veículos/habitante entre 1990 e 2011, e da hipertrofia do sistema rodoviário, os índices de congestionamentos (especialmente na á rea central da c apital) crescem diariamente, e a velocidade média do t rânsito diminui progressivamente, tanto para o automóvel quanto para o ônibus. Segundo a CET (gráfico 8), entre 1980 e 2008 a velocidade média caiu $10 \mathrm{Km} / \mathrm{h}$. 
Gráfico 8: Município de São Paulo - Evolução da velocidade média $(\mathrm{km} / \mathrm{h})$ no trânsito (1980 / 2008)

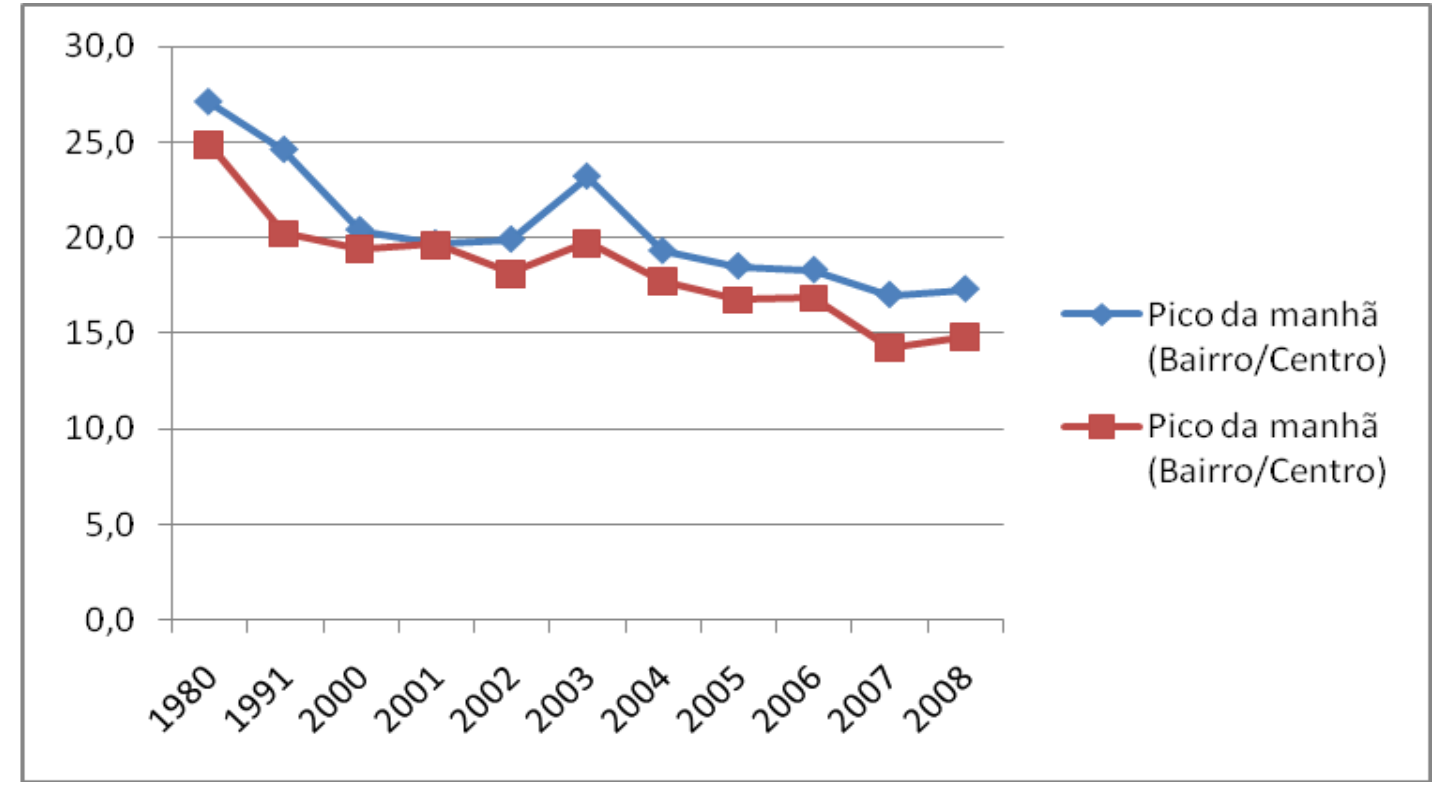

Fonte: Companhia de Engenharia de Tráfego/CET - Relatório de Desempenho - Velocidades

Decorre ainda desta progressiva e elevada concentração de veículos na capital um alto nível de poluição na atmosfera, que por sua vez levou a uma política de "rodízio de v eículos" iniciada em 1997, e c oordenada pela Companhia de Engenharia de Tráfego (CET), com a proposta de melhorar as condições ambientais, reduzindo a c arga de pol uentes na at mosfera. Esta política acabou por "extrapolar" suas funções originais, e logo passou a ter um caráter de m inimização dos congestionamentos e problemas de degr adação urbana, motivados pela intensidade dos fluxos dos veículos. Atualmente, a política de rodízio tornou-se uma medida "paliativa", dada a enor me dimensão do complexo problema da crise na circulação da Região Metropolitana de São Paulo. A figura a seguir mostra a c hamada "zona de r estrição" ${ }^{48}$ - que contempla o "centro expandido" da cidade de São Paulo - e os dias restritos para as respectivas placas dos automóveis particulares.

${ }^{48}$ O horário de restrição é das 07:00 as 10:00 e das 17:00 as 20:00 horas. 
Figura 9: Município de São Paulo - Área com rodízio municipal de veículos

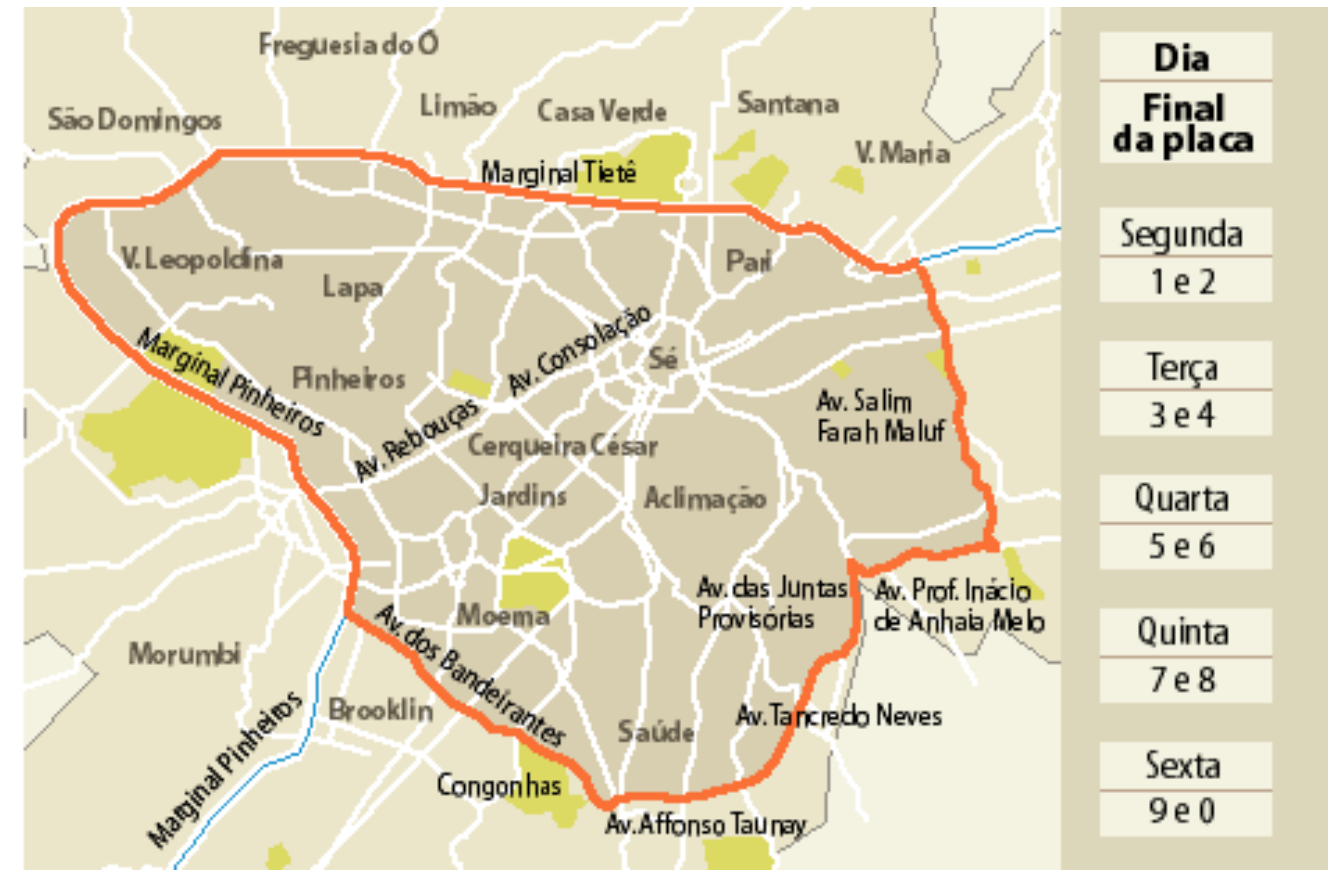

Fonte: Prefeitura de São Paulo (2010).

Para entender os significados dos modais de transporte e o s entimento da população em relação ao tema, recorremos à "pesquisa de opinião pública" que é realizada desde $1985 \mathrm{~s}$ ob coordenação da A NTP e que conta com a participação técnica e econômica de outras entidades operadoras e gestoras do transporte da R MSP. A pesquisa é a presentada no ar tigo de Gomes, Guedes e Silva (2000), intitulado "Percepções sobre o Transporte Coletivo na Região Metropolitana de São Paulo", e mostra resultados qualitativos para o ano de 1999. Em pesquisa mais atual ${ }^{49}$ (2011) a situação constatada era de queda na demanda dos sistemas regulares e aumento do transporte individual e por lotação; entretanto, houve uma nova dinâmica nos últimos anos com aumento da demanda por viagens coletivas de caráter público.

Acredita-se que a pesquisa de opinião é um recurso importante para o gerenciamento dot ransporte coletivo, reconhecendo as necessidades, expectativas e ní veis de s atisfação dos diversos segmentos da popul ação. Segundo mostram os dados destas pesquisas, existe uma "mescla" de aspiração de ascensão social por parte do cidadão, com a busca de minimizar

\footnotetext{
${ }^{49}$ Pesquisa de opinião pública dos transportes coletivos na Região Metropolitana de São Paulo. ANTP 2011.
} 
ou eliminar sua dependência do transporte coletivo. O resultado dessa "mescla" é sobretudo a idealização do transporte particular, tido como principal solução para a melhoria dos deslocamentos urbanos. Ressalta-se ainda as seguintes conclusões da pes quisa: 1. a "lotação" é considerada como uma alternativa muitas vezes mais interessante que o próprio o ônibus; 2 . o metrô é visto como o modo de maior qualidade dentre os coletivos; 3. o trem e ôn ibus intermunicipal são considerados como únicas opções de viagens de maior extensão.

A pesquisa de $2011^{50}$ aponta que, apenas $18 \%$ dos entrevistados acham que o transporte coletivo está bom, $41 \%$ acham que está ruim e $41 \%$ nem bom nem ruim; o sentimento dos usuários é de "crise dos transportes". Do ponto de vista técnico, embasado nas premissas de pl anejamento de transportes apresentadas por Barat (1978) no capítulo 1 e nas referências de Vasconcellos (2000), somadas ao universo de dad os dos sistemas de movimento de passageiros, também podemos afirmar que a crise existe e tende a se agravar.

A matriz do transporte na Região Metropolitana de São Paulo é rodoviária, com moto e automóvel para o individual e predomínio do ônibus para o c oletivo (figura 10). Tecnicamente, esses não s ão os meios mais adequados para o transporte de massa e, todavia enfrentam problemas de congestionamentos, estresse, custo elevado, baixa eficiência e, no m odo coletivo, superlotação, maior tempo de duração das viagens, indisponibilidade do serviço e até insegurança.

Figura 10: RMSP - Uso do transporte coletivo (2011)

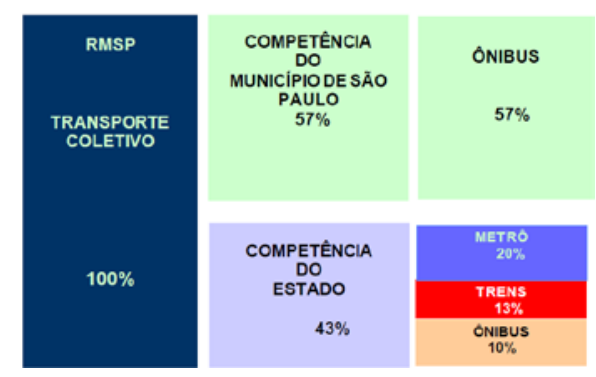

Fonte: Secretaria dos Transportes Metropolitanos 2011.

\footnotetext{
${ }^{50}$ Pesquisa de opinião pública dos transportes coletivos na Região Metropolitana de São Paulo. ANTP 2011.
} 
Outra forma de ent endermos as dificuldades e a c rise do t ransporte coletivo de ônibus é analisar o Índice de Passageiros por Quilômetro ${ }^{51}$ (IPK). Quando o índice está em baixa, afeta onerando a tarifa do transporte público, levando a um círculo vicioso de aumento de tarifas e perda de passageiros. As empresas operadoras implantam estratégias para assegurar sua lucratividade, o que vai contra o interesse coletivo do serviço de transporte.

Tabela 20: Estado de São Paulo - Índice de Passageiros por Quilômetro (IPK), passageiros transportados e quilômetros rodados dos sistemas de transporte público dos municípios paulistas (1998/2009)

\begin{tabular}{c|c|c|c}
\hline Ano & IPK & Passageiros transportados & Quilômetros rodados \\
\hline 1998 & 2,0119 & 343.275 .917 & 170.620 .517 \\
\hline 1999 & 1,6774 & 270.711 .336 & 161.384 .723 \\
\hline 2000 & 1,6774 & 281.343 .895 & 167.783 .158 \\
\hline 2001 & 1,6648 & 268.451 .194 & 161.255 .218 \\
\hline 2002 & 1,5301 & 229.105 .841 & 149.736 .216 \\
\hline 2003 & 1,5805 & 217.629 .422 & 137.694 .787 \\
\hline 2004 & 1,5388 & 221.934 .796 & 144.227 .807 \\
\hline 2005 & 1,7835 & 240.672 .794 & 134.943 .502 \\
\hline 2006 & 1,9520 & 261.809 .654 & 134.122 .260 \\
\hline 2007 & 1,9463 & 271.846 .271 & 139.671 .195 \\
\hline 2008 & 1,8175 & 251.614 .671 & 138.440 .688 \\
\hline 2009 & 1,8720 & 255.264 .276 & 136.359 .512 \\
\hline
\end{tabular}

Fonte: FIPE, 2009. Apud COCCO 2011.

Cocco (2011) apresenta a hipótese de que os processos de dispersão da cidade conduzem a inflexões no IPK. As operadoras usam esse índice para reajuste e maximização dos lucros, resultando na penalização dos usuários do sistema de transporte público por ônibus, afetando a qualidade do s erviço prestado.

Antes de tudo, é necessário salientar que o índice de passageiros por quilômetro - o IPK - associa a questão da di spersão da cidade, que aumenta a quilometragem do sistema, ao problema da perda relativa de usuários dos sistemas de transporte público para outros modos de transporte, quais sejam, o transporte individual por automóvel e motocicleta, o t ransporte fretado, a bi cicleta, o m oto-táxi e m esmo o deslocamento a pé, deflagrando, juntas, em inflexão do índice. Também é importante destacar que é es te índice que baliza as decisões sobre reajustes tarifários, conformando assim, dados estratégicos para as empresas operadoras (COCCO. 2011.p.107).

51 O IPK é um parâmetro que indica a média de passageiros transportados por quilômetro, permitindo comparações entre linhas e análises temporais por parte das empresas prestadoras de serviço e órgãos do governo. Tal índice permite uma análise do ní vel de utilização do serviço oferecido e análise da relação oferta/demanda. 
O IPK sofreu uma diminuição de 0,1399 passageiros transportados por Quilômetro nos entre 1998 e 2009, em uma média dos municípios do Estado de SP (tabela 20).

Além da análise das pesquisas realizadas pela ANTP, e do cotejamento do índice IPK, a pesquisa documental realizada para esta dissertação permitiu trazer mais elementos para identificarmos as principais características da atual "crise dos transportes" metropolitanos. Segundo essa pesquisa documental $\left(\right.$ GIBERTI, 2008) ${ }^{52}$ podemos afirmar que ex istem situações contrastantes e uma clara dualidade entre o modo coletivo e individual de deslocamento de passageiros nas metrópoles brasileiras. Inicialmente constata-se um predomínio de interesses corporativos nas definições das políticas públicas de transportes, que c laramente privilegiaram os istema rodoviário e o modo individual, com aumento progressivo da taxa de motorização associada à industrialização, metropolização e dispersão urbana, em um círculo vicioso de expansão/duplicação do es paço viário de fluxo e s aturação do mesmo pelo excesso de veículos.

O sistema de transporte público regular coletivo sempre apresentou problemas graves de of erta, precariedade, atrasos e i ndisponibilidade de serviços, gerando insatisfação, revolta e busca por alternativas que variam em casos extremos. Por exemplo, pela ausência de transporte público moradores chegaram a "seqüestrar" um ônibus para criar um itinerário não existente; por outro lado, devido aos congestionamentos, o uso do helicóptero surge como uma opção para executivos e indivíduos abastados economicamente.

É neste contexto de saturação que a oferta de serviços "clandestinos", por intermédio das lotações, ganhou espaço especialmente em itinerários

$52 \mathrm{O}$ trabalho oferece um conjunto de reportagens de jornais selecionadas no período de 20 anos (1980 - 2000), onde é possível identificar o resultado da combinação das políticas públicas, da atuação das empresas e das demandas dos usuários. Além disso, as reportagens mostram exemplos contrastantes das desigualdades do que denominamos "Crise dos Transportes", dentro do contexto de metropolização, assim como, observam a bu sca por alternativas de transporte, muitas vezes com casos inusitados e bizarros. 
negligenciados que conectam as periferias urbanas com as principais áreas de oferta de trabalho nas grandes cidades.

Foi neste contexto também que se realizou um expressivo processo de desconcentração industrial no estado de São Paulo, com a criação de novos centros regionais produtivos, que alteraram a matriz de demanda e oferta de serviços de transportes, assim como pela criação de novas áreas destinadas à habitação, como é o caso dos condomínios fechados nas periferias das cidades.

Alternativas de t ransporte (1993) eram apresentadas pela gestão pública, como os ônibus especiais, com maior conforto e tarifa mais elevada que o ôn ibus comum, entretanto o serviço foi encerrado por falta de passageiros. Em 1993 a pr efeitura de São Paulo realizou um censo identificando que $25 \%$ da frota era clandestina (aproximadamente 3 mil ônibus), posteriormente a prefeitura iniciou um processo a regulamentação e cadastro dos clandestinos, incorporando essa oferta de transporte ao sistema "oficial".

A pendularidade nesse período (1980/2000) se expandiu com residentes em Sorocaba, Campinas, Santos, Jundiaí e S ão José dos Campos, que diariamente se deslocam para São Paulo. Os limites municipais já não restringem o cotidiano da população, a metrópole e seus problemas são alvo de estudos por parte de c ientistas e do gov erno, assim como o tema dos transportes.

É neste contexto que os chamados "fretados" ganham grande difusão no contexto da Macrometropolitano Paulista. A situação de aumento da pendularidade e "crise dos transportes" é cada vez mais evidente, na década de 2000 o aumento do fluxo de passageiros e da densidade populacional revela-se um problema que ganha espaço na mídia e a at enção da administração pública, especialistas afirmam $^{53}$ que o po der público e

${ }^{53}$ GIBERTI 2008. 
empresários não conseguem fazer frente às novas necessidades dos transportes macrometropolitanos.

As referências anteriores apesar de serem extraídas de reportagens de jornais (GIBERTI, 2008), e não $r$ epresentarem um documento científico permitem identificar alguns aspectos importantes do que c hamamos da "crise dos transportes"

Atualmente, todos os modos motorizados apresentam dificuldades ${ }^{54}$ no transporte de pas sageiros, basicamente pela superlotação e congestionamento. Tal situação é am plamente analisada em livros e ar tigos acadêmicos, assim como por especialistas no tema (como é o c aso das publicações mais recentes da ANTP). Estes sinais de es gotamento são também comentados em jornais impressos, televisivos, radio. A sociedade civil em geral procura de forma mais espontânea se organizar para fazer frente a esta nova realidade dos sistemas de movimento macrometropolitanos: entre colegas de trabalho, escolas e universidades, as pessoas tentam se articular para oferecer carona e buscar alternativas.

Como observado nos dados da Pesquisa Origem/Destino (O/D) da RMSP 2007, o sistema viário suporta mais de $87,9 \%$ das viagens motorizadas e $66,1 \%$ do total de viagens, constituídas por automóveis, motos, ônibus, escolares, fretados e clandestinos. Além de suportar veículos para o transporte de passageiros, os istema viário tem papel fundamental na circulação de matérias primas, produtos agrícolas e industrializados que são importados e exportados para outras regiões.

É neste contexto que devemos observar os chamados transportes "fretados". Apesar de representarem apenas 2\% (514 mil) das viagens diárias motorizadas da Região Metropolitana de São Paulo em 2007, têm grande potencial de i mpactos positivos e negat ivos na c irculação da cidade, assim como permitem a c onexão com as redes de t ransporte coletivo público

${ }^{54}$ ANTP 2011. 
metropolitano (Metrô/CPTM/EMTU) e municipal (ônibus). Seu funcionamento pode ser caracterizado como um "híbrido" do transporte coletivo e individual, pois pode ser ao mesmo tempo compartilhado com outros usuários, mas com itinerários mais específicos e diretos, gerando mais rapidez e conforto para os passageiros. Sua atividade é regulada e fiscalizada por diversas autarquias da administração pública, como veremos no capítulo 3 .

Dentre as várias facetas da crise e busca por alternativas de transporte, identificamos of retado como uma alternativa concreta, regulamentada, que ganha uma amplitude maior no c ontexto do sistema de $\mathrm{m}$ ovimento macrometropolitano. Considerados pelos especialistas como uma forma "melhor que o transporte público", os "fretados" permitem atrair usuários do veículo particular, justamente por se constituírem num transporte coletivo de organização privada, com itinerários específicos que atende às expectativas dos usuários.

Sua inserção, significado, "vantagens e d esvantagens" são elementos que devem ser atentamente analisados dentro do contexto dos sistemas de movimentos macrometropolitano. Esta modalidade de transporte na es cala municipal e regional apresenta características diferenciadas de organização e gestão, que não depende diretamente do Estado para seu provimento.

\section{CAPITULO 3: Consolidação e atuação dos fretados como alternativa de transporte metropolitano}

Para tratar do tema específico dos fretados foi realizada inicialmente uma completa revisão bibliográfica do fenômeno, assim como uma pesquisa direta em órgãos públicos reguladores a ní vel estadual (ARTESP), metropolitano (EMTU) e municipal (SMT-SP). Além destas autarquias, foram também realizadas incursões nas empresas prestadoras de s erviços e suas respectivas associações (TRANSFRETRUR, FRESP), onde foram coletados dados de cadastro, documentos técnicos, legislação ef oram realizadas entrevistas com pessoas que trabalham diretamente no tema. 
Por fim, os intensos levantamentos em campo forneceram dados empíricos primários. Esse levantamento foi realizado por dois motivos: pela dificuldade em obter dados "oficiais" acerca dos fretados, e pela realidade constatada em campo, que n ão se encontra contabilizada nos cadastros oficiais (ou simplesmente o dado não está centralizado em apenas um órgão) ${ }^{55}$.

Para o levantamento empírico da atuação dos fretados foram testadas várias formas de $r$ egistro dos veículos envolvidos, incluindo o r egistro fotográfico digital com uma máquina de alta resolução. Por se tratar de um estudo regional, a pesquisa teve três pontos fundamentais para escolha dos locais para documentação:

- Seleção de pontos estratégicos nas rodovias que pudessem captar os fluxos intermunicipais.

- Pedido de autorização para as Concessionárias das Rodovias, Polícia Rodoviária Federal e Prefeituras.

- Pontos de amostragem que cobrissem diferentes partes da Macrometrópole.

Para documentar os fluxos intermunicipais, foi escolhido um ponto próximo aos limites municipais, que f osse seguro, pois toda e qu alquer documentação, seja def oto ou vídeo, chama a atenção da população, oferecendo riscos ao equipamento e à própria segurança do pesquisador. Também se considerou a c onfiguração da mancha urbana, priorizando os locais de maior aglomeração, juntamente com os principais eixos viários da região.

Dentre os locais analisados estavam passarelas, pedágios, entroncamentos rodoviários e postos policias. Foram definidos os locais de levantamento (figura 11) e, também, estabelecidos dois dias de trabalho para

${ }^{55}$ Os levantamentos de campo utilizados neste mestrado, a bem da verdade, foram iniciados no ano de 2004, no âmbito do Projeto Temático "Urbanização Dispersa e Mudanças no Tecido Urbano: Estado de S ão Paulo", coordenado pelo Prof. Nestor Goulart Reis Filho (LAP/FAU/USP). Parte deste levantamento foi atualizado no período desta investigação de mestrado, sendo que os principais resultados se encontram em anexo. 
cada ponto, documentando os fluxos nos dois sentidos da via nos "horários de pico".

Figura 11: Estado de São Paulo - Pontos de amostragem dos fretados

ESTADO DE SÃO PAULO

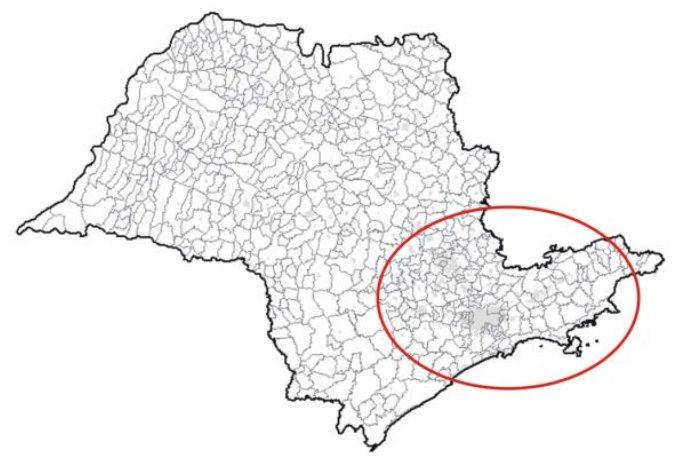

PONTOS DE AMOSTRAGEM

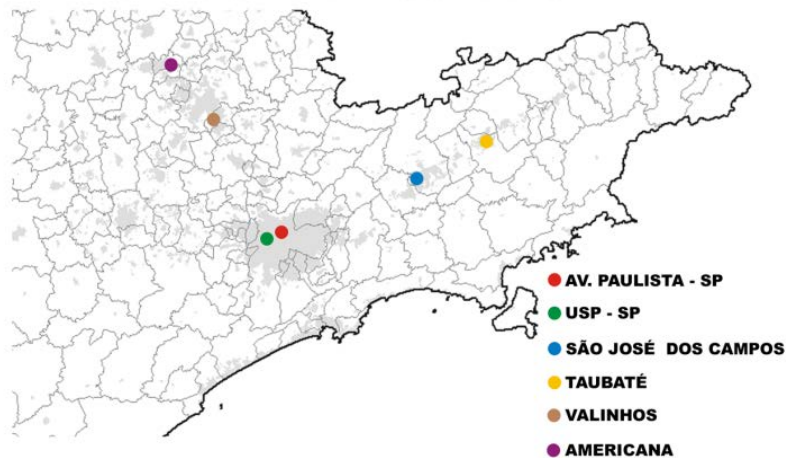

Elaboração: GIBERTI 2012.

Mais de mil fotos foram analisadas, procurando identificar as placas no pára-brisa dos veículos com a d enominação das linhas, itinerários e contratantes dos serviços (para efeito de posterior tabulação dos dados). A foto a seguir, mostra um exemplo de foto analisada ${ }^{56}$.

Foto 14: Ônibus fretado da EMBRAER

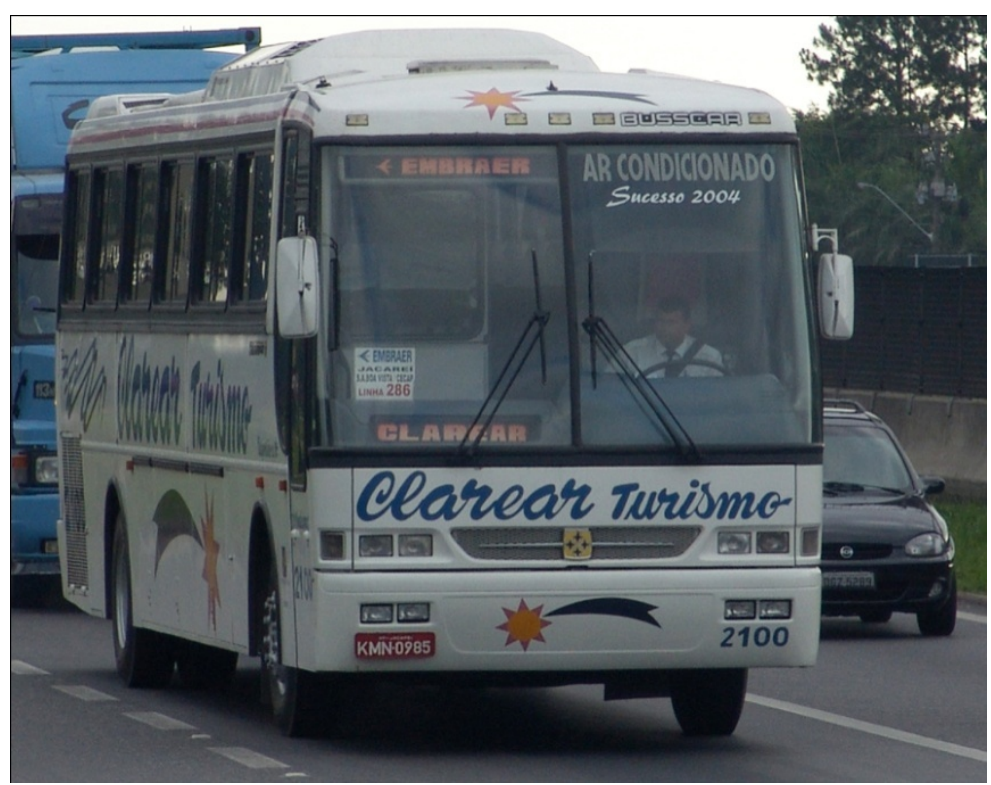

Autor: Giberti 2004.

${ }^{56}$ Em alguns casos, não havia placas com a informação das linhas, mesmo assim os veículos foram contabilizados, para conhecimento do fluxo de veículos. 
Como resultados, foram reconhecidos vários padrões de at uação dos fretados, além de uma variedade de veículos utilizados, empresas prestadoras de serviço, empresas contratantes e raio de abrangência. As tabulações do registro de campo dos fretados na íntegra constam no anexo desta dissertação.

A dificuldade de se obter os dados diretamente com as empresas que utilizam os fretados foi contornada com os levantamentos de $\mathrm{c}$ ampo, que também revelam características muito importantes para que possamos compreender a organização, atuação e significado dos fretados, elementos que muitas vezes não são passíveis de percepção apenas nos livros, tabelas e gráficos "oficiais". Como subproduto desse levantamento de bas e, que englobou as três vertentes de pesquisa, este trabalho oferece uma série de mapas e quadros com exemplos qualitativos e quant itativos da dinâmica dos fretados, em perspectiva macrometropolitano e intra-urbana.

\subsection{Gênese e evolução do sistema de movimento dos fretados}

Na década de 1950, a cidade de São Paulo iniciava seu processo de industrialização, aos moldes da metrópole moderna. Naquela época, a metropolização era um processo em franco desenvolvimento, sendo que o sistema de transportes não estava preparado para os fluxos intermunicipais que se processavam. De alguma forma, a of erta de transporte teria que se adaptar às mudanças econômicas e sociais advindas dessa metropolização, e não existia um órgão planejador de caráter metropolitano voltado para fazer frente a esta nova divisão territorial do trabalho em evolução. Muitas indústrias se instalavam na região atualmente conhecida como $A B C$, um local que na época era isolado da capital, e assim, o ac esso dos trabalhadores era dificultado pela falta de serviços de transporte.

Para fazer frente a este novo padrão de fluxos, já neste período começam a ser oferecidos serviços paralelos, fora do sistema regular. Neste contexto, surgiu o que atualmente é deno minado de transporte "fretado". Em artigo publicado no $15^{\circ}$ Congresso de Transporte e $\operatorname{Tr}$ ânsito, em 2005, os autores afirmam que: 
"O transporte de passageiros por fretamento, com as características que hoje apresenta, surgiu nos anos 50 como parte do processo de industrialização, especialmente na chamada região do $A B C$, em São Paulo. As fábricas instalavam-se em locais relativamente distantes, contavam com contingentes numerosos de empregados trabalhando em vários turnos e horários. Os sistemas de transporte público eram insuficientes para atender demandas concentradas situadas em pontos distantes e incidentes em horários adversos. As empresas passaram, então, a oferecer serviços de transporte para seus funcionários, provido, em geral, por empresas privadas que prestavam os serviços sob contratos" (LEITE, PEREIRA e SOARES, 2005, p.2).

$\mathrm{Na}$ tese de doutorado de Bernardo Alvim (1995), encontramos referências de que o fretamento é um fenômeno de alcance mundial, motivado pela sua flexibilidade em relação às regulamentações existentes e r elativa ausência do poder público na fixação das tarifas, onde a formação dos preços ocorre num ambiente de relativa liberdade de competição e apropriação dos custos e i tinerários por grupos coletivos privados. Na América do $\mathrm{N}$ orte, as linhas fretadas formaram-se como alternativa econômica ao transporte individual; na Irlanda do Sul, como alternativa às linhas regulares do transporte público ferroviário; na Inglaterra, como alternativa aos altos custos incorridos ao se adicionar veículos em linhas regulares para o atendimento da demanda nas "horas de pico". Segundo o autor:

"No caso brasileiro, ot ransporte coletivo por ônibus fretado surge, aparentemente, como substituto ao transporte público. Os serviços de fretamento seguem itinerários pré-fixados e, em alguns casos, submetidos à autoridade competente. No caso de transporte de funcionários, as empresas contratantes subsidiam o pagam ento dos serviços aos usuários. Nota-se, portanto a es colha devido a baixa confiabilidade do s istema de transporte convencional por ônibus. Por outro lado, o fretamento concorre com o transporte público em locais de baixas densidades populacionais, onde seria antieconômica a operação de linhas regulares" (ALVIM, 1995, p.11).

O autor esclarece que, para o atendimento da demanda de transporte de funcionários das indústrias, o transporte regular coletivo público apresenta as seguintes frequências: 1. muito baixa fora dos "horários de pico"; 2. baixa durante o "pico"; e 3. com frota ociosa entre os "picos". O custo de manter tais ociosidades reflete na tarifa cobrada a todos os usuários. Ainda segundo Alvim (1995, p. 18), quando uma empresa opta pelo fretado, ela arca diretamente com a oc iosidade do transporte, significando que s ua opção é "socialmente justa na m edida em que localiza o s egmento da sociedade que paga pela 
ociosidade do material rodante". Dessa forma, o fretado surge efetivamente em contextos metropolitanos, pela necessidade de t ransporte de dem andas específicas, geradas por "pólos", geralmente identificados como fixos geográficos de trabalho (indústrias, fábricas, empresas) ou de estudo (faculdades, universidades etc.).

É possível afirmarmos, portanto, que as linhas fretadas surgem em função do processo produtivo industrial, pois dentre os fatores de localização da indústria estão a di sponibilidade de $\mathrm{m}$ atéria prima, acesso ao $\mathrm{m}$ ercado consumidor, aspectos aglomerativos e d esaglomerativos e $\mathrm{v}$ alor da t erra, resultando muitas vezes em locais sem a i nfra-estrutura de transporte adequada para suprir o acesso e atendimento das viagens demandadas pela conexão entre residência/trabalho dos funcionários.

Em artigo publicado na Revista dos Transportes Públicos da ANTP em 1980, por Victor Abel Grostein, também fica claro que o fretado surgiu para suprir ot ransporte de funcionários das indústrias que, devido aos fatores locacionais da mesma, se instalavam em áreas com pouco - ou nenhum transporte público regular que assegurasse o ac esso dos trabalhadores. Nesses casos, a c riação de linhas regulares públicas era inviável economicamente, restando às indústrias a criação de linhas próprias mediante contrato de prestação de serviços com empresas para esse fim.

Na monografia de Sandra Stephani de Souza (2005), encontramos o primeiro registro da empresa Turismo Rodrigues (que inicia suas atividades em 1957), que prestava serviços de transporte fretado. Segundo a autora:

\footnotetext{
"Com a a bertura de modernas estradas e na década de 1960, com o alavanco da indústria automobilística principalmente na região do $A B C$ Paulista, houve expansão desta atividade conhecida como Transporte de Funcionários. As 3 primeiras linhas cumpridas pela Turismo Rodrigues, para a Volkswagen do Brasil em São Bernardo do Campo, RMSP, foram: Praça da República, Santo Amaro e Estação do Brás, todas na cidade de São Paulo" (SOUZA, 2005, p.17).
}

Podemos concluir que of retado, portanto, foi elemento crucial neste processo de dispersão territorial das indústrias, que consideravam outros 
fatores mais importantes para definir sua localização, com o ac esso dos trabalhadores facilmente solucionado pela implantação de linhas fretadas. Essa versatilidade ef lexibilidade na escolha locacional das indústrias, somada à facilidade e simplicidade de contratação dos serviços fretados, representavam uma grande vantagem no processo produtivo.

Bernardo Alvim (1995) explica que nas análises técnicas que davam respaldo à contratação dos "fretados", a escolha desta modalidade era validada pelos custos e fatores como "confiabilidade", "acessibilidade" e "conforto" para atender às demandas dos empregados na indústria. Essas qualidades também foram incorporadas aos empreendimentos residenciais em áreas de b aixa densidade populacional, que se proliferaram nesta parcela mais industrializada do território brasileiro. Nesse contexto, o fretamento ganhou impulso, pois com a dispersão urbana novas áreas sem transporte regular passaram a organizar novas linhas para manter uma ligação constante entre os condôminos e o resto da cidade, para a r ealização de suas atividades básicas (trabalho, estudo, compras e s erviços). Universidades e es colas também passaram a adotar o fretamento.

Alvim (1995) explica que, inicialmente, essa demanda nova que surgia não atraiu as empresas prestadoras do serviço regular, e n ovas empresas foram criadas para atender este novo setor. Posteriormente, as empresas do sistema regular também passaram a disputar esse mercado, resultando em um movimento das empresas que já atuavam no setor, que procuraram proteger seu mercado mediante participação efetiva nas decisões e regulamentações da esfera intermunicipal e metropolitana, estabelecendo condições e exigências como: capital mínimo integralizado, frota mínima, tradição em serviços de fretamento, entre outras. Estas limitações protegiam o mercado da concorrência de linhas clandestinas e do assédio das operadoras de transporte regular.

Do outro lado, as empresas regulares afirmavam que of retamento representava uma concorrência danosa ao t ransporte público. As linhas fretadas contam com itinerários ques uperpõem diversas outras linhas 
regulares; o pas sageiro do f retado deixa, portanto, de pagar as passagens relativas ao vários trechos do percurso que só poderia ser realizado utilizando mais de uma linha regular, e até mesmo de empresas diferentes, resultando em queda de arrecadação das linhas convencionais.

As indústrias, portanto, foram as pioneiras na ut ilização do fretado, fornecendo linhas de ônibus com itinerários específicos para seus funcionários. As empresas contratantes do serviço de fretamento eram basicamente do setor automobilístico, metalúrgico, manufatureiro e em presas públicas. Os serviços eram prestados por simples contratos de prestação de serviços, celebrado com uma pessoa jurídica; praticamente não havia nenhuma regulamentação específica. Com o pr ogressivo aumento da frota e seu relacionamento/possibilidade de concorrência com o sistema regular, o poder público passa a atentar mais aos fretados, com o estabelecimento de políticas de registro e controle.

A disseminação dos "fretados" como sistema de transporte alternativo ao transporte público que se originou na indústria, passou a ser adotado em outros setores empresariais, condomínios, escolas, universidades e órgãos públicos, dispersos ou n ão, com itinerários municipais, intermunicipais, intrametropolitanos e inter-metropolitanos. O aumento da pendularidade e vulgarização do fretado criou um cenário que exigiu um posicionamento da administração pública para ordenar essa atividade que se consolidava.

A conceituação do serviço de fretamento contínuo foi estabelecida pelo Departamento Nacional de E stradas de R odagem (DNER) e s eguida pelas instâncias estaduais de regulação dos transportes terrestres. No caso de São Paulo, o p rimeiro marco regulatório foi estabelecido pelo Departamento de Estradas de R odagem do E stado de S ão Paulo (DER-SP) que, em 1979, regulamentou o s erviço de transporte coletivo intermunicipal de passageiros sob regime de fretamento. A preocupação básica era classificar o s erviço, diferenciando-o do transporte de trabalhadores rurais, e implantar mecanismos que garantissem o poder de fiscalização dos serviços prestados, suas condições de segurança, conforto, e higiene dos veículos. 
Antes da r egulação do DER-SP, a aç ão normativa era praticamente inexistente, resumindo-se ao recolhimento de impostos e obrigações legais de firma constituída. De acordo com Grostein (1980), constava que na década de 1980 as regiões industriais existentes em pólos como Cubatão, ABCD, Jacareí e outras utilizavam quase que exclusivamente os transportes fretados.

Em 1982, a EMTU também regulamenta o serviço de transporte coletivo de passageiros, de i nteresse Metropolitano, sob o "regime de f retamento", estipulando o cadastro da pessoa jurídica em perfeita regularidade, assim como, a comprovação da capacidade técnica e econômica da prestação dos serviços. Também exigia cadastro e $\mathrm{v}$ istoria dos veículos com requisitos técnicos, de $s$ egurança, conforto, higiene $e v$ isual. Além disso, foram estabelecidas regras claras que, se não respeitadas, geravam multas e cancelamento das licenças. Com a criação da ARTESP em 2002, a a gência reguladora assume a responsabilidade de fiscalizar os serviços permissionados de transporte intermunicipal não metropolitano de passageiros, dentre eles o fretado.

Nesse contexto, o m unicípio de São Paulo se caracterizou como o principal pólo atrativo das viagens por fretamento no es tado. Essa alta convergência dos fluxos acarretou em problemas de nível local; o tecido urbano da capital, denso e saturado (especialmente nas áreas centrais e em algumas avenidas importantes), ao receber em alguns casos centenas de ônibus em um curto espaço de t empo, fica ainda mais saturado. Dentre os principais problemas identificados nas pesquisas documentais de nas pesquisas de campo encontramos a falta de estacionamentos, impactos no trânsito local, degradação dos bairros er eclamação dos moradores. Tal situação foi responsável pela regulamentação da atividade no âmbito municipal.

Com base nas pesquisas documentais dos órgãos públicos podemos afirmar que as regulações da ARTESP e EMTU se limitam ao c adastro da pessoa jurídica, análise da competência técnico-econômica da prestação dos serviços, cadastro e vistoria dos veículos segundo parâmetros estabelecidos, fiscalização da qualidade, segurança e satisfação dos usuários. A esfera 
municipal, ao contrário, trata diretamente da escala intra-urbana, permitindo (ou não) a circulação dos veículos em determinadas ruas, em determinados horários, definindo pontos específicos de em barque e de sembarque de passageiros. Também foram organizados os fluxos dos fretados de maneira articulada com o sistema público, com estações de integração com o transporte municipal e metropolitano intermodal, e def iniram-se áreas de restrição de circulação dos veículos fretados. O grande objetivo dessas políticas é minimizar o i mpacto negativo dos fretados e or ganizar a circulação dos veículos, de modo integrado à política municipal de transporte.

Esse processo de regulação a nível municipal pode ser analisado a partir de dois principais momentos; um entre 2001 e 2005 e outro entre 2009 e 2011. Neste primeiro momento, a Prefeitura de S ão Paulo estava sob gestão de Marta Suplicy, que lançou as bases de toda a política atual, com normatização de nível do planejamento de transporte e de tráfego. No segundo momento indicado, a Prefeitura de São Paulo estava sob gestão de Gilberto Kassab, que complementou as primeiras iniciativas citadas, com mecanismos de controle e cadastro ainda mais rigorosos e sistemáticos para atender ao grande volume de solicitações de autorizações e demandas de controle diário dos fretados. Ambos foram constituídos com leis, decretos e por tarias que se complementaram e formataram a legislação vigente.

Esse esforço da administração pública em todas as esferas de governo para regular, cadastrar e fiscalizar a at ividade de fretamento foi ocasionado pela realidade inegável de que diversos setores da s ociedade passaram a organizar um sistema de transporte coletivo de caráter privado, de acordo com os interesses de gr upos relativamente pequenos e, muitas vezes, com demandas pontuais e de baixa densidade, com itinerários específicos e fora do alcance do transporte regular.

Feitas estas considerações iniciais sobre o surgimento e a evolução dos transportes fretados no contexto macrometropolitano paulista, podemos nos perguntar: como se dão atualmente estes fluxos? Que atores estão envolvidos na prestação de serviços deste tipo? Quais os principais "pólos" geradores de 
demanda dos fretados? Para tentar responder estas questões, a seguir, serão apresentadas as principais pesquisas quantitativas identificadas na pesquisa bibliográfica realizada, que mostram a evolução dos fretados que motivaram a implantação e apr imoramento de m ecanismos de r egulação e fiscalização pública.

Nos artigos de Grostein (1980), identificamos que no final da década de 1970 a frota estadual de fretamento era de aproximadamente 11.000 veículos. No texto também encontramos referências de um a pesquisa realizada pela ANTP, que constatou que dos 175.000 funcionários das 39 empresas paulistas pesquisadas, $51,4 \%$ (90.000) eram transportados por fretamento oferecido pela empresas. Ainda segundo o autor, a pesquisa O/D de 1977 estimou que foram realizadas diariamente na RMSP, 600.000 viagens por fretamento, valor maior que as viagens por metrô (550.000), trem (500.000) e táxi (520.000). Estima-se que nesta época a frota de fretados da RMSP era de aproximadamente 6.000 veículos, número significativo, pois a f rota de ôni bus regular era de quase 12.000 veículos, responsáveis, no entanto, por 8.000 .000 dia viagens diárias.

Com base nos levantamentos realizados diretamente nos arquivos das pesquisas $O / D$, apresentamos a tabela a seguir com a evolução das viagens fretadas entre 1987 e 2007.

Tabela 21: RMSP e Município de São Paulo - Viagens diárias por fretamento -

Evolução da Pesquisa O/D $(1987,1997,2007)$

\begin{tabular}{|c|c|c|c|}
\hline \multicolumn{2}{|r|}{ Viagens } & $\begin{array}{c}\text { Município de São } \\
\text { Paulo }\end{array}$ & RMSP \\
\hline \multirow{5}{*}{1987} & Total de Viagens & 20.024 & 29.400 \\
\hline & Motorizadas & 13.360 & 18.642 \\
\hline & Fretados & 248 & 653 \\
\hline & Fretados / Total & $1.24 \%$ & $2.22 \%$ \\
\hline & Fretados I Motorizadas & $1.86 \%$ & $3.50 \%$ \\
\hline \multirow{5}{*}{1997} & Total de Viagens & 19.614 & 31.432 \\
\hline & Motorizadas & 13.456 & 20.458 \\
\hline & Fretados & 162 & 461 \\
\hline & Fretados / Total & $0.83 \%$ & $1.47 \%$ \\
\hline & Fretados / Motorizadas & $1.20 \%$ & $2.25 \%$ \\
\hline \multirow{5}{*}{2007} & Total de Viagens & 23.519 & 38.094 \\
\hline & Motorizadas & 16.095 & 25.167 \\
\hline & Fretados & 167 & 514 \\
\hline & Fretados / Total & $0.71 \%$ & $1.35 \%$ \\
\hline & Fretados / Motorizadas & $1.04 \%$ & $2.04 \%$ \\
\hline
\end{tabular}

Fonte: Pesquisa O/D 1987, 1997 e 2007. Organização: GIBERTI 2012.

OBS: As viagens absolutas estão em milhares (x 1.000) 
Nesse período de 30 anos (1987/1997/2007), as viagens diárias fretadas sofreram tendência de queda nos valores absolutos e nos percentuais, em relação ao "número total de viagens" e ao "número total de $v$ iagens motorizadas". Essa queda foi maior entre 1987/1997, com relativa recuperação em 2007, porém sem chegar ao patamar de 1987; essa recuperação foi maior na RMSP que na c apital. Não foi possível identificar os motivos dessa queda, mas poderíamos lançar a hipótese de que um maior controle e fiscalização por parte da administração pública poderiam ter alguma relação na diminuição das viagens fretadas, especialmente no município de São Paulo, onde o controle é mais rigoroso. Porém, para corroborar ou negar tal hipótese, seria necessário um estudo específico fora do â mbito deste trabalho. Na RMSP, em 2007, o total das viagens fretadas (514.00) representava $2,04 \%$ das viagens motorizadas; desse total, $84 \%$ das viagens eram motivadas por trabalho, $10,3 \%$ por estudo e $5,5 \%$ por outros motivos.

A pesquisa O/D de 2003 da Região Metropolitana de Campinas (RMC), se comparada à pesquisa O/D 2007 da R MSP, deixa claro que a presença do fretado é absolutamente menor (164.464 viagens diárias); entretanto, sua participação em relação aos demais modais é be $\mathrm{m}$ maior. Os dados são expressivos para toda a Região, com os fretados representando $4,5 \%$ de todas as viagens e $7,5 \%$ do total das viagens motorizadas. Em casos extremos, como nos municípios de E ngenheiro Coelho, Jaguariúna e Holambra, os fretados correspondem, respectivamente, a $39,4 \%, 28,4 \%$ e $24,7 \%$ do total das viagens motorizadas de cada município; no caso do município de Campinas, esse valor é de $4,5 \%$.

Se analisarmos a c omposição dos modais not otal das viagens por "motivo", podemos observar a importância do fretado na Região: o caso mais significativo é o da indústria, onde o fretado corresponde a $25 \%$ de todas as viagens e $34,2 \%$ das viagens motorizadas. Nos demais "motivos", a participação dos fretados not otal das viagens e not otal das viagens motorizadas é bem menor, abaixo de $7 \%$. Constatamos, portanto, que o uso dos transportes "fretados" na RMC é expressivamente vinculado à movimentação de funcionários para as indústrias da Região. 
No caso da pesquisa O/D da Região Metropolitana da Baixada Santista (RMBS) de 2007, foram contabilizadas 61.552 viagens diárias por fretamento, ou seja, $2,9 \%$ do total e $5,5 \%$ de todas as viagens motorizadas. Somando as três pesquisas mais atuais das regiões metropolitanas do Estado de São Paulo (RMSP e RMBS de 2007 e RMC de 2003), a título de simples mensuração, computamos aproximadamente 740.000 viagens diárias por fretamento.

Os dados anteriores são de grande valor e permitem a per cepção da evolução temporal dos fretados. Outro dado de grande importância, que corrobora o c rescimento dos fretados entre 1992 até 2011, é o cadastro de veículos fretados na EMTU. No gráfico 10 podemos visualizar uma série temporal com significativo recuo histórico, obtida para a RMSP, e observarmos um incremento de 6.279 veículos, variando de 3.402 para 9.699, ou s eja, crescimento da ordem de $285 \%$ em 19 anos. Para efeito de comparação, neste mesmo período a frota regular de ônibus na RMSP passou de 3.119 para 4.545 , um crescimento de $145 \%$.

Gráfico 9: RMSP - Evolução da frota regular e fretada cadastrada na EMTU (1992/2011)

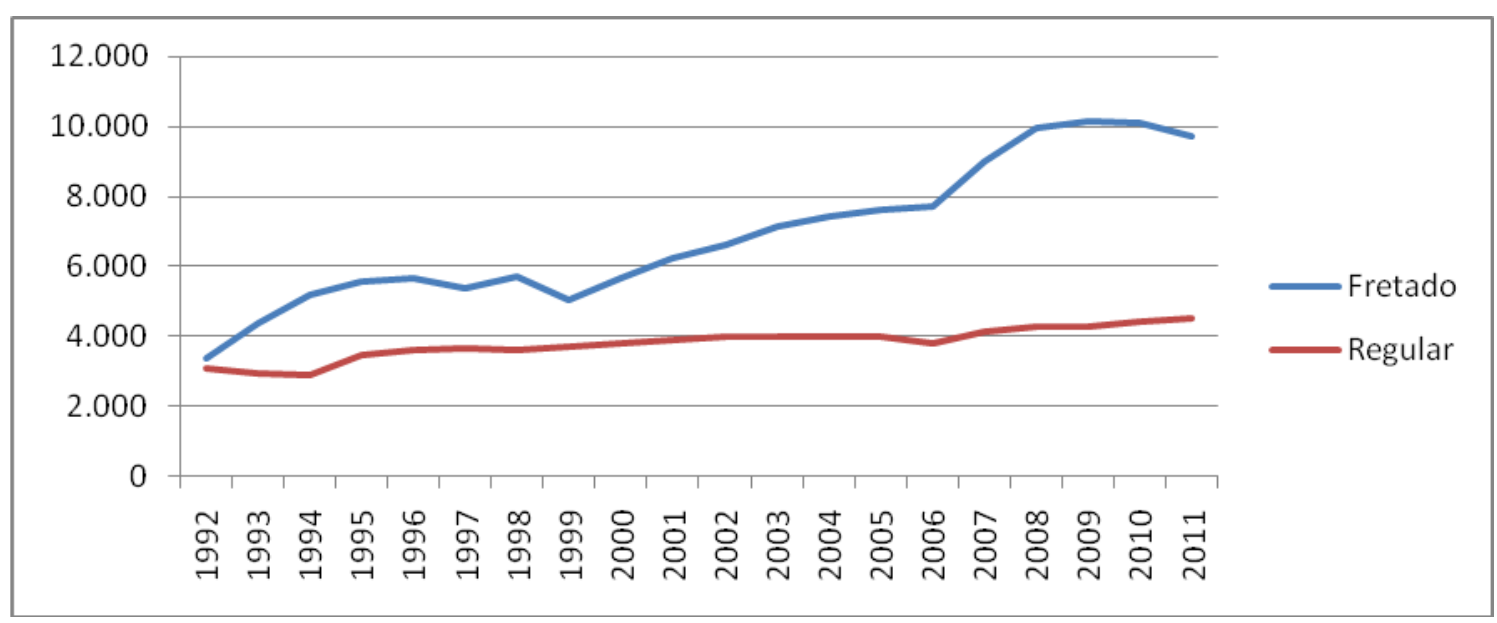

Fonte: EMTU-RMSP 2012. Organização: GIBERTI 2012.

Com menor recuo histórico, e considerando também a RMC e a RMBS, constata-se no gr áfico 13 que houve uma tendência de crescimento e estabilização da frota de veículos de fretamento cadastrados na EMTU, para as três regiões metropolitanas do estado, entre 2007 e 2011. A pesquisa não 
conseguiu identificar outros cadastros em perspectiva temporal, o uni verso disponível, portanto, restringiu-se aos dados da pesquisa O/D e ao cadastro da EMTU.

Gráfico 10: RMSP, RMBS e RMC - Evolução da frota de veículos fretados cadastrados na EMTU (2007/2011)

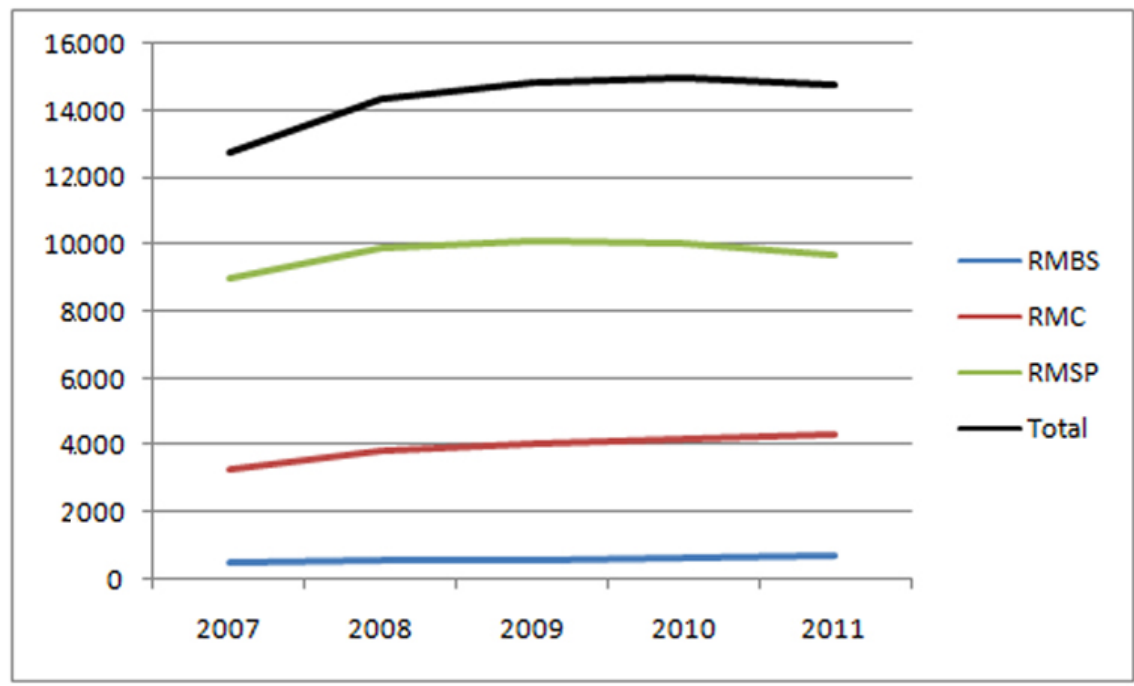

Fonte: EMTU-RMSP 2012. Organização: GIBERTI 2012.

Os fretados que, aparentemente, sofreram uma perda de participação desde 1987 estão se recuperando e são, de fato, um sistema consolidado no cotidiano Macrometropolitano. Afinal, porque o fretamento se consolidou dessa forma?

Além das questões já citadas no início deste capítulo, de suprir áreas dispersas com baixa densidade de infra-estruturas (e de serviços de transporte regular) e garantir a eficácia do acesso da mão de obra aos postos de trabalho, os fretados podem complementar e concorrer com o transporte público, além de atrair usuários dos veículos particulares. As linhas conectam diversos pontos da metrópole, e o fretado assume assim uma característica de "híbrido" entre o transporte coletivo público e o transporte individual particular:

"O transporte sob o regime de fretamento se caracteriza como uma modalidade intermediária ao transporte público e individual [...] verificase que o transporte coletivo por ônibus fretado pertence à mesma faixa daqueles realizados por táxis, prestados mediante aluguel de veículos e por modalidade de transporte coletivo de caráter reservado" (ALVIM, 1995, p.10). 
Do ponto de vista das "vantagens" e "desvantagens" do fretamento por parte das empresas e usuários, segundo Grostein (1980), podemos afirmar o seguinte: para as empresas, as principais vantagens são a garantia de chegada dos trabalhadores no horário e a incorporação do custo do transporte ao funcionário como vantagem salarial; para os funcionários, destacam-se o baixo custo, o conforto (as viagens obrigatoriamente não podem ser em pé) e o caráter de serviço personalizado, com itinerários mais convenientes que o do sistema regular.

Dentre as "desvantagens" para a em presa, consta o al to custo de manutenção do serviço (embora em termos locacionais o serviço "compense" mais pelo menor custo de produção) e a necessidade de espaço interno para estacionamento dos veículos. Para o funcionário, caso ocorra algum problema e ele perca o ônibus, isso pode representar um dia de trabalho perdido, pela falta de outras formas de acesso (transporte regular / transporte individual).

Em uma pesquisa de opinião promovida pela ANTP (2000), o fretado foi avaliado pelos usuários como "excelente" e "bom" em $97 \%$ das entrevistas. Estes valores são superiores aos concedidos ao metrô, que $f$ oram considerados por $96 \%$ dos entrevistados como "excelente" e "bom",perdendo apenas para o aut omóvel (98\%). Outra pesquisa divulgada pela FRESP ${ }^{57}$, realizada em 2005 pela Zimber Consulting, que e ntrevistou 400 em presas, questionando as vantagens do fretamento sob o ponto de vista das empresas e funcionários, é apresentada na tabela 22. Em síntese, o sistema de transporte fretado oferece mais "comodidade" aos usuários, e "itinerários mais convenientes" à população, assegurando maior confiabilidade no acesso dos funcionários às indústrias e um a relação custo/benefício interessante para ambos, tendo como referência o transporte regular e individual.

\footnotetext{
${ }^{57}$ Federação das Empresas de Transporte de Passageiros por Fretamento do Estado de São Paulo.
} 
Tabela 22: Benefícios do fretamento segundo empresas e funcionários

\begin{tabular}{|c|c|c|c|}
\hline \multicolumn{2}{|c|}{ EMPRESA } & \multicolumn{2}{c|}{ EMPREGADOS } \\
\hline VANTAGEM & $\begin{array}{c}\text { PERCENTUAL } \\
\text { RESPOSTAS }\end{array}$ & VANTAGEM & $\begin{array}{c}\text { PERCENTUAL } \\
\text { RESPOSTAS }\end{array}$ \\
\hline Pontualidade & $35,9 \%$ & Comodidade & $35,1 \%$ \\
\hline Custo + Benefício & $21,0 \%$ & Conforto & $14,1 \%$ \\
\hline Comodidade & $12,2 \%$ & Pontualidade & $13,2 \%$ \\
\hline Não quis opinar & $9,9 \%$ & Outros & $10,7 \%$ \\
\hline Outros & $8,8 \%$ & Custo + Benefícios & $9,3 \%$ \\
\hline Segurança & $7,2 \%$ & Não quis opinar & $8,3 \%$ \\
\hline Integração & $2,8 \%$ & Segurança & $7,3 \%$ \\
\hline Conforto & $2,2 \%$ & Integração & $2,0 \%$ \\
\hline
\end{tabular}

Fonte: Zimber Consulting 2005.

Em perspectivas gerais, of retado é apr ovado pelos contratantes e usuários, tornando-se uma estratégia de melhoria da mobilidade em suas diversas motivações, no $\mathrm{c}$ enário de " crise dos transportes" macrometropolitanos. Assume potencial de c omplementar, competir ou simplesmente viabilizar o acesso a determinados locais, sejam eles dispersos ou centrais, em viagens de escala local ou regional, com itinerários complexos e de baixa demanda, que não seriam viabilizados pelo serviço regular. Também é uma alternativa viável aos usuários do transporte individual, por sua característica "híbrida" entre coletivo e individual. Consolida-se como suporte da pendularidade e alternativa ao veículo particular, onde as linhas rodoviárias e suburbanas não atendem adequadamente às demandas pendulares cotidianas. Do ponto de $v$ ista da qualidade de vida, o us uário sofre menos estresse no trânsito por ter seu espaço pessoal assegurado e também permite que o usuário aproveite os tempos de deslocamento, realizando atividades particulares como "trabalhar", estudar, conversar com colegas ou simplesmente repousar.

Ainda que benefícios exaltados possam ser criticados por ser extremamente eficiente para as próprias empresas, a pes quisa documental 
realizada sobre ot ema dos fretados mostra que e sta capacidade de a trair usuários dos veículos particulares ("tirando carros das ruas"), permite uma melhora na qualidade de vida dos usuários das redes-suporte viárias urbanas, com ganho de produtividade e pontualidade nas empresas e diminuição do consumo de combustível e em issão de poluentes. Os atrativos divulgados pelas empresas, no i ntuito de expandir seu mercado, concentram-se em argumentos para solução dos problemas de t rânsito, tais como: engarrafamento, rodízio, greve do sistema de transporte, acidentes de trânsito, faltas ou a trasos ao trabalho, estresse, horas perdidas no trânsito, pedágio e má qualidade de vida. Dependendo do contrato, também reembolsam o cliente por falha de operação e não atendimento do horário programado.

Também mostram com ênfase que os veículos fretados são constantemente vistoriados pelos órgãos governamentais, aumentando a segurança e o conforto dos deslocamentos deste tipo.

Dentre as principais críticas aos fretados podemos destacar os seguintes argumentos: of retado complica e c ongestiona o trânsito pela falta de estacionamentos e pelo alto volume de veículos em ruas já saturadas, com embarque e des embarque em locais inadequados, além de "invadir" a infraestrutura do sistema viário do transporte regular, competindo com o sistema regular e "roubando" passageiros, onerando o custo do sistema.

Os malefícios e be nefícios externados pelos diversos segmentos da sociedade devem ser ponderados no contexto do Sistema de Movimentos da Macrometrópole, considerando que existem neste verdadeiro "campo de forças" que é o espaço geográfico (SANTOS, 2002), interesses distintos - e conflitantes - de ordem econômica, política es ocial. Devemos atentar, portanto, aos impactos positivos e negativos no cotidiano da população e da cidade, tendo como foco o que poderíamos chamar da "função social do fretado".

Como exposto na síntese realizada da pesquisa documental e bibliográfica, a maior parte dos argumentos apresentados pelos atores 
interessados (empresas prestadoras do serviço, empresas demandadoras do serviço e us uários) são bastante plausíveis. Segundo ainda nosso entendimento da ques tão, caberia à s ociedade e ao Estado uma análise política e técnica do fenômeno como um todo, para estabelecer uma normatização que permita o convívio em harmonia entre o transporte regular e o fretado, de forma a des envolver o potencial positivo de ambos os serviços, com o melhor uso possível da infra-estrutura viária e conexão intermodal.

\subsection{Organização, normas, atores e usuários dos fretados}

Hoje ot ransporte fretado encontra-se presente em boa p arte das cidades do país, nos mais diversos segmentos, e pode s er dividido em duas modalidades: os fretados contínuos e os eventuais. No caso deste trabalho, nos interessa o modo contínuo, destinado à condução de grupos definidos de pessoas, caracterizado como serviço de transporte de passageiros prestado a pessoa física ou jurídica, mediante contrato específico, para um determinado número de viagens, sem cobrança individual de passagens, com itinerários préestabelecidos e não tendo caráter de "serviço aberto ao público".

As regulações dos órgãos públicos impõem normas e c ontrole na efetivação dos serviços, entretanto não regulam as tarifas, que acabam por se formar a partir de acordos entre os atores envolvidos diretamente (dentro das "leis do mercado" específico).

O fretamento de modo contínuo envolve o transporte para empresas (indústria, serviços, comércio e lazer), escolas, universidades, condomínios residenciais, entre outros. Ele pode ser realizado no âmbito municipal, intermunicipal, metropolitano e intermetropolitano. Para cada escala de atuação existe um órgão concedente, que regulamenta e fiscaliza o serviço. No caso da Macrometrópole Paulista, uma síntese com a relação dos órgãos reguladores é apresentada no quadro 2 . 
Quadro 2: Macrometrópole Paulista - Órgãos controladores das diferentes escalas de atuação do transporte fretado contínuo

\begin{tabular}{|c|c|}
\hline Órgão & Atuação \\
\hline $\begin{array}{c}\text { ARTESP (Agência Reguladora de Serviços Públicos } \\
\text { Delegados de Transporte do Estado de São Paulo) }\end{array}$ & $\begin{array}{c}\text { Fluxos Intermunicipais "fora” da } \\
\text { Região Metropolitana }\end{array}$ \\
\hline STM (Secretaria dos Transportes Metropolitanos) & Regiões Metropolitanas \\
\hline SMT (Secretaria Municipal de Transportes da Cidade de \\
São Paulo)
\end{tabular}

Elaboração: GIBERTI 2012.

Cada empresa de fretamento deve ter seu registro no órgão fiscalizador, de acordo com sua área de atuação. Para obter o alvará é preciso cumprir uma série de exigências com relação à c apacidade econômica, técnica e operacional da empresa e também de seus dirigentes. Todos os veículos são submetidos a vistorias de s egurança, com periodicidade anual (ou menor), conforme a idade do veículo. Podem ser utilizadas vans, micro-ônibus, ônibus rodoviários "executivos" e/ou "de luxo". Caso o itinerário englobe as três jurisdições, a empresa terá te atender às normas dos três órgãos reguladores.

Foto 15: VAN

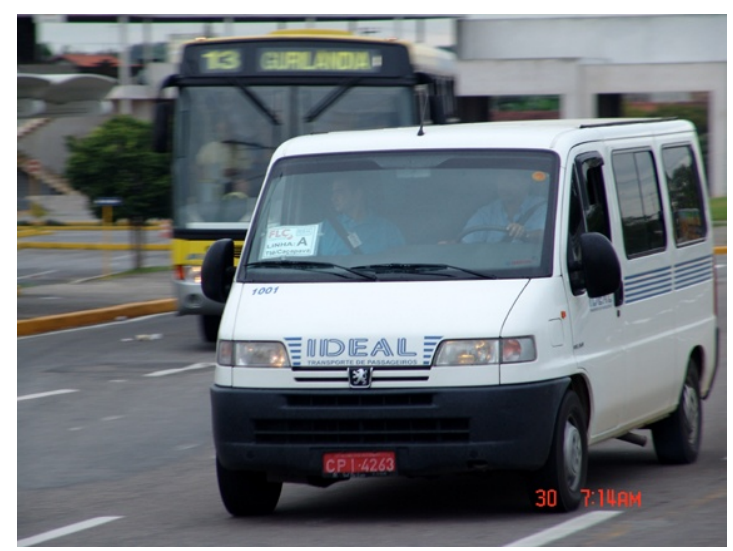

Autor: GIBERTI 2012.
Foto 16: Micro-ônibus

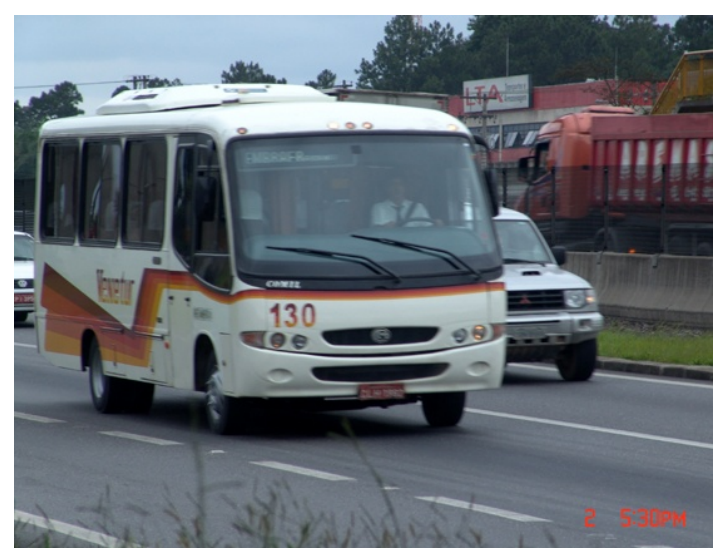

Autor: GIBERTI 2012. 
Foto 17: Ônibus executivo

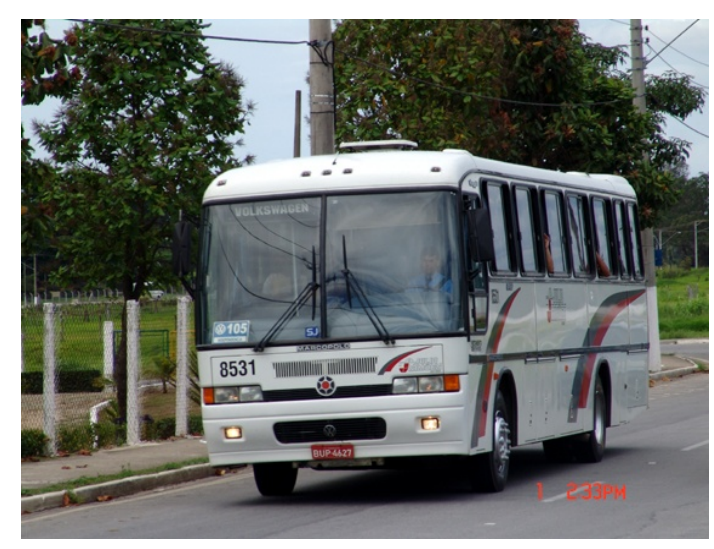

Autor: GIBERTI 2012.
Foto 18: Ônibus de luxo

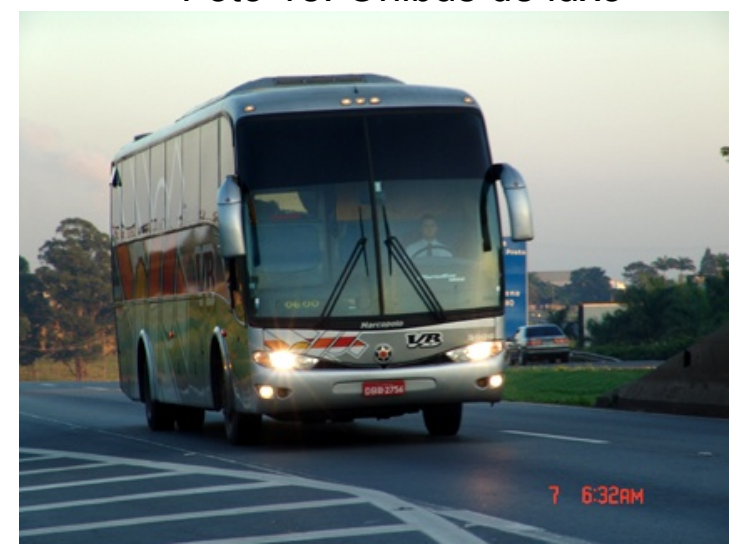

Autor: GIBERTI 2012.

A ARTESP e a STM (EMTU) apresentam normas semelhantes exigindo, basicamente, documentos que comprovem os seguintes procedimentos/informações ${ }^{58}: 1$. a regularidade da prestadora de serviços; 2 . cadastro; 3. autorização da e mpresa; 4. documento de v istoria válido do veículo; 5. formulário de s olicitação do s erviço com cópia do $c$ ontrato da prestação de serviços; 6 . relação dos passageiros transportados e do condutor (com nome e núm ero de doc umento); 7. nota fiscal do s erviço; 8. local de origem, destino e m otivo da $v$ iagem. Todos os passageiros devem viajar sentados (em hipótese alguma um passageiro poderá viajar em pé).

Do ponto de $v$ ista da $r$ egulação, a principal diferença entre os procedimentos da ARTESP e de EMTU é que a ARTESP não permite o uso de "vans" para a prestação dos serviços. Na ARTESP, estão cadastrados 11.829 ônibus e 455 empresas. Na EMTU, por sua vez, encontram-se registrados 14.750 veículos e 1.254 empresas, sendo que a $m$ aior frota corresponde à RMSP $(65,7 \%)$, seguida pela RMC $(29,5 \%)$ e RMBS $(4,6 \%)$. Desse total, $57 \%$ dos veículos são ônibus, $28 \%$ vans e $15 \%$ microônibus. Ambos os órgãos reguladores não impõem restrições de horários e vias de circulação. Também existem regulações específicas nos municípios de Campinas e Sorocaba.

${ }^{58}$ ARTESP 2012. EMTU 2012. 
Para aprofundar de forma mais sistemática esta parte de nossa pesquisa documental, selecionamos o caso da Secretaria Municipal de Transportes da Cidade de São Paulo que, além das exigências solicitadas pela ARTESP e STM, demandam dos prestadores de s erviços outras condicionantes, mais rigorosas.

Com a nova regulamentação de 2009 a autorização da SMT depende de uma análise prévia do i tinerário, solicitado por parte da equi pe técnica do Departamento dos Transportes Públicos (DTP). Atualmente, após mudanças e complementações de leis, decretos, portarias e r esoluções, a sistemática de autorização do serviço de fretamento contínuo que envolve o município de São Paulo ocorre da seguinte maneira ${ }^{59}$ :

1- A empresa prestadora de serviços deve realizar cadastro de p essoa jurídica, solicitando um Termo de A utorização (TA) no qual comprova, basicamente, sua regularidade jurídica, fiscal e autorização para fretamento de outras instâncias reguladoras de sua área de at uação (intermunicipal e metropolitano). Cada empresa conta com apenas um TA, ou seja, é um cadastro da empresa prestadora de serviços junto à prefeitura. A validade da TA é de um ano e passível de renovação periódica.

2- Para cada veículo utilizado na atividade deverá ser solicitado um Certificado de V ínculo ao S erviço (CVS), comprovando a pr opriedade do veículo, sua regularidade junto aos órgãos de trânsito (registro e licenciamento), aprovação da vistoria técnica, recolhimento de impostos, apólice de seguro individual ou coletivo, comprovante da idade máxima do veículo permitida (15 anos para ônibus e 10 anos para micro-ônibus e vans) e, por fim, o cumprimento das normas de acessibilidade para pessoas portadoras de deficiência e mobilidade reduzida e emissão do nível máximo de enxofre. $A$ validade do CVS é de um ano e passível de renovação periódica.

3- Deverá ser apresentado um plano de operação do veículo sujeito a aprovação, com cópia do c ontrato e not a fiscal da pr estação do s erviço, juntamente com a lista de passageiros e cópia da habilitação do condutor na

${ }^{59}$ DTP 2012. 
categoria adequada, assim como a aut orização da mesma para o transporte coletivo.

4- No caso de São Paulo, a cidade é dividida em dois setores, denominados “Área Livre” e "Zona Máxima de Restrição aos Fretados (ZMRF)". O segundo setor apresenta restrição de circulação de segunda à sexta feira, das $05 \mathrm{~h} 00$ às 21h00. Para itinerários que entrem na ZM RF, deverá ser solicitada uma Autorização Especial de Trânsito (AET), que só é em itida quando o contratante do s erviço é u ma pessoa jurídica. Para tanto, o interessado deverá enviar essa solicitação com o plano detalhado de operação até as $12 \mathrm{~h} 00$ do dia anterior comprovando que o endereço de origem (ou destino) está dentro da zona de restrição; também deve constar na solicitação informações sobre o local de embarque e des embarque de pas sageiros preferencialmente nas instalações disponibilizadas pela contratante do serviço, ou em pontos específicos previamente estabelecidos e aut orizados pela secretaria. Dessa forma, haverá tempo hábil para que o pedido seja deferido (ou indeferido) após análise de sua regularidade cadastral e possíveis adequações do itinerário. Essa solicitação é feita mediante um site na internet. Já na c hamada "Área livre", os veículos podem circular sem restrições, respeitando as demais regras de trânsito.

Foi possível identificar nessa pesquisa documental também que e $\mathrm{m}$ hipótese alguma será permitido o ingresso de veículos na ZMRF sem a $A E T$, também sendo proibido o embarque e desembarque de passageiros em pontos de paradas, estações de transferência ou terminais do sistema de transporte coletivo regular (salvo naquelas autorizadas pela secretaria). Também é vedado o uso de vias públicas para o estacionamento dos veículos, cabendo à operadora dos serviços dispor de local adequado. Em caráter excepcional e transitório, a s ecretaria poderá autorizar o estacionamento dos veículos em vias públicas, desde que não cause transtornos à vizinhança.

O não c umprimento das regras ou irregularidade cadastral e na prestação dos serviços acarretará em aplicação de m ultas e ev entual suspensão das licenças concedidas. A fiscalização da circulação dos veículos é realizada nos limites da ZMRF, mediante o leitor automático de placas (LAP); 
caso seja registrada uma placa dentro da zona de restrição, sem a A ET vinculada, automaticamente serão aplicadas multa e advertência. Com essa regulamentação ef iscalização, a Prefeitura conta com instrumentos para organizar e racionalizar a at ividade dos fretados em consonância com 0 sistema público regular, buscando assegurar uma "fluidez mínima" no trânsito da cidade. Para tanto, foram criados pontos de em barque e desembarque preferencial para os fretados em locais de conexão intermodal com o transporte público (figura 12).

Figura 12: Município de São Paulo - Zona de máxima restrição de fretamento

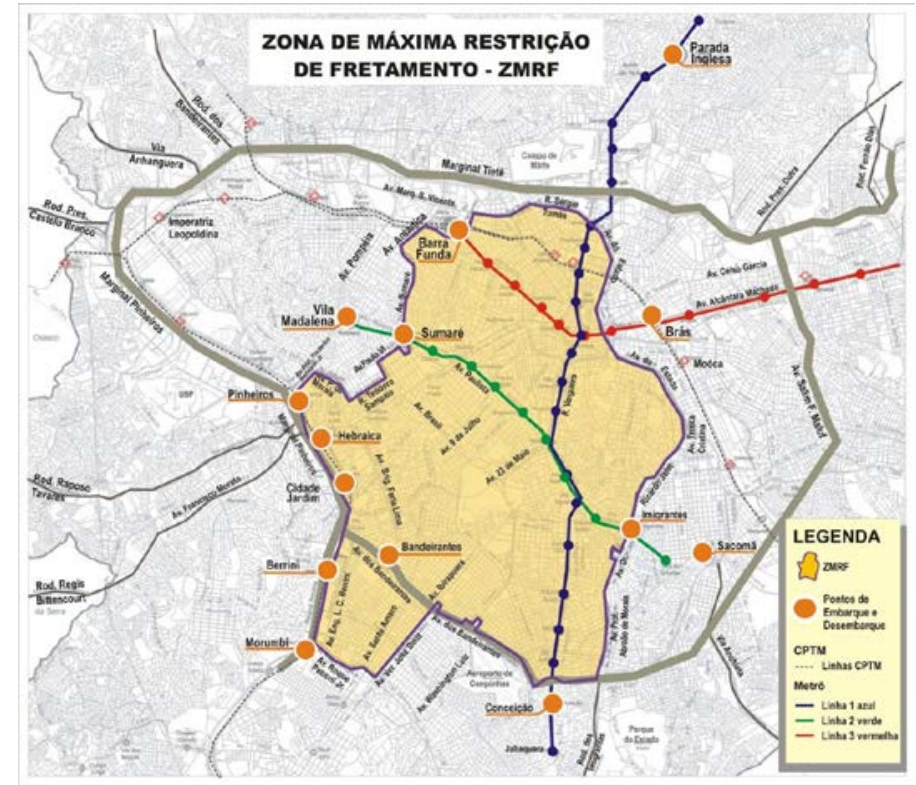

Fonte: Prefeitura de São Paulo 2012.

Além da pesquisa documental que serviu de base para a redação deste terceiro capítulo, pudemos realizar também algumas entrevistas com especialistas e técnicos do setor, visando dar maior consistência ao argumento da dissertação, Em uma destas entrevistas, o Sr. Jorge Miguel dos Santos, diretor da TRANSFRETUR ${ }^{60}$, afirma que a transição para o novo modelo regulatório de 2009 foi relativamente "polêmica", com usuários e empresários sofrendo pela falta de organização, com perda de receita e com esforço do setor para se recuperar. Destaca ainda que as políticas limitam o potencial de expansão da oferta do serviço de fretamento; sugere a organização de novas linhas, mediante um cadastro geral que possa articular itinerários alternativos

${ }^{60}$ Sindicato das Empresas de Transporte de Passageiros por Fretamento e para Turismo de São Paulo e Região 
aos usuários de c arros, que al mejam um serviço melhor que o transporte público. ${ }^{61}$

Para entendermos melhor o significado atual deste "universo" composto pelos serviços de transportes fretados, podemos lembrar que, segundo o DTP, em 17/1/2012 existiam 13.078 veículos cadastrados e $995 \mathrm{t}$ ermos de autorização. Em todo o hi stórico do novo cadastro ${ }^{62}$ (iniciado em 29/07/2009 até 15/02/2012), foram analisados 13.311 protocolos, dos quais 9.457 foram deferidos, ou seja, não apresentavam regularidade cadastral ou contavam com informações incompletas. Assim, $71 \%$ das solicitações de a utorização de veículos para fretamento regular no município foram aprovadas, todas com prazo máximo de um ano, passível de renovação.

O sistema de m ovimento dos fretados, portanto, é c omposto pelas seguintes instituições: 1. órgãos reguladores (ARTESP, STM, Prefeituras Locais); 2. empresas prestadoras de serviços (representadas pelos seus respectivos sindicatos, com destaque para o $S$ indicato das Empresas de Transporte de Passageiros por Fretamento e para Turismo de São Paulo e Região (TRANSFRETUR) e Feder ação das Empresas de Tr ansportes de Passageiros por Fretamento do Estado de São Paulo (FRESP); 3. contratantes (empresas de $\mathrm{v}$ ários setores da ec onomia, universidades, escolas, condomínios, grupo de moradores, órgãos públicos), na figura de pessoa física ou jurídica; e, por fim, 4. os usuários, representados, basicamente, pelos trabalhadores (dos ramos da indústria, serviços e c omércio) e pel os estudantes.

\footnotetext{
${ }^{61}$ Segundo ainda o entrevistado Sr. Jorge Miguel dos Santos, ocorreria atualmente uma disputa pelo mercado entre os principais modais, e que, apesar de todos estarem "saturados", ainda há uma preferência generalizada do automóvel particular em relação aos "fretados"; em função desta situação, é possível afirmar que o modo de transporte fretado se encontra "ocioso". Para ele, o setor quer dialogar com as autoridades que regulam este tipo de serviço, e está disposto a seguir regras para expandir os serviços. Também afirma que o fretado é o único modo que realmente pode cativar o usuário de veículo próprio, e que o setor está investindo na renovação da frota e aprimoramento de seus serviços.

${ }^{62}$ Nova metodologia de cadastro, análise, deferimento ou indeferimento das solicitações de viagens por fretamento contínuo e eventual. Anteriormente existiam outros métodos.
} 
Essas relações ocorrem em um campo de aç ão resultante da combinação dos atores, normas e redes-suporte analisados no decorrer da dissertação. Os movimentos dos fretados, por sua vez, não se restringem aos limites político administrativos dos municípios em que o s erviço é pr estado, mas sim à vida de relações macrometropolitana. Como identificar este alcance dos fluxos dos fretados no $c$ ontexto da Macrometrópole paulista? Como mapear os atores e suas estratégias? Que tipos de empresas são as mais demandantes deste tipo de serviço? Quais os principais pólos de "atração" do serviço dos "fretados".

Para tentar responder estas questões, apresentamos a seguir, no quadro 3 , algumas instituições que utilizam os fretados, na $R$ egião Metropolitana de $C$ ampinas e no $V$ ale do $P$ araíba. Explicar que é um a amostragem de campo.

Quadro 3: RMC e Vale do Paraíba Paulista - Registro de campo - Instituições que utilizam transporte fretado (2005)

\begin{tabular}{|c|c|}
\hline ADELBRAS & KIDDE BRASIL \\
\hline A.J. Rorato & Kodak \\
\hline A.RAYMOND & KS - PISTÕES \\
\hline AKZO NOBEL & LETANDE \\
\hline Alstom & LG Electronic \\
\hline ALUJET & LG Philips \\
\hline Ambev & METAL LIGHT \\
\hline Amplimatic & Monsanto \\
\hline ASTER & Novelis \\
\hline Autoliv & ONÇA \\
\hline Avibrás & Oxiteno \\
\hline BOSCH & Panasonic \\
\hline BSH CONTINENTAL / LG & Parker \\
\hline Bundy & Petrobrás \\
\hline CEBRACE & Pducação e Cultura / Transporte Escolar \\
\hline CELESTICA & PROCTER \& GRAMBLE \\
\hline Cognis & PPG Indústria do Brasil LTDA \\
\hline
\end{tabular}




\begin{tabular}{|c|c|}
\hline Colégio Poliedro & PUCCAMP \\
\hline Confab & Radic \\
\hline CORREIOS & RIDARP \\
\hline COTIL & RIPASA \\
\hline CTEEP & ROBERT BOSCH \\
\hline Daido & SAINT GOBAIN \\
\hline Daruma & SANTISTA \\
\hline Delphi & Schrader \\
\hline EATON & TAMPAS CLICK \\
\hline EATON & TECH TOWN \\
\hline Embraer & TECSAT \\
\hline Ericsson & TELEMAX \\
\hline EXEL DO BRASIL & Tigroup \\
\hline FACCAMP & TNT LOGISTICS \\
\hline Ford & TOPACK \\
\hline Fujifilm & UNICAMP \\
\hline GEVISA & UNILEVER \\
\hline GM & Universidade do Vale do Paraíba (UNIVAP) \\
\hline GOODYEAR & Universidade Paulista (UNIP) \\
\hline Heatcraft & Usiminas \\
\hline HEXIS CIENTÍFICA & VILLARES \\
\hline Hitachi & Villares \\
\hline INGERSOLL RAND & VIVO / CLARO \\
\hline Johnson \& Johnson & Volkswagen \\
\hline Kaiser & Votorantin \\
\hline
\end{tabular}

Fonte: Levantamentos de campo. Autor: Giberti 2012.

Esse campo de relações cotidianas intermediado pelo fretamento resulta em vários padrões de uso dos fretados, associados a pólos urbanos (dispersos ou não), revelando também uma hierarquia de fluxos, origens e destinos, que pode ser observada na es cala macrometropolitana. Como identificar melhor essa vida de fluxos animada pelo movimento dos fretados?

3.3 Pólos, densidades, direções, alcance e impacto dos fretados

De todo o material pesquisado, foram selecionados alguns exemplos de atuação dos serviços "fretados" para elucidar a diversidade de organização e a 
amplitude de at uação das linhas, como suporte à pendu laridade macrometropolitana. Esta pendularidade acaba por conformar um cotidiano que escapa ao limites municipais "tradicionais", fazendo da vida de boa parte dos trabalhadores/estudantes cada vez uma vida "regionalizada", fenômeno esse possibilitado pelo fretado.

Como vimos anteriormente, a mobilidade cotidiana em escala regional e inter-regional ocorre com freqüência no estado de São Paulo, motivada principalmente por deslocamentos para trabalho e estudo. Verificamos também a tendência de e xpansão dos fretados, em detrimento do transporte convencional suburbano.

Segundo a TRANSFRETUR ${ }^{63}$, em 2002, 550 mil pessoas eram transportadas diariamente na R egião Metropolitana de São Paulo por fretamento, em aproximadamente 18 mil viagens, o que equivale a uma frota de 4.500 veículos (com média de quatro viagens por veículo/dia).Os fretados, portanto, pelo seu custo competitivo, flexibilidade e facilidade de organização, tanto por parte de empresas quanto por organizações públicas e civis, oferece boas condições de transporte em massa para interligar todos os pontos do território.

A dificuldade de locomoção da população pelas linhas regulares, com itinerários rígidos, passa a ser substituída por essa nova forma de transporte. Todos os dias novas linhas são criadas, atendendo a itinerários cada vez mais diversificados; assim, as novas formas urbanas dispersas no território já não dependem exclusivamente do transporte convencional, sendo que as linhas fretadas surgem como uma alternativa real e eficaz.

Os fretados passam a ser organizados e utilizados pelas empresas de vários ramos, órgãos públicos, setores de c omércio/serviço/lazer, grandes condomínios residenciais, universidades, escolas e até por redes sociais "virtuais". $\mathrm{Na}$ internet é possível acessar diversos sites que of erecem linhas fretadas (particularmente no endereço www.fretados.com) e, caso a I inha

${ }^{63}$ www.transfretur.com.br 
pretendida não exista, é pos sível fazer um cadastro e formar novas linhas a partir de pesquisas direcionadas.

Porém, os serviços de fretados são em grande parte requisitados por grandes empresas, que necessitam de um eficaz sistema de movimento de seus funcionários, para que $s$ uas atividades se realizem da forma mais eficiente possível. Neste sentido, direcionamos também parte da pesquisa empírica para identificar as principais instituições/empresas demandantes dos serviços dos "fretados" em parcelas específicas da Macrometrópole Paulista.

Com base nos levantamentos de c ampo ${ }^{64}$ (2004/2012) foram selecionados vários exemplos de pólos urbanos que exercem um poder de atração de v ários quilômetros sobre a popu lação, espalhada em toda Macrometrópole Paulista. Mediante os produtos apresentados as eguir, podemos comparar a funcionalidade de cada pólo, sua localização e o poder de atração sobre a população. Os exemplos buscam representar a diversidade encontrada durante toda a pesquisa.

\section{Indústrias:}

\section{- LG PHILIPS}

Localizada no m unicípio de $S$ ão José dos Campos, às margens da Rodovia Dutra, atua no setor de eletroeletrônicos. Foi possível constatar em campo o movimento intenso e dinâmico da atuação dos fretados nas chamadas "trocas de turno" da fábrica, no período da manhã. Foram registrados aproximadamente 12 ônibus fretados, entretanto, as placas identificavam as linhas por códigos e não por itinerário. Tal movimento demonstrou que a troca do turno funciona de $\mathrm{m}$ aneira mecânica, semelhante ao f uncionamento da própria indústria, onde ot empo e a m obilidade dos funcionários são cronometrados e integrantes do processo de produção. Em 45 minutos, estes 12 ônibus estacionaram em frente à fábrica, os funcionários desceram dos

\footnotetext{
${ }^{64}$ Ver anexo.
} 
ônibus e entraram no local. Os ônibus foram embora e, nas proximidades da fábrica, fizeram o retorno e estacionaram novamente em frente à fábrica. Em alguns minutos, os funcionários do turno que acabava saíram da fábrica e ingressaram nos ônibus que já os esperavam. Após o embarque de todos, os ônibus gradativamente iam embora, levando os funcionários para suas residências.

Figura 13: Fábrica da LG PHILIPS na beira da Rodovia Presidente Dutra

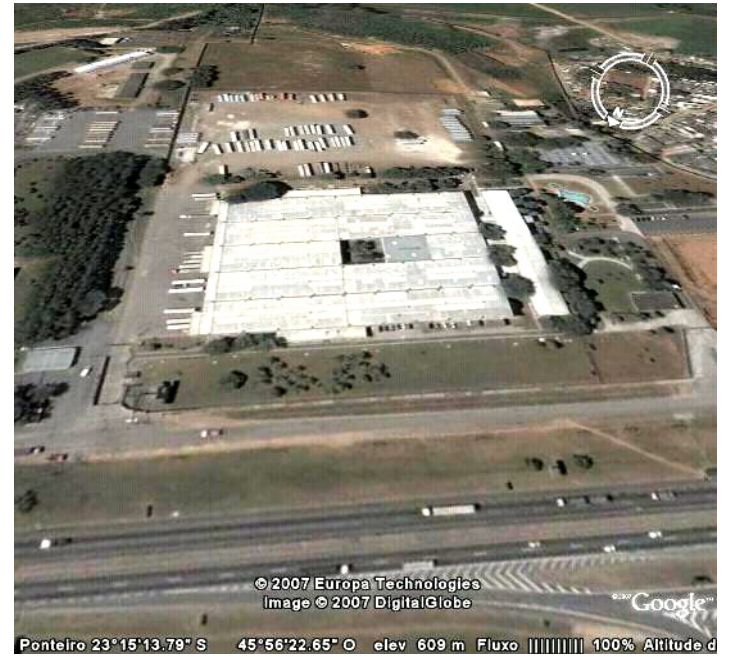

Fonte: Google Earth 2007.

Todos os ônibus estavam aparentemente lotados, tanto no embarque quanto no desembarque de funcionários; outro fato interessante é que todos os veículos andam em comboio. Em questão de segundos, a en trada da fábrica que estava tranqüila é dominada pelos ônibus que chegam com o novo turno. Em poucos minutos, os ônibus já aguardam a saída do turno que se encerra e, como parte do processo de produção, ocorre a troca do turno e, desta maneira, assegura o funcionamento ininterrupto da fábrica, que trabalha com três turnos. 
Foto 19: Chegada do primeiro ônibus fretado. Foto 20: Concentração de fretados e desembarque dos funcionários.

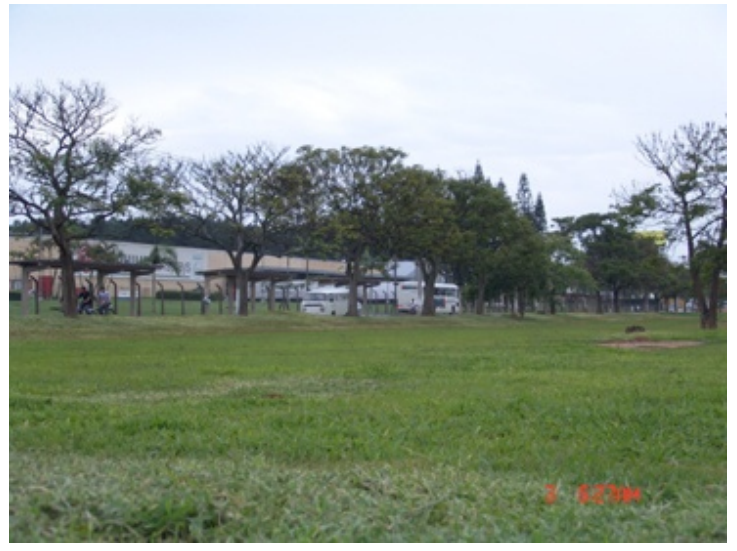

Autor: GIBERTI 2007

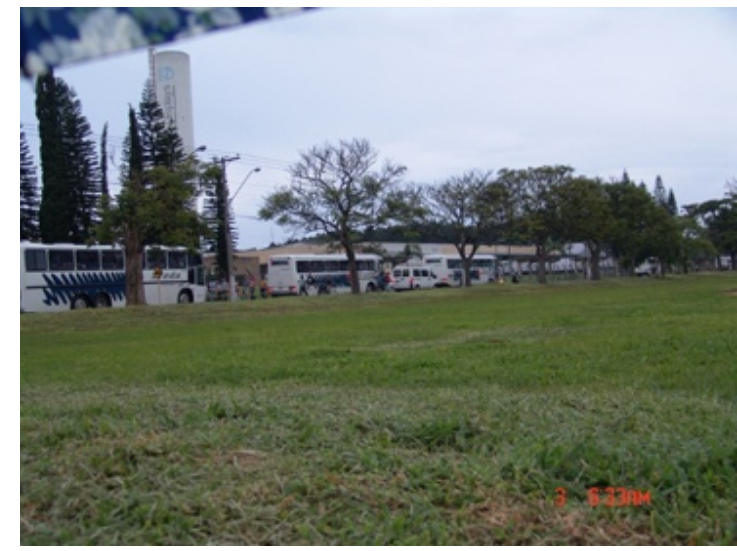

Autor: GIBERTI

\section{- VOLKSWAGEM}

Situada no município de Taubaté, em uma área dispersa próxima a um bairro operário, a indústria atua no setor automobilístico e recruta sua mão de obra através de dezenas de linhas fretadas com um raio registrado de $70 \mathrm{~km}$, atingindo cidades mais "distantes" da rede urbana, como Lorena, Aparecida e Roseira. Suas linhas também atendem a todas as áreas próximas da cidade de Taubaté, sendo que são atendidos bairros de alto e baixo padrão, revelando a diversidade de qualificação da mão de obra recrutada pela empresa. (Ver mapa 26).

Figura 14: Fábrica da Volkswagen.
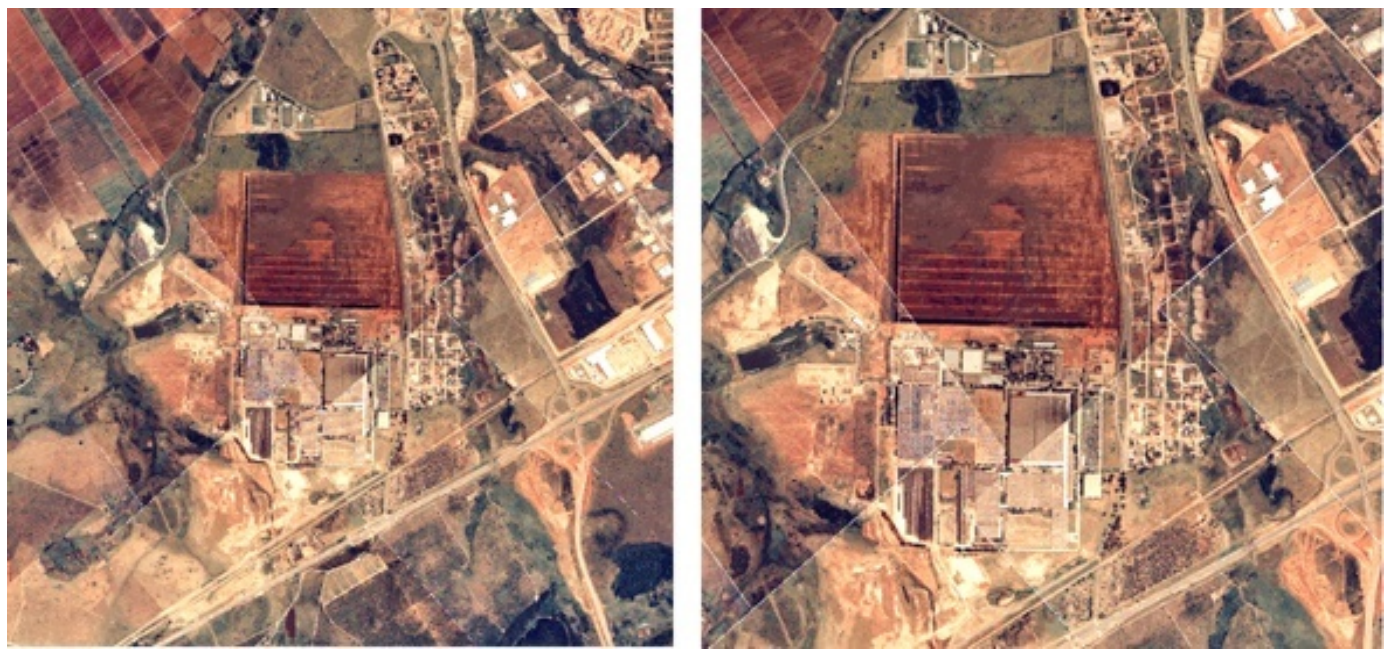

Fonte: Prefeitura de Taubaté 2001. 
Mapa 26: VOLKSWAGEM - Linhas Fretadas - Raio de Atração - 2005

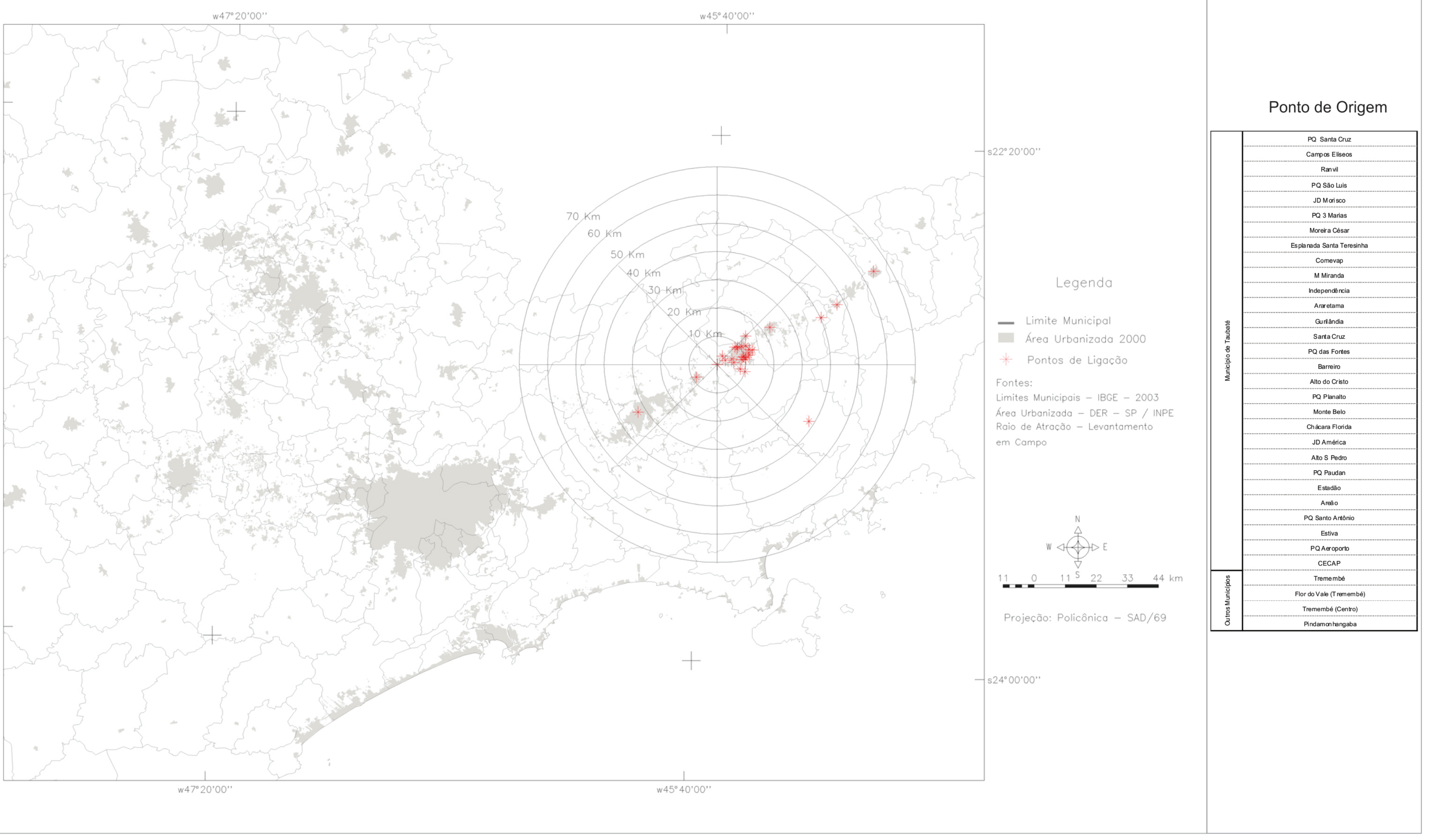




\section{- EMBRAER}

Localizada no m unicípio de $S$ ão José dos Campos, às margens da Rodovia Dutra, atua no setor aeronáutico, considerado um dos segmentos mais importantes na ec onomia do Vale do Paraíba Paulista. As atividades da Empresa Brasileira de Aeronáutica S.A. (EMBRAER) exigem profissionais altamente capacitados para as atividades de al ta tecnologia desenvolvidas nesta indústria, resultando no recrutamento de mão de obra em um raio de 130 $\mathrm{km}$, atingindo Campinas e $\mathrm{c}$ idades mais próximas do $\mathrm{V}$ ale do $\mathrm{P}$ araíba, especialmente Jacareí, Taubaté e Tremembé. Suas linhas fretadas passam por bairros operários e por bairros de alto padrão, revelando a diversidade técnica da mão de obra. (mapa 27).

\section{- EATON}

Localizada no município de Valinhos, próximo ao limite com Campinas, em uma área de bai xa densidade populacional, atua no s etor de ener gia, a indústria oferece dezenas de linhas fretadas que passam por bairros de todas as regiões de Campinas, chegando até o município de Moji-Mirim, formando uma raio de $70 \mathrm{Km}$ de atração. (mapa 28).

\section{Órgãos Públicos:}

- Secretaria da Agricultura do Estado de São Paulo

Localizada naz ona sul do município de São Paulo atua no setor agropecuário, de segurança alimentar, na abertura de créditos e apoio técnico aos produtores rurais. Oferece linhas fretadas em um raio de $40 \mathrm{~km}$ para seus funcionários, especialmente nos bairros mais periféricos de São Paulo, além de cidades do ABC Paulista. Notamos que o próprio poder público também adota o transporte fretado (mapa 29). 
Mapa 27: EMBRAER - Linhas Fretadas - Raio de Atração - 2005

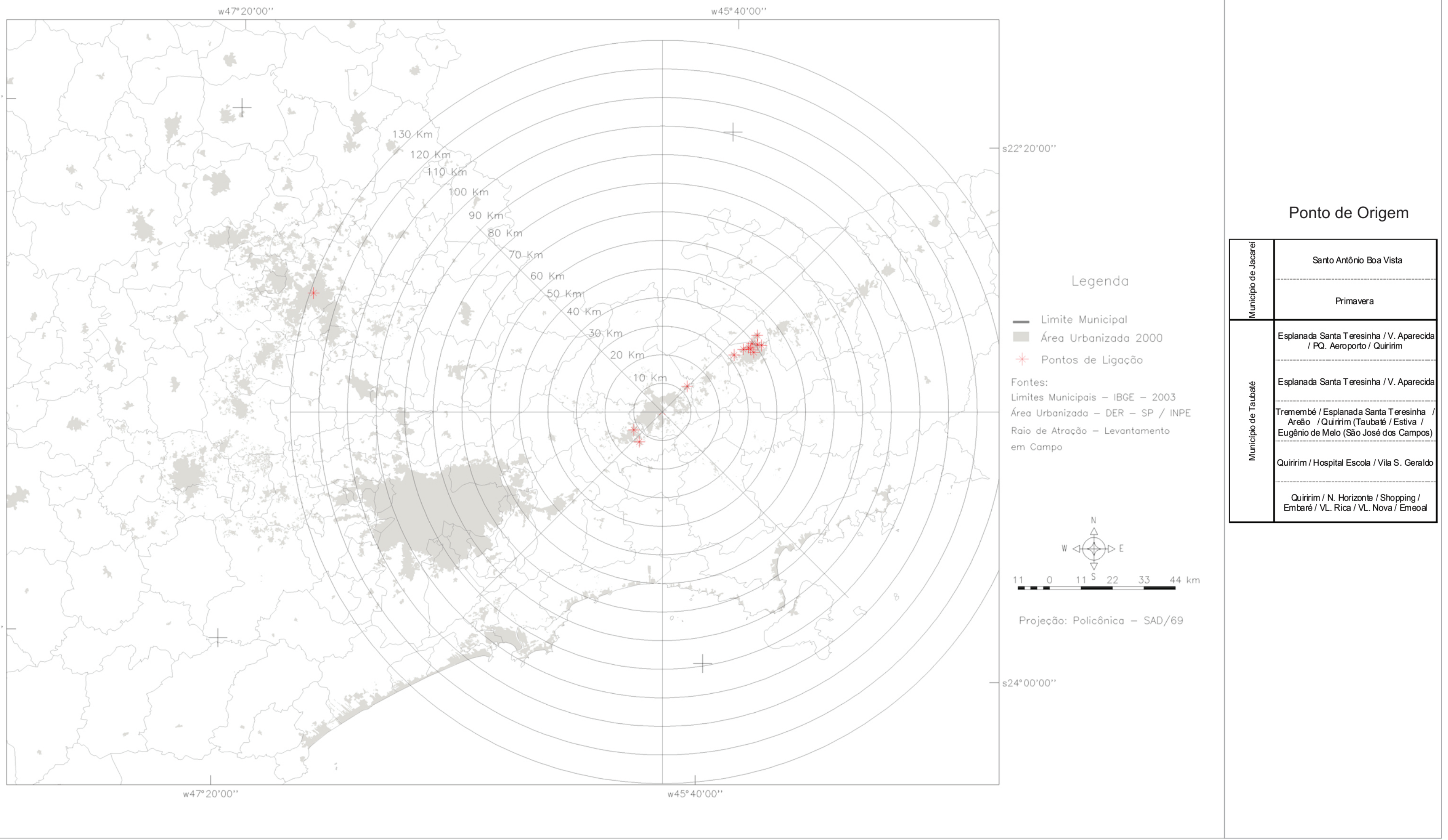


Mapa 28: EATON - Linhas Fretadas - Raio de Atração - 2005

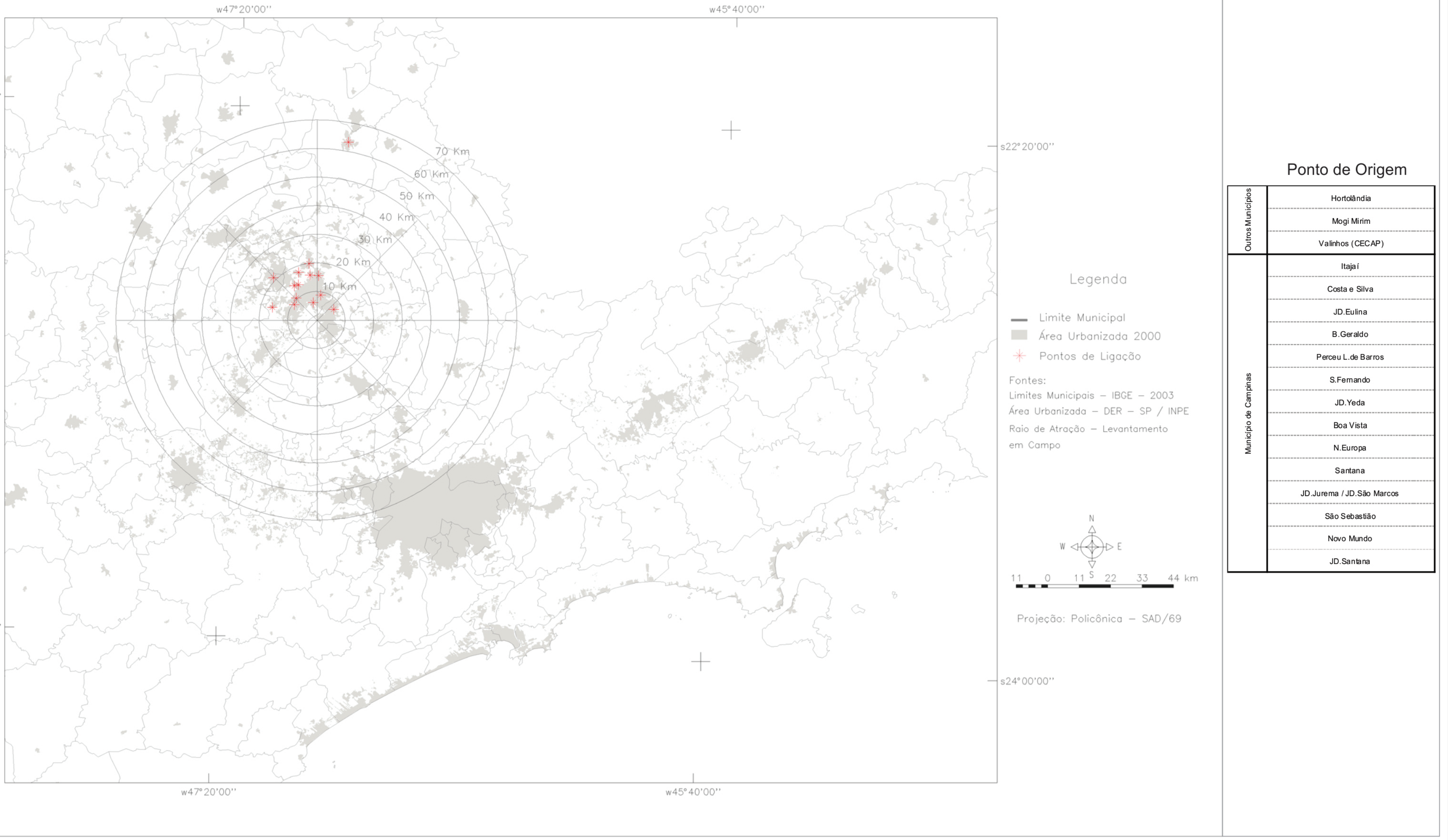


Mapa 29: Secretaria da Agricultura - Linhas Fretadas - Raio de Atração - 2005

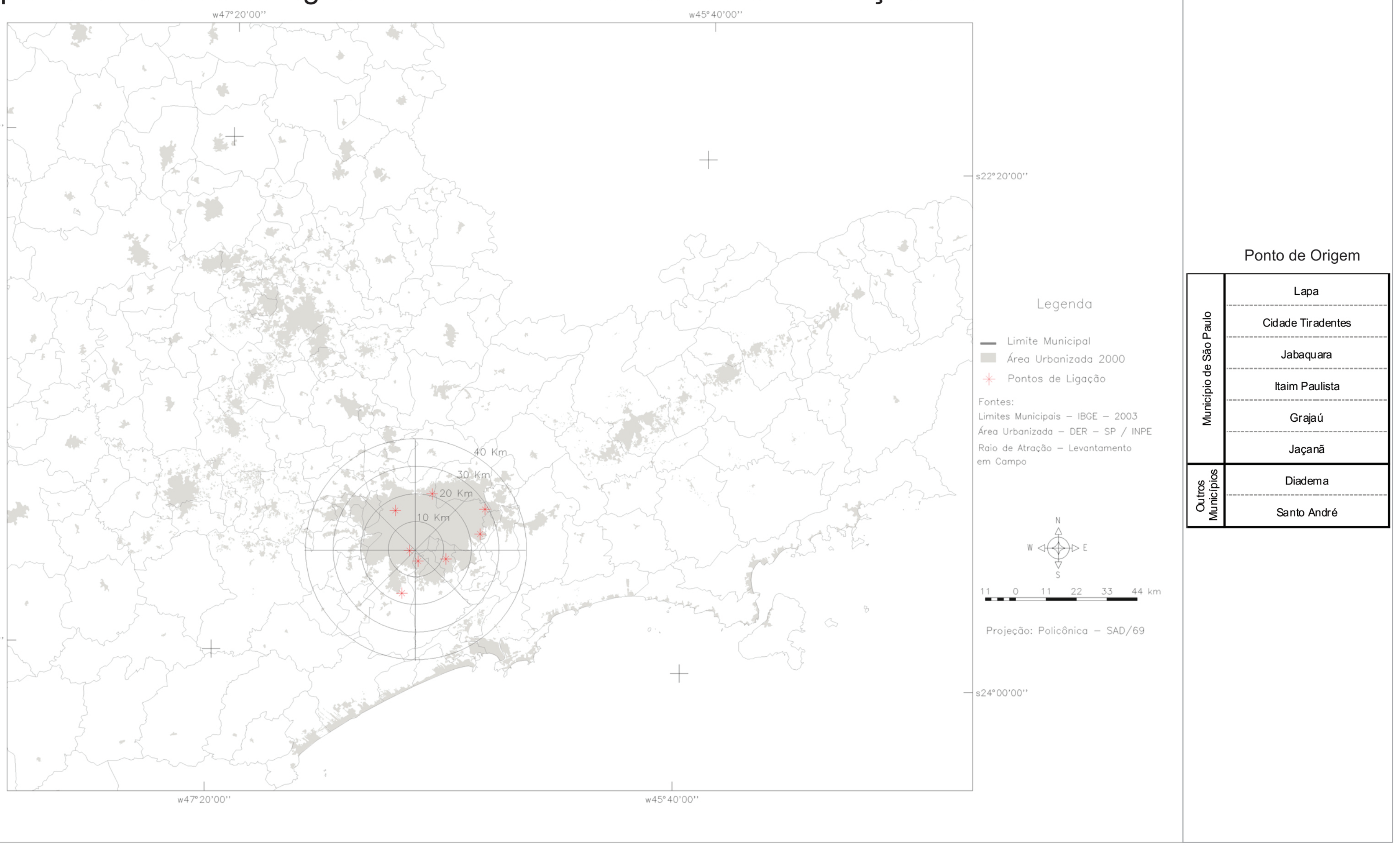


Figura 15: Secretaria da Agricultura do estado de São Paulo.
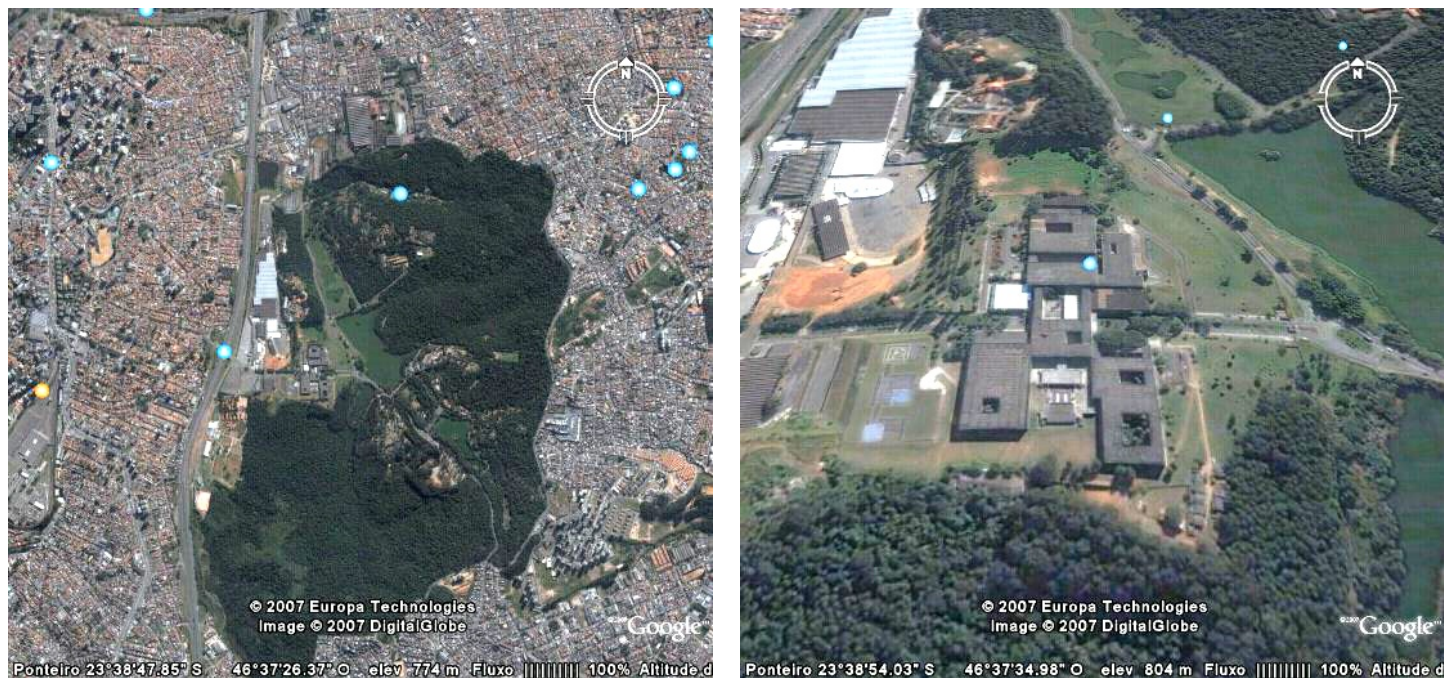

Fonte: Google Earth 2007.

\section{Universidades:}

- UNIP

Esta Universidade se destaca pelo poder de at ração de estudantes. Situada no limite de São José dos Campos com Jacareí, sua polarização atrai diariamente alunos do Litoral Norte Paulista e de cidades do Vale do Paraíba. Para o pleno funcionamento da universidade, o c ampus foi construído com todos os serviços fundamentais: serviços gráficos (xérox, papelaria), vários quiosques de a limentação, segurança, limpeza, além de um imenso estacionamento para comportar o grande fluxo regional de carros particulares, vans e ônibus fretados, seguindo a lógica das novas formas de organização e dispersão do tecido urbano. Foram identificadas 116 linhas fretadas de vans (mapa 30).

Figura 16 e 17: Campus da UNIP
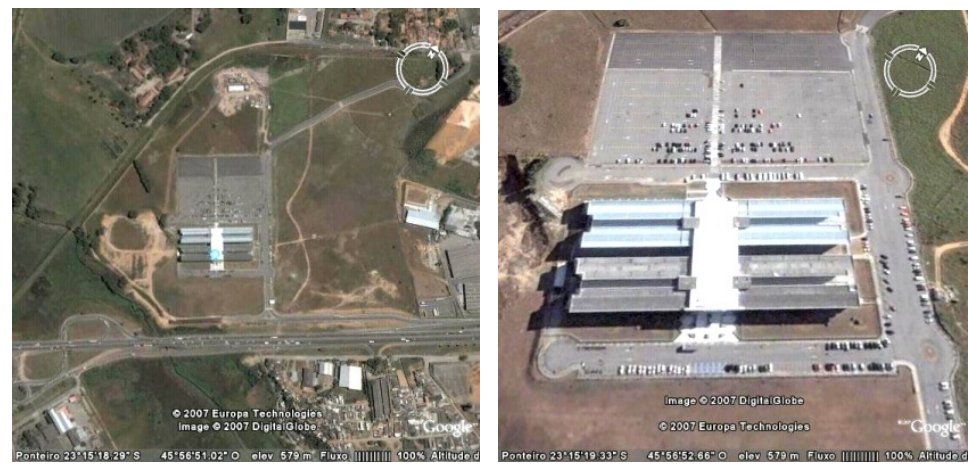

Fonte: Google Earth 2007. 
Mapa 30: UNIP - Linhas Fretadas - Raio de Atração - 2005

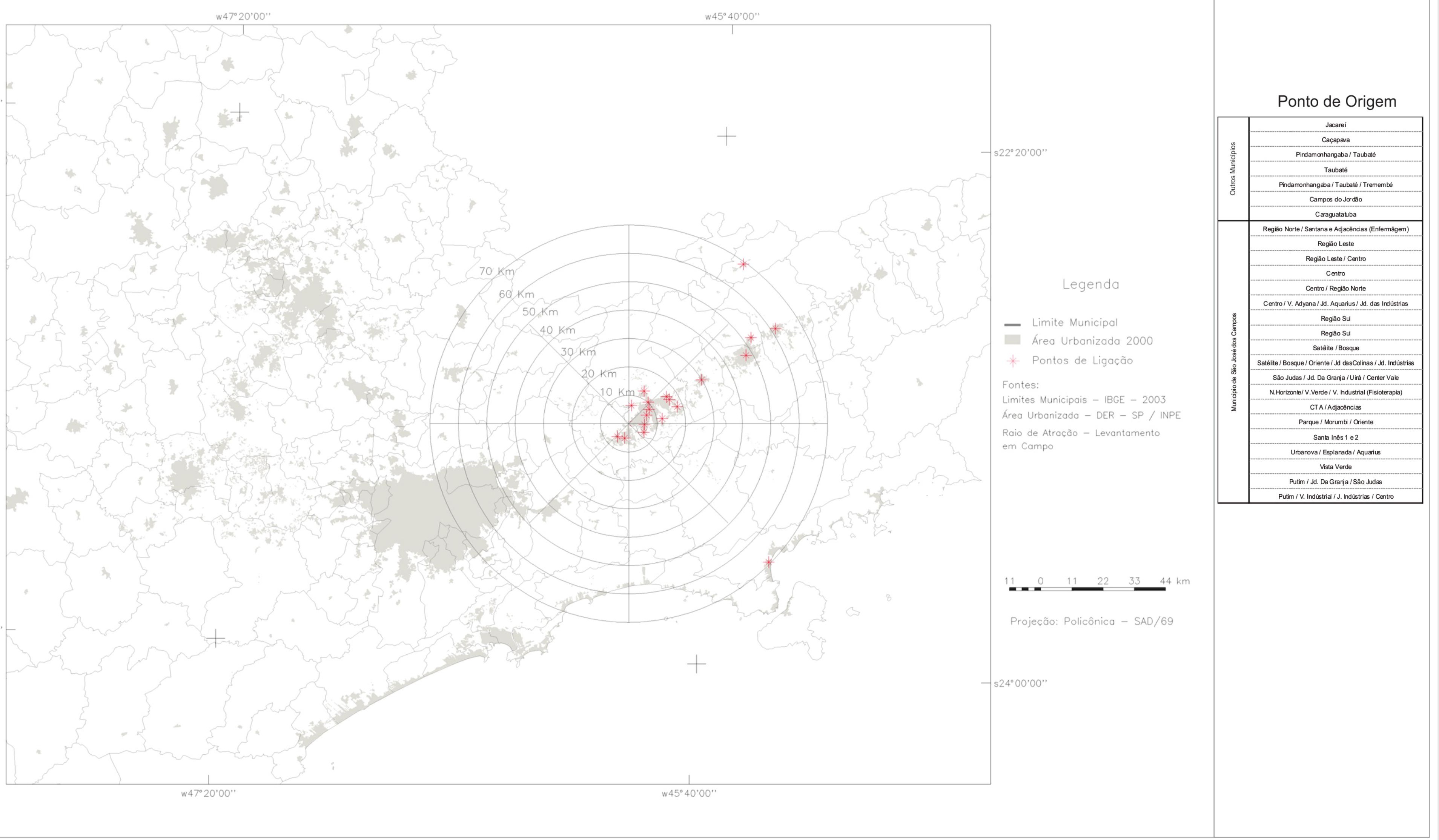


Foto 21 e 22: Campus da UNIP em área dispersa; Entrada do campus

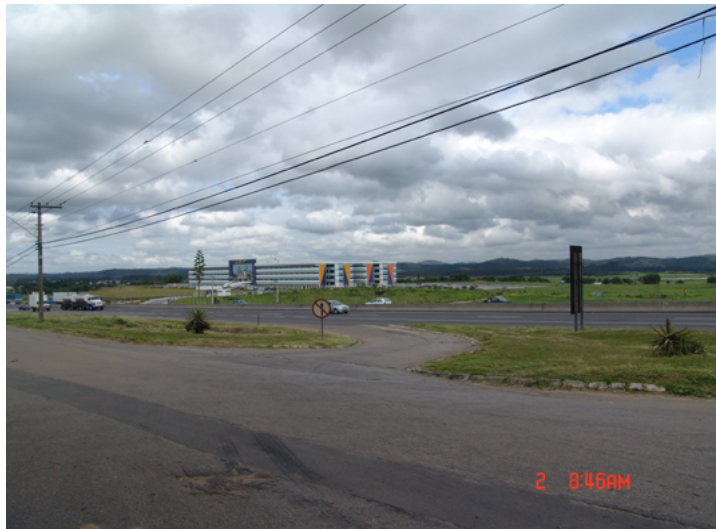

Autor: GIBERTI 2007

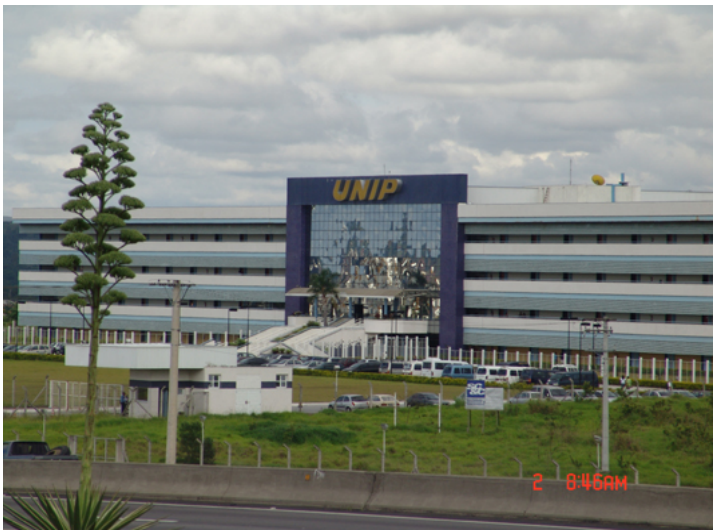

Autor: GIBERTI 2007

Foto 23: Acesso do campus à rodovia Dutra Foto 24: Estacionamento do campus

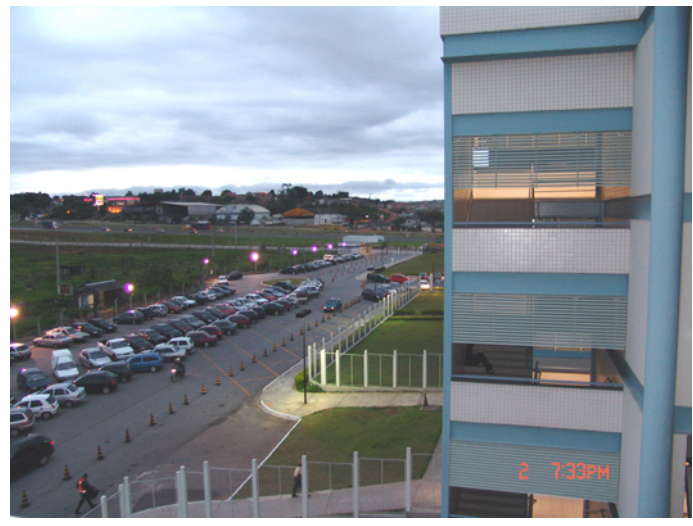

Autor: GIBERTI 2007

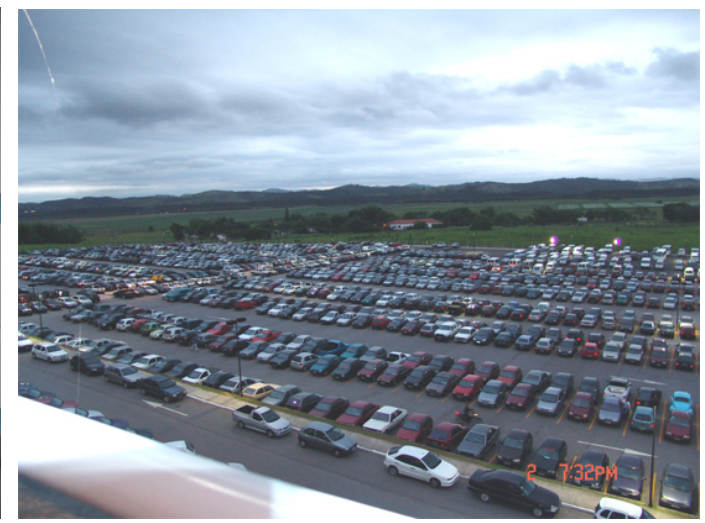

Autor: GIBERTI 2007

- USP

Localizada na zona oeste da cidade de São Paulo é considerada umas das Universidades mais importantes do Brasil, seu raio de atração de passageiros por "fretados" atinge $130 \mathrm{~km}$, buscando alunos em vários pontos espalhados pela Macrometrópole Paulista. Os principais eixos de circulação regionais - assim como as cidades mais importantes da rede urbana - estão ligadas à U SP. Existe grande diversidade de em presas que or ganizam tais linhas, com mais de 18 origens diferentes, a maioria proveniente de outros municípios, com predomínio de ônibus executivos. As linhas atendem não só aos estudantes, mas também a f uncionários do Instituto de $P$ esquisas Tecnológicas (mapa 31). 
Mapa 31: USP - Linhas Fretadas - Raio de Atração - 2005

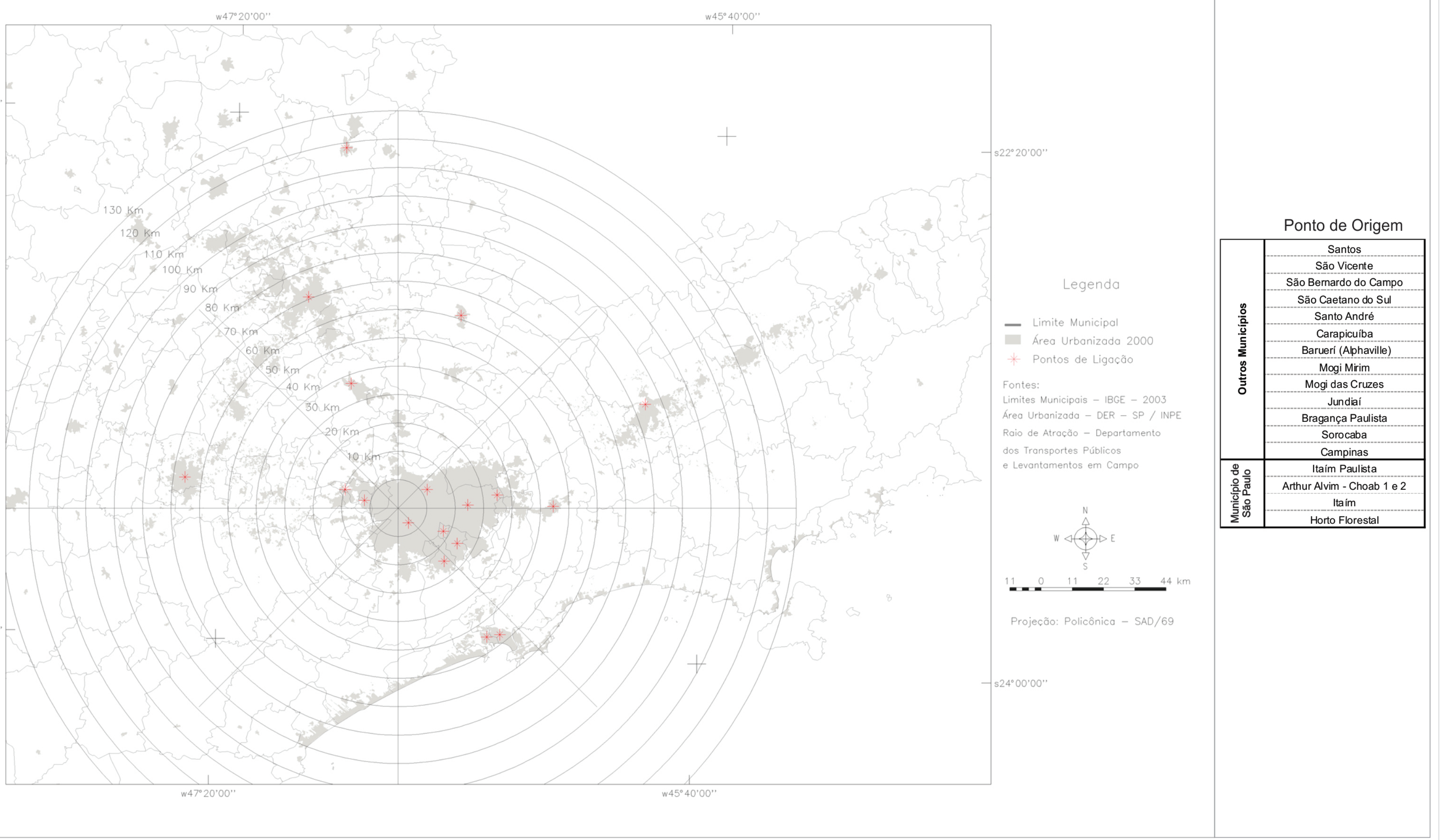


Localizada em um bairro relativamente "periférico" de Campinas (Barão Geraldo), também é grande referência entre as universidades brasileiras, atingindo um raio de at ração de $100 \mathrm{~km}$, com ligações de vários bairros de Campinas e cidades da região. O próprio site eletrônico da universidade já disponibiliza uma relação de $\mathrm{m}$ ais de cem linhas fretadas para o acesso ao campus; aqui foram selecionadas as mais representativas (mapa 32).

\section{Conjuntos Habitacionais:}

- Bairro Quiririm

Neste bairro operário de T aubaté, localizado em uma área dispersa, encontram-se vários Conjuntos Habitacionais que fornecem mão de obra para fábricas espalhadas pelo Vale do Paraíba, como EMBRAER, VOLKSWAGEN, ALSTOM e FORD. Diariamente, dezenas de linhas fretadas conduzem os moradores aos seus postos de trabalho. Este pólo residencial, portanto, fornece boa parte da força de trabalho industrial da região, atingindo um raio de $40 \mathrm{~km}$ (mapa 33). O bairro se expande com programas habitacionais do governo estadual.

Figura 18 e 19: Bairro Quiririm
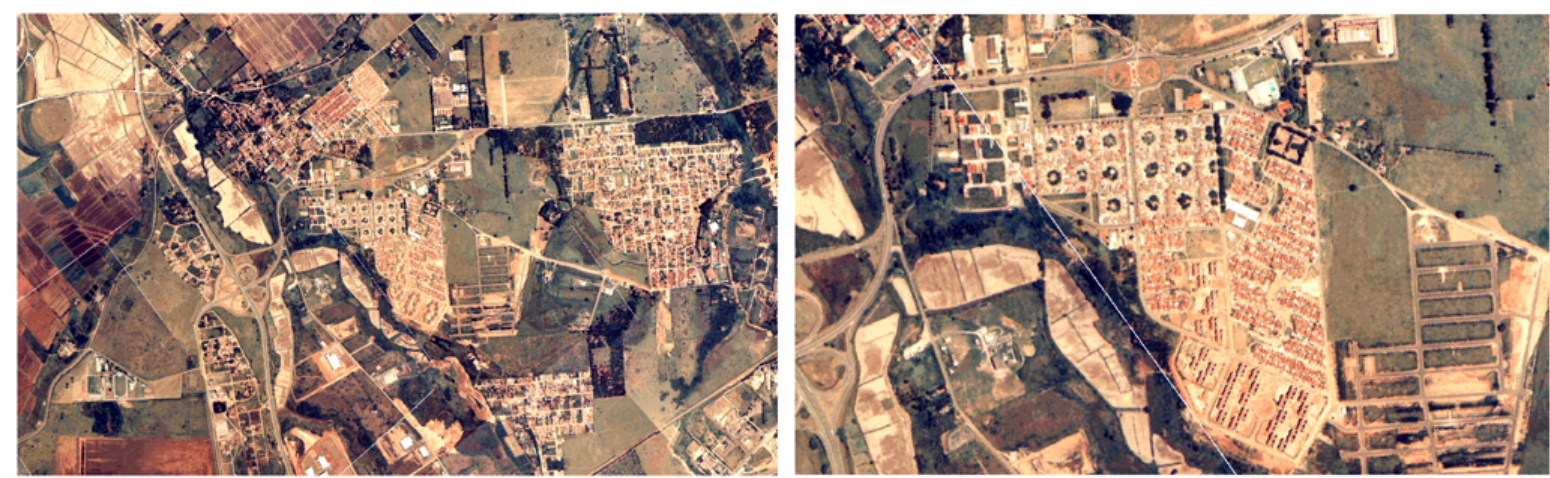

Fonte: Prefeitura de Taubaté 2001. 
Mapa 32: UNICAMP - Linhas Fretadas - Raio de Atração - 2005

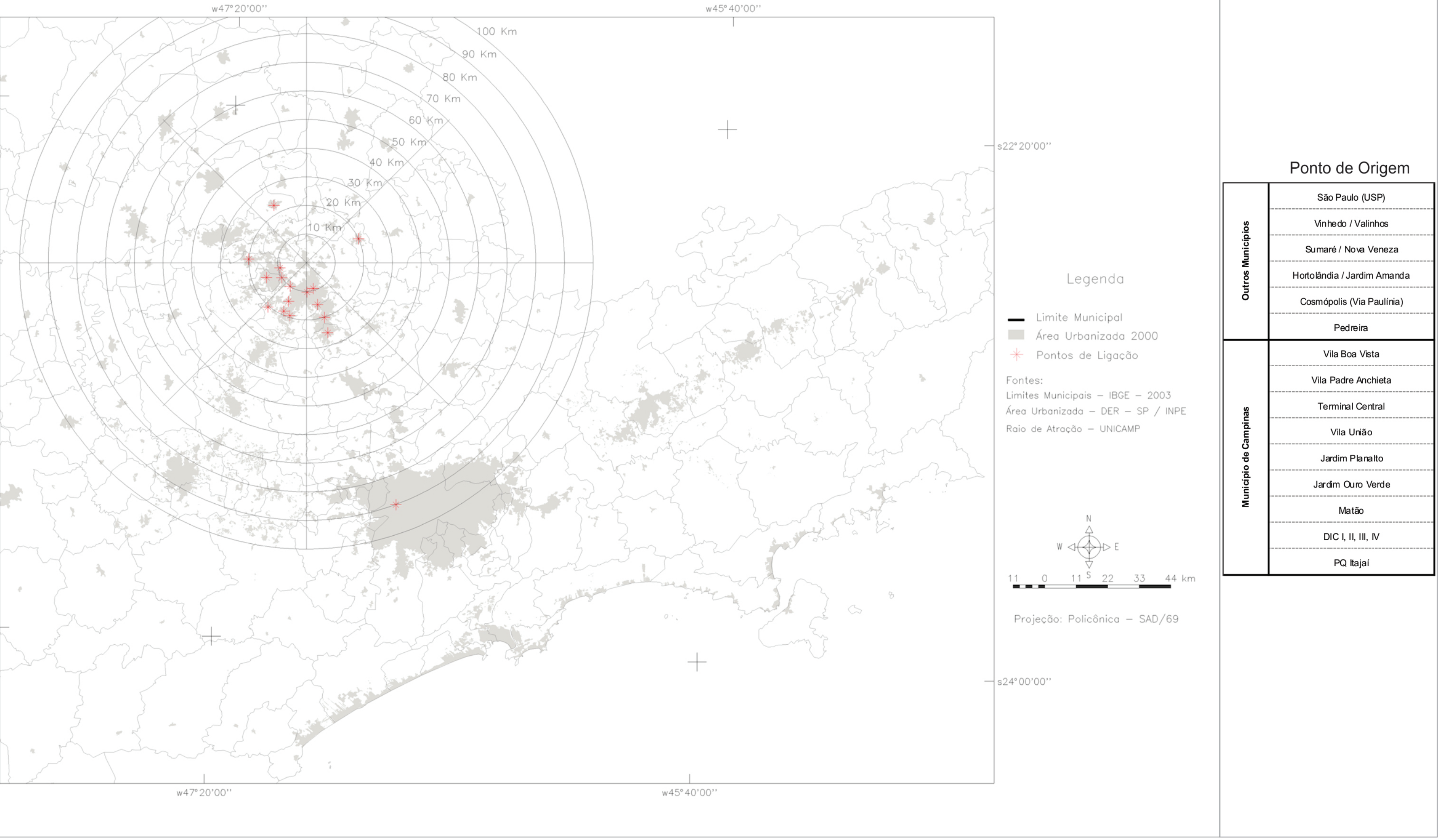


Mapa 33: Quiririm - Linhas Fretadas - Raio de Atração - 2005

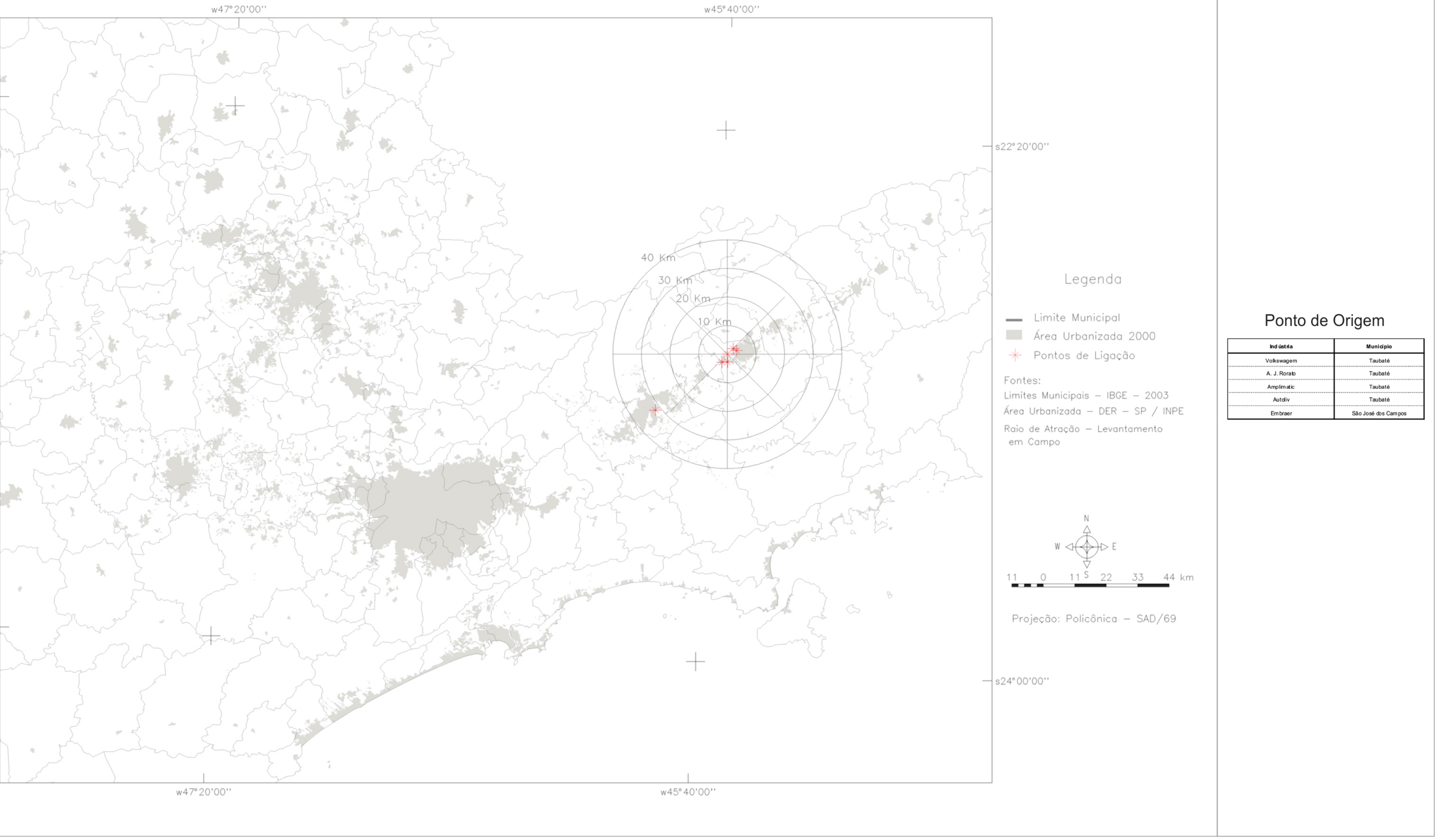


Foto 25: Cecap 1

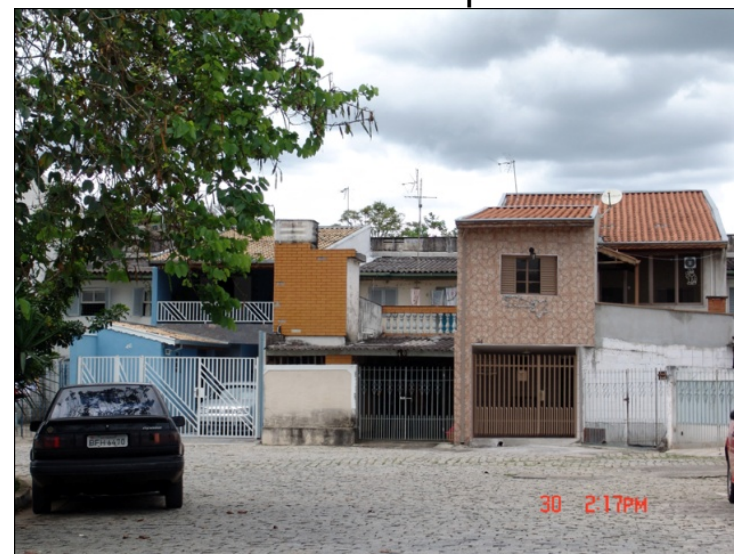

Autor: GIBERTI 2007
Foto 26: Cecap 3

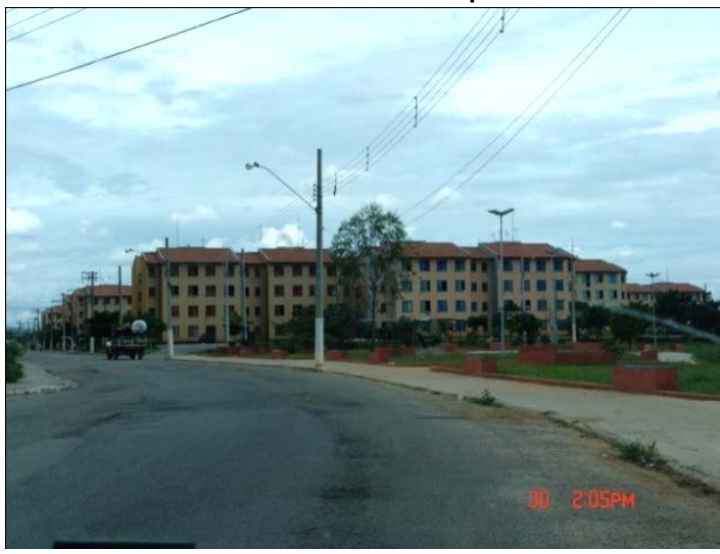

Autor: GIBERTI 2007

Foto 27: Novos conjuntos habitacionais em inauguração e construção.

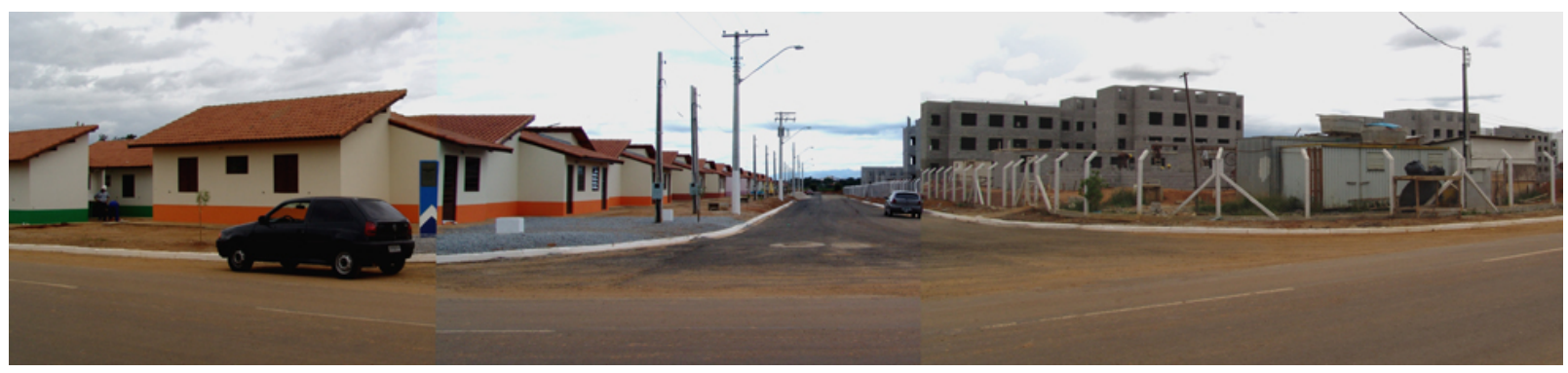

Autor: GIBERTI 2007.

\section{Serviços / Lazer:}

- Hopi Hari

Este centro de I azer localizado em uma área dispersa de $\mathrm{V}$ inhedo apresentou o maior raio de atração encontrado em toda a pesquisa, atingindo o poder de atração de $450 \mathrm{Km}$. Cidades como Londrina e Curitiba no Estado do Paraná contam com linhas fretadas semanais que ligam os usuários ao parque de diversões. Este fixo geográfico possui, portanto, uma área de influência que ultrapassa os limites do estado de São Paulo. Suas linhas fretadas também contemplam quase todas as cidades da Baixada Santista e vários bairros da cidade de São Paulo, além de cidades mais próximas a sua localização (mapa 34). 
Mapa 34: Hopi Hari - Linhas Fretadas - Raio de Atração - 2005

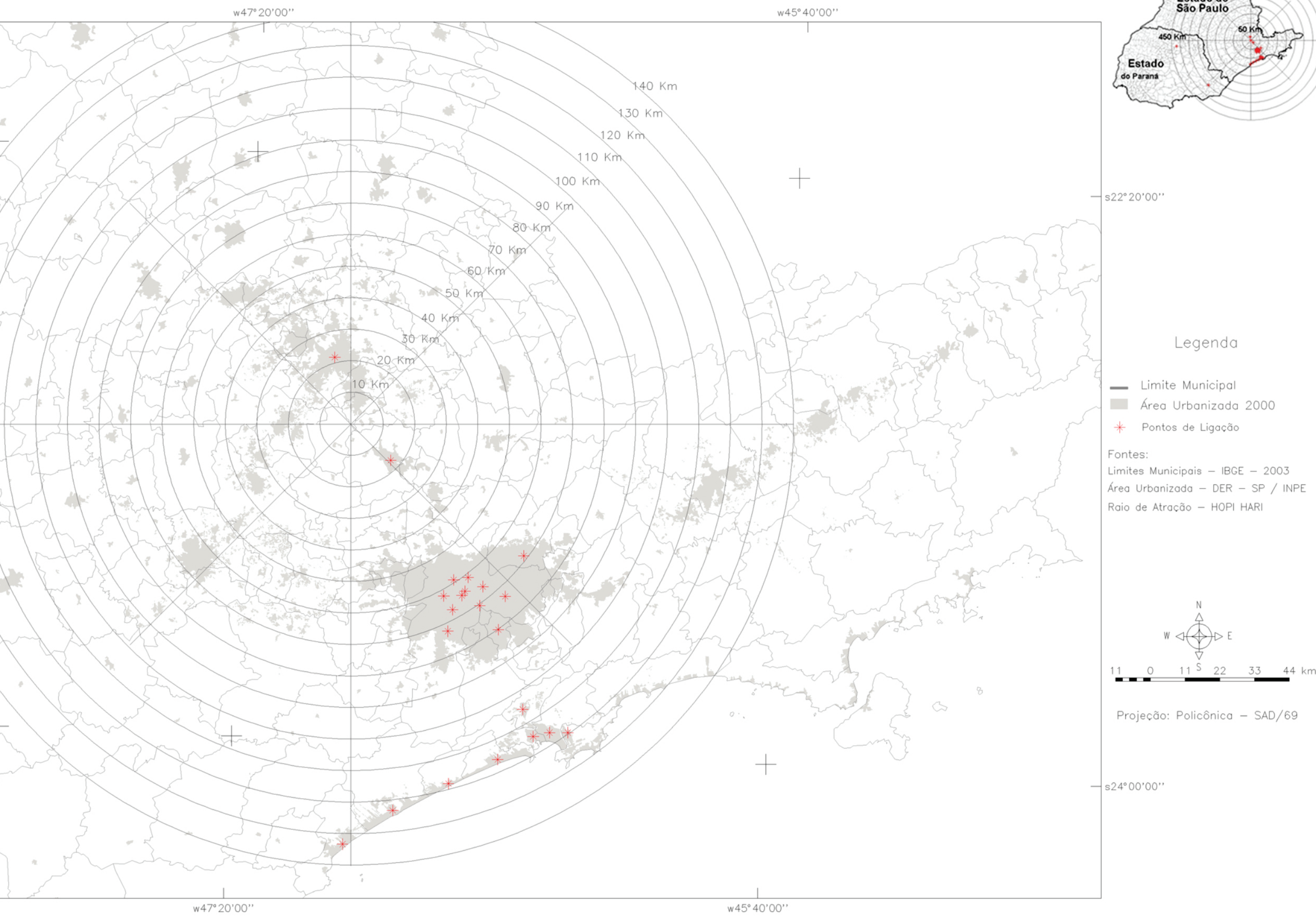

Ponto de Origem

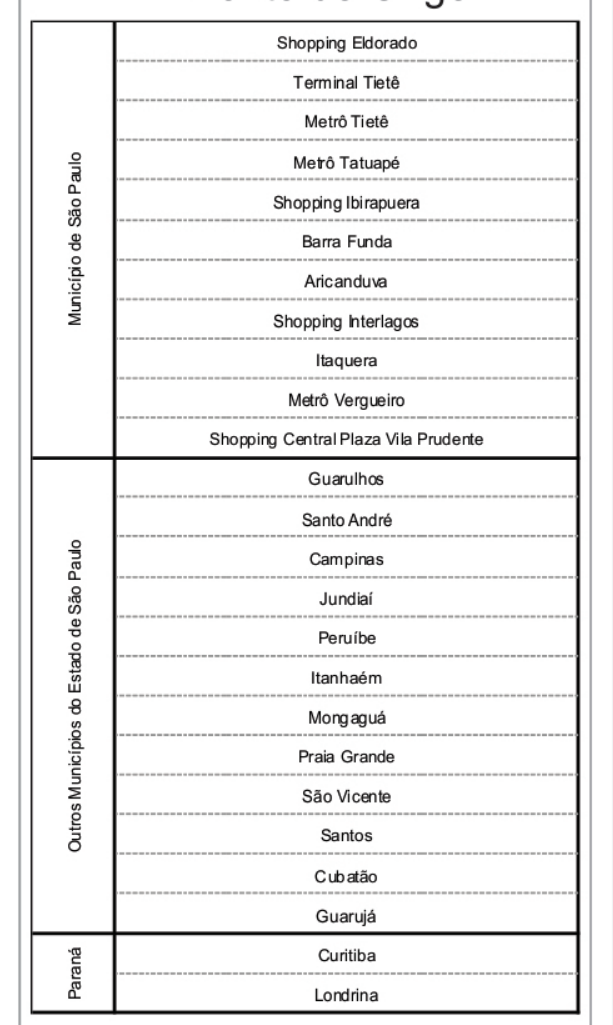


Figura 20 e 21: Hopi Hari

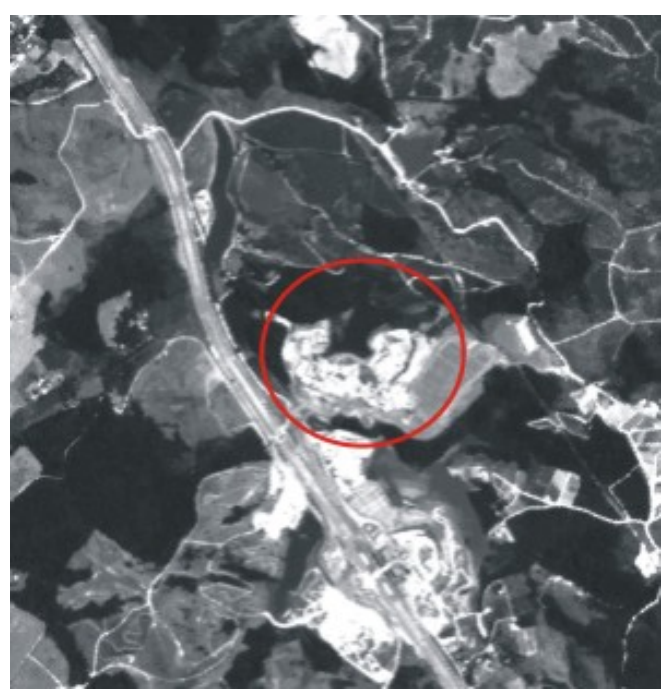

Fonte: INPE 2003.

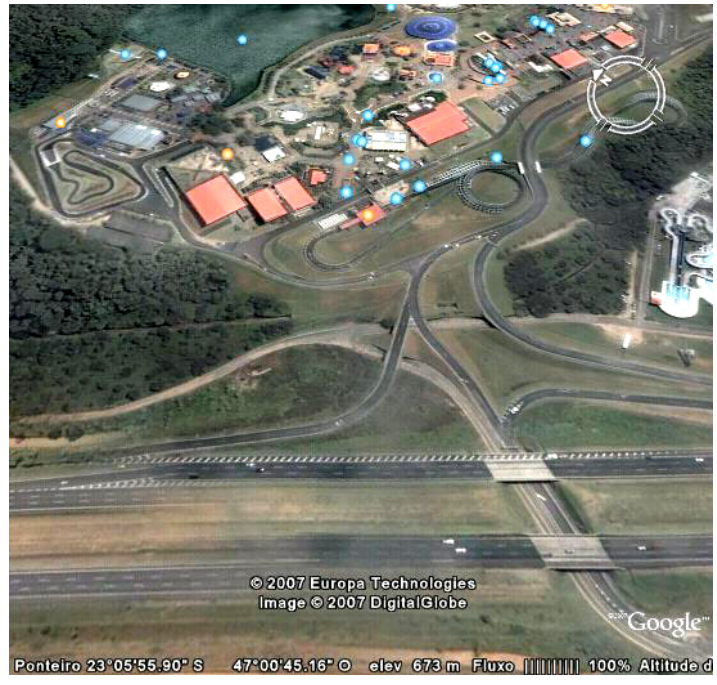

Fonte: Google Earth 2007.

Foto 28 e 29: Hopi Hari

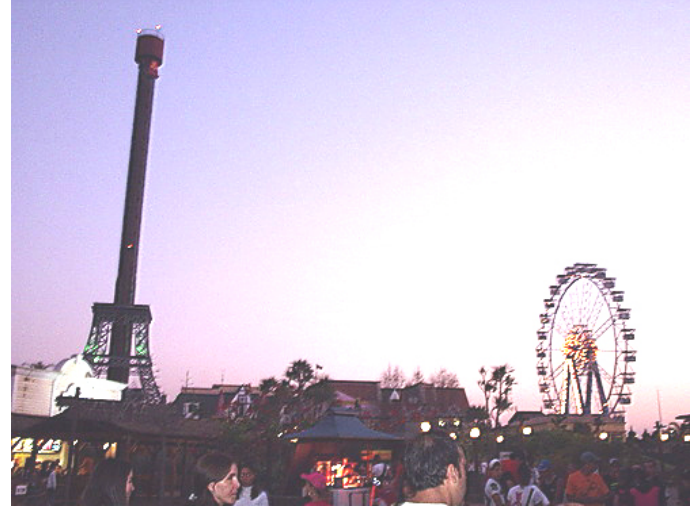

Autor: Desconhecido

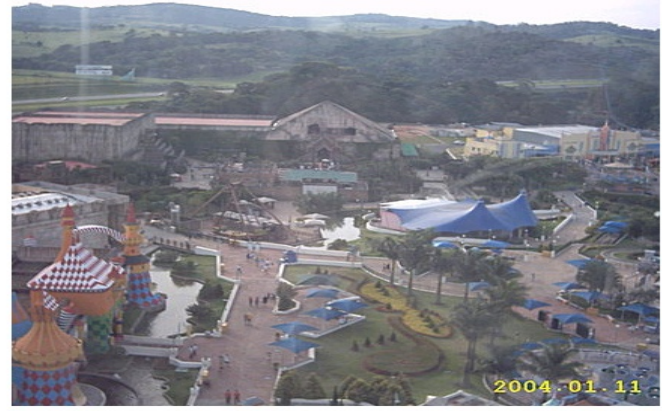

Autor: Desconhecido

\section{Pólo Urbanos de Usos Múltiplos:}

- Alphaville

Localizada na c idade de B arueri, nas redondezas da Região Metropolitana de São Paulo, este pólo reúne atividades residenciais, empresariais e comerciais, se caracterizado como um pólo multifuncional. As linhas fretadas mapeadas em nossa pesquisa indicaram um raio de atração de $80 \mathrm{Km}$, ligando diversos bairros da zona sul da cidade de S ão Paulo, assim como bairros mais centrais. Também conecta cidades da Baixada Santista e Região Metropolitana de $C$ ampinas. Podemos deduzir que se trata de 
Mapa 35: Alphaville - Linhas Fretadas - Raio de Atração - 2005

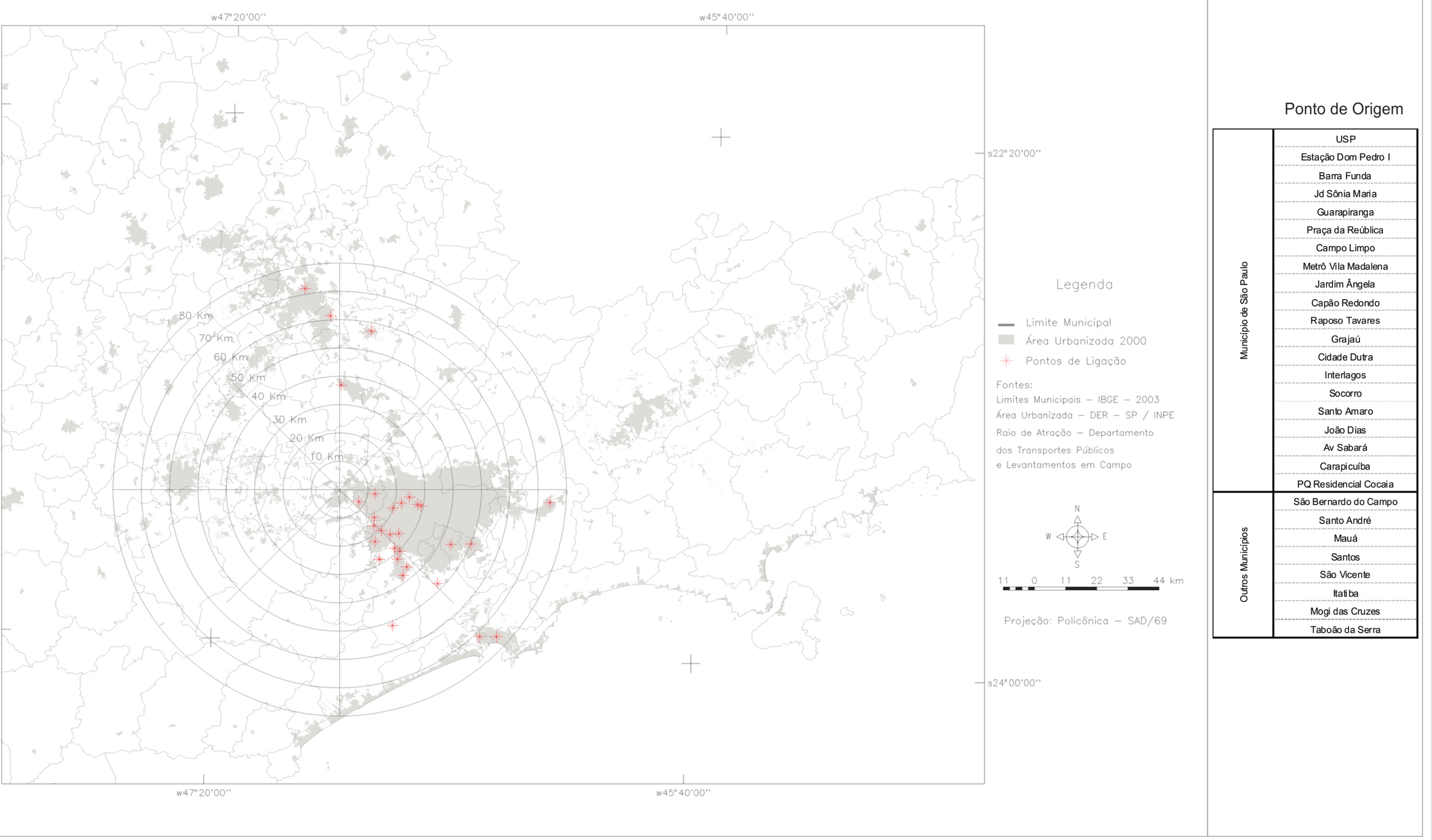


deslocamentos residência/trabalho com destino a Alphaville. Também existem algumas linhas fretadas que levam os moradores deste pólo a locais estratégicos da cidade de S ão Paulo como a U niversidade de São Paulo e Avenida Paulista (mapa 35).

Figura 22: Alphaville

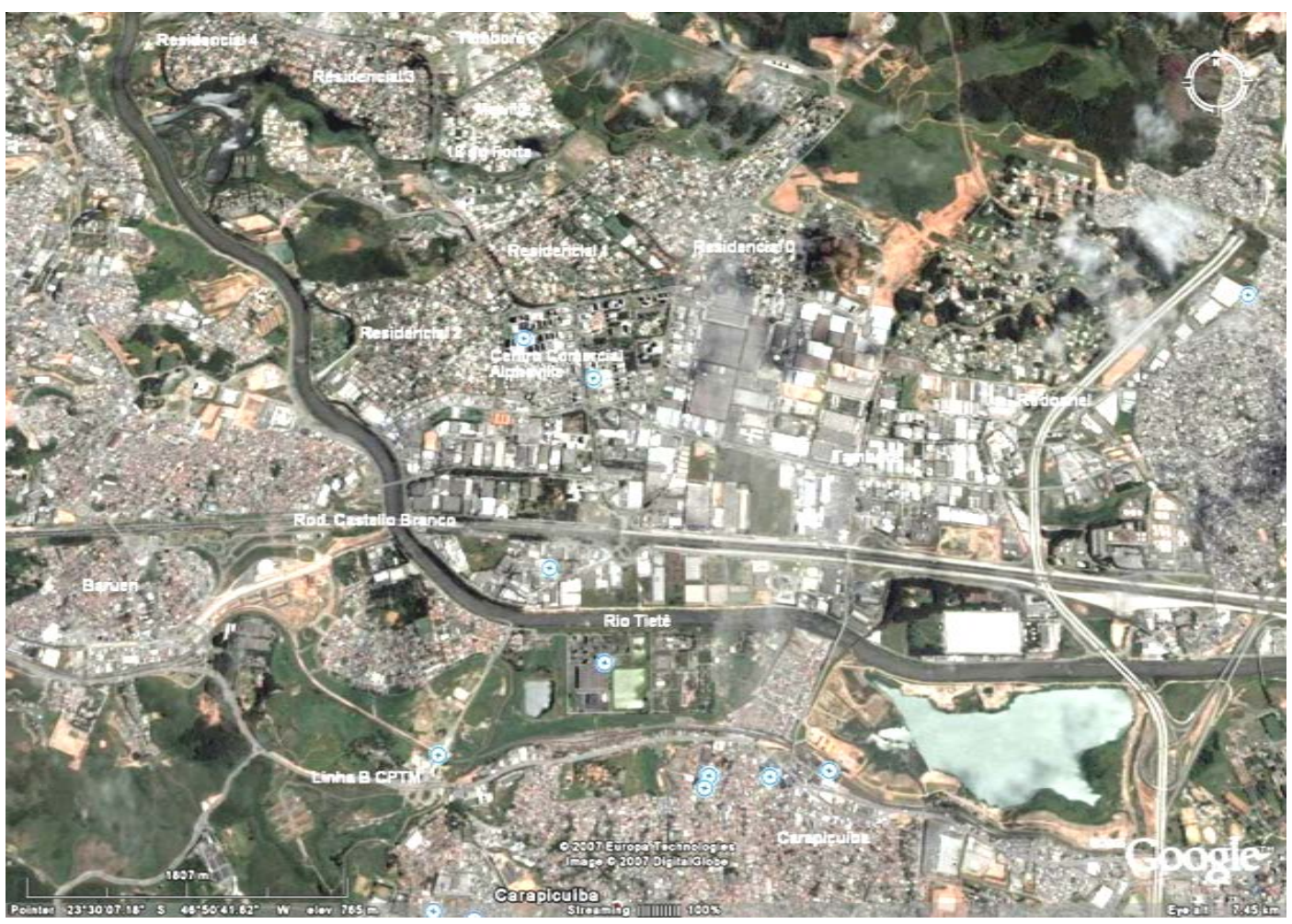

Fonte: Google Earth 2007.

Figura 23: Alphaville

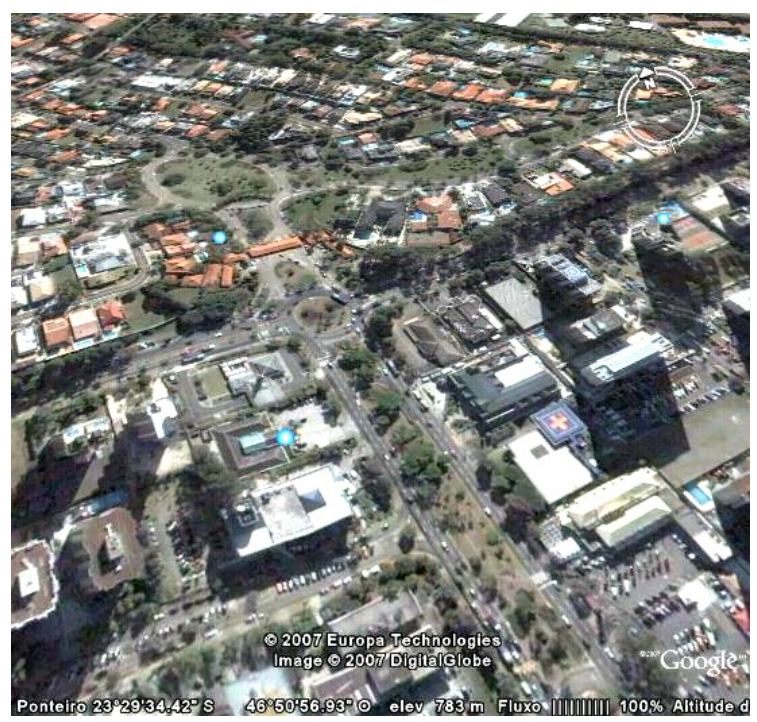

Fonte: Google Earth 2007. 
- Avenida Paulista

Esta parcela da cidade de S ão Paulo é um dos principais centros financeiros do Brasil, reunindo em alta densidade grandes grupos econômicos, sedes das indústrias e em presas espalhadas pelo Estado de $\mathrm{S}$ ão Paulo, formando um aglomerado de empresas e atividades extremamente intensivas em capital e em informação. Por este motivo, diversos fluxos convergem neste ponto do território. Seu raio de atração atinge $120 \mathrm{Km}$. A maioria das linhas que servem a ár ea da A venida Paulista é d a Região do ABCD. Suas ligações contemplam ainda os principais centros regionais e sub-regionais do Complexo Metropolitano, como Campinas, Americana, São José dos Campos, Santos e outras cidades (mapa 36).

Figura 24 e 25: Avenida Paulista e arredores

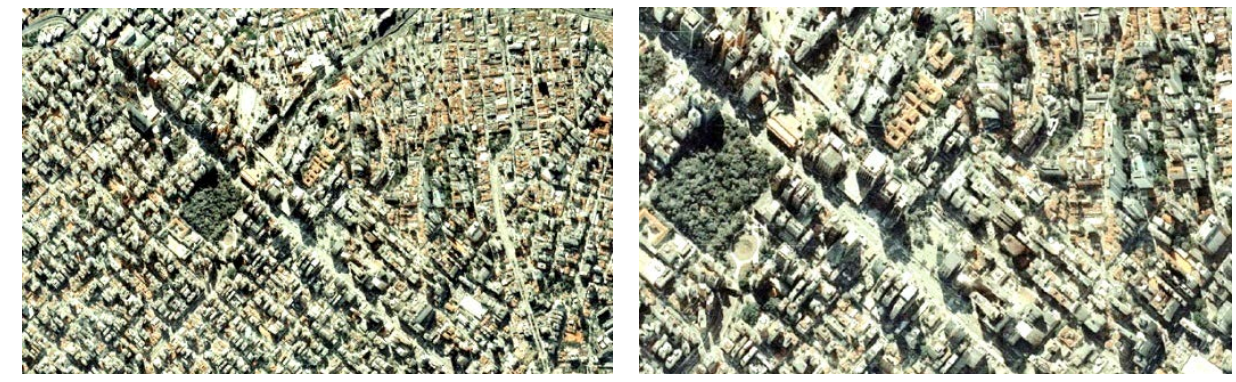

Fonte: $\underline{\text { http://infolocal.prefeitura.sp.gov.br/ }}$

Foto 30: Avenida Paulista.

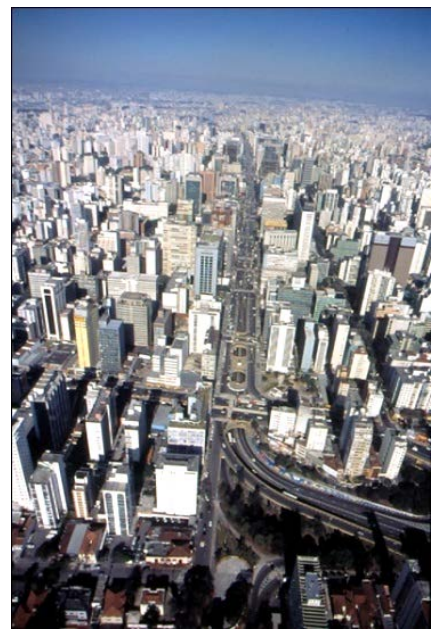

Autor: Stepan Norair. 2004. Acervo do LAP-FAU-USP. 
Mapa 36: Região da AV. Paulista - Linhas Fretadas - Raio de Atração - 2005

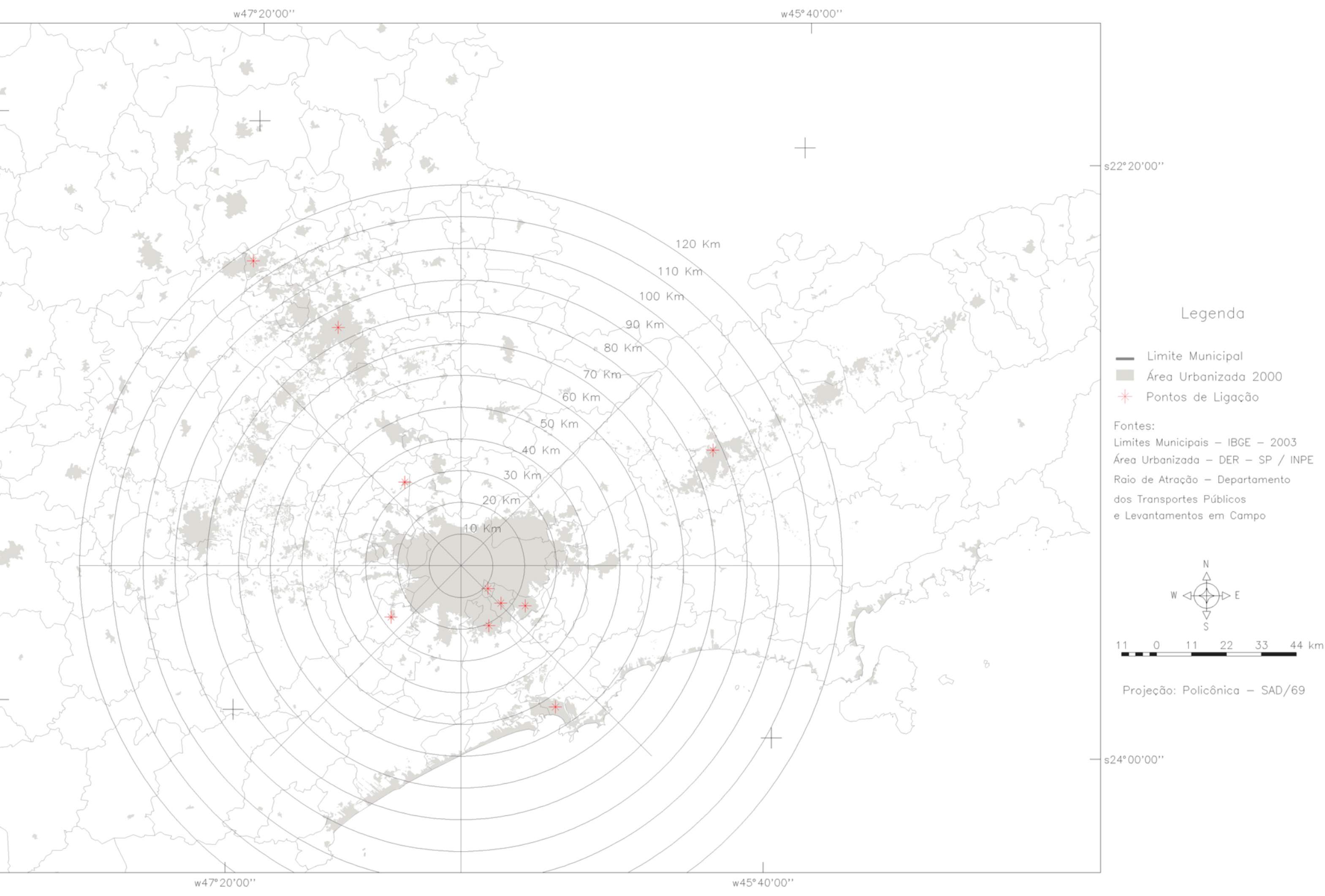

Ponto de Origem São Bernardo do Campo São Caetano do Sul Santo André Mauá

Santos

Campinas

Americana São José dos Campos Cajamar

Itapecerica da Serra 


\section{Outros pontos de Concentração de fretados na Cidade de São Paulo:}

Como já visto no estudo dos fluxos pendulares, a cidade de São Paulo é o maior destino da pendularidade da Macrometrópole Paulista. Essa atração expressiva de fluxos de pessoas se deve ao fato da cidade concentrar ofertas de trabalho, estudo, comércio e s erviços. Os diversos setores da c idade apresentam atividades especializadas e, portanto, convergem linhas fretadas oriundas de bairros paulistanos, assim como de out ras cidades do ent orno macrometropolitano.

A pesquisa de campo que realizamos permitiu estabelecer uma análise - ainda que exploratória - de alguns dos pontos de concentração de fretados e as origens das linhas. Os dados apresentados permitem uma caracterização mais aproximada da atração que São Paulo exerce sobre os fluxos pendulares. Notamos que o município, em seus diversos pontos de c oncentração, se conecta com praticamente todo a Macrometrópole Paulista, revelando-se um pólo atrativo de alto poder, apresentando vários motivos para tal atração.

Os trabalhos de campo realizados permitiram identificar alguns pontos de concentração de fluxos de "fretados", representados no mapa 37; de forma simplificada, pode-se dizer que as linhas fretadas pesquisadas têm origens diferentes e des tinos iguais. Os destinos que $m$ ais se apresentaram foram considerados; cada ponto de concentração dos fretados foi associado com uma relação dos principais pontos de origem das linhas. Cada ponto exerce uma funcionalidade que, de fato, é o motivo do destino da viagem.

Assim, as funcionalidades das cidades que trocam fluxos pendulares de população contribuem para a análise da dinâmica regional, demonstrando que a cidade de São Paulo concentra diversas atividades, atraindo, consequentemente, fluxos de diferentes origens com interesses distintos e/ou semelhantes. A Avenida Paulista, além de s er um dos principais centros financeiros do país, conta com inúmeras empresas, comércios e prestadoras de serviços, atraindo fluxos de todas as Regiões Metropolitanas do Estado, além do $\mathrm{V}$ ale do $\mathrm{P}$ araíba. A Universidade de $\mathrm{S}$ ão Paulo, uma das mais 
Mapa 37: Município de São Paulo - Pontos de Concentração de Fretados - 2005

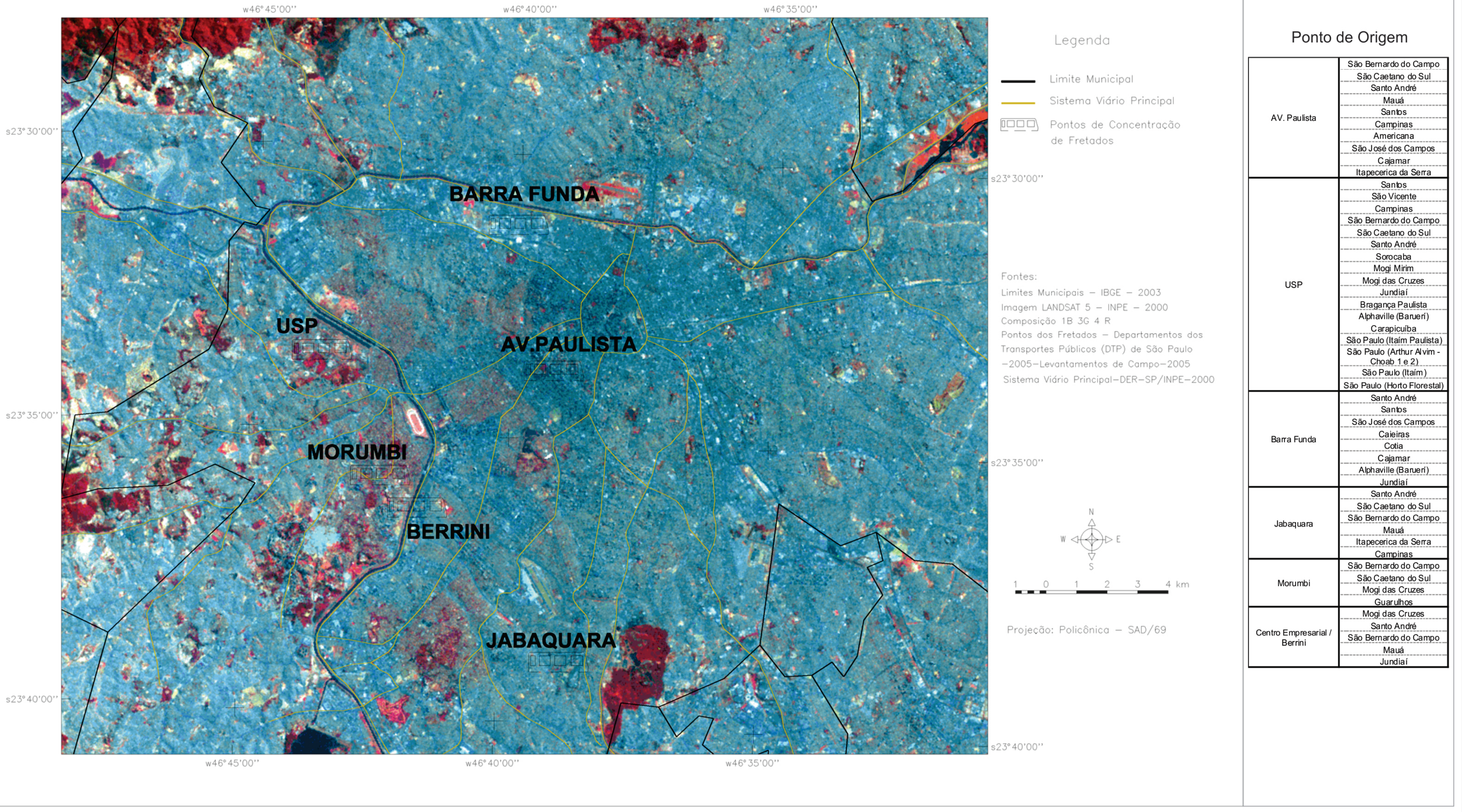


renomadas do paí $\mathrm{s}$, também atrai uma gama diversificada de f luxos, provenientes de q uase todos os principais aglomerados urbanos da Macrometrópole.

O bairro paulistano da Barra Funda (situado na zona oeste da cidade) é uma área importante para a anál ise dos fretados por abrigar um terminal metroviário, ferroviário e r odoviário, funcionando, portanto, como uma "plataforma" para um novo deslocamento; ou seja, as pessoas chegam por meio do veículo fretado e continuam seu deslocamento até o destino final, atraindo, principalmente os fluxos da própria RMSP, seguido de Santos, São José dos Campos e Jundiaí.

O Terminal Rodoviário do Jabaquara (situado no b airro de mesmo nome) também funciona como uma "plataforma" para o m etrô, convergindo com linhas fretadas do ABC Paulista. Os trabalhos de campo empreendidos no bairro do Morumbi acabaram por permitir a identificação de linhas de fretados do ABC Paulista, Guarulhos e Mogi das Cruzes. Entretanto, não ficou clara a sua funcionalidade, tendo em vista que é uma área predominantemente residencial de al to padrão, com algumas instituições destacadas, como o Hospital Albert Einstein que usa muito o fretamento para seus funcionários. A Avenida Luis Carlos Berrini, novo centro empresarial da cidade, recebe linhas do ABC, Mauá, Jundiaí e Mogi das Cruzes.

Por fim cabe destacar ot rabalho de Menezes (2009) que apresenta um estudo da fábrica da Volkswagen no município de São Bernardo do Campo na RMSP. A unidade tinha aproximadamente $15 \mathrm{~m}$ il funcionários entre terceirizados e contratados diretos, dos quais $76 \%$ (11.425) utilizavam o transporte fretado oferecido pela empresa, a maioria residia em vários locais da RMSP e a minoria na RMBS. No caso da Volkswagen, do ABC, a contratação de funcionários é or ientada à população residente, próxima às linhas de fretados já existentes, tornando-se esse um fator decisivo para a efetivação de novos trabalhadores. 
Segundo Regina Rocha, advogada da FRESP, existem casos em que a unidade industrial se reinstala em outro município, carregando consigo o quadro de funcionários, como, por exemplo, no caso de Jaguariúna para Sorocaba. As linhas fretadas ofereciam ônibus luxo com sinal de internet para trabalho, estudo e lazer.

Segundo os levantamentos de campo, assim como as entrevistas realizadas, foi possível identificar alguns pontos de alta convergência dos fretados, como por exemplo, na área da Avenida Paulista (2004). Até 2009 existiam pontos que geravam impactos intra-urbanos negativos, dentre eles destacam-se:

- Congestionamento da circulação dos veículos: Muitas vezes o itinerário dos fretados passa por vias inadequadas, já saturadas, aumentando o congestionamento e afetando o transporte regular. Como não existem pontos de parada específicos para a maior parte deste tipo de fluxos, todo lugar é um ponto em potencial, o que c ontribui para a di minuição da velocidade de circulação no município.

-Estacionamentos nas vias públicas: Muitos estacionam nas ruas, o que é proibido por lei, diminuindo o espaço para circulação.

-Rodoviárias clandestinas/Clandestinidade: a difusão dos fretados leva também a instalação de terminais inadequados para o transbordo de passageiros, causando ainda problemas relativos a falta de s egurança, à "competitividade desleal" com as empresas regulares, etc.

-Impacto visual: Os comerciantes reclamam que nas áreas de grande concentração de fretados, a $v$ isão do consumidor é afetada, dificultando o exposição - e a comercialização - de seus produtos.

- Impacto ambiental e sonoro: O excesso de veículos gera fumaça e barulho, especialmente em ruas estreitas. 
Esses pontos de concentração devem ser pensados juntamente com as regiões com que es tão conectados, em uma eventual intervenção urbana. Também se deve planejar o itinerário mais adequado, buscando a integração com os demais sistemas det ransporte dac idade. Entretanto, devemos considerar os impactos positivos também, a saber:

- Um ônibus fretado (que tem capacidade média de transporte de quarenta passageiros) sem dúvida contribui para que o núm ero de veículos particulares em circulação diminua, resultando no m elhor aproveitamento do es paço das vias de circulação, já que, geralmente, os carros nunca trafegam com mais que 2 passageiros.

- Com a diminuição de v eículos em circulação, menos combustível será queimado e menos poluição lançada na atmosfera.

- A qualidade do deslocamento é out ro elemento importante, pois os passageiros podem viajar dormindo, lendo, descansando, evitando o estresse habitual dos motoristas. Além disso, as viagens têm menor número de paradas, chegando mais rápido ao destino final.

Com base em todos os exemplos e as pectos apresentados anteriormente podemos concluir que nesse período de pesquisa 2004/2012 os pontos de alta convergência dos fretados antes de 2009 foram dispersos pela zona máxima de restrição aos fretados. A Secretaria Municipal de Transporte mediante o Departamento de Transporte Públicos de São Paulo reordenou as normas de circulação dos fretados em 2009 conforme apresentado no capítulo 3.1. Os prestadores de serviços representados pela FRESP e TRANSFRETUR buscam aproximação e aprimoramento junto aos órgãos e políticas públicas visando a expansão des uas atividades. O planejamento de transporte metropolitano não po de ignorar a i mportância do f retado nos sistemas de movimento de passageiros. A atuação dos fretados deve ser incorporada como alternativa e complementação ao transporte coletivo e individual, as políticas públicas devem equalizar os potenciais e os problemas. 
Cabe uma reflexão dos possíveis impactos positivos e negativos sobre a atuação dos fretados para definir se esta é uma alternativa eficaz ou se ainda pode ser aprimorada, mas para tanto, devemos fazer uma leitura sem preconceitos e compromissada com a cidade e com a sociedade.

\section{Considerações Finais}

O Estado de São Paulo apresenta uma configuração urbano-regional complexa, caracterizada por um conjunto de c idades grandes, médias e pequenas interligadas por diversas redes de comunicação e circulação, além de atividades complementares, formando um espaço de grande complexidade. Como em todas as redes, existem pontos centrais e mais importantes, assim como pontos de menor grau de significação. No caso da rede urbana paulista, é importante destacar que as cidades de São Paulo, Campinas, Santos, São José dos Campos e Sorocaba exercem a f unção de pont os centrais de articulação no território, justamente nesta área em que a divisão territorial do trabalho assume enorme sofisticação e densidade. Estes pontos convergem e distribuem fluxos materiais e imateriais que circulam por toda a região. Tais cidades apresentam um peso demográfico e econômico muito grande, associado ao processo de metropolização e conurbação. Diversos trabalhos tentam definir os limites desta região, cada qual com suas temáticas, premissas e objetivos, resultando em diversas leituras do fenômeno.

A reestruturação produtiva reorganizou as atividades industriais $\mathrm{e}$ inaugurou uma nova lógica de urbanização, com tendência à di spersão territorial de atividades produtivas e de m odernas redes-suporte, movimento esse seguido pela desconcentração de empreendimentos residenciais, comerciais e de serviços, apoiado nos grandes eixos rodoviários e m aior flexibilidade de localização, exigindo uma maior mobilidade de todos os tipos de fatores produtivos (insumos, informação, mão de obra etc) e, também, uma maior "pendularidade" da população.

As cadeias produtivas industriais metropolitanas que se formaram no estado, assegurando a mão de obra em até cinco turnos diários, muitas vezes 
em áreas sem oferta de transporte regular é que fizeram surgir os primeiros "fretados", há mais de 50 anos, iniciada principalmente pelo setor automobilístico. Os fretados surgiram, portanto, como parte integrante desta nova divisão territorial do trabalho instalada no estado.

A regionalização do mercado de trabalho passou a influenciar outras atividades urbanas, reorganizando os fluxos pendulares e a $v$ ida de relações das cidades. Diversos pólos começaram a se instalar às margens da rodovia, contando com usuários/funcionários de toda a r egião, e at é áreas "fora" da Macrometrópole paulista. Os raios de atração revelaram que as indústrias que necessitam de $m$ ão de obr a especializada, escassa, alcançaram um raio de $130 \mathrm{~km}$ para completar seu quadro de funcionários.

As universidades também se organizam para atender aos estudantes de toda a região, com locais estratégicos e linhas diversificadas. $\mathrm{O}$ fixo geográfico que mostrou maior amplitude de atração de fluxos de fretados foi o parque temático HOPI HARI, uma área de I azer que, por ser uma das únicas no território brasileiro, chega a apresentar linhas fretadas interestaduais (além, é claro, de linhas nos grandes centros urbanos próximos).

Como observado nos vários exemplos, o f retado foi incorporado ao cotidiano macrometropolitano e passou a es truturar dinâmicas associadas ao atendimento de demandas específicas. Representa assim uma alternativa ao sistema regular e ao transporte individual, devendo ser mais estudada. Os mecanismos regulatórios devem se aprimorar para maximizar os possíveis benefícios dos fretados, assim como aperfeiçoar a fiscalização dos possíveis pontos negativos, em políticas integradas com o setor de transporte metropolitano e uso do solo.

Questões como acessibilidade, mobilidade, pendularidade e redes de circulação instaladas no território são elementos de suma importância para a reflexão do cotidiano e qualidade de vida da população, que exerce suas atividades ora como "força de trabalho", ora como "consumidora" de bens e serviços. 
Por todos os fatores elencados nos capítulos da dissertação, podemos afirmar que o pa drão de circulação viária nas cidades faz com que se perca a capacidade de transporte de produtos e s erviços, o que ac aba por afetar diretamente a ec onomia de praticamente todas as empresas instaladas na região. O modelo adotado de desenvolvimento dos transportes foi seletivo e acabou por excluir grande parte da po pulação, entretanto, mesmo a fatia da população mais privilegiada também sofre, pois o sistema de circulação está saturado e já não poupa ninguém.

Também é nec essário reconhecer que $\mathrm{t}$ ratamos de um problema complexo, não sendo fácil propor um modelo que seja realmente eficaz em uma cidade com 11 milhões de habitantes, ou em uma região com 25 milhões de habitantes. Existem órgãos públicos e funcionários compromissados com tais questões, entretanto, com sérias dificuldades e restrições de trabalho.

O fato é que, com o surgimento dos fretados, parte da população passa a ter uma capacidade de planejar e criar diversas linhas fretadas, mediante cartazes espalhados nas universidades, redes sociais e virtuais, sem esperar e depender completamente do Estado para ter acesso a tais serviços. É importante lembrar, porém, que a população mais carente é mais dependente do transporte público e acaba sendo mais prisioneira das distâncias. Tempo e espaço acabam sendo relativos, pois a mobilidade depende de uma série de questões como a renda dos usuários, seu local de moradia, seu local de trabalho, a ex istência de linhas regulares, os custos dos deslocamentos, os sistemas técnicos (modais) disponíveis, entre outros fatores.

A formação de um "quadro regional" parece ser uma tendência da rede urbana e fortes investimentos em rodovias são realizados, ao passo que alguns projetos tentam melhorar ot ransporte metropolitano. Novas formas de transporte também são organizadas, entretanto, a saturação das vias só tende a piorar com a per manência da po lítica de e stímulo ao c onsumo de automóveis. Fica nítido que o sistema viário não acompanha esse crescimento, resultando na saturação das vias e na crise de circulação da cidade. 
A tendência de busca por flexibilização e alternativas de transporte de passageiros surgiu em resposta à c arência e pr ecariedade dos transportes públicos, pelos congestionamentos, saturação das vias de circulação e, pelas novas formas corporativas de organização espacial de grandes pólos urbanos e seus usuários/funcionários. O sistema de fretamento contínuo surge como um novo modelo, capaz de atender às expectativas de parte dos empregados, empregadores, estudantes e o utros usuários, revelando um forte índice de crescimento e aprovação. Isto denuncia que tanto empresas, órgãos, públicos, universidades e or ganizações civis e virtuais passam a or ganizar as novas linhas que surgem todos os anos.

Notamos, portanto, que a d ispersão territorial das formas e conteúdos urbanos estimula a pendularidade, exigindo um sistema de movimento que comporte grandes quantidades de fluxos, com altas velocidades, assim como um planejamento integrado (entre as diversas autarquias de regulação dos transportes metropolitanos). Nesta perspectiva, as formas alternativas de transporte ganham importância, especialmente os fretados, com capacidade ociosa se comparada ao serviço regular.

Os fluxos pendulares, suportados por automóveis e fretados, seguem em grande parte a hierarquia da rede urbana, tendo os municípios periféricos como responsáveis pela maioria das origens dos fluxos, enquanto os centros regionais e sub-regionais se caracterizam como destino dos mesmos. Predomina a pendularidade intra-regional, sempre com destino ao centro da região; os fluxos inter-regionais também ocorrem, mas em menor intensidade. Tais trocas de fluxos são possibilitadas pelos eixos rodoviários fortemente articulados, assim como pela flexibilização dos transportes, tendo como uma de suas manifestações mais recentes a difusão do transporte fretado. Os pólos passam a organizar cada vez mais linhas fretadas, assim como a população em geral.

Os fluxos dos fretados estão ampliando cada vez mais a escala geográfica do "cotidiano" das metrópoles, permitindo a pr oposta de um a "regionalização do cotidiano" (WERLEN, 2000) a partir da análise deste tipo de 


\section{Mapa 38: Macrometrópole Paulista}

Principais Pontos de Origem e Destino das Viagens Fretadas Pesquisadas

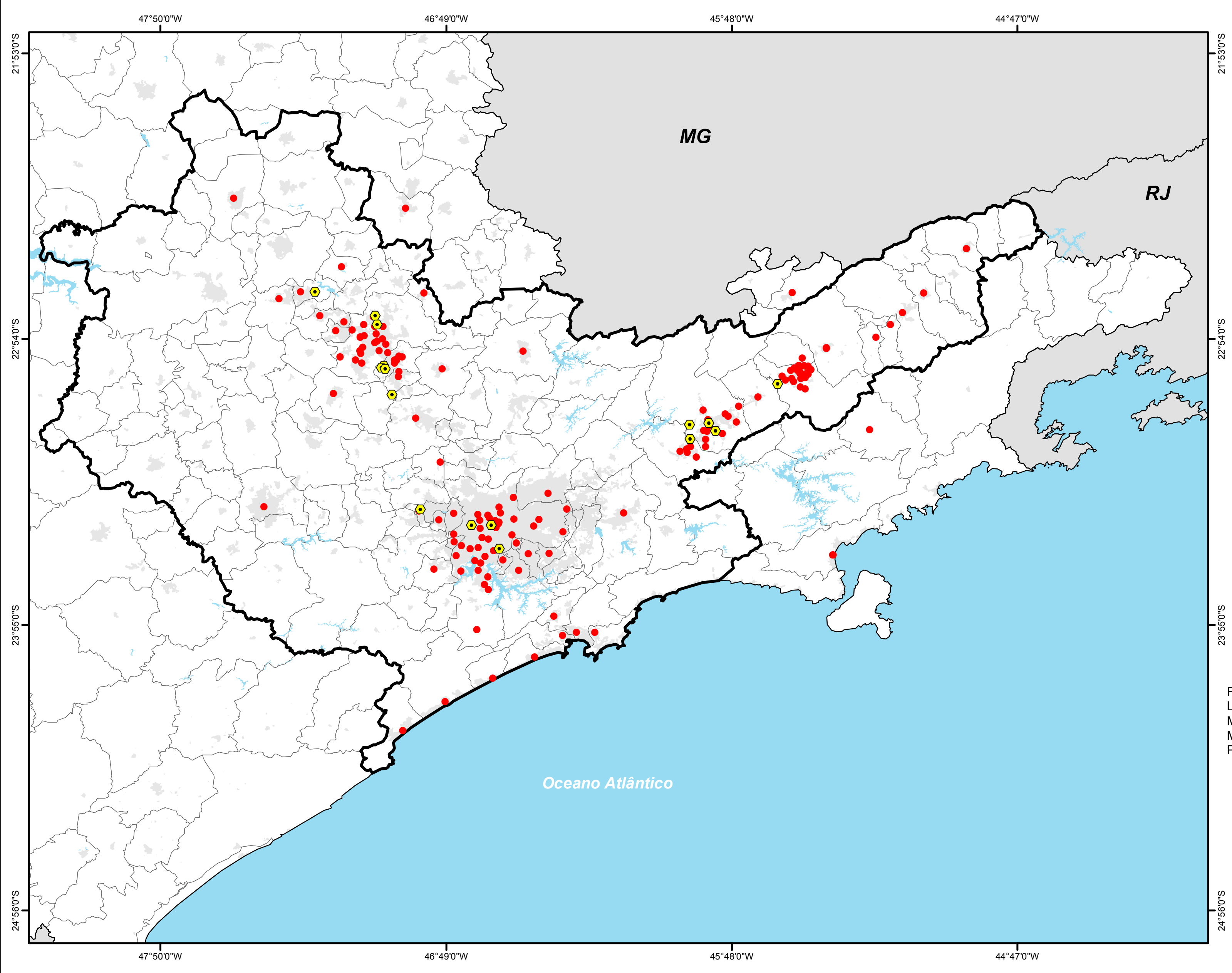

Localização Geral no Estado de São Paulo

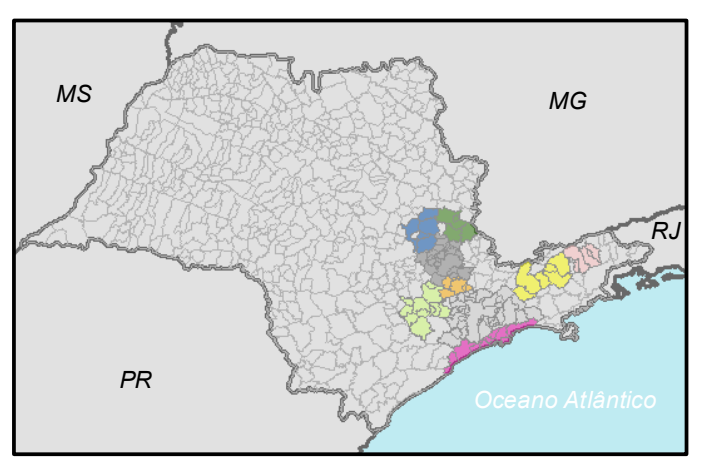

Legenda

$\square$ Limite Estadual

Limite Municipal

Oceano / Represa

Área Urbanizada 2005

$\square$ Macrometrópole

- Pontos de Destino

- Pontos de Origem

Fontes:

Estadual - IBGE 2012. Mancha Urbana - ProBio 2005.

Pontos de origem e destino dos fretados - GIBERTI 2012.

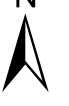

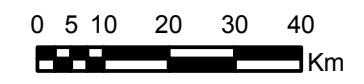

Sistema de Coordenadas Geográficas Datum WGS 84

$\begin{aligned} \text { Elaboração: GIBERTI } 2012 . & 230 .\end{aligned}$ 
fluxos. Ao atentarmos para esta forma contemporânea de des locamento metropolitano, é pos sível visualizar o que seria uma região de gr ande "intensidade do uso de transportes fretados". O mapa 38, por seu caráter sintético, permite uma visualização mais circunstanciada do fenômeno que pesquisamos ao longo destes anos de investigação:

Por fim, é possível afirmarmos que os transportes fretados podem viabilizar deslocamentos em áreas que não têm opção alguma de transporte, podendo complementar viagens com o automóvel e o sistema de transportes públicos, ou mesmo competir efetivamente com todos os modais/serviços regulares instalados, dependendo para tanto de s ua regulação, gestão e fiscalização. Para equacionar estas questões, torna-se fundamental o diálogo entre a administração pública, prestadores de serviço, contratantes e usuários.

Se bem planejado, of retado pode auxiliar na m obilidade geral da população macrometropolitana, pois é um a espécie de hí brido, com características de transporte "coletivo-público" e "individual-particular", sendo, atualmente, uma alternativa capaz de atrair o usuário do automóvel, além de complementar e competir com o transporte público.

Dessa forma, acreditamos que o entendimento do significado e atuação dos fretados pode contribuir para uma reflexão coletiva sobre os temas da divisão territorial do trabalho, da rede urbana, da regionalização do espaço, da metropolização e do pape I dos transportes nos estudos regionais brasileiros.

A investigação conduzida foi fruto de um intenso levantamento de campo, somado aos trabalhos de revisão bibliográfica, e de pesquisas em órgãos públicos, além da v ivência na $r$ egião e $s$ uas diversas redes. Os posicionamentos e juízos estabelecidos na dissertação não pretendem colidir frontalmente com nenhum aspecto específico de organizações governamentais, empresariais ou de "organizações sociais", mas sim mostrar algumas discrepâncias e c ontradições do modelo atual, além de s ugerir 
elementos para a reflexão e elaboração de soluções sérias e compromissadas com uma sociedade mais eqüitativa.

\section{Bibliografia}

ALVIM, Bernardo Guatimosim. Análise Estatística dos Fatores SócioEconômicos e de Mobilidade que Atuam Sobre a Demanda por Serviços de Ônibus Fretado no E stado de S ão Paulo. Tese de Doutorado. FFLCH-GEOGRAFIA. São Paulo. 1995.

ANDRADE, Manuel Correia de. História Econômica e Administrativa do Brasil. Atlas S.A. São Paulo - SP. 1983.

ANDRADE, Manuel Correia de. As Alternativas no Nordeste. Universidade Federal de Pernambuco. Ed. Universitária. Recife. 1983.

ANTICO, Cláudia. Deslocamentos Pendulares nos Espaços Sub-regionais da Região Metropolitana de São Paulo. In: XIV Encontro Nacional de Estudos Populacionais. Minas Gerais. 2004.

ARANHA, Valmir. Mobilidade Pendular na Metrópole Paulista. In: São Paulo em Perspectiva. V19. n4. São Paulo. 2005

ASSOCIAÇÃO NACIONAL DOS TRANSPORTES PUBLICOS. ANTP. Pesquisa da Imagem dos Transportes da Região Metropolitana de São Paulo. 2011.

BALBIM, Renato. Práticas Espaciais e Informatização do Espaço da Circulação. Tese de Doutorado. FFLCH-GEOGRAFIA. São Paulo. 2003.

BARAT, Josef. Práticas A Evolução dos Transportes no Brasil. IBGE. Rio de Janeiro. 1978. 
BRASIL. Instituto Brasileiro de Geografia e Estatística. IBGE. Censo Demográfico. Rio de Janeiro. 2000.

BRASIL. Instituto Brasileiro de Geografia e Estatística. IBGE. Censo Demográfico. Rio de Janeiro. 2010.

BRASIL. Instituto Brasileiro de Geografia e Estatística. IBGE. Diretoria de Geociências. Região de I nfluência das Cidades. 2007. Rio de Janeiro. 2008.

BRASIL. Instituto Brasileiro de Geografia e Estatística. IPEA. Instituto de Pesquisa e Estudos Avançados. Estudos Básicos para a Caracterização da Rede Urbana. Série Caracterização e Tendências da Rede Urbana do Brasil. Brasília. 2002.

CADAVAL, Maurício. Transformações no Mercado e a Gestão das Empresas de Transporte. Consultor de Transportes. São Paulo. 2001.

COCCO, Rodrigo Giraldi. Interações Espaciais e Sistemas de $\operatorname{Tr}$ ansporte Público: Uma Abordagem para Bauru, Marília e Presidente Prudente. Tese de Mestrado. FFLCH-GEOGRAFIA. São Paulo. 2011

CONTEL, Fábio, Betioli. Milton Santos: Categorias, Conceitos e Interpretação da Realidade Contemporânea. In: Encontro com o Pensamento de Milton Santos; o Homem e sua obra. ED: Edufba. Salvador. 2009.

CONTEL, Fábio, Betioli. O sistema de m ovimento do território brasileiro. In: SANTOS, M.; SILVEIRA, M.L. O Brasil: território e sociedade no início do século XXI. Ed. Record. Rio de Janeiro. 2008.

CORREA, Roberto, L. Estudos sobre a Rede Urbana. Ed. Bertrand Brasil. 2006. 
CUNHA, José Marcos Pinto. Redistribuição espacial da população: tendências e trajetória. In: São Paulo Perspectiva. v. 17, n. 3-4. São Paulo. 2003.

DIAS, Leila Christina. Redes, Sociedades e Territórios. Capitulo: Os Sentidos da Rede: Notas Para Discussão. São Paulo. 2005.

DINIZ, Clélio Campolina. Impactos Territoriais da Reestruturação Produtiva. In: RIBEIRO, Luiz César de. (org). O Futuro das Metrópoles: desigualdades e governabilidade. Revan: Fase. Rio de Janeiro. 2000.

ESTADO DE SÃO PAULO. Companhia do Metropolitano de São Paulo. Pesquisa Origem e Destino 2007. RMSP. Dezembro 2008.

ESTADO DE SÃO PAULO. Companhia do Metropolitano de São Paulo. Pesquisa Origem e D estino 1967-1977-1987-1997. RMSP. CD Multimídia. Dezembro 2008.

ESTADO DE SÃO PAULO. Empresa Metropolitana de P lanejamento da Grande São Paulo AS. Complexo Metropolitano Expandido de São Paulo. Sérgio Zarantin. São Paulo. 1996.

ESTADO DE SÃO PAULO. Empresa Metropolitana de $P$ lanejamento da Grande São Paulo AS. Rede urbana e regionalização do Estado de São Paulo. São Paulo. 2011.

ESTADO DE SÂO PAULO. SEADE/FAU-USP. Projeto Urbanização Dispersa e Mudanças no Tecido Urbano. Relatório. São Paulo. Abril 2008.

ESTADO DE SÃO PAULO. Secretaria dos Transportes Metropolitanos. Pesquisa Origem e Destino 2007. RMBS. 2007.

ESTADO DES ÃO PAULO. Secretaria dos Transportes Metropolitanos. Pesquisa Origem e Destino 2003. RMC. 2003. 
ESTAdO DE SÃO PAULO. UNICAMP. NEPO - Núcleo de E studos Populacionais. Atlas da Região Metropolitana de Campinas. 2004.

FIGUEROA, Oscar. Transporte Urbano y Globalización, Políticas y Efectos en América Latina. 2005.

FURTADO, André; MONTALI, Lilia; PATARRA, Neide. Desconcentração Industrial. Emprego e Condições de Vida. Série São Paulo 80, v3. SEADE. São Paulo. 1986.

FURTADO, Celso. Formação Econômica do B rasil. Companhia Editora Nacional. São Paulo. 1974.

GAUDEMAR, Jean-Paul de. Mobilidade do trabalho e acumulação do capital. Editora Estampa. Lisboa. 1977.

GIBERTI, Pedro Paulo Cadena. Mobilidade e Pendularidade no Complexo Metropolitano Expandido de São Paulo: O Sistema de Tr ansporte Fretado como Alternativa de Deslocamento. Trabalho de Graduação Individual. USP. São Paulo. 2008.

GOMES, Augusto C. Portugal; GUEDES, Cecília E.F.; SILVA, Maria Cristina Freitas. Percepções sobre o $\mathrm{Tr}$ ansporte Coletivo na $\mathrm{R}$ egião Metropolitana de São Paulo. In: Documentos Setoriais ANTP. O Transporte Clandestino no Brasil. n.1. Julho 2000.

GONÇALVES, Maria Flora. Novas Configurações no Desenvolvimento Urbano Paulista. Revista Espaços e Debates n³8. São Paulo. 1994.

GOTTMANN, Jean. A Urbanização e a P aisagem Americana: O Conceito de Megalópole. In: Geografia Humana. Nos Estados Unidos. Ed: Forum. Rio de Janeiro. 1967. 
GROSTEIN, Victor Abel. Características do Serviço de Ô nibus Fretado. In: Revista dos Transportes Públicos. ANTP. Ano 3. n.10. Dezembro 1980.

GROSTEIN, Victor Abel. Ônibus Fretado e Transporte Público. In: Revista dos Transportes Públicos. ANTP. Ano 2. n.8.Junho 1980.

GROSTEIN, Marta Dora; MEYER, Regina Maria Prosperi; BIDERMAN, Ciro. São Paulo Metrópole. Ed. EDUSP. São Paulo. 2004.

INSTITUTO BRASILEIRO DE G EOGRAFIA E ES TATÍSTICA. Diretoria de Geociências. Região de I nfluência das Cidades. 2007. Rio de Janeiro. 2008.

KOWARICK, Lúcio; CAMPANÁRIO, Milton. São Paulo in Novos Estudos CEBRAP, São Paulo n¹3, 1985.

LEITE, Raimundo Claoberto Soares; PEREIRA, Arnaldo Luis Santos; SOARES, Luis Américo. Fretamento: Esfinge ou Monalisa? Panorama do Sistema de Fretamento nas Regiões Metropolitanas do Estado de São Paulo. In: $15^{\circ}$ Congresso de Tr ansporte e Tr ânsito. Goiânia. 2005.

LENCIONI, Sandra. Concentração e centralização das atividades urbanas: uma perspectiva multiescalar. Reflexões a partir do caso de São Paulo. In: Revista de Geografia Norte Grande n³9. São Paulo. 2008.

LENCIONI, Sandra. Da Cidade e sua Região à Cidade-região. In: Panorama da Geografia Brasileira I. São Paulo: Annablume, 2006.

LENCIONI, Sandra. Geografia, Tradições e Perspectivas: A Presença de Pierre Monbeig / Amália Inês Geraiges de Lemos, Emerson Galvani (org.). 1ed. Ed.CLACSO, Expressão Popular. São Paulo. 2009. 
LENCIONI, Sandra. Reestruturação Urbana Industrial no Estado de São Paulo: A Região da $\mathrm{M}$ etrópole Desconcentrada. In: Revista Espaços e Debates n³8. São Paulo. 1994.

LENCIONI, Sandra. Região e Geografia. Edusp. São Paulo. 2009.

LEVY, Jacques. Os Novos Espaços da Mobilidade. Revista GEOgraphia. Ano 3, no. 6. Rio de Janeiro. Dez. 2002.

LOBATO CORREAA, Roberto. Estudos Sobre a Rede Urbana. Ed. Betrand Brasil Ltda. Rio de Janeiro. 2006.

MENEZES, Thais Zucheto de. Indústria Automobilística na $\mathrm{R}$ egião Metropolitana de São Paulo: Fluxos Diários de Trabalhadores na Fábrica da Volkswagen. Trabalho de $\mathrm{G}$ raduação. FFLCHGEOGRAFIA. São Paulo. 2009.

MONBEIG, Pierre. Pioneiros e fazendeiros de $S$ ão Paulo. São Paulo. Hucitec/Polis.1984.

MORAES, Antonio Carlos Robert. A Valorização do Espaço. Hucitec. São Paulo. 1984.

PEREIRA, William Alberto de Aquino. Ônibus Clandestino - Espécie em Extinção? In: Documentos Setoriais ANTP. O Transporte Clandestino no Brasil. n.1. Julho 2000.

RAFFESTIN. Claude. Por Uma Geografia do Poder. Ed. Ática. São Paulo. 1993.

REIS FILHO, Nestor Goulart. (Coord). Brasil Estudos sobre a D ispersão Urbana. FAU - USP. São Paulo. 2007. 
REIS FILHO, Nestor Goulart. Memória do $\operatorname{Tr}$ ansporte Rodoviário: desenvolvimento das atividades rodoviárias em São Paulo. São Paulo: CPA. Consultoria de Projetos e Artes Ltda. 1997.

REIS FILHO, Nestor Goulart. Notas sobre a or ganização das Regiões Metropolitanas. Cadernos de Pesquisa do L AP 12. Série Urbanização e Urbanismo. Faculdade de Arquitetura e U rbanismo. Universidade de São Paulo. São Paulo. 1996.

REIS FILHO, Nestor Goulart. Notas sobre a ur banização dispersa e nov as formas de tecido urbano. Ed. Via das Artes. São Paulo. 2006.

REIS FILHO, Nestor Goulart. Projeto Temático: Urbanização Dispersa e Mudanças no Tecido Urbano apresentado à FAPESP. São Paulo: LAP-FAUUSP, julho de 2002.

REIS FILHO, Nestor Goulart. São Paulo Vila Cidade Metrópole. Ed. Via das Artes. São Paulo. 2004.

ROCHEFORT, Michel. Métodos de E studo das Rêdes Urbanas. In: Boletim Geográfico. Conselho Nacional de Geografia. Instituto Brasileiro de Geografia e Estatística. 1961. Transcrição.

ROLNIK, Raquel. A Cidade e a Lei. Legislação, política urbana e territórios na cidade de São Paulo. Studio Nobel. São Paulo. 1997.

SALGUEIRO, Heliana Angotti. (Org). Pierre Monbeig e a G eografia Humana Brasileira. Edusc. Bauru - SP. 2006.

SAMPAIO, S. S. 1970 - Adensa-se a Trama Territorial das Relações Interindustriais, em meio às Aglomerações que se estendem; principais atores e ações possibilitadoras. In: Indústria e território. A Estruturação do M ulticomplexo Territorial Industrial Paulista. Ed. Alínea. Campinas - SP. 2009. 
SANTOS, Milton. Manual de Geografia Urbana. Hucitec. São Paulo. 1989.

SANTOS, Milton. Metrópole Corporativa Fragmentada. Nobel. São Paulo. 1990.

SANTOS, Milton. A Natureza do Espaço. Edusp. São Paulo - SP. 2002.

SANTOS, Milton. O Retorno do Território. In: SANTOS, Milton, SOUZA, Maria Adélia A. de \& SILVEIRA, Maria Laura (org). Território Globalização e Fragmentação. 4ª Edição. Ed. HUCITEC. São Paulo. 1998.

SANTOS, Milton. A Urbanização Brasileira. Edusp. São Paulo. 2009.

SANTOS, Milton; SILVEIRA. Maria Laura. O Brasil: Território e sociedade no início do século XXI. Ed. Record. São Paulo. 2008.

SILVA, Moacir. Geografia dos Transportes no Brasil. IBGE. Rio de Janeiro. 1949.

SORRE, Max. Migrações e mobilidade do ecúmeno. Org: Januário Francisco Megale. Tradução Januário Francisco Megale, Maria Cecília França e Moacyr Marques. In: Coleção grandes cientistas sociais. N.46. Ed. Ática. São Paulo. 1984.

SOUZA, Maria, Adélia. Metrópole e P aisagem: caminhos e de scaminhos da urbanização. In: História da c idade de São Paulo. A cidade na primeira metade do século XX. Organização Paulo Porta. Ed: Paz e Terra. São Paulo. 2004.

SOUZA, Sandra Stephani de. Análise do Modo de Transporte por Fretamento e a Regulamentação na Cidade de São Paulo. Monografia de PósGraduação. Faculdade Estadual de Ciências Econômicas de Apucarana - FECEA. 2005. 
THÉRY, Hervé; MELLO, Neli Aparecida de. Atlas do B rasil, Disparidades e dinâmicas do território. Ed. Edusp. São Paulo. 2005.

ULIAN, Flavia. Sistemas de Transportes Terrestres de Passageiros em Tempos de Reestruturação Produtiva na Região Metropolitana de São Paulo. Tese de Doutorado. FFLCH-GEOGRAFIA. São Paulo. 2008.

VASCONCELLOS, Eduardo. Transporte Urbano, Espaço e E quidade. Ed. Annablume. São Paulo. 2001.

VASCONCELLOS, Eduardo. A Cidade e o Tr ansporte. In: Documentos Setoriais ANTP. O Transporte Clandestino no Brasil. n.1. Julho 2000.

VILLAÇA, Flávio. Espaço Intra-Urbano no B rasil. Ed. Estúdio Nobel; FAPESP. São Paulo. 1998.

WERLEN, Benno. Geografia Social das Regionalizações Cotidianas. 1992.

WERLEN, Benno. Regionalismo e S ociedade Política. Revista GEOgraphia. Ano II, N4. 2000.

Internet

Agência Reguladora de Transportes do Estado de São Paulo

http://www.artesp.sp.gov.br

Companhia Brasileira de Trens Urbanos

http://www.cbtu.gov.br/

Companhia de Engenharia de Tráfego - CET

http://www.cetsp.com.br

Companhia do Metropolitano de São Paulo

http://www.metro.sp.gov.br/ 
Companhia Paulista de Trens Metropolitanos

http://www.cptm.sp.gov.br/

Departamento de Estradas de Rodagem

http://www.der.sp.gov.br

Departamento Nacional de Infraestrutura de Transportes

http://www.dnit.gov.br/

Departamento de Transportes Públicos

http://www.prefeitura.sp.gob.br/cidade/secretarias/transportes/institucional/dtp/i ndex.php? $\mathrm{p}=3627$

DETRAN

http://www.detran.sp.gov.br

Empresa Metropolitana de Transportes Urbanos

http://www.emtu.sp.gov.br

Empresa Paulista de Planejamento Metropolitano SA.

www.emplasa.sp.gov.br

Instituo Brasileiro de Geografia e Estatística

http://www.ibge.gov.br

Instituto Nacional de Pesquisas Espaciais

http://www.inpe.br

NEPO. Núcleo de E studos Populacionais - UNICAMP - Atlas da R egião Metropolitana

de Campinas

www.nepo.unicamp.br/vulnerabilidade/atlas/p1 demografia.pdf

Prefeitura de São Paulo 
http://www.prefeitura.sp.gov.br

SEADE

http://www.seade.gov.br

São Paulo Transporte SA

http://www.sptrans.com.br/

Secretaria Estadual de Logística e Transporte

http://www.transportes.sp.gov.br

Secretaria dos Transportes Metropolitanos

http://www.stm.sp.gov.br

Sistema IBGE de Recuperação Automática - SIDRA

http://www.sidra.ibge.gov.br 
Anexo 2 - Tabulação do Registro de Campo dos Fretados 


\section{Índice}

Tabela 1 - Município de São Paulo - Rua Cincinato Braga (paralela à Av. Paulista) - Tabulação dos Fr etados -1/10/04 - das 7: 00 às 9:00. 01

Tabela 2 - Município de São Paulo - Un iversidade de São Paulo (portaria 2 Campus da Capital) - Tabulação dos Fretados - 17/11/05 - das 7:00 às 9:00

Tabela 3 - Município de São Paulo - Un iversidade de São Paulo (portaria 2 Campus da Capital) - Tabulaç ão dos Fretados - 05/12/05 - das 16:00 às 19:00.

Tabela 4 - Município de São Paulo - Un iversidade de São Paulo (portaria 2 Campus da Capital) - Tabulaç ão dos Fretados - 19/04/2012 - das 7:00 às 9:00.

Tabela 5 - Município de São José dos Ca mpos - Posto Rodoviário Policial da Rod. Dutra (sentido São José dos Cam pos/Jacareí) - Tabulação dos Fretados 2/12/04 - das 6:00 às 9:00 .05

Tabela 6 - Município de São José dos Ca mpos - Posto Rodoviário Policial da Rod. Dutra (sentido São José dos Cam pos/Jacareí) - Tabulação dos Fretados 2/12/04 - das 17:00 às 19:00 .06

Tabela 7 - Município de São José dos Ca mpos - Posto Rodoviário Policial da Rod. Dutra (sentido Jacareí/São José dos Campos) - Tabulação dos Fretados $3 / 12 / 04$ - das $6: 00$ às 8:00 
Tabela 8 - Município de São José dos Ca mpos - Posto Rodoviário Policial da Rod. Dutra (sentido Jacareí/São José dos Campos) - Tabulação dos Fretados $3 / 12 / 04$ - das $17: 00$ às 18:30. 08

Tabela 9 - Município de Taubaté - Em frente ao Taubaté Shopping (sentido Shopping/Dutra) - Tabulação dos Fretados - 30/11/05 - das 6:00 às 8:30.......09

Tabela 10 - Município de Taubat é - Em fr ente ao Taubaté Shopping (sentido Shopping/Dutra) - Tabulação dos Fretados - 30/11/05 - das 16:00 às 18:00...10

Tabela 11 - Município de Taubat é - Em fr ente ao Taubaté Shopping (sentido Dutra/Shopping) - Tabulação dos Fretados - 1/12/05 - das 6:00 às 8:00. 11

Tabela 12 - Município de Taubaté - Bai rro Quiririm, em frente à entrada do CECAP - Tabulaç ão dos Fretados - 1/12/05 - das 14:00 às 16:00. 12

Tabela 13 - Município de Taubat é - Em fr ente ao Taubaté Shopping (sentido Dutra/Shopping) - Tabulação dos Fretados - 1/12/05 - das 16:00 às 18:30......13

Tabela 14 - Município de Valinhos - Próximo ao Pedágio de Valinhos, KM 83 da Rodovia Anhanguera (sentido Valinhos/C ampinas) - Tabulação dos Fretados $12 / 04 / 05$ - das $6: 00$ às 8:00 14

Tabela 15 - Município de Valinhos - Próximo ao Pedágio de Valinhos, KM 83 da Rodovia Anhanguera (sentido Valinhos/C ampinas) - Tabulação dos Fretados $12 / 04 / 05$ - das $5: 00$ às 6:00 15

Tabela 16 - Município de Valinhos - Próximo ao Pedágio de Valinhos, KM 83 da Rodovia Anhanguera (sentido Campinas/V alinhos) - Tabulação dos Fretados $13 / 04 / 05$ - das $6: 00$ às $8: 00$ 
Tabela 17 - Município de Valinhos - Próximo ao Pedágio de Valinhos, KM 83 da Rodovia Anhanguera (sentido Campinas/V alinhos) - Tabulação dos Fretados $13 / 4 / 05$ - das $16: 00$ às 18:00

Tabela 18 - Município de Americana - Po sto Rodoviário Policial da Ro dovia Anhanguera (sentido Americana/Campinas) - Tabulação dos Fretados - 7/4/05 das 6:00 às $8: 30$. 18

Tabela 19 - Município de Americana - Po sto Rodoviário Policial da Ro dovia Anhanguera (sentido Americana/Campinas) - Tabulação dos Fretados - 7/04/05 - das 16:00 às 18:00. 19

Tabela 20 - Município de Americana - Po sto Rodoviário Policial da Ro dovia Anhanguera (sentido Campinas/Americana) - Tabulação dos Fretados - 8/4/05 das 6:00 às $8: 00$. 20

Tabela 21 - Município de Americana - Po sto Rodoviário Policial da Ro dovia Anhanguera (sentido Campinas/Americana) - Tabulação dos Fretados - 8/4/05 das 16:00 às 18:00. 
Tabela 1 - Município de São Paulo - Rua Cincinato Braga (paralela à Av.Paulista) - Tabulação dos Fretados - 1/10/04 - das 7:00 às 9:00.

\begin{tabular}{|c|c|c|c|c|}
\hline Placa & Itinerário & Empresa de Ônibus & Telefone & Responsável \\
\hline GPT 0475 & $\begin{array}{c}\text { Mauá / Santo André / São Caetano / } \\
\text { Av.Paulista / Centro Velho }\end{array}$ & Cinter Turismo & 92170068 & \\
\hline BWG1848 & $\begin{array}{c}\text { JD.Varginha / Av.Paulista / Berrini / } \\
\text { Brigadero Luis }\end{array}$ & Mitur & & \\
\hline $\mathrm{BXC}$ & São José dos Campos & Banini & 99097822 & Marisa \\
\hline CLJ 6378 & São Judas / Barra Funda & Gerdau & & \\
\hline CYN6771 & Santa Maria & Uelpa & (13) 32861621 & www.uelpa.com.br \\
\hline CBS0856 & $\begin{array}{l}\text { Res.Cocaia / Av.Interlagos / Av.Paulista / } \\
\text { Consolação / Centro }\end{array}$ & Gomestur & & \\
\hline BXB8194 & $\begin{array}{l}\text { V.Luzita / Santo André / São Caetano do Sul } \\
\text { / Av.Paulista }\end{array}$ & Banini & 96328684 & Eliseu \\
\hline CYR3298 & $\begin{array}{l}\text { Vergueiro / Metrô Ana Rosa / Av.Paulista / } \\
\text { Metrô Clinicas / VI.Madalena / USP }\end{array}$ & Aebs & & \\
\hline BWS8524 & $\begin{array}{c}\text { Santo André / São Caetano do Sul / } \\
\text { Av.Paulista / Itaim }\end{array}$ & Banini & 32482333 & Jacira \\
\hline BTB0669 & Santos / São Paulo & Ilha Bela Turismo & & \\
\hline BWQ4868 & $\begin{array}{c}\text { SDC.Demarchi / Vergueiro / Av.Paulista / } \\
\text { Rebouças / Faria Lima }\end{array}$ & Aeba / Villageo & 44360991 & Luis \\
\hline BWC4762 & Parque São Rafael / Av.Paulista & Não identificado & & \\
\hline CYR2213 & Santos / São Paulo & Não identificado & & \\
\hline BWD7649 & $\begin{array}{l}\text { Mauá / São Caetano do Sul / Santo André / } \\
\text { Av.Paulista }\end{array}$ & Anceltur & & \\
\hline BTB3555 & $\begin{array}{l}\text { V.Luzita / Santo André / Av.Paulista / } \\
\text { Consolação }\end{array}$ & - & 30857877 & Eliseu \\
\hline BXH8305 & $\begin{array}{l}\text { V.Luzita / Santo André / Av.Paulista / } \\
\text { Consolação }\end{array}$ & Não identificado & 32482333 & Jacira \\
\hline KSN0553 & $\begin{array}{c}\text { CN.Jaú / Av.Nações / Itamaraty / } \\
\text { Fund.Santo André / Fórum SC do Sul / } \\
\text { Av.Goiás Emílio / Ipiranga / Av.Paulista / } \\
\text { Consolação }\end{array}$ & Anceltur & 96930554 & \\
\hline GVK 3768 & $\begin{array}{l}\text { Metrô Santa Cruz / Av.Paulista / Centro / } \\
\text { CTO Itaú / Mooca }\end{array}$ & Transul & & \\
\hline BWG8807 & $\begin{array}{c}\text { Ida:Ipiranga / Vila Mariana / Av.Paulista / } \\
\text { Av.Brasil } \\
\text { Volta:Ipiranga / Vila Ema }\end{array}$ & Colmeia Expressa & 95459877 & \\
\hline BSF2962 & $\begin{array}{l}\text { Santo André / São Caetano do Sul / Ipiranga } \\
\text { / Paulista / Consolação }\end{array}$ & Benfica & & \\
\hline AAT7120 & Cidade Tiradentes / Av.Paulista & APCT & $\begin{array}{l}62826435 \\
91965532\end{array}$ & \\
\hline LBB5811 & $\begin{array}{c}\text { Santo André / São Caetano do Sul / } \\
\text { Av.Paulista / Rebouças / Faria Lima / Itaim }\end{array}$ & Costa Atlântica & 43557602 & \\
\hline BWT0180 & Parque São Rafael / Av.Paulista & Banini & $\begin{array}{l}96328684 \\
67025839\end{array}$ & Eliseu \\
\hline BSF 2963 & $\begin{array}{l}\text { Santo André / São Caetano do Sul / } \\
\text { Av.Paulista / Rebouças / Faria Lima / Itaim }\end{array}$ & Benfica & 43557692 & \\
\hline BYE5649 & J.Mendes / Liberdade / Paraíso & Santa Adélia & 9171194 & \\
\hline Não Identificado & $\begin{array}{l}\text { São José dos Campos / Av.Paulista (São } \\
\text { Pedro / Adriático / Av.São Bernardo / Vila } \\
\text { Luzita / Av. dom Pedro II / IMES / UNI ABC / } \\
\text { Av.Paulista) }\end{array}$ & Não identificado & 42385520 & Iraci \\
\hline
\end{tabular}

Fonte: Pesquisa realizada mediante gravação de vídeo na rua Cincinato Braga em 1/10/04

Pesquisador: Pedro Paulo Cadena Giberti LAP-FAU-USP 
Tabela 2 - Município de São Paulo - Universidade de São Paulo (portaria 2 - Campus da Capital) -

\begin{tabular}{|c|c|c|c|c|}
\hline Hora & Placa & Origem/ Linha & Tipo de Veículo & Empresa de ônibus \\
\hline 6:58 AM & BWC 6687 & 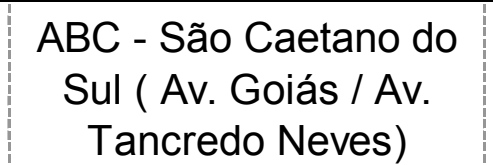 & Ônibus Executivo & Dinâmica \\
\hline $6: 58 \mathrm{AM}$ & BTS 9194 & \begin{tabular}{l|l} 
ABC (Estaąă Santo \\
Andro / Via A Achinta)
\end{tabular} & Ônibus Executivo & Dinâmica \\
\hline 7:02 AM & llegivel & Sem & Ônibus Executivo & Dinâmica \\
\hline 7:04 AM & KOD 0003 & $A B C$ & Ônibus Executivo & Dinâmica \\
\hline 7:05 AM & DBB 2782 & Sem & Micro - Ônibus & Capellini \\
\hline 7:08 AM & DAH 7828 & Linhas USP J3 & Ônibus Luxo & Viação Mimo \\
\hline 7:08 AM & llegivel & $\begin{array}{l}\text { Santo André / São } \\
\text { Berrardo do campo }\end{array}$ & Ônibus Executivo & Dinâmica \\
\hline 7:09 AM & DAH 7842 & Linha USP J4 & Micro - Ônibus & Viação Mimo \\
\hline 7:09 AM & CPG 9074 & Linhas USP & Ônibus Luxo & Santa Cruz \\
\hline 7:12 AM & CQH 5879 & Linhas USP & Ônibus Luxo & Santa Cruz \\
\hline 7:17 AM & BWI 8080 & Sem & Ônibus Executivo & Natal \\
\hline 7:17 AM & GVK 3787 & AEBS 17 & Ônibus Luxo & Transul \\
\hline 7:17 AM & GVK 3787 & $\begin{array}{l}\text { Metró Jabaquaral } \\
\text { Banderanates PPinheiros } \\
\text { IUSP }\end{array}$ & Ônibus Luxo & Santa Cruz \\
\hline 7:18 AM & CPG 8757 & Linhas USP 09 & Ônibus Luxo & Santa Cruz \\
\hline 7:19 AM & GVK 0071 & Santos & Ônibus Luxo & Náutica Turismo \\
\hline 7:25 AM & BWF 3916 & Mogi das Cruzes 13 & Ônibus Executivo & Não Identificado \\
\hline 7:28 AM & AFE 1176 & $\begin{array}{l}\text { AEBS } 11 \text { Metrô } \\
\text { Conceicâo } \\
\text { Banderantes Marg. } \\
\text { Pinheiros / USP }\end{array}$ & Ônibus Executivo & Transul \\
\hline 7:28 AM & BXG 0435 & $\begin{array}{l}\text { Anhanguera/ Marg. } \\
\text { Pinheiros / CEAGESP }\end{array}$ & Ônibus Executivo & Aguia \\
\hline 7:28 AM & AFE 1176 & $\begin{array}{l}\text { AEBS } 1 \text { 1 Metró } \\
\text { Conciciço } \\
\text { Bandeirants / Marg. } \\
\text { Pinheiros / USP }\end{array}$ & Ónibus Executivo & Transul \\
\hline 7:28 AM & BXG 0435 & $\begin{array}{l}\text { Unicamp / Mrg. } \\
\text { Pinhnirso / CEAGESP }\end{array}$ & Ônibus Executivo & Àguia \\
\hline 7:28 AM & CPR 4979 & IPT L03 / Itaim & Ônibus Executivo & Line Tour \\
\hline 7:29 AM & CGR 8741 & Sem & Ônibus Executivo & Gatti \\
\hline 7:29 AM & BXC 1244 & IPT L12 & Ônibus Executivo & Line Tour \\
\hline 7:29 AM & BXA 0600 & IPT 08 & Ônibus Executivo & Não Identificado \\
\hline 7:29 AM & BYC 4096 & $\begin{array}{l}\text { IPT L L 5 / H Horto } \\
\text { Florestal }\end{array}$ & Ónibus Executivo & Line Tour \\
\hline 7:30 AM & BXG 6492 & IPT 11 & Ônibus Executivo & Gracimar \\
\hline 7:32 AM & HUS 0737 & Não Visível & Ônibus não identificado & Ipojucatur \\
\hline 7:33 AM & BTR 9007 & Carapicuiba & Ônibus Executivo & Flexa de Ouro \\
\hline 7:33 AM & CPR 4996 & IPT L2 & Ônibus Executivo & Line Tour \\
\hline 7:34 AM & CHP 7381 & IPT 10 & Ônibus Executivo & Line Tour \\
\hline 7:35 AM & BXF 3886 & IPT 18 & Ônibus Executivo & Gracimar \\
\hline 7:35 AM & llegivel & IPT & Ônibus Executivo & Line Tour \\
\hline 7:36 AM & AHC 9587 & 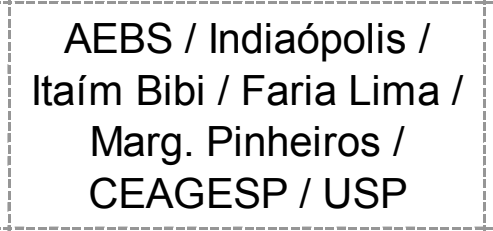 & Ônibus Luxo & Náutica Turismo \\
\hline 7:36 AM & CNI 2305 & IPT 04 & Ônibus Executivo & Gracimar \\
\hline 7:38 AM & Não Visivel & IPT & Ônibus Executivo & Line Tour \\
\hline 7:38 AM & Não Visivel & Linhas USP J4 & Micro - Ônibus & Viação Mimo \\
\hline 7:41 AM & CPR 4983 & IPT 5 & Ônibus Executivo & Line Tour \\
\hline 7:41 AM & BXF 0020 & IPT & Ônibus Executivo & Gracimar \\
\hline 7:42 AM & BYB 6433 & Itaim Paulista L42 & Ônibus Executivo & Quirino Trans Tur \\
\hline 7:44 AM & Não Visivel & IPT 13 & Ônibus Executivo & Gracimar \\
\hline 7:45 AM & Não Visivel & IPT 06 & Ônibus Executivo & Line Tour \\
\hline 7:45 AM & Não Visivel & IPT 09 & Ônibus Executivo & Gracimar \\
\hline 7:45 AM & CVP 1827 & Linhas USP J2 & Ônibus Luxo & Viação Mimo \\
\hline 7:48 AM & DJE 5205 & Marinha & Ônibus Executivo & Line Tour \\
\hline 7:53 AM & llegivel & $\begin{array}{l}\text { AEBS - Vergueiro / Ana } \\
\text { Rosa / Pauilial } \\
\text { Clinicas / Vilusadalena } \\
\text { /UPS }\end{array}$ & Ônibus Executivo & Line Tour \\
\hline 7:57 AM & Não Visivel & $\begin{array}{l}\text { Marg. Pinheiros / } \\
\text { CAGESP }\end{array}$ & Ônibus Executivo & Aguia \\
\hline 8:00 AM & BYE 9523 & $\begin{array}{l}\text { Bragancal F Fria Lima / } \\
\text { USP }\end{array}$ & Ônibus Executivo & Bragança \\
\hline 8:07 AM & BTA 3055 & Sem & Micro - Ônibus & Eldorado Turismo \\
\hline 8:08 AM & BWH 6395 & AUTA & Ônibus Executivo & Line Tour \\
\hline 8:14 AM & Não Visivel & Linhas USP J14 & Ônibus não identificado & Viação Mimo \\
\hline 8:16 AM & CQH 3581 & Linhas USP / Adriana & Ônibus Luxo & Santa Cruz \\
\hline $8: 21 \mathrm{AM}$ & DAH 7822 & $\begin{array}{l}\text { Linhas USP J4 (CEASA } \\
\text { (LARK USP) }\end{array}$ & Ônibus não identificado & Viação Mimo \\
\hline 8:23 AM & Não Visivel & Sem & Ônibus não identificado & Gatti 38313977 \\
\hline $8: 23 \mathrm{AM}$ & BWH 6405 & AUTA & Ônibus Executivo & Line Tour \\
\hline
\end{tabular}

Fonte: Pesquisa realizada mediante registro fotográfico dos 
Tabela 3 - Município de São Paulo - Universidade de São Paulo (portaria 2 - Campus da Capital) Tabulação dos Fretados - 05/12/05 - das 16:00 às 19:00.

\begin{tabular}{|c|c|c|c|c|}
\hline Hora / Sentido & Placa & Origem/ Linha & Tipo de Veículo & Empresa de ônibus \\
\hline 4:41 PM / Entrando & BYE 9521 & $\begin{array}{l}\text { Bragança a Paulista / Faria } \\
\text { Lima SPP) / ISPP / } \\
\text { Bragança Paulista }\end{array}$ & Ônibus Executivo / Luxo & Bragança \\
\hline 4:42 PM / Saindo & CPG 9074 & Linhas USP / Adriana & Ônibus Não Identificado & Santa Cruz \\
\hline 4:42 PM / Saindo & CVP 1827 & Jundiaí 2 & Ônibus Executivo / Luxo & Viação Mimo \\
\hline 4:42 PM Entrando & CPG 8796 & Sem & Ônibus Não Identificado & Benfica \\
\hline 4:45 PM / Entrando & BTR 9007 & Carapicuiba & Ônibus Executivo & Flecha de Ouro \\
\hline 4:48 PM / Entrando & CPR 4979 & Itaím L3/ IPT & Ônibus Executivo & Line Tour \\
\hline 4:52 PM / Entrando & AHC 9587 & $\begin{array}{l}\text { São Vicente / Santos (P. } \\
\text { Wilson / Praias Glicério / } \\
\text { Ferry Boat) }\end{array}$ & Ônibus Executivo / Luxo & Náutica Turismo \\
\hline 4:53 PM / Entrando & BWF 3916 & $\begin{array}{c}\text { Mogi Mirim / USP / Mogi } \\
\text { Mirim }\end{array}$ & Ônibus Executivo & Não Identificado \\
\hline 4:54 PM / Entrando & llegivel & IPT Linha 51 & Ônibus Executivo & Line Tour \\
\hline 4:54 PM / Entrando & GQY 3008 & Arthur Alvim & Ônibus Executivo & Ramos 3(968)189069 \\
\hline 4:54 PM / Entrando & BWH 6395 & llegivel & Ônibus Executivo & Não Identificado \\
\hline 4:55 PM / Entrando & llegivel & Sorocaba & Ônibus Executivo / Luxo & Ipojucatur \\
\hline 4:56 PM / Saindo & DAH 7822 & Jundiaí & Ônibus Executivo / Luxo & Viação Mimo \\
\hline 4:57 PM / Entrando & CPR 4996 & ABC / IPT Linha 2 & Ônibus Executivo & Line Tour \\
\hline 4:57 PM / Entrando & BYC 4096 & $\begin{array}{l}\text { Horto Florestal / IPT } \\
\text { Linha } 5\end{array}$ & Ônibus Executivo & Line Tour \\
\hline 4:57 PM / Saindo & BUD 4362 & Jundiai Linha 3 & Ônibus Executivo / Luxo & Viação Mimo \\
\hline 4:58 PM / Entrando & CHP 7381 & IPT & Ônibus Executivo & Line Tour \\
\hline 4:59 PM / Entrando & llegivel & sem & Ônibus Executivo & TT Natal \\
\hline 5:00 PM / Entrando & KRA 1080 & IPT & Ônibus Executivo / Luxo & Gracimar \\
\hline 5:00 PM / Entrando & CPR 4978 & IPT & Ônibus Executivo & Line Tour \\
\hline 5:00 PM / Entrando & llegivel & IPT & Ônibus Executivo & Gracimar \\
\hline 5:01 PM / Entrando & BXG 0435 & $\begin{array}{l}\text { UNICAMP / Prefeitura de } \\
\text { Campinas / PUCC }\end{array}$ & Ônibus Executivo & Águia \\
\hline 5:02 PM / Entrando & BXC 3191 & IPT & Ônibus Executivo & Gracimar \\
\hline 5:03 PM / Entrando & llegivel & IPT & Ônibus Executivo & Line Tour \\
\hline 5:04 PM / Saindo & Não Visível & UNICAMP / Adriana & Ônibus não identificado & Santa Cruz \\
\hline 5:05 PM / saindo & DJE 5205 & Marinha & Ônibus Executivo & Line Tour \\
\hline 5:06 PM / Saindo & KNP 0781 & $\begin{array}{l}\text { Av Bandeirantes / São } \\
\text { Caetano / Santo André / } \\
\text { São Bernardo do Campo }\end{array}$ & Ônibus Executivo & Dinâmica \\
\hline 5:07 PM / Saindo & BWC 6687 & $\begin{array}{l}\text { ABC (Av Portugal / Av } \\
\text { Goiás / Av Pedro II) }\end{array}$ & Ônibus Executivo & Dinâmica \\
\hline 5:07 PM / Saindo & KOD 0003 & $\begin{array}{c}\mathrm{ABC} \text { (Anchieta / Shopping } \\
\mathrm{ABC} \text { ) }\end{array}$ & Ônibus Executivo & Dinâmica \\
\hline 5:09 PM / Saindo & GVK 0071 & Santos (13-91128860) & Ônibus Executivo / Luxo & Náutica Turismo \\
\hline 5:12 PM / Saindo & Não Visivel & $\begin{array}{l}\text { Santos (Canal 1/ Glicério } \\
\text { / Afonso Pena / Epitácio) }\end{array}$ & Ônibus Executivo & Transul \\
\hline 5:13 PM / Saindo & Não Visível & São Vicente / Santos & Ônibus Não Identificado & Transul \\
\hline 5:13 PM / Saindo & Não Visivel & Mogi das Cruzes & Ônibus Não Identificado & Não Identificado \\
\hline 5:14 PM / Entrando & BWY 7834 & $\begin{array}{l}\text { PRODESP (Embú / Via } \\
\text { BR } 116 \text { / Maria Rosa) }\end{array}$ & Ônibus Não Identificado & Gracimar \\
\hline 5:19 PM / Entrando & CPG 9074 & Adriana & Ônibus Executivo / Luxo & Santa Cruz \\
\hline 5:20 PM / Saindo & BWI 8080 & Sem & Ônibus Executivo & TT Natal \\
\hline 5:22 PM / Saindo & BTR 9007 & Carapicuiba & Ônibus Executivo & Flecha de Ouro \\
\hline 5:22 PM / Saindo & Não Visível & $\begin{array}{l}\text { UNICAMP / Terminal } \\
\text { Central / Prefeitura / } \\
\text { PUCC }\end{array}$ & Ônibus Executivo & Águia \\
\hline 5:22 PM / Saindo & Não Visível & Sorocaba & Ônibus Não Identificado & Ipojucatur \\
\hline 5:25 PM / Saindo & GQY 3008 & $\begin{array}{c}\text { Cohab } 1 \mathrm{e} 2 \text { / Via Arthur } \\
\text { Alvim }\end{array}$ & Ônibus Executivo & $\begin{array}{l}\text { Ramos } 35189069 \text { - } \\
\text { www.apsm.com.br }\end{array}$ \\
\hline 5:28 PM / Saindo & CPN 1440 & Bragança Paulista & Ônibus Executivo / Luxo & $\begin{array}{c}11-40224723- \\
\text { www.saexbra.com.br }\end{array}$ \\
\hline 5:31 PM / Saindo & llegivel & Jundiaí & Ônibus Não Identificado & Viação Mimo \\
\hline 5:33 PM / Entrando & CNP 1827 & Jundiai - J2 & Ônibus Executivo / Luxo & Viação Mimo \\
\hline 5:33 PM / Saindo & CQH 2600 & $\begin{array}{c}\text { Campinas - Linha 2 } \\
\text { Barão Geraldo / Linha } 3 \\
\text { Centro }\end{array}$ & Ônibus Executivo / Luxo & Santa Cruz \\
\hline 5:54 PM / Saindo & BTR 7938 & llegivel & Ônibus Executivo / Luxo & Redenção Turismo \\
\hline 6:04 PM / Entrando & llegivel & $A B C$ & Ônibus Executivo & Dinâmica \\
\hline 6:30 PM / Saindo & CAP $1827 ?$ & Jundiai - J2 & Ônibus Executivo / Luxo & Viação Mimo \\
\hline 6:31 PM / Entrando & llegivel & Marinha & Ônibus Executivo & Line Tour \\
\hline 6:34 PM / Saindo & CPG 9074 & $\begin{array}{l}\text { Campinas / Barão } \\
\text { Geraldo }\end{array}$ & Ônibus Executivo / Luxo & Santa Cruz \\
\hline 6:44 PM / Saindo & Ilegivel & $A B C$ & Ônibus Executivo & Dinâmica \\
\hline
\end{tabular}

Pesquisador: Pedro Paulo Cadena Giberti LAP-FAU-USP 
Tabela 4 - Município de São Paulo - Universidade de São Paulo (portaria 2 - Campus da Capital) - Tabulação dos Fretados - 19/04/2012 - das 7:00 às 9:00.

\begin{tabular}{|c|c|c|c|c|}
\hline Hora & Placa & Origem/ Linha & Tipo de Veículo & Empresa de ônibus \\
\hline 7:00 AM & EGJ 6456 & - & Van & - \\
\hline 7:07 AM & KNC 6196 & Itaim Paulista/USP & Ônibus Executivo & Quirino \\
\hline 7:11 AM & CSK 2934 & Linha $3 /$ USP & Ônibus Luxo & Santa Cruz \\
\hline 7:12 AM & CZB 0336 & Santos/USP & Ônibus Luxo & Arca Turismo \\
\hline 7:17 AM & CSK 2892 & Linha Extra/USP & Ônibus Luxo & Santa Cruz \\
\hline 7:17 AM & DTC 9678 & - & Van & - \\
\hline 7:19 AM & HUV 7616 & USP/Jundiaí & Ônibus Luxo & - \\
\hline 7:19 AM & & Ipt/Linha 2/ttaim & Ônibus Luxo & Rápido Campinas \\
\hline 7:20 AM & LSC 0859 & $\begin{array}{c}\text { Santos/S.Vicente/Metro } \\
\text { Conceição/USP }\end{array}$ & Ônibus Luxo & RC Tur \\
\hline 7:21 AM & CSK 2894 & Linha 4/USP & Ônibus Luxo & Santa Cruz \\
\hline 7:22 AM & ЕСТ 1536 & UEBS & Ônibus Luxo & Breda \\
\hline 7:23 AM & HYR 4349 & USP/Jundiaí & Ônibus Luxo & Viação Mimo \\
\hline 7:26 AM & DVT 3500 & Ipt/Cotia & Ônibus Luxo & Marcopolo \\
\hline 7:26 AM & DTC 6916 & USP/CENESP/Linha 2 & Ônibus Executivo & Marcopolo \\
\hline 7:27 AM & CVP 7784 & Ipt/Linha 2/ttaim & Ônibus Luxo & Rápido Campinas \\
\hline 7:28 AM & CVP 7881 & Ipt/Linha 4/Guarulhos & Ônibus Luxo & Rápido Campinas \\
\hline 7:30 AM & BWF 3807 & Mogi/São Paulo & Ônibus Executivo & Oceano \\
\hline 7:30 AM & DPC 1699 & Santos/USP & Ônibus Luxo & Poney \\
\hline 7:31 AM & DPF 8769 & Ipt/Embu & Ônibus Luxo & - \\
\hline 7:31 AM & DBL 1665 & Ipt/Carapicuiba & Ônibus Executivo & Gracimar \\
\hline 7:32 AM & BWF 8635 & USP/Guarulhos & Micro-Ônibus & Valle \\
\hline 7:33 AM & EJV 4710 & - & Ônibus Luxo & ES Oliveira \\
\hline 7:34 AM & ECM 6622 & Mogi/São Paulo & Ônibus Luxo & AL Turismo \\
\hline 7:34 AM & DVT 0716 & - & Micro-Ônibus & Rápido Campinas \\
\hline 7:37 AM & CVN 1444 & - & Ônibus Executivo & Max Tour \\
\hline 7:37 AM & EFW 7020 & CTMSP & Ônibus Luxo & Marinha \\
\hline 7:38 AM & CVP 7885 & Ipt/Linha6/Horto & Ônibus Luxo & Rápido Campinas \\
\hline 7:39 AM & DTC 4445 & Linha 3/USP/lpt/ltapevi & Ônibus Luxo & Ação \\
\hline 7:41 AM & BUD 4677 & - & Ônibus Executivo & Max Tour \\
\hline 7:42 AM & ECM 9886 & Mogi/São Paulo & Ônibus Luxo & Natal \\
\hline 7:43 AM & CVP 7528 & Ipt/Linha 1/ABC & Ônibus Luxo & Rápido Campinas \\
\hline 7:48 AM & ETU 1462 & - & Ônibus Luxo & JC Turismo \\
\hline 7:52 AM & DVT 3463 & - & Ônibus Luxo & Expresso Fátima \\
\hline 7:55 AM & DPF 8770 & Ipt/Osasco & Ônibus Luxo & - \\
\hline 7:58 AM & CDL 3209 & Jundiaí/USP & Ônibus Executivo & Viação Mimo \\
\hline 8:01 AM & DTB 3544 & AEBS & Ônibus Luxo & Line Tour \\
\hline 8:06 AM & CSK 2933 & Linha 6/Auxiliar/USP & Ônibus Luxo & Santa Cruz \\
\hline 8:08 AM & CSK 2935 & Linha 6/USP & Ônibus Luxo & Santa Cruz \\
\hline 8:14 AM & DTD 6037 & - & Van Escolar & \\
\hline 8:20 AM & DVT 3872 & - & Ônibus Luxo & Expresso Fátima \\
\hline 8:29 AM & KMI 4816 & - & Ônibus Executivo & Hamer Tur \\
\hline 8:30 AM & GAT 1174 & - & Van & \\
\hline 8:31 AM & DAH 7868 & Jundiaí/USP & Ônibus Luxo & Viação Mimo \\
\hline 8:46 AM & CVP 3904 & - & Ônibus Luxo & Atibaia \\
\hline 8:46 AM & BNZ 4746 & - & Van & - \\
\hline
\end{tabular}

Fonte: Pesquisa realizada mediante registro fotográfico dos ônibus no portão 2 da Cidade Universitária da USP Capital. Pesquisador: Pedro Paulo Cadena Giberti LAP-FAU-USP 
Tabela 5 - Município de São José dos Campos - Posto Rodoviário Policial da Rod. Dutra (sentido São José dos Campos/Jacareí) Tabulação dos Fretados - 2/12/04 - das 6:00 às 9:00.

\begin{tabular}{|c|c|c|c|c|c|}
\hline Hora & Placa & Linha / Destino & Origem & Tipo de Veículo & Empresa de ônibus \\
\hline 5:54 AM & llegivel & GM B 24 & São José dos Campos & Ônibus Executivo & Kuba \\
\hline 6:00 AM & BXE 7774 & Petrobrás 120 OA-10 & Não Consta & Ônibus Executivo & Viação Jacareí \\
\hline 6:00 AM & CVN 7905 & Embraer & Não Consta & Ônibus Executivo & Clarear \\
\hline 6:02 AM & llegivel & Johnson \& Johnson & Não Consta & Ônibus Executivo & Breda \\
\hline 6:09 AM & BXE 7880 & Ambev 08 & Não Consta & Ônibus Executivo & Viação Jacareí \\
\hline 6:10 AM & Ilegivel & Johnson \& Johnson & llegivel & Ônibus Executivo & Breda \\
\hline 6:14 AM & Ilegivel & Petrobrás & Não Consta & Ônibus Executivo & Viação Jacareí \\
\hline 6:23 AM & BWU 5861 & Johnson \& Johnson & llegivel & Ônibus Executivo & Viação Jacareí \\
\hline 6:23 AM & BXG 3312 & Johnson \& Johnson & llegivel & Ónibus Executivo & Breda \\
\hline 6:23 AM & Ilegivel & Johnson \& Johnson & llegivel & Ônibus Executivo & Breda \\
\hline 6:31 AM & BXC 4884 & GM B 21103 & Não Consta & Ônibus Executivo & Breda \\
\hline 6:31 AM & Ilegivel & GMB 2 & Não Consta & Ônibus Executivo & Breda \\
\hline 6:32 AM & BXH 1581 & GM B 21101 & Não Consta & Ônibus Executivo & Breda \\
\hline 6:32 AM & llegivel & Embraer & Jacareí & Ônibus Executivo & Clarear \\
\hline 6:45 AM & Ilegivel & Kodak & Não Consta & Mini Ônibus & Redenção - Turismo \\
\hline 6:46 AM & Ilegivel & Kodak & Não Consta & Mini Ônibus & Redenção - Turismo \\
\hline 6:53 AM & BYA 1412 & $\begin{array}{l}\text { Destino à São Paulo, Via Term. Tietê, } \\
\text { Tiradentes, República, Consolação e } \\
\text { Paulista }\end{array}$ & Não Consta & Ônibus Executivo & Pássaro Marrom \\
\hline 6:55 AM & llegivel & Faculdade & Não Consta & Ônibus Executivo & Trans Vip \\
\hline 6:57 AM & BTR 9367 & $\begin{array}{l}\text { Destino à Jacarei via rodovia velha, } \\
\text { Caçapava }\end{array}$ & Taubaté & Ônibus Executivo & Pássaro Marrom, \\
\hline 7:02 AM & llegivel & Colégio Poliedro & Não Consta & Ônibus Executivo & Aries \\
\hline 7:07 AM & BWJ 0170 & Faculdade UNIP? & Não Consta & Ônibus Executivo & Sem \\
\hline 7:15 AM & BWF 2490 & Votorantin Rota 12 & Não Consta & Ônibus Executivo & Ação \\
\hline 7:15 AM & BWF 2457 & Votorantin Rota 11 & Não Consta & Ônibus Executivo & Ação \\
\hline 7:18 AM & CWB 6363 & UNIP & Não Consta & Van - Sprinter & UNIP- (12) 39217396 \\
\hline 7:20 AM & CLK 2958 & Kodak - UNIP? & Não Consta & Van - 1 porta & Redenção - Turismo \\
\hline 7:21 AM & Não Visível & $\begin{array}{c}\text { Destino à Mogi das Cruzes, Via Arujá - } \\
\text { Jacareí }\end{array}$ & Não Consta & Ônibus Executivo & Trans Vip \\
\hline 7:23 AM & BWT 0748 & LG Philips 101 & Não Consta & Ônibus Executivo & Breda \\
\hline 7:23 AM & BXG 3475 & LG Philips 102 & Não Consta & Ônibus Executivo & Breda \\
\hline 7:23 AM & BXH 1568 & LG Philips 103 & Não Consta & Ônibus Executivo & Breda \\
\hline 7:23 AM & BWY 6167 & LG Philips 104 & Não Consta & Ônibus Executivo & Breda \\
\hline 7:24 AM & BWY 6170 & LG Philips 105 & Não Consta & Ônibus Executivo & Breda \\
\hline 7:24 AM & BWY 6172 & LG Philips 106 & Não Consta & Ônibus Executivo & Breda \\
\hline 7:29 AM & BSF 1701 & Panasonic Linha 10 & Putim & Ônibus Executivo & Braga Turismo \\
\hline 7:29 AM & BSF 1032 & Panasonic & Não Consta & Ônibus Executivo & Braga Turismo \\
\hline 7:30 AM & CPI 441 & Monsanto & N. Horizonte & Mini Ônibus & Venetur \\
\hline 7:30 AM & BSF 0775 & Kaiser 11 & Não Consta & Mini Ônibus & Viação Jacareí \\
\hline 7:31 AM & CVN 7951 & Embraer & Não Consta & Ônibus Executivo/Luxo & Clarear Turismo \\
\hline 7:32 AM & BXI 8778 & Monsanto & ADM Caçapava & Ônibus Executivo & Venetur \\
\hline $7: 32 \mathrm{AM}$ & KMN 0985 & Embraer Linha 286 & $\begin{array}{l}\text { Jacarei, S.A. Boa Vista / } \\
\text { CECAP }\end{array}$ & Ônibus Executivo/Luxo & Clarear Turismo \\
\hline 7:36 AM & CPI 3449 & Monsanto & Não Consta & Mini Ônibus & Venetur \\
\hline 7:36 AM & CLH 1168 & Cognis 10 & Não Consta & Ônibus Executivo & Viação Jacareí \\
\hline $7: 38 \mathrm{AM}$ & CLH 1139 & Kaiser 10 & Não Consta & Ônibus Executivo & Viação Jacareí \\
\hline 7:40 AM & CPG 2063 & CEBRACE & Jacareí & Mini Ônibus & Redenção - Turismo \\
\hline 7:41 AM & BXE 7332 & Ambev 09 & Não Consta & Ônibus Executivo & Viação Jacareí \\
\hline 7:42 AM & CVN 7966 & Embraer & Não Consta & Ônibus Executivo/Luxo & Clarear Turismo \\
\hline 7:45 AM & BXI 9250 & UNIP & Não Consta & Van - Hyundai & UNIP \\
\hline 7:45 AM & llegivel & UNIP & Não Consta & Van - Hyundai & UNIP \\
\hline 7:45 AM & CPJ 6555 & UNIP & Não Consta & Van - Hyundai & UNIP (12) 97646989 \\
\hline 7:46 AM & BXE 7980 & Ambev 08 & Não Consta & Ônibus Executivo & Viação Jacareí \\
\hline 7:46 AM & CAH 0686 & UNIP & Não Consta & Van -Besta & UNIP \\
\hline 7:47 AM & BXC 4586 & GM B 11102 & Não Consta & Ônibus Executivo & Breda \\
\hline 7:47 AM & BX1 9579 & Panasonic Linha 29 & JD. Colonial & Ônibus Executivo & Braga Turismo \\
\hline 7:48 AM & BX1 9578 & Panasonic & Não Consta & Ônibus Executivo & Braga Turismo \\
\hline 7:48 AM & CLH 1433 & Panasonic Linha 14 & N. Horizonte & Ônibus Executivo & Braga Turismo \\
\hline 7:48 AM & CPI 4140 & UNIP & Não Consta & Van - Besta & UNIP \\
\hline 7:50 AM & CGR 5288 & UNIP & Não Consta & Van - Topic & UNIP \\
\hline 7:50 AM & CVN 7905 & Embraer & Não Consta & Ônibus Executivo/Luxo & Clarear Turismo \\
\hline 8:03 AM & CPI 4365 & Eaton & Jacareí & Mini Ônibus & Braga Turismo \\
\hline 8:10 AM & BXG 3311 & Johnson \& Johnson Linha 111 & llegivel & Ônibus Executivo & Breda \\
\hline $8: 13 \mathrm{AM}$ & BWY 6179 & Johnson \& Johnson Linha 123 & Ilegivel & Ônibus Executivo & Breda \\
\hline
\end{tabular}

Fonte: Pesquisa realizada mediante registro fotográfico dos ônibus, no Posto Policial Rodoviário Federal em São José dos Campos.

Pesquisador: Pedro Paulo Cadena Giberti LAP-FAU-USP 
Tabela 6 - Município de São José dos Campos - Posto Rodoviário Policial da Rod.Dutra (sentido São José dos Campos/Jacareí) Tabulação dos Fretados - 2/12/04 - das 17:00 às 19:00.

\begin{tabular}{|c|c|c|c|c|c|}
\hline Hora & Placa & Linha / Destino & Origem & Tipo de Veículo & Empresa de ônibus \\
\hline 4:48 PM & BXE 7910 & Kaiser & Sem & Ônibus Executivo & Viação Jacareí \\
\hline 4:51 PM & BXE 7343 & Johnson Controls 04 & Sem & Ônibus Executivo & Viação Jacareí \\
\hline 4:55 PM & BWF 3607 & Monsanto & ADM Santana & Ônibus Executivo & Venetur \\
\hline 4:57 PM & Sem & Panasonic & Sem & Micro Ônibus & Tursan \\
\hline 4:58 PM & BXE 7779 & Petrobrás 116 0A-06 & Sem & Ônibus Executivo & Viação Jacareí \\
\hline 5:00 PM & BWT 6852 & Monsanto & Sem & Ônibus Executivo & Venetur \\
\hline 5:02 PM & BWT 6964 & Monsanto & llegivel & Ônibus Executivo & Venetur \\
\hline 5:04 PM & BXI 8854 & Monsanto & ADM JD. Emilia & Ônibus Executivo & Venetur \\
\hline 5:16 PM & BXE 7766 & Ambev & llegivel & Ônibus Executivo & Viação Jacarei \\
\hline 5:20 PM & BWY 3455 & TECSAT & Guararema ADM & Ônibus Executivo & Venetur \\
\hline 5:22 PM & BSF 1721 & Panasonic Linha 3 & Igarapés & Ônibus Executivo & Braga Turismo \\
\hline 5:22 PM & BXI 9578 & Panasonic Linha 5 & JD. Paraiso & Ônibus Executivo & Braga Turismo \\
\hline 5:23 PM & CLH 1433 & Panasonic Linha 9 & Galo Branco & Ônibus Executivo & Braga Turismo \\
\hline 5:23 PM & BSF 1032 & Panasonic Linha 10 & Putim & Ônibus Executivo & Braga Turismo \\
\hline 5:23 PM & BXI 9328 & Panasonic Linha 14 & N. Horizonte & Ônibus Executivo & Braga Turismo \\
\hline 5:23 PM & BWP 1362 & Panasonic & Sem & Ônibus Executivo & Braga Turismo \\
\hline 5:23 PM & llegivel & Panasonic Linha 25 & Bosque & Ônibus Executivo & Braga Turismo \\
\hline 5:24 PM & llegivel & Ericsson & llegivel & Ônibus Executivo & Redenção \\
\hline 5:26 PM & CPI 4365 & Radic & Jacareí & Micro Ônibus & Braga Turismo \\
\hline 5:30 PM & BXE 7422 & Normal / Intermunicipal & $\begin{array}{l}\text { Mogi das Cruzes via São } \\
\text { José, Cacapava e e } \\
\text { Taubaté }\end{array}$ & Ônibus Executivo & Viação Jacareí \\
\hline 5:30 PM & llegivel & Embraer & Não Consta & Micro Ônibus & Venetur \\
\hline 5:31 PM & BXC 8360 & Poliedro & Não Consta & Ônibus Executivo & Aries \\
\hline 5:31 PM & Ilegivel & GM B 2 & llegivel & Ônibus Executivo & Breda \\
\hline 5:32 PM & BXG 3312 & Johnson \& Johnson & Ilegivel & Ônibus Executivo & Breda \\
\hline 5:32 PM & BGX 3311 & Johnson \& Johnson & llegivel & Ônibus Executivo & Breda \\
\hline 5:33 PM & BWG 8697 & Johnson \& Johnson & Ilegivel & Ônibus Executivo & Breda \\
\hline 5:33 PM & BWG 8768 & Johnson \& Johnson & llegivel & Ônibus Executivo & Breda \\
\hline 5:36 PM & CVN 7851 & Embraer Linha 111 & Jacareí & Ônibus Executivo / Luxo & Clarear Turismo \\
\hline 5:36 PM & llegivel & Embraer Linha 113 & Jacareí & Ônibus Executivo / Luxo & Clarear Turismo \\
\hline 5:36 PM & KMN 0988 & Embraer Linha 287 & Jacareí & Ônibus Executivo / Luxo & Clarear Turismo \\
\hline 5:45 PM & BWG 8656 & Johnson \& Johnson & llegivel & Ônibus Executivo & Breda \\
\hline 5:47 PM & CPI 3594 & Faculdade & Não Consta & Ônibus Executivo & Trans Vip \\
\hline 5:50 PM & CLK 2765 & Hitachi & Jacareí & Ônibus Executivo & Venetur \\
\hline 5:56 PM & BXE 7650 & Tigroup & ADM Jacareí & Ônibus Executivo & Venetur \\
\hline 6:02 PM & BWF 2493 & Faculdade & Não Consta & Ônibus Executivo & Trans Vip \\
\hline 6:03 PM & llegivel & Faculdade & Não Consta & Ônibus Executivo & Trans Vip \\
\hline 6:03 PM & BSF 0838 & Faculdade & Não Consta & Ônibus Executivo & Trans Vip \\
\hline 6:03 PM & CPI 3347 & Faculdade & Não Consta & Ônibus Executivo & Trans Vip \\
\hline 6:03 PM & BSF 2242 & Faculdade & Não Consta & Ônibus Executivo & Trans Vip \\
\hline 6:18 PM & BZS 6591 & LG Eletronics 101-A & P. Meia Lua & Ônibus Executivo & Viação Jacareí \\
\hline 6:20 PM & BWF 2401 & Avibrás II & Jacarei / Esperança & Ônibus Executivo & Trans Vip \\
\hline 6:27 PM & CLH 1362 & LG Eletronics 101-B & Não Consta & Ônibus Executivo & Viação Jacareí \\
\hline 6:40 PM & llegivel & UNIP & Não Consta & Van - Topic & UNIP \\
\hline 6:48 PM & llegivel & UNIP & Não Consta & Van - Topic & UNIP \\
\hline 6:48 PM & llegivel & UNIP & Não Consta & Van - Topic & UNIP \\
\hline 6:49 PM & llegivel & UNIP & Não Consta & Van - Topic & UNIP \\
\hline 6:50 PM & llegivel & UNIP & Não Consta & Van - Topic & UNIP \\
\hline 6:51 PM & CZC 7628 & UNIP & Não Consta & Van - Topic & UNIP \\
\hline 6:51 PM & llegivel & UNIP & Não Consta & Van - Topic & UNIP \\
\hline 6:51 PM & llegivel & UNIP & Não Consta & Van - Topic & UNIP \\
\hline 6:53 PM & llegivel & UNIP & Não Consta & Van - Topic & UNIP \\
\hline 6:53 PM & llegivel & UNIP & Não Consta & Van - Topic & UNIP \\
\hline 6:54 PM & BXI 9196 & UNIP & Não Consta & Van - Topic & UNIP \\
\hline 6:54 PM & llegivel & UNIP & Não Consta & Van - Topic & UNIP \\
\hline 6:56 PM & llegivel & UNIP & Não Consta & Van - Topic & UNIP \\
\hline 6:57 PM & llegivel & UNIP & Não Consta & Van - Topic & UNIP \\
\hline 6:58 PM & llegivel & UNIP & Não Consta & Van - Topic & UNIP \\
\hline 6:56 PM & llegivel & Alstom 09 & Não Consta & Ônibus Executivo & Tursan \\
\hline 7:00 PM & CPI 3930 & UNIP & Não Consta & Van - Topic & UNIP (12) 39164967 \\
\hline 7:00 PM & llegivel & UNIP & Não Consta & Micro Ônibus & UNIP (12) 39286561 \\
\hline 7:01 PM & llegivel & UNIP & Não Consta & Van - Topic & UNIP \\
\hline
\end{tabular}

列

Pesquisador: Pedro Paulo Cadena Giberti LAP-FAU-USP 

Fretados - 3/12/04 - das 6:00 às 8:00.

\begin{tabular}{|c|c|c|c|c|c|}
\hline Hora & Placa & Linha / Destino & Origem & Tipo de Veículo & Empresa de ônibus \\
\hline 6:06 AM & llegivel & Ambev 09 & Sem & Ônibus Executivo & Viação Jacareí \\
\hline 6:07 AM & Ilegivel & Petrobrás & Sem & Ônibus Executivo & Viação Jacareí \\
\hline $6: 15 \mathrm{AM}$ & Ilegivel & Petrobrás & Sem & Ônibus Executivo & Viação Jacareí \\
\hline 6:19 AM & Ilegivel & Hitachi & Sem & Ônibus Executivo & Venetur \\
\hline 6:19 AM & Ilegivel & Petrobrás & Sem & Ônibus Executivo & Viação Jacareí \\
\hline 6:24 AM & Ilegivel & Petrobrás & Sem & Micro Ônibus & Viação Jacareí \\
\hline 6:24 AM & Ilegivel & LG Philips & Sem & Ônibus Executivo & Breda \\
\hline $6: 25 \mathrm{AM}$ & Ilegivel & GM B 106 & Sem & Ônibus Executivo & Breda \\
\hline 6:27 AM & BXG 3475 & LG Philips 156 & Sem & Ônibus Executivo & Breda \\
\hline 6:29 AM & SWY 6170 & LG Philips 401 & Sem & Ônibus Executivo & Breda \\
\hline 6:29 AM & Ilegivel & LG Philips 157 & Sem & Ônibus Executivo & Breda \\
\hline 6:29 AM & BXT 9301 & LG Eletronic 101-A & P.Meia Lua & Ônibus Executivo & Viação Jacareí \\
\hline 6:30 AM & Ilegivel & LG Philips & Sem & Ônibus Executivo & Breda \\
\hline 6:31 AM & Ilegivel & LG Philips & Sem & Ônibus Executivo & Breda \\
\hline 6:31 AM & BWY 6167 & LG Philips 155 & Sem & Ônibus Executivo & Breda \\
\hline 6:31 AM & BXC 2057 & LG Philips 152 & Sem & Ônibus Executivo & Breda \\
\hline 6:31 AM & Ilegivel & LG Philips & Sem & Ônibus Executivo & Breda \\
\hline 6:32 AM & llegivel & LG Philips 151 & Sem & Ônibus Executivo & Breda \\
\hline 6:32 AM & Não Visível & Colégio Poliedro & Sem & Ônibus Executivo & Aries \\
\hline 6:32 AM & CPI 4292 & LG Philips 404 & Sem & Van - Sprinter & Sem \\
\hline 6:32 AM & Não Visivel & Embraer & Sem & Ônibus Executivo & Clarear Turismo \\
\hline 6:32 AM & BSF 0024 & LG Philips 154 & Sem & Ônibus Executivo & Breda \\
\hline 6:37 AM & Ilegivel & LG Philips 161 & Sem & Ônibus Executivo & Breda \\
\hline 6:39 AM & BXC 2057 & LG Philips 152 & Sem & Ônibus Executivo & Breda \\
\hline 6:40 AM & Ilegivel & LG Philips 151 & Sem & Ônibus Executivo & Breda \\
\hline 6:45 AM & BXE 7766 & Ambev 07 & Sem & Ônibus Executivo & Viação Jacareí \\
\hline 6:45 AM & Ilegivel & Ambev & Sem & Ônibus Executivo & Viação Jacareí \\
\hline 6:45 AM & Ilegivel & Embraer & Sem & Ônibus Executivo/Luxo & Clarear Turismo \\
\hline 6:45 AM & CVN 7951 & Embraer & Sem & Ônibus Executivo & Clarear Turismo \\
\hline 6:48 AM & CVN 7966 & Embraer & $\begin{array}{c}\text { Jacarei/B.Branca/ Santa } \\
\text { Maria }\end{array}$ & Ônibus Executivo/Luxo & Clarear Turismo \\
\hline 6:48 AM & KMN 0985 & Embraer linha 286 & Jacarei/SJ. Boa Vista & Ônibus Executivo/Luxo & Clarear Turismo \\
\hline 6:48 AM & CPI 3609 & Embraer & São Paulo/Tiradentes & Ônibus Executivo & Trans Vip \\
\hline 6:49 AM & BWT 4425 & Embraer & Campinas & Ônibus Executivo & Mimo \\
\hline 6:49 AM & Ilegivel & Embraer & Metrô Tiradentes/São Paulo & Ônibus Executivo & Trans Vip \\
\hline 6:50 AM & BWF 2401 & Avibrás II & Jacarei / Esperança & Ônibus Executivo & TransVip \\
\hline 6:52 AM & BXE 7773 & Petrobrás 115 0A-05 & Sem & Ônibus Executivo & Viação Jacareí \\
\hline 6:52 AM & CLH 1537 & Heatcraft & Sem & Micro Ônibus & Venetur \\
\hline 6:52 AM & llegivel & Embraer & Ilegivel & Ônibus Executivo & Trans Vip \\
\hline 6:53 AM & BYA 3441 & Ericsson 003 & Sem & Ônibus Executivo & Redenção \\
\hline $6: 54$ AM & BSF 1721 & Panasonic & Igarapés & Ônibus Executivo & Braga Turismo \\
\hline 6:57 AM & BYA 5480 & Cebrace & Sem & Ônibus Executivo & Redenção \\
\hline 6:59 AM & BXI 9227 & Colégio Juarez Wanderley & Sem & Ônibus Executivo & Venetur \\
\hline 7:03 AM & BUS 9925 & GM B 0301 & Sem & Micro Ônibus & Tursan \\
\hline 7:04 AM & BXE 7960 & Amber Suprimentos & São José dos Campos & Ônibus Executivo & Viação Jacareí \\
\hline 7:10 AM & BWY 3455 & Tecsat & Guararema ADM & Ônibus Executivo & Venetur \\
\hline 7:15 AM & CLH 1555 & Kaiser 26 & Sem & Ônibus Executivo & Viação Jacareí \\
\hline 7:20 AM & BXE 7897 & Monsanto & ADM Campo Grande & Ônibus Executivo & Venetur \\
\hline 7:21 AM & CPI 3599 & Monsanto & Ilegivel & Micro Ônibus & Venetur \\
\hline 7:26 AM & BWT 6964 & Monsanto & ADM JD. Emilia & Ônibus Executivo & Venetur \\
\hline 7:26 AM & BSF 1392 & Monsanto & ADM Sto. Ant. B. Vista & Ônibus Executivo & Venetur \\
\hline 7:32 AM & BWP 1362 & Panasonic Linha 16 & JD. Colonia & Ônibus Executivo & Braga Turismo \\
\hline 7:33 AM & BXI 9328 & Panasonic & Sem & Ônibus Executivo & Braga Turismo \\
\hline 7:34 AM & BWD 2804 & Panasonic Linha 25 & Bosque & Ônibus Executivo & Braga Turismo \\
\hline 7:34 AM & BXC 2050 & Johnson \& Johnson & Sem & Ônibus Executivo & Breda \\
\hline 7:35 AM & BWY 6178 & Johnson \& Johnson & Sem & Ônibus Executivo & Breda \\
\hline 7:35 AM & BWG 8697 & Johnson \& Johnson & Sem & Ônibus Executivo & Breda \\
\hline 7:39 AM & Não Visível & Kodak & Sem & Micro Ônibus & Redenção \\
\hline 7:41 AM & BWD 1559 & Ambev 28 & Sem & Ônibus Executivo & Viação Jacareí \\
\hline 7:43 AM & CPI 4365 & Eaton & Jacareí & Micro Ônibus & Braga Turismo \\
\hline 7:45 AM & CLK 3042 & Kodak & Sem & Micro Ônibus & Redenção \\
\hline 7:48 AM & BSF 1032 & Panasonic Linha 10 & Putim & Ônibus Executivo & Braga Turismo \\
\hline 7:52 AM & BXI 9578 & Panasonic & Sem & Ônibus Executivo & Braga Turismo \\
\hline 7:52 AM & CLH 1363 & Cognis 07 & JD. Paraiba & Ônibus Executivo & Viação Jacareí \\
\hline 7:52 AM & CLH 1168 & Cognis 10 & Sem & Ônibus Executivo & Viação Jacareí \\
\hline 7:52 AM & BXI 9579 & Panasonic Linha 29 & JD. Colonial & Ônibus Executivo & Braga Turismo \\
\hline 7:53 AM & CLH 1433 & Panasonic Linha 14 & N. Horizonte & Ônibus Executivo & Braga Turismo \\
\hline 7:55 AM & BXG 3475 & LG Philips 102 & Sem & Ônibus Executivo & Breda \\
\hline 7:55 AM & BSF 1805 & Cognis 08 & Sem & Ônibus Executivo & Viação Jacareí \\
\hline 7:58 AM & BWL 4996 & GM B 20701 & Sem & Ônibus Executivo & Breda \\
\hline 7:59 AM & Ilegivel & Cebrace & Sem & Ônibus Executivo & Redenção \\
\hline 8:01 AM & BWY 6167 & LG Philips 104 & Sem & Ônibus Executivo & Breda \\
\hline 8:01 AM & BUS 9925 & Panasonic & Sem & Micro Ônibus & Tursan \\
\hline
\end{tabular}

Fonte: Pesquisa realizada mediante registro fotogrático dos ônibus, no Posto Policial Rodoviário Federal em São José dos Campos.

Pesquisador: Pedro Paulo Cadena Giberti LAP-FAU-USP 
Tabela 8 - Município de São José dos Campos - Posto Rodoviário Policial da Rod. Dutra (sentido Jacareí/São José dos Campos) Tabulação dos Fretados - 3/12/04 - das 17:00 às 18:30.

\begin{tabular}{|c|c|c|c|c|c|}
\hline Hora & Placa & Linha / Destino & Origem & Tipo de Veículo & Empresa de ônibus \\
\hline 4:50 PM & CVN 7966 & Embraer Linha 192 & $\begin{array}{c}\text { Jacareí/Primavera/ } \\
\text { C.Grande }\end{array}$ & Ônibus Executivo/Luxo & Clarear Turismo \\
\hline 4:51 PM & KMN 0988 & Embraer Linha 083 & Jacareí/llegível & Ônibus Executivo/Luxo & Clarear Turismo \\
\hline 4:55 PM & BWE 9862 & GM B 21104 & Não Consta & Ônibus Executivo & Breda \\
\hline 5:06 PM & lleível & Fujifilm & Jacareí & Micro Ônibus & Não Identificado \\
\hline 5:10 PM & CLK 3034 & Kodak & Não Consta & Micro Ônibus & Redenção \\
\hline 5:12 PM & BWD 1095 & Parker Linha 50 & Não Consta & Ônibus Executivo & Viação Jacareí \\
\hline 5:17 PM & BXE 7332 & Parker Linha 09 & Não Consta & Ônibus Executivo & Viação Jacareí \\
\hline 5:18 PM & CLK 3042 & Kodak & Não Consta & Micro Ônibus & Redenção \\
\hline 5:18 PM & BXE 7910 & Cognis 10 & Não Consta & Ônibus Executivo & Viação Jacareí \\
\hline 5:19 PM & BSF 1805 & Kaiser 10 & Não Consta & Ônibus Executivo & Viação Jacareí \\
\hline 5:19 PM & CPI 4411 & Monsanto & Não Consta & Micro Ônibus & Venetur \\
\hline 5:20 PM & BXE7996 & Kaiser 11 & Não Consta & Micro Ônibus & Viação Jacareí \\
\hline 5:22 PM & CPG 2063 & Cebrace & Não Consta & Micro Ônibus & Redenção \\
\hline 5:29 PM & CLH 1433 & Panasonic Linha 09 & Galo Branco & Ônibus Executivo & Braga Turismo \\
\hline 5:29 PM & BWD 2640 & Panasonic Linha 10 & Putim & Ônibus Executivo & Braga Turismo \\
\hline 5:30 PM & lleível & Panasonic & llegível & Ônibus Executivo & Braga Turismo \\
\hline 5:30 PM & lleível & Panasonic & llegível & Ônibus Executivo & Braga Turismo \\
\hline 5:41 PM & BXE 7960 & Schrader & Escritório CECAP & Ônibus Executivo & Viação Jacareí \\
\hline 5:45 PM & BXE 7341 & Ambev 08 & Não Consta & Ônibus Executivo & Viação Jacareí \\
\hline 5:45 PM & BWD 1832 & Ambev 09 & Não Consta & Ônibus Executivo & Viação Jacareí \\
\hline 5:48 PM & $\mathrm{BHI} 4129$ & Votorantim Rota 11 & Não Consta & Ônibus Executivo & Ação \\
\hline 5:48 PM & BWF 2490 & Votorantim Rota 12 & Não Consta & Ônibus Executivo & Ação \\
\hline 5:48 PM & CLH 1555 & KAISER 07 & Não Consta & Ônibus Executivo & Viação Jacareí \\
\hline 5:50 PM & BWF 2351 & Votorantin Rota 13 & Não Consta & Ônibus Executivo & Ação \\
\hline 5:56 PM & CLH 1361 & PARKER Linha 2 & Não Consta & Ônibus Executivo & Viação Jacareí \\
\hline 5:57 PM & BXE 7779 & Petrobrás 116 0A-06 & Não Consta & Ônibus Executivo & Viação Jacareí \\
\hline 6:00 PM & Não Visível & PARKER Linha 01 & Não Consta & Ônibus Executivo & Viação Jacareí \\
\hline 6:01 PM & CLH 1537 & DELPHI & $\begin{array}{l}\text { Jacareí/Pq. Meia } \\
\text { Lua }\end{array}$ & Micro Ônibus & Venetur \\
\hline 6:10 PM & Não Visível & Embraer & Não Consta & Micro Ônibus & Clarear Turismo \\
\hline 6:11 PM & Não Visível & Faculdade & Não Consta & Ônibus Executivo & Trans Vip \\
\hline 6:12 PM & Não Visível & DELPHI & Não Consta & Micro Ônibus & Venetur \\
\hline 6:19 PM & Não Visível & Faculdade Mogi 01 & Não Consta & Ônibus Executivo & Trans Vip \\
\hline 6:21 PM & Não Visível & Panasonic & llegível & Ônibus Executivo & Braga Turismo \\
\hline
\end{tabular}

Fonte: Pesquisa realizada mediante registro fotográfico dos ônibus, no Posto Policial Rodoviário Federal em São José dos Campos.

Pesquisador: Pedro Paulo Cadena Giberti LAP-FAU-USP 
Tabela 9 - Município de Taubaté - Em frente ao Taubaté Shopping (sentido Shopping/Dutra) - Tabulação dos Fretados - $30 / 11 / 05$ - das 6:00 às 8:30.

\begin{tabular}{|c|c|c|c|c|c|}
\hline Hora & Placa & Linha / Destino & Origem & Tipo de Veículo & Empresa de ônibus \\
\hline 5:59 AM & BXG 0405 & Não Identificado & Não Identificado & Ônibus não identificado & Breda Turismo \\
\hline 6:02 AM & BWQ 9597 & GMB 21011 & Sem & Ônibus Executivo & Breda Turismo \\
\hline 6:05 AM & Não Visível & Vilares T - $02 ?$ & Sem & Ônibus Executivo & Rio Manso \\
\hline 6:15 AM & llegível & Embraer & llegível & Ônibus Executivo & Redenção \\
\hline 6:15 AM & llegível & Embraer & llegível & Ônibus Executivo & Redenção \\
\hline 6:16 AM & CLK 3013 & Embraer & llegível & Ônibus Executivo & Redenção \\
\hline 6:20 AM & llegível & LG Eletronics & llegível & Ônibus Executivo & Redenção \\
\hline $6: 25 \mathrm{AM}$ & BWF 5378 & LG Eletronics 01 & llegível & Ônibus Executivo & Redenção \\
\hline 6:27 AM & Ilegível & Ford & llegível & Ônibus Executivo & Rosa \\
\hline $6: 28 \mathrm{AM}$ & llegível & Ford & llegível & Ônibus Executivo & Rosa \\
\hline $6: 30 \mathrm{AM}$ & llegível & LG Eletronics & llegível & Ônibus Executivo & Redenção \\
\hline $6: 32 \mathrm{AM}$ & llegível & Ford & llegível & Ônibus Executivo & Rosa \\
\hline 6:34 AM & llegível & Ford & llegível & Ônibus Executivo & Rosa \\
\hline 6:34 AM & BTT 6182 & Ford 02 & Sem & Ônibus Executivo & Rosa \\
\hline 6:37 AM & BTT 8261 & Ford 03 & llegível & Ônibus Executivo & Rosa \\
\hline 6:38 AM & llegível & Ford & llegível & Ônibus Executivo & Rosa \\
\hline 6:39 AM & BTT 8259 & Ford 01 & Sem & Ônibus Executivo & Rosa \\
\hline $6: 42 \mathrm{AM}$ & CLH 1404 & Daido & Sem & Ônibus Executivo & Marson \\
\hline $6: 46 \mathrm{AM}$ & Não Visível & Ericsson 01 & Sem & Ônibus Executivo & Não Identificado \\
\hline 6:48 AM & CPI 4572 & Petrobrás 113 & Sem & Ônibus Executivo & Viação Jacareí \\
\hline 6:51 AM & Não Visível & LG Eletronics & Sem & Ônibus Executivo & Redenção \\
\hline $6: 51 \mathrm{AM}$ & CLK 2857 & Daruma & Sem & Van & Sislog? \\
\hline 6:53 AM & llegível & LG Eletronics & Sem & Ônibus Executivo & Redenção \\
\hline 7:05 AM & BUP 4615 & Volkswagem & PQ Santa Cruz & Ônibus Executivo & Júlio Simões \\
\hline 7:10 AM & CPI 3343 & Sem & Sem & Micro - Ônibus & Venetur \\
\hline $7: 10$ AM & CLK 3187 & CTEEP - ESTIVA & Sem & Micro - Ônibus & Não Identificado \\
\hline 7:17 AM & CPI 4263 & FLC / Taubaté - Caçapava & Sem & Micro - Ônibus & Ideal \\
\hline 7:31 AM & DAH 7398 & Volkswagem 51 & Campos Eliseos & Ônibus Executivo & Júlio Simões \\
\hline 7:32 AM & HVS 3615 & Volkswagem 19 & Flor do Vale & Ônibus Luxo & Tursan \\
\hline 7:32 AM & CPG 2466 & Volkswagem 31 & Pindamonhangaba & Ônibus Executivo & Tursan \\
\hline 7:40 AM & BWF 3098 & Alstom 05 & Sem & Ônibus Executivo & Tursan \\
\hline 7:41 AM & DAJ 8190 & Alstom 01 & DER & Ônibus Executivo & Tursan \\
\hline $7: 43$ AM & Não Visível & Autoliv & Sem & Ônibus Executivo & Viação Jacareí \\
\hline 7:47 AM & BXE 7207 & Bundy & Sem & Ônibus Executivo & Venetur \\
\hline 7:57 AM & Não Visível & Ford 19 & llegível & Ônibus Executivo & Rosa \\
\hline 8:10 AM & KDZ 6974 & Usiminas Mecânica Linha 02 & Sem & Micro - Ônibus & Não Identificado \\
\hline
\end{tabular}

Fonte: Pesquisa realizada mediante registro fotográfico dos ônibus, em frente ao Taubaté Shopping em taubaté..

Pesquisador: Pedro Paulo Cadena Giberti LAP-FAU-USP 
Tabela 10 - Município de Taubaté - Em frente ao Taubaté Shopping (sentido Shopping/Dutra) - Tabulação dos Fretados - 30/11/05 - das 16:00 às 18:00.

\begin{tabular}{|c|c|c|c|c|c|}
\hline Hora & Placa & Linha / Destino & Origem & Tipo de Veículo & Empresa de ônibus \\
\hline 3:55 PM & BTT 8197 & Ford 14 & Ilegível & Ônibus Executivo & Rosa \\
\hline 3:56 PM & BTT 8182 & Ford 13 & llegível & Ônibus Executivo & Rosa \\
\hline 3:56 PM & BTT 8260 & Ford 15 & llegível & Ônibus Executivo & Rosa \\
\hline 3:57 PM & BWI 7528 & Forde 17 & Tremembé (Padre Eterno) & Ônibus Executivo & Rosa \\
\hline 4:03 PM & BWY 9283 & Ford $14 \mathrm{~A}$ & Sem & Ônibus Executivo & Rosa \\
\hline 4:06 PM & DAH 7386 & Wolkswagem 92 & Ranvil & Ônibus Executivo & Júlio Simões \\
\hline 4:15 PM & DAH 7398 & Wolkswagem 70 & PQ São Luis & Ônibus Executivo & Júlio Simões \\
\hline 4:15 PM & DAJ 8199 & Novelis 02 & PQ Aeroporto & Ônibus Executivo & Tursan \\
\hline 4:22 PM & LNC 9898 & Volkswagem 73 & JD Morisco & Ônibus Luxo & Tursan \\
\hline 4:23 PM & CPG 2379 & Volkswagem & Sem & Ônibus Executivo & Tursan \\
\hline 4:27 PM & CPG 2491 & Embraer 223 & $\begin{array}{l}\text { Taubaté (Espl. S. Teresinha } \\
\text { / V. Aparecida / PQ } \\
\text { Aeroporto / Q uiririm) }\end{array}$ & Ônibus Executivo & Redenção \\
\hline 4:34 PM & BWU 5860 & Johnson \& Johnson & Sem & Ônibus Executivo & Breda \\
\hline 4:39 PM & BWL 5464 & Alstom 03 & Vera Cruz & Ônibus Executivo & Tursan \\
\hline 4:40 PM & BWF 5377 & LG Electronics 17 & Sem & Ônibus Luxo & Redenção \\
\hline 4:46 PM & BWD 1074 & Autoliv 64 & Sem & Ônibus Executivo & Viação Jacareí \\
\hline 4:52 PM & CLK 2892 & LG Electronics 16 & Sem & Ônibus Executivo & Redenção \\
\hline 4:53 PM & BYA 3441 & LG Electronics 35 & Sem & Ônibus Executivo & Redenção \\
\hline 4:53 PM & Não Visível & LG Electronics 04 & Sem & Ônibus Executivo & Redenção \\
\hline 4:55 PM & CLK 2918 & LG Electronics 11 & Sem & Ônibus Executivo & Redenção \\
\hline 4:58 PM & BTS 4573 & Wolkswagem 89 & PQ 3 Marias & Ônibus Executivo & Tursan \\
\hline 4:59 PM & BWF 6064 & LG Electronics 36 & Sem & Ônibus Executivo & Redenção \\
\hline 5:09 PM & DAJ 8190 & Confab 06 & Quiririm & Ônibus Executivo & Tursan \\
\hline 5:23 PM & CPI 4572 & Petrobrás 113 & Sem & Ônibus Executivo & Viação Jacareí \\
\hline 5:34 PM & CLK 2931 & Oxiteno & Sem & Micro - Ônibus & Matos \& Matos \\
\hline 5:36 PM & CDL 3554 & Villares TT02 & Sem & Ônibus Luxo & Rio Manso \\
\hline 5:40 PM & CLH 1359 & Daido & Sem & Ônibus Executivo & Marson \\
\hline 5:52 PM & Não Visível & Ford 07 & $\begin{array}{l}\text { São Gonçalo / Cidade de } \\
\text { Deus }\end{array}$ & Ônibus não identificado & Rosa \\
\hline 5:57 PM & CLK 2823 & LG Electronics 14 & Sem & Ônibus Executivo & Redenção \\
\hline 6:02 PM & Não Visível & Ford 06 & Sem & Ônibus não identificado & Rosa \\
\hline
\end{tabular}

Fonte: Pesquisa realizada mediante registro fotográfico dos ônibus, em frente ao Taubaté Shopping em taubaté.

Pesquisador: Pedro Paulo Cadena Giberti LAP-FAU-USP 
Tabela 11 - Município de Taubaté - Em frente ao Taubaté Shopping (sentido Dutra/Shopping) - Tabulação dos Fretados - 1/12/05 - das 6:00 às 8:00.

\begin{tabular}{|c|c|c|c|c|c|}
\hline Hora & Placa & Linha / Destino & Origem & Tipo de Veículo & Empresa de ônibus \\
\hline 6:08 AM & llegível & Petrobras & sem & Onibus Executivo & Viação Jacareí \\
\hline 6:09 AM & llegível & llegível & llegível & Ônibus Executivo & Tursan \\
\hline $6: 18 \mathrm{AM}$ & llegível & Embraer & llegível & Ônibus Executivo & Redenção \\
\hline 6:21 AM & BXG 0356 & GMB 1005 & sem & Ônibus Executivo & Breda \\
\hline 6:23 AM & BWF 5378 & LG Electronics & sem & Ônibus Executivo & Redenção \\
\hline $6: 30 \mathrm{AM}$ & CPG 2371 & Volkswagem 350 & Moreira Cesar & Ônibus Executivo & Tursan \\
\hline $6: 30 \mathrm{AM}$ & DAJ 8191 & Volkswagem 318 & Tremembé (Centro) & Ônibus Executivo & Tursan \\
\hline 6:30 AM & Não Visível & Volkswagem & llegível & Ônibus não identificado & Tursan \\
\hline 6:31 AM & BXI 9860 & Villares TT02 & sem & Ônibus Luxo & Rio Manso \\
\hline 6:31 AM & HVS 2014 & Volkswagem 388 & Espla. Santa Teresinha & Ônibus Luxo & Tursan \\
\hline $6: 32 \mathrm{AM}$ & CGS 0824 & Volkswagem 642 & Comevap & Ônibus Executivo & Tursan \\
\hline 6:32 AM & CPG 2464 & Volkswagem 300 & sem & Ônibus Executivo & Tursan \\
\hline 6:32 AM & HVS 3615 & Volkswagem 334 & Flor do vale & Ônibus Luxo & Tursan \\
\hline 6:32 AM & DAJ 7469 & Volkswagem 337 & sem & Ônibus Luxo & Tursan \\
\hline $6: 34 \mathrm{AM}$ & BWI 8048 & Volkswagem 642 & llegível & Ônibus Executivo & Tursan \\
\hline 6:37 AM & KDZ 6974 & Usiminas Mecânica 02 & sem & Micro - Ônibus & Não Identificada \\
\hline $6: 40 \mathrm{AM}$ & BWY 9283 & Ford & llegível & Ônibus Executivo & Rosa \\
\hline $6: 42 \mathrm{AM}$ & CLH 1359 & Daido & sem & Ônibus Executivo & Marson \\
\hline $6: 43 \mathrm{AM}$ & BYE 9286 & Alstom 06 & Padre Eterno & Ônibus Executivo & Tursan \\
\hline $6: 52 \mathrm{AM}$ & CLK 2823 & LG Electronics 14 & sem & Ônibus Executivo & Redenção \\
\hline $6: 23 \mathrm{AM}$ & Não Visível & LG Electronics 12 & sem & Ônibus não identificado & Não Identificada \\
\hline $6: 55 \mathrm{AM}$ & Não Visível & LG Electronics & Não Visível & Ônibus Executivo & Não Identificada \\
\hline 6:59 AM & CLK2931 & Oxiteno & sem & Micro - Ônibus & Matos \& Matos \\
\hline 7:03 AM & BTT 8260 & Ford & Terra Nova & Ônibus Executivo & Rosa \\
\hline $7: 25 \mathrm{AM}$ & BTT 8197 & Ford 22 & Tremembé / Taubaté & Ônibus Executivo & Rosa \\
\hline 7:25 AM & BWD7850 & Ford 20E & llegível & Ônibus Executivo & Rosa \\
\hline 7:41 AM & BXE 7207 & Bundy & sem & Ônibus Executivo & Venetur \\
\hline
\end{tabular}

Fonte: Pesquisa realizada mediante registro fotográfico dos ônibus, em frente ao Taubaté Shopping em taubaté.

Pesquisador: Pedro Paulo Cadena Giberti LAP-FAU-USP 
Tabela 12 - Município de Taubaté - Bairro Quiririm, em frente à entrada do CECAP - Tabulação dos Fretados - 1/12/05 - das 14:00 às 16:00.

\begin{tabular}{|c|c|c|c|c|c|}
\hline Hora & Placa & Linha / Destino & Origem & Tipo de Veículo & Empresa de ônibus \\
\hline 2:17 PM & BTR 7986 & Volkswagem 28 & M Miranda & Ônibus Executivo & Tursan \\
\hline 2:27 PM & BTA 3161 & A.J. Rorato 01 & Bonfim & Ônibus Executivo & Tursan \\
\hline 2:27 PM & BWA 1496 & A.J. Rorato 02 & Sta Teresinha & Ônibus Executivo & Tursan \\
\hline 2:32 PM & Não Visível & Volkswagem 196 & llegível & Ônibus Executivo & Julio Simões \\
\hline 2:33 PM & BUP 4627 & Volkswagem 105 & Independência & Ônibus Executivo & Julio Simões \\
\hline 2:41 PM & CPG 2491 & Embraer 244 & $\begin{array}{l}\text { Espl. Sta. Terezinha / V. } \\
\text { Aparecida }\end{array}$ & Ônibus Executivo & Redenção \\
\hline 2:46 PM & BWF 6058 & Amplimatic & Sem & Ônibus Executivo & Gran Sul \\
\hline 3:15 PM & Não Visível & Autoliv 158 & llegível & Ônibus Executivo & Viação Jacareí \\
\hline 3:28 PM & HWR 4919 & Volkswagem 27 & Araretama & Ônibus Executivo & Tursan \\
\hline 3:29 PM & CPG 2491 & Volkswagem 36 & Tremembé & Ônibus Executivo & Tursan \\
\hline 3:29 PM & llegível & Volkswagem & llegível & Ônibus Executivo & Tursan \\
\hline 3:29 PM & BSF 0218 & Volkswagem 09 & Gurilândia & Ônibus Executivo & Tursan \\
\hline 3:29 PM & BYE 9286 & Volkswagem 58 & Santa Cruz & Ônibus Executivo & Tursan \\
\hline 3:29 PM & DAH 7398 & Volkswagem 70 & PQ São Luiz & Ônibus não identificado & Julio Simões \\
\hline 3:29 PM & Não Visível & Volkswagem 24 & $P Q$ das Fontes & Ônibus Executivo & Tursan \\
\hline 3:29 PM & BWF 3098 & Volkswagem 75 & Barreiro & Ônibus Executivo & Tursan \\
\hline 3:29 PM & JKW 1592 & Volkswagem 105 & Independência & Ônibus Executivo & Julio Simões \\
\hline 3:30 PM & HVS 2814 & Volkswagem 45 & PQ São Luiz & Ônibus Executivo & Tursan \\
\hline 3:30 PM & BXG 5106 & Volkswagem 69 & Alto do Cristo & Ônibus Executivo & Tursan \\
\hline 3:30 PM & BUP 4627 & Volkswagem 92 & Ranvil & Ônibus Executivo & Julio Simões \\
\hline 3:30 PM & Não Visível & Volkswagem 28 & M. Miranda & Ônibus Executivo & Tursan \\
\hline 3:30 PM & KNP 9047 & Volkswagem 87 & PQ Planalto & Ônibus Executivo & Tursan \\
\hline 3:30 PM & DAJ 8185 & Volkswagem 07 & Monte Belo & Ônibus não identificado & Tursan \\
\hline 3:30 PM & DAH 7397 & Volkswagem 107 & Chácara Florida & Ônibus não identificado & Julio Simões \\
\hline $3: 32 \mathrm{PM}$ & CPG 2372 & Volkswagem 83 & JD América & Ônibus Luxo & Tursan \\
\hline 3:32 PM & DAH 7385 & Volkswagem 08 & JD América & Ônibus Executivo & Julio Simões \\
\hline 3:32 PM & BYA 2841 & Volkswagem 01 & Alto S. Pedro & Ônibus Executivo & Tursan \\
\hline 3:32 PM & DAJ 8191 & Volkswagem 49 & PQ P ou F aduan & Ônibus Executivo & Tursan \\
\hline 3:32 PM & CPG 2467 & Volkswagem 99 & Estadão & Ônibus Executivo & Tursan \\
\hline 3:32 PM & BWA 1496 & Volkswagem 93 & Flor do Vale & Ônibus Executivo & Tursan \\
\hline 3:32 PM & LNC 9898 & Volkswagem 73 & Morisco & Ônibus Luxo & Tursan \\
\hline 3:32 PM & BWU 7970 & Volkswagem 25 & Areão & Ônibus Executivo & Tursan \\
\hline 3:33 PM & CPG 2476 & Volkswagem 40 & PQ Santo Antonio & Ônibus Executivo & Tursan \\
\hline 3:33 PM & BWG 5749 & Volkswagem 88 & Espl. Sta. Teresinha & Ônibus Executivo & Tursan \\
\hline 3:33 PM & BUP 2899 & Volkswagem 86 & Estiva & Ônibus Executivo & Julio Simões \\
\hline 3:33 PM & HVS 3615 & Volkswagem 17 & PQ Aeroporto & Ônibus Executivo & Tursan \\
\hline 3:33 PM & DAH 7391 & Volkswagem 96 & PQ Planalto & Ônibus não identificado & Julio Simões \\
\hline 3:35 PM & CPG 2369 & CTEEP & Sem & Micro - Ônibus & Não Identificada \\
\hline 3:35 PM & BWI 8048 & Volkswagem 91 & CECAP & Ônibus Executivo & Tursan \\
\hline
\end{tabular}

Fonte: Pesquisa realizada mediante registro fotográfico dos ônibus, em frente ao Taubaté Shopping em taubaté..

Pesquisador: Pedro Paulo Cadena Giberti LAP-FAU-USP 
Tabela 13 - Município de Taubaté - Em frente ao Taubaté Shopping (sentido Dutra/Shopping) - Tabulação dos Fretados - 1/12/05 - das $16: 00$ às 18:30.

\begin{tabular}{|c|c|c|c|c|c|}
\hline Hora & Placa & Linha / Destino & Origem & Tipo de Veículo & Empresa de ônibus \\
\hline 3:58 PM & BXG 0356 & GMB1 1005 & Sem & Ônibus Executivo & Breda \\
\hline 3:59 PM & Não Visível & GMB2 1005 & Sem & Ônibus Executivo & Breda \\
\hline 4:19 PM & CLH 1982 & Embraer & $\begin{array}{l}\text { Eug. De Melo / Quiririm / } \\
\text { Estiva / Espla. Sta. } \\
\text { Terezinha / Areão / } \\
\text { Tremembé }\end{array}$ & Micro - Ônibus & Não Identificado \\
\hline 4:24 PM & BTT 8198 & Ford 23 & PQ Santo Antônio & Ônibus Executivo & Rosa \\
\hline 4:31 PM & CLK 3062 & Embraer 140 & $\begin{array}{c}\text { Quiririm / Hospital Escola } \\
\text { / Vila S. Geraldo }\end{array}$ & Ônibus Executivo & Redenção \\
\hline 4:43 PM & BTA 3161 & Volkswagem & Sem & Ônibus Executivo & Tursan \\
\hline 5:05 PM & BTT 8259 & Ford 01 & Ilegível & Ônibus Executivo & Rosa \\
\hline 5:05 PM & BTT 8260 & Ford 09 & Tremembé & Ônibus Executivo & Rosa \\
\hline 5:05 PM & BTT 8182 & Ford 02 & llegivel & Ônibus Executivo & Rosa \\
\hline 5:06 PM & ВTT 8197 & Ford 04 & llegível & Ônibus Executivo & Rosa \\
\hline 5:06 PM & ВTT 8197 & Ford 05 & Ilegível & Ônibus Executivo & Rosa \\
\hline 5:06 PM & Não Visível & Ford & llegível & Ônibus Executivo & Rosa \\
\hline 5:06 PM & Não Visível & Ford 07 & llegível & Ônibus Executivo & Rosa \\
\hline 5:06 PM & Não Visível & Ford & llegível & Ônibus Executivo & Rosa \\
\hline 5:07 PM & BWY 9283 & Ford 08 & Padre Eterno & Ônibus Executivo & Rosa \\
\hline 5:08 PM & Não Visível & LG Electronics 16 & Sem & Ônibus Executivo & Redenção \\
\hline 5:23 PM & CPI 4572 & Petrobrás 113 & Sem & Ônibus Executivo & Viação Jacacreí \\
\hline 5:25 PM & CPG 2380 & Wolkswagem 31 & Pindamonhangaba & Ônibus Executivo & Tursan \\
\hline 5:25 PM & DAJ 8199 & Wolkswagem 31 & Gurilândia & Ônibus Executivo & Tursan \\
\hline 5:25 PM & HVS 3615 & Wolkswagem 19 & Flor do Vale & Ônibus Luxo & Tursan \\
\hline 5:26 PM & BXE 7331 & Autoliv 172 & Sem & Ônibus Executivo & Viação Jacacreí \\
\hline 5:27 PM & DAH 7398 & Wolkswagem 51 & Campos Elisios & Ônibus Executivo & Júlio Simões \\
\hline 5:38 PM & CLH 1404 & Daido & Sem & Ônibus Executivo & Marson \\
\hline 5:41 PM & BWF 5379 & Ericsson 001 & Sem & Ônibus Executivo & Redenção \\
\hline 5:41 PM & CPI 3449 & Delphi & Sem & Micro - Ônibus & Venetur \\
\hline 5:45 PM & BYE 9286 & Alstom 05 & São Gonçalo & Ônibus Executivo & Tursan \\
\hline 5:46 PM & KKK 1223 & Alstom 01 & DER & Ônibus Luxo & Tursan \\
\hline 6:04 PM & CLK 2892 & LG Electronics 16 & Sem & Ônibus Executivo & Redenção \\
\hline 6:05 PM & CLK 3063 & Embraer 98 & $\begin{array}{l}\text { Quiririm / N. Horizonte / } \\
\text { Shoppinh / Embaré / VI. } \\
\text { Rica / VI. Nova / Emeoal }\end{array}$ & Ônibus Executivo & Redenção \\
\hline 6:15 PM & CGS 8108 & Sem & Sem & Ônibus Executivo & Translourdes \\
\hline 6:15 PM & BYD 6108 & Sem & Sem & Ônibus Executivo & Translourdes \\
\hline
\end{tabular}

Fonte: Pesquisa realizada mediante registro fotográfico dos ônibus, em frente ao Taubaté Shopping em taubaté..

Pesquisador: Pedro Paulo Cadena Giberti LAP-FAU-USP 
Tabela 14 - Município de Valinhos - Próximo ao Pedágio de Valinhos, KM 83 da Rodovia Anhanguera (sentido Valinhos/Campinas) Tabulação dos Fretados - 12/04/05 - das 6:00 às 8:00.

\begin{tabular}{|c|c|c|c|c|c|}
\hline Hora & Placa & Linha / Destino & Origem & Tipo de Veículo & Empresa de ônibus \\
\hline $6: 12 \mathrm{AM}$ & llegível & ALUJET & Não Consta & Ônibus Executivo & Não Identificado \\
\hline 6:13 AM & llegível & EATON & llegível & Ônibus Executivo & Rápido Campinas \\
\hline 6:13 AM & llegível & EATON & llegível & Ônibus Executivo & Rápido Campinas \\
\hline 6:14 AM & llegível & EATON & llegível & Ônibus Executivo & Não Identificado \\
\hline 6:16 AM & llegível & EATON & Mogi Mirim & Ônibus Executivo & Rápido Campinas \\
\hline 6:31 AM & BWQ 4825 & EATON & Não Consta & Ônibus Executivo & Rápido Campinas \\
\hline 6:31 AM & BWG 1595 & EATON & Itajaí & Ônibus Executivo & Rápido Campinas \\
\hline 6:31 AM & BWG 1495 & EATON & Hortolandia & Ônibus Executivo & Rápido Campinas \\
\hline 6:31 AM & BWG 1160 & EATON & Não Consta & Ônibus Executivo & Rápido Campinas \\
\hline 6:32 AM & BWG 1469 & EATON & Costa e Silva & Ônibus Executivo & Rápido Campinas \\
\hline 6:40 AM & CQH 1861 & ONÇA & Não Consta & Ônibus Executivo & Capellini \\
\hline $6: 41 \mathrm{AM}$ & BTS 8423 & Linha 9 / UNICAMP & Não Consta & Ônibus Executivo & Santo Ignácio \\
\hline $6: 41 \mathrm{AM}$ & CQH 4842 & PROCTER \& GRAMBLE & Campinas & Micro-Ônibus & Não Identificado \\
\hline $6: 42 \mathrm{AM}$ & $\mathrm{CQH} 4841$ & PROCTER \& GRAMBLE & Campinas & Micro-Ônibus & Branca de Neve \\
\hline $6: 50 \mathrm{AM}$ & BWC 1631 & ONÇA & Não Consta & Ônibus Executivo & Capellini \\
\hline $6: 52 \mathrm{AM}$ & BTR 7961 & $\begin{array}{l}\text { SP/Campinas/SP ( Via Zona Sul, } \\
\text { Sto.Amaro, AV.Interlagos) }\end{array}$ & Campinas & Ônibus Luxo & Redenção, Fretado? \\
\hline 6:53 AM & BWQ 4979 & CORREIOS & Jardim do Lago & Ônibus Executivo & Transmimo \\
\hline 6:55 AM & BWG 1302 & A.RAYMOND & Não Consta & Ônibus Executivo & Rápido Campinas \\
\hline 7:04 AM & Não Visível & LETANDE & Valinhos & Ônibus Executivo & BRASAL \\
\hline $7: 10$ AM & BWO 2848 & LETANDE & Indaiatuba & Ônibus Executivo & BRASAL \\
\hline 7:10 AM & EHR 1501 & LETANDE & Sumaré & Micro-Ônibus & BRASAL \\
\hline 7:10 AM & KPQ 8030 & UNICAMP L31 / PÃO DE AÇUCAR & Não Consta & Ônibus Executivo & Transmimo \\
\hline $7: 15$ AM & DAH 9401 & UNICAMP L39 & Não Consta & Ônibus Executivo & Rápido Campinas \\
\hline 7:17 AM & LJF 2559 & UNICAMP & Via Agrícola & Ônibus Executivo & Não Identificado \\
\hline 7:18 AM & DBC 7125 & $\begin{array}{l}\text { MULT VIAS / Campinas Junadiaí; } \\
\text { CPFL - CPOD }\end{array}$ & Jundiaí & Ônibus Executivo & Não Identificado \\
\hline 7:19 AM & KTL 8754 & UNICAMP DIRETO & Não Consta & Ônibus Luxo & Viação Mimo \\
\hline 7:19 AM & BSF 2867 & UNICAMP DIRETO & Não Consta & Ônibus Executivo & Viação Mimo \\
\hline $7: 20$ AM & BWT 4425 & PUCC Linha 3 & Não Consta & Ônibus Executivo & Viação Mimo \\
\hline $7: 20 \mathrm{AM}$ & BWO 9268 & PUCC Linha 2 & Não Consta & Ônibus Executivo & Viação Mimo \\
\hline $7: 20 \mathrm{AM}$ & DAH 0987 & PUCCAMP & Não Consta & Micro-Ônibus & Oriente \\
\hline $7: 23$ AM & BSF 2903 & PUCCAMP & Não Consta & Ônibus Executivo & Não Identificado \\
\hline 7:24 AM & CLU 9278 & L M14 / BOSCH & Não Consta & Ônibus Executivo & Chechinato \\
\hline 7:28 AM & BWQ 4826 & L M13 / BOSCH & Não Consta & Ônibus Executivo & Rápido Campinas \\
\hline 7:34 AM & CQH 1861 & SAINT-GOBAIN & Vinhedo / Valinhos & Ônibus Executivo & Capellini \\
\hline 7:36 AM & DBB 2745 & A 14 / TECH TOWN & Não Consta & Ônibus Executivo & Capellini \\
\hline 7:49 AM & Não Visível & EATON & llegível & Ônibus Executivo & Rápido Campinas \\
\hline 7:59 AM & BWQ 4979 & CORREIOS & Jardim do Lago & Ônibus Executivo & Transmimo \\
\hline 8:00 AM & DAH 9468 & BSH CONTINENTAL / L.G & Não Consta & Ônibus Executivo & Rápido Campinas \\
\hline 8:05 AM & BTA 1401 & Linha 3 / KIDDE BRASIL & Não Consta & Ônibus Executivo & Capellini \\
\hline
\end{tabular}

Fonte: Pesquisa realizada mediante registro fotográfico dos ônibus, no Posto Policial Rodoviário Federal em São José dos Campos. 
Tabela 15 - Município de Valinhos - Próximo ao Pedágio de Valinhos, KM 83 da Rodovia Anhanguera (sentido Valinhos/Campinas) - Tabulação dos Fretados - 12/04/05 - das 5:00 às 6:00.

\begin{tabular}{|c|c|c|c|c|c|}
\hline Hora & Placa & Linha / Destino & Origem & Tipo de Veículo & Empresa de ônibus \\
\hline 5:02 PM & DBB 2745 & ONÇA & Não Consta & Ônibus Executivo & Capellini \\
\hline 5:17 PM & BTA 9841 & METAL LIGHT & Não Consta & Ônibus Executivo & Teac \\
\hline 5:18 PM & BWG 1535 & EATON & Itajaí & Ônibus Executivo & Rápido Campinas \\
\hline 5:18 PM & BWG 1495 & EATON & Hortolândia & Ônibus Executivo & Rápido Campinas \\
\hline 5:18 PM & BWQ 4828 & EATON & Jd.Euliana & Ônibus Executivo & Rápido Campinas \\
\hline 5:18 PM & BWQ 4825 & EATON & llegível & Ônibus Executivo & Rápido Campinas \\
\hline 5:19 PM & llegível & EATON & llegível & Ônibus Executivo & Rápido Campinas \\
\hline 5:19 PM & llegível & EATON & llegível & Ônibus Executivo & Rápido Campinas \\
\hline 5:19 PM & BWG 1497 & EATON & Não Consta & Ônibus Executivo & Rápido Campinas \\
\hline 5:19 PM & DAH 5430 & UNILEVER & Não Consta & Ônibus Executivo & Rápido Campinas \\
\hline 5:20 PM & BUD 8159 & EATON & Não Consta & Ônibus Executivo & Rápido Campinas \\
\hline 5:20 PM & llegível & EATON & Não Consta & Ônibus Executivo & Rápido Campinas \\
\hline 5:21 PM & Não Visível & SAINT GOBAIN & Rio Claro & Ônibus Executivo & Capellini \\
\hline 5:32 PM & CQH 2672 & Linha 2 / KIDDE BRASIL & Não Consta & Ônibus Executivo & Capellini \\
\hline 5:34 PM & DAH 5331 & L A16 / TECH TOWN & Não Consta & Ônibus Executivo & Rápido Campinas \\
\hline 5:36 PM & CQH 4907 & PROCTER \& GAMBLE & Campinas ADM & Ônibus Executivo & Branca de Neve \\
\hline
\end{tabular}

Fonte: Pesquisa realizada mediante registro fotográfico dos ônibus, no Posto Policial Rodoviário Federal em São José dos Campos.

Pesquisador: Pedro Paulo Cadena Giberti LAP-FAU-USP 
Tabela 16 - Município de Valinhos - Próximo ao Pedágio de Valinhos, KM 83 da Rodovia Anhanguera (sentido Campinas/Valinhos) Tabulação dos Fretados - 13/04/05 - das 6:00 às 8:00.

\begin{tabular}{|c|c|c|c|c|c|}
\hline Hora & Placa & Linha / Destino & Origem & Tipo de Veículo & Empresa de ônibus \\
\hline 6:21 AM & llegivel & $\begin{array}{l}\text { São Paulo passa por lugares } \\
\text { especificos }\end{array}$ & Não Consta & Ônibus Executivo & Mimo \\
\hline 6:24 AM & BTA 9831 & ONÇA & Não Consta & Ônibus Executivo & Capellini \\
\hline 6:26 AM & llegivel & $\begin{array}{l}\text { São Paulo passa por lugares } \\
\text { específicos }\end{array}$ & Não Consta & Ônibus Luxo & Mimo \\
\hline 6:29 AM & BWC 0866 & ONÇA & Não Consta & Ônibus Executivo & Capellini \\
\hline 6:35 AM & CPG 9080 & $\begin{array}{c}\text { São Paulo Via Pte.Eusébio Matoso, } \\
\text { Berrine, CENE?P, Santander, Verbo } \\
\text { Div(n)?o } \\
\text { www.executivocampinas.com.br }\end{array}$ & Campinas & Ônibus Luxo & Santa Cruz \\
\hline 6:37 AM & BSF 1906 & Linha $1 /$ ASTER & Não Consta & Ônibus Executivo & Rápido Vinhedo \\
\hline 6:37 AM & CPG 8857 & $\begin{array}{l}\text { Alphaville via cCentro Empresarial, } \\
\text { Av.Tamboré, Al.Rio Negro, Av.Ceci, } \\
\text { Al.Mamoré, Al.Amazonas, } \\
\text { Al.Araguaia, Al.Tocantins. Tel } 11 \text { 9763 } \\
2371\end{array}$ & Não Consta & Ônibus Luxo & Santa Cruz \\
\hline 6:41 AM & llegivel & $\begin{array}{l}\text { São Paulo passa por lugares } \\
\text { especificos }\end{array}$ & Não Consta & Ônibus Luxo & Santa Cruz \\
\hline 6:44 AM & DAH 5311 & LD $17 / \mathrm{BOSCH}$ & Não Consta & Micro-Ônuibus & Rápido Campinas \\
\hline 6:45 AM & CQH 2334 & $\begin{array}{c}\text { São Paulo Via Pinheiros, Faria Lima, } \\
\text { ltaim }\end{array}$ & Cond. Columbia & Ônibus Luxo & Santa Cruz \\
\hline 6:49 AM & CPG 8852 & São Paulo, VIVO, Claro & Não Consta & Ônibus Luxo & Santa Cruz \\
\hline 6:51 AM & CQH 5651 & $\begin{array}{l}\text { São Paulo Via Lapa, Av.Brig.Faria } \\
\text { Lima, Av.Juselino Kubschek, } \\
\text { Av.República do Libano }\end{array}$ & Não Consta & Ônibus Luxo & Santa Cruz \\
\hline 6:52 AM & CQH 4907 & PROCTER \& GAMBLE & Campinas & Ônibus Executivo & Branca de Neve \\
\hline 6:54 AM & CGS 7756 & LETANDE & Indaiatuba & Ônibus Executivo & Brasal \\
\hline 6:55 AM & Ilegivel & SAINT GOBAIN & Rio Claro & Ônibus Executivo & Capellini \\
\hline 6:56 AM & BUD 6131 & AKZO NOBEL & Campinas & Ônibus Executivo & Transmimo \\
\hline 6:58 AM & KLP 4453 & HEXIS CIENTÍFICA & Indaiatuba & Micro-Ônuibus & Famatur \\
\hline 6:59 AM & CQH 3671 & PROMOM ITAIM & Não Consta & Ônibus Luxo & Caprioli \\
\hline 7:01 AM & BWC 2894 & São Paulo Via Metrô Armenia & Não Consta & Ônibus Executivo & Caprioli \\
\hline 7:02 AM & BUD 4539 & Linha 6 USP & Adriana & Ônibus Luxo & Santa Cruz \\
\hline 7:02 AM & BWT 6840 & TNT LOGISTICS & \multirow{2}{*}{$\begin{array}{l}\text { Indaiatuba / Junadiaí } \\
\text { Não Consta }\end{array}$} & Ônibus Executivo & Piccoolotur \\
\hline 7:05 AM & BWF 3556 & TELEMAX & & Ônibus Executivo & Vesper \\
\hline 7:06 AM & Não Visível & UNICAMP & Não Consta & Ônibus Executivo & Transmimo \\
\hline 7:07 AM & BUD 4489 & INGERSOLL RAND & $\begin{array}{l}\text { Largo do Pará / } \\
\text { Campinas }\end{array}$ & Ônibus Luxo & Planetatur \\
\hline 7:12 AM & BSG 0991 & Linha 2 / TAMPAS CLICK & Campinas & Ônibus Executivo & Santo Ignacio \\
\hline 7:28 AM & DAH 5436 & EATON & Costa e Silva & Ônibus Executivo & Rápido Campians \\
\hline 7:28 AM & CNG 8190 & Linha 3 / UNILEVER & P.Portugal & Ônibus Executivo & Santo Ignacio \\
\hline 7:28 AM & DAH 5308 & EATON & Hortolandia & Ônibus Executivo & Rápido Campians \\
\hline 7:30 AM & BUD 6178 & EATON & B.Geraldo & Ônibus Executivo & Rápido Campians \\
\hline 7:30 AM & DAH 5335 & EATON & \multirow{2}{*}{$\begin{array}{l}\text { Perceu L. de Barros } \\
\text { Não Consta }\end{array}$} & Ônibus Executivo & Rápido Campians \\
\hline 7:30 AM & BWQ 4736 & EATON & & Ônibus Executivo & Rápido Campians \\
\hline 7:30 AM & BWG 1527 & EATON & S.Fernando & Ônibus Executivo & Rápido Campians \\
\hline 7:31 AM & DAH 5448 & EATON & Jd.Yeda & Ônibus Executivo & Rápido Campians \\
\hline 7:31 AM & BWQ 4744 & EATON & Jd.Eulina & Ônibus Executivo & Rápido Campians \\
\hline 7:32 AM & BWQ 4731 & EATON & Boa Vista & Ônibus Executivo & Rápido Campians \\
\hline 7:34 AM & BWQ 4732 & EATON & N.Europa & Ônibus Executivo & Rápido Campians \\
\hline 7:35 AM & BWQ 4734 & EATON & Santana & Ônibus Executivo & Rápido Campians \\
\hline 7:36 AM & CQH 2672 & Linha 2 / KIDDE BRASIL & Não Consta & Ônibus Executivo & Capellini \\
\hline 7:38 AM & CQH 6739 & Ônibus 01 / IVIAN & Não Consta & Ônibus Luxo & Caprioli \\
\hline 7:38 AM & $\mathrm{CQH} 6743$ & Ônibus 02 / IVIAN & Não Consta & Ônibus Luxo & Caprioli \\
\hline 7:38 AM & CQH 6738 & Ônibus 03 / IVIAN & Não Consta & Ônibus Luxo & Caprioli \\
\hline 7:39 AM & BWQ 4979 & CORREIOS & Jardim do Lago & Ônibus Executivo & Transmimo \\
\hline 7:39 AM & BUD 6159 & UNILEVER AMARELOO & Não Consta & Ônibus Executivo & Rápido Campinas \\
\hline 7:40 AM & CZC 8774 & UNILEVER AZUL & Não Consta & Ônibus Executivo & Rápido Campinas \\
\hline 7:47 AM & BWQ 9181 & EXEL do BRASIL & $\begin{array}{l}\text { ADM Valinhos / } \\
\text { Campinas }\end{array}$ & Ônibus Executivo & Vesper \\
\hline
\end{tabular}

Fonte: Pesquisa realizada mediante registro fotográfico dos ônibus, proximo ao pedágio de Valinhos.

Pesquisador: Pedro Paulo Cadena Giberti LAP-FAU-USP 
Tabela 17 - Município de Valinhos - Próximo ao Pedágio de Valinhos, KM 83 da Rodovia Anhanguera (sentido Campinas/Valinhos) Tabulação dos Fretados - 13/4/05 - das 16:00 às 18:00.

\begin{tabular}{|c|c|c|c|c|c|}
\hline Hora & Placa & Linha / Destino & Origem & Tipo de Veículo & Empresa de ônibus \\
\hline 4:08 PM & DAH 5443 & EATON & Jd.Yeda & Ônibus Executivo & Rápido Campinas \\
\hline 4:09 PM & BWQ 4825 & EATON & llegível & Ônibus Executivo & Rápido Campinas \\
\hline 4:09 PM & CQH 1837 & Linha 4 / KIDDE BRASIL & Não Consta & Ônibus Executivo & Capellini \\
\hline 4:10 PM & DAH 5340 & EATON & Não Consta & Micro-Ònibus & Rápido Campinas \\
\hline 4:24 PM & BWG 1498 & EATON & CECAP & Ônibus Executivo & Rápido Campinas \\
\hline 4:30 PM & DBB 2745 & ONÇA & Não Consta & Ônibus Executivo & Capellini \\
\hline 4:32 PM & CZC 8938 & EATON & $\begin{array}{c}\text { Jd.Jurema / Jd. São } \\
\text { Marcos }\end{array}$ & Ônibus Executivo & Rápido Campinas \\
\hline 4:40 PM & BWC 6596 & TAMPAS CLICK & São Paulo & Ônibus Executivo & Santo Ignácio \\
\hline 4:40 PM & BWG 1535 & EATON & Itajaí & Ônibus Executivo & Rápido Campinas \\
\hline 4:41 PM & BUD 6182 & L A 26 / EATON & São Sebatsião & Ônibus Executivo & Rápido Campinas \\
\hline 4:42 PM & BWQ 4828 & L 7 / CELESTICA & Campos Eliseos & Ônibus Executivo & Rápido Campinas \\
\hline 4:47 PM & DAH 5320 & ADELBRAS & Não Consta & Ônibus Executivo & Rápido Campinas \\
\hline 4:50 AM & BWQ 4734 & EATON & Novo Mundo & Ônibus Executivo & Rápido Campinas \\
\hline 4:50 PM & BWT 6962 & EATON & Costa e Silva & Ônibus Executivo & Rápido Campinas \\
\hline 4:52 PM & BWG 1468 & EATON & B.Geraldo & Ônibus Executivo & Rápido Campinas \\
\hline 4:52 PM & BWG 1550 & EATON & Jd.Santana & Ônibus Executivo & Rápido Campinas \\
\hline 4:55 PM & BWG 1495 & EATON & Não Consta & Ônibus Executivo & Rápido Campinas \\
\hline 4:55 PM & BWG 1521 & UNILEVER & Não Consta & Ônibus Executivo & Rápido Campinas \\
\hline 4:55 PM & BWD 2848 & LETANDE & Indaiatuba & Ônibus Executivo & Brasal \\
\hline 4:56 PM & BWC 6597 & TAMPAS CLICK & Não Consta & Ônibus Executivo & Santo Ignácio \\
\hline 4:57 PM & BWQ 4742 & EATON & N.Europa & Ônibus Executivo & Rápido Campinas \\
\hline 5:04 PM & EHR 1501 & LETANDE & Sumaré & Micro-Ònibus & Brasal \\
\hline 5:12 PM & BWT 4425 & Linha 3 / PUCC & Não Consta & Ônibus Executivo & Viação Mimo \\
\hline 5:16 PM & CLJ 6678 & GEVISA & Leopoldina / Campinas & Ônibus Executivo & Urubupungá \\
\hline 5:34 PM & BWG 1142 & D 13 / BOSCH & Não Consta & Ônibus Executivo & Rápido Campinas \\
\hline 5:39 PM & llegível & PUCCAMP & Não Consta & Ônibus Executivo & acaba com tem \\
\hline 5:42 PM & llegível & UNICAMP & Não Consta & Ônibus Luxo & Santa Cruz \\
\hline 5:43 PM & Ilegível & PUCCAMP & Não Consta & Micro-Ònibus & acaba com tem \\
\hline 5:46 PM & Ilegível & USP & Não Consta & Ônibus Executivo & Santa Cruz \\
\hline
\end{tabular}

Fonte: Pesquisa realizada mediante registro fotográfico dos ônibus, próximo ao pedágio de Valinhos.

Pesquisador: Pedro Paulo Cadena Giberti LAP-FAU-USP 
Tabela 18 - Município de Americana - Posto Rodoviário Policial da Rodovia Anhanguera (sentido Americana/Campinas) - Tabulação dos Fretados - 7/4/05 - das 6:00 às 8:30.

\begin{tabular}{|c|c|c|c|c|c|}
\hline Hora & Placa & Linha / Destino & Origem & Tipo de Veículo & Empresa de ônibus \\
\hline 6:23 AM & BTT 5270 & Turno LT 18 / RIPASA & Não Consta & Ônibus Executivo & Ouro Verde \\
\hline 6:27 AM & $\mathrm{CCH} 2714$ & SAINT GOBAIN & Rio Claro & Ônibus Executivo & Capellini Turismo \\
\hline $6: 30 \mathrm{AM}$ & BWS 0579 & TOPACK & Romano & Ônibus Executivo & Visatur \\
\hline 6:32 AM & BWS 2425 & $\begin{array}{c}\text { Prefeitura Municipal de } \\
\text { Americana.Secretaria de Educação e } \\
\text { Cultura Transporte Escolar Linha 7A }\end{array}$ & Não Consta & Ônibus Executivo & Visatur \\
\hline 6:33 AM & BWT 6941 & TOPACK & A.F.Ramos & Ônibus Executivo & Visatur \\
\hline 6:37 AM & BUD 4415 & LT-20 / RIPASA & Não Consta & Ônibus Executivo & Vesper \\
\hline 6:39 AM & BWS 0595 & TOPACK & C.Nova & Ônibus Executivo & Visatur \\
\hline $6: 41 \mathrm{AM}$ & DAH 5339 & L 20 / TECH TOWN & Não Consta & Ônibus Executivo & Rápido Campinas \\
\hline $6: 47 \mathrm{AM}$ & BWF 9372 & TOPACK & S.B.O Centro & Ônibus Executivo & Visatur \\
\hline $6: 52 \mathrm{AM}$ & BUD 4585 & Linha 03 / SANTISTA & Não Consta & Ônibus Executivo & Vesper \\
\hline $6: 53 \mathrm{AM}$ & JNW 0111 & PPG Indústria do Brasil LTDA & Americana & Ônibus Executivo & West Side \\
\hline 7:03 AM & BTT 5250 & UNICAMP / FACAMP & Não Consta & Ônibus Executivo & AA \\
\hline 7:05 AM & BXH 5152 & UNICAMP & Não Consta & Ônibus Executivo & AA \\
\hline 7:07 AM & BWS 7186 & KS-PISTÕES & Não Consta & Ônibus Executivo & Vesper \\
\hline 7:08 AM & CLH 5201 & $\begin{array}{c}\text { Prefeitura Municipal de } \\
\text { Americana.Secretaria de Educação e } \\
\text { Cultura Transporte Escolar Linha } 6\end{array}$ & Não Consta & Ônibus Executivo & Visatur \\
\hline 7:11 AM & BWS 2443 & $\begin{array}{c}\text { Prefeitura Municipal de } \\
\text { Americana.Secretaria de Educação e } \\
\text { Cultura Transporte Escolar Linha } 7\end{array}$ & Não Consta & Ônibus Executivo & Visatur \\
\hline $7: 12$ AM & BUS 2894 & Linha 13 / GOODYEAR & Não Consta & Ônibus Executivo & Ouro Verde \\
\hline $7: 22 \mathrm{AM}$ & BMG 1149 & M 12 / BOSCH & Não Consta & Ônibus Executivo & Rápido Campinas \\
\hline 7:47 AM & DAH 0266 & TOPACK & Romano & Micro-Ônibus & Visatur \\
\hline 7:54 AM & BXI 3716 & 202 / VILLARES & Não Consta & Ônibus Executivo & Rápido Sumaré \\
\hline 8:04 AM & DAH 5332 & Linha A21 / TECH TOWN & Não Consta & Ônibus Executivo & Rápido Campinas \\
\hline 8:12 AM & BUD 4415 & RIPASA & Não Consta & Ônibus Executivo & Vesper \\
\hline
\end{tabular}

Fonte: Pesquisa realizada mediante registro fotográfico dos ônibus, no Posto Policial Rodoviário Federal em Americana.

Pesquisador: Pedro Paulo Cadena Giberti LAP-FAU-USP 
Tabela 19 - Município de Americana - Posto Rodoviário Policial da Rodovia Anhanguera (sentido Americana/Campinas) - Tabulação dos Fretados - 7/04/05 - das 16:00 às 18:00.

\begin{tabular}{|c|c|c|c|c|c|}
\hline Hora & Placa & Linha / Destino & Origem & Tipo de Veículo & Empresa de ônibus \\
\hline 4:35 PM & CZC 8949 & L M12 / BOSCH & Não Consta & Ônibus Executivo & Rápido Campinas \\
\hline 4:47 PM & СBB 2736 & Turno 1 / PIRELLI & Não Consta & Ônibus Executivo & Capellini \\
\hline 5:52 PM & BWS 2425 & $\begin{array}{c}\text { Prefeitura Municipal de } \\
\text { Americana.Secretaria de Educação e } \\
\text { Cultura Transporte Escolar Linha 7A }\end{array}$ & Não Consta & Ônibus Executivo & Visatur \\
\hline 5:55 PM & BYH 9525 & $\begin{array}{c}\text { Prefeitura Municipal de } \\
\text { Americana.Secretaria de Educação e } \\
\text { Cultura Transporte Escolar }\end{array}$ & Não Consta & Ônibus Executivo & Visatur \\
\hline
\end{tabular}

Fonte: Pesquisa realizada mediante registro fotográfico dos ônibus, no Posto Policial Rodoviário Federal em Americana.

Pesquisador: Pedro Paulo Cadena Giberti LAP-FAU-USP 
Tabela 20 - Município de Americana - Posto Rodoviário Policial da Rodovia Anhanguera (sentido Campinas/Americana) - Tabulação dos Fretados - 8/4/05 - das 6:00 às 8:00.

\begin{tabular}{|c|c|c|c|c|c|}
\hline Hora & Placa & Linha / Destino & Origem & Tipo de Veículo & Empresa de ônibus \\
\hline 6:19 AM & BWS 4810 & $\begin{array}{c}\text { Prefeitura Municipal de } \\
\text { Americana.Secretaria de Educação e } \\
\text { Cultura Transporte Escolar Linha } 13\end{array}$ & Não Consta & Ônibus Executivo & Visatur \\
\hline $6: 25 \mathrm{AM}$ & BXH 8168 & RIDARP & Não Consta & Ônibus Executivo & Não Identifivado \\
\hline 6:32 AM & BYH 9525 & $\begin{array}{c}\text { Prefeitura Municipal de } \\
\text { Americana.Secretaria de Educação e } \\
\text { Cultura Transporte Escolar Linha } 3\end{array}$ & Não Consta & Ônibus Executivo & Visatur \\
\hline 6:32 AM & BWS 4811 & $\begin{array}{c}\text { Prefeitura Municipal de } \\
\text { Americana.Secretaria de Educação e } \\
\text { Cultura Transporte Escolar Linha } 22\end{array}$ & Não Consta & Ônibus Executivo & Visatur \\
\hline 6:36 AM & BWS 0595 & TOPACK & C.Nova & Ônibus Executivo & Visatur \\
\hline $6: 44 \mathrm{AM}$ & BWT 6941 & TOPACK & A.F.Ramos & Ônibus Executivo & Visatur \\
\hline $6: 52 \mathrm{AM}$ & DAH 9407 & L .D20 / ROBERT BOSCH & Não Consta & Micro-Ônibus & Rápido Campinas \\
\hline $6: 53 \mathrm{AM}$ & LAJ 7661 & COTIL & Limeira & Ônibus Executivo & Exclusiva \\
\hline $6: 54 \mathrm{AM}$ & LBB 4349 & COTIL & Limeira & Ônibus Executivo & Exclusiva \\
\hline 6:57 AM & GLI 3063 & COTIL & Não Consta & Ônibus Executivo & Imigrante \\
\hline 7:37 AM & BWS 7186 & KS-PISTÕES & Não Consta & Ônibus Executivo & Vesper \\
\hline 7:35 AM & DBB 2783 & ADM A3 / PIRELLI & Não Consta & Ônibus Executivo & Capellini \\
\hline
\end{tabular}

Fonte: Pesquisa realizada mediante registro fotográfico dos ônibus, no Posto Policial Rodoviário Federal em Americana.

Pesquisador: Pedro Paulo Cadena Giberti LAP-FAU-USP 
Tabela 21 - Município de Americana - Posto Rodoviário Policial da Rodovia Anhanguera (sentido Campinas/Americana) - Tabulação dos Fretados - 8/4/05 - das 16:00 às 18:00.

\begin{tabular}{|c|c|c|c|c|c|}
\hline Hora & Placa & Linha / Destino & Origem & Tipo de Veículo & Empresa de ônibus \\
\hline 4:15 PM & BTA 7211 & KS-PISTÕES & Não Consta & Ônibus Executivo & Vesper \\
\hline 4:20 PM & BWF 9372 & TOPACK & S.B.O Centro & Ônibus Executivo & Visatur \\
\hline 4:33 PM & BUD 4415 & Verificar & Americana & Ônibus Executivo & Vesper \\
\hline 5:07 PM & DBB 2736 & Turno 1 / PIRELLI & Não Consta & Ônibus Executivo & Capellini \\
\hline 5:08 PM & DAH 5339 & L 20 / TECH TOWN & Não Consta & Ônibus Executivo & Rápido Campinas \\
\hline 5:22 PM & FHD 1402 & $\mathrm{BOSCH}$ & Americana & Micro-Ônibus & Brasal \\
\hline 5:30 PM & BXA 7837 & L38 / GEVISA & Não Consta & Ônibus Executivo & Capellini \\
\hline 5:36 PM & DAH 0266 & TOPACK & Romano & Micro-Ônibus & Visatur \\
\hline 5:47 PM & CVN 4362 & 402/1 / VILLARES & Não Consta & Ônibus Executivo & Ouro Verde \\
\hline
\end{tabular}

Fonte: Pesquisa realizada mediante registro fotográfico dos ônibus, no Posto Policial Rodoviário Federal em Americana.

Pesquisador: Pedro Paulo Cadena Giberti LAP-FAU-USP 